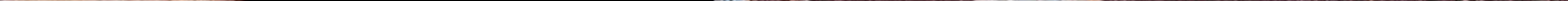




\section{A Transposição do rio \\ São Francisco: contradições \\ da presença-ausência da \\ obra ao longo de seus eixos}

Programa de Pós-graduação da

Faculdade de Arquitetura e Urbanismo

da Universidade de São Paulo

\section{Aluna}

Carolina Jessica Domschke Sacconi

\section{Orientação}

Karina Oliveira Leitão

Área de Concentração

Habitat 
Esta pesquisa contou com apoio da bolsa do Programa Nacional de Pós-Graduação , pelo Programa de Pós-Graduação em Arquitetura e Urbanismo da Universidade de São Paulo (FAU-USP).

Autorizo a reprodução e divulgação total ou parcial deste trabalho, por qualquer meio convencional ou eletrônico, para fins de estudo e pesquisa, desde que citada a fonte.

Email da autora: carolsacconi@usp.br

Catalogação na Publicação

nico de Bibliotec

Canismo da Universidade de São Paulo

Sacconi, Carolina Jessica Domschke

A Transposição do rio são Francisco: contradições da ao longo de seus eixos / Carolina Sâno Paulo, 2019 .
Sân p 231 .

Dissertação (Mestrado) - Faculdade de Arquitetura e urbanismo da Universidade de são Paulo. Área de concentração: Habitat.

1. Transposição. 2. Rio São Francisco. 3. Planejamento
egional. I. Leitão, Karina Oliveira, orient. II. Título.
A Transposição do rio

São Francisco: contradicões

da presença-ausência da

obra ao longo de seus eixos

\section{Banca examinadora}

Prof. Dr.:

Julgamento:

Instituição

Assinatura

Prof. Dr.

Julgamento:

Instituição

Assinatura

Prof. Dr.

Julgamento:

Instituição

Assinatura 


\section{Agradecimentos}

Agradeço aos
pelo apoio essenciais para que, que foram pesenvolver este trabalho. Esses anos da construcão da minha vida profissiona e sem esse apoio da família, isso não seria possível. Também foram anos que que admiro, com quem troco muito e coincidiram com momentos marcantes
para nós como família, que só se uniu para nós como família, que so se uniu mais diante dos acontecimentos. Ao
meu pai, muito querido, que me apoia meu pai, muito querido, que me apoia
e me alegra sempre. Ao meu irmão, por e me alegra sempre. Ao meu irmão, por
quem tenho muito amor e que me apoia muito também. À minha mãe, arquiteta em quem me espelho, admiro e que me acarretou de termos a mesma profissão. Na academia, também nos aproxi
através dos estudos das águas.

Agradeço à minha orientadora, grande achado nesse meu percurso (e no de que guia minha pesquisa, é magnífica e humilde, entusiasmada e entusiasmante,
sensível e forte, articuladora dos saberes sensivel e forte, articuladora dos saberes,
acontecimentos e pessoas, generosa,

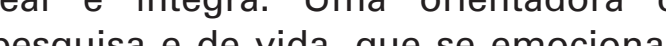
cada passo conquistado pelas pessoas que acompanha. Grande professora
que se tornou uma grande amiga.

Às bolsistas de graduação científica Ana e Andrea, que me acompanharam
durante praticamente toda a pesquisa, durante praticamente toda a pesquisa,
sendo fundamentais para o processo, na interlocução, na construção das ideias, das perceppçốes de campo, na construçãó dos mapas, nas tabulaçōes de notícias.

Obrigada à Profa. Dra. Regina Lins ao Eng. Prof. Dr. Francisco Sarmento,
que compuseram a minha banca de que compuseram a minha banca de
qualificação, ajudando a guiar os rumos desta dissertação. E ao Eng. Rômulo Macedo, que esteve presente na me
banca e contribuiu nas discussões.

À Luciana, Sofia e Tomás, pelo apoio no trabalho de campo, permitindo que
ele ocorresse em um momento em que ele ocorresse em um momento em que
eu ainda não tinha apoio financeiro dicação! Um pesquisador de ponta, apoiou na realizaca do trabalho me poeta, com quem troco muito, aprendo e campo no Trabalho de Conclusão da querido.

Graduação, em que Tomás e Sofia me acompanharam

A Profa. Dra. Paula Santoro e Profa. Dra. À Lélia e minha avó Lydia, que é a ingressar, na pós-gradicentivaram fundame sempre instigou em mim a curiosidade e uma das pesquisas que precedeu essa a vontade de pesquisar. Sempre muito dissertação, na

tudo o que eu faço.

Obrigada à Profa. Dra.Vanessa Empinotti,

que acredito e que me orgulho de

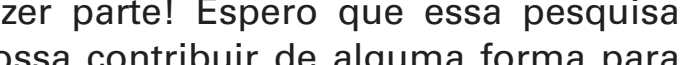

Aos “Cabides", Bia Falleiros, Cadu Marino, Guido D'Elia Otero, Hannah Arcuschin
Machado, amigos muito amados, da categoria amigos-família,

pelas conversas no início da pesquisa,
pelo convite em assistir sua disciplina na UFABC, que elucidou muitos conceitos, utilizados nesta pesquisa.

Ao Prof. Alexandre Delijaicov, por ter discutido conosco sobre o projeto da sobre outras transposicōes, sugerindo cartografias e viabilizando reuniōes entre grupos de pesquisa. Suas aulas conversas me incentivaram muito, ao longo da vida, a minhabusca por estudar as águas, os canais, os grandes projetos. Ao Vitor Ferrão e Berta Oliveira, que contataram familiares moradores de que nos recebessem em suas casas contribulçoes muito importantes para família-Fresta: Anita Freire, Lun Carone, a viabilizaçao do trabalho de campol Otávio Sasseron e Tais Freire! Obrigada E obrigada a seus familiares que no perre (a) grupo cada vez mais e que a gente Grande (PB), e Juliana Quirino, em João

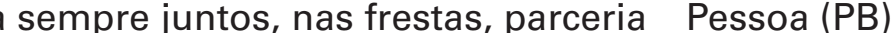

Ao Eng. Irani Ramos, Eng. Prof. Dr. Francisco Sarmento, Juliana Barros e Arq. Andrei Almeia, pessoas que trabalharam e/ou estudaram muito a Ao Tong Tiago Testa, Renata Gaia e Silvia suas generosidades na concessão de Acar, famila escolhida, amigos pra informaçoes ou pela realizaçao de to. Obrigada pelo apoio ao longo da dissertação e para realizar o campo. Aos integrantes do Ministério da ogus, que proporcionaram companharam nossa visita a campo: os engenheiros e assistentes sociais Marcus Leme, Franciney, Francisco
Motta, Helena Barros. Aos entrevistados em campo, já que sem seus depoimentos a pesquisa não teria sido possível. E um agradecimento especial à comunidade indígena Truká, que nos recebeu com muito carinho e nos hospedou em suas casas. Seus depoimentos foran fundamentais para a pesquisa, e
encontros foram muito marcantes. os meus amigos da pós-graduação, obrigada pelas trocas, desde os estudos trocas ao longa nós, bem como nas na participação de congressos, revisão textos e pelos bons momentos: . Helterson Ribeiro, João, Chivia Peretto, Pedro Volpato, Fabio Pereira, Bruno Portes, RosieYamaguti e Lara Ferreira.

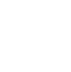




\section{Resumo} Partindo de uma análise crítica das Based on a critical analysis of the
práticas de planejamento adotadas planning practices adopted by the pelo Governo Federal em especial de Federal Government in particular 2003 a 2018, o presente trabalho aborda from 2003 to 2017, this investigation abrangência regional, a Transposição on regional scale the São Francisco do rio São Francisco ou Projeto de river's Transfer, later renamed São Integração do Rio São Francisco com Francisco River Integration Project with Bacias do Nordeste Setentrional (PISF), the Northern Northeast Basin (PISF), on tal como nomeada no início da gestão the beginning of its execution, during em que iniciou a ser executada, no Luiz Inácio Lula da Silva's government. governo Lula (2003-2011). A pesquisa The investigation is based on a debate on partiu de um debate sobre os discursos the technical and political speeches that
técnico e político que embasaram o set the project's main ideas, ideas that ideário sobre a obra, idealizada desde o have been developed since the Empire Brasil Império, e enfocou a investigação in Brazil, in the 19th century. The research sobre como a obra se relacionou com has focused on the question of how the as estruturas sociais e ambientais do construction has dialogued with the semiárido, levando em consideraçáo social and environmental structures of

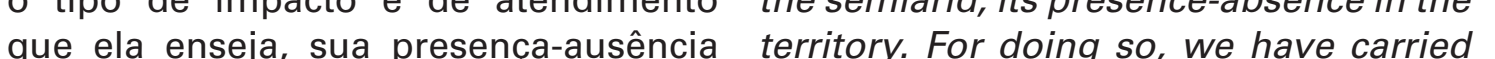
no território. Para tanto, dedicou-se out to an analysis of efficial documents, fortemente a uma analise ancorada conducted fieldwork and interviews, na leitura de documentos oficiais, tabulated news and produced a na realização de trabalhos de campo cartography that assists in the analytical e entrevistas, alem de na tabulação elucidation of the arguments that have de noticias e na produçao de uma been developed.

cartografia que auxilia na elucidação dos
argumentos elaborados.

Palavras-chave

Transposição, rio São Francisco

\section{Key words}

Regional Planning

planejamento regional. 
Lista de abreviaturas e siglas

AATR - Associação de Advogados de Trabalhadores Rurais no Estado da

Bahia

AESA - Agência Executiva de Gestão das Áquas da Paraíba

ANA - Agência Nacional de Águas

\section{AP - Audiência Pública}

APOINME - Articulação dos Povos e Organizaçốes Indígenas do Nordeste,

BNDES - Banco Nacional do

Desenvolvimento

CBHSF - Comitê da Bacia Hidrográfica do Rio São Francisco

CGU - Controladoria Geral da União

CHESF - Companhia Hidro Elétrica do São Francisco

CIMI - Conselho Indigenista Missionár CIM

CMRSF - Comissão de Melhoramento do Rio São Francisco

CNRH - Conselho Nacional de Recursos Hídricos

Codevasf - Companhia de

Desenvolvimento dos Vales do São

Francisco e do Parnaíba

COMPESA - Companhia Pernambucana

de Saneamento

CONAMA - Conselho Nacional do Mei Ambient

CPP - Conselho Pastoral dos Pescador

CRA - Centro de Recursos Ambientais

DNOCS - Departamento Nacional de

Obras Contra as Secas
DNOS - Departamento Nacional de

Obras e Saneamento

DOU - Diário Oficial da União

EIA-RIMA - Estudo de Impacto

Ambiental e Relatório de Impacto

Ambiental

ENIDS - Eixos Nacionais de Integração e Desenvolvimento

FHC - Fernando Henrique Cardoso

FUNAI - Fundação Nacional do Índio

FUNASA - Fundação Nacional de Saúde

FUNCATE - Fundação de Ciência

Aplicações e Tecnologias Espaciais

IBAMA - Instituto Brasileiro do Meio

Ambiente e dos Recursos Naturais

Renováveis

CMBIO - Instituto Chico Mendes de

Conservação da Biodiversidade

IDH - Índice de Desenvolvimento Humano

FOCS - Inspetoria Federal de Obras

Contra as Secas

IBGE - Instituto Brasileiro de Geograf e Estatística

INPE - Instituto Nacional de Pesquisas Espaciais

IRSA - Iniciativa para a Integraçẫo Regional da Infraestrutura Sul-

LDO - Lei de Diretrizes Orçamentária

LI - Licença de Instalação

LO - Licença de Operação
LOA - Lei Orçamentária Anual

LP - Licença Prévia

MI - Ministério de Integração Nacional

MIR - Ministério de Integração Regional MMA - Ministério do Meio Ambiente

\section{MPF - Ministério Público Federal}

NECTAS-UNEB - Núcleo de Estudos em Acõ Socios da Bahia

PAC - Programa de Aceleração do Crescimento

PBA - Planos Básicos Ambientais

PCRBHSF - Projeto de Conservação e Revitalização da Bacia Hidrográfica do São Francisco

PIB - Produto Interno Bruto

PISF - Projeto de Integração do Rio São Francisco com as Bacias do Nordest

PPA - Plano Plurianua

PPI - Projeto Piloto de Investimentos PRAD - Plano de Recuperação de Áreas Degradadas

SEPRE - Secretaria Especial de Políticas Regionais

TCU - Tribunal de Contas da União

UFCG - Universidade Federal de Campina Grande

UFAM - Universidade Federal da

Amazônia

USP - Universidade de São Paulo 
13 Do contexto e justificativas

59 Capítulo 2 - A compensação

Do processo de trabalho e dos $60 \quad 2.1 .0$ contexto das exigências materiais utilizados não se concretizam

18 O objetivo e o recorte da pesquisa

19 Dos conceitos utilizados ambientais

21 Da organização dos capítulos

2.2. A disputa ambiental em torno Ja Transposiçáo e a construção de sua justificativa técnica sem a escuta social

23 Capitulo 1 - Historiografia do 70 23.1. 0 discurso que legitimou projeto de Transposição do rio São o projeto e a elaboração do ElA-RIMA Francisco: ideário, contextos e interfaces do Projeto de Integração de Bacias da obra

do rio São Francisco com o Nordeste

25 1.1. Notas introdutórias sobre o Setentrional

sertão norde

81 2.3.2. Os Programas Ambientais

$\begin{array}{llll}27 & 1.2 . & \text { A ideia da Transposição do } \\ \text { rio São Francisco ao longo } & 87 & \text { 2.4. Ainserção regional prometida }\end{array}$ da história brasileira

91 Capítulo 3 - A viabilização da obra

29 1.2.1. A primeira ideia de transpor e sua inserção no território

as águas do São Francisco.

30 1.2.2. Projetos no tempo de Dom $\begin{array}{ll}93 & \text { 3.1. A viabilização financeira da } \\ \text { obra } & \text { (PAC) e a divisão da obra entre }\end{array}$ Pedro II empreiteiras

35 1.2.3. IOCS e a dificuldade de 103 3.2. Em que consiste a obra do transpor a Chapada do Araripe PISF

37 1.2.4. A solução para o relevo, 103 3.2.1. Dados técnicos ilustrados da outras obras hidráulicas e a corrupção obra

39 1.2.5. Governo militar ea proposta 129 3.2.2. A presença-ausência da ambiciosa obra no território

43 1.2.6. A nova Constituição e a 177 3.3. Notas gerais do capítulo 3 questão ambiental

181 Capítulo 4 - Considerações finais

45 1.2.7. FHC, O Eixo Leste e a do projeto

189 Capítulo 5 - Referências bibliográficas

51 1.2.8. Governo Lula: a ação estatal por meio de uma carteira de obras de alto 
Introdução

Das questões que originaram a pesquisa

A presente pesquisa teve origem com a vontade de se pensar na contribuição do que não apenas o metropolitano, na

escala regional para além do perímetro $J$ edifício, contextos e escalas mais usuais infraestrutura, essa grande obra de para o arquiteto. Surgiu, portanto, da Francisco, como caso para se refletir vontade de se pensar em outros tipos sobre a açáo do Estado nesse territórí de território, outros tipos de urbano, de semiárido, e, através da compreensáo culturas, espaços e formas de habitar. a ação pública perante o planejamento
regional no Brasil. Buscou-se Somando-se uma afinidade e um compreender como foi concebida essa eixos, como ela no semiárido brasileiro estimulou a incidiu no território, como a obra se continuaçáo daquelas pesquisas em relacionou com as estruturas sociais pós-graduacão No primeiro trabalho em consideração o tipo de impacto e de Xique Xique Cidade Destino (SACCONH, atendimento que elo onseja. 2012), , estudou-se as cidades de origem

de migrantes nordestinos do estado

da Bahia, que se mudaram para São

Paulo e que, naquele momento, dadas

as politicas economicas e sociais do

governo de Luiz Inácio Lula da Silvã
(2003-2011), retornavam a sua região

de origem, mas para as cidades médias

e não para as cidades de origem, que eram em geral menores que as novas cidades-destino desses migrantes.

O segundo trabalho foi realizado no ano seguinte, em 2013, no contexto de pesquisadores e assistentes de curadoria da $X$ Bienal de Arquitetura pesquisa mencionada e realizada no

Trabalho de Conclusão da Graduação, mas agora dando enfocando o estudo principalmente nas cidades médias ${ }^{2}$ do

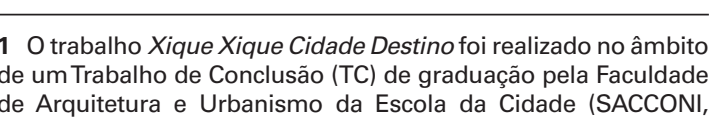

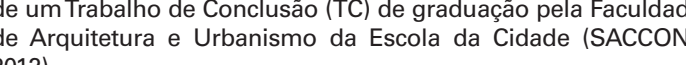

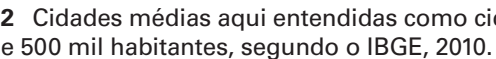

\section{contexto e justificativas}

início da década de 2000 foi um polítca econômica uma conduçáo da mo uma de suas propostas de gestão expansão do mercado interno, via corporação de parcelas maiores da opulação ao mercado de consumo. No mbito das politicas socioeconômicas, friges à programas dirigidos à populaçâa ransferência de renda e um conjunto de políticas sociais destinadas a aumentar inserção de parcelas da população à agenda federal de políticas públicas. Cabe também destacar a retomada dos investimentos públicos e privados, por de Aceleracão do Crescime trograma O Programa de Aceleraçăóo do Crescimento, criado em 2007

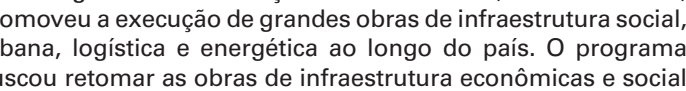

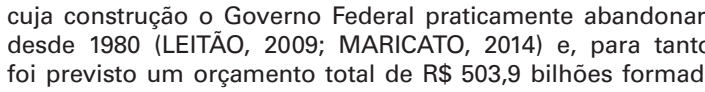


e o Minha Casa, Minha Vida (MCMV), ${ }^{4}$ semiárido, ${ }^{6}$ que tem especial interesse além do fomento a outros setores para a presente pesquisa.

econômicos especificos, por exemplo
o automobilístico, a construção naval, Por outro lado, as obras de infraestrutura entre outros (ROLNIK \& KLINK, 2011, p. promovidas pelogovernofederal naquele do governo federal brasileiro no espaço uma carteira de obras promovida pelo regional a partir de 2003, e no caso Programa de Aceleração do Crescimento mais específico do Nordeste, deu sinais (PAC), de maneira pouco ou nada de mudanças e, ao mesmo tempo, de articuladas com os planos e políticas permanências, que seráo pano de fundo de desenvolvimento regional (LEITÃO para o tema aqui tratado. 2009, pp. 220, 224), que permaneceran Tratou-se de um período que assistiu a do que form de fato exo discurso gestões consecutivas (dois mandatos de promocão dessas grandes obras. A Luiz Inácio Lula da Silva e dois de Dilma infraestrutura ocorreu em diversos Rousseff, o último deles interrompido) 5 locais do país, gerando impactos que promoveram políticas federais em econômicos, urbanos, ambientais e diferentes âmbitos. Políticas de combate à sociais nas regiôes brasileiras onde as pobreza (como por exemplo, o programa obras em questão foram executadas. Bolsa Familia); elaboraçăo de planos Dessas obras, a Transposição do rio São de Desenvolvimento Regional (PNDR): a se chamar Projeto de Integraçaso do destinacão de subsídios massivos para a Rio São Francisco (PISF), é o tema da construção de habitação social através do presente dissertaçâo.

MCMV; desenvolvimento de programas

para acesso a infraestruturas básicas O PISF, um projeto cujo ideário veio como os programas Luz para Todos, Agua sendo construido desde o século XIX para Todos, Um Min há de Cisternas, além anunciando um projeto que solucionaria da expansáo dos polos universitários a questão da seca do semiárido ganhou, tiveram relacão direta com a alteracão Lula, uma conotação mais forte de um no Índice de Desenvolvimento Humano projeto voltado ao desenvolvimento (IDH), do Produto Interno Bruto (PIB) per social e à integração regional. Muito capita, incluindo aumento da renda, maior embora isso tenha sido reapresentado acesso a universidades, à moradia e a bens e reforçado na gestão de Lula (2003 de consumo (ARAUS, a 2016 ). Năo sem 201 ), tanto a idela do desenvolvimento contradiçoes, fala-se em programas que a partir de eixos quanto a concepção históricas de regiões de pouco dinamismo naquele momento já haviam sido econômico, tais como a sub-região do apresentados em gestões anteriores do governo federal, em especial na gestão de Fernando Henrique Cardoso (FHC -

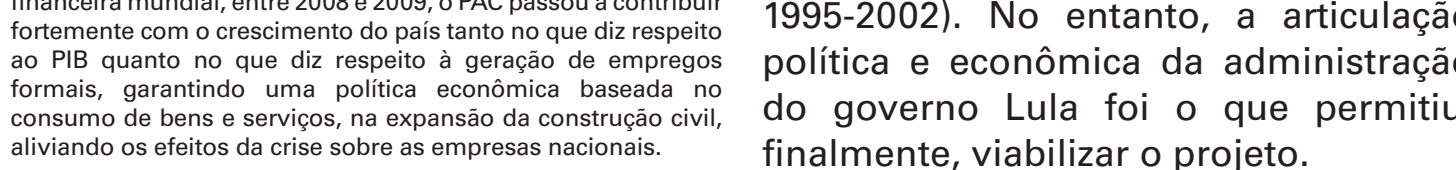

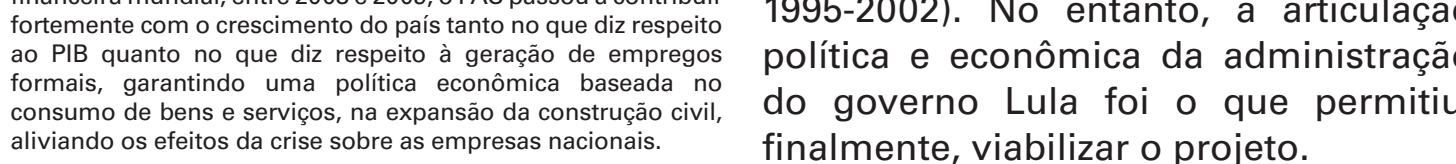

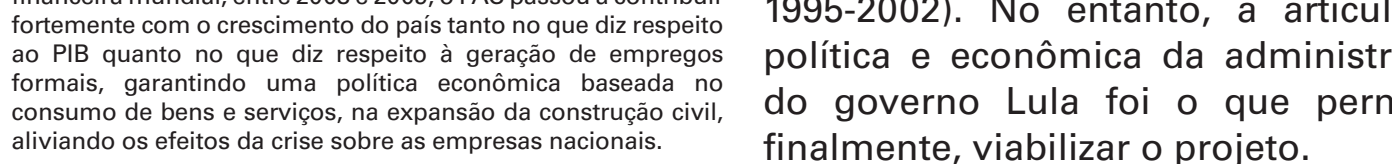

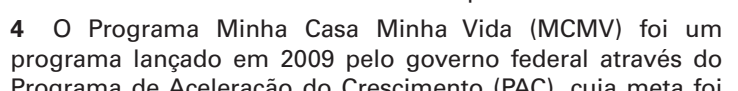

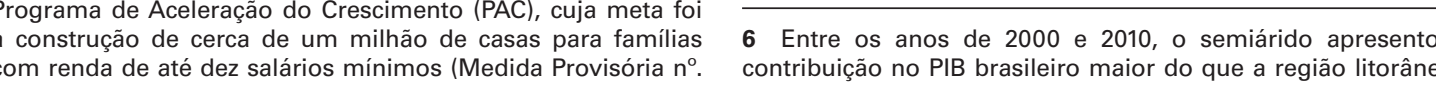
5 Intererompido num contexto politico muito controverso de

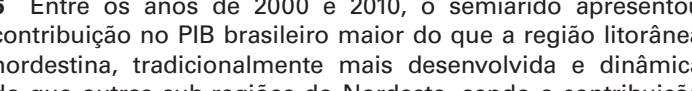

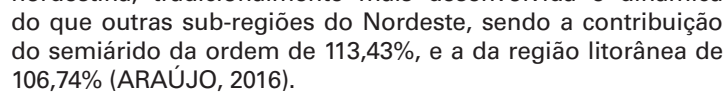

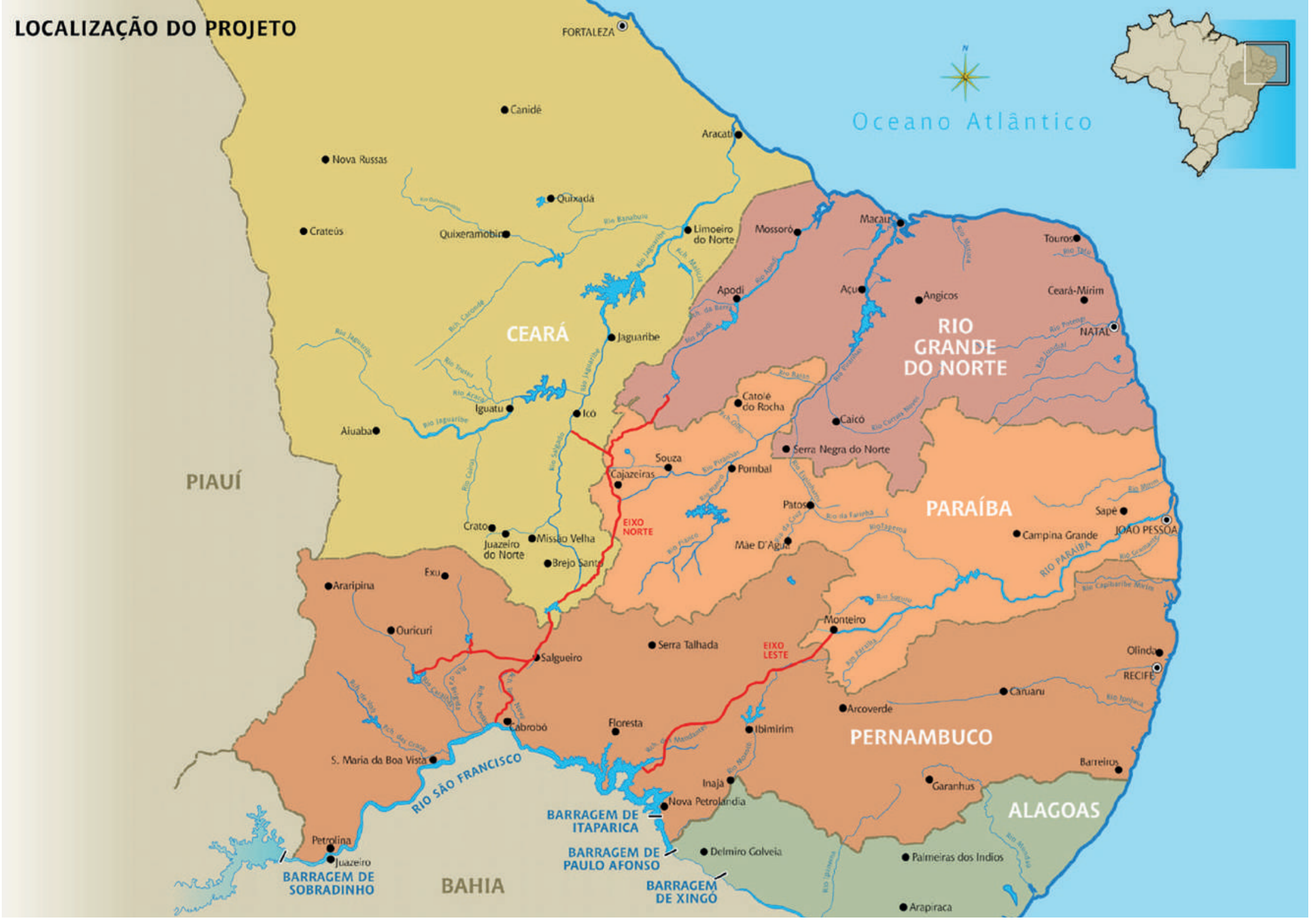

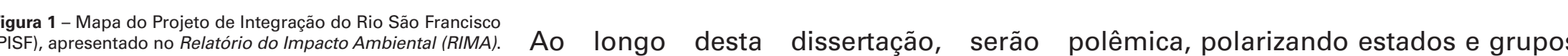

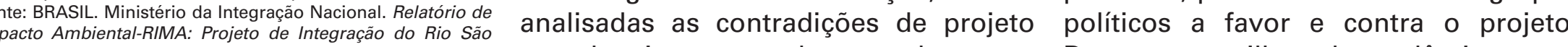

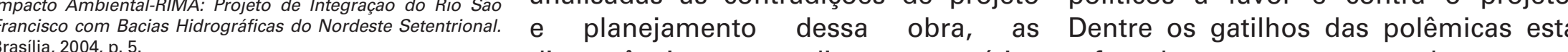
discrepancias entre o discurso, a prática o fato de que, por se tratar de um canal região e nos territórios por onde passou. clima semiárido, o índice de evaporação O PISF, que atualmente está em grande da água dentro do canal poderia ser parte executado, previu para o desvio muito alto (AMORIM, 1998). Além disso, das águas do rio São Francisco $700 \mathrm{~km}$ a Transposição permitiria a criação de de canais de concreto em dois grandes perimetros irrigados para plantaçôes, Eixos (Norte e Leste) ao longo do como ocorre em Petrolina e Juazeiro, territorio dos estados de Pernambuco, proposta que encontra resistência po conforme a Figura 1 demonstra, que defendem que a irrigacão pode com investimento de R\$10,7 bilhões gerar a salinizacăo do solo do Semiárido estimado até sua conclusão (BRASIL, (MARINHO, 2006, p. 72; SOUSA, 2010, 2018b). Sua proposta e a de levar água $\quad$ p. 8). O traçado dos Eixos Norte para abastecimento das áreas, em Leste também foi motivo de muita especial urbanas e metropoltanas, do discordância, pois há quem compreenda semiarido, segundo discurso oficial, que o canal pois há que najortariamente doze milhões de habitantes de trezentos os pequenos agricultores (HENKES, eno municípios (BRASIL, 2004 p. 2008, p. 310), como é declarado no 9), numa estimativa que será discutida Estudo de Impacto Ambiental e Relatório ao longo do trabalho.

(EIA-RIMA) do PISF (BRASIL, 2004, p. 50). O impacto Tratou-se de um projeto histórico que, ambiental e social que a obra promoveu, em especial a partir da década de 90, alèm de seu alto custo e erros técnicos a a implantação das leis ambientais também foram pauta de críticas que também não sem contradições, (HENKES, 2008, p. 214). permitiram um maior debate questionamento sobre a ação do estado Porem, para além de uma discussão no território nacional), foi objeto de muita contra ou a favor a obra, uma vez 
que esta já se encontra praticamente Do processo de trabalho e dos inteiramente construída, a crítica sobre

a Transposiçao que suscitou interesse

para a presente pesquisa tem relação Dessa forma, avaliou-se nessa pesquisa do programa de pós-graduacão do seu processo de planejamento e de Faculdade de Arquitetura e Urbanismo se tornou o de analisar criticamente sua obra, investigando como ela se da Universidade de São Paulo. Como o processo de planejamento e a obra relacionou com as estruturas sociais e dito anteriormente, o trabalho parte executada, buscando compreender a ambientais do semiárido, investigando de um conhecimento prévio da região relação dessa alternativa ao contexto sua presença-ausência no território, Conforme se verá a seguir, a pesquisa oficiais, tais como os Estudos de Insercão as transformações socioespaciais Regional (BRASIL, 2000a) e os Estudos e Impacto Ambiental (BRASIL, 2004), transposição do Rio São Francisco. No incluindo seus desdobramentos nos início do processo de pesquisa, essa
Programas Básicos Ambientais (PBA). $O$ análise seria feita em duas escalas, uma estudo também se apoiou na realização entrevistas com distintos atores sociais envolvidos com o tema, na tabulação cartografia que auxiliou na elucidaça analítica dos argumentos elaborados.

primeira regional envolvendo todos os municípios por onde a obra passou, (AID) pela obra no EIA-RIMA: Direta segunda escala de estudo, observando partir de dois estudos de caso, as cidades de Salgueiro (PE) e Monteiro (PB).

Porém, com um segundo trabalho de campo, realizado previamente a banca $\mathrm{O}$ trabalho de campo foi realizado em de qualificação (no primeiro ano do setembro de 2017 e foram visitados os corstaduaçao) e viabilizado estados da Paraiba, Pernambuco e Ceará. obteve-se maior clareza de que as a viagem durou nove dias, contou com duas cidades náo dariam conta da concedeu equipe e automóvel para complexidade de questóes da obra e acompanhamento dos deslocamentos; planificacãa mais aderente ao território Grande (UFCG), que fez uma carta-convite regional. Dessa forma, a análise das à equipe da pesquisa, havendo uma transformações do PISF nos perímetros recepção de alguns professores da UFCG urbanos do semiárido, exemplificadas por no campus da universidade; da Aldeia dois municipios como estudos de caso, Indigena Truka, que hospedou a equipe começou a deixar de ser un objetivo. por dois dias em Cabrobó; além de todos $\mathrm{Na}$ banca de qualificação, realizada para as conversas e fornecimento de em abril de 2018, os professores informaçōes. Foram entrevistados convidados, a Profa. Dra. Regina Lins entidades governamentais em instância (UFAL) e o Prof. Dr. Francisco Sarmento federal, estadual, municipal; populaçăo (UFPB), reforçaram essa intenção atingida; população beneficiada que se iniciou no trabalho de campo, especialistas em recursos hídricos que jă trabalharam no projeto de Transposição e e mobilização social no Projeto de recursos hidricos e servidor público do especialistas de recursos hidricos que são Transposiçąo do rio Sáo Francisco, de Ministerio da Integraçáo Nacional (MI), ja professores de indústrias locais, comerciantes e cantisar o contio en tomo do Projeto Desenvolvimento Regional do Ministério prestadores de serviço. Ao todo, foram de Transposiçăo das águas do Rio São da Integração Nacional. Atualmente (2015campo, pesquisadores, administradores públicos discursos, práticas e grupos de interesses acompanhou o projeto desde o início de estaduais de presidentes de companhias envolvidos. Esse trabalho possur um sú constuçao e pôde esclarecer uma do Ministério da Integração Nacional etc.), por Barros em suas experiências obra, além de questoes técnicas do projeto populaçãoatingidapelaobraeengenheiros profissionais na região, de modo que a envolvidos com o projeto. Além disso, autora pôde comparar os discursos que ao campo, foram realizadas outras onze mobilizadoras acionadas na tomada entrevistas, totalizando um número de de posições e na construção de aç̃os fo trinta e duas entrevistas ao longo de coletivas contestatórias. a empresa Engecorps, empresa que for ainda é constantemente contratad pelo Ministério da Integração Regional
(MI) para a realização de estudos e todo o trabaho, que contribuiram năo a segundo destaque será dado ao dos também para as analises da pesquisa. Professor Francisco Jácome Sarmento, Dessa forma, as fontes desta dissertação engenheiro que, dentro do governo provêm majoritariamente de informaçāo federal, nas gestōes de Fernando uma entrevista com a mesma pesco ao dz longo dos dois anos da pesquisa. da Silva, participou da elaboração de estudos, planos, além da definição de algumas características do projeto final Foram também sistematizados materiais de transposição. A partir da primeira de fontes diretas, tais como os inúmeros entrevista com o Prof. Sarmento,
documentos oficiais de gestóes distintas realizada durante o trabalho de campo, $\begin{array}{ll}\text { documentos oficiais de gestoes distintas } & \text { realizada durante o trabalho de campo, } \\ \text { do governo federal que compuseram o } & \text { o profissional se tornou um especialista }\end{array}$ do governo federal que compuseram o o profissional se tornou um especialista
planejamento da obra, estudos e pareceres sempre consultado ao longo da pesquisa. ambientais oficiais entrevistas com Sarmento foi membro participante planejadores do projeto (que estão ou da banca de qualificação da presente estiveram no governo, ou foram emalgum pesquisa e suas publicaçōes sobre momento participantes terceirizados) e a obra, em especial seus dois livros, entrevistas com populaçoes beneficiadas Transposição do Rio Sao Francisco ou impactadas pela obra. Também foram Realidade e obra a construir, publicado
sistematizados materiais de fontes em 2005, e Transposiçâo do rio São indiretas, tais como teses e dissertaçōes Francisco-Os bastidores da maior obra acerca da Transposição do rio São Francisco hídrica da América Latina, publicado $\begin{array}{ll}\text { e entrevistas com outros pesquisadores em 2018, foram fontes de extrema } \\ \text { sobre o assunto e reportagens/notícias. } & \text { importância na estruturação do trabalho. }\end{array}$ sobre o assunto e reportagens/notícias.

Ainda em relação às fontes da Outros dois entrevistados que tiveram pesquisa, faz-se necessário destacar muita importância para a compreensão do
especificamente alguns trabalhos e planejamento e elaboracãa do projeto do especificamente alguns trabalhos e planejamento e elaboração do projeto do
entrevistas/entrevistados que foram de PISFforamoengenheiro Irani Braga Ramos extrema importância para a concepção e o arquiteto Andrei Almeida. O primeiro, da estrutura e desenvolvimento do consultado diversas vezes ao longo dos presente trabalho. $\mathrm{O}$ primeiro deles foi a dois anos de pesquisa, é especialista em dissertação intitulada Odesencantamento Entevista realizada no dia 11 de setembro de 2017 en

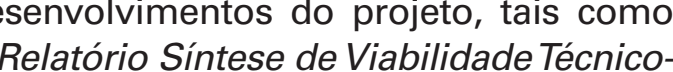
Conômica e Ambiental (BRASIL, 2000b) projeto básico do Trecho I, que serviu dos os ouros desenvolvimento Relatorio Final dos Projetos Executivos do A (BRASIL, 2012). Suas entrevistas

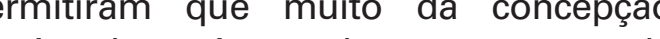

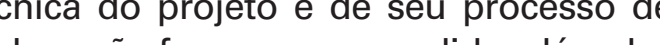
.

relação aos materiais produzidos na esquisa, destacam-se as cartografia

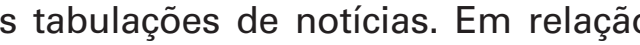
te noticias, elas foram 2017 e 2019, com tudo o que era clissificou-se as notícias, portítulo, fonte k, resumo, observações específicas, se a imagens para compor um banco a notícia havia alguma de com algum item, capitulo ou . . relaçáo à produção de cartografias omentos, visavam ilustrar o que porvezes 
não se encontrou em documentos oficiais, $\mathbf{O}$ objetivo e o recorte da tais como as cartografias do historico pesquisa

de propostas da obra, apresentadas

no capítulo 1 , realizadas a partir de Conforme dito no item anterior, o objetivo documentos históricos (encontrados no da pesquisa foi o de analisar criticamente ou notícias antigas), também a partir de executada, permitindo reflexóes sobre do governo Lula (abarcando os governos informações encontradas em reportagens a acão do Estado perante a prática do do Dilma Rousseff e de Michel Temer), do ou trabalhos de outros pesquisadores. Já desenvolvimento regional a partir deste ano de 2003 até o presente momento da outras cartografias foram produzidas para estudo de caso.A partirdessa análise crítica conclusão desta dissertação, em 2019. elucidar as distintas classificações das do planejamento, do projeto e da obra, No entanto, a cada debate levantado regioes mais secas do semiärido, utilizadas objetivou-se tambemm ilustrar a presença- nos capitulos, quando necessário, fez-se conforme a necessidade para se leghtimar ausência da obra nos territorios por onde digressóes temporais para a discussão as discursos nos planos oficiais, como passou, de maneira a compreender a do tema. Por exemplo, no capitulo capítulo 2). Outras, ainda, para localizar socioespacial regional. O recorte espacial período imperial brasileiro. Já no capítulo no territorio a presença-ausencia da obra foi organizado em função dos eixos 2, recorreu-se aos documentos do projeto (Figura 127, do capítulo 3), ilustrando a de desenvolvimento da obra, para a às leis ambientais dos anos 90 . Ao mesmo complexidade de questoes levantadas compreensão do que significaria essa tempo, trata-se de uma pesquisa que marca em campo a partir dessa intervenção. infraestrutura pensada em eixos incidindo uma trajetoria da obra até o ano de 2019, Além disso, utilizou-se muitas cartografias no território, diferentes áreas que cada ou seja, uma dissertação feita sobre uma desenhos técnicos retirados dos transformaçăo e impacto iráabranger. obra em construçao, que a todo momento tornar mais clara a compreensão do que consistia essa obra do PISF.
Por se tratar de um projeto bastante Transposição do rio São Francisco troux a a necessidade de ser compreendida de forma interdisciplinar. Note-se
que ela está calcada em um vasto que ela está calcada em um vasto tanto em relação ao seu planejamento, quanto referentes a sua viabilizaçãa e execução. Nesta pesquisa, optou-
se por traçar um panorama geral da Transposição, apresentando essa complexidade e trazendo um olhar global à interdisciplinaridade das questōes temas que o projeto poderia abarcar (cada mais desenvolvido em outras pesquisas).

Também se fez o esforço de reunir cada questão abordada sobre o PISF no campo da arquitetura e do urbanismo. que como disciplina possui a função de pensar o social, o ambiental e a infraestrutura de modo integrado, Portanto, entendeu-se que esse esforço, o de reunir as questōes trazendo um olhar global à Transposição, seria poder contribuir com o entendimento do

\section{Dos conceitos utilizados}

Nesta dissertação, fez-se o uso de termos e conceitos muito debatidos e por vezes disputados, dentro dos
campos da arquitetura, da geografia e da economia. Não foi o propósito deste trabalho se aprofundar nestes debates, muito menos se aprofundar na polêmica discussão sobre as diferentes formas de se usar os termos técnicos e teóricos (tais como espaço, território,
região, desenvolvimento, planejamento regiáo, desenvolvimento, planejamento disciplin, impacto) nesses campos a definições desses conceitos embasadas em autores que se debruçaram sobre esses debates e que adotaram caminhos que pareceram convenientes
propósitos desta investigação.

Para o conceito de "território", propõePara o conceito de "territorio", propoe-
se uma aproximaçăo à abordagem que Rogério Haesbaert traz em sua obra desde os anos de 1990. Para o autor, o conceito nasce com uma dupla conotaçao, material e simbolica, referentes a uma relação entre espaço
e poder, seja ela a partir da dominação e poder, seja ela a partir da dominação
(poder político) ou da apropriação (poder político) ou da apropriaçáo, (HAESBAERT, 2007, pp. 20-21). No artigo escrito por Haesbaert em conjunto com Limonad (2007), os autores definem três abordagens básicas para o conceito de território, que parecem coerentes com o
presente trabalho. São elas: a jurídicopolítica, em que se exerce um poder de e dominação de um espaço; a centido da apropriação do aves do imaginario e/ou esistência ou consequência do processo de fragmentação global) a tendência
da homogeneizacăo promovida pela da homogeneizaçao promovida pela 2007, p. 41); e a economicista, em que a "(des)territorialização é vista como produto espacial do embate entre classes sociais e da relação capital-trabalho
(HAESBAERT \& LIMONAD, 2007, p. 45).
Embora se compreenda que para muitos "tradicional" de regiáo, privilegiou-se (t) a (a) forma distinta, da reproduçáo do capital, nas formas ce espritório 作 a ropriação concreta ou simbólica, no da luta de classes e do conflito social em pesente trabalho, a leitura que se fará escala mais geral (OLIVEIRA, 1981, p. 71): tem abrade Raffesticica que ele opera sobre 1986) a partir da obra A pledefebvre , Heeshert (1997, 2004) buscou a territorializacão um sentido de dominaçáo e apropriação do espaço enquanto relaçấo de dominaçáa e apropriaçáo sociedadeespaço que se descobra ao longo de um conômica mis co dominaçao poltticopropriacão mais subjetiva e/ou culturatmbólica" (HAESBAERT, 2004). Ao fim ao cabo, nesta pesquisa, os conceitos espaço, território e territorialização polomicas distinçôes conceituais campo da geografia.

No que toca ao conceito de "região" ora se recorreu ao termo em referência as delimitações geopolíticas oficiais Norte, Sul, Sudeste e Centro-Oeste); naturais, ou seja, um espaço definido por suas características ambientais, semiárido nordestino dentro do clima naturais da caatinga, agreste, carrasco, serido, cariris-velhos, curimataú, serras
sertáo (MARIN, SANTOS, 2013). Essas delimitaçōes que trazem consigo a forma trataram as homogeneizações espaciais se usar, por vezes, o conceito mais
Desse ponto de vista, podem e existem "regiōes" em determinado espaço
nacional, tanto mais determinadas quanto sejam difererfeiados os processos assinalados, e, no limite, num sistema econômico de base da reprodução do capital e de suas concentração e centralização que acabaria por fazer desaparecer as investigação (OLIVEIRA, 1981, p. 27).

Já para a noção de "planejamento prionau, compreendeu-se como a ação plaja do Estado sobre o espaço noção de "desenvolvimento regional " respeito às práticas, ações e políticas do Estado para impulsionar melhorias conômicas e sociais nas regioes, que buscam diminuir as disparidades intergionais (CAMPOLINA, 2009, p. 230). Ao m diferentes regimes:Império peńblica democrática e ditadura Ou seja esse planejamento se deu de formas muito distintas ao longo desses dois séculos, imbolizando ações políticas ora mais centralizadoras, ora mais autoritarias, específicas. De todo mais globais mbora se retome o planejamento outros tempos para reconstituir historico do projeto da Transposição do São Francisco, o foco do trabalho incice sobre o periodo democrático mais recente, desde a década de 90, com mais noc̃o de "desenvolvimento rquanto eso 
ênfase a partir de 2003, enfatizando um relação à incidência territorial dessa obra foram relacionadas questões mais planejamento laborado por umgoverno de grande impacto nos assentamos subjetivas e imateriais que o proje

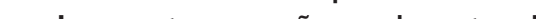

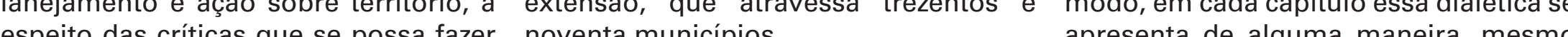
a ele. Para Lefebvre (1983, p. 100) a presenca- que não de forma explíita, mas tendo Para o conceito de "impacto ambiental", ausência é algo que pode estar entre de elaboração do projeto e execução da foi utilizado o termo utilizado nos o evidente e o oculto, o subjetivo e o obra refletiram no território, na prática processos de licenciamentos ambientais físico, o material e o imaterial e nas do planejamento, na ação do estado, nas no Brasil, definido pela primeira vez na diversas formas de compreensão ou transformaçōes físicas dos lugares. Resolução Conama em 1986 (BRASIL, representação do espaço. Representando 1986).9 Um impacto consiste em extremos, a presença e a ausência, qualquer alteraçao das propriedades ocorrem de maneira inseparável, ambiente, causada por qualquer forma possível conformar uma leitura sobre de matéria ou energia resultante das essa obra, que foi executada de maneira atividades humanas, afetadas direta tão contraditória naquela região. ou indiretamente (BRASIL, 1986).10 Entretando, também se adotou a Ao longo de todos os capítulos, essa crítica realizada a esse processo de presença-ausência em torno do projeto institucionalização do debate ambiental, do planejamento ou da obra, fo ACSELRAD (2010, p. 107), visto que o com relacão ao ideário que vai sendo icenciamento ambiental perdeu sua construído ao longo dos séculos, cheio função contestatária ao priorizar muitas de lacunas na compreensão daquele vezes os propósitos desenvolvimentistas território, na ação do Estado perante o dos empreendimentos, que almejam subdesenvolvimento, ou no constante a rentabilizaçáa de capilais em nome abandono do projeto a cada retomada, da geração de emprego e renda. Dessa questões que serão abordadas no passaram a ser, em grande parte processo de planejamento da obra, já dos casos, apenas mais uma etapa que conforme dito no parágrafo anterior, administrativa do empreendimento, o capítulo 2 vai evidenciar que o espaço sem entrar em questão, por exemplo, de diálogo e contestação do projeto a possibilidade de os estudos de promovido pelas leis ambientais não avaliação ambiental recomendarem a possibilitaram efetivamente um espaço

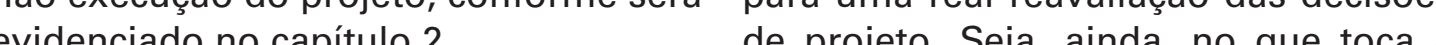
de projeto. Seja, ainda, no que toca à
execução da obra, tratada no capítulo Por fim, um recurso analítico 3, que por sua presença impactante, fundamental para o trabalho se deu a foi sentida de maneiras diversas: pela partir da abordagem ancorada no par proximidade ou pela distância dos dialético que sugere análises a partir da canais, pela água que chega ou que não presença-ausência em Lefebvre (1983), chega, pelas fortes transformaçöes ou que articulou todas as abordagens da permanencias que a obra gerou na vida

do rio São Francisco, em especial em

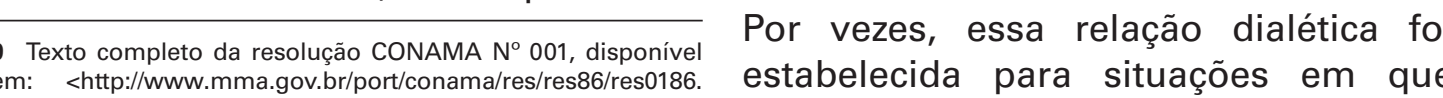
hitml s. Acessado em 21 dejulho de 20183.

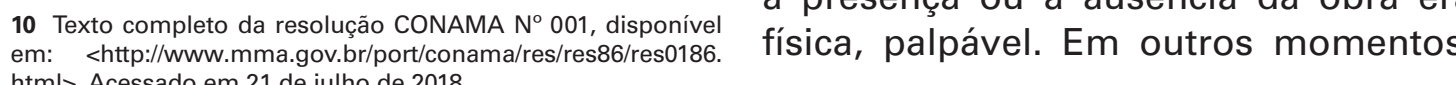

\section{Da organização dos capítulos} A dissertaçáo foi organizada em tres capítulos, além da introdução, dus dito anteriormente, além de a pescom cich e a obra da Transposição do rio São Erancisco, o que articulou as abordagens foi a dialética constante entre a presençaausência da obra no território, seja ainda
na fase de seu planejamento, a cada na fase de seu planejamento, a cada retomada do projeto, nos instrumentos
e documentos que a viabilizaram, seja já em sua ex que a viabilizaram, seja aderiu ao território.

No capítulo 1, foi realizado um levantamento da historiografia do projeto de transposição, abrangendo no século XIX, até a proposta atual, do nécuéculo XIX, ate a proposta atual, do a ser construído. Procurou-se analisar cartograficamente cada proposta ao
longo desses dois séculos, além de compreender o objetivo e o contex político em que cada uma surgiu. $O$ objetivo foi compreender em que
consistiu a construção da ideia de se
transpor o rio São Francisco, avaliando as diferenças e semelhanças entre propostas, os motivos de resgate e abandono do projeto e o que isso revelava da ação do Estado perante a seca e a pobreza na região, ou perante região semiárida.

que se viu foi uma repetida ação governo ao longo de séculos, resgatando o projeto de transposição na ocorrência de secas de longa duração e sempre o que preponderou na maioria das vezes que as grandes secas as mazelas acões emergenciais do Estado (ou das oligarquias nordestinas), que passavam por esvaziar o semiarido, estimulando a migração a outras regióes, ou mesmo empregando setanojos na construção ae obras hidricas emergenciais contra teoricamente garantindo maior acesso seca em troca de alimentação. Ou da população ao processo de elaboração eja, pouco ou nada se viu em termos do projeto por melo dos processos de 作 Unerabilidade do semiárido. A de proto se vi foram planos por vezes 作 abandono de sua viabilização, foi- ou construídos para contra-argumenta construindo um ideário de que as criticas socioambientais ao projeto Transposiçao seria a obra que de engenharia, sendo que, conforme solucionaria" os problemas da seca. abordado no capítulo 1, se pôde ver que haveria contradiçôes entre seus primeiro capítulo vão não garantindo uma dos canais, Pontradições do participação da população para o debate projeto ao longo de suas versões, de suas soluções.

o seu traçado que não muda, os a discussáo mais transformou o debate em torno do projeto

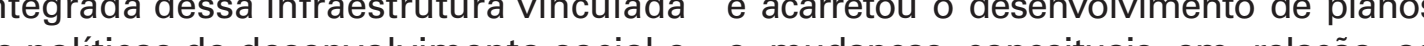
as re derma retórica, ou para construir phanos, por mais que fossem elaborados os argumentos a favor de sua execucão) por equipes muito competentes (composta capitulo 2, portanto, tratará da análise da elaboração dos documentos que nvolvidos com o projeto), teriam e diagnósticos em relação às realidades
ocais e diversidades territoriais, talvez em que as leis ambientais começam a por uma limitação do instrumento ser empregadas e em que, pela primeira ambiental em efetivamente possibilitar 0 vez, o projeto começa a ser questionado questionamento em relação à matriz do gerar. Nesse sentido, diversos estudos políticos e sociais em torno do projeto. obra, justamentenordos para justificar partir da obra começa a ser constrúdo.

Dessa forma, no capítulo 3, tratou-se de obra e explorar analiticamente como as contradições do planejamento viabilização da obra foram se revelando 2, a existência dos instrumentos em campo. O primeiro item (3.1) do ambientais, por um lado, garantiu maior capítulo 3 elabora um panorama discussão de direitos e impactos, que viabilizou financeiramente essa 1 A questáo do desenvolvimento economico e o combate grande obra, o Programa de Aceleraçãa

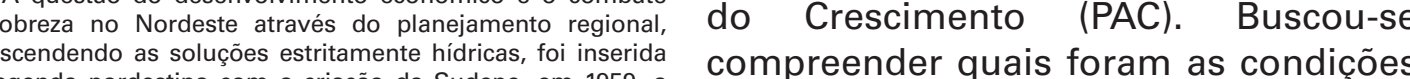

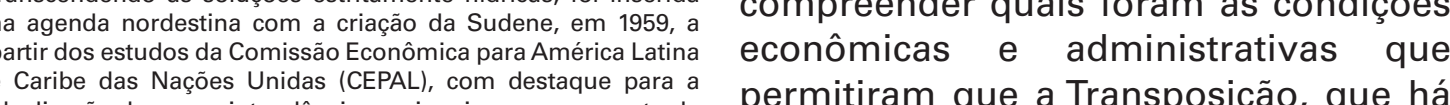

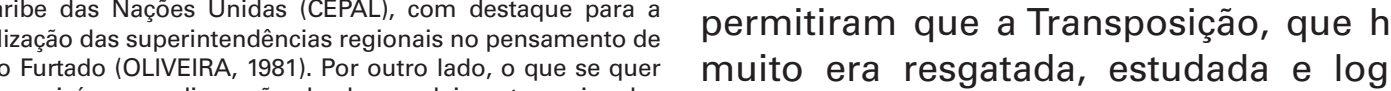

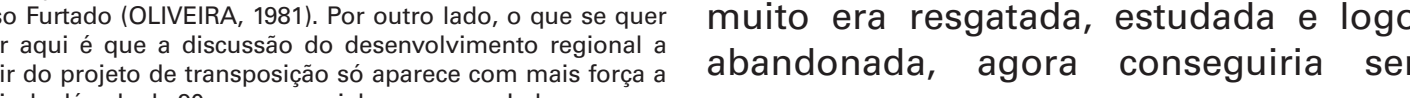


executada. Muito embora tenha havido um grande esforço administrativo para que empreendimentos como esse fossem construídos, a viabilização da obra através do PAC comporia as contradições da execução da Transposição do rio São Francisco, reveladas muitas vezes em notícias de jornal, reforçando a presença-ausência da obra em campo.

Em um segundo momento, no item 3.2.1, houve o esforço de revelar com mais clareza o projeto dos canais, destrinchando-os pelos elementos construtivos que compõem seu funcionamento, explicando-os tecnicamente. Além disso, houve o esforço de ilustrar como cada detalhe técnico foi construído, sua dimensão na realidade, sua presença no território, dado que a partir do projeto e das representações gráficas disponíveis seria difícil de se compreender a obra em seu funcionamento e em o que significaria seu impacto no território. As fotos de campo foram apresentadas aqui para auxiliar na compreensão do porte dessa obra de grande impacto, que transforma em diversas esferas (presença-ausência) os locais por onde passa, abordagem que será tratada no item seguinte.

No item 3.2.2, apresentaram-se exemplos de locais específicos ou de situações-tipo ao longo dos Eixos, que revelam essa dialética entre a presençaausência. Esse item foi essencialmente elaborado a partir do material levantado no trabalho de campo realizado em 2017, em comparação com os planos oficiais e notícias de jornal. A partir desse processo de investigação, foi possível compreender a complexidade dessa obra, suas contradições em campo e a diversidade de questões (tipos de assentamentos, culturas, contextos etc.) encontradas em um mesmo semiárido.

Dado que o capítulo 3 possui abordagens bastantes diversas em relação à viabilização e execução da obra, o item
3.3 buscou fazer uma leitura final do capítulo, reiterando as relações entre as questões abordadas.

Por fim, nas considerações finais, buscou-se retomar os principais pontos elucidados na pesquisa ao longo dos três capítulos, os complementando com as principais discussões que surgiram ao longo da pesquisa. Assim, realizou-se reflexões sobre como o PISF incidiu sobre o território, identificando sua presença em cada lugar bem as ausências que causou nessas mesmas regiões, analisando criticamente o processo de planejamento e a obra executada, permitindo reflexões sobre a ação do Estado perante a prática do desenvolvimento regional a partir deste estudo de caso. 


\section{Historiografia do projeto \\ de Transposição do rio São \\ Francisco: ideário, contextos e interfaces da obra}

âmbito da construção dessa ideia de se transpor águas para o rio São Francisco visando o combate à seca, resgatase aqui desde a primeira proposta registrada, no século XIX, até a proposta atual, do século $\mathrm{XXI}$, quando o projeto começou a ser construído. Procurouse analisar cartograficamente cada proposta ao longo destes dois séculos, além de compreender o objetivo e contexto político em que cada uma surgiu.

A partir dessa historiografia, foi possível compreender contradições primárias deste projeto, como por exemplo as mudanças de objetivo ao longo das diferentes versões e a permanência do traçado, historiografia esta que irá ajudar a esclarecer amplamente sobre o projeto que se viabilizou.
Embora a seca esteja na agenda das ações governamentais desde os tempos do Império, a insistência em saná-la via obras hídricas de grande impacto permanece até os dias atuais, incluindo a execução recente da obra de transposição aqui mencionada. Muito embora já houvesse um pensamento crítico amplamente construído em relação a esse tipo de intervenção na região, a obra em questão encontrase parcialmente executada, com uma série de contradições entre os objetivos propostos no discurso técnico e político e a prática, perdendo seu caráter de obra para promover o desenvolvimento regional e se tornando mais uma grande obra hídrica, como veremos nos capítulos seguintes.

Para a compreensão do que se tratou no 


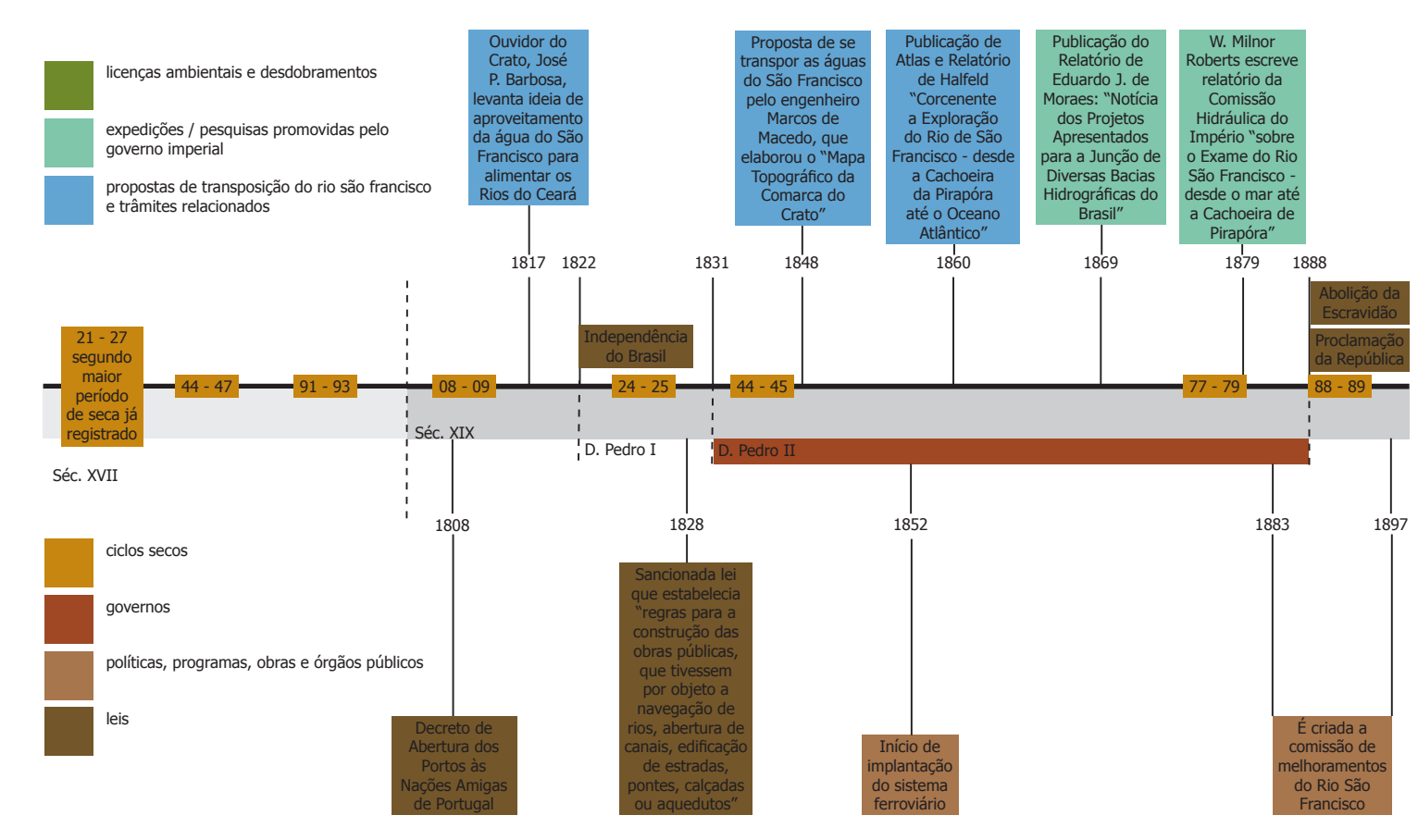

1.1
Notas introdutórias sobre o
sertão nordestino e a seca

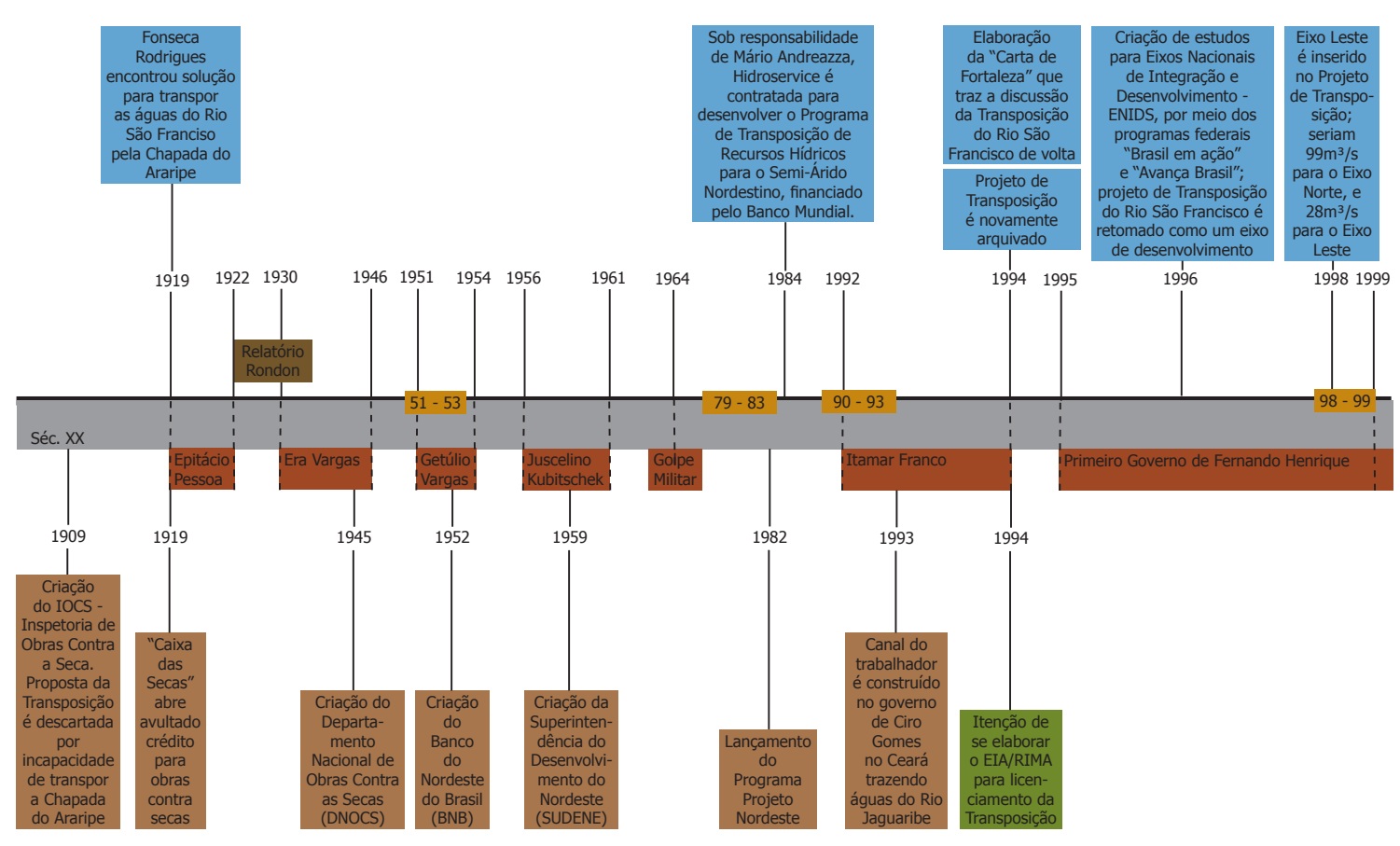

O Nordeste semiárido é um território que no século XX foram registrados 27 fisico, ecológico e antropogeográfico anos de seca, com a mais abrangente da ordem espacial de duas a tres vezes delas durando de 1979 a 1984. Foram a do estado de Săo Paulo. O nivel de registradas ainda secas intensas em interiorizaçáo do amblente sertanejo 1998,2001 e de 2012 a 2017 (ver Figura muitos casos, de 600 a $700 \mathrm{~km}$ ) desde Hídricos do Ceará, Francisco Teixeira os limites com a Zona da Mata até os (2018, informação verbal - cf. nota de sertões mais distantes, ou desde a praia até o chamado alto sertão ou, ainda, há uma média razoável, de $800 \mathrm{~mm} /$ desde o Rio Grande do Norte até o Sul- ano, porem as chuvas são irregulares, Sudeste do Piaui (AB'SABER, 1999, p. 14). abundantes em certos periodos Traduzindo em naBmeros o tamanho do inexistentes en outros, os periodos de total do Nordeste e, aproximadamente, oito meses. Nas palavras do Secretário: $40 \%$ de sua população. No semiérido, a precipitacão média anual é inferior a 800 mm (SUASSUNA, 2005). Dessa forma parte considerável da regiáo Nordeste brasileira convive historicamente com 0

A área de clima semiárido tem chuvas escassas e mal distribuídas ao longo do ano, concentradasno período defevereiro a maio. A precipitação média anual é de $600 \mathrm{~mm}$, e as taxas de evaporação dessa regiáo podem atingir valores superiores a $2000 \mathrm{~mm}$. A temperatura solos dessa regiâo são em geral rasos 作 agricultura irrigada também sejam da seca, mas a história revelou uma encontrados. A vegetação predominante repetida ação espasmódica contra os é a de Caatinga constituída por espécies seus impactos, baseada em reaçoes
lenhosas e espinhosas, cujas folhas pouco estruturadas e não continuadas lenhosas e espinhosas, cujas folhas

A convivência com a adversidade climática foi e ainda e uma das maiores preocupaçoes da população do semiárido nordestino. Grande parte da populaçáa depende da captaçáo e armazenamento dos rios e de chuvas é inerniente irregular e os solos costumam apresentar reduzida capacidade de retençáa de agua. Segundo a Embrapa, a estiagem costuma atingir de 18 a 20

A gente sabe que a gente vive com A chuva no primeiro meses que é para chover mais, e a certeza da seca no segundo e ermos de chuva é que dezembro, não chove. Então se voc náo acumular água nesse primeiro você não pode depender de chuva, porque ela não virá. 
que eram abandonadas com a volta do periodo chuvoso. Segundo Francisco de Oliveira (1985, pp. 54-55), a atuaçáo do $\mathrm{XX}$, inclusive reiterou o poder político das oligarquias nordestinas, uma vez que as barragens e poços não eram públicas, mas sim construídas em propriedades de grandes e médios fazendeiros. Atuava-se quando os magros recursos dos pequenos sitiantes haviam se esgotado à espera das chuvas nas grandes secas nordestinas, de maneira que essa populaçáo mais pobre para a construção das barragens feitas nas propriedades dos grandes fazendeiros $\mathrm{e}$ e No artigo "Sertões e sertanejos: uma interior dos grandes latifúndios geógrafia humana sofrida" (1999), O OLIVEIRA, 1985, p. 55), o que se chamo de frentes de trabalho.

Tal acumulação primitiva utilizava implantação de benfeitorias nas grandes propriedades, e sua
forma de financiamento chegou a forma de financiamento chegou a
constituir-se em outro pilar da força e do poder político dos «coronéis», da oligarquia algodoeira-pecuária.
(...) As "emergências" criaram outra forma de enriquecimento e de reforço da oligarauia: não apenas tinham prioridade para engajamento nas frentes de trabalho, como os pululavam. Obras-fantasmas
e trabalhadores, "cassacos" fantasmas, povoavam as frentes
de trabalho das secas. Não é ocasional que o controle político do
DNOCS tenha permanecido durante décadas nas mãos dos políticos particularmente os oligárquicos,
do Estado do Ceará, talvez entre OLIVEIRA 1985, p. 55) - oligárquico

Assim como as frentes de trabalho eram realizadas em momentos emergenciais
das grandes secas, o projeto que em grande medida foi conhecido por Transposição do rio São Francisco, teve sua primeira idealização no século XIX, mesma forma abandonado, sempre na seca, ao longo desses dois séculos.

utura hídrica,

$[\ldots]$ cujos supostos poderes
transformadores da realidade subjugam até o clima " "amansandado" de grandes dimensōes não são por si inadequadas ou validam porém requerem mutaraônico: quando os investimentos publicos excluem providências básicas em pesquisa e tecnologia e concentram da "virtualidade dos mitagres" (SARMENTO, 2005, p. 51).

artigo "Sertōes e sertanejos: uma de que, muito embora existisse havia muito tempo a noção e a discussão de que as propostas para amenizar as
implicaçóes das secas residiam ideias e projetos integrados, o que mais se viu foi a insistência em projetos infreja, para o engenheiro, investir em

infraestruturas hídricas no semiárido seria
aticulados com a tão importante quanto investir em políticas realidade sertaneja.

Projetos pontuais isolados ou regionais valem muito pouco
quando se tem uma ideia mais objetiva sobre a dimensão os atributos do espaço total do $\left(700 \mathrm{mil} \mathrm{km}^{2}\right)$. Antes mesmo de projetos tecnológicos, de altíssimo custo e demorada elaboração, agrupamento de acōes e por un que possam ter significância para o universo dos sertōes. Com toda certeza fica bem mais em conta, aplicar recursos em proposiçōes articuladas, do que em projetos faraônicos, sugeridos por políticos poderosos ao poder central. Em atrás - criticavam-se os grandes projetos de duvidosa validade social e econômica, tão perniciosos à economia e ao endividamento em pleno período de país. Agora tendem a recrudescer por razōes politicas e eleitoreiras, para alegria intersse de grandes empreiteiras

Ogeógrafo também desfez as costumeiras generalizaçōes sobre a região semiárida. Ab'Saber entendia que o conhecimento Ou seja, as providências a
séculos (salvo raras exceções, em das bases físicas e ecológicas do Sertão especial no século XXI), além de não não explicava por si so as razóes do serem continuas e náo enfrentaram grande drama dos grupos humanos que região (SAERMENTO, 2005, p. 51), condicionantes do meio naturalconstitúa hão trataram o fenômeno como uma um dado importante para explicar causas questáo socioeconômica mais global, básicas de una questão que se insere no mas sim como uma questão técnica, a cruzamento dos fatos físicos, ecológicos ser resolvida apenas com grandes obras e sociais.
Já para o engenheiro Francisco Sarmento $^{3}$ (2005, p. 9), embora no Nordeste haja barreiras sociais polticas, como a exclusão social, añônica a questão ḑẫo territoria cón desenvolvimento do Nordeste:

0 anacrônico modelo de ocupação territorial, a persistênncia en induzem à concentracăão de renda e à exclusão social perduram no semiárido brasileiro como públicas que quebrem políticas vicioso subdesenvolvimentista, concomitantemente se impố o SARMENTO, 2005, p. 123). elaçoes socioeconômicas que geram Como integra de renda e poder na regiáa. Como integrante da equipe técnica que Cardoso (1995-2033) quanto no govern de Luiz Inácio Lula da Silva (2003-2011) ele explica as questoes técnicas referentes ao projeto de transposição em sua última ma obra hidrica, mas como uma obra hídric $a^{4}$ para o desenvolvimento da regia seguir serão analisadas as versões do projeto, a construção dessa ideia de transposiçao, os diferentes objetivos que foram propostos ao longo de suas versoes a região en ada retomada do projeto.

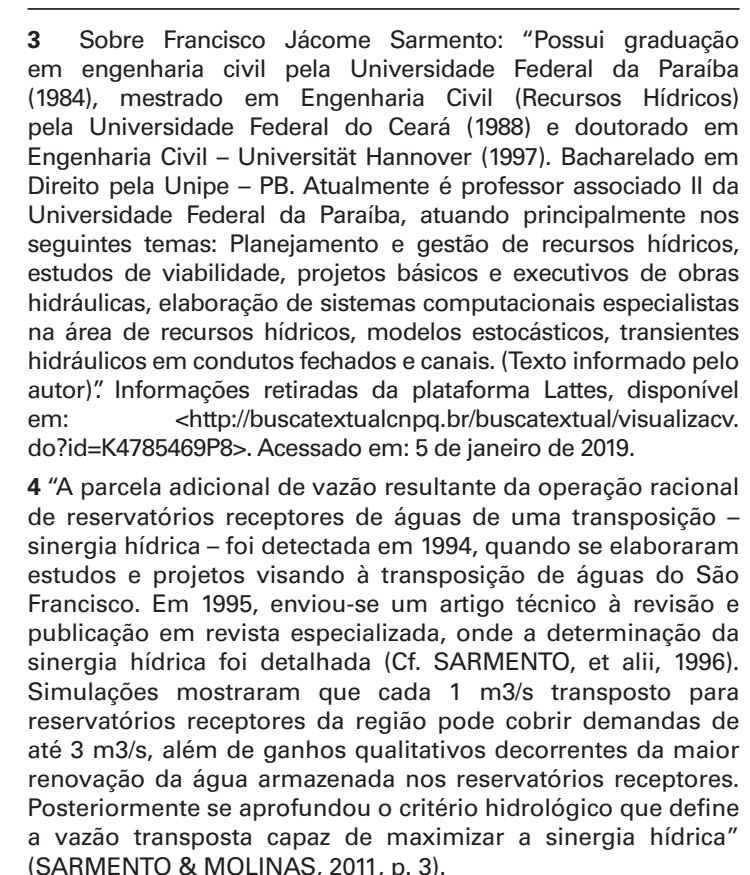
determinantes históricos. Assin tanto no governo de Fernando Henrique versao para justificà-lo, não apenas como setentrional nordestina. Diante disso,
A ideia da Transposição do rio São Francisco ao longo

da história brasileira

Para a compreensão deste projeto de quase dois seculos - suas mudanças ao longo do tempo, a implicaçáo de cada decisăo e a relaçáo com o momento político, tendo em vista as concepções tinha em cada versão-é preciso recorrer a referências bibliográficas de diversas natureza. Faz-se necessária a consulta a livros e artigos publicados, teses, páginas na internet de órgãos públicos, como o Departamento Nacional de Obras contra a Seca (DNOCS), ou privados, bem como entrevistas com especialistas e profissionais que atuam ou atuaram no projeto e conhecem parte de sua história. Nesse sentido, a presente pesquisa buscou sistematizar parte dessas perspectivas, que muitas vezes se apresentam de forma conflitante. sintese, que tentaram, em larga medida indicar aspectos centrais de cada um dos projetos e que serão apresentadas a seguir.

Além disso, buscou-se contextualizar o momento historico e político de cada cada versão e suas interfaces consistia De antemão, pode-seobservarquepouco do ideário inicial de projeto foi alterado ao longo dos anos. Ao final, propõe-se uma reflexăo sobre como a permanência desta ideia e da propria concepção de traçado estáo impregnadas na obra hoje 
1.2.1

A primeira ideia de transpor as águas do São Francisco.
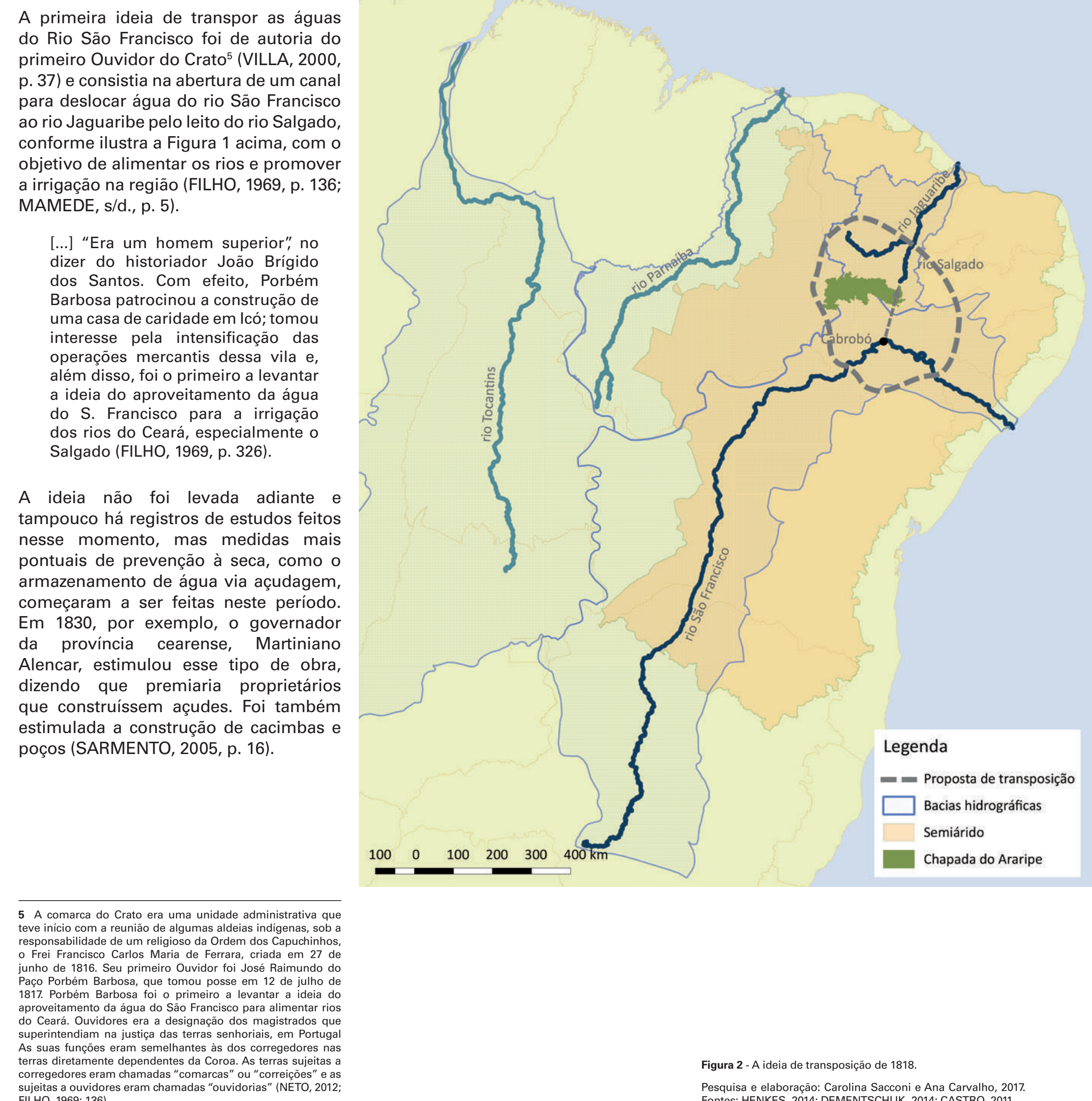
1.2 .2

Projetos no tempo de Dom

Pedro II

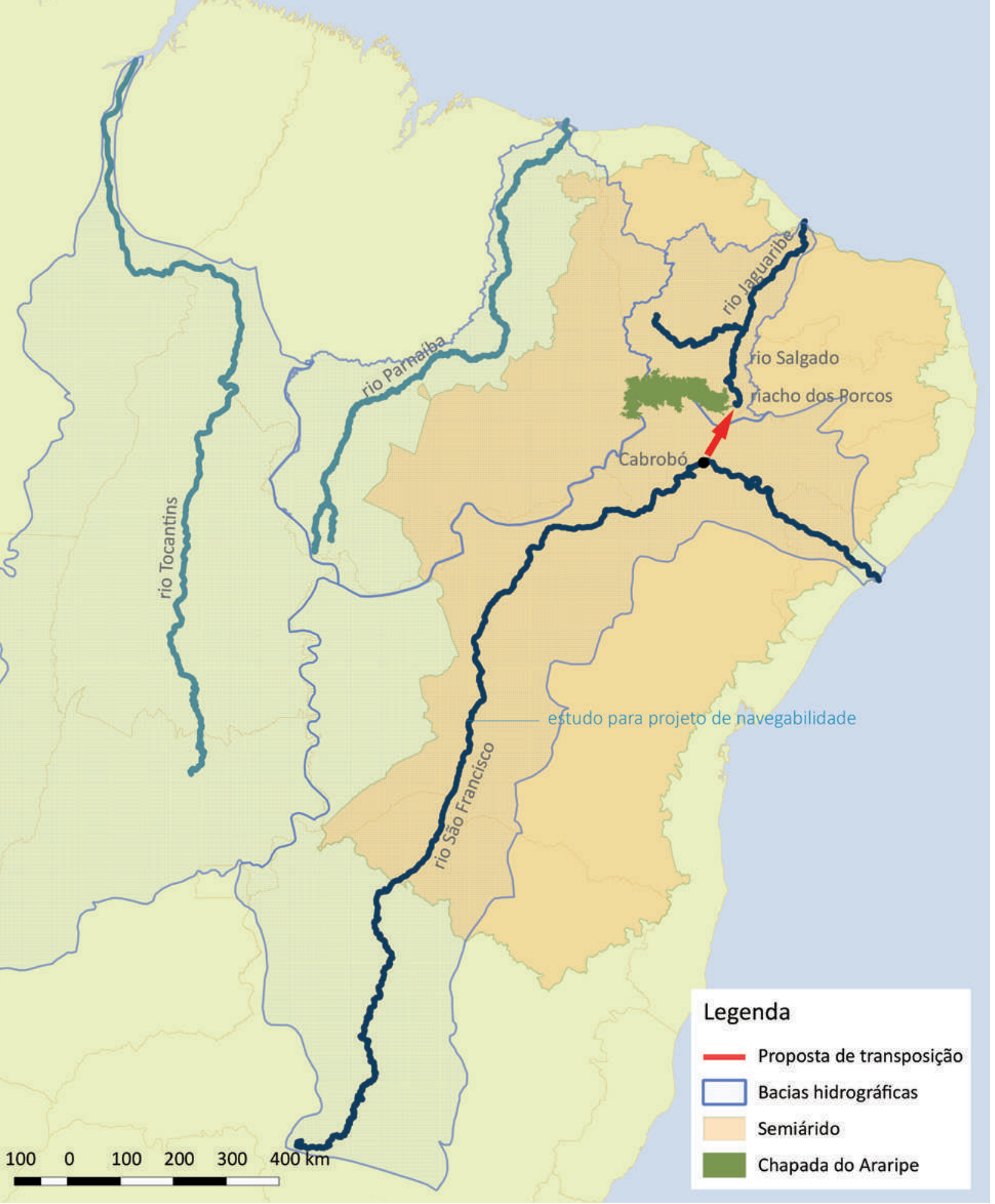

Figura 3 - A ideia de transposiçăo de 1847 .

Pesquisa e elaboracäa: Carolina Sacconie AAna Carvalho, 2017.
Fontes: HENKES, 201; DEMENTSHUK, 2014; CASTRO, 2011.
A segunda retomada da ideia de se transpor o rio Sao Francisco para Nordeste setentrional surgiu em 1847, quando o engenheiro cearense Marcos de Macedo, deputado pelo Estado ao imperador Dom Pedro proposito de amenizar os problemas gerados pela grande seca nordestina de 1845. Macedo elaborou em 1848 - "Mapa topográfico da comarca do Crato, provincia do Ceara" (ver Figura 4) indicando a possibilidade de um canal Vista, onde hoje se encontra o município de Cabrobó (PE), para comunicar com o rio Jaguaribe, através do riacho dos Porcos e do rio Salgado (ver Figura 3). Nada foi realizado, mas Cabrobó (PE) aparece pela primeira vez como ponto permanecendo em todas as versõs do projeto seguintes, incluindo a últim versão, que foi efetivamente construída (FIORAVANTI，2016，s/p; SARMENTO, 2005, p. 18).

A segunda metade do século XIX foi marcado por mudanças significativas negreiro (1850) a abolicão da do cravático (1888) e o início da implantação do sistema ferroviário (1852). Aliado às mudanças políticas e de infraestrutura houve a criaçăo de instifuiçós que, posteriormente se intransformaram

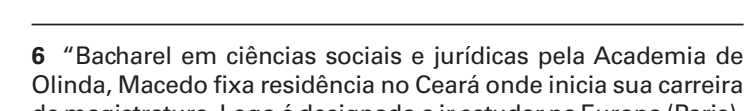

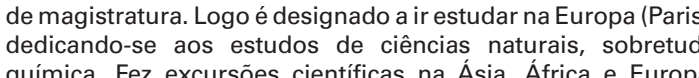

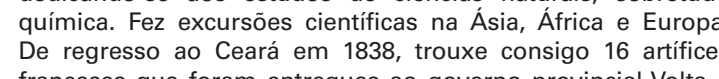

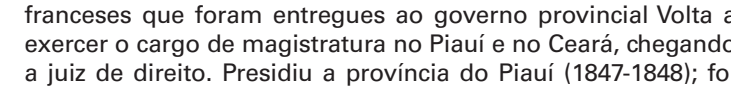
Em 1847 idealizou e eapresentou a Dom Pedro oll o projeto no Jaguaribe, assegurando a viabilildade do canal Embora nâo havia ainda estudos tecricos sobre sua execuugâo. Seus

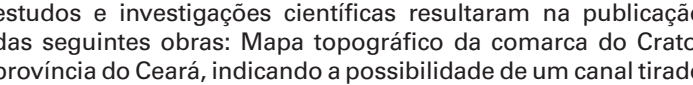

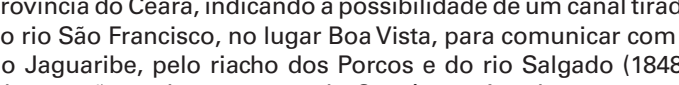

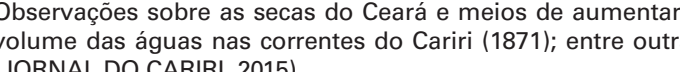

a contratação de engenheiros estrangeiros e nacionais, contribuindo de exploraçoes pelo pais e produça cartografias e propostas de intervercas em prol do progresso do país. Foram rroviárias, demarcadas fronteiras, feitos estudos e melhoramentos de portos e rios para navegaçao, que para

Como a preocupação com as transaçoes comerciais pelo interior Império a construcão dagenda do de ferro, melhoria no sistema de navegação, reaparelhamento de portos e outros melhoramentos eram melos de criar faclidades de com isso, intensificar as transacões comerciais. O rio São Francisco estaria num ponto privilegiado: a sua locallzaçáo pavorecia o escoamento para mar, e, uma vez melhorado o sistema fluvial, fomentaria as transaçōes comerciais do vale com
os principais centros (COSTA, 2013, os princip
p. 130).

A viabilidade da navegação fluvial ganhou grande destaque nos estudos encomendados pelo governo imperial
Dom Pedro II, com a preocupação de consa forma de trannere pejando sccomento das producões locais, seja como forma de desenvolver as regiōes, influenciou-se no desenvolvimento da engenharia europeia e norte-americana (DELIJAICOV, 2018, informação verbal), isso foram cahografados, com foi o caso

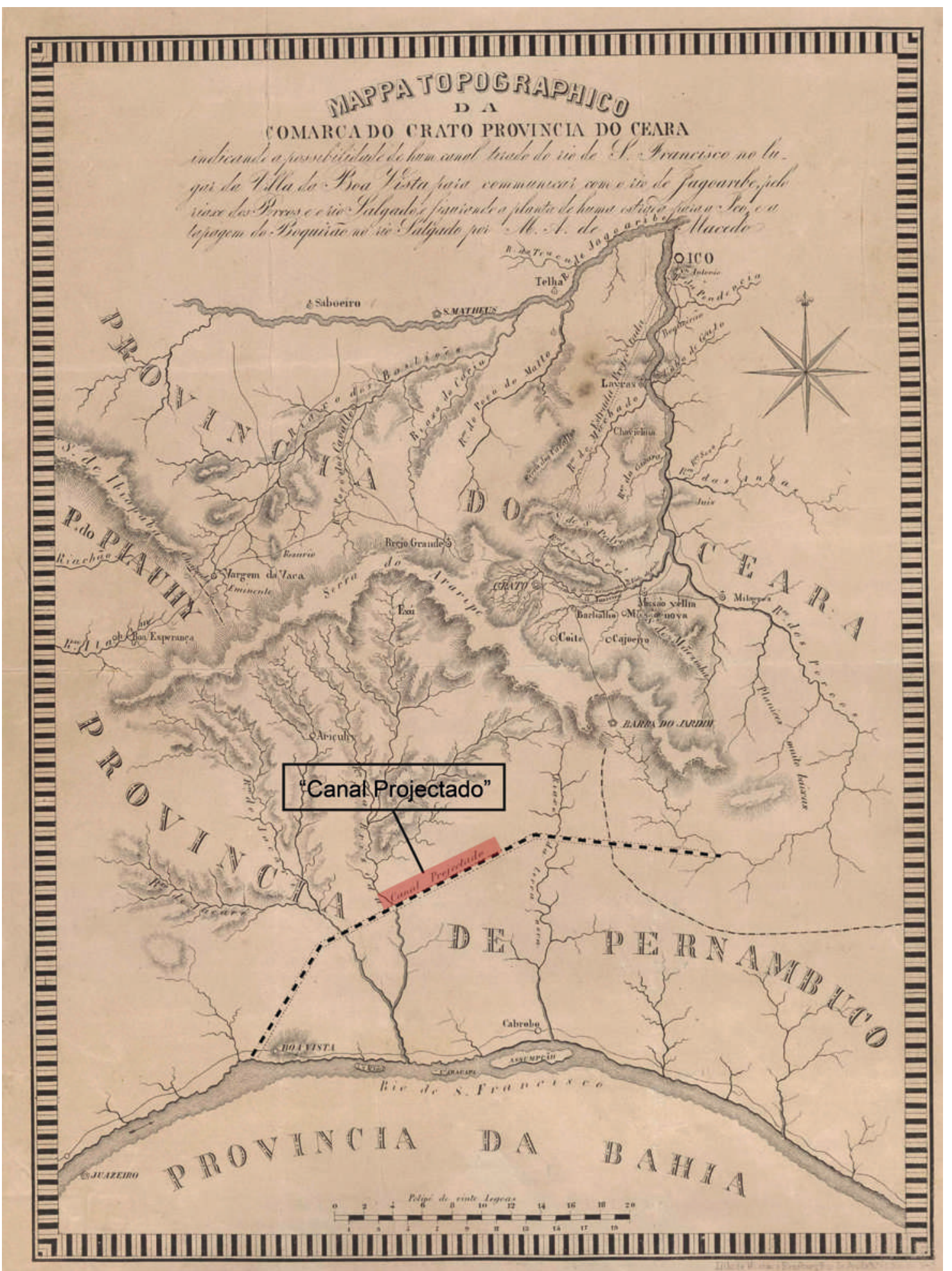

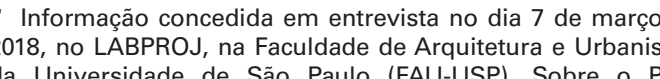
Alexandre Delijiaicov: "Aarquiteto eftetivo da Prefeititura de Sä de Arguitetura e Urbanismo da Universidade de Săo Paula Coordenador do grupo de pesquisa em projeteto de arautitel Equipamentos Públicos, do Laboratório de Projeto (LABPRO a FAU-USP. Mestrado em 1998, Tietê, os rios e o desenho

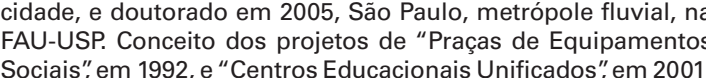


trazendo profissionais para integrar as proposta de Marcos Macedo, abordando Apesar de ter tido seu primeiro estudo quipes e abrindo espaço para o ensino o tema da transposiçăo das águas do em uma época em que a navegaçáo do de engenharia hidraulca nos cursos tio São Francisco para a bacia do tio tios era a pauta principal do governo de engenharia no Brasil. O rio Sao Jaguaribe, com o intuito de combater os imperial, a proposta de transposiçấo Francisco se tornou, assim, naquele efeitos da seca do Nordeste setentrional aqui estudada desde o princípio tinh importante dispositivo na busca pelo Pernambuco e Piaú (HALFELD, 1860 , seca do Nordeste setentrional Como aproveitamento das possibilidades 36; COSTA, 2013, pp. 132-135; HENKES, se pode ler na citação acima, Halfeld econômicas da região, refletindo a 2008, p. 303; FIORAVANTI, 2016). No mapa trouxe a navegação no canal como uma postura do Governo em explorar e apresentado, o engenheiro aponta onde possibilidade a ser verificada, caráter dominar as diversas regioes do Império seria o local de retirada da água para essa que náo seria retomado em nenhum (COSTA, 2013, pp. 39, 130-131). transposiçãa (ver Figura 5), na altura de proposta posterior da Transposição. Boa Vista, próxima à Villa de Cabrobó, en

Dessa forma, as expedições que eram um trecho do rio em que a navegação se Nos anos seguintes à publicação realizadas no rio Sao Francisco tinham tornava mais dificil, entre as cachoeiras de do Atlas e Relatório Concernente Para realizar a primeira, Dom Pedro desde a Cachoeira da Pirapora até ao "I contratou o engenheiro alemão Éneste ponto, onde pessoasilustradas, Oceano Atlântico", outras expediçõos Henrique Guilherme Fernando Halfeld, ${ }^{8} \quad$ particularmente o Dr. Marcos Antônio ao rio São Francisco foram realizadas que percorreu o rio São Francisco da de Macedo, julgam que sera possivel e novos relatórios foram produzidos, Atlântico nos anos de 1852, 1853 e 1854, Francisco um canal em direção para o sempre utilizando e discutindo a partí riacho dos Porcos, e canalizar-se este dos estudos de Halfeld, mas sem que de Capanema (FIORAVANTI, 2016, s/pi al algado e este até sua embocadura muito debatida. Em um desses relatórios CASTRO, 2011, p. 9; LEITE, 2005, p. 7). Ao no rio Jaguaribe, e finalmente deste posteriores ao de Halfeld, elaborado po voltar, o engenheiro publicou em 1860 um rio até sua foz no mar. O projeto é Eduardo José de Moraes (1969)," houve relato de cinquenta e sete páginas pela gigantesco, porém se for possivel a proposiçaao de uma outra transposiçâa Lithographia Imperial, intitulado Atlas e conduzir-se a sua execução, terá o da bacia do rio São Francisco à bacia do Relatório Concernente à Exploraçäo do transcendência para as provincias do rio Parnaiba, com a retirada das águas Reará, Pernambuco, Piaú, Goiás e em outro ponto do rio, onde a topografia (HALFELD, 1860) em que ele levantava particularmente para a provincia do proposta que teve o objetivo principal em texto e cartografia légua por légua ceara que de primeira máo receberáa de conectar o sul e o norte do país através do rio, identificando as vias livres e os comercial do mar para o interior do da navegação. Mas seria uma proposta empecilhos à franca navegação, bem como sugerindo as possiveis soluçöes para os obstáculos encontrados. Os mapas que acompanham o relatório fornecendo a localização das vilas e províncias, cachoeiras, afluentes, as profundidades de cada trecho do rio e os locais das possíveis intervenções de maior porte.

Nesse mesmo relatório, Halfeld retomou a

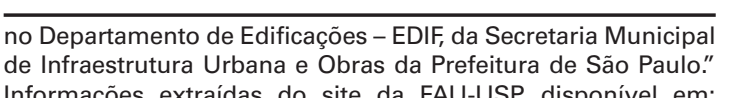

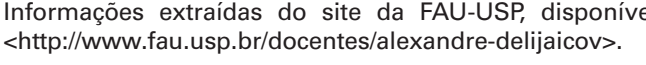

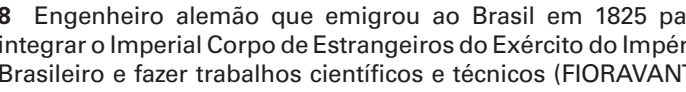

st águas do rio $\mathrm{S}$. Francisco para irrigação das suas terras, como mejo contra o horrivel flagelo das grand secas que lá, quase anualmente, põem em consternaçao grande parte dos tabińm a comunicaz̃a direta do mas para o Vale do $\mathrm{S}$. Francisco e dos seus tributários seria o melhor impulso a fim de acordar a indústria, que em profundo letargo jaz naquelas regioes, habitantes (HALFELD, 1860, p. 36 grifos nossos).

\section{mbém não sairia do papel.}

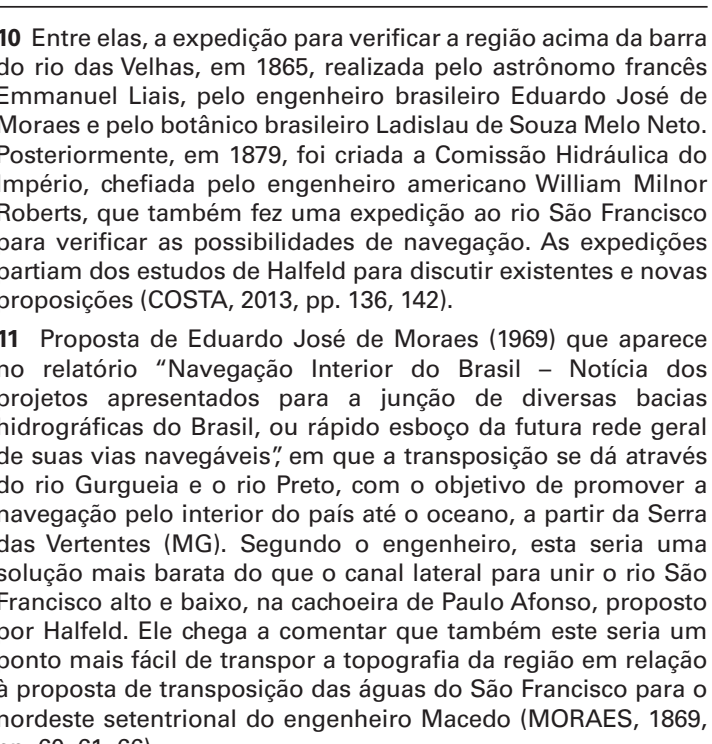

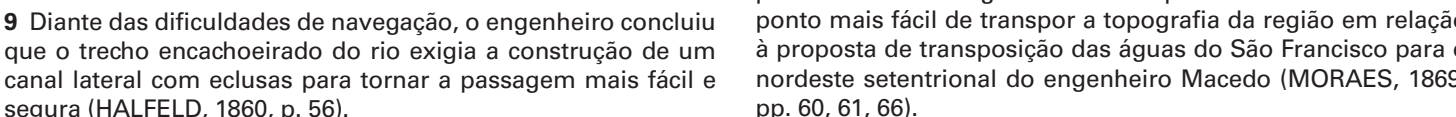

"Baixada pela qual convem examinar-se direç̧ão do Canal que se projecta abrir do

Rio de S. Francisco

pela Província do

Ceará e valle do Rio

Jaguaribe, até o ma

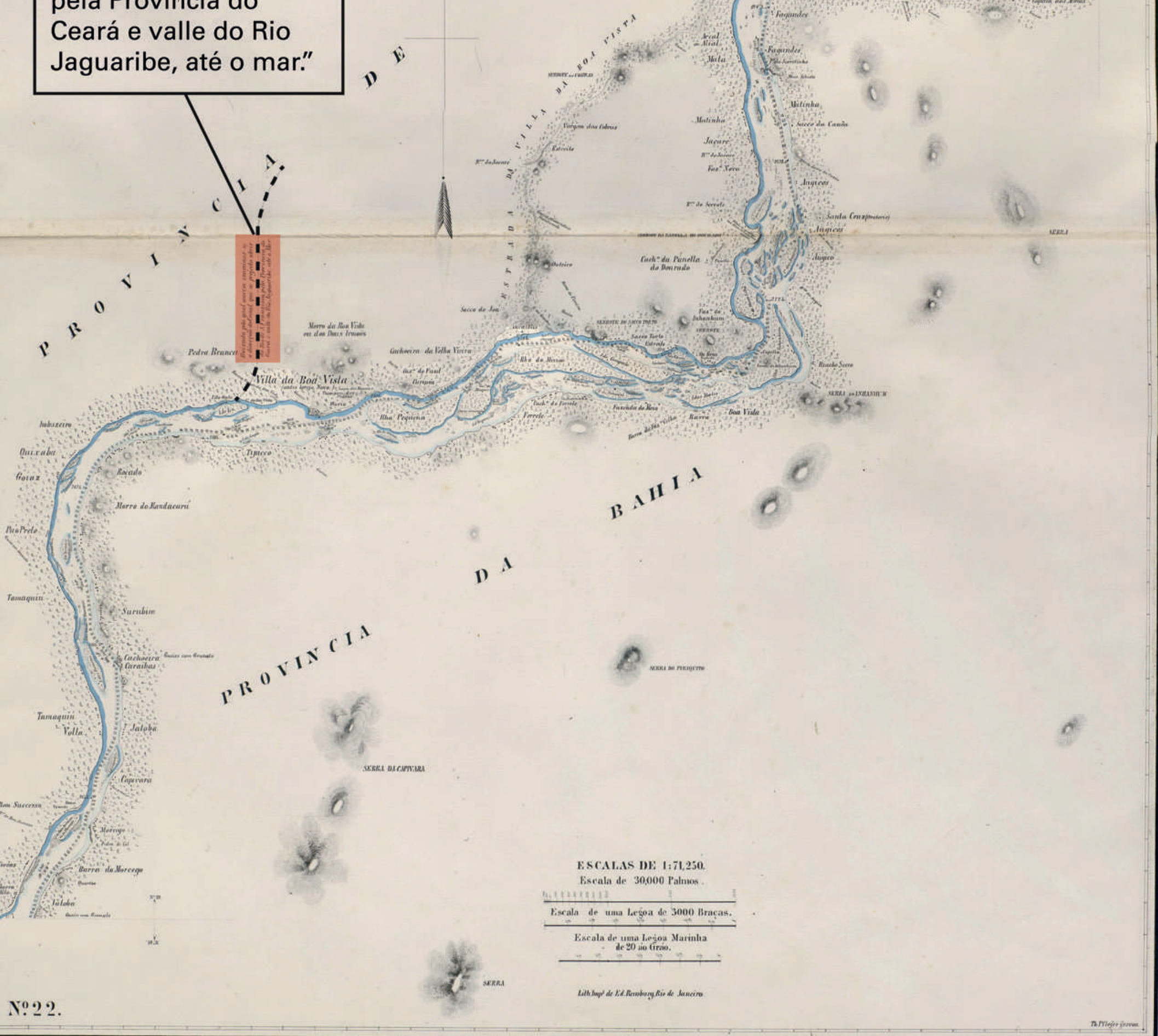


1.2 .3

IOCS e a dificuldade de

transpor a Chapada do Araripe

1912

A proposta da transposição elaborada por Halfeld foi levada a debate parlamentar e não obteve êxito, foi arquivada, pois governo imperial estava priorizando portúrias, intervencões que tarlvez a de uma nação moderna (FIORAVANTI, 2016, $\mathrm{s} / \mathrm{p}$ ). Apesar disso, foi nesse
momento que a seca iniciou a ser levada em consideração na agenda pública: para abastecer os povoados sertanejos, optou- Os estudos realizados por Halfeld se por abrir estradas, perfurar poços e e outros realizados em expediçōes 18), através de frentes de trabalho, pá pelo astrônomo francês citadas anteriormente. L Liais (1865) e pela Comissão Hidráulica do Império (ROBERTS, 1880) deram
do Com uma nova seca ocorrida em 1886, a suporte técnico para a realização de proposta seria brevemente retomada pelo melhoramentos no rio São Francisco $e$ deputado da provincia de Natal, ocearense consequentemente, contribuiram para Tristão Alencar Araripe, ${ }^{12}$ que sugeriu viabilizar o sistema hidroviário através vue abra comuniçąão de São Francisco a Comissão de Menho Imperial criou om o rio Salgado e rio Jaguaribe, de São Francisco (CMRSF) em março de modo que nesses dois rios estabelecesse 1883, e foram expedidas instrucões para uma corrente perene (CASTRO, 2011, p. 9; a execução das obras necessária para VILLA, 2000, p. 37). Mas a proposta logo tornaro rionavegável. Os melhoramentos seria abandonada novamente. consistiam em sondagens, levantamento As décadas de 1860 a 1880 foram da velocidad das com enterminaça objeto de intensos debates sobre as da velocidade das correntes maritimas secas. Vários competentes intelectuais desobstrução eda construcão dos diques contribuiram significativamente (COSTA, 2013, pp. 200, 203 e 207). com cronicas na midia ou palestras de desconhecimento, sobre leis físicas e meteorologicas e sobre os particularmente do semiárido. Há mudanças de foco debates. Primeiramente discutiu-se se

\section{que deveria ser objeto de} seca como problema vem com stimativa da catástrofe em termo de vida humana foi feita pelo jornalista écoca realizart $H$. Smith, que enco

isar como foi elaborado e como se vilizou posteriormente, no seculo XX Transposiçăo do rio Săo Francisco aq estudada, numa perspectiva já năo mais m associaça com o setor privado.
O início do século XX consagraria a solução, que já se via como iniciativa no governo imperial no século anterior, de se desocupar a área semiárida com transporte oficial gratuito, principalmente de látex Para amazonte à parte extraçao oficial à migração, construíram-se mais açudes no Ceará, o combate a secas compondo a "campanha" presidencial 1901 (SARMENTO, 2005, p. 20).

No artigo "Plano de uma Cruzada" (1904), incluído posteriormente na obra Contrastes e Confrontos (1907) Euclides da Cunha propunha soluçóes para questao da seca nordestina, como construção de açudes, arborização, pośácuas do e "provável derivaçáa tributários superiores do Jaguribe ed Piaú, levando perpetuamente à natureza torturada do norte do sertão os alentos a vida da natureza maraviho sul" (CUNHA, 1904 apud SARMENTO, 2005, pp. 20-21). O autor critica ai investidas governamentais na região:

Diante da enorme fatalidade cosmológica, temos uma atitude de Daíainstabilidadeeobaralhamento dos escravizado à sua cadência rímeno não Ihe antepomos à intermitência a continuidade dos esforços. Entretanto, opropriovariar dascausas precipitadas exigindo longos e pacientes estudos. É evidente que estes serão sempre estereis, adstritos aos paroxismos estivais, desdobrando-se na plenitude objetivo ilusório de as debelar, quando uma intervençáo realment pode consistir no prevenir as secas inevitáveis, do futuro (CUNHA, 1904

Em 1909, o governo republicano

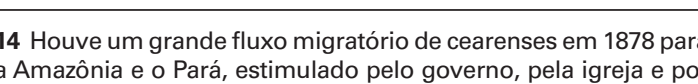

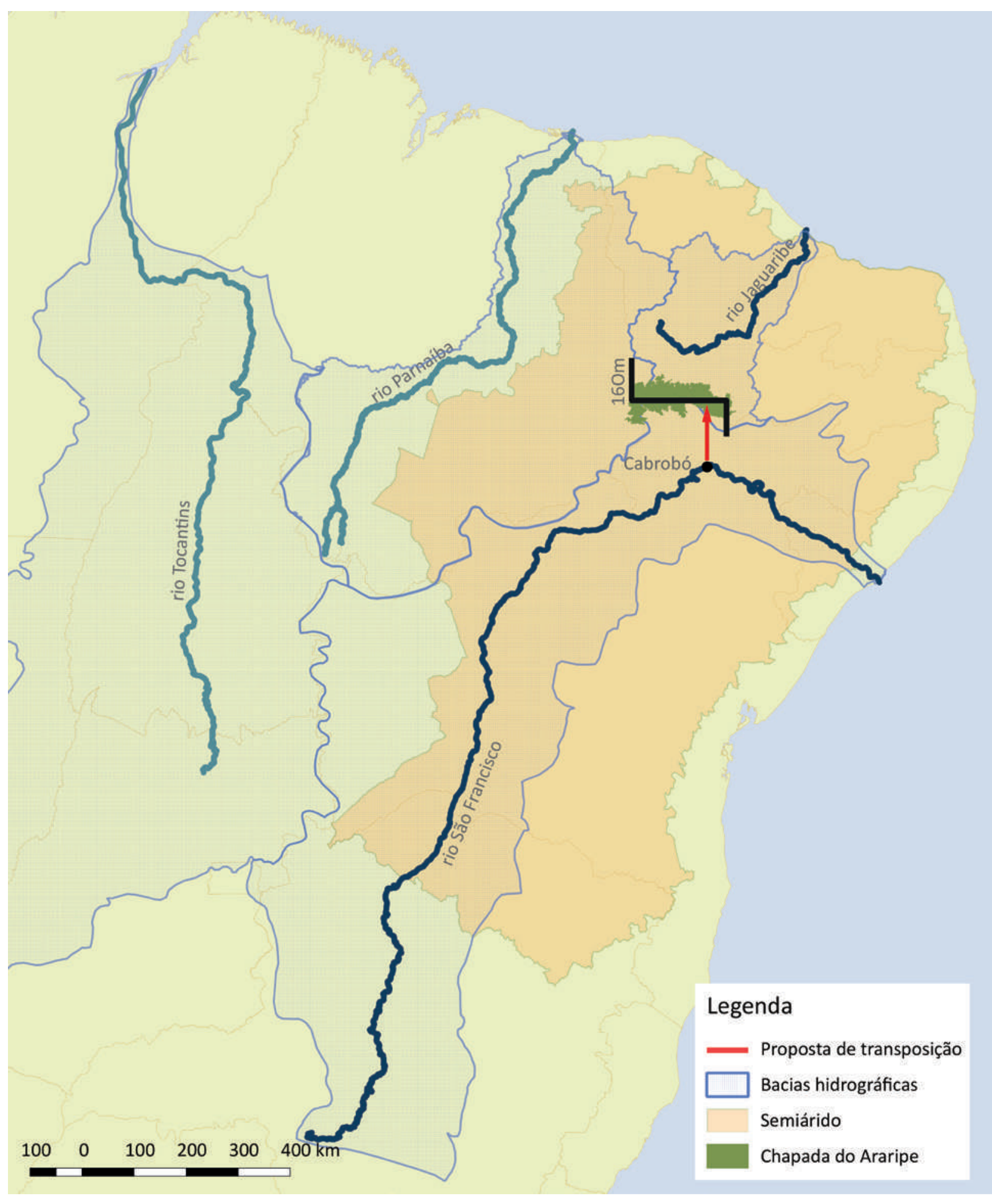


A solução para o relevo, outras obras hidráulicas e a corrupção

Inspetoria de Obras Contra a Seca (IOCS), embriāo do atual Departamento Nacional de Obras Contra as Secas (DNOCS). A foi cogitada do ro Sáo Francisco entáo IOCS, Miguel Arrojado Ribeiro Lisboa 15 no governo republicano de Hermes da Fonseca (1910-1914). A proposta foi descartada, sendo indicada como uma das razoes da recusa a inexistência de bombas de agua capazes de superar periores do Chapada do Araripe, p. 304; DEMENTSHUK, 2014). Para da questão técnica, 2014). Para alem anteriormente, a proposta pode ainda ter sido abandonada frente à outra alternativa então esboçada come relação ao semiárido, que previa, ao invés de

Um ponto muito interessante desse momento está no fato de que embora Miguel Arrojado Ribeiro Lisboa Este tipo de pensamento, assim como o fosse presidente da IOCS, um órgão de Euclides da Cunha (1904) por ter visão expecializado em executar obras critica à açăo do governo da época, era primeas contra as secas, ele foi um dos bastante ousado para a epoca, já que se tenha registro, a pensar na solucão em desenvolvimento do secto iria sensar para a pobreza e para a seca nordestina partir do planejamento rordeste a que fosse além das obras em si. Ele considerasse outras características defendia que o problema do Nordeste da região que não apenas a questão ra a educaçăo, conforme proferiu em hidrica. ${ }^{16}$ Segundo Francisco de Oliveira conferencia no dia 23 de agosto de (1985, pp. 75-76), Arrojado Lisboa,

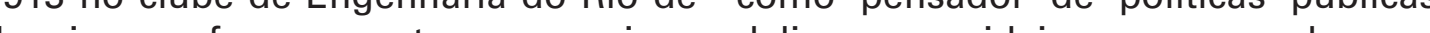
do Departarto Nacional de Obras durante váries décadas, prevaleceram Contra as Secas (DNOCS) e da Biblioteca Nacional (DEMENTSHUK, 2014):

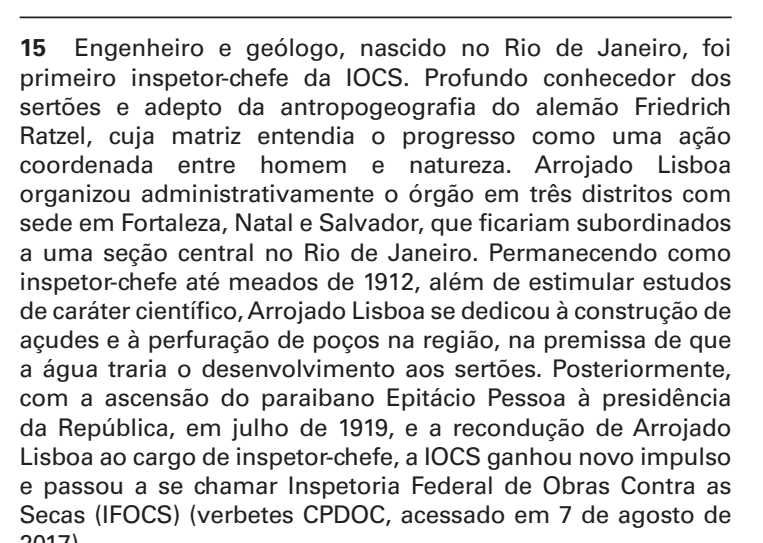

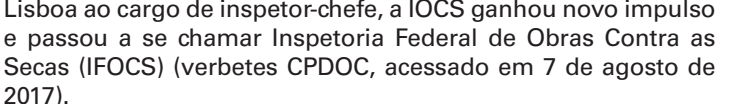

Miguel Arrojado defendia que
o problema do Nordeste era educação, conforme proferiu en 13, no clube de Engenhasia do o de Janeiro, conforme consta no de Obras Contra as Secas (DNOCS) assim, ao mais grave de todos os unicamente elacaçao! So ela aperfeicoe a irrigação, promov
ano indûncia compativel com a silo, não abandone o gado e melhoreOntaminada, devolva as culturas nas grandes várzeas irrigadas, abra compreenda, enfim, a importância esforço que está sendo empregado em prol do seu bem-

para Oliveira, como o primeiro grande ensador da formulaçaao e aplicação da complexidade do

Seca, no rigor léxico, significa
estiagem, falta de umidade, da chuva provém a água necessária secas assima. O problema das simplesmente o problema da agua, isto é, do seu suprimento. Mas a palavra seca, referida a uma homem tem significacáo pelo mais compreensiva. Com efeito, o fenômeno físico da escassez de chuva influi no homem pela para as condicốes econômicas decor região, que por sua vez se refletem na ordem social. Assim encarada a seca e um fenomeno muito vasto econômica e social fisica quanto múltiplo. Verdadeiramente não há um problema, há problema durante várias décadas, revelando-se,

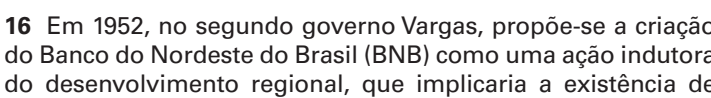

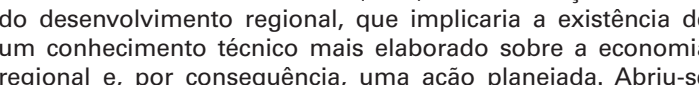

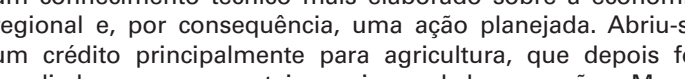

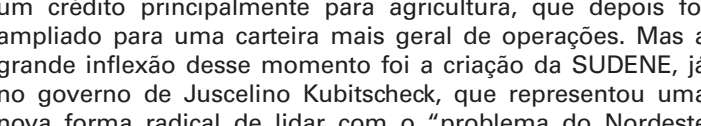

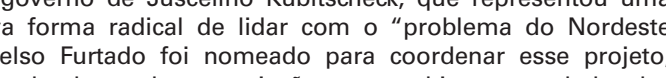

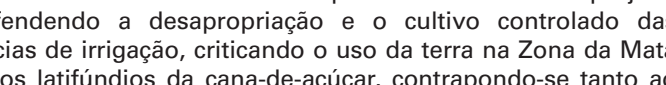

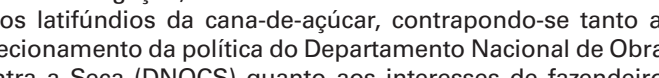

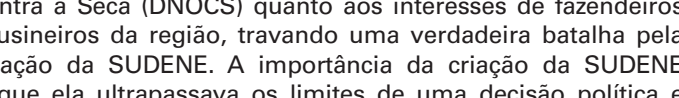

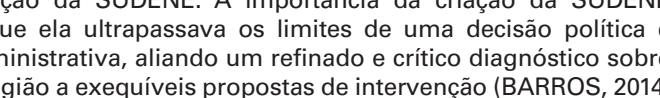

Quando assumiu a presidência, Epitácio essoa (1919 a1922) reconduziu Arrojado Lisboa ao cargo de inspetor-che da IOCS e inseriu a transposição Chapada do Araripe e a implantaçấ criando um programa de infraestrutura com grande frente de obras hidráulicas para o Nordeste. No mesmo ano, o órg passou a se chamar Inspetoria Federal de Obras Contra a Seca e ganhou novo regulamento. Nesse contexto, foi aberto um amplo credito para obras hídricas, o objetivo de modernizar os sertốs, diversas obras foram encetadas. Nesse período, também foram definidos os limites espaciais da regiáo que convencionou chamar de Nordeste."

Além de encaminhar a construção de 205 grandes açudes, 220 poços profundos ontratou Fonseca Rodrigues, que encontrou a solução para a transposição do relevo da Chapada do Araripe: havendo uma queda dágua na jusante de Cabrobo, em Pernambuco, era possivel gerar a energia hidráalica e mecânica para As obras foram interrompidas quando uma fiscalização constatou desvios de recursos, em 1922, e nesse contexto, mais uma vez, o projeto de transposiça foi arquivado (DEMENTSHUK, 2014).

Parlamentares do Sudeste alegavam estriçoes financeiras para se
executar o plano de Epitácio Pessoa, enquanto oligarquias nordestinas reapropriacáa de terras, mesmo
desau improdutivas. No trâmite burocrático executivo-legislativo, o plano passou na comissão de paulista contrário por parlamentar cuja postura emblemática refletia a
burguesia paulista, segundo Marco

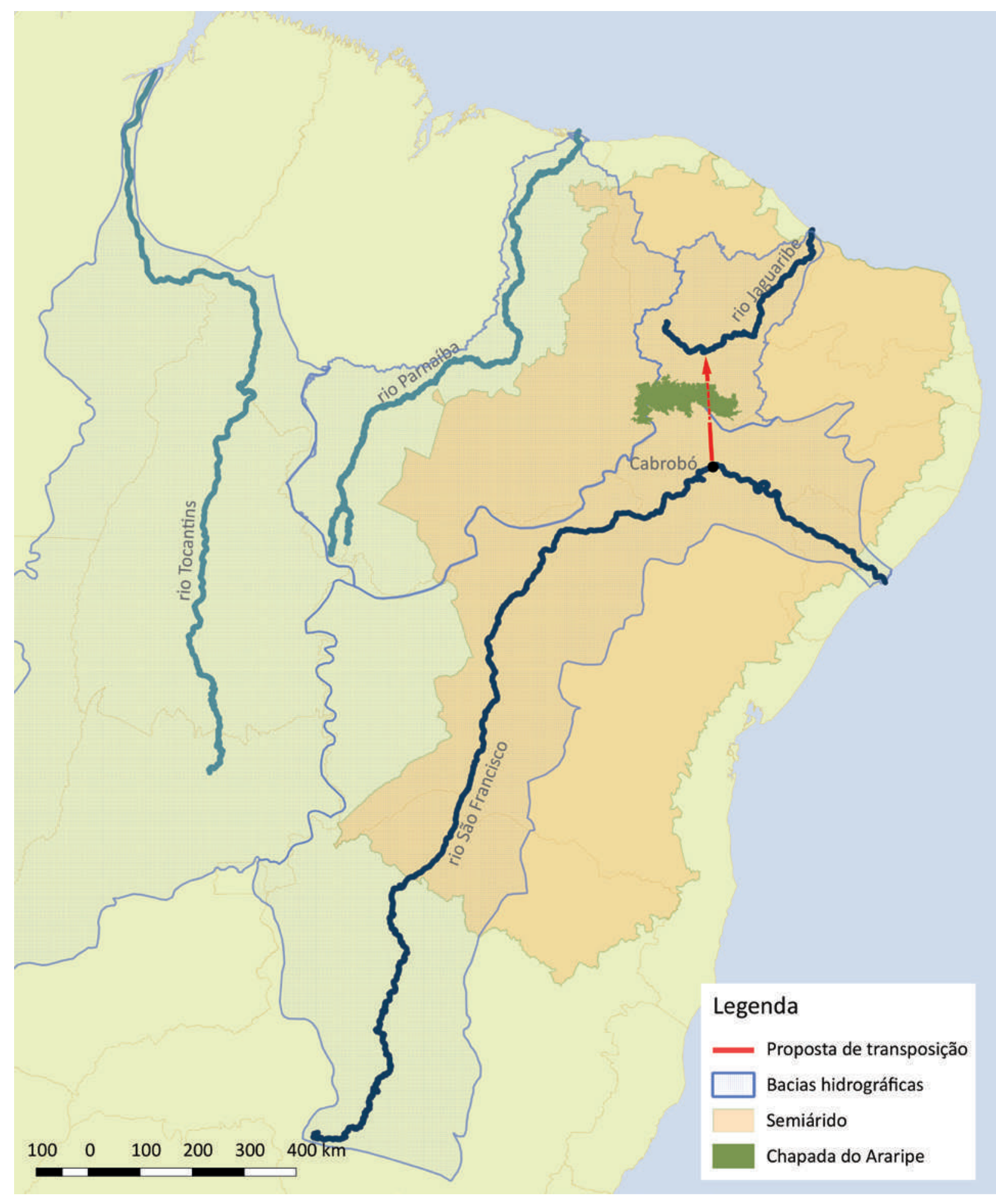


Antonio Villa: "arrecadar escola era

Amazônia, onde a producão de borracha profundas era desperdício de para o governo estadunidense estava em franca atividade (SARMENTO, 2005, pp. s obras dos açudes foram interrompidas $15,25,29$. Estas soluçoes imediatistas,

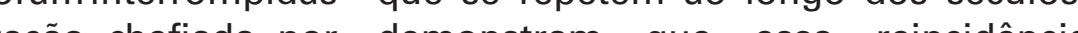
quando uma fiscalização chefiada por demonstram que essa reincidencia constatou desvios de recursos, em uma para um verdadeiro desenvolvimento, operação que gerou o famoso "Relatório que implicaria em romper a complexa Rondon", de 1922. E nesse contexto, mais estrutura social e política brasileira. uma vez, o projeto de transposição năo

Dez anos depois, no governo de Getulo

Dez anos depois, no governo de Getúlio Vargas, com a ocorrência de uma seca
em 1931 e a criação do Departamento Nacional de Obras contra as Secas (DNOCS), a transposição voltaria a ser estudada, mas novamente náo seguiria adiante (CASTRO, 2011, p. 9). Nesse mesmo momento, o ministro José concentracâa de Fortaleza, locais onde se conduziam e onde emergencialmente se atendiam os flagelados das secas, retomando com isso as frentes de trabalho que apoiavam as migrações para outras regioes do pais, ação padrão governamental para a região semiárida XIX. Ocorria em especial desde o seculo de corrupção e manipulacãa de envio de mantimentos e a forma de inscricăo nas frentes de trabalho (SARMENTO, 2005, pp. 21-24). Para Sarmento, essa realidade decorria da inadequação da abordagem e alimentava preconceitos recursos alocados.

Ações governamentais - como estímulo à migração para outras regiões; as chamadas frentes de trabalho, que consistiamnoemprego, porpartegoverno imperial ou republicano, de população via fornecimento de alimentos - foram reincidentes no combate à seca ao longo dos séculos, sendo a primeira frente de emergência registrada em 1721. Em 1941 o governo federal retoma o transporte de impactados pela seca ao Sul e à
Em 1984, tendo em vista a grande seca que assolou o Nordeste entre 1979 e 1983, o governo militar de Figueiredo (1979 a 1985) encomendou aos técnicos do Departamento Nacional de Obras uneamento (DNOS) a elaboração de rio São Francisco, a ser financiado pelo Banco Mundial (LOUREIRO et al, 2013, p. 4). O responsável na epoca foi o Ministro do Interior Coronel Mario Andreazza, e o DNOS subcontratou o consórcio formado pelas empresas de engenharia Hidroterra e, posteriormengenharia e entre 1985 e 1987, foram desenvolvidos estudos socioeconômicos para o empreendimento pelo consórcio HidroservicePRC SARMENTO, 2018, pp. 64-65).

Essa versão foi considerada a primeir que ultrapassou o nível de estudo que ultrapassou o nivel de estudo e que apesar de receber pequenas modificações ao longo dos anos, se manteria ate a versão que foi executada, no governo do presidente Luiz Inácio Lula da Silva. A nova versáa consistia em uma proposta ambiciosa, que Tocantins, para beneficiar os estados do Ceará, Piauí, Paraíba, Rio Grande do Norte e Pernambuco (ver Figura 8), com previsão para ser executada em quarenta anos. Com o intulto de promover a inigaçáa extensiva no deáguas no rio ranspostas da bacia hidrográfica do rio Tocantins, direcionando $330 \mathrm{~m} 3 / \mathrm{s}$ do rio São Francisco ao semiárido e $300 \mathrm{~m}^{3} / \mathrm{s}$
do rio Tocantins ao rio São Francisco

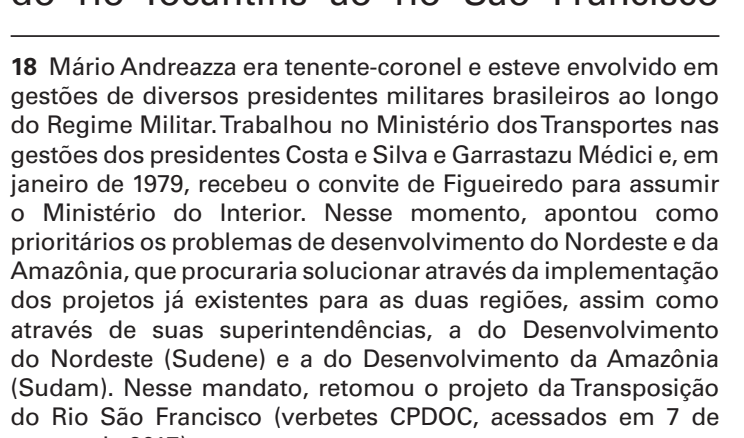

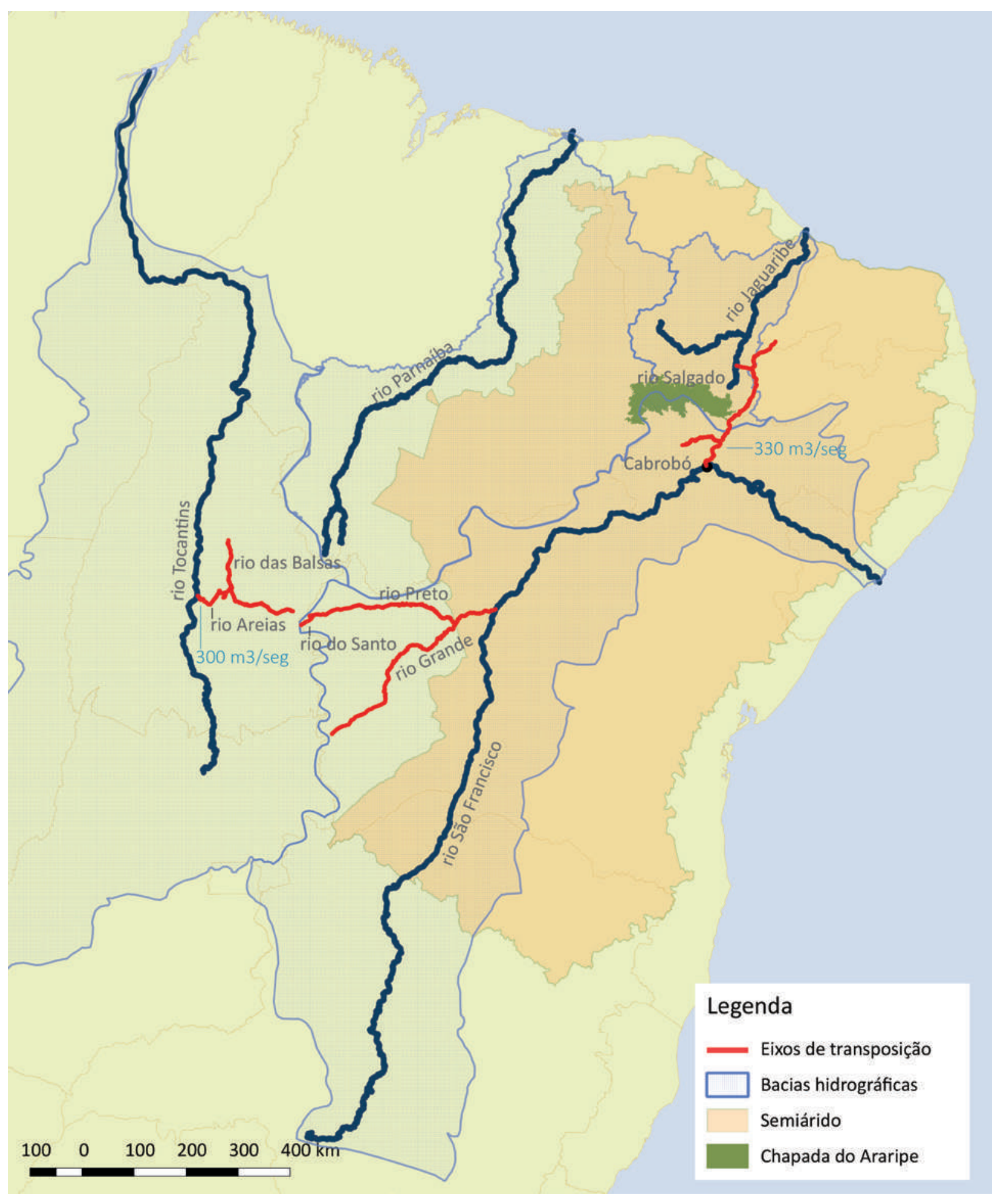

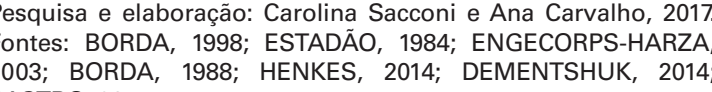


(TEIXEIRA, 2018, informação verbal). ${ }^{19}$ É hidrelétricas no semiárido do rio São programa bastante amplo, que previa que ilustra a citaçáo abaixo, retirada de Francisco, tais como a barragem de medidas para questoes econômicas Paulo da Sobradinho $(B A)^{21}$ e complementações e de infraestrutura da região, voltado época (Cf. CLAUSEL, 1984):

Se discute, agora, a perenização $\mathrm{O}$ plano, em suas linhas gerais, já se encontra pronto, e denominase Programa de Transposição de Nordestino, que utilizaria árido do Rio São Francisco. O projeto é antigo, mas antes faltava energia elétrica para o bombeamento, elevações que para antepor as novo das águas. Estudos realizados pelo Projeto Radam evidenciaram a existência, no Nordeste, de potencial
de terras irrigáveis. As atuais açudagens não são, entretanto, suficientes para irrigar sequer 10\% das terras disponiveis. Esse grande rio, o "Chico, náo teria excedentes e desviaria um volume considerável de água de Paulo Afonso. A solução definitiva seria a utilizaçấo de água desviando parte Tocantins (que, no futuro, poderia ser reforçado pelo Araguaia), nas proximidades de Carolina, para o Rio Balsas, que já alimenta a Barragem

Como mencionado na citação acima m que o governo federal apostou em projetos afinados com o ideário do Nordeste (SUDENE) em 1982 (vert desenvolvimentista, impulsionados por Figura 9), que resultou no lancamento $\mathrm{m}$ crescimento da economia, chamado do programa Projeto Nordeste, ${ }^{23}$ um de Milagre Econômico Brasileiro 20 que experimentara seu clímax na década anterior. Alguns desses megaprojetos, tais como as usinas hidreletricas de

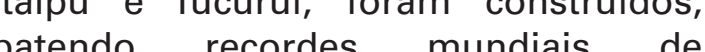
dimensões e capacidade de geração Foi também entre a década de 1970 . 1980 que a Companhia Hidro Elétrica do São Francisco (CHESF) empreendeu a construção de uma série de barragens

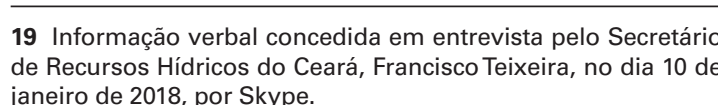

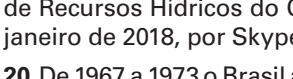

no complexo hidrelétrico de Paulo Afonso principalmente para apoiar o pequen

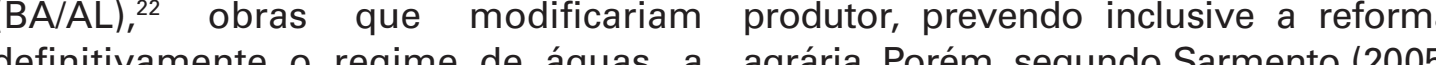
vida dos ribeirinhos e a navegabilidade $\mathrm{p}$. 30), o que saiu do papel foi apenas um o rio São Francisco. № interior sofisma de reforma agrária, que favoreceu dessa lógica desenvolvimentista e de uma minoria menos necessitada, além egaprojetos foi elaborada a primeira dos grandes projetos de infraestrutura 作 era para trazer água para desenvolvimento da irrigação, que 60. [...] era para poder resolver os a ideia do Celso Furtado no grup de trabalho de desenvolvimento do Nordeste, em 1959: uma das agricultura moderna através daça irrigação com vales úmidos, no desenvolvendo a irrigação. em entrevista pelo Secretário de Recursos Hídricos do Cear janeiro de 2018, por Skype.

Projetos como esse, propostos pelo governo federal através da SUDENE, statal que buscava tratar a questão da pobreza do Nordeste para além de uma consequência climática, mas também lidando como uma questão de diferenças socioeconomicas que exigiria politicas públicas para superá-las. ${ }^{24} \mathrm{E}, \mathrm{no}$

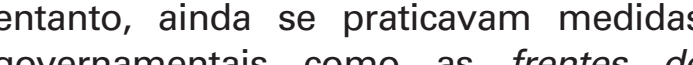
trabalho (ver Figura 10) que estimus de esvaziamento do semiárido (como se tal processo fosse de fato plenamente exequível) e a migração dos sertanejo para as areas onde haveria necessidade de mão de obra por parte do governo federa

Com o fim da seca, dado o farto co gerado pelo processo de redemocratizaçao, o andamento do proje foi paralisado (LOUREIRO et alii, 2013, p.

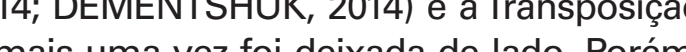
dessa vez, deixava de lado. Porén rjeto técnico, que seria retomado em gestōes seguintes.
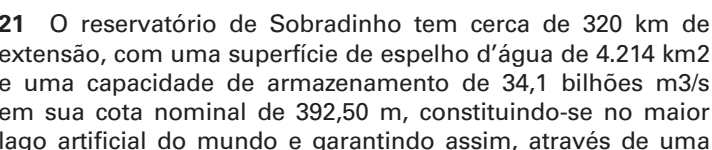

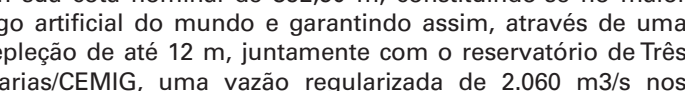

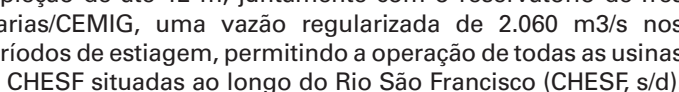

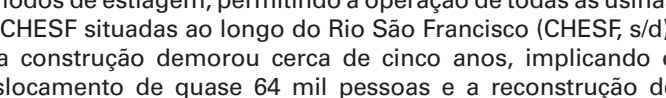

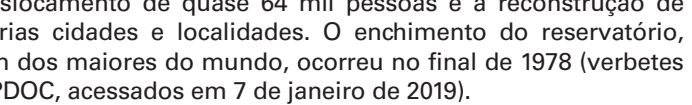

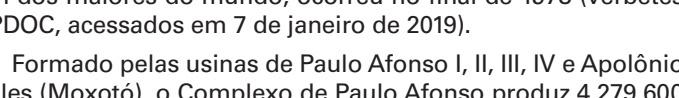

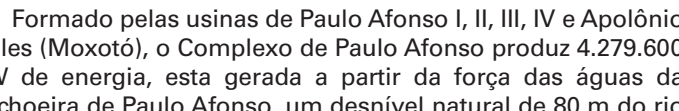

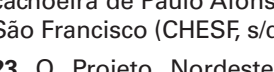

O Projeto Nordeste era um programa completo, que
comportava o Programa de Appoio ao Pegueno Produtur (PAAPP.

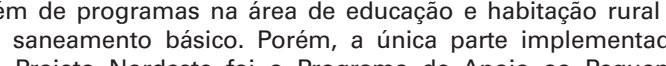

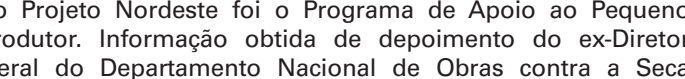

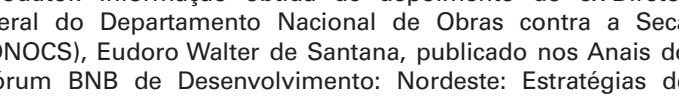

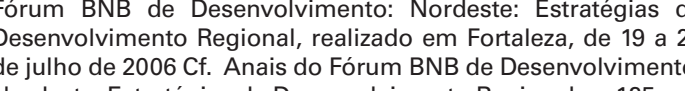

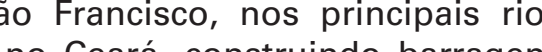
chuvoso inverno de 1984 e o instáve

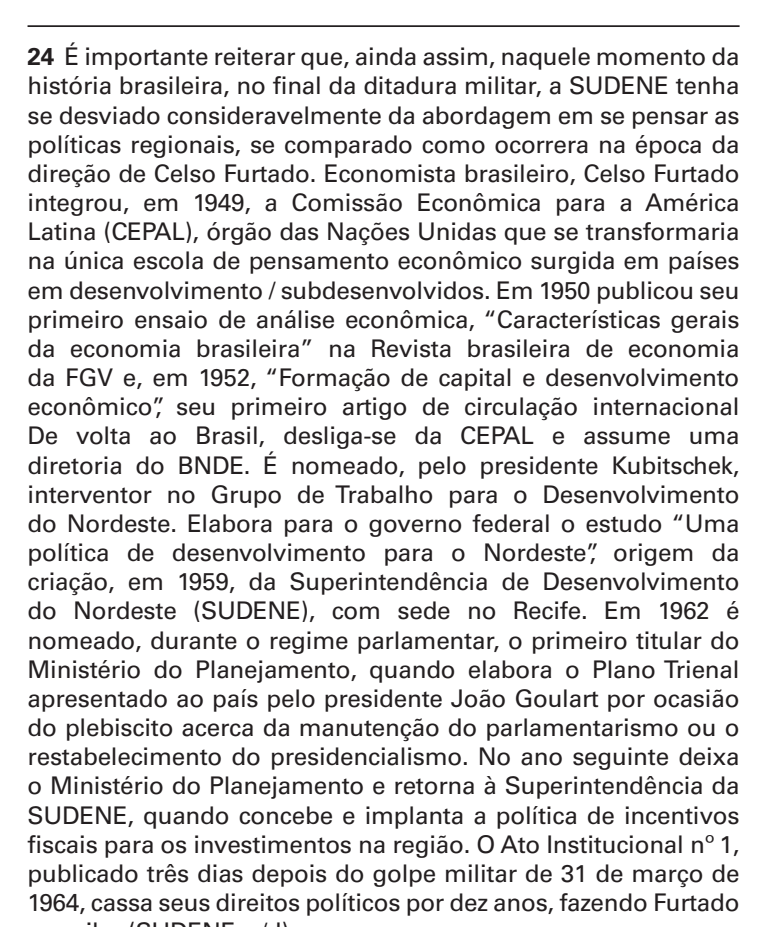

POLÍTICA

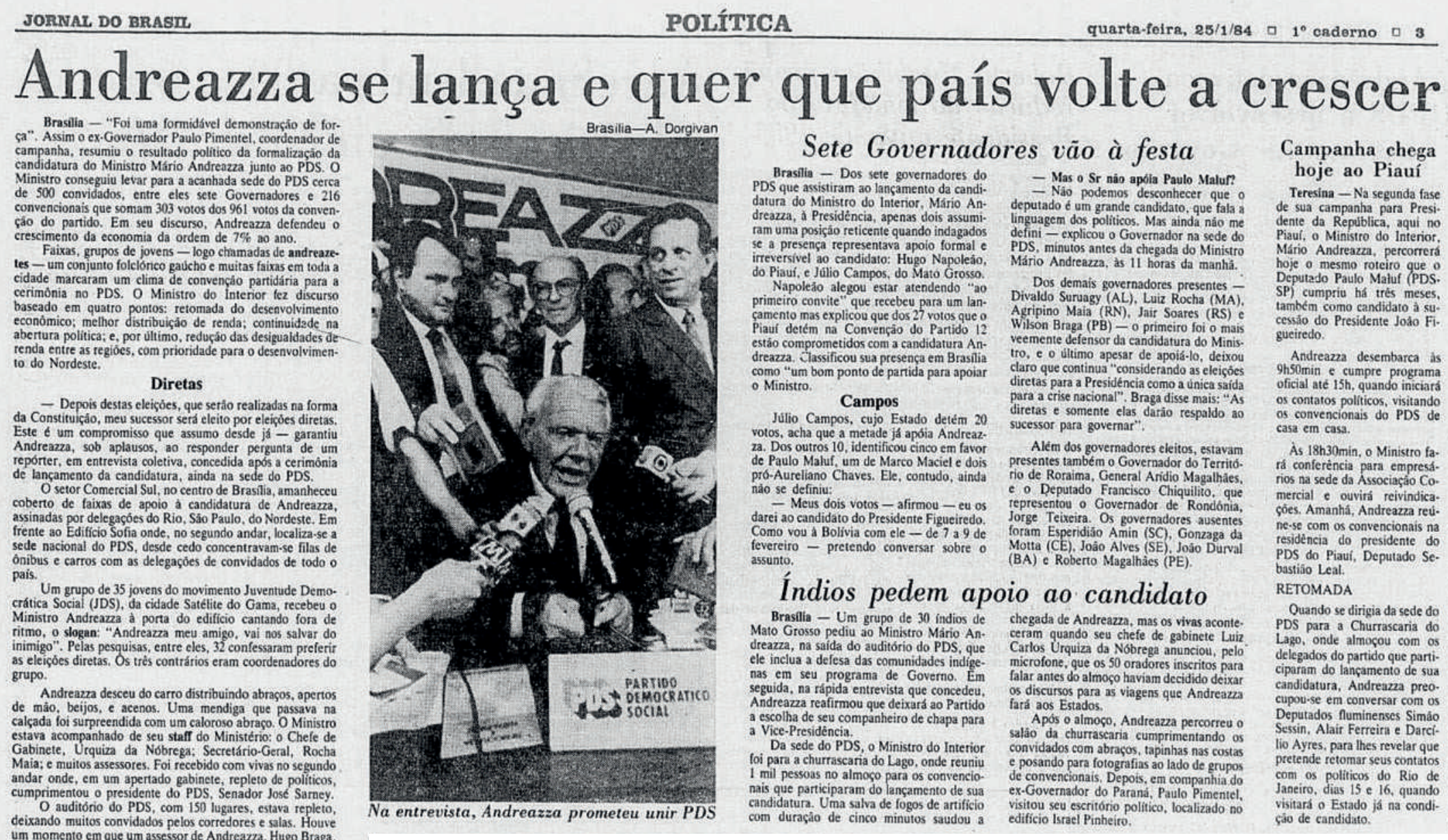

\section{$r:--\bar{N}^{\top} \bar{\top}$ Sūdene}

Recife - O Ministro Mário Andreazza mudou de idéia e decidiu comparecer à reuniáo da SUDENE da próxima sextafeira no Recife, para manifestar o seu apreço aos governadores do Nordeste que, em sua maioria, compareceram ao 1 lançamento da sua candidatura em Brasília.

I: Há cerca de 15 dias, depois de consulta à SUDENE, I Andreazza decidira náo comparecer ao encontro mensal do Conselho Deliberativo. Ontem à tarde, entretanto, o Ministro mandou avisar a direção da SUDENE que estará presente não I apenas à reuniáo do Conselho Deliberativo como também I comparecerá ao encontro programado para quinta-feira, I quando os governadores discutirão o "Projeto Nordeste" a ser financiado pelo Banco Mundial.

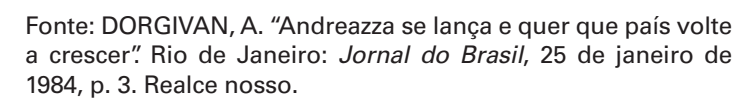


SORNAL DO RRABLL

NACIONAL

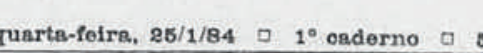

Sudene fecha frentes contra seca no Piauí e Maranhão

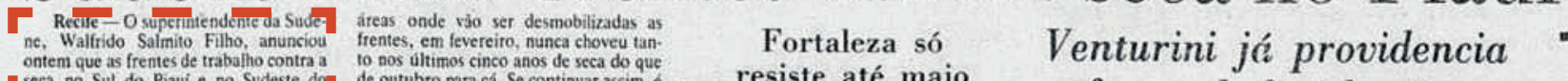

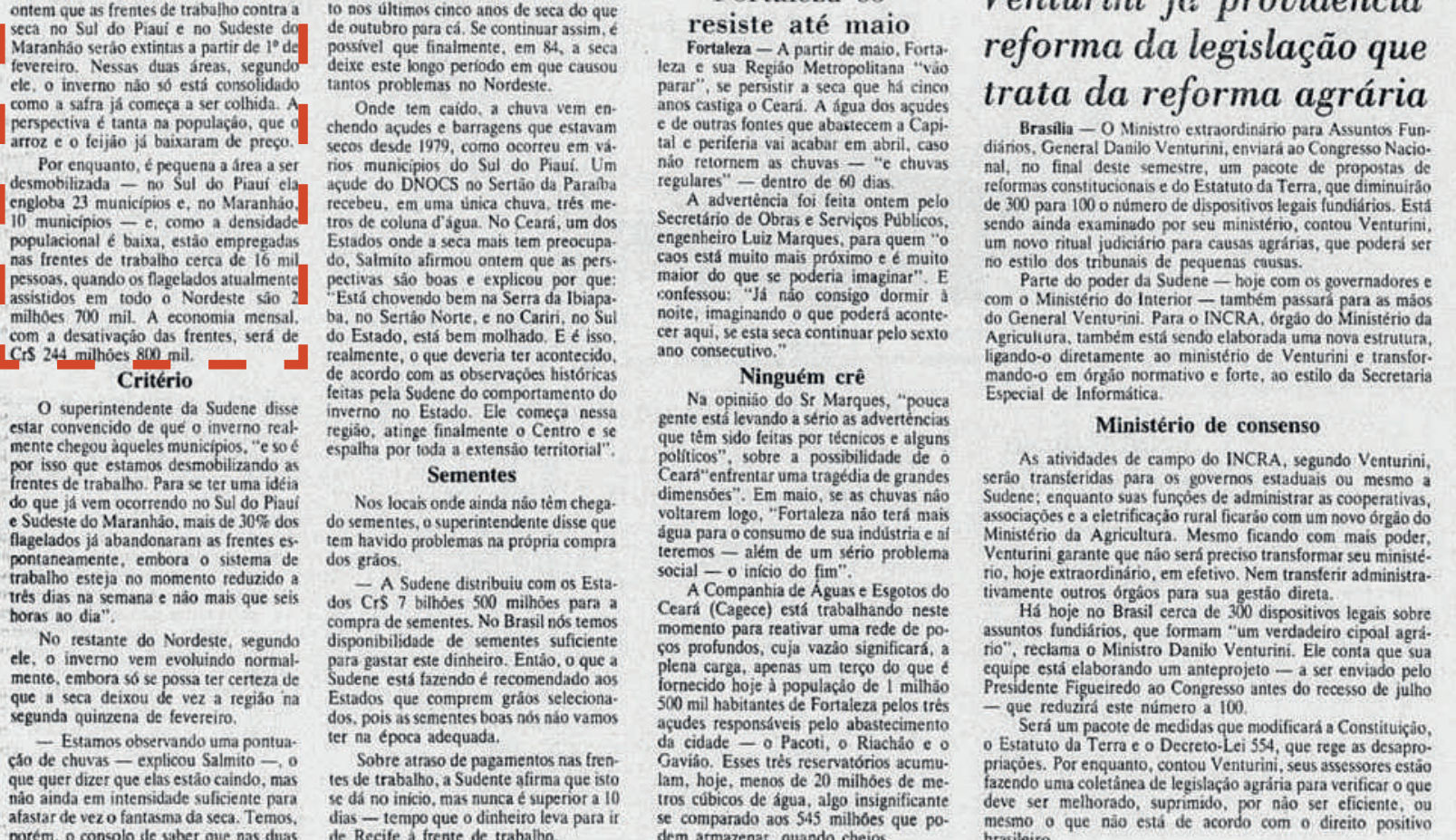

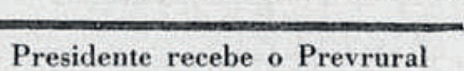

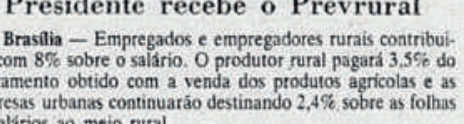

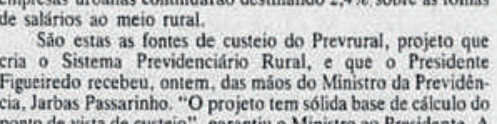

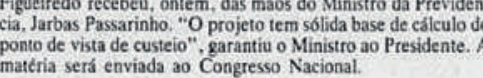
INPS vai revisar invalidez

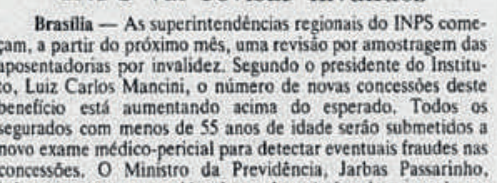

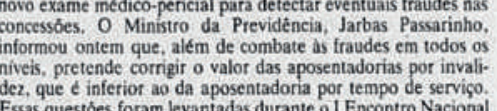

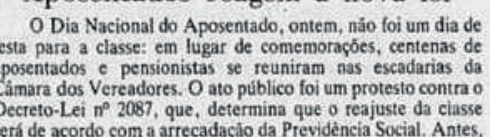

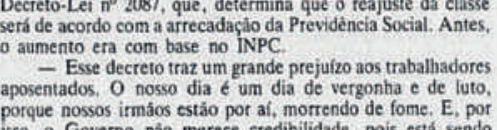

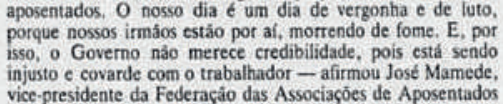

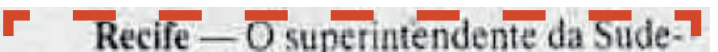
ne, Walfrido Salmito Filho, anuncio ontem que as frentes de traballo contra a I seca no Sul do Piaui e no Sudeste do fevereiro. Nessas duas áreas, segundo I como a safra já começa a ser colhida. $A$ perspectiva c tanta na populą̧a, que o

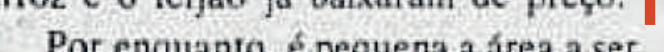
Por enquanto, é pequena a área a ser
desmobilizada - no Sul do Piaú elal engloba 23 municínios e, no Maranhio, I 10 municipios - e, como a densidade I nas frentes de trabalho cerca de 16 mil pessoas, quando os flagelados atualmente mithöes 700 mil A economia mensal com a desativaçảo das frentes, será de LCr\$2 244 milhöes 800 mil. _ -
1.2 .6

A nova Constituição e a

questão ambiental

1994

No governo de Itamar Franco (19921995) a ideia voltou a cena outra vez encabeçada pelo Ministro da Integraçăo Regional, Aluisio Alves, ${ }^{25}$ e pelo Ministro do Planejamento, Beni Veras. ${ }^{26}$ Diante ocorrida entre os anos de 1991 e 1993, grupos de políticos interessas no e signatarios da Carta de Fortaleza, ${ }^{27}$ aproveitaram a ascensão do deputado favoravel à Transposiçãa, Aluisio Alves, ao cargo de Ministro da Integraçáa Regional, em 1994, e debate em torno da viablizazano projeto, com base no projeto que havia sido produzido em 1984 por Mario Andreazza (LOUREIRO et alii, 2013, p. 14; SARMENTO, 2018, pp. 68, 72). Essa versão da Transposiçáa ficou sendo considerada a segunda versão do projeto apresenta como um estudo ou idela preliminar (SARMENTO, 2018, p. 82).

25 Em marco de 1994, Aluísio Alves foi nomeado por Itamar
Franco $(1992-1994)$ ministro da Integraçäa Regional sua principal realizaçáo no cargo foi o anuncio de um polêmm Sao Francisco para abastecer cerca de duzentas e vinte cidad bilhoos de déláres, a obra era combatida por seus altos custos

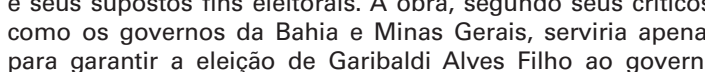

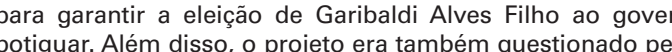

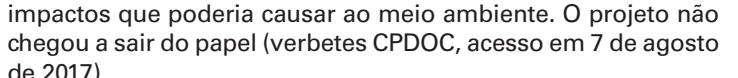
26 Beni Veras diplomounse em administracáao e marketing
pela Escola de Administracáa do Ceará em 1967 . Entre 1984 e

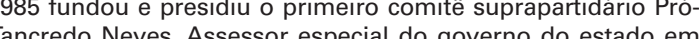
1987, nomeado pelo governador Tasso Jereissati (1987-1991), de 1987 a 1988 , no pleito de outubro de 1990 elegeu-se senat Entre 1991 e 1992 atuou como suplente da mesa direto

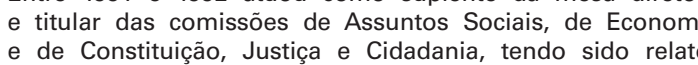
da comissäo mista para a modernizacáo do Departament
Nacional de Obbras contra a Seca (DNOCS) e, ainda, como

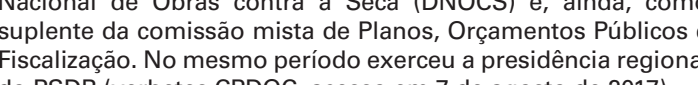

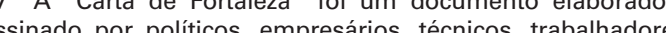

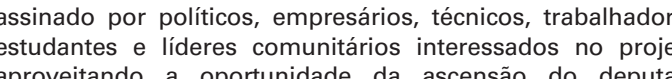

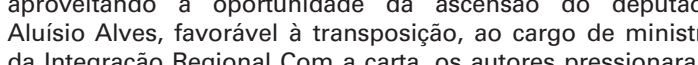
o governo para retomar o debate em torro da viabilizach

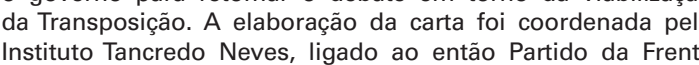
Liberal (PFLL), hoje Partido dos Democratas (DEM). O dato

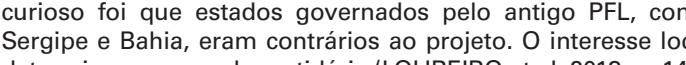

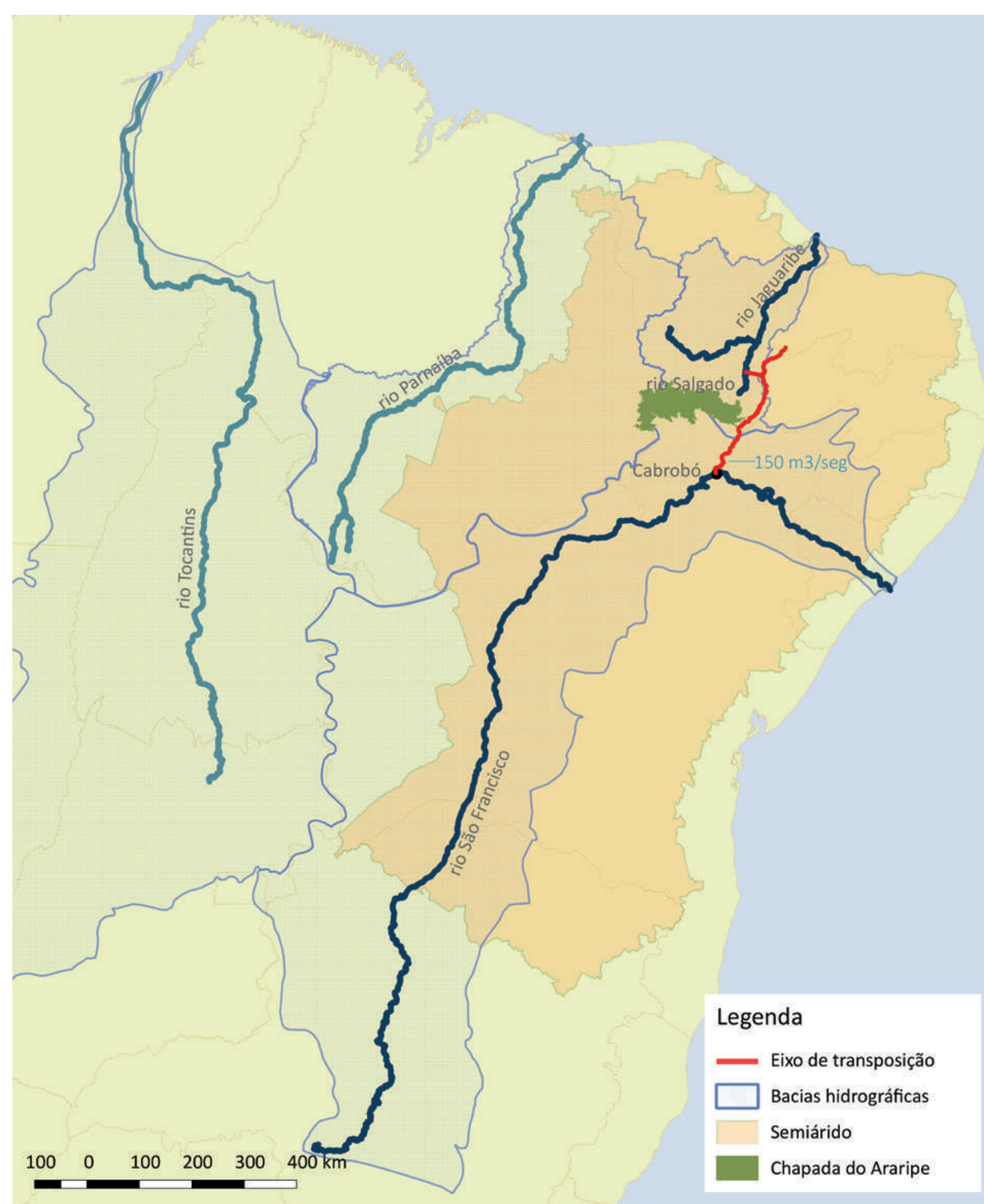

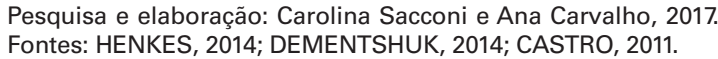


Embora tenha permanecido pouco mais de um ano no cargo - de 08 abril de 1994 a 01 janeiro de 1995 , ano em que o Brasil teria Cardoso - - Aluísio Alves concentrou energia na reinserção do tema da Transposiçao na agenda governamental, do Ministério de Integração Regional (MIR). Para a tarefa de coordenação geral dos trabalhos de engenharia, o ministro Aluísio Alves designou o engenheiro civil Conforme citação acima, o traçado do
Rômulo de Macêdo Vieira, ${ }^{28}$ reconhecido canal continuava o mesmo do projeto por sua elevada capacidade técnica e de Andreazza, assim como a concepção the eram confiadas (SARMENTO, 2018, p. tempos do Transposiçáa, ainda dos 88).

Em poucos meses, Rômulo Macêdo, como ficaria mais conhecido, Engenharia de Recursos Hídricos com experiência no semiárido nordestino e montou três escritórios completos, que nada ficavam engenharia consultiva brasileiras. 0 maior deles foi instalado em Fortaleza - CE, com o apoio do DNOCS, órgão cidade de Mossoŕem Salqueiro - PE, cidade localizada a $64 \mathrm{~km}$, em linha reta, do ponto de captacăo da água da Transposição,
na direção sudoeste (SARMENTO, 2018, p. 73).

A "usina de projetos", nos termos Sarmento $(2018$, p. 81$)$, montada por
Macedo funcionava a todo o vapor, e a terceira versão do projeto da necessário Francisco somente quando Transposição do Rio São Francisco seria Esse conceito, da sinergia hídrica, seria concluida em nove meses. Como na aperfeiçoado nas versōes seguintes do versão de Andreazza, a água era captada
na altura da cidade de Cabrobó, em

Pernambuco, elevada por bombeamento Foi também nesse governo que se iniciou e conduzida em canais, aquedutos, túneis o processo de licenciamento ambiental
e barragens. O desnível topográfico entre da Transposiçăo, ao ser formulado, em 10 e barragens. O desnivel topográfico entre da Transposiçăa, ao ser formulado, em 10
o rio São Francisco e o destino das águas, de maio de 1994, o Termo de Referência cerca de $180 \mathrm{~m}$ de altura, era vencido vencido que obrigava a elaboracão dos Estudos por três estações de bombeamento, de Impacto Ambiental (EIA-RIMA) e os trajeto com cerca de $140 \mathrm{~km}$ até alcançar (PBAs). Naquele momento, conforme as cabeceiras das bacias hidrográficas será explicado no capítulo 2, tornavamecestoras, proximas à frontera entre se obrigatorios esses documentos para os Estados da Paraiba e do Ceara analisar os impactos que a obra causaria e as necessárias mitigaçöes dos mesmo A ideia inicial, considerada desde mesmo ano, anunciada a intenção de
os tempos do Império, estava Arecução do projeto, oTribunal de Contas à qual a primeira versão do projeto da União publicou um parecer contrário do DNOS também fora fiel. [...] à à ideia, resultando mais uma vez no seu
1.2.7

FHC, o Eixo Leste e a

elaboração do arcabouço

documental do projeto

\section{8, p. 82-83).}

Arguindo o caráter emergencial do licenciamento ambiental, os esponsaveis procuraram defini "um critério não cabalístico" que Justificasse a vazáo de transposiça de $150 \mathrm{~m} 3 / \mathrm{s}$. No prazo da arguição,
considerados os favoraveis $\begin{array}{lll}e & \text { surpreendentes resultados } \\ \text { dos } & \text { estudos de Engenharia de }\end{array}$ dos estudos de Engenharia
Recursos Hídricos, adotou-se critério hidrológico baseado $\mathrm{n}$ umentar o aproveitamento dos recursos hídricos nas bacias do São Francisco somente quando necessário. O governo Itamar Franco

terminou, e a iniciativa não saiu das
pranchetas (SARMENTO, 2005, p. 32).

Muito embora a Transposição não tenha mais uma vez seguido adiante,
outras obras hídricas de características semelhantes, em menor escala, estavam sendo pleiteadas ou mesmo construídas na mesma época. Ciro Gomes, então governador do Ceara, construiu dias, trazendo águas do Rio Jaguaribe para Fortaleza (CE), salvando a capital cearense de um iminente colapso que teria sido gerado por aquela seca de Cis. Na Paraiba, o governador na epoca Cucena, pleiteou sem sucesso Moxotó para construir a adutora Grande (PB) com águacer Campina Francisco (DEMENTSHUK, 2014, s/p) Isso trvez tenha fortalecido a ideia de que construçao da Transposição estava cada mais proxima de se tornar realidade.

(n)

autorização ambiental para a obra, já não o a

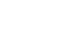

No governo do presidente Fernando Henrique Cardoso foram elaborados os programas federais "Brasil em
Ação" (1996-1999) (ver Figura 13) e Ação" (1996-1999) (ver Figura 13) e
posteriormente o "Avança Brasil" posteriormente ${ }^{\circ}$ "Avança Brasil"
(2000-2003), que se basearam em um estudo que tinha como objetivo a criação de Eixos Nacionais de Integração e Desenvolvimento (ENIDs) (ver Figura 14). Estes priorizavam integrar competitivamente espaços dinâmicos do Brasil ao mercado externo, dotando-os de acessibilidade e deixando em segundo plano áreas mais impactas - jus competicão exacerbada (ARAÚJO, 1999). Os projetos selecionados para compor
o portfólio dos ENIDS foram aqueles apresentados aos Planos Plurianuais
(PPAs 1996/1999 e 2000-2003) e que consistiam em antigas demandas ajuste com elites regionais, os ENIDs corresponderam aos interesses da União de consolidação da política de integraçao regional da America do Sul, numa logica muito aproximada ao que vinha sendo discutido dentro do projeto da Iniciativa para a Sul-Americana (IIRSA) que também previa a implantacáo de corredores de exportação como elementos centrais do desenvolvimento regional, neste caso, sul-americano (LEITÃO,
2009 , p. 138). Foi nesse contexto que se retomou, mais uma vez, o Francisco, como um eixo de suposto desenvolvimento.

Além do enfoque predominantemente competitivo e logistico, o projeto dos ENIDs projetava um crescimento que supostamente se difundiria a partir de eixos ou vetores de país. Nessa perspectiva, a ação estatal, no campo do desenvolvimento regional, ficava reduzida à previsão de oferta de infraestrutura de transportes

\section{6 \\ 2002}

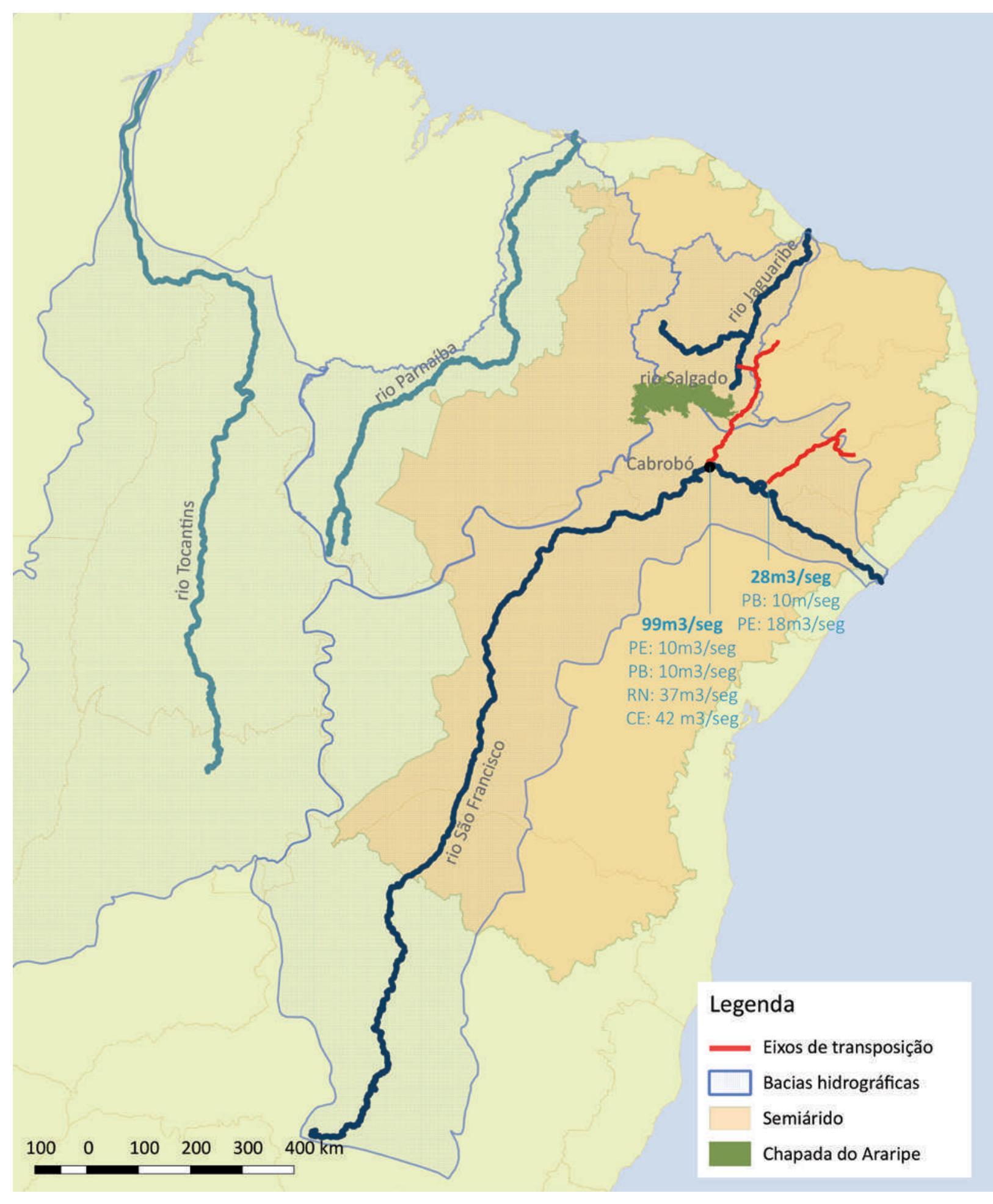




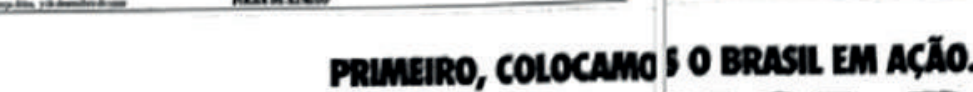

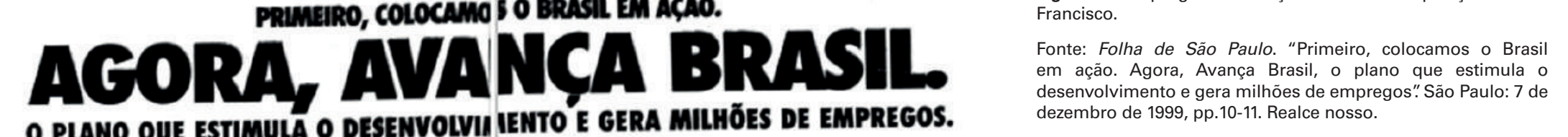
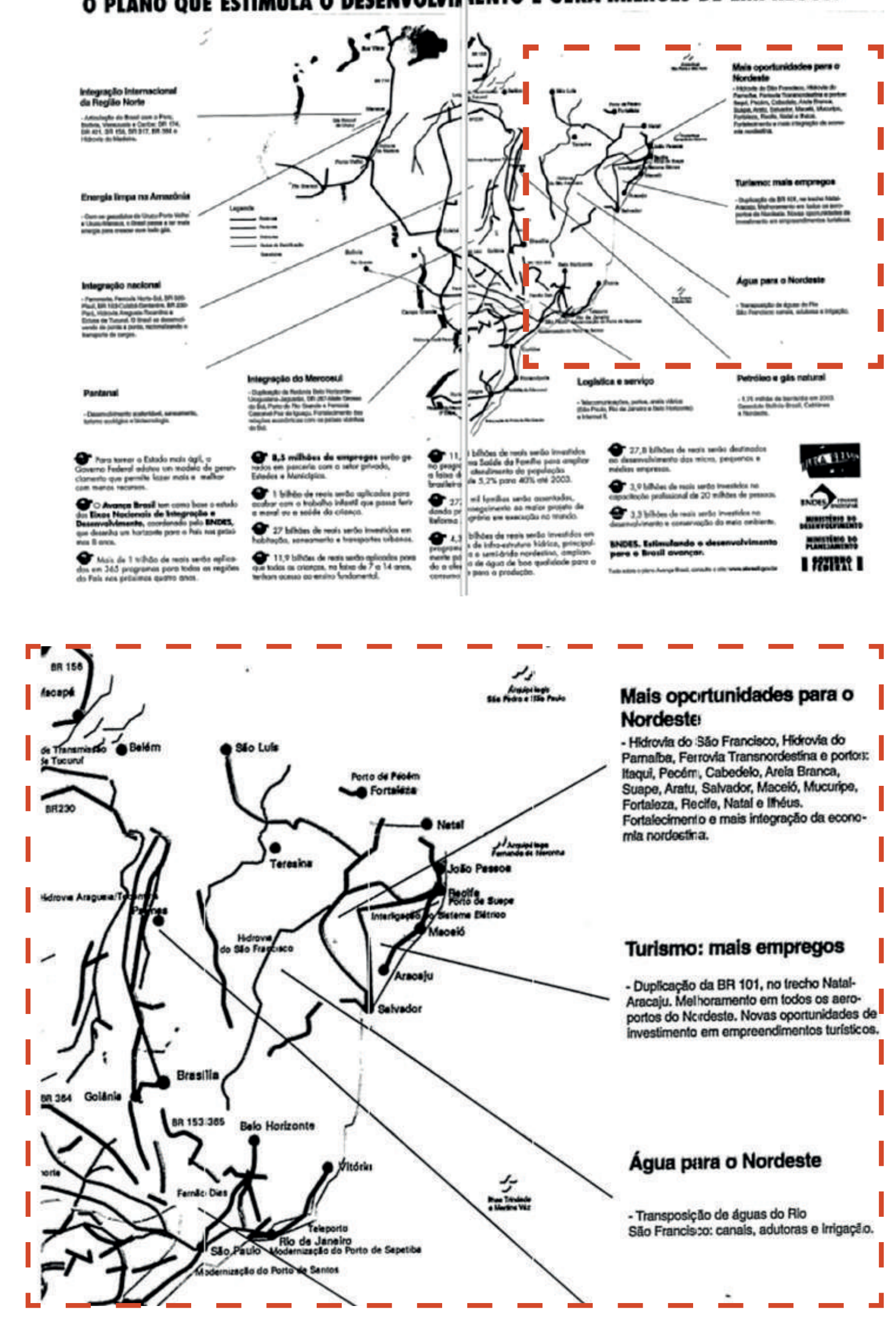

Figura $14-$ Estudo Final dos Eixos Nacionais de Integraçăo de
Desenvolvinento.
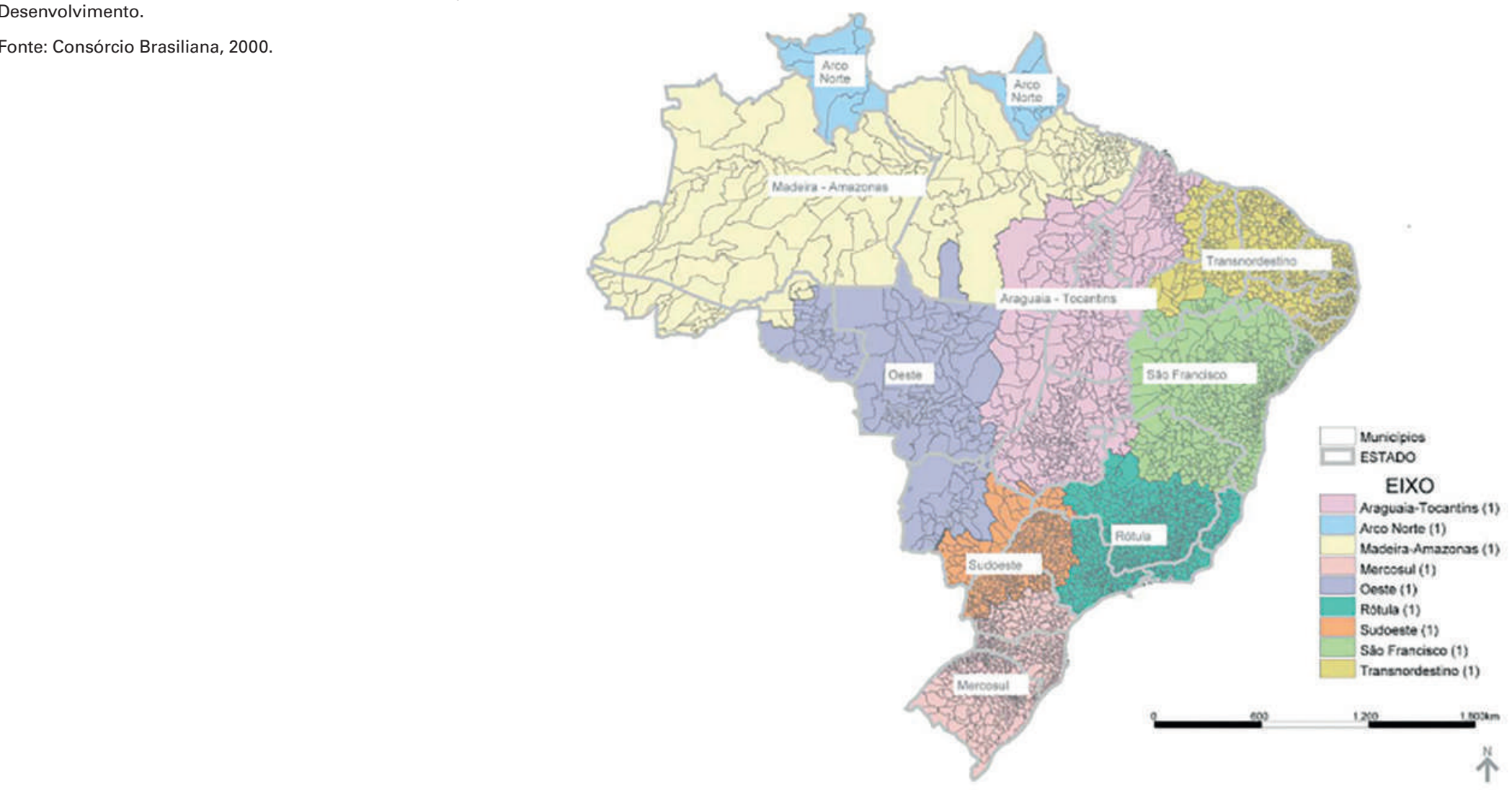

em corredores de exportação, mais racional, com vazōes muito menores reforçando a tradiçao brasileira de que as propostas anteriores. Na busca da p̧olos e o do velvimento brosileiro em um dos pontos de destaque do seu historicamente concentrado. Dessa plano desenvolvimentista "Avança Brasil" maneira reforçava-se a fragmentação (HENKES, 2014, p. 500; BARROS, 2014, em detrimento da integração do país, p.22; FILGUEIRAS, 2014, LEITE, 2005, p. 7). repetia-se a trajetoria de concentraçao

espacial e acirravam-se as historicas No iníio do segundo mandato de FHC, 29 de jutho de 1999, seria criado, em

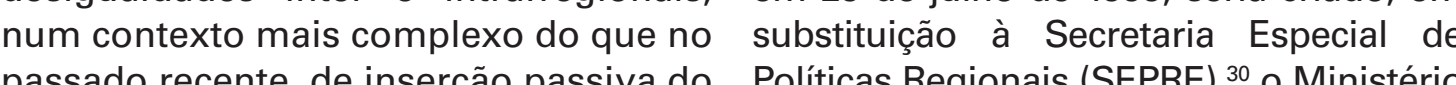
Brasit recolo (LEITÃo, 2009, p. 68). frente da pasta o empresário e senador

Durante os dois mandatos do presidente Fernando Henrique Cardoso (FHC), o projetorecebeu alyuns estudos diferentes. prevendo tanto a captacão de águs do rio São Francisco quanto a do ivo do Sono, na bacia do Tocantins, assim como vazoes maiores nas retiradas de àgua. Jà em 1998, ano eleitoral, agora candidato à reeleição $\mathrm{FHC}$, apresentou uma versão frente da pasta o empresário e e senador

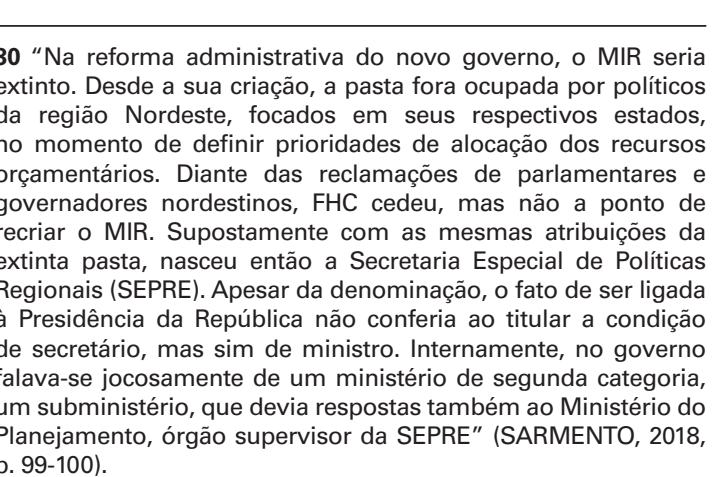


do governo no Senado, que permaneceria Pesquisas Espaciais (INPE), vinculado ao da sinergia hídrica para o cálculo de ministro até junho de 2001. Em seus Ministerio da Ciência e Tecnologia (MCT), vazôes, conceito utilizado inicialmente poucos mais de dois anos na pasta, órgăo supenvisor da SEPRE, entraila no na segunda versăo do projeto, ainda no trouxe de volta e trouxe de volta a cena pública federal o a Fundação de Ciência, Aplicaçōes e e que seria aprofundado nas versões

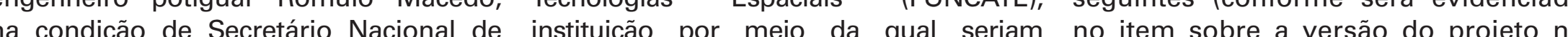
作 estava alocado o projeto (SARMENTO, do projeto básico de engenharia do Trecho 2005, p. 167). Ele retomaria os estudos I do Eixo Norte (concluído em dezembro niciados quando coordenou a segunda de 2000), correspondentes à primeira versão da Transposição, no início da versão dos Estudos de Impacto Ambiental

Foi nessa versão do projeto que surgiu 2000 bem um novo canal proposto, o Eixo Leste, que Regional da Transposicão, conclúdos em levaria água para Paraíba e Pernambuco, março de 2000 (SARMENTO, 2018, p. 155). beneficiando as regiões agreste de Já o projeto básico de engenharia do Eixo Penambuco e o Cariri Paraibano. Entre as Leste se daria de forma diferente: com a complinçao da SEPRE e a criaçao do Ministerio frequentes cosos de os cada vez mais da lnegraçao Nacional (M), sería montado população numerosa sob o risco de total São José dos Campos (SP), cidade sede (SARMENTO, 2018 p da FUNCATE, coordenado por Rômulo 156). Este novo Eixo foi encomendado Macedo. Uma nova equ pelo entâo govenador de Pernambuco, convidada e contratada pela Fundação Argues, que demandou que o diretamente e náo via subcontrataçáo de

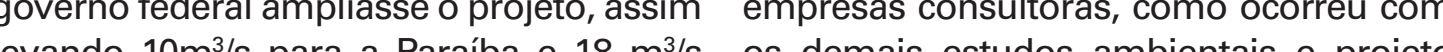
para retirados $99 \mathrm{~m}^{3 / \mathrm{s}}$ sendo $10 \mathrm{~m}^{3} / \mathrm{s}$ para Note (SARMENTO, 2018, $\mathrm{pp}$. 233-234) Pernambuco $10 \mathrm{~m}^{3} / \mathrm{s}$ para a Paraiba $37 \mathrm{~m}^{3} / \mathrm{s}$

para o Rio Grande do Norte e $42 \mathrm{~m}^{3} / \mathrm{s}$ para o Conforme será melhor apresentado no Ceará. Ou seja, entre os dois Eixos, um total Capítulo 2, nesse momento o debate de $127 \mathrm{~m} / \mathrm{s}$ de retirada de água do rio que ambiental em torno da Transposição

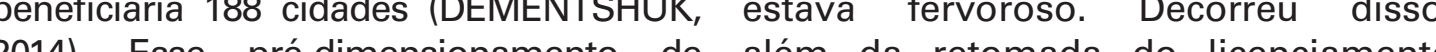
vazōes a apenas água para consumo humano mas de Insergão Regiçana dos Estudos também água para irrigacão de terras nos quatro estados beneficiados (SARMENTO, 2018, p. 168-171.

Esta se tornaria a terceira versão do projeto daTransposiçãa, contemplando o Eixo Norte e o Eixo Leste, além de outros documentos
complementares, seja referentes ao licenciamento ambiental seja de ordem e as condiçōes para a implementação Inserçáo Regional do projeto, Também por conta destes conflitos
que, segundo Sarmento (2018, pp. de cunho socioambiental em torno da 156-157), seriam concebidos para se Transposição (ver notícia referente tornarem a fonte bibliográfica que manifestaçoes de oposiçáa ao Projeto na conteria respostas técnicas para os Figura 15), durante o governo Fernando mis importantes questionamentos Henrique Cardoso houve contribuiçõos 15 estudos temáticos, além de um de constituicão do projes no processo Relário Geral É nesse contexto que medidas compensatórias e preventivas foi desenvolvido o primeiro trabalho para preservação do rio, que seriam nordando a temática da gestão de águas uma condição para que o projeto fosse no âmbito da interligação hidrográfica aprovado posteriormente, como do projeto, conforme será apresentado proposta (SARMENTO \& MOLINAS, Projeto de Conservação e Revitalização
no capítulo 2. O Instituto Nacional de 2011, pp. 7-8), retomando o conceito da Bacia Hidrográfica do São Francisco Na história da luta pela transposição
há um momento nítido quando há um momento nítido quando que o empreendimento saísse do on, a vontade política necessitav neutralizar os argumentos com forte pelos setores contrários ao substância justificatória ao frio projeto de engenharia hidráulica
mais uma vez em gestação (terceira versão) que o Governo Federal de Inserção Regional" do projeto pretendia fornecer resposta a todas as questôes relevantes levantada veracidade da dependência hídrica etentrional de uma fonte externa e m longo prazo, a real capacidad io São Francisco para
SECA Obra no Säo Francisco, estimada em US $\$ 3$ bi, enfrenta oposição de BA, SE eAL FHC quer transposição de rio no NE

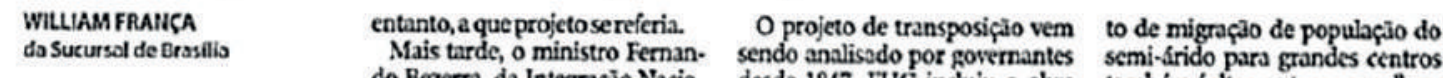

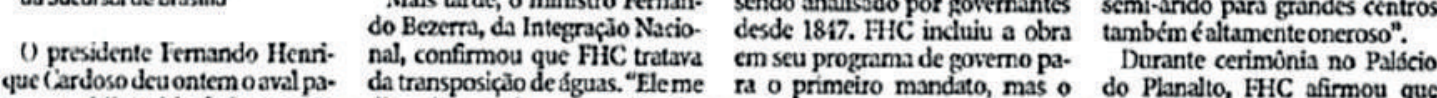

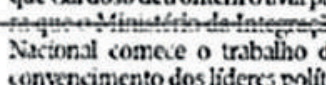
vontade política nâe bastava para embasado, capaz de discutir

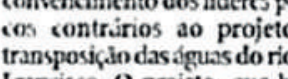

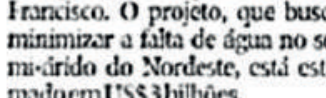

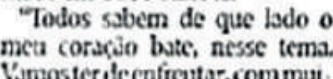

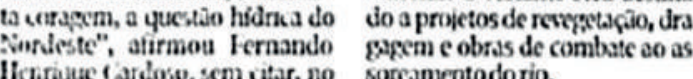
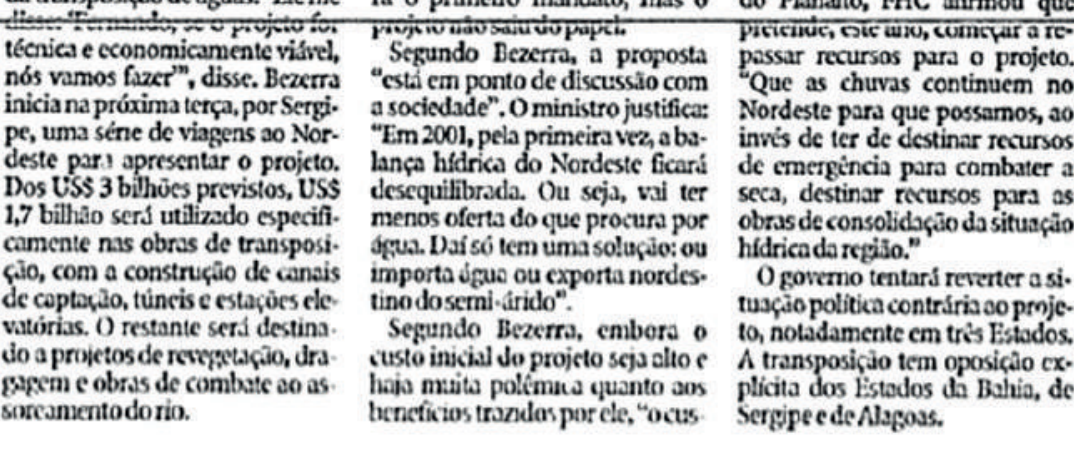

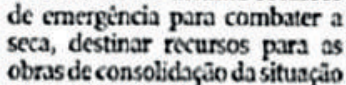

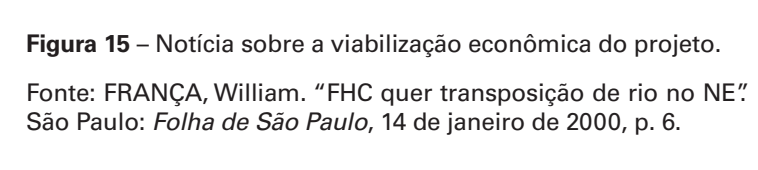

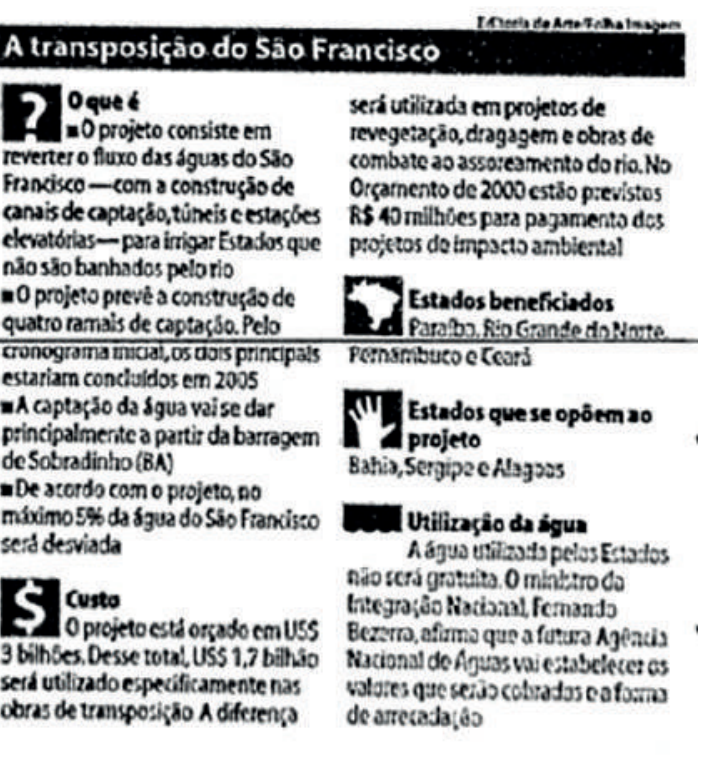

(PCRBHSF), além da criação do Comitê Luiz Inácio da Silva (Lula), deliberou pela (1) janeiro 2000; e o EIArancisco (CBHSF). Contribuições estas para o Projeto, ${ }^{32}$ houve uma articulação para análise no Instituto Brasileiro do não necessariamente a revitalização Nacional de Recursos Hídricos (CNRH) Renováveis (IBAMA). Porém, no mesmo do rio seria realizada com ênfase, para invalidar a decisão do Comitê de ano, o processo de licenciamento foì permanecendo essa pauta como Bacia (BARROS, 2014, p. 94). suspenso por ação civil pública solicitada problema a ser enfrentado até o presente $\quad$ pelo Ministério Público da Bahia, fazendo momento da escrita dessa dissertaçao, Apesar das polêmicas, no ano 2000 os com que a obra mais uma vez não se prestes a sbra do Eixo Norse estani documentos necessarios estavam quase vivbilzase.

prestes a ser concluída, e o Eixo Leste todos prontos para a viabilização da prestes a entrar em operaça. Aluca do Comitê tenha servido em alguma Estudos de Inserção Regional, bem como Säo Paulo (ver Figura 16 a seguir) em projeto, quando este, já no governo de técnicos de cunho ambiental; o pedido apresentava a sua menor vazão em 30

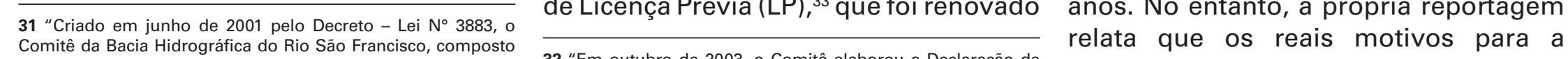

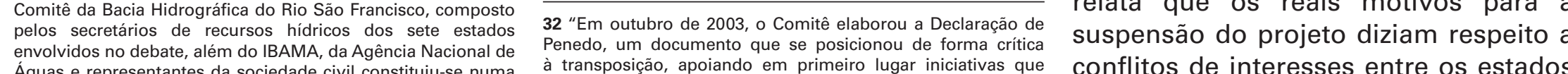
resposta às mudanças em curso em vários paises no campo beneficiassem as populaçées do Semiarrdo Setentrional, com dom

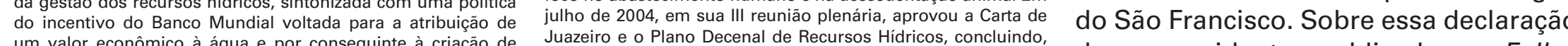

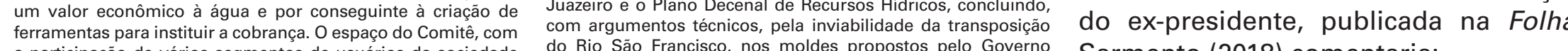

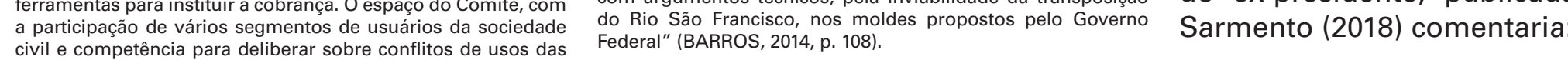

detalhes no capitulo 2 . 


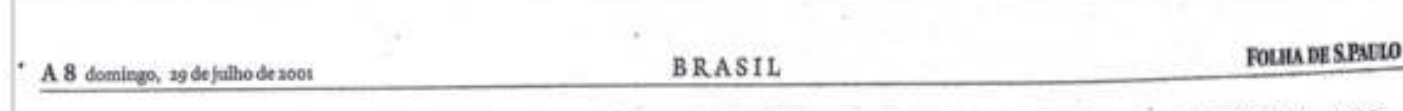

\section{FHC desiste de transpor o rio São Francisco}

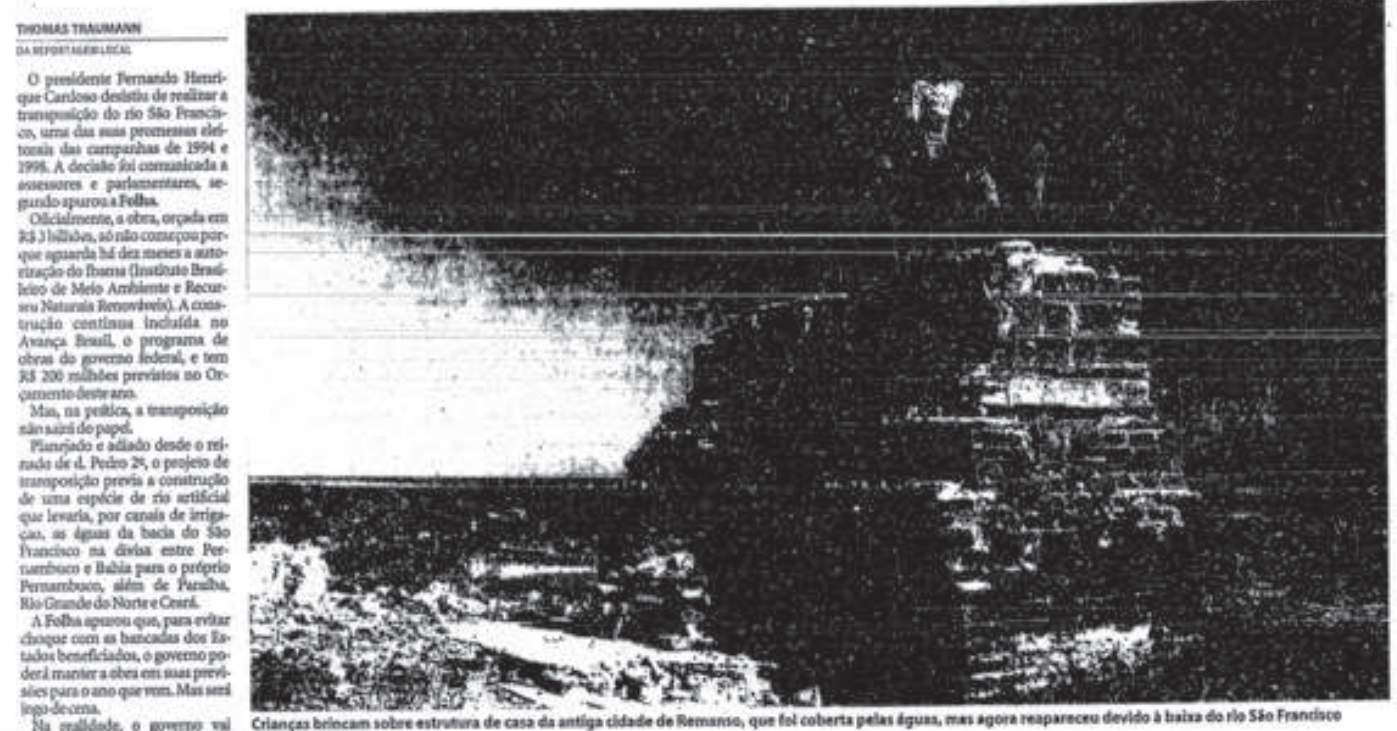
Transposiç̣ão somente evidenciava que a pouca água disponivel-fato tão circunstancial quanto simplificador da desistèn dúvida prestara como uma desculpa frágil. Afinal, a obra evaria anos para ser executada, e o baixo nivel de armazenamento de não perduraria até o ano seguinte. [...] A matéria deixa de fora o mais mportante motivo da desistência: a falta de vontade pollica de fazer a

m entrevista recente ${ }^{34} \mathrm{o}$ ex-ministro de Integração Nacional e atual Secretário de Recursos Hidricos do Ceará, Francisco Teixeira, comentou um pouco sob esses conflitos:

\begin{abstract}
[...] o grande conflito do São menos de questôes de ordem ambiental, de questōes de ordem social, e mais de disputa pelo espaço
fiscal e financeiro, orçamentário que o projeto precisaria. E, claro, naquela epoca que começou a ser debatido, a gente nao tinha ainda alguns anos da era Lula, que o Brasil conseguiu ter um certo caixa e montar o Programa com alguma sobra de recursos.
\end{abstract}

Dois anos depois, o IBAMA reprovou e devolveu o Projeto ao Ministério da (LOUREIRO et alii, 2013, p. 15). Essa seria a última versão do projeto apresentada, que seria retomada e desenvolvida no governo Lula, governo que finalmente conseguiri viabilizar esse projeto de quase do
1.2 .8

Governo Lula: a ação estata por meio de uma carteira de obras de alto impacto e a construção da Transposição

0 anúncio da retomada da Transposição do São Francisco no Governo Lula causou surpresa em boa parte de seu eleitorado, vinculado a a movimentos
sociais organizados, já que a decisão do Partido dos Trabalhadores (PT) e não havia sido mencionada nas campanhas eleitorais, nem se encontrava no seu plano de governo. De certa forma, tal surpresa em um primeiro momento impediu os movimentos sociais de e manifestarem contra a obra, visto político eleito que os representava $\mathrm{Em}$ contraponto à contestação crítica a alguns movimentos sociais, principalmente as das comunidades localizadas na região doadora, ou seja, da bacia do rio São Francisco, muitos trabahhadores furais das áreas de sequeiro já idealizavam descrenca de que a obra de fato sairia do papel (BARROS, 2014, pp. 23, 25). Notícias de jornal comentaram aquela decisão do novo presidente como uma jogada politica para manter seu eleitorado, como evidenciou a Figura 18 a seguir, indicando pue a

Luiz Inácio Lula da Silva, migrante confesso da seca, assumiu a Presidência em junho do mesmo ano, um decreto designando à Vice-Presidência da Republica com respeito a coordenação Integração Nacional Meiorial com Planejamento, Orçamento e Gestão, Fazenda e Casa Civil, visando analisar propostas existentes para viabilizar a ransposição de aguas para o semiaridido nordestino (SARMENTO, 2005, p. 34). A esponsabilíade direta do Projeto era (MI), que durante quase todo o prime mandato do governo Lula (2003-2006) foi assumido por Ciro Gomes, político cearense conhecido por sua fervorosa posiçao favorável ao projeto (ARAUJO, 2012, p. 8 


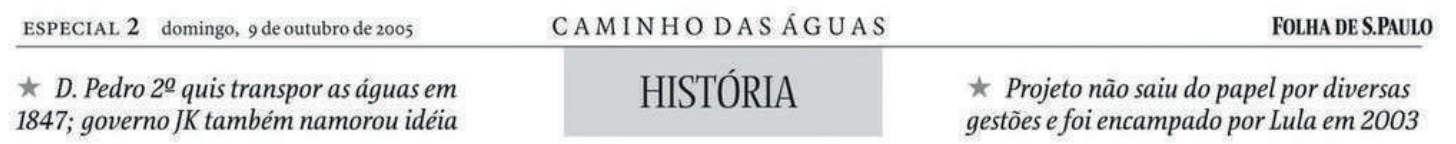

Debate sobre curso do rio remonta ao Império

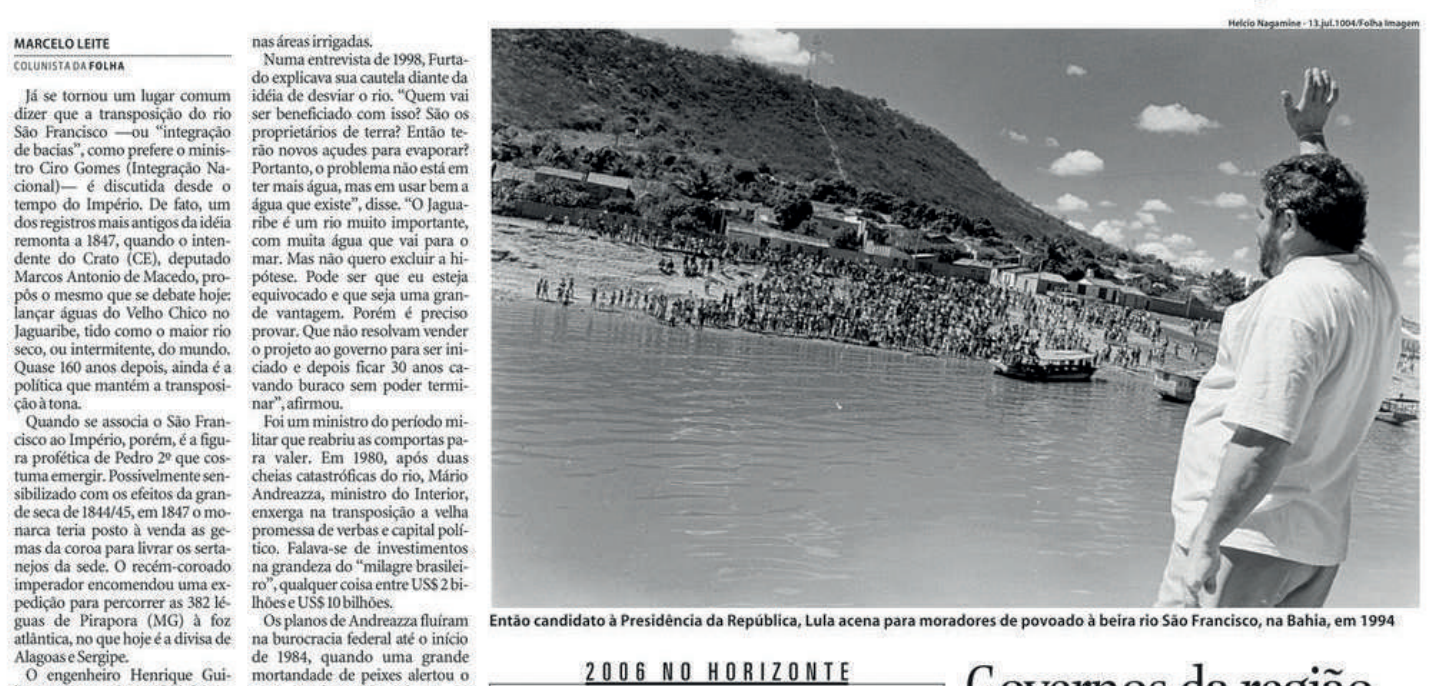

200610 म08120015 Governos da região

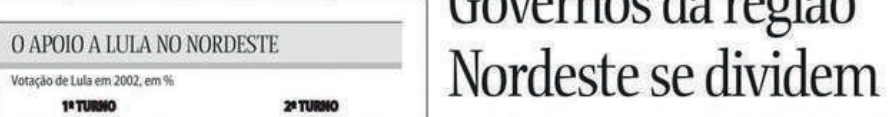

(1) (1)

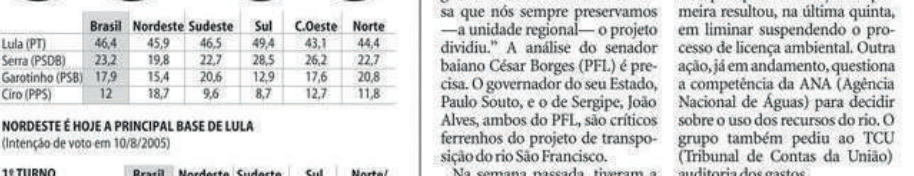

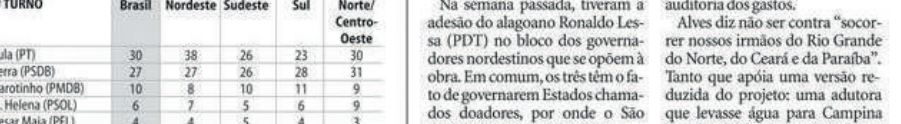

$=$

Obräpodefuncionarcomo

| trunfo eleitoral para Lula

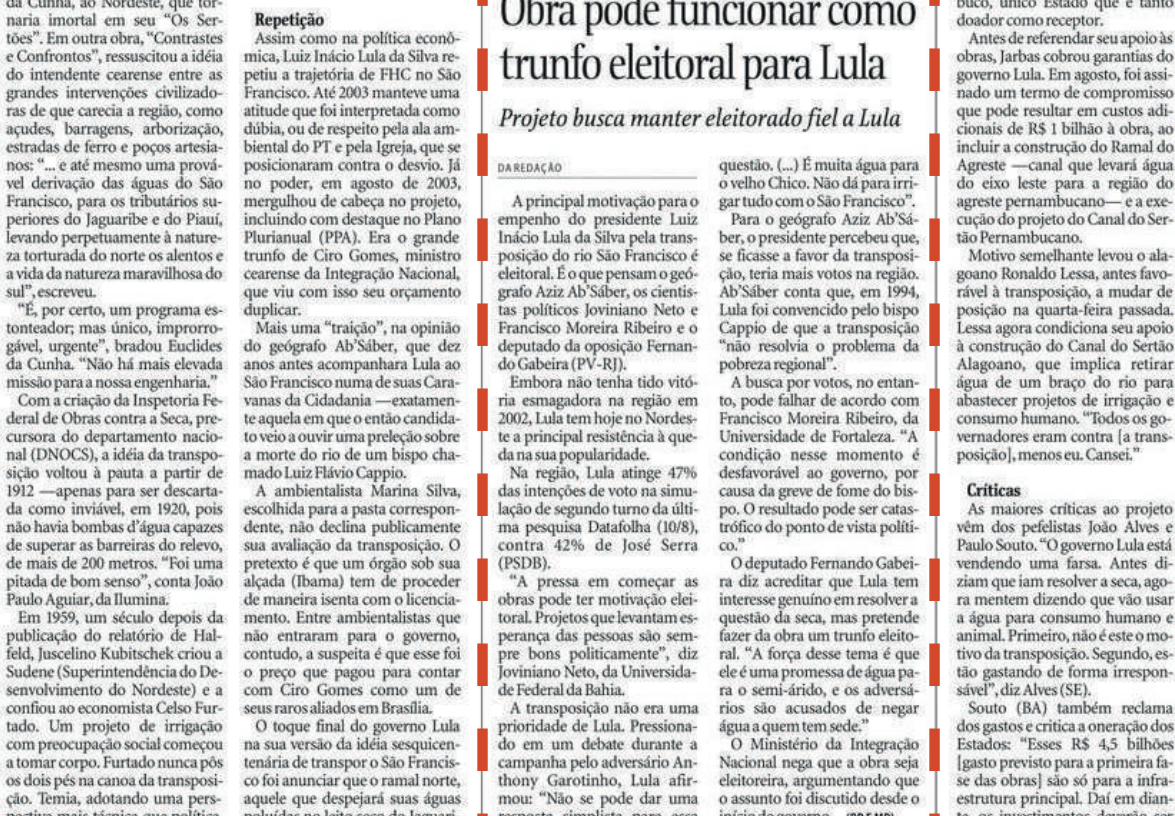

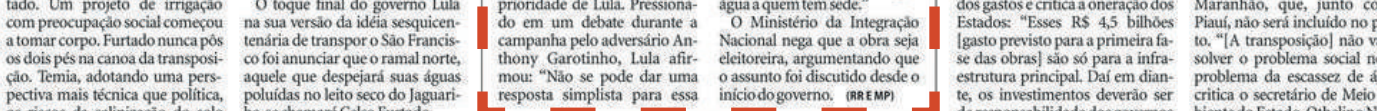

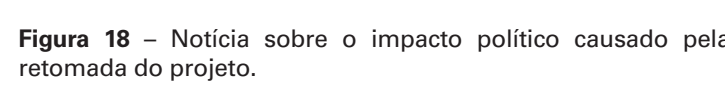

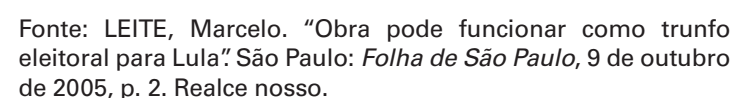

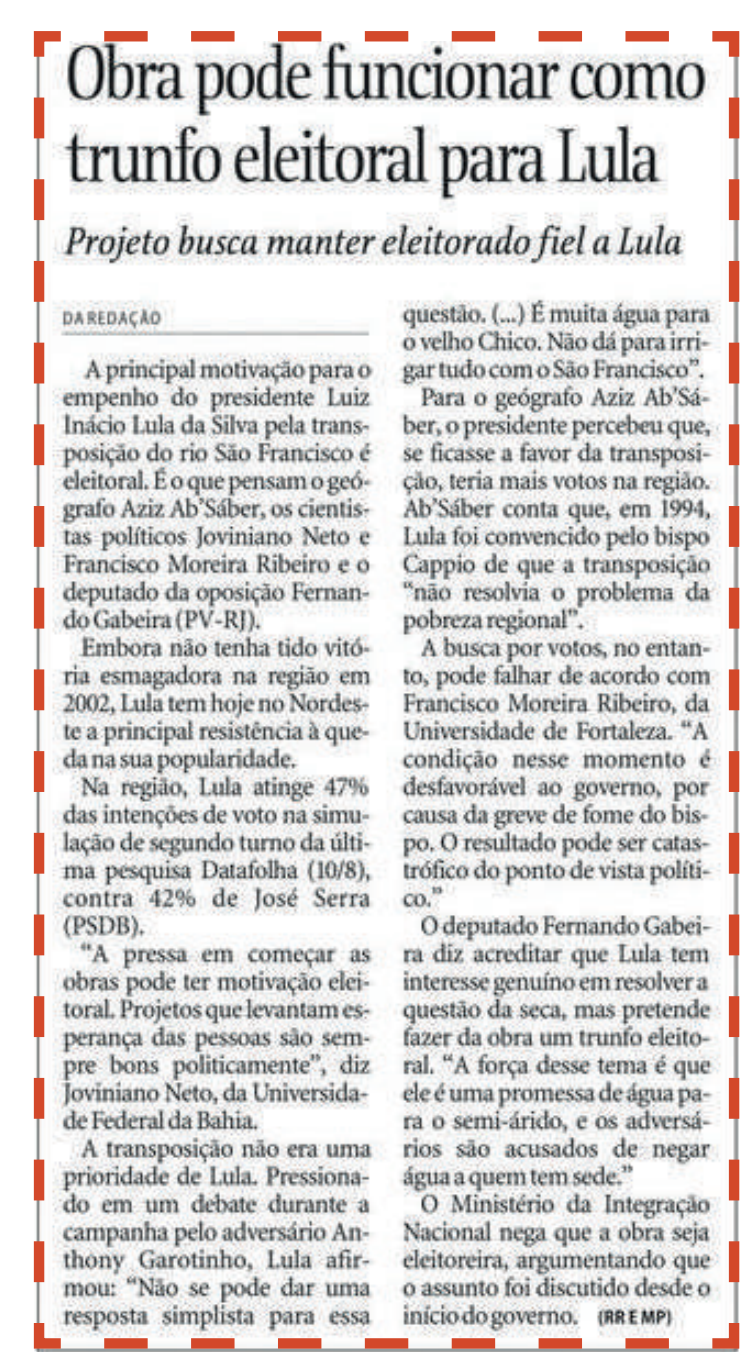

Segundo Sarmento $(2005$, p. 34), que de Aceleração do Crescimento (PAC), integrou 0 Grupo Interministerial, que promoveu a execuçăo não apenas - vice-presidente José Alencar dessa obra, mas de outras grandes promoveu audiencias pablicas nos obras de infraestrutura social, urbana estados beneficiados pelas águas do logistica e energetica distribuidas pelo e nos demais estados com insercão macroeconômico promovido pento no semiárido. Reuniu-se com órgãos PAC, que promovia diversos outros financeiros nacionais e internacionais, interesses econômicos, que o governo discutiu o projeto no Senado e na federal conseguiu driblar os interesses Câmara dos Deputados, articulou-se regionais divergentes e aprovar a e debateu tecnicamente. Dai resulta construçao da obra da Transposição. - Plano Sáo Francisco - Plano de Aliás, talvez este tenha sido um dos Brasileiro, consolidado no Relatório execucão da obra, ou seja a entrada Técnico Conclusivo, em outubro de de outros grupos econômicos de maior 2003, que o vice-presidente apresentou peso nessa disputa, representativos e o Presidente da República e os de um capital industrial mais poderoso ministérios envolvidos aprovaram. $\mathrm{O}$ e conectado com uma gama de Relatorio abrangia também o Programa interesses transnacionais - expressos, de Revitalização do Sáo Francisco, principalmente, nos empreendimentos Hrojetos de Integraçáa de Bacias da Ferrovia Transnordestina, do Distribuição de Água Ações Localizadas (PE) - sustentando a decisão política de Infraestrutura e Acões de Gestão de de realização do Projeto, a custo de Recursos Hídricos. Ou seja, programas divergências regionais não totalmente e estudos complementares ao projeto contornadas (BARROS, 2014, p. 91-92). de transposição em si, evidenciando No capitulo 3, a viabilizaçáo da obra se realizasse a revitalizaçao da bacia profundidad (SARMENTO, 2018, pp. 209-211).

o projeto que foi retomado era o que havia sido desenvolvido na gestão

A Transposição do rio São Francisco, eque, como dito anteriormente, consistia que a partir de juho de 2004 passou a equ ser chamada de Projeto de Integraçáa em nivel técnico desenvolvido para do

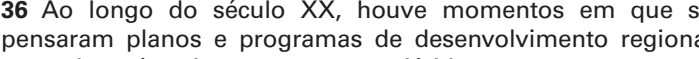

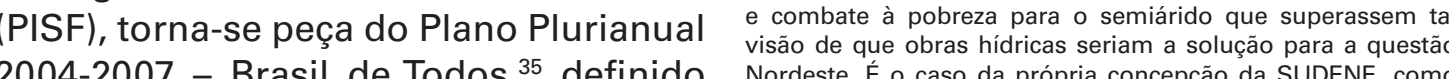
2004-2007 - Brasil de Todos, ${ }^{35}$ definido Nordeste. É o caso da própria conceppăo da SUDENE, comos pelo Governo Federal. A mudança de regionais no pais e promover o desenvolvimento da regiä nome teve importância na retórica a partir de financiamento de projetos aue deveriam ter sida

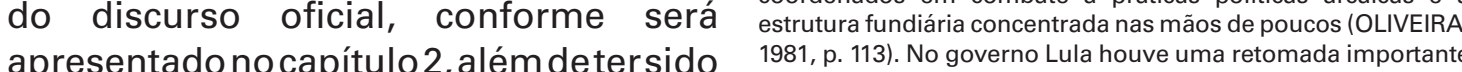

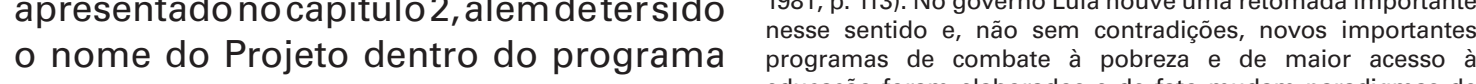
o nome do Projeto dentro do programa programas de combate a pobreza e de maior caesso 2007, o projeto foi inserido no Program

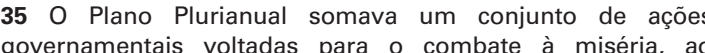
desemprego e à fome, com especial atencăa para os problemas a dos mais obores, mas tamberm obras

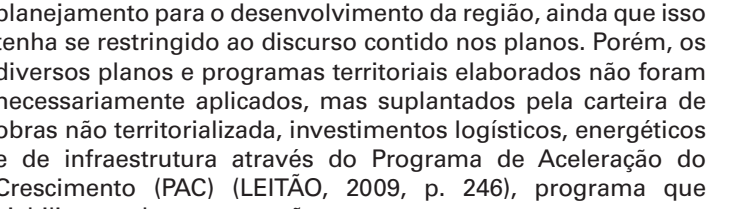

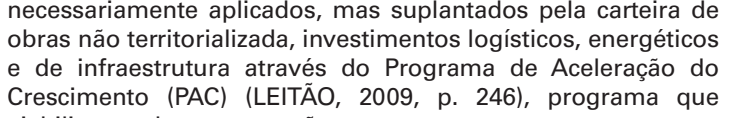


Transposição do rio São Francisco, São Francisco o PISF no governo Lula bombeamento, vinte e dois aquedutos, elaborado na década de 1980 . O que manteve sua caracteristica de obra seis túneis e vinte e seis reservatórios foi sendo modifiado ao longo destas en escala regional, prevendo 700 de pequeno porte. Ainda foram previstas versoes foi o objetivo do projeto e, junto $\mathrm{km}$ de canais de concreto, os Eixos duas pequenas centrais hidrelétricas junto a isso, a vazão de retirada da àgua do rio Norte e Leste, cruzando os estados aos reservatórios de Jati e Atalho, no Sao Francisco. Tratava-se da versão mais de Pernambuco, Paraiba, Ceara e Rio Ceará, com respectivamente 40 MW e 12 máxima de transportar até $127 \mathrm{~m}^{3} / \mathrm{s}$. águas do rio (ver Figura 17). Para efeito de ilustração, $700 \mathrm{~km}$ é, por exemplo, a $\mathrm{O}$ ponto de captação do Eixo Leste Além de ter apresentado a menor vazão distância aproximada por terra entre São encontra-se na represa de Itaparica, entre as versóes apresentadas até então, Paulo e Florianópolis e corresponde a no município de Floresta. Esse Eixo o Projeto no governo Lula propôs uma um percurso de aproximadamente nove possui cerca de $220 \mathrm{~km}$ indo ate o rio grande mudança em seu objetivo: com horas em deslocamento por terra, com Paraiba (PB), transportando em média 1990 , tornou-se fundamental para a as águas do São Francisco significa transpor água para o açude Poço da viabilização datransposição oargumento desviar águas da bacia deste rio para Cruz (PE) e para o rio Paraíba que ể de salvar cidades do semiárido que outras bacias nordestinas, ${ }^{39}$ através responsavel pela manutençắo dos haviam crescido consideravelmente de estações de bombeamento, canais níveis do açude Epitácio Pessoa (PB) nas uittimas decadas e se encontravam artificiais que, no caso da Transposição tambèm chamado de Boqueirăo. Esse em um iminente colapso hídrico. aqui estudada, sáo feitos de concreto, Eixo e chamado tambem de Trecho Portanto, diferentemente de versōes túneis, aquedutos e reservatorios." No nos documentos oficias de projeto (ver 1984, cujo projeto enfatizava fortemente no no Estudo de Impacto Ambiental (ElA- de bombeamento, cinco aquedutos, dois (t) de àgua para se estimular a irrigação oficial de divulgaçăo dro

no semiárido -, nesta versaao, o urbano Transposiçáo abasteceria doze milhoes ganhou foco, e o objetivo passou a ser o de pessoas, habitantes de trezentos e Para embasar a diminuiçáo da vazão

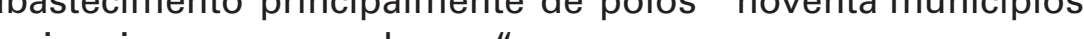

hídrica" do rio são ara "segurança essas impotantes cidades sertanejas? moposta A captaça do Elxo None ocore em raciosta nessa novaversia, eagegrúo dos um volume médio de $45,2 \mathrm{~m}^{3} / \mathrm{s}$ pelo conceito de sinergia hídrica, que, como SARMENTO \& MOLINAS, 2011, p. L sistema. Este levará água para os rios dito anteriormente, foi desenvolvido TEIXEIRA, 2018, informação verbal; Brígida (PE), Salgado (CE), do Peixe e com mais profundidade nos Estudos SOUSA, 2017, informação verbal). ${ }^{38}$ Piranhas-Açu (PB e RN) e Apodi (RN), de Inserção Regional (BRASIL, 2000a). Para efeito de ilustração, foi elaborado garantindo o fornecimento de agua para A sinergia hidrica pressuporia que uma um mapa (ver Figura 19) contendo a os açudes Chapéu (PE), Entremontes parcela adicional de vazáo do rio Sâo topografia da regia, oscanais do de seus centros urbanos, de forma a Cruz (RN) e Armando Ribeiro Gonçalves oferta desigual de água entre bacias a tornar a compreensão do que significa (RN). Pela sua extensão, foi dividido em populações (BRASIL, 2004, p. 25). Ou a escala dessa intervençáo regional e cinco trechos, denominados Trechos I, seja, quando Sobradinho estivesse na visualizar como se dá a concentração III, III, IV e VI, que foram posteriormente iminência de verter, a vazão mínima de urbana no Nordeste.

viabilizados por diferentes construtoras retirada de água do rio, que é $26,4 \mathrm{~m}^{3 / 5}$ na obra (ver Figura 19). Esse Elxo è para abastecimento, poderia ser Ainda que em sua versão mais modesta, composto por, aproximadamente, $402 \mathrm{~km}$ aumentada para ate $127 \mathrm{~m} / \mathrm{s}$, sendo

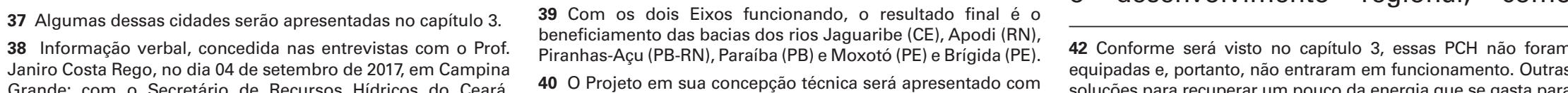

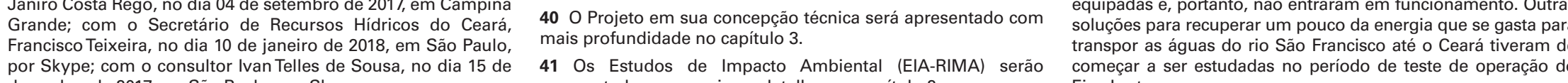

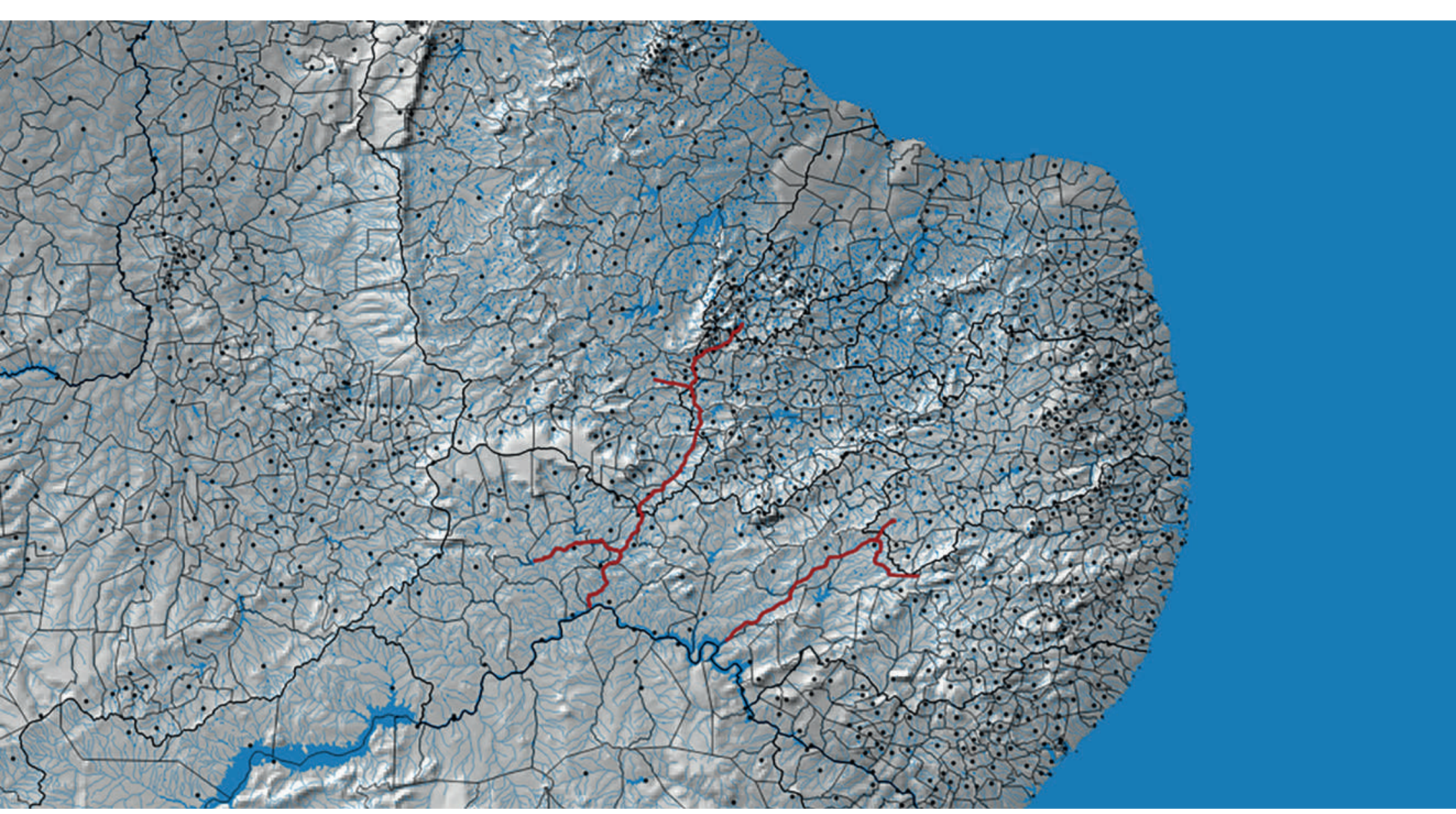

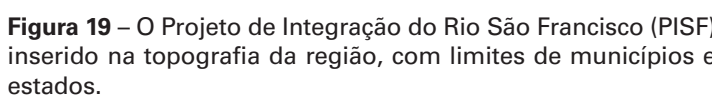

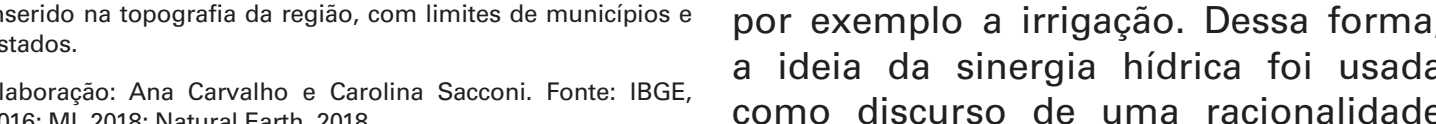
como discurso de uma racionalidade reservatórios, sem que comprometesse a disponibilidade da bacia, sem prejudicar o desenvolvimento local dos estados 2011, p. 3):

Os chamados eixos de integracãoNorte e Leste - têm respectivamente uma capacidade de condução de 99 $\mathrm{m}^{3} / \mathrm{s}$ e $28 \mathrm{~m}^{3} / \mathrm{s}$. Ora, se para consumo $\mathrm{m}^{3} / \mathrm{s}$, por que uma capacidande total
de $127 \mathrm{~m}^{3} / \mathrm{s}\left(99+28 \mathrm{~m}^{3} / \mathrm{s}\right)$ ? Para garantir, apenas com os excessos de água nos periodos de cheia do São Francisco, a sustentabilidade do Semiárido Francisco ocorrem, em média, em quatro anos por década, durante à plena carga, transferindo para os
açudes do Semiárido Setentrional a irrisória fração de $1 \%$ do volume das 391-392).

Como será apresentado no capítulo 2 do Projeto em 2004, muitos foram os documentos elaborados para embasa as justificativas do projeto. Porem, no a averno Lula, pode-se observar que à recorrência de criticas, se antecipar mudanças no discurso, que aparecem oficial do EIA-RIMA (BRASIL, 2004). Bem enumeradas por Barros (2014, p. 34), as mudanças na retórica do PISF foram as seguintes:

i) mudança do nome, onde
"integração" no lugar de
"transposiçãa" traz a noção de
benefício compartilhado por
todos, tentando romper com a
dicotomia "ganhos para estados
receptores das águas" e "perdas
para os estados doadores",


Notas gerais sobre a

historiografia do projeto

enfatizado através do conceito de da tese da revitalizacâão do Ro Rio São Francisco, ainda que com um aporte de recursos orçamentários
de valor ínfimo em relação ao total da obra; iii) tônica na lei e não
mais na capacidade tecnológica (a institucionalização da Política Nacional de Recursos Hidricos, do Samo Fra Bacia Hidrografica do Plano Decenal dos Recursos Hidricos, somada à vasta legislação ambiental, foram propulsoras dos centrados na legalidadeh iv) deslocamento do foco do rural - da irrigação - para o urbano, perdendo folego o eixo da reforma agrária, $v$ ) isolada (complementaridade obm açōes estaduais e com tecnologias de convivencia com o Semiárido); vi) como resultado do contlatetirada, produçáa energética monopolizada pela CHESF; vii) em termos de
representacăo regional, tem-se um parâmetro de desenvolvimento $e$ Nordeste litorâneo e não mais no Sul/Sudeste; viii) previsão de programas ambientais como medidas compensatórias (BARROS,

Com as articulações políticas realizadas pelo governo Lula, em especial pelo Grupo Intermisterial e Ciro Gomes; promovido pelo PAC. com econômico do novo EIA-RIMA em 2004 o desenvolvimento dos Programas Básicos Ambientais (PBAs); em 2007 o PISF obteve a Licença de Instalação (LI), a obra fosse iniciada

Embora o PISF tenha aparentemente se tornado, emsuaúltimaversão, um projeto territoriais, visando o desenvolvimento regional e, em especial, a segurança hídrica das cidades nordestinas, 0 que se poderá ver é que essas ideias mantiveram-se preponderantemente no campo do discurso. O que se viu ua pratica foi a construça de mais uma grande obra hidrica de combate planejado e o executado, assim como de mprevistos em sua viabilizacão, afina não se trataria de uma obra simples, mas uma obra muito complexa e sofisticada.

A seguir, no capítulo 2, serão apresentados os documentos que em especial os que tratam questões territoriais, da relação com os assentamentos, os que trouxeram concepção de desenvolvimento regiona do Projeto. Ja o capitulo 3 tratará das caracteristicas técnicas do projeto, de sua viabilizaçáa via PAC e da sua execuçāo se deu a presença (ou ancincia) do obra nos lugares por onde passou, em suas relações com as condições preexistentes. 1818. A PRIMEIRA IDEIA DE TRANSPOR AS AG

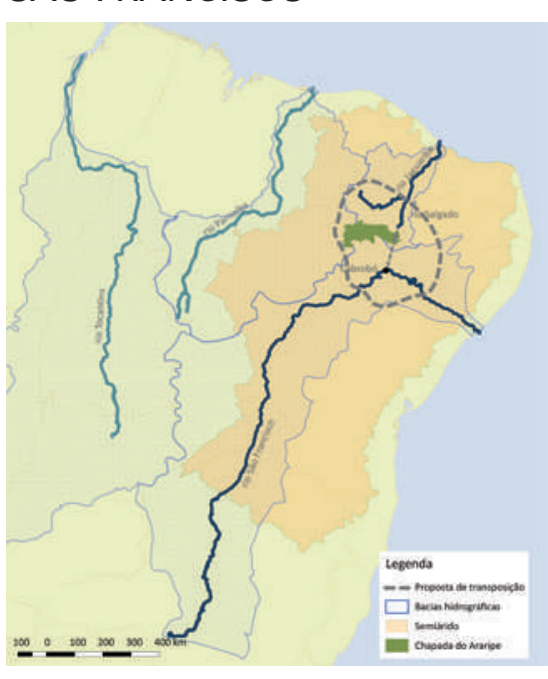
DOM PEDRO II

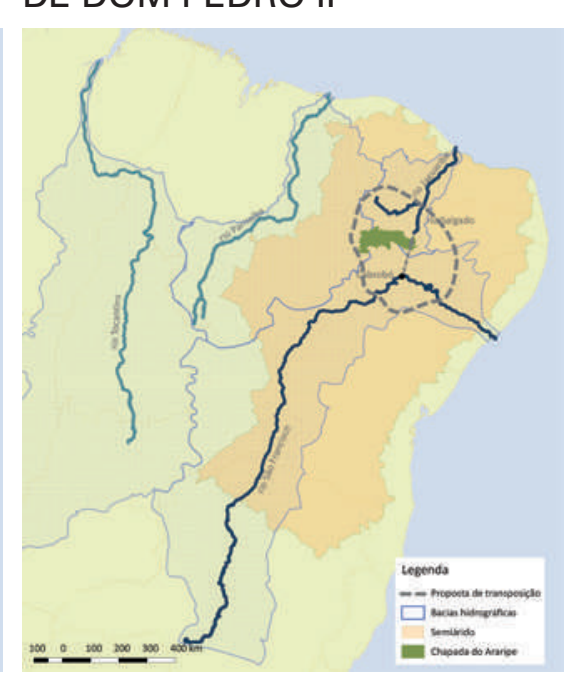

1984. GOVERNO MILITAR EA PROPOSTA AMBICIOSA

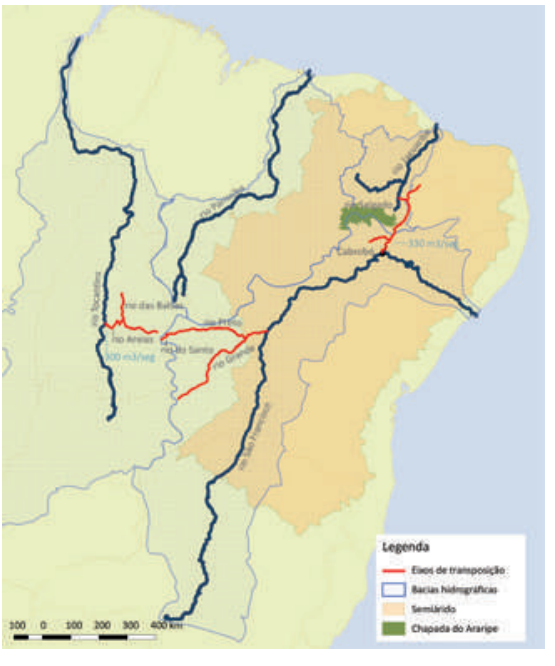
94. A NOVA CONSTITUIÇÃ

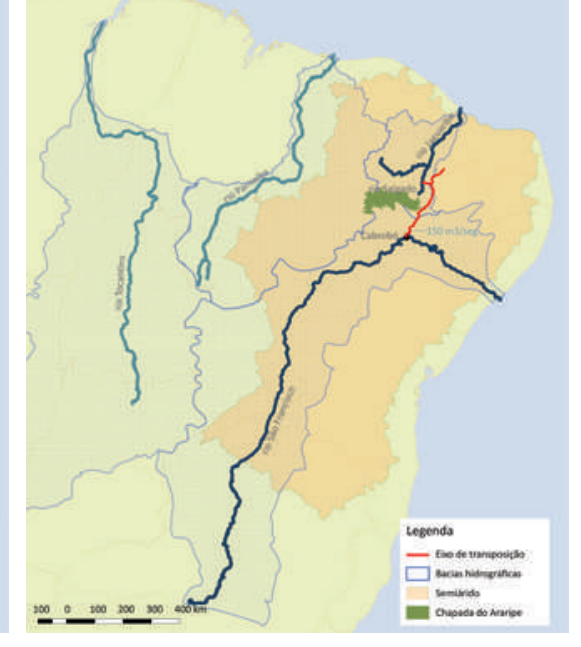

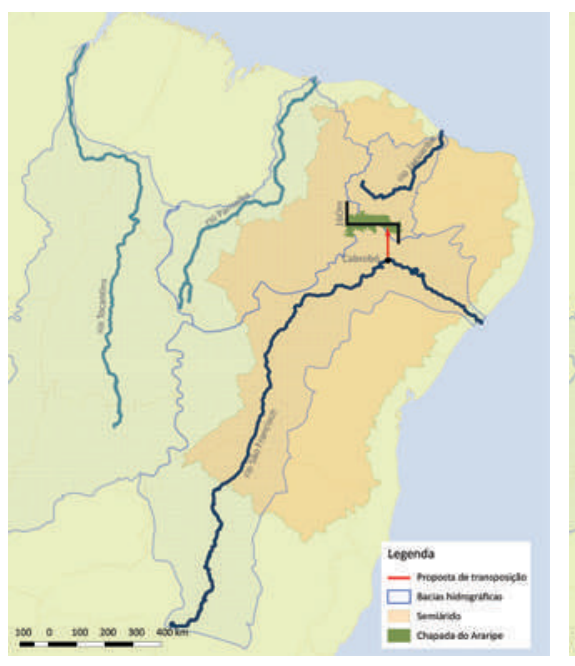

1996-2002. FHC, O EIXO

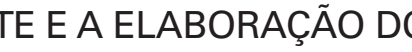
DO PROJETO

1919. A SOLUCÃO PARA

促

RRUPÇAO

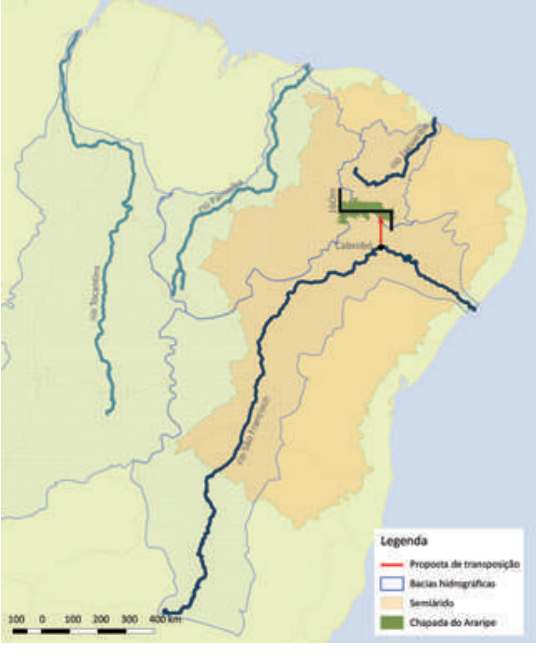

2003. GOVERNO LULA: A AÇA ESTAAL POR ME OBARAS DE ALTO IMPACTO EA CONSTRUCÃO DA TRANSPOSIÇẢO
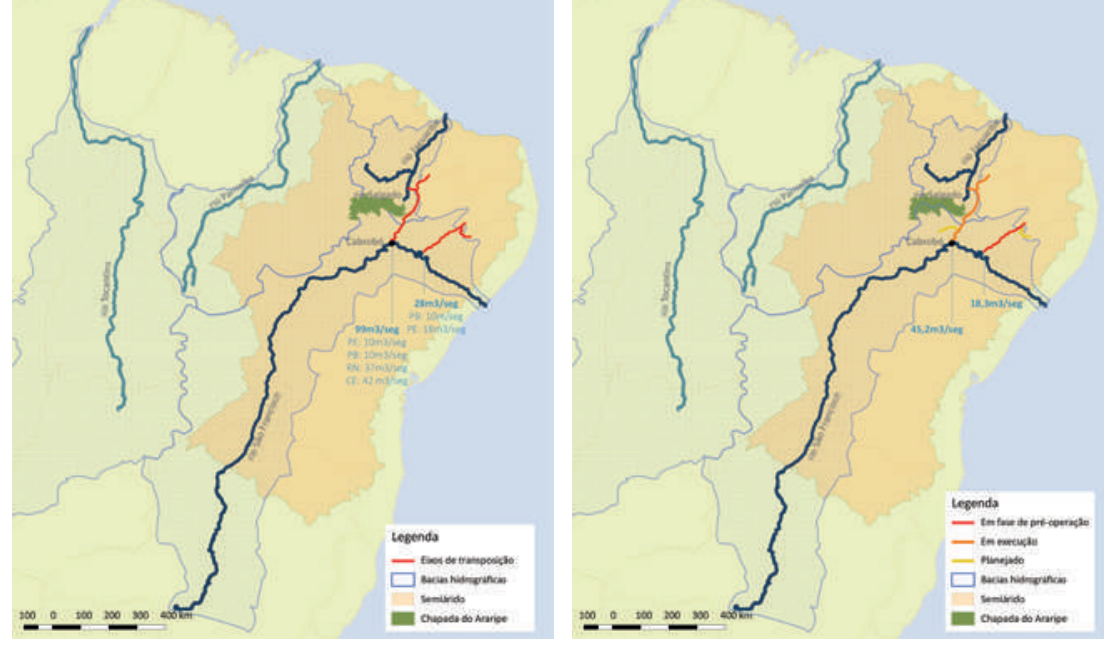
Após uma breve historiografia da obra da Transposição do rio São Francisco é possível observar que o projeto foi resgatado em diversos momentos ao longo da história, geralmente em decorrência de alguma grande seca, sendo que, terminada a estiagem, o projeto era abandonado. Além disso, a cada retomada, independentemente do momento histórico, do tipo de governo, fosse ele imperial, militar, governo democrático de direita e esquerda, alteravam-se os interesses e objetivos do projeto, porém seu traçado pouco mudou (ver Figura 20). ${ }^{43}$ Note-se que algumas ideias se desenvolveram no século $X I X$, mas no século $X X$, quando a questão regional assumiu centralidade no debate governamental, a profusão de projetos para transpor o rio se tornou menos espaçada. Já no início do século $X X I$, a ideia se realizou, num momento em que a gestão federal empreende esforços para recuperação da capacidade de planejamento e de investir em infraestrutura regional e urbana.

Embora houvesse um discurso técnico e/ou político que embasasse as especificidades de cada versão do projeto ao longo da história, inclusive a última, que foi parcialmente construída, as divergências e permanências entre elas evidenciam que o modelo de infraestrutura foi pouco questionado, permanecendo a ideia da grande obra como a grande solução para a seca, ou a grande infraestrutura para promover desenvolvimento, independente do objetivo final, dos seus grandes impactos socioambientais e de como esse grande objeto se relacionaria com os lugares por onde passasse, lugares que tanto mudaram ao longo do tempo.

Apresentado como a grande "solução para a seca", formatada em um sistema ainda mais complexo e vultoso de engenharia, [tal modelo]

$43 \mathrm{Um}$ agradecimento aos engenheiros Francisco Jácome Sarmento e Rômulo Macedo, que em entrevista no dia 11 de setembro de 2017, em João Pessoa, puderam contribui com mais informações e confirmações do mosaico aqui cartografado.

\begin{abstract}
pode ser caracterizado com o que Milton Santos (1994) denomina de "grandes objetos": grandes coisas artificiais localizadas no espaço, produtos da história dos homens e dos lugares, e cujos sistemas técnicos definem-se pela ubiquidade, universalidade, tendência à unificação, sob um mesmo comando; servem aos atores hegemônicos da economia, da cultura, da política; tornam-se a problemática regional de uma região que resta natural para uma quantidade de coisas e que, de supetão, recebe objetos imensos, cheios de intencionalidades, dotados de uma força que jamais antes se viu (BARROS, 2014, p. 28).
\end{abstract}

Pensada desde o meio do século XIX, a grande obra da Transposição atravessou um mesmo território em estados radicalmente diversos. Enquanto no início do século $X X$ a região semiárida encontrava-se em processo de despovoamento, em um contexto de tentativa de diminuição das pressões fundiárias pelo Estado, no século XXI, um semiárido já urbanizado recebia uma proposta de Transposição que se convertera prioritariamente na promoção de segurança hídrica aos centros urbanos da região. Em suma, a Transposição perpassou todas essas transformações do território sem grandes alterações em seu desenho, conformando-se, pois, em uma obra que certamente gerou e ainda pode gerar muitos conflitos em sua realização e operação. 


\section{A compensação ambiental e a integração regional que não se concretizam}

\begin{abstract}
A partir da década de 70 , houve no Brasil (e no mundo) um crescimento importante na discussão acerca da questão ambiental, da necessária busca por caminhos alternativos de desenvolvimento, da necessidade da avaliação dos impactos que a industrialização promoveu. Esse movimento ocasionou no Brasil a institucionalização dessas pautas, sendo criadas leis, instituições e órgãos governamentais destinados à proteção ambiental. Em 1981, o licenciamento ambiental passou a fazer parte do ordenamento político administrativo brasileiro como instrumento da Política Nacional do Meio Ambiente (PNMA), pela lei 6.938. Já em 1988, a Constituição Brasileira ratificou o licenciamento por meio do artigo $225 \S 1^{\circ}$, ao prever a necessidade de Estudo de Impacto Ambiental (EIA-RIMA) para atividades causadoras de significativa degradação ao meio ambiente.
\end{abstract}

Nesse contexto, a condição para que a obra daTransposição do rio São Francisco saísse do papel era cumprir os requisitos para a obtenção das licenças ambientais, o que deu origem à realização do Estudo de Impacto Ambiental (EIA-RIMA) e dos Planos Básicos Ambientais (PBAs). Em decorrência disso, como apresentado no capítulo 1, no governo de Itamar Franco (1992-1995), foi iniciado o processo de licenciamento daTransposição conforme exigência da legislação ambiental. O Estudo de Impacto Ambiental teve sua primeira versão elaborada no governo Fernando Henrique Cardoso (1995-2003), foi protocolado e teve o licenciamento suspenso algumas vezes com as disputas políticas em torno do projeto.

Além dos estudos que geraram os documentos para o licenciamento da Transposição do rio São Francisco, houve outros documentos técnicos que fizeram parte de seu processo de planejamento, tais como os Estudos de Inserção Regional ou o Relatório Síntese de ViabilidadeTécnico-Ambiental, ambos publicados em 2000, elaborados no governo $\mathrm{FHC}$ e considerados na gestão seguinte, ou seja, na última versão do projeto. ${ }^{1}$ A última versão do EIA-RIMA foi elaborada no governo Lula, viabilizando, assim, o projeto.

Apesar de um amplo conjunto de documentos elaborados por exigência da legislação ambiental, as condicionantes da Licença de Instalação (LI) tiveram uma discrepância entre o discurso retórico em torno da obra e a prática, inclusive havendo algumas denúncias sobre problemas ou falta de execução das condicionantes ao longo da obra, o que dificultou até certo ponto a obtenção da Licença de Operação (LO) (IBAMA, 2018), ${ }^{2}$ como se verá mais adiante. $O$ debate ambiental, no caso da Transposição, serviu em grande medida para a construção dos argumentos e readequações no projeto por parte do governo federal para que ele se viabilizasse. Neste capítulo, serão apresentadas um pouco dessas disputas em torno da questão ambiental e um pouco sobre como se deu o processo de planejamento da Transposição (com enfoque no tema da inserção regional) e a elaboração dos documentos técnicos e ambientais que permitiram a viabilização da obra. Não se trata aqui de avaliar com detalhes o tipo de mitigação de impacto proposto, ou como se refletem ou não na execução do Projeto (conforme será visto no capítulo 3), mas sim de avaliar como se deu esse planejamento.

1 Isso pode ser afirmado pois os Estudos de Inserção Regional se encontram no site do Ministério de Integração, na página dos documentos técnicos referentes ao Projeto de Integração do rio São Francisco com Bacias Hidrográficas do Nordeste Setentrional (PISF), demonstrando que eles foram considerados no projeto vigente. Documentos disponíveis em: <http://www. integracao.gov.br/web/projeto-sao-francisco/documentostecnicos $>$. Acessado em 20 de agosto de 2018.

Além disso, em entrevista no dia 20 julho de 2017, em São Paulo, o engenheiro Marcos Godoi, da Engecorps - empresa do Relatório Síntese de Viabilidade Técnico pela elaboração Ambiental (2000) e pelo projeto básico do Trecho I, que serviu de modelo para o desenvolvimento de todos os outros trechos -, afirmou que o documento foi considerado na versão seguinte do projeto.

2 Informações podem ser verificadas no site do Instituto Brasileiro do Meio Ambiente e dos Recursos Naturais Renováveis (Ibama), nos documentos do processo de Licenciamento Ambiental do PISF, disponível em: <https://servicos.lbama.gov. $\mathrm{br} /$ licenciamento/consulta_empreendimentos.php $>$. Acessado em: 02 de agosto de 2018. 
2.1

\section{$O$ contexto das exigências}

ambientais

No final da década de 60 , o debate das exigências socioambientais terem ambiental foi tomado por problemas que sido uma conquista para a luta pelos emergiram associadosaindustrializaçao. direitos sociais e para a preservaçăa poluição industrial, radiaçăo atômica, do meio ambiente, o processo de expansáo urbana e crescente percepçăo institucionalizaçao do debate teve suas da escassez dos recursos naturais, contradiçoes, havendo muitas críticas da relação entre ambiente e sociedade. daqueles que se entendiam como parte Dessa forma, nos anos 70, o resultado do "movimento ambientalista",alegandoprático desse debate e da movimentação se que as leis de licenciamento ambienta social, política e cientifica dessa epoca foi passaram a ocultar os conflitos com a criação de departamentos de governo seu pragmatismo ao propor soluçōes para o meio ambiente na maioria das paliativas, sem questionar e mudar legislação e do planejamento ambiental, que os empreendimentos propmento con organizações ambientais internacionais

e um rápido aumento no número de $\mathrm{O}$ licenciamento ambiental foi instituído membros de organizaçôes ambientais pela Lei 6.938/81, que criou a Política não-governamentais (SOUZA, 2009, pp. Nacional de MeioAmbiente (PNMA) eque 2, p. 52). estabelece, em seu artigo $2^{\circ}$, como um os seus objetivos "assegurar condiçōe

Segundo Souza (2009, p. 39), a primeira do der fase do debate se deu até os anos 60 , quaniental conservacionista. Jáa a desenvolvimento econômico-social com segunda fase se desenvolveu na virada a preservaçáo da qualidade do meio dos anos 60 para os anos 70, quando ambiente e do equilíbrio ecológico" a percepção dos problemas causados (BRASIL, 1981).

pelo processo de industrialização

pela Esse artigo $4^{\circ}$ da Lei da PNMA já meio poderia indicar o que se tornou um

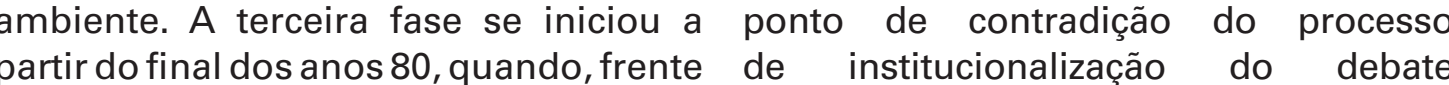
ao fracasso experimentado na década ambiental, visto que o licenciamento de 70 quanto ao enfrentamento da crise ambiental perdeu sua funçāo ambiental, pautado pela oposiçáa entre contestatária ao priorizar muitas vezes discussão passou e mero ambita em torno as propositos desenvolvimentistas das mudancas ambientais globais. a rentabilização de capitais em nome da geracão de emprego e ron No Brasil, a relação entre meio ambiente (ACSELRAD, 2010, p. 107). Dessa forma, a luta por justiça social ganhou os licenciamentos ambientais passaram importância no final da década de 80, a ser, em grande parte dos casos, quando ocorre a institucionalizaçáo das de leis e políticas de protecão do męo ambiente. Houve também o surgimento de organizações com corpo técnico administrativo profissionalizado, com capacidade sistemática de captaçáo de recursos financeiros. Porem, apesar apenas mais uma etapa administrativa $\S 1^{0,7}$ ao prever a necessidade de No caso do Projeto de Integração do Rio do empreendimento, sem colocar em estudo de impacto ambiental para Sao Francisco com as Bacias Hidrográficas questão, por exemplo, a possibilidade atividades causadoras de significativa do Nordeste Setentrional (PISF), a Licença de os estudos de avaliaçao ambiental degradação ao meio ambiente, com a Previa' foi emitida em 29 de abril de 2005 , projeto.

O conceito de impacto ambiental foi definido em 1986 por meio da Resolução
Conama $n^{\circ} 01 / 86$, que, segundo o artigo $1^{\circ}$, consiste em "qualquer alteração das propriedades fisicas, quimicas e por qualdo forma ambiente, causada por qualquer forma de matéria ou humanas que, direta ou indiretamente, afetam: I- a saúde, a segurança e o bemestar da população; II - as atividades do meio açoes esteticas e sanitárias agosto de 1981, sobre a Politica Nacional recursos ambientais" (BRASIL, 1986)..$^{5}$ 99.274, publicado em 1990, estabeleceu resolução $n^{\circ}$ 01/86 ainda exigiu a competência do Conselho Nacional Ambiental (EIA) para o de de atividades modificadoras do meio Estudos de Impacto Ambiental para ambiente, estabelecendo a inclusão fins de licenciamento, assim como, das questôes socioeconómicas no definindo o conteúdo desses estudos
diagnóstico ambiental e análise dos no que toca a: diagnóstico ambiental diagnostico ambiental $\mathrm{e}$ análise dos no que toca a: diagnostico ambiental impactos ambientais do projeto e da área; descrição da ação proposta e
suas alternativas. No Art. $11 \S 2^{\circ}$, a suas alternativas; identificação, análise resolução institui a Audiência Pública e previsão dos impactos significativos, (AP) como instrumento de informação positivos e negativos (BRASIL, 1990). sobre o projeto e seus impactos Também no mesmo decreto foram ambientais e discussão do Relatório de definidos os três tipos de licenças Impacto Ambiental (RIMA), tendo sido emitidas pelo poder público
regulamentada em dezembro de 1987 processo de licenciamento:

regulamentada em dezembro de 1987 e estabelecendo que seria obrigatório

I-Licença Prévia (LP) “na fase preliminar conteúdo do EIA em análise e do seu do planejamento de atividade, contendo 年 criticas e sugestōes los presentes as nas fases de localizaçaoo, instalação 1986). 6

Em 1988, o licenciamento ambiental Brasileira, por meio 5Texto completo da resoluca conama

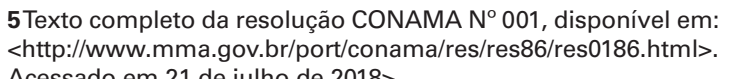

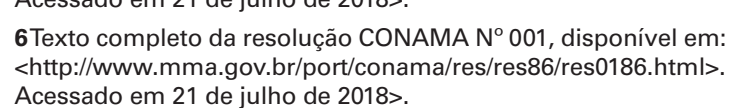

operaçaoo, observados os planos municipais, estaduais ou federais de us do solo" (BRASIL, 1990):

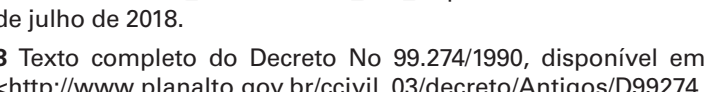

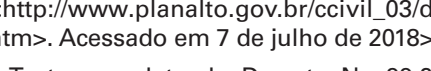

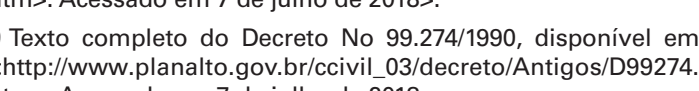

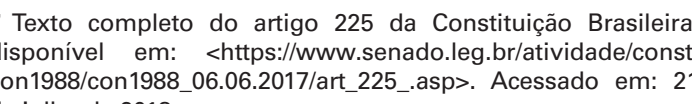
com a entrega dos Estudos
reelaborados (IBAMA, 2005).

II-Licença de Instalação (LI), "autorizando o início da implantação, de acordo com as especificaçoes constantes do Projeto Executivo aprovado" (BRASIL, 1990)." Para que um empreendedor obtenha a Ll, poranto, ê preciso seguir as programes contan incluindo as medidas de controle modo que para solicitar é necessário "lecriço e regularidade no Cadastro "écnico Federal (CTF), Processo de licenciamento ambiental federal ativo; ( Ambiental (PBA) aprovado e Cópia da publicaçáo do pedido da Licença de nstalação (LI)" (IBAMA, 2017). ${ }^{4}$

Conforme a Instrução Normativa $\mathrm{N}^{\mathrm{a}}$ ião (DOU) no dia 18 Oe ficial da 15 a concessão da julho de stalação (LI) é subsidiada pelo Projeto

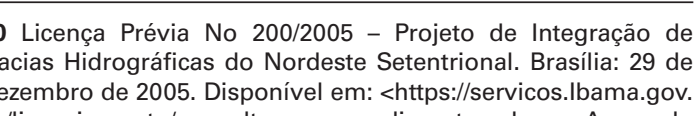

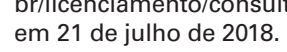
I Parecer No $031 / 2005$ - COLLC/CGLCIIILO/BAMA. Anális

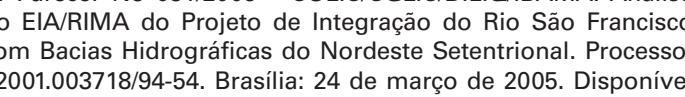

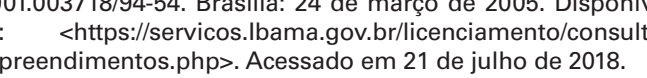

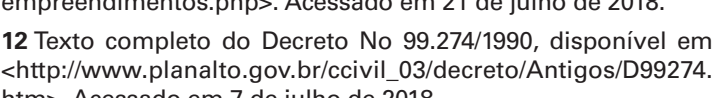

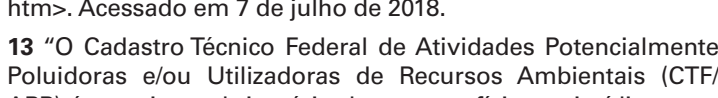

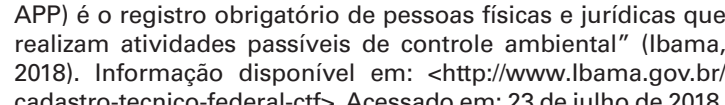

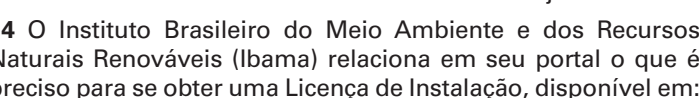

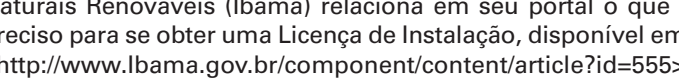

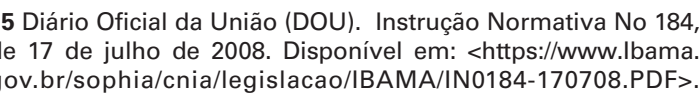


Básico Ambiental (PBA), o Plano de Prévia e de Instalação" (BRASIL, 1990). ${ }^{19}$ empresas poluidoras e governos, Compensaçáo Ambiental e, quando couber, o Plano de Recuperação de
Áreas Degradadas (PRAD) e o Inventário Florestal para emissão de autorização de supressão de vegetação.

O PBA, o Plano de Compensacăa
Ambiental e o Inventário Florestal deverão ser elaborados em conformidade com os impactos metodologias, normas e padrōes
estabelecidos pelo IBAMA, bem como estabelecidos pelo IBAMA, bem como
aos fixados nas condicionantes da LP aos fixados
(DOU, 2008).

No caso do PISF a Licença de Operação parcialmente concedida, visto quve Eixo sociais (ACSELRAD, 2010, movimentos Norte ainda se encontrava em obras, como OPISF, os emmpendimentos muitas portanto ainda longe de se obter a LO. vezes tiveram como suposta justificativa ã o Eixo Leste havia entrado, no ano de estimular o desenvolvimento economico, 2017, em período de pré-operação (em que colocando a questão ambiental como foram feitos testes de operaçao e últimos um empeciho, pelo fato de justament reparos e obras), obtendo a LO em outubro as propostas de desenvolvimento se de 2018. Porem, a operaçao propriamente basearem na lógica e nas prioridades de dita ácio de 2019, pois os estados ainda do meio ambiente logica da preservaça estavam assinando os contratos de minorias e diversidades territoriais.

Para o PISF, a Licença de Instalação'16 "compra" da água, fazendo com que a foi concedida em 23 de março de 2007, LO não fosse, todavia, pública, e algumas dado que o Instituto Brasileiro do Meio questōes de operação do PISF, tais como Ambiente e dos Recursos Naturais valor do $^{3}$ de água e gestão dos recursos Renovávis (IBAMA) considerou hídricos, ainda se encontrassem en que as condicionantes da LP foram discussăo. Enquanto a agua se encontra na empreendedoro Ministério deIntegração é do Operador Federal que, até o momento Nacional (MI), e que os detalhamentos da entrega desta dissertação, era dos programas ambientais apresentados Companhia de Desenvolvimento dos Vales foram considerados adequados (IBAMA, do São Francisco e do Parnaíba (Codevasf) 2007). ${ }^{17}$ Porem foram exigidas cinquenta (Decreto n. 5.995/2006). ${ }^{20}$ No entanto, nove condicionates a serem já existia naquele momento a ideia, cumpridas antes do requerimento da projetada para um futuro não tão distante, Instalacão foi renovada em 2013,18 com validade para mais seis anos.
(RAMOS, 2018, informaçăo verbal).21.

III - Licença de Operação (LO), Aolongodosanosemqueasleisambientais autorizando, após as verificaçôes passaram a ser aplicadas, desenvolveu "icessarias, licenciada e o funcionamento de seus havido um processo de "substituição" de acordo com o previsto nas Licenças "ecologismo de resultados", progmático 16 Licenca de Instalaçăo No 438/2007- Projeto de Intregracăa de decnicista. Por outro, alguns atores e autores

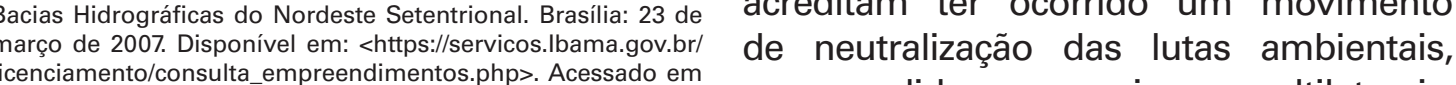
21 de julho de 2018.

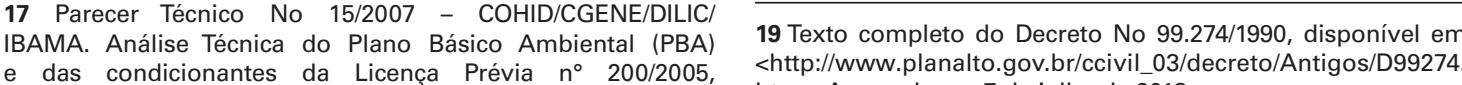

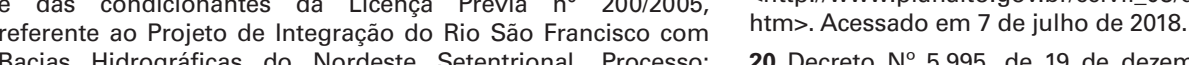
o debate ambiental brasileiro questão central: a de como engajar se em campanhas que evocam prioridades da lutac as evidentes a desigualdade social ou mostrandodesenvolvimentistas correntes que no renda. Em outros termos, como conquistar legitimidade para as questôes ambientais, quando, com trequência, a preocupação col um obstáculo ao enfrentamento do desemprego e à superação da pobreza? Como dar um tratamento e gocialmente aceitável às contra a desigualdade social pelo desenvolvimento econôm
(ACSELRAD, 2010, pp. 103-104).

assou a ser muito comum a contratação de empresas de consultoria para a elaboraçao . m prol de um jogo de interses transcendiao empreendimento eoterritór

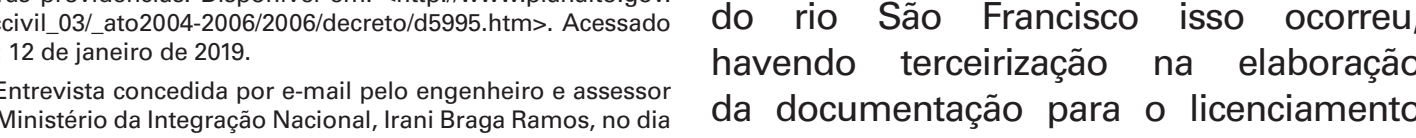

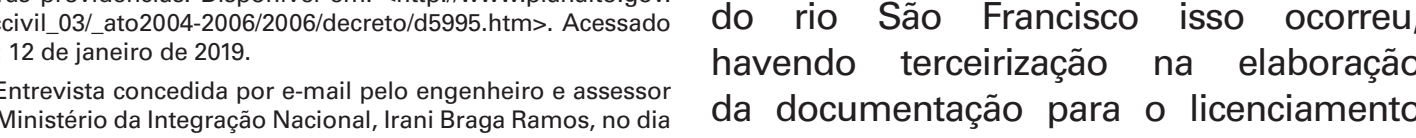

Esseconjunto deentidadesenvolvido a "proteção ao meio ambiente" e capaz de responder aos propósitos em questão. No caso da Transposiçẫo ambiental (que será apresentada no tem 2.3 deste capitulo) e nos Estudos de nserção Regional22 do projeto (que ser apresentados no item 2.4 desse capítulo gerando-se diagnósticos que se situaram da campo técnico e por vezes descolados luta social.

ederal. Já os setores que irrigação e recursos hídricos trazem tanto uma forte oposição quanto um poderoso lobby para
implementação da transposição (BARROS, 2014, p. 88). Em um contexto onde projeto, ambientais iniciou-se no governo $\mathrm{FHC}$, em icenciamento e execução de obras são 1997 , quando houve um convênio entre a executados pelo setor privado no pais, a Secretaria Especial de Políticas Regionais viabilizaçăo do PISF drenou um grande (SEPRE) eolnstituto Nacional de Pesquisas montante de recursos públicos para Espaciais (NPE), que contratou, por meio setores: i) empresas de consultoria de Ciência, Aplicações e Tecnologia ambiental e de engenharia que foram Espaciais (FUNCATE) para realização contratadas para a elaboração dos dos mesmos, justificando se tratar de estudos e projetos, empresas estas que se um projeto de natureza e magnitude tais agruparam em consórcios que concorriam que nao somente envolvia aspectos pelas verbas públicas de grandes projetos "engenharia civil, mas tambem, em seu

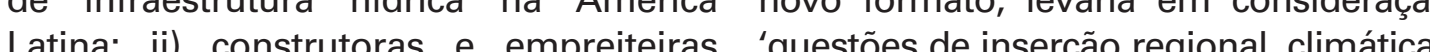
que participaram da obra dos eixos; iii) e ambientais'"' (SARMENTO, 2018, pp. grupos ligados ao hidronegócio, que com 229-230). Adicionalmente, esclareceu-se a disponibilidade de água transposta que a FUNCATE fora escolhida "por sua investiriam em projetos de irrigaçao, expertise nas áreas de sensoriamento sobretudo na Chapada do Apodi (RN) e remoto, geologia e cartografia, o que Vale do Jaguaribe (CE), assim Como o lhe conferla as necessálias condiçócs setor minero-siderúrgico, principalmente para gerenciar as atividades abrangidas indústria do turismo dos centros urbanos 2018, p. 230). A FUNCATE, por sua vez, litorâneos (BARROS, 2014, p. 88). Juliana subcontratou de modo irregular outro Barros (2014, p. 88), em sua dissertação dois consórcios - o consórcio Engecorp sobre os discursos e conflitos em torno do Harza, para a elaboração do Estud Projeto de Integração das águas do rio São de Viabilidade Ténico-Econômica, Francisco, entende que essas empresas o consórcio Jaakko Poyry/ahal, para privadas atuantes em diversos setores a elaboraçăo da primeira versão do com a implementação do projeto, tendo o subcontratou a empresaVBA Consultores próprio instrumental técnico e tecnológico para a elaboração dos Estudos de Inserção como modo de acumulação, e aquelas que Regional (BRASIL, 2000a), que serâo disputam o produto do empreendimento, analisados no item 2.4 deste capítulo. ou seja, a água transposta

As empresas de consultoria empreiteiras, de um modo geral,
defendem a execução do projeto concorrem entre si na realização

dos contratos com 0 Governo

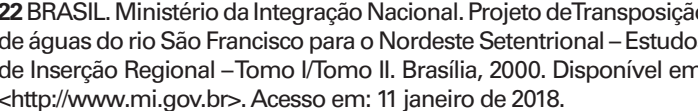

Vícios na própria contratação da
FUNCATE, na subcontrataçăa dessas empresas e outras levaram
oTCU, em seu Acórdaao 1045-26/06$P$, a afirmar que o "Estado estava criando "reserva de mercado"
e favorecendo determinadas organizaçōes privadas da espécie,
quer dizer, do ramo de consultoria
Como apresentado no capítulo 1 , a ambiental e de engenharia". A falt também revelou que o contrato foi fechado para acessar todo recurso disponivel no orçamento - cerca de fundadas em vínculos de confiança (BARROS, 2014, p. 89).

o governo Lula não foi diferente, e a empresas Ecology and Environment do Brasil, Prar Consultoria e Estudos Técnicos reformular os Estudos de Impacto Ambiental, entregues em 2004 (BARROS, 2014, p. 89; BRASIL, 2004, p. 4). Mas os scândalos quanto à ausencia de licitação

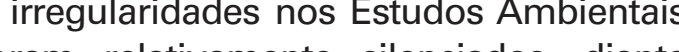
forame silenciados, diante ntre as construtoras, polerizan ha briga andes e as pequenas, que se organizaram consórcios, o que levou a sucessivas suspensōes e impugnações dos editais lançados. Sobre a execução da obra, el

seguir, veremos como se deu Construçăo da argumentação pela abra no governo Lula, construcão essa que foi assessorada pela elaboração dos documentos ambientais. Esse arcabouço documental para justificar projeto se deu muito em funçâa a questionamentos em torno dos mpactos ambientais que nele pareciam momento em que as leis ambientais comecavam a ser aplicadas, portanto tornando obrigatório esse tipo de estudo, ainda que ja se começassem a construir as criticas em torno dos anteriormente. 
2.2

\section{A disputa ambiental em torno \\ da Transposição e a construção \\ de sua justificativa técnica}

sem a escuta social

Desde o surgimento da primeira versão reavaliação do projeto de Transposição, do projeto da Transposição do São visando justificar seu porte, sua vazão, Francisco, na Ditadura Militar, até a seus efeitos e objetivos e, assim,
versão que começou a ser construída justificar sua viabilidade. A construçãão em 2007, pode-se identificar uma de sua justificativa técnica se iniciou readequação do projeto e de seu plano. no governo Itamar, quando se propôs relação às transformaçóes no semiárido, $\left(150 \mathrm{~m}^{3} / \mathrm{s}\right)$ em relação ao projeto dos como a crescente urbanização e militares $\left(300 \mathrm{~m}^{3} / \mathrm{s}\right)$, baseada no conceito o aumento do êxodo rural, mas de sinergia hídrica, que será reutilizado principalmente em relaçáa à construçao para o cálculo das vazoes nas versões de sua justificativa para definir seu porte seguintes do projeto, tanto na do e, assim, viabilizá-la. A definiçaao de seu governo fHC quanto na do governo supostamente "racional" construído a 1 o governo Itamar também foi partir de cálculos de engenharia que momento em que se deu o início do definiriam seu funcionamento hídrico, licenciamento ambiental, como também conforme Sarmento (2018, pp. 159, já foi mencionado anteriormente. $167,170)$ explica em seu livro recémpublicado, em que o autor narra os bastidores politicos e como se deram o processo de concepçáo do projeto neste período. Como é possivel verificar nessa publicação, o que pautou construção dessa justificativa foram os tensionamentos constantes que
os debates em torno da "questão ambiental" promoveram.

A partir do governo de Itamar Franco, a retomada do projeto de Transposição do São Francisco fez emergir dissonâncias entre tradicionais grupos oligárquicos do Nordeste e seus respectivos representantes políticos. Constitui-se assim um núcleo fortemente favoráve beneficiados com as águas transpostas, outro contrário, com os estados doadores das águas do São Francisco, ou seja, estados localizados na bacia hidrográfica do rio São Francisco. Essas disputas atravessaram e se acirraram nas gestões foi muitas vezes a pauta anbiental questionamentos sobre a pertinennia da Transposição (BARROS, 2014, p. 82; SARMENTO, 2018, pp. 77, 254).

Criou-se, assim, a necessidade
As balizas da escolha nesse momento eram: não poderia ser grand
demais (da ordem de centenas de metros cúbicos por segundol, pors a de metros cúbicos por segundo porque não haveria como suprir um número viável de hectares irrigáveis, objetivo esse que nunca deixar de acompanhar a Transposição, mesmo quando a água destinad (impos éćnico, a segunda versão $0^{23} \mathrm{do}$ projeto, apesar de ter revelado conceito de sinergia, naquele estágio apenas permitia avaliar qual era ganho sinérgico auferido em cada um dos grandes reservatorios receptores nos quatro estados, ou seja, sabiaganho sinérgico e que, faze-lo menor 2018, pp. 107-109).

Conforme apresentado no capítulo 1 , na

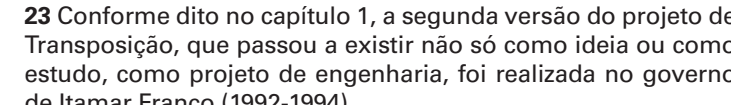
pois a resistência ao projeto seria de desenvolvimento o obetivo $150 \mathrm{~m} 3 / \mathrm{s}$ - havia associado un fôlego em sua elaboração especialmente ocorrer nas cidades de Penedo (AL), no segundo mandato do governo FHC Salvador (BA) e Juazeiro (BA) (IBAMA, (1999-2003) (SARMENTO, 2018, p. 2005, p. 2). O próprio presidente do 169), a vazáo diminuiu ainda mais (127 Instituto Brasileiro do Meio Ambiente $\mathrm{m}^{3 / s} \mathrm{~s}$. Trata-se do momento momento $\mathrm{e}$ dos Recursos Naturais Renováveis em que foram elaborados os Estudos (IBAMA) e seu diretor de licenciamento Ambiental (BRASI, 2000b): projeto e ãa por improbidade açăo criminal básico do Trecho 1 do Eixo Norte (SARMENTO, 2018, pp. 145-146).

(concluído em dezembro de 2000); o projeto básico do Trecho $\mathrm{V}$ do Eixo Quando findou o projeto básico dos dois Leste (concluidos em 2001); os Estudos eixos, em 2001, a Justiça acumulava de Inserção Regional (BRASIL, 2000a), dezenas de açoes em differentes instâncias, concebidos para se tornarem a fonte sempre com alegações de cunho os mais impon s mais importantes questionamentos 2018, pp. 145-146). Estava claro que, apesar
contrários à Transposição (concluídos dos diversos estudos que justificavam o em março de 2000), documento este projeto, este não deixava de ser de grande que será analisado no item 2.4 desse porte e, consequentemente, de grande capítulo; e a primeira versão dos Estudos efeito sobre aquele território, gerando de Impacto Ambiental (EIA-RIMA, concluídos em julho de 2000). Com a disponibilização da primeira versão $\mathrm{O}$ ano de 2003, no início do governo mandato do governo FHC, deu-se início Nacional (MI) retomou o procedimento a uma fase controversa das Audiências de licenciamento ambiental, que se Públicas (APs), previstas em lei para encontrava paralisado em decorrência serem realizadas tanto nos estados da receptores das águas transpostas:

As audiências nos estados receptores, as únicas que puderam acontecer, sem que políticos locais
e manifestantes impedissem - não ocorreram em Fortaleza (CE), Natal $(\mathrm{RN})$, Sousa (PB) e Salgueiro( (PE). Nos demais estados envolvidos, seriam
em Belo Horizonte (MG), Salvador (BA), Aracaju (SE) e Maceió (AL). No emblemático caso de Aracaju, a equipe do MI precisou ser escoltada
pela Policia Federal para podermos deixar o Centro de Convençōes em de plantấo na frente do hotel, onde nos hospedáramos, devido ao
receio de que manifestantes mais receio de que manifestantes mais
exaltados pudessem se dirigir para lá (SARMENTO, 2018, pe 145).

processo de licenciamento ambien sofreu intervenção judicial por meio
de duas Aços Civis Públicas: a de duas Ações Civis Públicas: a
primeira foi promovida pelo Centro de primeira foi promovida pelo Centro de
Recursos Ambientais (CRA), da Bahia, alegando ausência de critérios técnicos, e improbidade na condução das Audiências Públicas (APs). Com o mesmo argumento, a segunda foi impetrada pela GAMBA, organização ambientalista
não governamental do estado da Bahia. não governamental do estado da Bahia.
Isso, somado ao fato de a equipe do Isso, somado ao fato de a equipe do
Ministério de Integração Nacional (MI) ter sido recebida na cidade de Aracaju (SE) com muita violência, necessitando a suspenção da Audiência Pública em questão, causou o cancelamento das
demais audiências que estavam por asto da

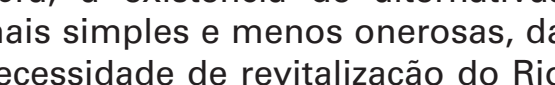
Săo Francisco. Outros argumentos aduzidos saao o "açodamento" da de "marketing politic" promoçãa da imagem do Governo ou do Presidente, não importa se do Presidente Fernando Henrique Cardoso ou do Presidente Luiz Estados receptores e o Governo federal argumentam que o Rio deve servir a todos os da Uniáo, Federação para garantir a "equidade no desenvolvimento econômico" na região nor
pp. 82-83).

Conforme comentado no capítulo cordenado um Grupo Interministerial, Alencar, encarregado das negociações com os movimentos sociais, com o Comitê da Bacia do São Francisco, com Ações Civis que tramitavam na Justiça. a I Igreja, sindicatos e organizações não
Assim, o IBAMA apresentou, em 16 de governamentais (SARMENTO, 2018, p. outubro de 2003, o Parecer Técnico $n^{\circ}$ 357). Alem disso, Lula havia convidado 2005, p. 2) ${ }^{24}$ No parece concluiu-se, integração, que passou a promover a dentre outros pontos, que o EIA-RIMA obra da Transposição (BARROS, 2014 não atendia integralmente ao Termo pp. 24, 85). Ciro veio defender os de Referência elaborado pelo IBAMA e interesses da elite cearense, interessada precisava ser reformulado. Foram entấo na obra, e como entusiasta do projeto, crivatas o consorcio de empresas defendia-o com argumentos técnicos, Prvironmentdo Brasil Agrar Consultoria os adverśrios da transposicão Estudos Técnicos e JP Meio Ambiente para complementar e reformular os Estudos de Impacto Ambiental, entregues em 2004 (BARROS, 2014, p. 89; BRASIL, 2004, p. 4).

Naquele momento, no início do governo dos conflitos entre parlamentares, quejá vinham medindo forças em momentos anteriores, como na jornada de debates promovida no grupo de trabalho criado majoritariamente por parlamentares (BARROS, 2014, pp. 82-83). Apesar dos diversos estudos feitos nas gestōes bem como adaptações no projeto em torno de argumentos tecricos, as disputas politicas e regionais torno do projeto se mantinham e tequerda e de direita, seja contra ou a favor do projeto (BARROS, 2014, p. 82).

Entre os opositores do Projeto, a
objeção gira em torno dos impactos

24 Informagáa extraida do Parceer Ténico para subsitiar
a LL, publicado no dia 24 de marco de 2005 , Procosso no
(2018, da

Para lidar com as disputas em torno da questao ambiental, primeiro a coordenaçáa Jrupo de Trabalho Interministerial (2003 7 de outubro de 2003 de julho de 2018 p. 207) de apresentações públicas reunioes fechadas com entidades envolvidas com a questão hidroambiental, transposição de águas.

Com a realização desses eventos, de expectativas e preocupaçōes no que dizia respeito aos aspectos

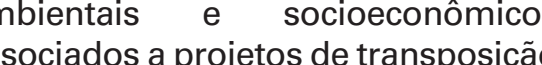
especificamente, bem como sobre (a) adversas peculiaridades à
(SARMENTO, 2018, p. 207) eferentes a cada um dos estados o problema da água como fator de 
Hídrica do Semiárido Brasileiro, também publicou no Diário Oficial da União As mobilizações públicas e conflitos mencionado no capitulo 1, se defendeu a (DOU) o recebimento da nova versáo mencionados acima se deram, pois, necessidade de se pensar na viabilizaçáa do Estudo de Impacto Ambiental (EIA) convocaçăo das primeiras Audiências a abrigatoriamena de aguas de forma e o respectivo Relatório de Impacto Públicas do governo Lula para obrigatoriamente concomitante à Ambiental (RiMA), reelaborado pelo apresentaçăo dos Estudos de Impacto Transposiz̃ não isolado do contexto multidimensional da documentação pelos técnicos da capitais, não abrangendo as populaç̃os $\mathrm{m}$ que estava inserida (SARMENTO, coordenação de licenciamento, o IBAMA diretamente afetadas da bacia 2018, p. 210). A mudança do nome do considerou que o documento atendia às negando o impacto nos territórios projeto proposta naquele momento recomendaçoes da Informaçáa Técnica indigenas, o que gerou o sentimento de para Projeto de Integraçăo do Rio São no $39 / 2003$, estando o EIARIMA apto à injustiça e deslegitimaçăo dos grupos Francisco com as Bacias Hidrográficas disponibilizaçáa ao público interessado da bacia. "Dessa toma, lançou-se măo $\begin{array}{lll}\text { do Nordeste Setentrional (PISF) também } & \text { (IBAMA, 2005, p. 2). }{ }^{27} & \text { de um "boicote" geral para invalidar } \\ \text { trouxe a ideia de um projeto que não } & \text { as Audiências. Porém, dada a falta } \\ \text { beneficiaria apenas a regiâo receptora } & \text { Dessa forma, em novembro de 2004, de participaçâao, as Audiências foram }\end{array}$ de águas, mas traria consigo uma ideia o IBAMA publicou no Diário Oficial da consideradas formalmente realizadas e de integração humanitária e sustentável, União um informe da realização de nove na sequência, foi emitida a Licença Prévi muito baseada no trabalho feito pela Audiências Públicas (APs), marcadas (LP) do empreendimento (BARROS, equipe Interministerial. A vazão que para o mês de dezembro, mas que em 2014, p. 109).

seria retirada constantemente do rio seguida foram canceladas por força pelos canais, de $26 \mathrm{~m} / \mathrm{s}$, representaria liminar. Porem, em janeiro de 2005 liberada pela represa de Sobradinho, o pela continuidade do procedimento que siginificava que a retirada da água de licenciamento e o IBAMA tornou a ão prejudicaria a bacia doadora. ${ }^{25}$ Os publicar no DOU sobre a realização de $127 \mathrm{~m}^{3} / \mathrm{s}\left(99 \mathrm{~m}^{3} / \mathrm{s}\right.$ do Eixo Norte $+28 \mathrm{~m}^{3} / \mathrm{s}$ oito Audiências Publicas nos estados do Eixo Leste) seriam retirados apenas envolvidos no projeto. Mas apenas a as cheias do Säo Francisco, garantindo quatro prime proj AP a sustentabilidade socioeconômica do 2018, pp. 309-310).

A palavra "integração", além de reiterar o apelo de o rio São "o rio da integração nacionolo coadunava-se com o planejamento governamental que colocara os
chamados Eixo Norte e Eixo Leste do projeto como mais dois canais para beneficiariam os próprios estados
da bacia doadora (SARMENTO, da bacia doadora (SARMENTO,

Em setembro de 2004, o IBAMA

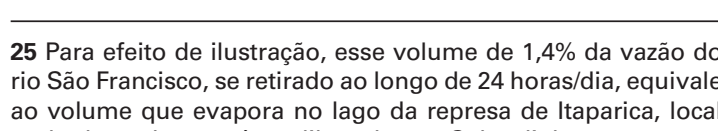

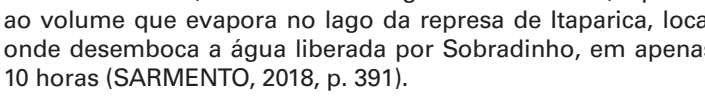

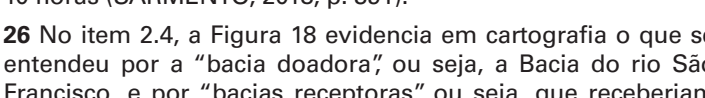

Aliado a isso, as declaraçōes públicas de representantes do Governo, cujo
porta-voz principal era Ciro Gomes conhecido pelo estilo tempestuos (entavam uma posicão "dude" pouca disponibilidade ao diálogo nenhum aceno de recepção das reivindicaçōes dos movimentos
sociais (BARROS, 2014, p. 109).

A partir daAudiência Pública prevista Como se pode observar, em torno do para Belo Horizonte, vários fatores impediram a realização das demais. riscos à segurance impeas realização dos eventos de Belo Horizonte e Salvador, os quals foram iniciados e posteriormente (IBAMA, 2005, p. 2). projeto sempre houve um forte embate, político e jurídico entre os opositores os defensores da Transposição. Apesa fe no governo Lula a equipe técnica ter (S) fechadas (SARMENTO, 2018, p. 254) além de sugerir a revitalização do São Francisco como imprescindível para que

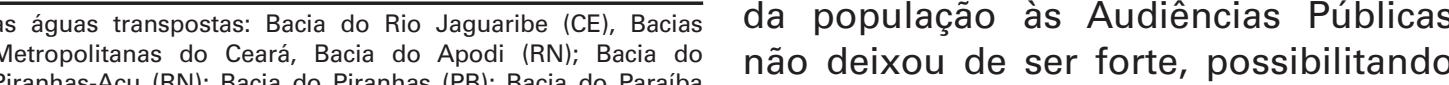

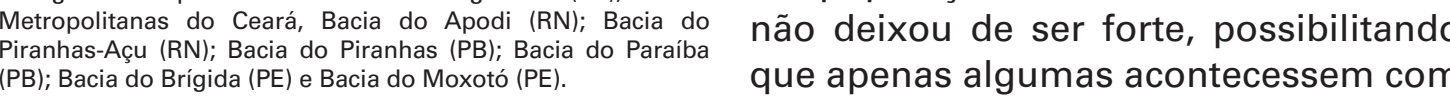

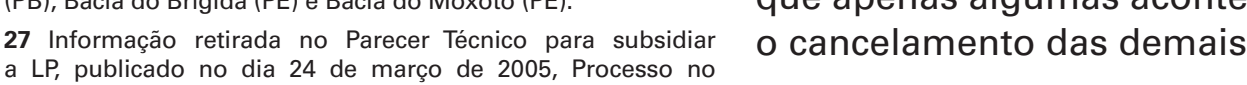

Isso se deu muito pelo de, conforme o processo padrão de um licenciamento

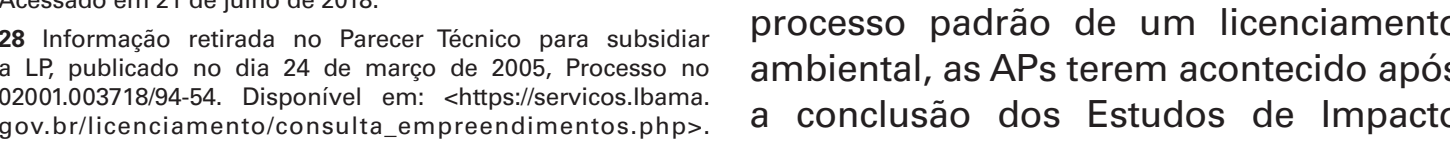

Ambiental (EIA-RIMA), e não durante governantes da bacia doadora e que se (período de construção entre 1954e 1979), sua reelaboraçao, reforçando a ideia mantiveram ate o governo Lula, eram gerando a consequente necessidade

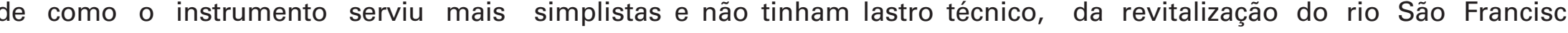
como uma etapa administrativa para propagandodistorçoesintencionalmente e um certo receio e a descrença com obtenção da LP do que para uma real moldadas para alimentar desconfianças, As Audiências Públicas representam o uma cono à palavra "Transposiçăo" único momento de pleito social previsto da degradacão do rio São Francisco impacto socioambiental. Deveriam ser, potanto, instancias estrategicas para a me participação da população local, para a ambiental foram muitas vezes apenas
obtençã de informaçes e a formulação desculpas que mascararam os reais

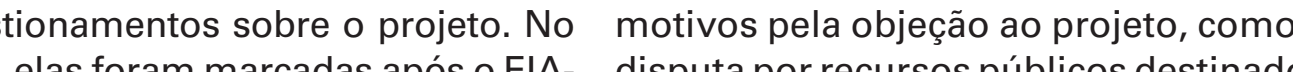
RIMA já estar reelaborado, com pautas a projetos de desenvolvimento regional sem um debate amplo e transparente da obra com a população que seria diretamente envolvida pela obra. Esse foi um posicionamento comum coletado em como a realizada com o cacique, tais Truká, Aurivan dos Santos ${ }^{30}$ conhecido por Neguinho Truká, com uma liderança indígena do povo Tumbalalá, Maria José Gomes Marinheiro, conhecida por Maria Tumbalaláa ${ }^{31}$ e com moradores d proximidades de Salgueiro (PE).

Para Sarmento (2018, pp. 75-76), alguns argumentos contra a obra, que vinham
desde a década de 1990 , por parte de

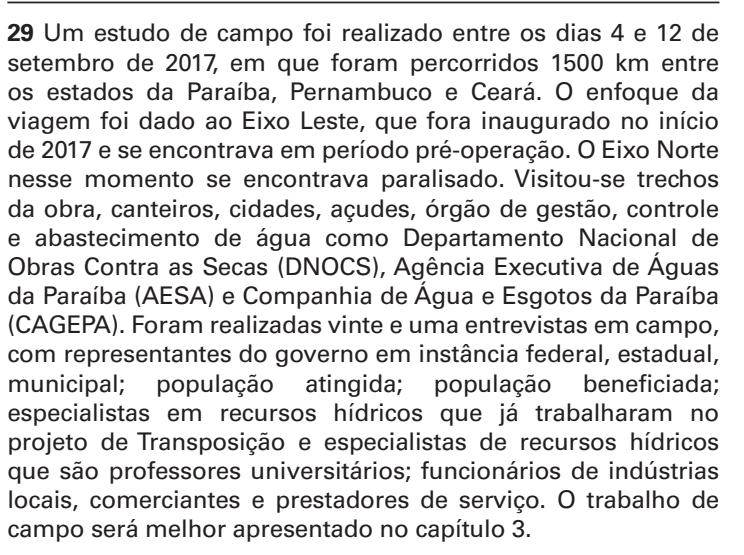
Na verdade, a principal causa dessa celeuma de quase três décadas úblicos. Como receptores das guas do Velho Chico, os Estados do Ceará, Paraíba e Rio Grande do dé água que os pothan aumentando suas chances de mpliar a fatia no bolo dos recursos públicos destinados a projetos principlme a aquicultura, bem como o pleito para mais recursos no setor de a neamento, visto não ser mais a
g gua o fator limitante (SARMENTO, 2018, p. 319).

outro lado, além de no processo reelaboração dos documentos mbientais as populações não terem sido consultadas, os momentos de debate da Transposição fizeram emergir, na bacia doadora, algumas lutas que vinham de
antes (MARINHEIRO, 2017, informação verbal), como a contestaçáo sobre a degradaça ambiental e expropriação hidrétricos promoveram no lemplexos

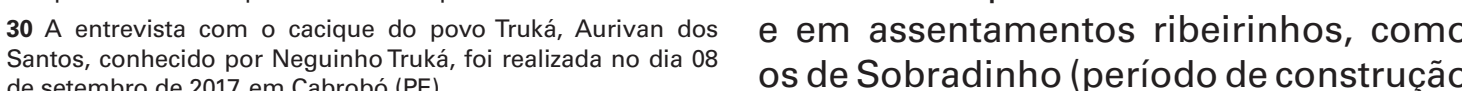

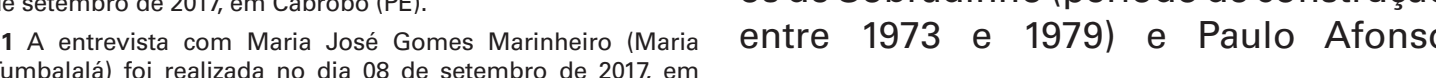

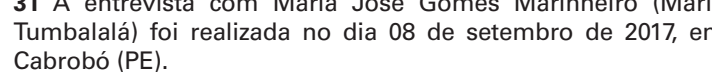

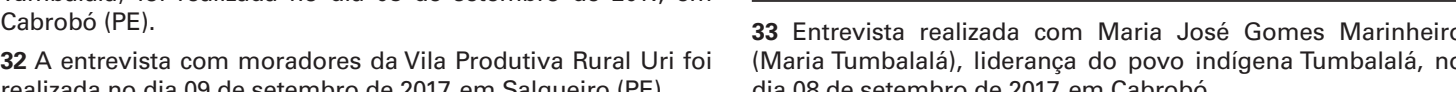

(laçao aos grandes empreendimentos Barros (2014, p. 85) demonstrou que, por ser um projeto antigo, a Transposição catesta padráo de intervençáa estatal sobre o

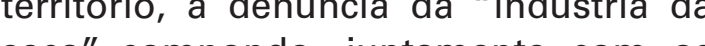
ecto de um sentido mercantil ao rio, propício ( empreendimentos hidrointensivos, como siderurgias, carcinicultura como promessas de desenvolvimento e progresso para resultas só fizeram seca" e cujos so fizeram reproduzir ou egião (BARROS, 2014, p. 110).

Eu acho que todas essas grandes obras que ocorreram no Nordeste, do outro os que não gostam. Nas grandes barragens que nós uma fragmentacão da sociedade em relação à importância dos projetos. A indústria da seca, ela é pautada ness

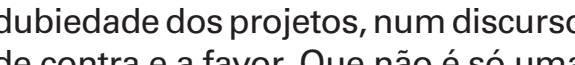
polarização política, mas também de miserabilidade de toda uma imagem que foi criada do Nordeste, as grandes obras, a grande fazend para resolver toda uma situação de Dexsado histrice existia. E isso foi populações. E por isso que seca, tanto é um discurso que pega, tanto pega que ele é recorrente, passa ser uma coisa de educacãa e se que as pessoas se envolvam num
postura favorável aos grandes 


\section{Trukás exigem terra em que passaria transposição do São Francisco}

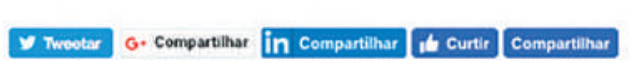

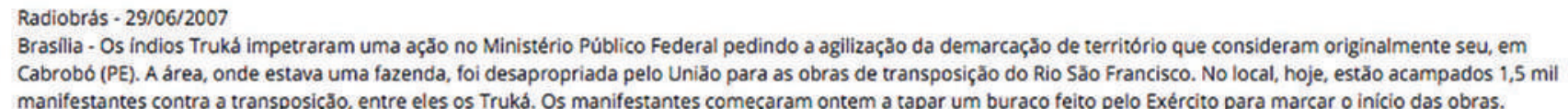

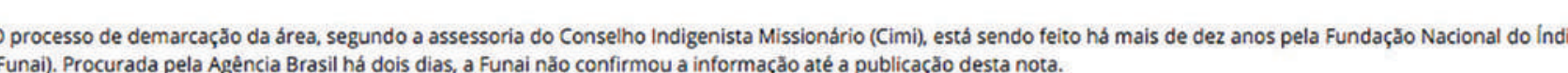

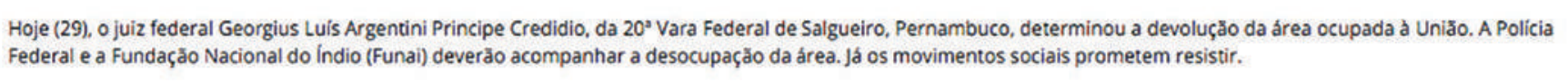

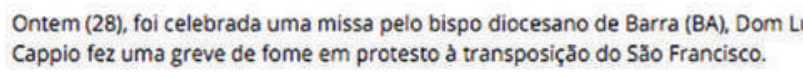

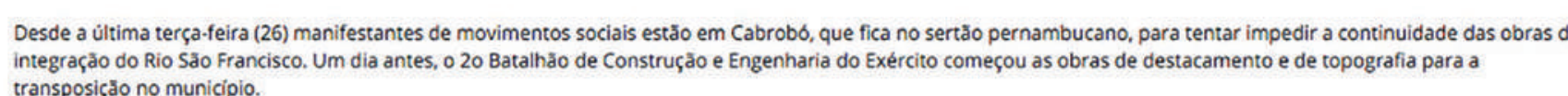

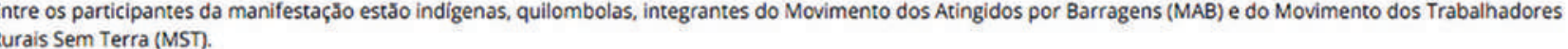

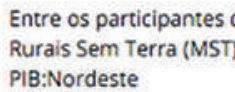

Figura 1 - Confito fundiário entre Trukás e projeto de
Transposiçâ.

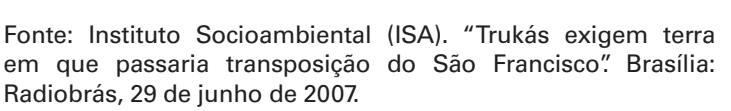

projetos. E a transposição não é
diferente. A transposiçẫo, ela veio com essa marca, a marca de uma resoluçăa de um problema de que aqui é um lugar ruim de se viver, somente os grandes projetos é que dão conta de sair dessa situação de miséria. A transposiçãa vem com essa marca. - Depoimento de campo, 20106/12 apud BARROS, 2014, p. 110.

Outro exemplo de debate que vinha de antes era a luta por demarcação de Terras Indigenas, localizadas em áreas onde (ver Figura 1). Questóes como essas foram arduamente combatidas pelo Estado ao Iongo daquelas Audiências Públicas marcadas para $2005 \mathrm{e}$, em alguns casos, utilizadas como forma de barganha para a pelas comunidades (MARINHEIRO, 2017 informação verbal).$^{34} \mathrm{Ou}$ seja, o processo de diálogo perante os conflitos que a Transposição fez emergir não foi fácil e nem se deu de forma ampla, pacífica, igualitária, com uma real escuta da população, nem nem nas do governo Lula. aparentemente não fossem diretamente o IBAMA fez uma análise técnica do da competência do projeto de Plano Básico Ambiental (PBA) do Transposição para serem resolvidas, e PISF e das condicionantes da Licença sim objetos para gerar outros programas Previa (LP) do projeto, eles concluíram RIMA da Transposicão com esses assuntos, como o fizeram por exemplo sugerindo a Revitalização do rio São Francisco (BRASIL, 2004, p.

34 Entrevista supracitada com Maria José Gomes Marinheiro
(Maria $T$ unmbalalal). mesmo Parecer Técnico ${ }^{36}$ citado

16), afinal a Transposição era um projeto coscala regional, com interferencia

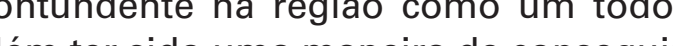
poio dos estados doadores para gitimar a obra.

O Projeto de Integração do Rio São do Nordesto Bacias Hidrográficas tendimento de demandas por recursos hidricos $[$ [..], para parte
do polígono das secas brasileiro. depende da boa execução dos Considerando ainda a disponibilidade hidrica para os usos atuais e futuros bacias receptoras, são necessárias os usuérios para garantir água par doçăo de medidas de preservaçáa isso, é de fundamental importância o Programa de Revitalizacãáo da Bacia taria Executiva Ministerio do Meio Ambient m parceria com o Ministério d realces nossos) ${ }^{35}$

e as condicionantes da LP foram

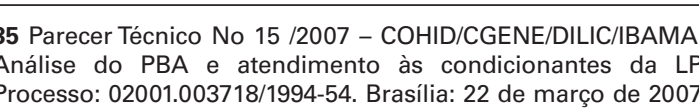

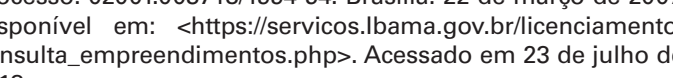

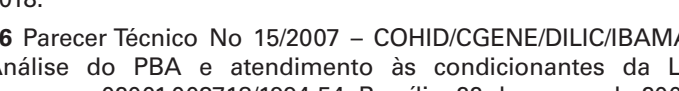

suficientemente atendidas pelo considerando que a Licença de Instalação abastecimento humano como prioridade como Nacional) e que os PBAs apresentados Públicas de apresentaçao do Projeto. (adequados, recomendando, (lito anteriormente, aTransposição no dia seguinte, 23 de março de 2007. documentos técnicos que a justificaram mo observa Sarmento $(2018$, p. 308). Mas que se questiona aqui é o como e para Conforme mencionado anteriormente, tendo também a intenção de responder apenas no campo técnico-burocrático exigiram, porém, que cinquenta e nove aos questionamentos socioambientais para viabilização da obra e não no campo

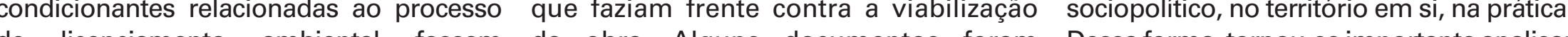
incen (a) entre elas, implementar integralmente ocorreu em menos de dois anos e será os conflitos, como eles apresentaram a dos programas propostos, apresentando analisado no item a seguir. Outros projeto e seus objetivos e, finalmente, relatórios semestrais de execução e foram estabelecidos com mais cuidado como eles se deram na prática, ao longo da eapresentar revisăo de alguns programas e tempo, como os Estudos de Inserção obra, quando as condicionantes da Licença

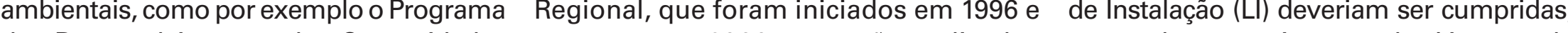

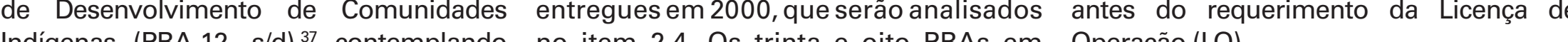
no item 2.4. Os tinta e oito PBAs em Oper

os aperfeiçoamentos a serem propostos alguns casos foram feltos rapidamente, tiveram variaçōes, foi construído o discurso em torno dos conjuntamente com os parâmetros porém não tiveram fácil acesso da estudos ambientais que vão legitimar quantitativos e de tipificaçao necessários à populaçáo que seria envolvida, como veremos no item 2.3.2. obra e que trataram das questões erritoriais, dos conflitos sociais e do Com muitos conflitos, a "questão Houve uma grande equipe de técnicos mascararam que se tratava de uma obra ambiental" aparentemente foi superada, competentes que atravessou algumas que sobrepunha alguns interesses sobre propostas colocadas nos documentos desses estudos que justificaram o projeto de um projeto de integração regional. Por técnicos e nos pareceres do IBAMA, e acreditavam nos argumentos técnicos ora, os itens tratarão mais dos processos mas, claramente, não no territorio, como suficientes para justificar uma de planejamento e do discurso oficial. Já obra que teria um objetivo tăo nobre, no

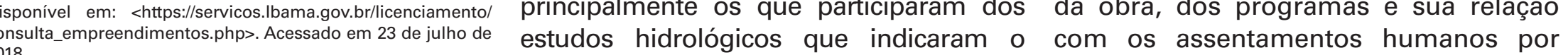
funcionamento hídrico da Transposição, onde passou.

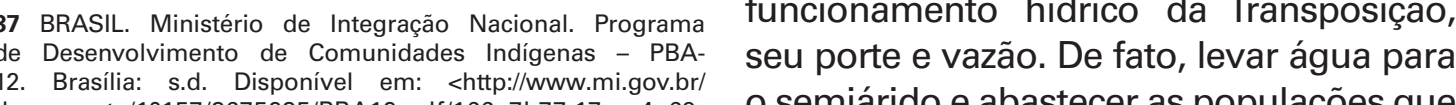

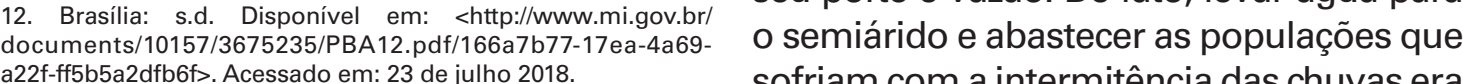

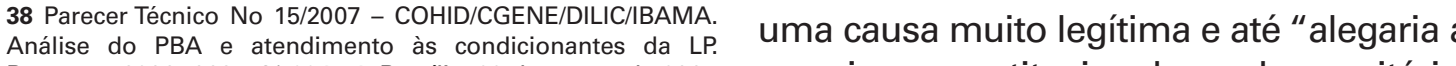

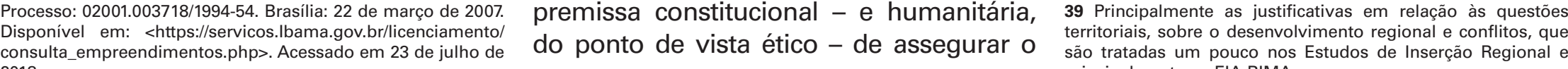


2.3

2.3

Os documentos ambientais

2.3.1

0 discurso que legitimou o

projeto e a elaboração do EIA-

RIMA do Projeto de Integração

de Bacias do rio São Francisco

com o Nordeste Setentrional

Retomando resumidamente o que foi item deste capítulo, a publicização escrito anteriormente, a última versão deste documento, obrigatória em todo do projeto da Transposiçáo do rio São processo de licenciamento ambiental e, Francisco teve uma primeira abertura como de praxe para o PISF, se deu pelo do processo de licenciamento no RIMA (Relatorio de Impacto Ambiental), a já no governo FHC (1995-2002), foi estudos em linguagem supostamente desenvolvida a primeira versão dos acessívelà compreensão pública. O RIMA Estudos de Impacto Ambiental e o do PISF se tratou de um resumo pouco Relatório de Impacto Ambiental (EIA- claro e bastante vago do que seriam as RIMA, protocolada em 2000). Em 2003, o compensaçoes socioambientais, sem IBAMA apresentou o Parecer Tecnico $n^{\circ}$ uma linguagem e cartografias de fato 55/2003 - CGLIC/DIL PaIBAMA 2005, p. 2) alegando que EIAAMA

Naquele momento, a FUNCATE gestóes muitos anos de embate das outras subcontratou o consórcio de empresas governo Lula se consolidou o discurso privadas formado pelas Ecology and que veio a legitimar a obra. Resolvido Enviroment do Brasil, Agrar Consultoria aparentemente na esfera política e Estudos Tecnicos e AP Meio Ambiente, e tecnocratica, como mostrado no BRASIL, 2004) sendo possivel obter suplantado pelo discurso supostamente a Licença Prévia (LP), em 2005. Para a humanitário do governo, optando pela obtenção da Licença de Instalação (LI) força simbólica do falso argumento que foi exigida a elaboração dos trinta e oito seria "matar a sede de doze milhôes Programas Básicos Ambientais (PBAs), de nordestinos" (BRASIL, 2044, p. que seriam o desenvolvimento de 9), informaçao que seria fortemente premissas estabelecidas no EIA-RiMA, divulgada pela midia (ver Figura o1 so que para execução. Os Programas abaixo). A falta de água foi apontada elaborados no mesmo ano e em 2007, miséria do sertanejo, havendo inclusiva após quase dois séculos, a obra de uma leve crítica em relação à ação transposição foi iniciada. sempre emergencial dos governo anteriores perante a seca, indicando que Neste item, trataremos de apresentar não fazer a obra seria estar conivente o discurso oficial sobre o projeto com essa situação

de Transposiçao no governo Lula, documento mais abrangente e descritivo sobre os vários aspectos sociais, econômicos, ambientais e políticos envolvidos na proposta de intervenção da Transposiçaao, indo desde a formulaçăo do diagnostico, do problema a ser atacado, às possibilidades de soluçáa satatais. Conforme dito no primeiro

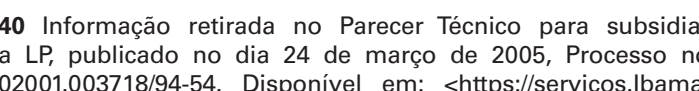

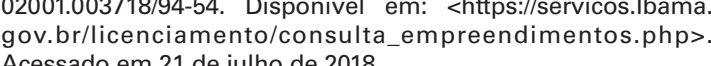

O semiárido nordestino, na área do de cerca de 12 milhoes de habitantes. Sem àgua, essa regiáo estara fadada número de brasileiros restarão poucas alternativas de desenvolvimento social e econômico [...] Sujeito consequentes acóes emergancias dos governos, o semiárido nordestino Projeto, concentra uma população tem na falta de água o maior obstáculo para a prática de atividades produtivas fundamentais para o seu 9-10).

O discurso oficial explorou dimensões culturais como o espírito de 2014, p. 96) ou dos ribeirinhos do São Francisco para com os habitantes de regiôes do semiárido que dependiam do regime intermitente de chuvas, sem ros perenes, assimilando a tradicional deia de que a seca condicionaria - subdesenvolvio da regiáo, distribuição fundiária ou à falta de políticas sociais e econômicas:

[...] o governo investiu no discurso da escassez hidrica e elaborou um a crítica de "bairrista", com aproximaçōes aos interesses da indústriadaseca equeapresentava como uma questão local - reletiva ao semiárido nordestino - e de âmbito nacional - tendo em vista a difusāo, por todo o pais, dos sintomas da (BARROS, 2014, p. 84). Nessa ideia, o EIA-RIMA trouxe uma foi chamado de "Nordeste Setentrional" (BRASIL, 2004, p. 11), como zona de planejamento differenciada e mais sujeita às tragedias do fenômen anatico, diferente do que predominava omogeneidade do "Nordeste das secas", ou do "Semiárido" (BARROS, 2014, p. 85) (ver Figura 2). Como se pode ver na Figura 2 abaixo, para se compreender essezoneamento das áreas da seca utilizado pelo PISF, construiuse um mapa a partir de diferentes - Abastecimento Urbano do Áge (BRASIL, 2006) e o estudo publicado no livro Um século de secas - Por que as políticas hídricas não transformaram
o semiárido brasileiro? (BARBOSA,

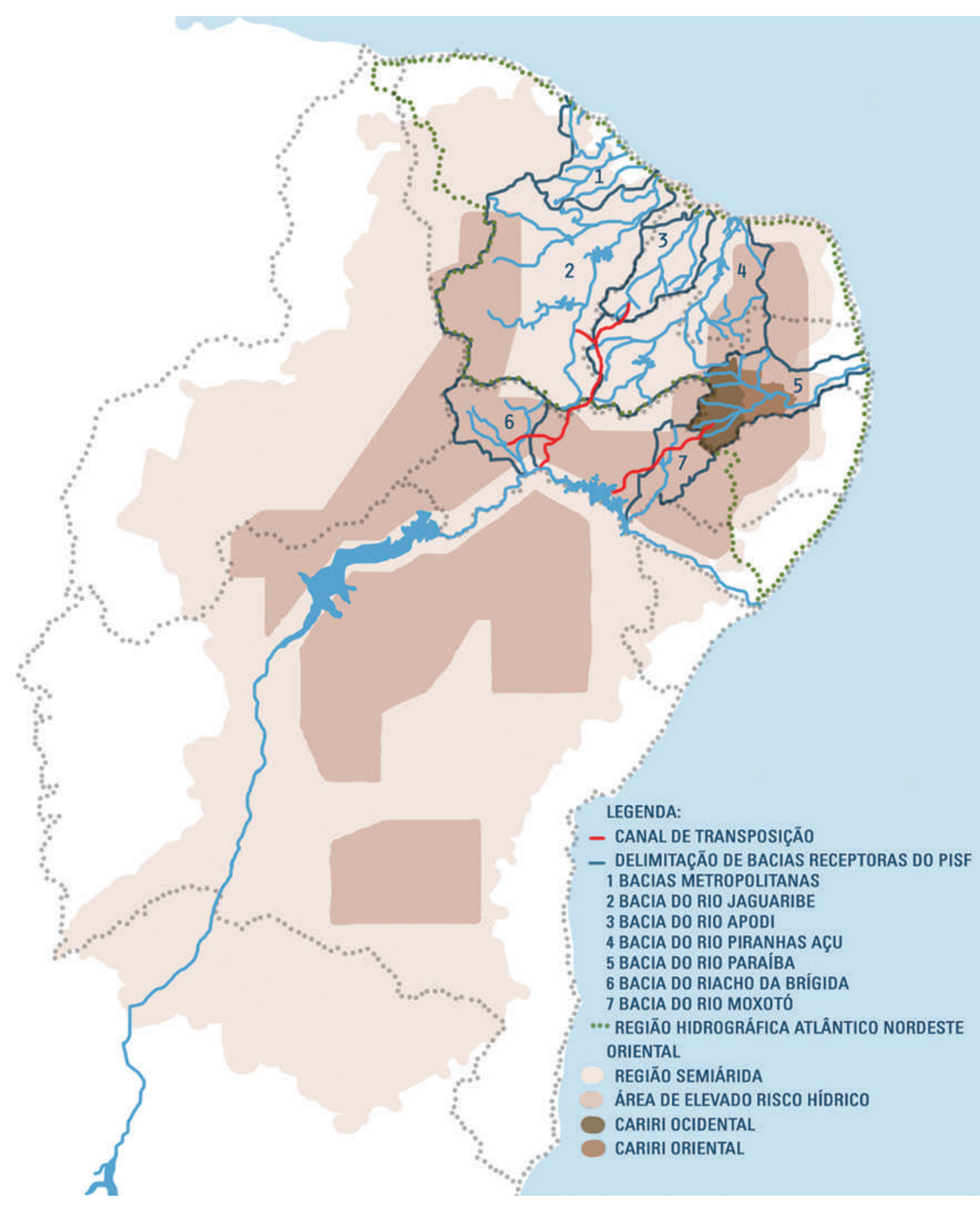

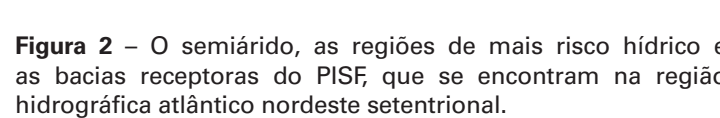

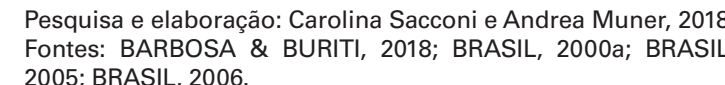


BURITI, 2018), que classificam áreas extrativa a partir da chegada das águas. de elevado risco hidrico, todas dentro O PDSA ainda sugeriu que a situaçăo da area geografica de abrangencia do de disponibindade hidica na bacia do to

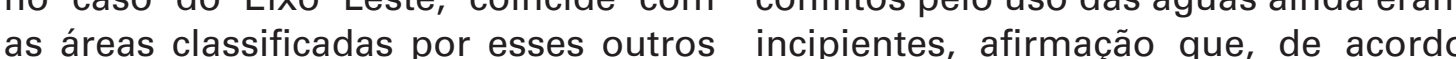
decumentos como as áreas de maior com a própria obra da autora (BARROS risco hídrico, embora o Eixo Norte 2014), aliada ainda a outras fontes, naa coincida, evidenciando que essa como por exemplo noticias de jornais, classificaçăo utilizada pelo PISF pode mostra-se notoriamente falsa. ter sido utilizada mais como objetivo de que por uma efetiva necessidade de se passar a obra pelas áreas mais sujeitas veja-se a Figura 2 abaixo:

Nos anos de 2003 e 2005, no início da gestăo Lula, o governo federal elaborou outros planos e programas territoriais para o Nordeste, ficando evidente que, ao comparar os diferentes planos, de justificativas e informaçōes sobre o projeto da Transposicão do rio São Francisco entre eles, utilizadas conforme a necessidade de estruturar o discurso do documento em questão.

Carimbado com suposta autoridade cientifica, o EIA-RIMA é o "guarda-
chuva" de um amplo discurso polític que comporta interesses de várias clientelas $[$...] e que será utilizado em partes conforme a localização go nas lutas por legitimação. ratando-se de um documento Ingo, na prática pouco acessível à exercícios de traduportarávários seleção de destaques, omissōes representaçōes cartográficas, que serão construídas a favor dos que a veiculam e disputam interpretaçōes/visōes sobre o projeto (BARROS, 2014, pp. 26-27).

Um exemplo disso foi descrito por O slogan escolhido para compor o Barros (2014, p. 35), que compara o discurso foi "São Francisco: água Sustentável do Semiárido (PDSA) p. 97) e, apesar disso, o EIA-RIMA (BRASIL, 2005) e os Estudos de Impacto relacionou com clareza como se daria Ambiental do PISF (BRASIL, 2004), distribuição e o consumo da água, observando que o EIA-RIMA do PISF tampouco foi enfatizada a prioridade de O cálculo de atendimento de doze
usou para justificar a transposicão das fornecimento da água transposta para milhões de pessoas foi feito com base na usou para justicar a transposiça das fornecimento da água transposta para milhôes de pessoas foi feito com base na aguas a maior densidade populacional cidades nordestinas, conforme previsto projeçáo do número de habitantes dos Nordeste Setentrional em relação à 2018, p. 312). Mas sim, a questão do a obra passaria em 2025 (SARMENTO ribeira do São Francisco, enquanto abastecimento urbano, que ganha 2018, p. 309), mas dado que a obra terí que o PDSA (BRASIL, 2005, p. 100) grande protagonismo no projeto do o principal destino de abastecer centros enfatizou a carência de água frente à governo Lula foi colocada no documento urbanos e que nem todo assentamento abundância de recursos minerais na deformabreve, sem ênfaseamo doçáo a humano nesse percurso dos canais regiăo, que podita estaria contemplado com agua, ess numero era impreciso (RAMOS, 2017,

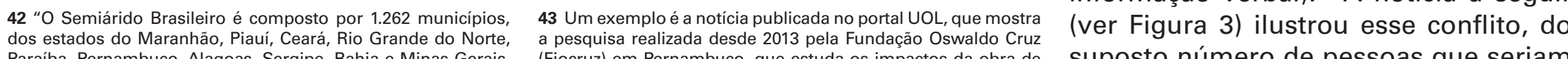

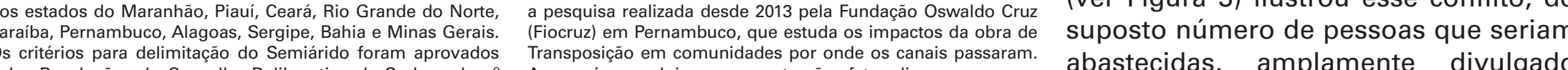

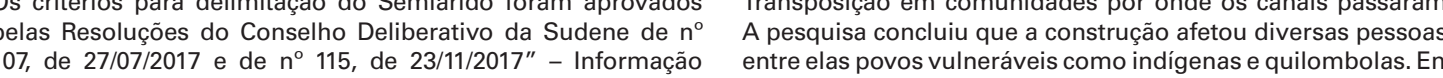

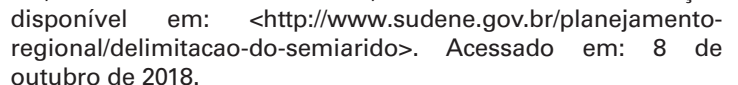

A populaçãa, tanto urbana quanto e grandes agricultores e todos poderão usar a água disponivive para gerar empregos, renda e qualidade de vida. Se a chuva nâo cirantion São Francisco humano, as safras agrícolas e as atividades industriais e
(BRASIL, 2004, pp. 10-11).

Apesar da falta de ênfase, algumas áreas A banas foram indicadas, demonstrando no Ceará, na bacia do rio Jaguaribe craleza pelo canal do Trabalhador Paraíba, na bacia do rio Paraiba, Pernambucano, com 1,1 milhão pessoas nas bem de 1,3 milhão de (n) de habitantes, cerca de $2 / 3$ dos quais dependentes de abastecimento partir dos grandes açudes da regia 44 Informacăa concedida em entrevistan no dia 20 de marce

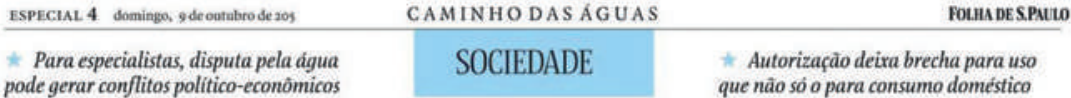

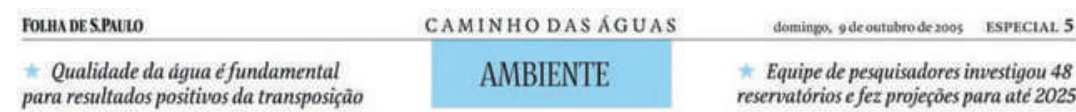

Governo quer levar água a 12 milhões de pessoas

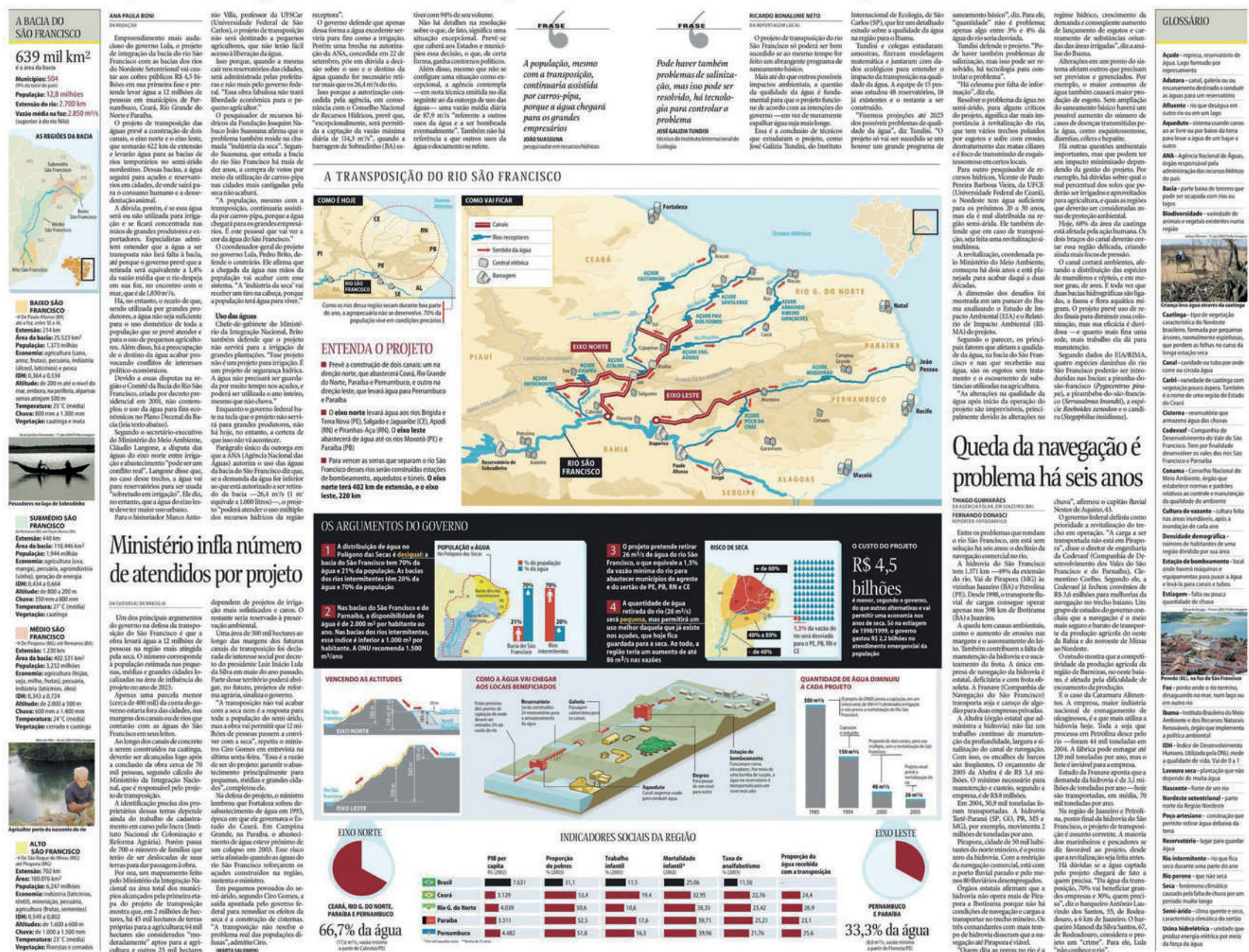

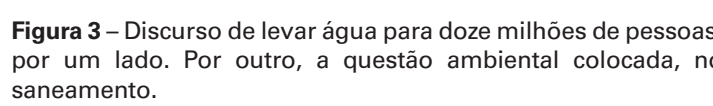

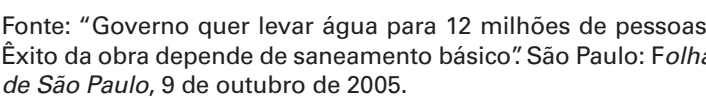

pelo governo federal e, por outro tais como a poluição das águas na estimativa, indicando que, desses brevemente um pouco do que havia sido doze milhões de pessoas, apenas uma estabelecido pelo EIA-RIMA. parcela de quatrocentos mil habitantes ${ }^{45}$

seria abastecida quando não residente No início do documento, o RIMA de zonas urbanas. Além disso, a noticia apresentou planos e programas para também evidenciou a necessidade o controle e preservação do rio São da execuçao de infraestruturas
complementares ao projeto, como obras Francisco, tais o Plano decenal da bacia, para que possíveis o Programa de Revitalização da Bacia problemas ambientais fossem evitados, Hidrográfica do Rio São Francisco, o Engenharia Civil pela Universidade de Săo Paulo (1999). Atua Plano São Francisco, assim como o

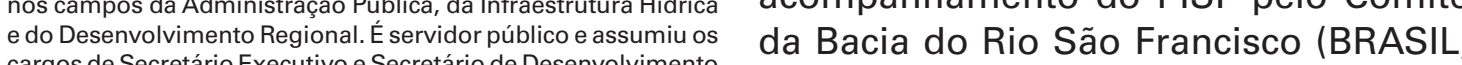

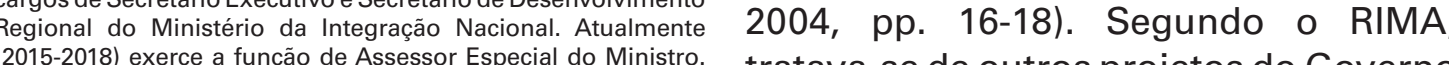
Texto informado pelo autorl!" Intormaceose extraidas da tratava-se de outros projetos do Governo

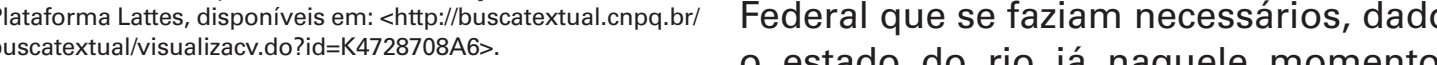

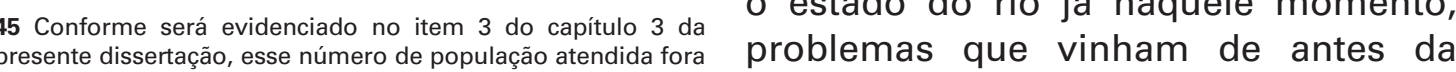
das cidades publicado na Folha de São Paulo em 2005 discrepa Transposição ser construída situacão

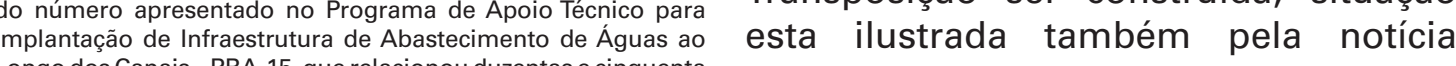

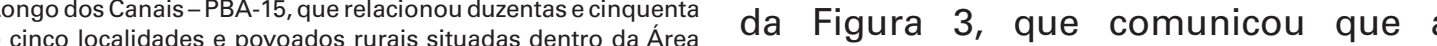

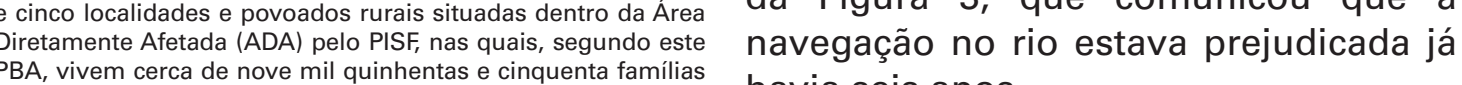
eaproximadamente quarenta e cincon mil pessoas, que seriam havia seis anos. 
O RIMA reiterou que a vazão retirada do rio São Francisco ao Nordeste Setentrional seria apenas $3,5 \%$ da vazāo ideia de ene áém de bedinho, dando a região que necessita de água para desenvolver, a não retirada dessa vazão seria um desperdício da água, que seria despejada no mar, na foz do rio:

Ou seja, dos quase 90 bilhöes de metros cúbicos de água que o rio
São Francisco despeja no mar em média por ano, cerca de 2 bilhōes de metros cubicos seráo captados pelo Projeto, de acordo com a

em relação às intervenções projetos de irrigação falidos) também e elencado como fator de criação de tensōes sociais, a merecer cuidadoso programa de comunicação socia são apresentados 24 programas ambientais - posteriormente aumentados para $38-$ a seren
implantados junto com as obras que teriam o condão de contribu para uma mudança local positiva [.. (BARROS, 2014, p. 33).

bacias receptoras; risco de redução da tipos de programa e intervenções risco de tensões durante a fase de obra que precisariam ser feitos na região, interferências no patrimônio cultura nas cidades, comunidades e áreas (sítios históricos); risco de introdução Diante dessa pequena porcentagem de preservaçao ambiental para que a de especies de peixes daninhos, etc. de água que serviria para tanta coisa, RIMA relativizou o porte da obra ao dando-se uma ideia bastante superficial

pontuar que a falta dessa informação, e otimista dos mesmos, subestimando Para a realização dos diagnósticos de retirada, poderia levar a se acreditar que dos programas ali propostos, a impacto ambienal, foram definidos a Transposição consistiria em uma "obra complexidade da obra e sua inserção no Área de Influência Indireta (All), faraônica, de imensas proporçōes" território, complexidade esta que será onde ocorreriam os efeitos indiretos (BRASIL, 2004, p. 24), como se a retirada ilustrada no capitulo 3. O saneamento da integraçáo das aguas, e Area de de apenas uma porcentagem de àgua basico nas cidades que receberiam a Influência Direta (AID), onde se darian pudesse significar que os impactos tho agua sempre foi uma pauta da discussáo principalmente as transformações ambiental em torno do projeto, pois ambientais diretas (ou primarias)

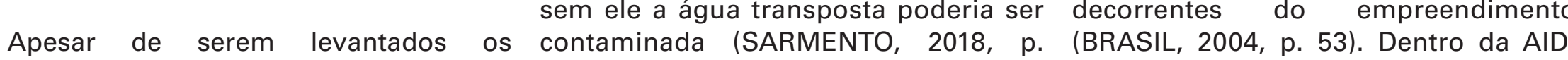
possíveis impactos que a obra geraria, 76), pauta que foi retomada na notícia foi estabelecido um terceiro e mais o que implicaria cada um, as questôes da Figura 3, que anunciava o Projeto aprofundado nível de detalhamento e conflitos diante de cada um foram em momento posterior à obtenção para os estudos ambientais. Foi a área colocados de forma pouco aprofundada da Licença Previa, indicando que os chamada de Area Diretamente Afetada nósicos Am Basicos Ambientais (PBAs), que se questăo. Mas como sera evidenciado diretos entre as estruturas físicas do obtenção da Licença Prévia (LP) a os PBAs, a ampliação das redes de estações de bombeamento, etc.) pedido do IBAMA $\left(2005\right.$, p. 2), ${ }^{46}$ foram saneamento nas cidades por onde a a região onde ele seria implantado,

introduzidos no RIMA também de forma obra passou não havia sido executada compreendendo uma faixa de $10 \mathrm{~km}$
superficial:
até o momento em que as obras do Eixo tendo como eixo o traçado dos canais superficial:

Interessante notar que o desgaste

função do passado de desconfianças

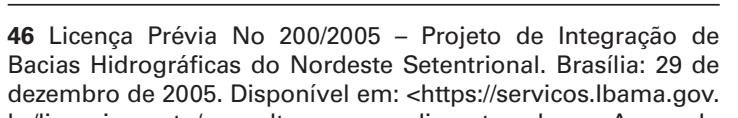

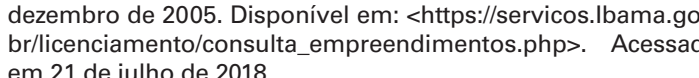
Leste estavam em que as obras do Eixo tendo como eixo o traçado dos canais. Tal area ompreende uma superficie da
ordem de $7.750 \mathrm{~km}^{2} 48$ muito maior do Em sua proposta, o EIA-RIMA apresentou

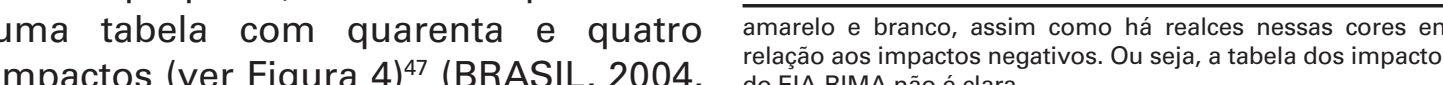

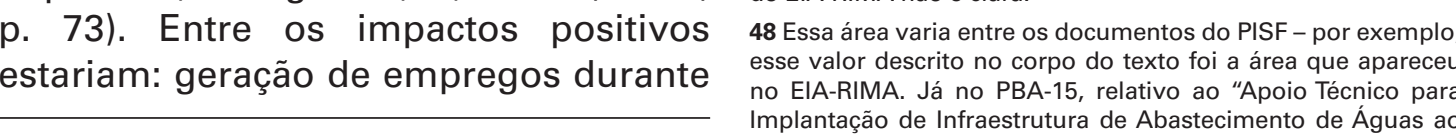

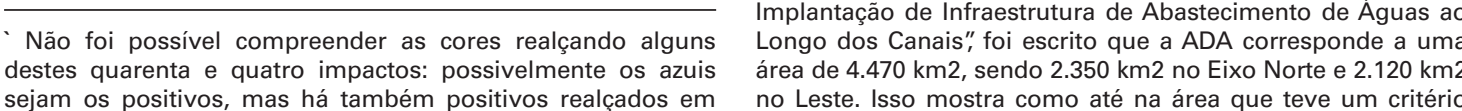

Figura 4- Lista dos ourenta e quatrop incopsing

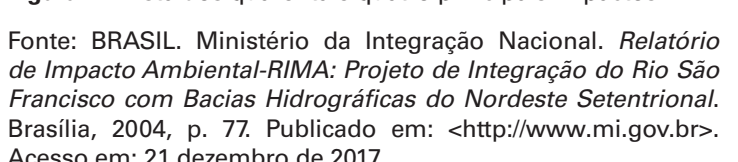

IMPACTOS

Ruppura de relaşeses socicomunitirias durante a fase de ob

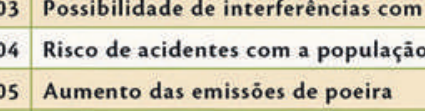

Aumento das emissioes de peeira

Aumento da demanda por infra-estrutura de saúd

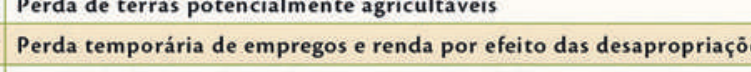

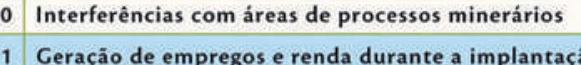

Dinamizaçäo da economia regional

Thessio sobre a infta-estrutura urbana

Especulazái imobiliaria nas varazes
itrigaveis no entorno dos canais

Aumento da ofercta e da garantia hidricia

Aumento da oferta de gasua para abastecimento urban

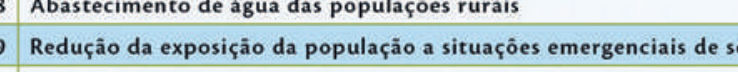

Dinamizasáo da atvividade agricola e incorporaçio de novas sireas

20.

Reduçio da pressio sobre ainfra-estrutura de solde

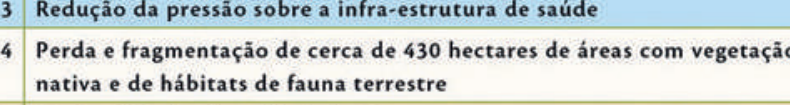

Diminuiçio da diversidade de fauna terrestren

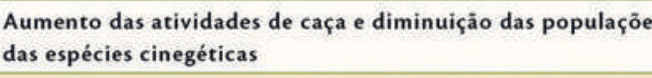

Modificació da composisiso das Comunidades Biologicicar

28 Risco de redusio da biodiversidade das Comunidades Biologicas

Comprometimento do conhecimento da historia bigeograficec
dos grupos Biologicos Aquaticos Nativos

Risco de introduçao de especies de

11 Interferéncia sobre a pesca nos a audes receptores

Risco de proliferaçio de vetores

Instabilizacáo de encoscram animais peronhentos

Inicio ou aceleraçio de processos erosivives e carreamento de sedimen

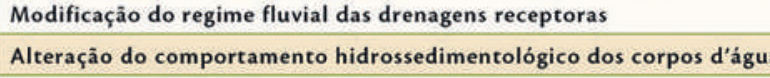

38 Risco de eutrofizacaio dos novos reservatobrios

Aumento da recarga fluvial dos aquifieros

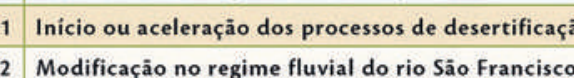

Reduçio da gerengio de

Diminusio gerescio de energia elér 

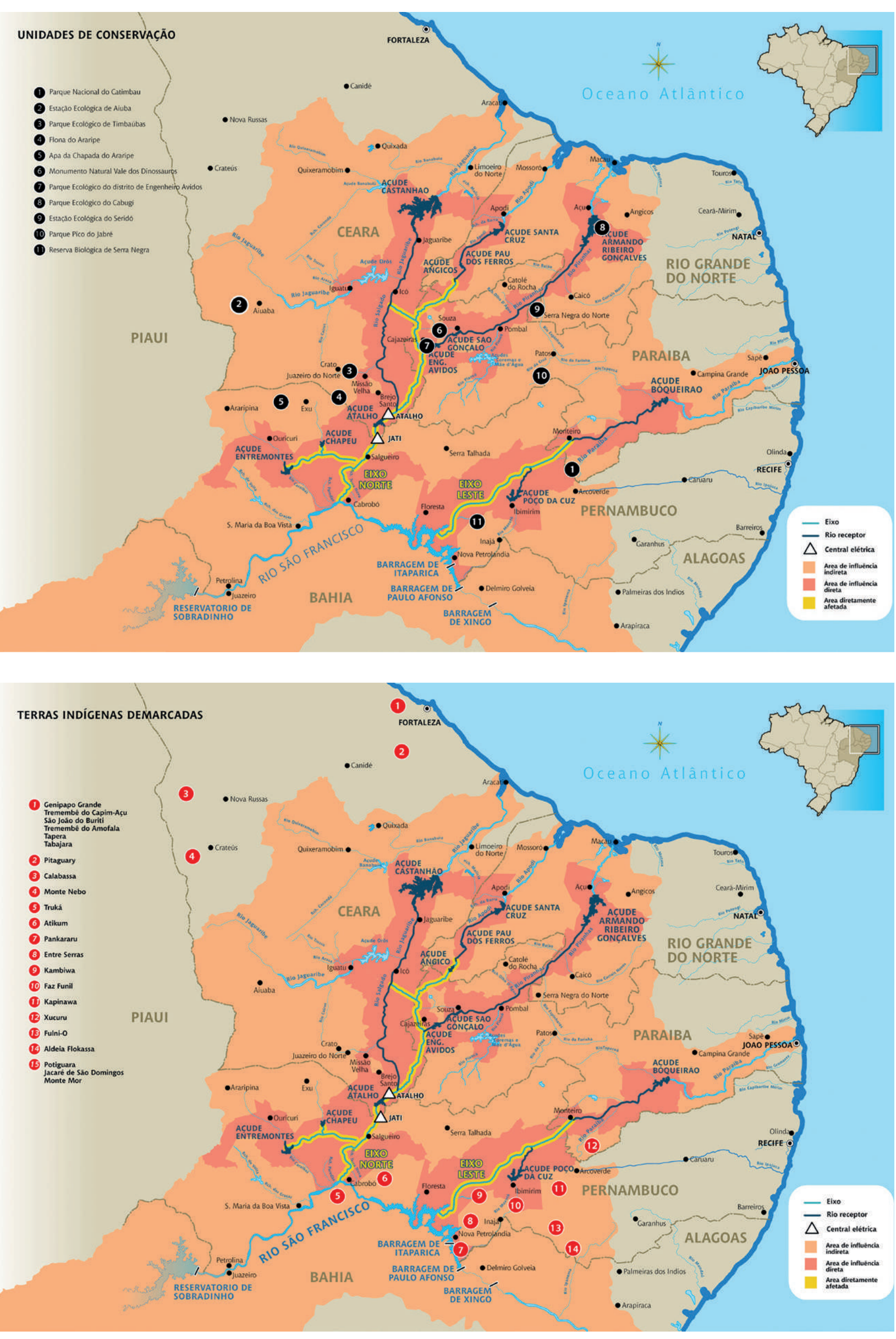

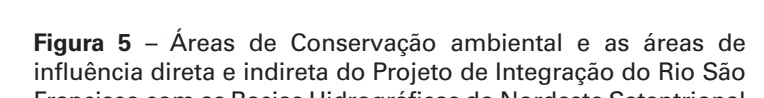

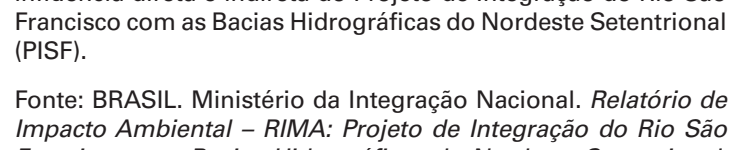

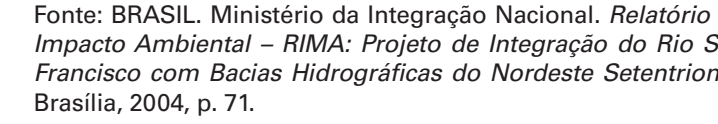

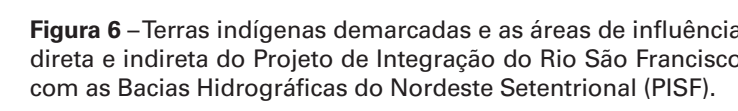

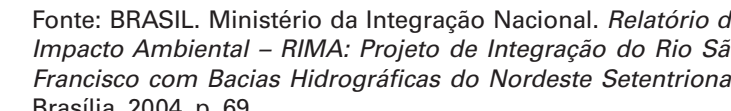

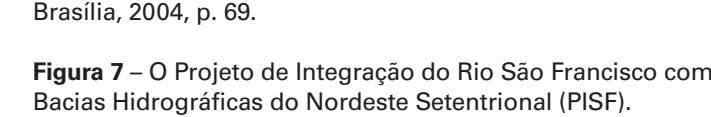

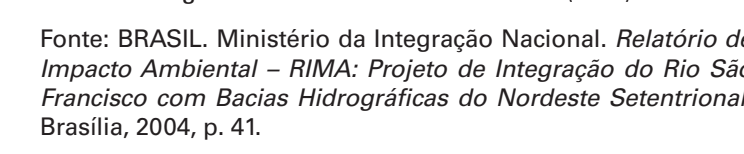

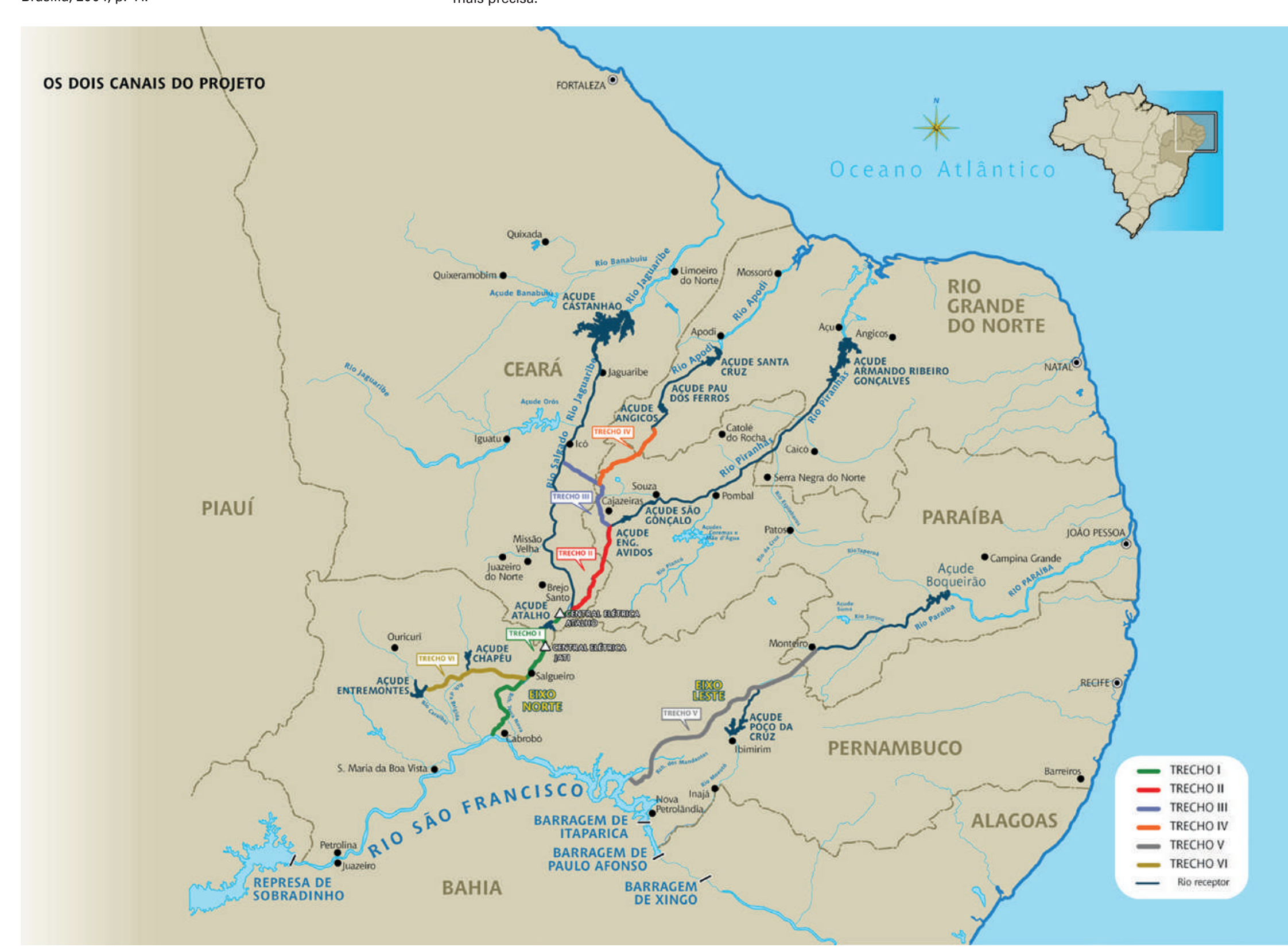

que a área onde ocorreriam as obras, compreender como é esse território correspondente a uma faixa de $200 \mathrm{~m}$ que a obra passou, suas múltiplas ao longo dos canais (BRASIL, 2004, p. formas de ocupaçao, assentamentos, mais bem definida, essas áreas são um reassentamento, etc. Nấo se pode tanto abstratas, vide que os critérios não compreender quais áreas seriam foram detalhados, não se compreende abastecidas pelo PISF nos municípios que tipo de influência ocorreria em das áreas de influência como um todo. cada lugar, e tampouco o território foi Demonstrou-se o abastecimento a partir bem apresentado no documento. dos açudes onde a agua vai passar,

como um grande sistema hidrico, em Ainda sobre a apresentaçăo do território que os sujeitos beneficiados não foram cartorias especifics como a das unidades de conservacão em se a Figura 7 em que foram demonstrados

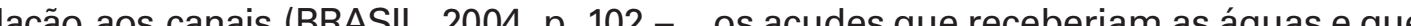
ver Figura 5) e como a das terras indígenas evidenciam os trechos nos quais a obra em relação aos canais foi repartida para desenvolvimento dos (BRASL, 2004, p. 67-ver Figura 6), porém, projetos executivos e para licitação de

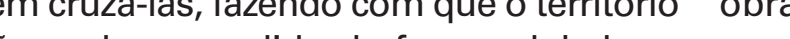

não pudesse ser lido de forma global em PISF não foram em nenhum momento A caracterização daquela região no RIMA cartografados ou citados elementos for feita de forma muito mais escrita do referentes a inserçáo nacional e que cartográfica, náo apresentando uma internacional do projeto (BARROS, leitura aprofundada da caracterizaçáa 2014, p. 35). Nâo houve nenhum mapa A partir do RIMA a A parir do RIMA na se pode que o astaviou a ouros megapojelos

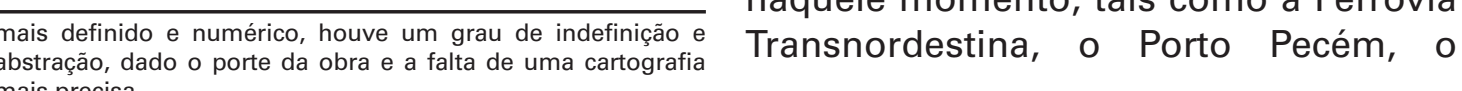


Porto Suape (BRASIL, 2005), projetos que estariam ligados a uma logica de integraçáo territurial voltada ao fluxo de capitais, alinhada as orientações macrorregionals da Iniciativa de (Integraçao da Infraestrutura Regional seguir), renomeada para Conselho de Infraestrutura e Planejamento da Unasul (COSIPLAN) (BRASIL, 2015), ,99 que, por outro lado, ap 2005, p. 34):

As açōes ora implementadas no têm sido concebidas

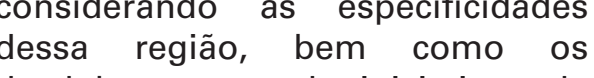
desdobramentos de iniciativas de território semiárido. Dentre elas destacam-se as especificadas e descritas a seguir: Desenvolvimento Áregrado e Sustentavel do Sem Sustentabilidade de Espaços SubRegionais-Promeso; Organizacāo
Produtiva de Comunidades PobresProdutiva de Comunidades Pobres-
Produzir; Promoção e Inserção Produzir; Promoçăa e e Inserçăo
Econômica de Sub-Regióes-
Promover; Integração do Rio São Francisco às Bacias Hidrográficas do Nordeste Setentrional; Proágua
Semi-Árido; Recuperação de Semi-Arido; Recuperação de da Irrigaçāo; PAN-Brasili; Cenários do Bioma Caatinga; Inclusão Digital; Arranjos Produtivos Locais-APL; Trabalho ascravo; Exploraçãa do Gás Natural; e Ferrovia Transnordestina (BRASIL, 2005, p. 34.

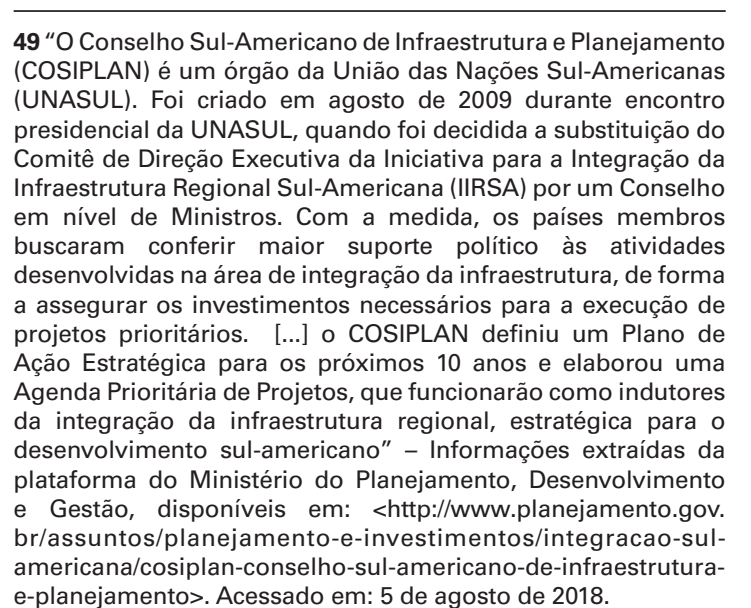

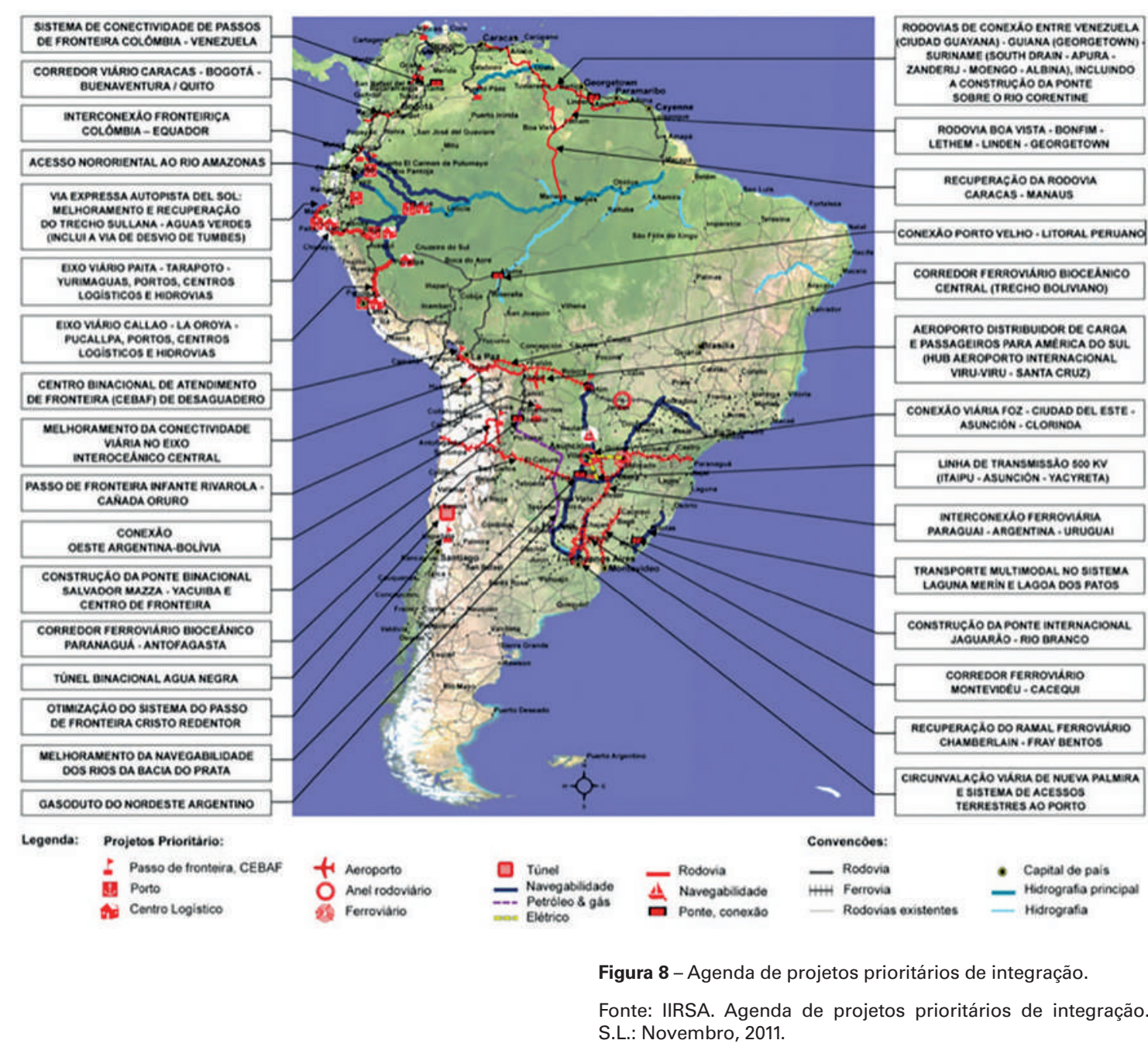

Fonte: IIRSA. Agenda de projetos prioritatrios de integracáa
SLL: Novembro. 2011
Ou seja, muito do que viabilizou o projeto acordos com a equipe do projeto de dos eixos. Embora no RIMA não tenha con contexto mais mactoeconómico, engenhara, que promoveram algumas sido explicitado que a água transposta - náo fol apres a mesmo tempo, os arguntos ténicos exemplo, em sitios de interesse todos que se encontravam no percurso apresentados com clareza a público, comulodades rurais. No RIMA (BRASIL, engenheiros alegavam que caso todas embora tenham sido utilizados como 2004, p. 35) essa informação também as comunidades rurais fossem atendidas impactos da obra. Um exemplo deles definir por onde o PISF percorreria, foram para as cidades.

foi o conceito de sinergia hidrica, que analisadas vinte e duas possibilidades na descrição do documento ao públyco de traçado e o caminho escolhido foi o foi tão resumida que se tornou quase que melhor atendeu a quesitos técnicos, seria essa forma de que o mínimo de água fosse perdida por evaporação, um pouco na lógica de ilustrar que através dessa racionalidade náo se trataria de uma obra faraônica; mas por outro lado, sem que houvesse a vazazo transposta aumentaria e que destinada às atividades para estimular o desenvolvimento econômico e regional (SARMENTO, informação verbal, 2017).50

Em entrevista concedida por Ivan Telles de Sousa, ${ }^{51}$ da Ecology and Enviroment do Brasil, engenheiro agrônomo que RIMA e a elaboração dos PBAs dentro da empresa entre os anos de 2003 e 2004, o engenheiro comentou sobre as dificuldades em relação à elaboração do EIA-RIMA. A começar pelo descompasso das distintas formas de enxergar 0 projeto e o próprio território entre os comentou que houve muito conflito entre os estudos ambientais e os de engenharia, que buscaram en geral o melhor traçado dos canais a partir de argumentos técnicos e cálculos de engenharia, e nāo o melhor traçado para preservação do meio ambiente. Sousa entende que durante a reelaboração do dos estudos ambientais, sob projeto inviável financeiramente, uma [... tem uma parte que são
a.ternativas que a gente mostra alternativas que a gente mostra
$e$ o que a engenharia pensava em fazer. Então existem conflitos, por exemplo, relacionado com a
proximidade dos Trukás, dos índios,
que tiveram que se afastar um que tiveram que se afastar um
pouco de onde eles viviam. Teve pouco de onde eles viviam. Teve
problemas com a questáo do vale dos dinossauros, eles iam passar um canal la dentro, tiramos o canal. Agora, o vale dos dinossauros água, mas passando dentro de dio provocar impacto no vale dos dinossauros. Outra questão e a questão de proximidades de
comunidades. [...] A gente tentou diminuir um pouco essa coisa de vocé passar por cima das pessoas,
das áreas rurais. Porque às vezes quando você faz um projeto desses, ele vai passar ali, porque ali tem um bom relevo, tem um bom isso, tal, e a gente entáo tirava o projeto concedida em entrevista verba consultor Ivan Telles de Sousa dia 15 de dezembro de 2017, em São Paulo, por skype.

...] quando a gente via que bilidade de atender
dade à beira de un rio, a gente dizia assim "olha, o reservatorio tem que deixar uma comunidade aqu que ali na frente". Então teve muita coisa que a gente pensou nesse sentido. claro que teve um momento dificil, admitiam, eles diziam assim "senão âo vai ter àgua para urbano", porque eles sabem que tem muita gente no caminho que precisa de agua, mas o foco era a vazão necessária dos rios para atender as populaçoes que usavam roupa, comer, plantar, entendeu? - Informação verbal concedida en entrevista pelo consultor Ivan Telles 2017.

Em entrevista com o assessor recursos hídricos e desenvolvimento regional no Ministério de Integracão, Iran Braga Ramos, ${ }^{52}$ colheu-se a declaração de que 0 abastecimento urbano sempre foi uma prioridade nessa última versão do projeto, e que o abastecimento das
comunidades rurais ocorreria apenas equipe responsável pela reelaboração comunidades no percurso tornaria

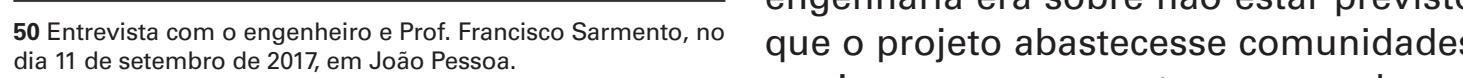
STEntrevista realizada em 15 de dezembro de 2017, em sào 
2.3.2

Os Programas Ambientais e o

plano-discurso

verbal).53 Ou seja, a Transposição estaria para que as mitigações de impacto do empreendimento.

destinada às atividades e aos usuários fossem integralmente cumpridas que consigam bancar os austos dessa conforme o EIA-RIMA:

operação de transposição

Na entrevista citada acima, Sousa também afirmou que no processo de mediar todos os atores envolvidos nas discussões sobre o Projeto, dada sua abrangência, porte e os distintos interesses envolvidos: representados
por ministérios, políticos, população etc. Segundo ele, como coordenador sido necessário mais tempo para a elaboração do mesmo e assim se ter maior maturidade das questões relativas aos estudos ambientais e ao projeto. Com mais tempo, teria sido possível uma discussão mais ampla, expandindo mais os canais de comunicação, o que Diante da análise do documento e das entrevistas realizadas com técnicos Meio Ambiente e dos Recursos Na do participantes do processo de elaboração Os impactos, diante dessa perspectiva Renováveis (IBAMA), conforme dito do EIA-RIMA do PISF, pode-se concluir de argumentação, foram minimizados de 0 instrumento teve uma funçao Em relação às Audiências Públicas contestação da viabilização obra. Dada sua complexidade exposta, sendo canceladas ou realizadas, que não possível uma versão de EIA-RIMA de ambientais superficialmente descritos no projeto, conforme descrito no item documento que abordaria as questōes ambientais ainda fossem ser detalhados 2.2 deste capitulo, Sousa confirmou no socioambientais da regiấo, assim como nos PBAS. Dessa forma, para se depoimento supracitado que emalgumas os conflitos envolvidos, o minimo para compreender como foram planejadas de estados doadores, que em geral eram real adequação do projeto ao território, a execução das diretrizes de mitigaçáa contra o Projeto, as APs foram bastante desenvolvendo-o em seu potencial seria e de desenvolvimento regria conflituosas ou té mesmo não puderam escutar a população, dar abertura para apresentadas no EIA-RIMA, a segion, ocorrer, havendo inclusive casos em modificações, quá, dar abertura para apresentadas no EIA-RIMA, a seguir, no que toda a equipe de consultores já Audiências Públicas, único momento PBAs, a partir da leitura de cada um dos estivessem na cidade em questáo para a de contato das populações a respeito trinta e oito documentos, disponíveis no realização da Audiência. Porém, segundo dos resultados dos estudos. Ou seja, site do Ministério de Integração. ${ }^{54}$ o engenheiro, os conflitos não se deram conforme a critica feita por Acselrad apenas em campo, por pressoes politicas $(2010, \mathrm{pp} .105-106)$, apresentada no início perante o desenvolvimento dos estudos deste capitulo, os estudos ambientais projeto pouco antes da tenra ser iniciada o trojeram o papel de contesta $\begin{array}{ll}\text { projeto pouco antes da obra ser iniciada o Projeto, mas pareceram ser um } \\ \mathrm{em} \text { 2007. Para Sousa, seria necessário } & \text { instrumento de aprovaçâo do mesmo }\end{array}$ maior fiscalização e acompanhamento em nível administrativo, que propôs 53 Informagăo concedida em entrevista no dia 20 de março de questionar o modelo de desenvolvimento
Além disso, o documento publicado que população, o RIMA, ao fim e ao cabo não demonstrou com clareza a magnitude dos seus impactos, apresentando que não cruzaram informaçōes com superficialidade. Os objetivos do projeto foram colocados de form municípios e nem qualquer atividade argumentos tecnicos foram colocados de forma quase ininteligivel e o porte da água retirada do São Francisco, como se

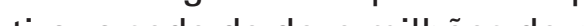

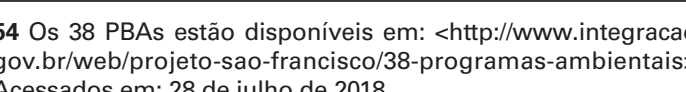
todas as comunidades e ou cidades dos a
Como dito anteriormente, na Licença prevenção e proteção dos mesmos, Previa (LP), emitida em 2005, foram como de compensaçao e supressão para exigidos que todos os programas o empreendimento, sendo os PBAs 09, ambientais propostos no EIA-RIMA 10,12, 22, 23, 24, 37 e 38 destinados para fossem desenvolvidos para a obtençáa da isso, 4 ) referentes ao meio antrópico, que metodologia responável tóchico e das condicões socioconômicas da cronograma físico de implantação. A população afetada, sendo os PBAs 07,08 , (1) emitida em 2007 e renovada em 11, 12, 15, 16, 17, 18, 19, 30 e 32 destinados $2013^{57}$ aprovou, por sua vez, os PBAs a esse assunto (BRASIL, 2018a). ${ }^{59}$ apresentados, exigindo algumas revisoes e cinquenta e nove condicionantes Os PBAs seriam os planos já em nivel ambientais a serem cumpridos antes do executivo, as diretrizes aprovadas no (LO). No EIA-RIMA foram apresentados Porém, os trinta e oito PBAs publicados vinte $e$ quatro mas ao final foram na página do Ministério da Integração desenvolvidos trinta e oito Programas Nacional, ${ }^{60}$ para conhecimento da Básicos Ambientais, que podem ser lidos população, foram elaborados de forma no site do Ministério da Integração. ${ }^{58}$ resumida, com metodologias ainda Os PBAs foram organizados em 4 estabelecidas como diretrizes, sendo nomeado o órgão responsável grandes grupos: 1) estrategicos ou pela implementação do PBA em questão. medição de conflitos socioambientais e mapas, dificultando ao leitor a localização a formação de capacidades e habilidades de onde, territorialmente, seria executada das comunidades direta e indiretamente cada ação. Tampouco se encontravam afetadas pelo empreendimento, sendo detalhamentos da execução, ou a os PBAs 01, 03 e 04 destinados a esse informaçao sobre de onde seriam alocados assunto; 2) referentes ao meio fisico, recursos para cada açáo, ou sobre quanto elaborados visando acompanhar e cada PBA custaria. Muito embora seja ambientais relacionadas às obras de aos PBAs nos balanços do Programa de engenharia civil do Projeto de Integração Aceleração de Crescimento $(\mathrm{PAC})^{61} \mathrm{e}$ em do rio São Francisco com Bacias alguns outros portais do Governo Federal, Hidrográficas do Nordeste Setentrional como será evidenciado no capitulo 3, nos (PISF), sendo os PBAs 02, 05, 06, 26, 27, PBAs oficialmente divulgados isso não 28,34 e 35 destinados a essa frente, 3) ficou claro. Essa limitaçăo de informaçōes referentes ao melo biotico, programas nos docimentos publcados pode ter flora da região, podendo ser tanto de amplo com a população sobre os PBAs.

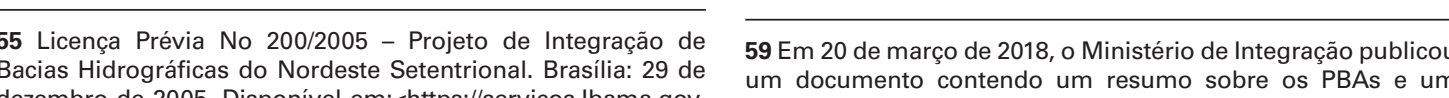

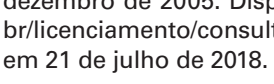

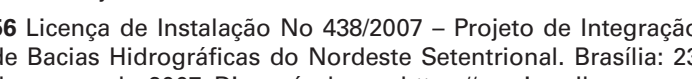

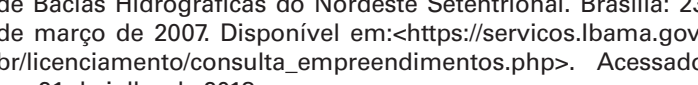

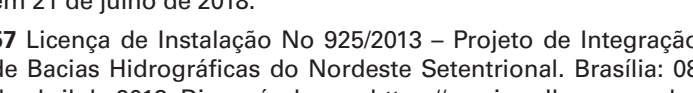
nemprenndimentos spopps: Acessad 21 de julho de 2018.

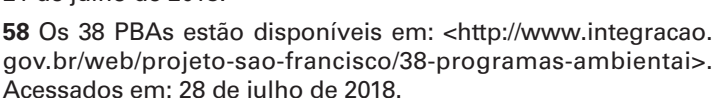

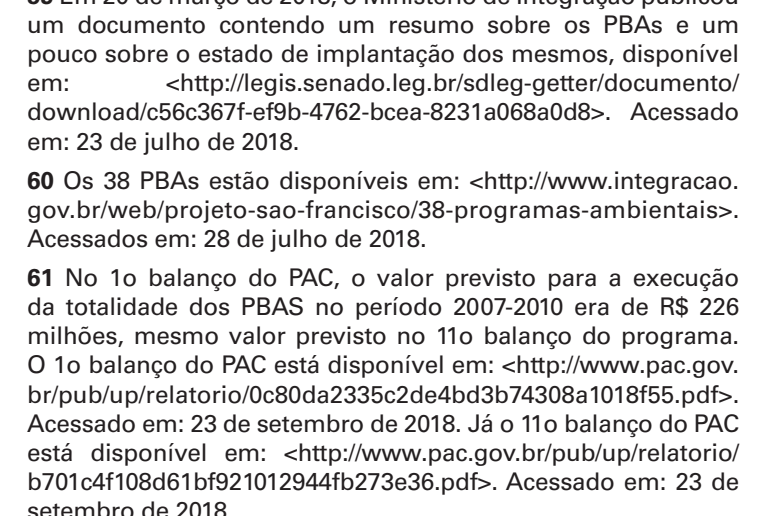




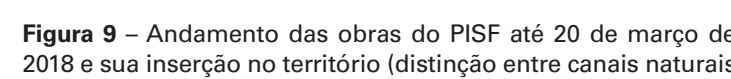

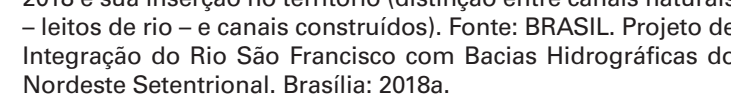

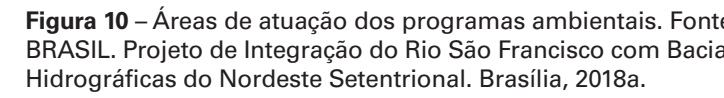

Além disso, na página do IBAMA, ${ }^{62}$ de verificar se o empreendimento relatório (BRASIL, 2018a), ${ }^{68}$ expondo um portal oficial para acompanhamento fornecia as condiçoes adequadas e os resumo sobre o projeto e implantaçăo dos licenciamentos que ocorrem pelo instrumentos regulatorios suficientes da obra e, principalmente, expllichndo Brasil promovidos pelo governo federal, para garantir a conclusáo das obras, bem as frentes principais dos programas era possivel saber em que etapa se como operação e manutençãa, alem da ambientais e sua execução. Apesa possivel compender quais acões já haviam sido implementadas dos PBAS necessárias à Transposição, postergou a que demonstraram com mais clareza o nem como haviam sido cumpridas, execuçăo das principais linhas de açoes, andamento da obra, como ela se inseriu Mesmo assim, através de outros meios as tarefas e atividades necessárias à no território, onde se localizaram as |relatórios de outros órgãos federais e realização da operação do Projeto para ações ${ }^{69}$ dos programas ambientais, en noticiasde jornal, como serăapresentado garantir a operaçao, manutençáo e que estágio se encontravam e ate mesmo

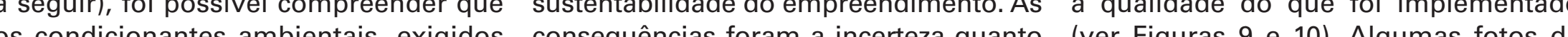
os condicionantas a cotos da Instalação (IBAMA, 2007, p. 2) $)^{63}$ tardaram a inadequação da estrutura necessária à também foram apresentadas (alaumas a ser executados, evidenciado pelo fato gestão e operação do PISF (BRASIL, 2017, serão apresentadas no capítulo 3) para de que a LO, solicitada em 2016, não pp. 6-7).66 havia sido concedida até início de 2018, momento em que o Eixo Leste ja havia Em relação ao atendimento das sido inaugurado, ${ }^{64}$ ainda que em fase de populaçoes ao longo dos canais, do Eixo Norte já estava quase finalizada, haviam sido atendidas, demenstrando que o objetivo do projeto não ficou claro O Ministério da Transparência e nem para organizaçōes de controle do Controladoria Geral da União (CGU) próprio governo federal, talvez pela elaborou um relatório de avaliação imprecisáo do discurso erior.

Integração do Rio São Francisco (PISF) em novembro de $2017^{65}$ com o objetivo

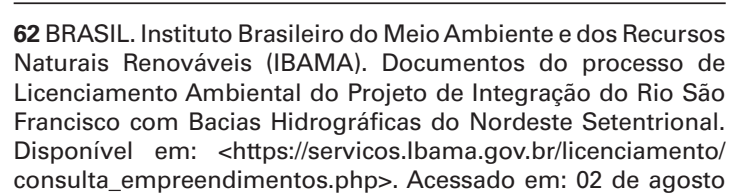

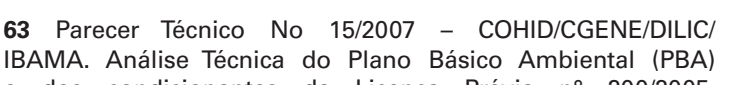

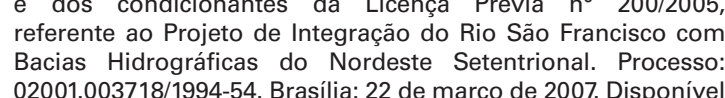

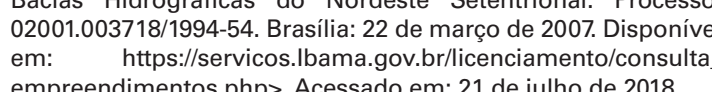

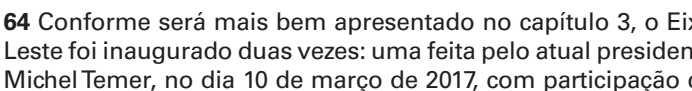
hove dias depois, feita pelo ex-presidente Lula, em 19 de Marco de 2017, que atraiu milhares de pessoas. Apesar disso,
ainformacăo de que a o obra se encontrava em teste de pre

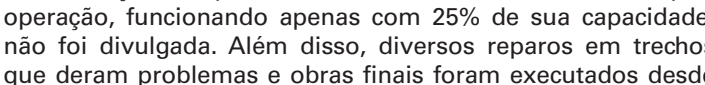

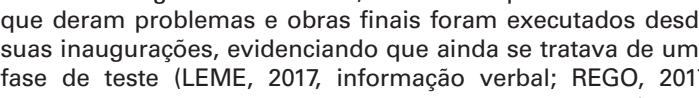

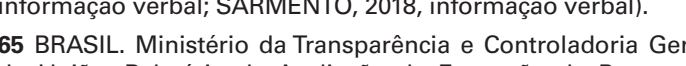

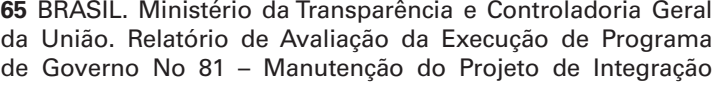

Atualmente, o PISF encontra-se orçado em aproximadamente $R \$ 9$
bilhöes. 67 Essa verba não inclui os investimentos adicionais para levar encontram nas áreas lindeiras dos do sertão. Estima-se que o custo final da obra, quando concluidas (BRASIL, 2017, p. 5).

Além deste, em 20 de março de 2018 Ministerio da Integração publicou un

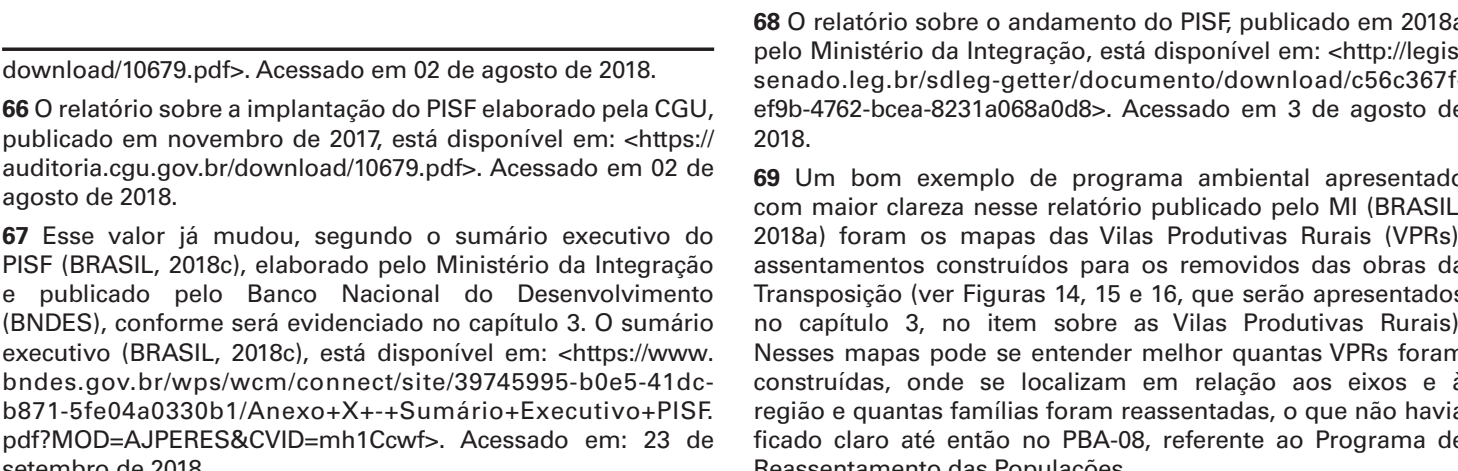

PROJETO DE INTEGRAÇÃO DO RIO SÃO FRANCISCO COM BACIAS HIDROGRÁFICAS DO NORDESTE SETENTRIONAL - PISF

O CAMINHO DAS ÁGUAS
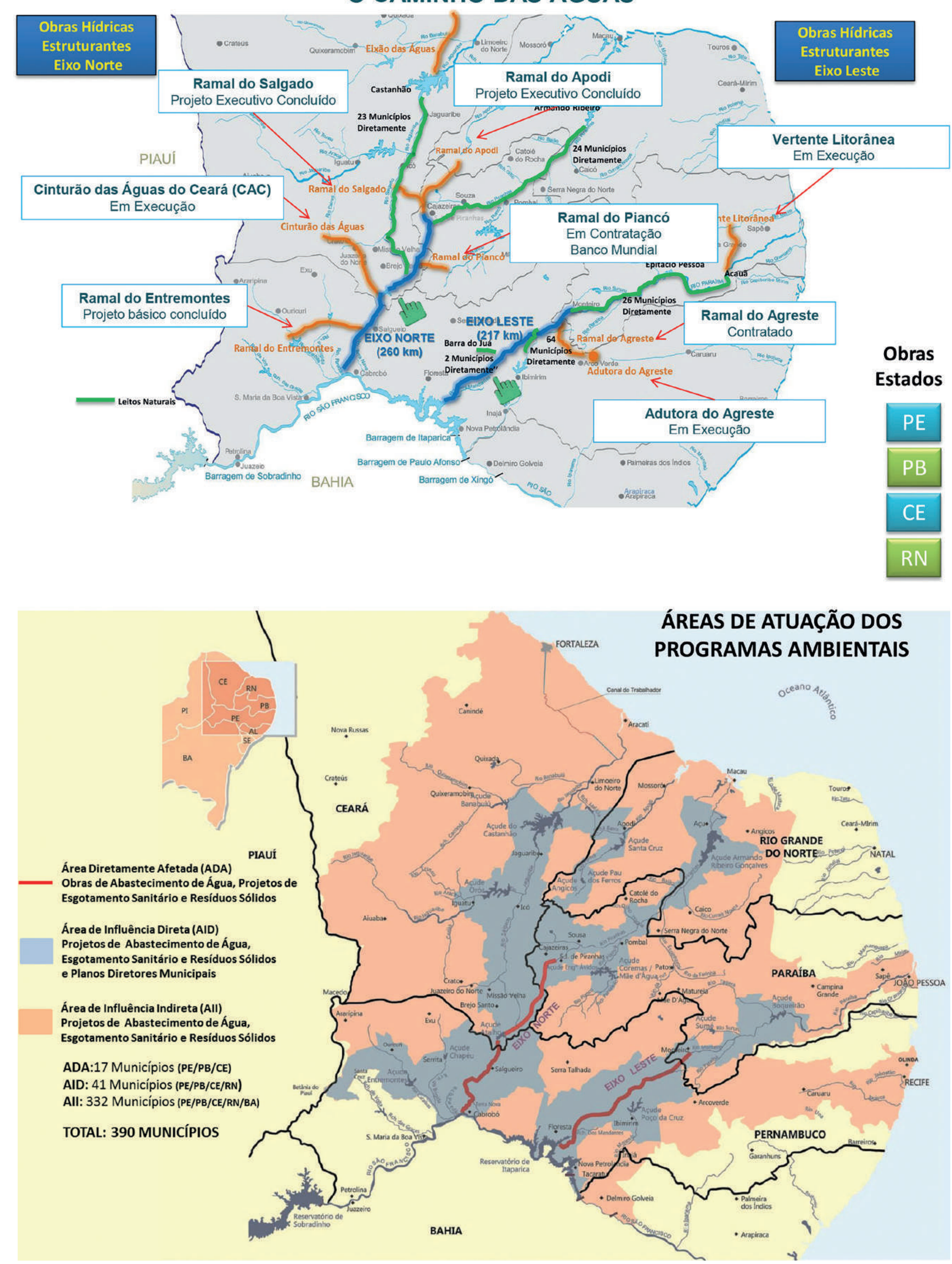
O relatório do MI (BRASIL, 2018a) ${ }^{70}$ LICENÇA DE INSTALAÇÃO No 925/2013 indicou que, naquele momento, quase todas as condicionantes já haviam Júneçado a ser atendidas $(56,45 \%)$ ou já haviam sido atendidas $(29,03 \%)$, mas pouquissimas atendiam ao prazo da pela tabela da Figura 11 a sentado reafirmando que a LO não poderia ser concedida, apesar do Eixo Leste já ter sido inaugurado.

Segundo o relatório do MI (BRASIL, 2018a), mais de $90 \%$ das ações de supervisão deobrase proteção daslinhas de transmissão já estavam concluídas, mas as ações compensatórias e socioambientais se encontravam concluídas em apenas $75,17 \%$ (ver motivo do atraso pela obtenção da LO.

Além dos relatórios oficiais, diversas notícias de jornal foram publicadas a longo dos anos de execução da obra dos canais e problemas socioambientais decorrentes da obra. Muitos desses problemas socioambientais nos PBAs, e as denúncias estavam ocorrendo ou pela não execução correta do programa, ou por um planejamento mal feito e, portanto, mal mitigado.

Como exemplo, elencou-se aqui uma notícia que denunciava as obras de Monteiro (ver Figura $131^{71}$, resule de no despejo de esgoto sanitário e lixo no sistema fluvial e contribuindo assim para a contaminaçâo da água recebida da transposição. Esse impacto poderia ter sido evitado, teoricamente, atraves de PBAs, tais como o Programa de e Limnomenia - PBA 22" " "Programa de Apoio às Acões de Vigilância da Qualidade da Agua para Consumo Humano - PBA 30" e o "Programa de Apoio ao Saneamento Básico - PBA 32". Ainda sobre o saneamento, pouco depois da inauguraçáo do Eixo Leste, a encaminhou ofício à presidente do Instituto Brasileiro do Meio Ambiente e dos Recursos Naturais Renováveis comprovam que as condicionantes não vinhamsendocumpridasnaintegralidade pelo Ministério da

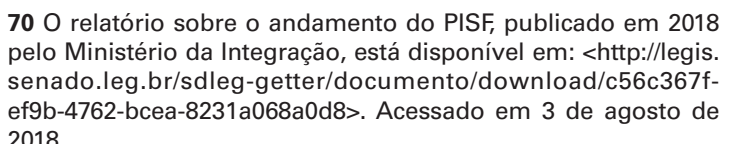

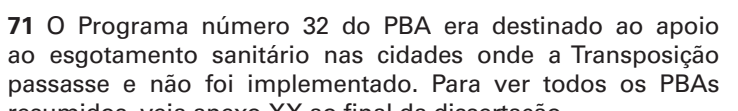
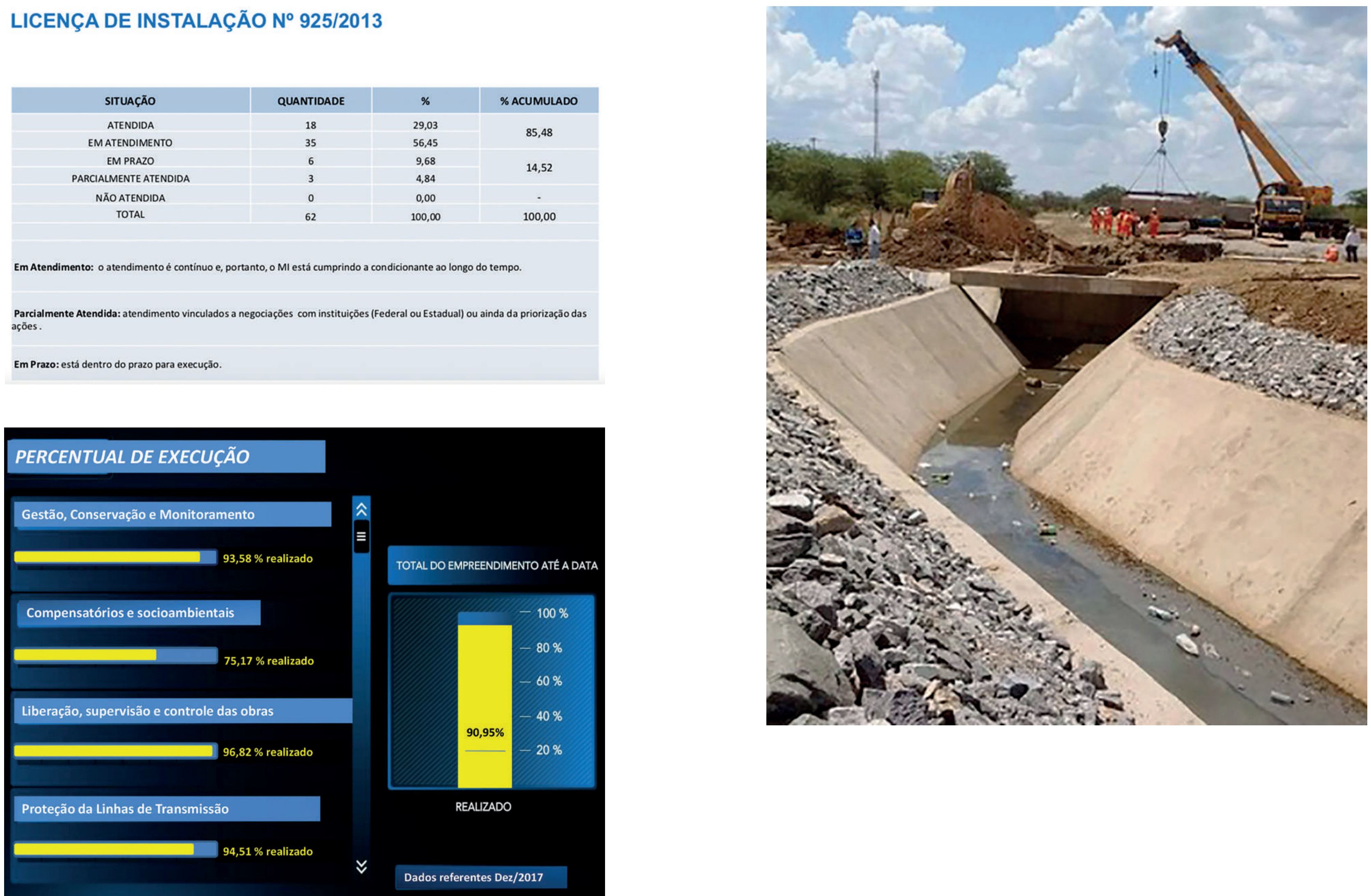

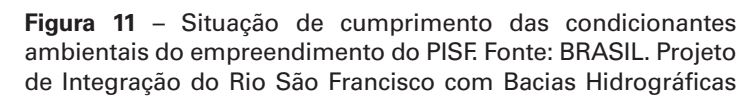

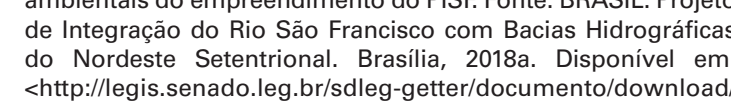

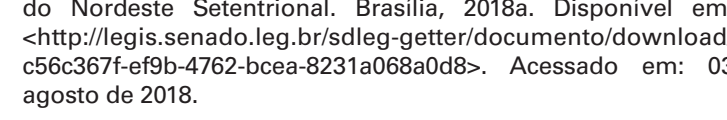

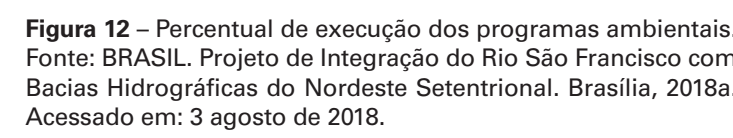

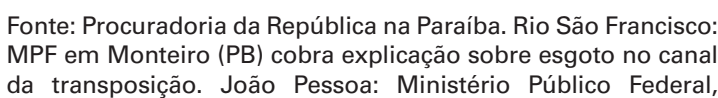

fazendo com que este acordasse com - Ministerio Público Federal (MPF) a realizaçáo de uma fiscalizaçâo das condicionantes das licenças previas de instalaçáo. nos reassentamentos das da revitizacão do rio Pariba esgotamento sanitário nos municípios por onde o Eixo Leste passa e abastece $(\mathrm{MPF}, 2018)^{72}$

Finalmente, apesar dos relatórios e denuncias, em outubro de 2018 a eicm aue fosse possivol com enitida e acompanhar se as diversas condicionantes previstas para sua obtenção, as que estavam ainda em andamento e as que tiveram problemas, haviam sido concluidas. A LO não for divulgada oficialmente, mas sim por diversos canais de comunicaçaào
(METRÓPOLES, 2018; BORGES, 2018). Em entrevista com B engenhero assessor do Ministério da Integração, Irani Ramos ${ }^{73} \mathrm{o}$ profissional alegou que a LO ainda năo era pubblica, portanto ainda nao havia sido publicada oficialmente, jà que alèm de a operaçăo propriamente dic que arm de a operacio propriamente ainda não haviam assinado os contratos com o governo federal para "compra" e uso da água. Portanto, ainda haviam questōes de gestáo dos recursos hídricos e negociaçoes tambèm financeiras em Assim como não foi possível
compreender como os PBAs seriam executados por meio dos seus documentos, também não foi possível compreender de forma completa e por fontes oficiais como eles se deram na pratica. Pelo pouco que se pode ver, os havendo uma bastante simplificados, discurso apresentado no EIA entre prática apresentada na execucão dos programas. Por ora, apresentou-se um pouco de como se deu o planejamento e a divulgaçáo dos documentos oficiais do projeto. Ja no capitulo 3 , serâo apresentados um pouco de como se PBAs a partir do trabalho de a dos entrevistas com moradores beneficiados e impactados.

Uma vez que essas ações dos PBAs fariam com que o empreendimento transcendesse sua funçáo de ser superar a seca, estimulando atividades

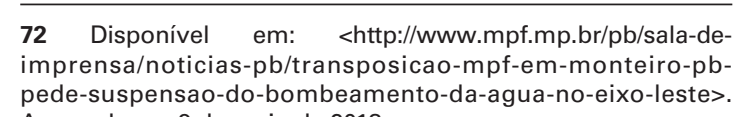
Acessado em 9 de maio de 2018 .
73 Entrevista concedida por e-m.

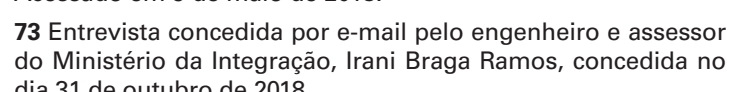


para o desenvolvimento regional e fortalecimento local relacionadas ao projeto, os PBAs talvez fossem uma planejamento. Sua nãante de todo o leva a se pensar que o objetivo do desenvolvimento regional a partir dessa obra de infraestrutura ficou apenas no campo administrativo, permanecendo a Transposiçaao na categoria de mais uma e

Muito embora esse discurso de atrelado à obra tenha sido reforçado no discurso político do governo Lula, como dito anteriormente, o primeiro estudo aprofundado que definiu a inserção regional do projeto e, portanto, tratou do que seria o desenvolvimento regional prometido pela obra, foi elaborado na gestáo FHC. Trata-se dos Estudos de niciados na primeira gestão desse, expresidente e concluídos na segunda, no ano 2000.

$\mathrm{O}$ documento em questão não fez parte do Licenciamento Ambiental e portanto aáo procurou conaúsístar no discurso as licenças, mas sim, se construiu a partir das críticas ambientais, argumentando ecnicamente cada ponto, e definiu o que de fato o Projeto entendia por território, documento este que foi considerado no governo Lula. Portanto, importante a análise desses estudos. que será feita a seguir, no item 2.4 .

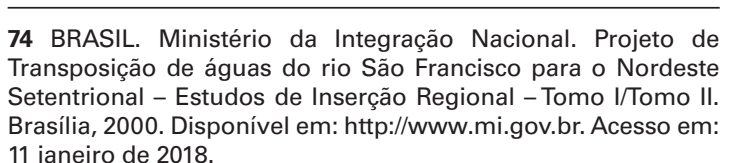

2.4

A inserção regional prometida

Os Estudos de Inserção Regional referentes ao Projeto de Transposiçãa de Águas do rio São Francisco para - Nordeste Setentrional foram encomendados pelo Ministério de de Ciência Aplicacões e Tecnologia Espaciais (FUNCATE), que por sua vez contratou, com dispensa de licitação, a VBA Consultores, ${ }^{75}$ sendo iniciados em 1996 e publicados em 2000, no governo FHC. Os estudos, que custaram R\$ 2.448.195,06 para serem elaborados, foram compilados ém um Relatorio dois tomos, o primeiro com duzentas sessenta e nova páginas e o segundo com quatrocentas e cinquenta e seis, publicados no site do Ministério de integração.

documento apresentou estudos recotoras das águas tras aseas elaborados de forma extensa, detalhada, contendo textos, muitas tabelas, gráficos, alem de mapas elaborados por assunto e por areas especificas (ora ora por bacias etc.), sem ser possíve final, sem uma proposta síntese final de inserção regional do projeto. Entendeuse por estudos setoriais os estudos relacionados à gestão dos recursos hídricos e possibilidades a partir do tais como:

[...] identificar e quantificar as demandas hidricas atuais e futuras nas bacias receptoras, quantificar de cada local receptor; analisar o comportamento dos açudes de
regularização de vazōes das bacias avaliar o impacto as águas transpostas sobre as hessas bacias; avaliar o impacto
didras local sobre a geração de hidroenergia no rio de reposicão das perdas; identificar inerentes à transposição das águas, em especial os geomorfológicos e as perdas ho treje, formular cenários hídricos $\mathrm{e}$, através da realização de balanços hidricos, definir alternativas de vazoes a transpor; avaliar os formular as opçōes de modelos de (BRASIL, 2000a, Tomo I, p. 1-2).

Entendeu-se por "região doadora" a area de tomada das águas, trecho do rio se estado de Pernambuco earia (submédio), estendendo-se até a foz localizada entre Alagoas e Sergipe (baix isco); e por "região receptora" a drea de construçáo dos canais por a de correnam as aguas transpostas, cia do Ri Jaguaribe (CE) Bacias: tropolitanas do Ceará indiretamente eceptoras, face à conexão com a do rio guaribe através de eixos de integração (R) Acu (RN), Bacia do Piranhas (PB); Bacia do Paraiba (PB); Bacia do Brigida (PE) e ilustra abaixo.

os Estudos de Inserção Regional, foram laborados estudos das características fisiográficas da regiáo e seus potenciais por exemplo tipos de solo, recursos hidricos subterrâneos etc.); das tendências estatisticas (por exemplo, manda hídrica per capita e para cad po de atividade etc.). e se identificaram ubprojetos integráveis ao projeto Transposiçáo a partir de políticas úblicas federais e estaduais em curso a região. Em relação aos subprojetos, 


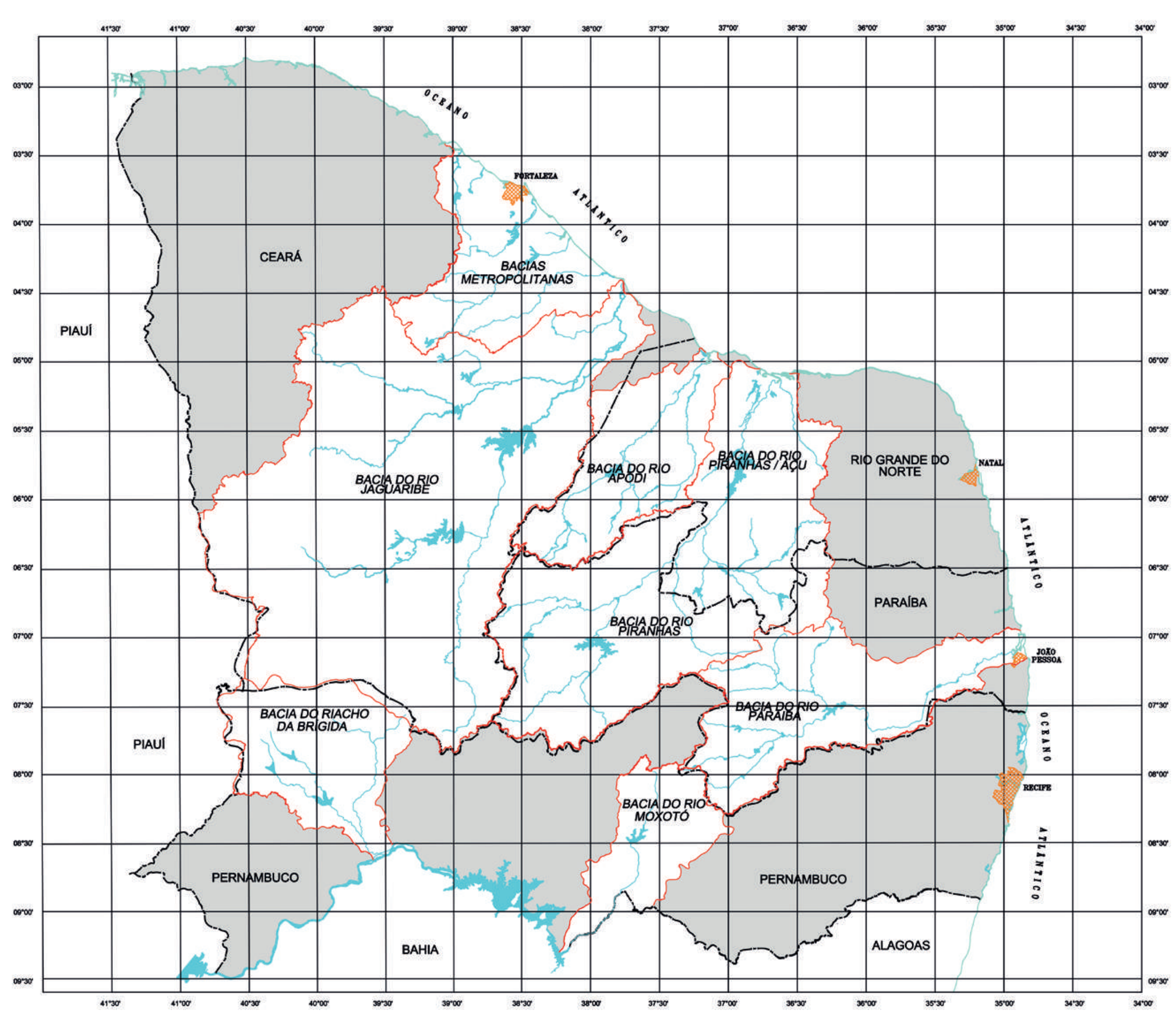

estes foram compatibilizados com os lo, mas sim legitimá-lo, justificá-lo, cenários estabelecidos nos estudos de identificando, analisando e quantificando Análises Prospectivas do Abastecimento todos os fatores que poderiam reforçar Irrigação, elaborados no próprio excluídos os aspectos puramente de documento dos Estudos de Inserção engenharia de obras e ambientais, alvos Regional. Alguns desses subprojetos de outros contratos (BRASIL, 2000a, não haviam sido concebidos com a Tomo l, p. 1-2). Foi, portanto, a partir intenção explícita de serem incorporados desse documento que foram construídos ao projeto de transposiçaa, mas os argumentos técnicos como resposta faziam parte dos planos estaduais ou às críticas ambientais que vinham federais de abastecimento urbano, ocorrendo no governo FHC, momento e de aproveitamento hidroagrícola. Já ambiental e de acirramento das disputas outros, em especial os relacionados políticas e ideológicas em torno do $\begin{array}{lll}\text { objetivo específico de aproveitamento } & \text { 2.2., reforçado pela citação a seguir: }\end{array}$ complementar de águas transpostas ao uso de recursos hidricos to
2000a, Tomo II, p. 10-2).

Como foi declarado no próprio documento, os Estudos de Inserçẫo Regional não tiveram por objetivo O foco desses estudos recairia sobre os temas que envolviam a subjetiva dimensão ambiental, muito útı como cortina de fumaça para discursos contrários à obra, mass com cada questão tida como relevante
e levantada pelos opositores inseríamos um novo trabalho para compor o Termo de Referencia bibliográfico que seria denominado Projeto de Transposiçąao do Rio Săo seu papel de dar o estofo técnico as justificativas da necessidade deixadas pelas versões anteriores da Transposiçao (SARMENTO, 2018, p. 180).

Estes argumentos técnicos a favor da pribliogránica do 125), e dariavras de Sarmento (2018, 125), e dariam o tom da promessa de que relacionou de maneira mais precisa estimular. Embora elaborados no overno FHC, os Estudos de Inserção "Estudos de Inserção Regional do preencheria a maioria obra, pois to lacumento se dado que se tratou do único documento as atividades que o projeto pretendia

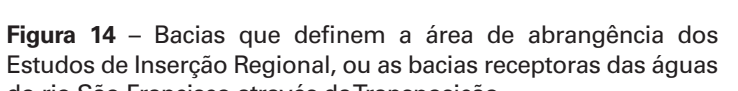

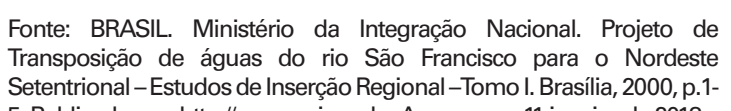

Regional foram utilizados também como documento oficial para a integraçáo regional prometida do PISF, versão do projeto no governo Lula, embasando o trabalho do Grupo Interministerial reuniu-se a documentacão . Ou seja, (SA organizada no governo Lula para que dessa maneira houvesse todos os

da obra e sua inserção regional. Como relacionado anteriormente, as possibilitando que o empreendimento na inserção regional da obra seriam projeto de aumento de oferta de água - abastecimento urbano (humano e mas também como um instrumento de industrial), a irrigação e os "usos difusos" gestão de recursos hídricos (BRASIL,
(BRASIL, 2000a,Tomol, p. 2-3), entendidos 2000a, pp. 4-18; SARMENTO, 2018, p. por piscicultura, abastecimento humano 180 ). Como já dito anteriormente, esse
$\mathrm{em}$ áreas rurais e pecuária. A justificativa conceito seria amplamente utilizado para o abastecimento urbano ter se posteriormente no governo Lula como ornado prioridade também foi explicado justificativa da racionalidade do projeto. já nesse documento ${ }^{78}$ dado que 0 semiarido brasileiro tinha sua população espalhada em centenas de cidades e 政 do seu perfil demográfico e passando de rural para urbano (BRASIL, 2000a, 105). Os critérios de abastecimento foram definidos da de abunte meira nos Estudos de Inserção Regional:

[...] todas as sedes municipais situadas da transposição deverão ter, de forma garantida, o fornecimento de água para o abastecimento da populaçãa $\mathrm{e}$ das atividades econômicas urbanas. receber o mesmo tratamento as sedes dos municipios com população superior a 5.000 habitantes e situadas até a distância de $50 \mathrm{~km}$ do eixo de das obras necessárias, tais como dutoras e estaçoes de tratamento, foi realizado a partir de projetos verter, seria transposto e destinado
a atividades de "usos nobres". Pode-

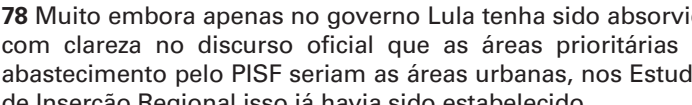
[...] uma regra operacional flexível
aquela em que as aducōes de aquela em que as aduçoes de mazós a serem transpostas náo situação de armazenamento nas acias receptoras, e sim da situação armazenamento de águas en duções sempre que os níveis $d$ de um certo valor do volume útil, ou quando houvesse risco de Setentrional de água no Nordeste industrial e, mesmo, manutençăo

Ou seja, a sinergia hídrica calculada para a Transposiçáa permitiria que quando estivesse na iminência de se entender aqui "usos nobres" como

indicar que a sinergia evitaria a perda de água na iminência de Sobradinho verer, um conceito que propunha um esperdícs. Nos Estuda agua, sem Regional ainda foi colocado que eşa peração flexível do projeto, evitando desperdício e destinando a água para "usos nobres", permitiria a redução "dos conflitos de usos da agua na bacia do rio Sáo Francisco e beneficiaria, RRASIL, 2000a, Tomo II, p. 7-22). Tratava-se de um argumento réc2. visando efetivamente justificar a obra pois os conflitos não foram reduzidos essa inovaçao, talvez por ter sido ma plamente divulgada a população, propor ta faltado uma cou cenvolvimento regional.

Dessa forma, os Estudos de Inserção Regional consistiram por um lado, em un documento muito detalhado no a a rectora identificando o cresimento urbano e o aumento do êxodo rural, fator que ajudou a justificar a mudança de objetivo da Transposiçãa de agora abastecer especialmente areas urbanas

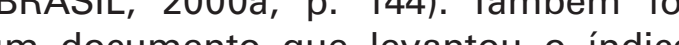
devarice una em cada estado o consumo per e urbano, estudo dos tipos de demandas hídricas, balanço hídrico cada bacia, análise dos solos etc. uma infinidade de estudos setoriais, fertos com seriedade, que justificaram as

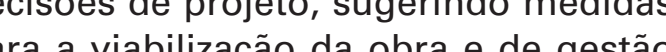
政 egional foi pensada apenas sob a erspectiva dos impactos ebenefícios em ermos de recursos hidricos, elencandoatividades de desenvolvimento regionado se os tipos de usos da água que o projeto de se transpor as águas, além de poderia fortalecer e determinando quais 
deles justificariam economicamente o projeto. Outras questões que seriam importantes na inserção regional para uma obra desse porte não foram contempladas com profundidade, como as diversas características culturais, ambientais, sociais e territoriais (no sentido das diversas formas de ocupação e assentamentos existentes nessa região) do semiárido setentrional. Posteriormente, para suprir essa demanda, o EIA-RIMA e os PBAs foram elaborados, mas como se pode ver, tiveram uma serie de contradições e limitações entre seu planejamento, discurso e execução (esta dimensão será analisada com maior profundidade no capítulo 3).

Para Sarmento, essa concentração populacional nas cidades, por um lado, reduziu o sentido de se ter um projeto voltado para o suprimento da agricultura irrigada na região, mas, por outro, criou um cenário em que a prioridade de levar água para abastecimento humano nas zonas urbanas tomaria o lugar no foco de projeto de desenvolvimento regional, marcante na Transposição, desde os tempos de Andreazza (SARMENTO, 2018, p. 105). Entretanto, segundo Sarmento, ${ }^{79}$ a questão da segurança hídrica nas cidades poderia ser resolvida com obras menores e menos custosas do que a Transposição do São Francisco, que por sua vez só se justificaria quando o projeto completo fosse implementado, utilizando a água para estimular atividades econômicas que promoveriam o desenvolvimento regional, conforme os Estudos de Inserção Regional propunham.

Em relação ao que se pode observar acerca do potencial de uma obra de transposição de grande porte, como infraestrutura de apoio ao desenvolvimento, a Transposição do São Francisco supera importantes projetos implantados mundo afora, tendo esses projetos representado

\begin{abstract}
um fator indispensável na transformação socioeconômica emergente, com a disponibilização da água para regiões onde as potencialidades locais não podiam ser exploradas em sua integralidade, em função da escassez hídrica (SARMENTO, 2018, pp. 50-51).
\end{abstract}

Porém, os Estudos de Inserção Regional, ao serem constituídos a partir das disputas territoriais e políticas daquele momento, tendo o objetivo de legitimar a obra a qualquer custo, sem uma real escuta das populações, sem um real cuidado com atingidos, trouxeram discussões limitadas aos recursos hídricos, muito técnicas e pouco globais em relação a outros assuntos da região. Isso pode ter gerado um distanciamento entre o que se entendia por inserção regional e a realidade, apesar de os diagnósticos terem sido feitos por equipes que contaram com profissionais altamente qualificados para sua elaboração.

A seguir, no capítulo 3 , será analisado como a obra se viabilizou e como foi sua execução até o presente momento, no início de 2019. Será possível ver que a inserção regional e os programas territoriais (entende-se como territoriais aqui os PBAs, elaborados a partir das diretrizes do EIA-RIMA para execução), tiveram muitas limitações e discrepâncias entre o discurso e o que foi efetivamente implantado. A obra de transposição, da forma que foi sendo viabilizada, perdeu muito de sua característica de ser uma obra de apoio ao desenvolvimento regional, tornandose cada vez mais uma grande obra hídrica de combate à seca, solução esta nada inovadora, reiterando a antiga ação do Estado perante o problema da seca e da pobreza no semiárido. 


\section{A viabilização da obra e sua inserção no território}

\begin{abstract}
No capítulo 1, foram realizadas análises sobre a concepção do projeto desde sua primeira versão até sua reelaboração no período do governo Lula, quando inicia-se sua construção, dando um panorama dos contextos políticos ao longo desse tempo, bem como ideias que permaneceram e transcenderam contextos políticos tão distintos. Já no capítulo 2, foram apresentados os documentos técnicos da versão final, cuja elaboração abrangeu as gestões de FHC e Lula, sendo possível perceber algumas contradições nesse processo para a viabilização da obra, referentes aos conflitos entre o discurso oficial, o técnico e os distintos interesses em torno do projeto. Essa complexidade do projeto gerou disputas políticoterritoriais que atravessaram décadas, não sendo totalmente superadas para a viabilização da obra.
\end{abstract}

Como foi apresentado também no capítulo anterior, os programas ambientais serviram muito mais para viabilizar a obra no campo político do que para de fato estimular e ou questionar a concepção de desenvolvimento regional do empreendimento. Isso se não apenas se revelaria no âmbito do planejamento, nas contradições entre documentos, mas também pode ser averiguado em campo, através das entrevistas com diferentes atores sociais envolvidos, tanto beneficiados pelas águas transpostas, quanto atingidos pela obra. Em poucas palavras, é possível afirmar que se tratou de uma obra que não concretizou seu plano de inserção regional, atravessando o território apenas como mais uma grande obra hídrica.

Dessa forma, a partir do entendimento da concepção do projeto, do planejamento e do contexto em que isso se deu, o capítulo 3 pretende apresentar como se deu a inserção da obra no território até o ano de 2018. Trata-se de momento em que o Eixo Leste já havia sido concluído e se encontrava em fase de pré- 


\section{A viabilização financeira da \\ obra (PAC) e a divisão da obra}

entre empreiteiras

operação, sofrendo ajustes e pequenas desenhos técnicos e fotografias tiradas ntervençoes necessárias para seu bom em dois trabahos de campo, um

realizado em 2013 e outro realizado em
2017, este já destinado especialmente à ainda se encontrava em obras. presente dissertação.

Assim como o projeto, o território ond

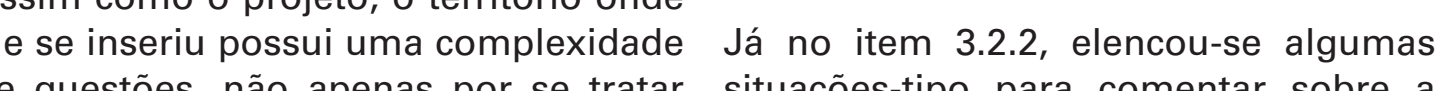
de uma grande área, cruzando quatro situaçōes-tipo para comentar sobre a estados diferentes, mas também por e o que ela gerou, transformou, esse território possuir uma ampla impactou. Trata-se de locais levantados diversidade de tipos de assentamentos, como estudos de caso a partir de do formas de vida, aluas, formas de trabahos de campo, un

de notícias de jornais, pretendeu-se implantacão da deu este processo objetivo de, após as análises documen化 a execuçăo dessa grande infraestrutura como se dá a inserçăo da obra por onde erritório la se relacionou com esse cela passa, ou seja, entende-la na prática tempo, buscou-se apresentar outros que havia sido planejado.

fatores de viabilizacão da obra, não mais

no contexto politico e técnico, como ja

apresentado no capítulo 2, mas também

no âmbito financeiro, e como isso refletiu na execução da obra.

No item 3.1, será apresentado como essa obra se viabilizou através do Programa um panorama geral sobre o que isso significou na administração pública $e$ contextualizando um pouco dos valore da obra e das fases de licitação como isso refletiu nas organizaçōes de

Já no item 3.2, será apresentado uma caracterização geral da obra, abordandose o modo como ela se inseriu no como sua relação com as paisagens $e$ assentamentos diversos que atravessou.

O item 3.2.1 se dedicará a ilustrar a significação de cada trecho da obra
in loco, bem como de suas soluçóes técnicas nas cartografias quando se vai a campo, buscando possibilitar que leitor compreenda sua magnitude no território. Confrontou-se cartografias,
Conforme mencionado brevemente no capitulo 1, a obra da Transposição do rio São Francisco foi viabilizada
através do Programa de Aceleracão através do Programa de Aceleração federal em 2007 para destinar recursos prever os valores dos empreendimentos públicos para a execucão de grandes estruturantes e, sob vários aspectos, foi obras de infraestrutura social, urbana, uma quebra de paradigma na gestão do logística e energética pelo país. No orçamento público, porque permitiu ver contexto de crise financeira mundial orçamentariamente empreendimentos do periodo 2008-2009, o PAC passou a estruturantes estendidos por vários contribuirforeme PIB quanto à formais, garantindo uma política ano. Logo, ferrovias, rodovias, portos, econômica baseada no consumo de aeroportos até então não podiam ser bens e serviços e na expansão da iniciados, a não ser por iniciativa privada construção civil e aliviando os efeitos (RAMOS, 2018, informação verbal). ${ }^{3}$ O da crise sobre as empresas nacionais. PAC evidenciou, portanto, uma grande o programa buscou retomar as obras capacidade administrativa na operação de in construçáo echovica e social do oçamento público da Uniáo, por praticamente abandonara desde 1980 gestão no governo Lula, orientando um (LEITÃO, 2009, p. 220; MARICATO, 2014), montante de recursos públicos enorme como foi o caso da Transposiçăo, um a obras públicas, em uma escala nunca projeto que vinha sendo retomado por antes vista na história de governos quase todas as gestōes desde 1984 .

[...] em janeiro de 2007, o governo Aceleração do Crescimento (PAC), desenhado para estimular o crescimento da economia do em infraestrutura a medidas institucionais (de estímulo ao crédito e ao financiamento, de melhoria do anbrãa de investiment de tributário, de gestão e medidas fiscais de longo prazo). O objetivo do PAC e, em linhas gerais, o de (por mar o investimento publico de $0,5 \%$ do superávit pro realizado a título do Projeto Piloto de Investimentos (PPI), junto com sobretudo da PETROBRÁS-Petróleo

O programa estabeleceu para o período os de infraestrutura logistica (que se refere à construção aeroportos e hidrovias); energética lque engloba a geração e transmissáo de energia elética e a produçáo, gás natural e combustiveis renovíveis) social e urbana (que abrange os setores de habitação, saneamento, metrôs, intitulado "Luz para Todos"4) (LEITÃO 
2009, pp. 224-225). A obra do Projeto de Orçamento Fiscal, ou seja, foram sa nova forma de gerir os recursos, como

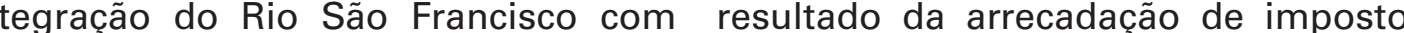
Setentrional (PSTriatia encaixada nesse sem empréstimo e endividamento do ac último eixo, de infraestrutura social e Estado.

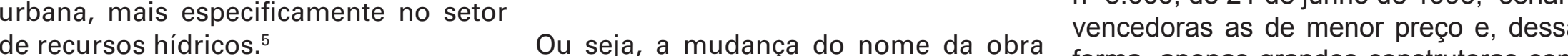

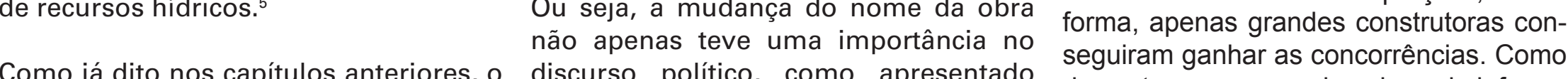
projeto que até entãotinhasido idealizado discurso político, como apresentado de costume nas grandes obras de infraese conhecido como a Transposiçấo do representou o nome pelo qual a obra foi consem acordos de preço, às vezes rio São Francisco, ganhou no governo viabilizada atraves do PAC, em que até abaixo do que as menores poderiam, Lula outro nome e veio a se mas vencem as licitações em questão. do Projeto de Intora o do Rio São 作 do Nordeste Setentrional (PISF). Dentro desenvolvimento regional da obra, nem ralsarlam pobra.

do programa, o PISF se desdobrou em toda compensação necessariamente Dessa forma, em 2007, mesmo ano algumas açôes orçamentárias para sua seria uma obra, mas as ações em que se institui a Lei do PAC, foram execuçao, sendo as duas principais orçamentârias do PISF apresentadas iniciadas as obras da Transposiçãa. as da construção dos canais - O Eixo $(12 \mathrm{EP}, 5900,12 \mathrm{EO}$ e $12 \mathrm{GG}$ ) diziam respeito $O$ canteiro de obras foi inicialmente Norte (código da ação: 5900) e o Eixo a obras, năo ficando claro como foram implantado pelo Batalhăo de Engenharia 作 relativas às compensaçōes ambientais, $\quad$ canais de aproximaçăa ${ }^{9}$ (SARMENTO, comuns aos dois Eixos, tais como a de A administração financeira do PAC, 2018, p. 477) e posteriormente, as reassentamento de população (código justamente por quebrar paradigmas, ao construtoras vencedoras das licitações da ação: 12EO) e a de recuperação de propor uma nova forma de organizar iniciaram as obras dos canais. que se interligarão ao PISF (código da a viabilizar essa e outras obras, Os dezesseis lotes foram subdivididos as acốes do PISF, conforme a Lei aprimorada ao longo dos anos da vezes se organizaram em consórcios, Orçamentária Anual ( $(\mathrm{LOA})^{6} \mathrm{e}$ as diretrizes implementação do programa, de modo tornando a gestão da obra bastante estabelecidas na Lei de Diretrizes que o controle orçamentário se tornou complexa. Isso somado a problemas Orçamentária (LDO) ', provieram do bastante complexo, como veremos de projeto e de fiscalização, houve mais adiante nesse item da dissertação. atrasos e até mesmo paralisaçoes de

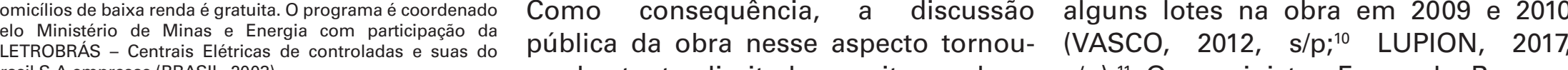
Informacăo extraida da páosi.

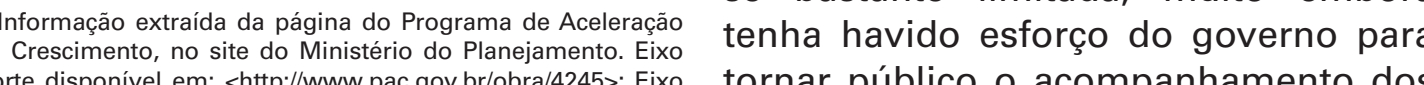

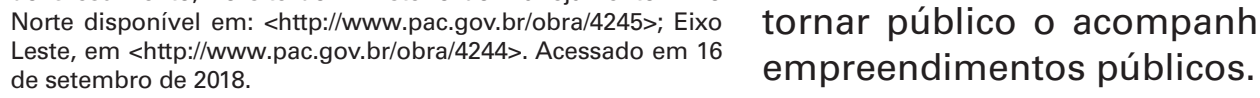

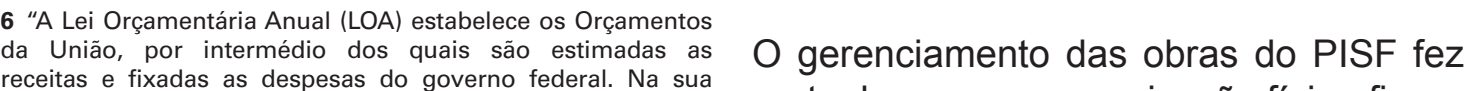

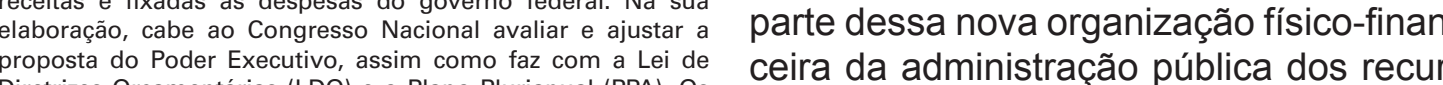

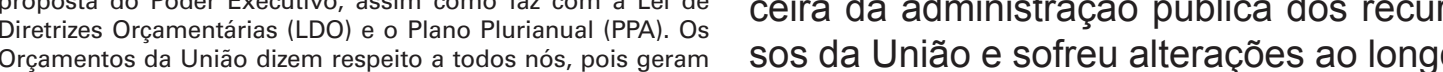

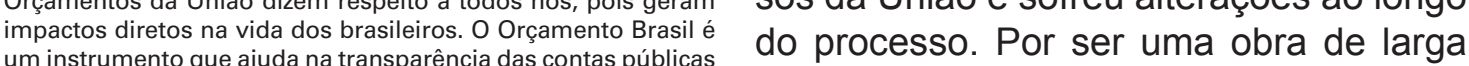

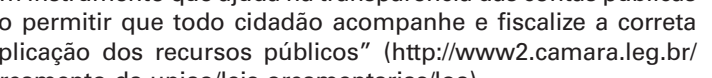

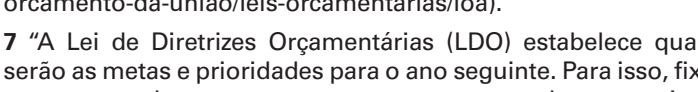
escala e também para se enquadrar nes-

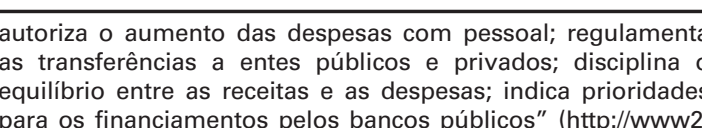

(11

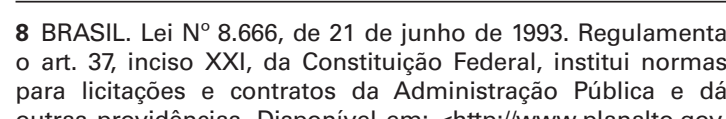

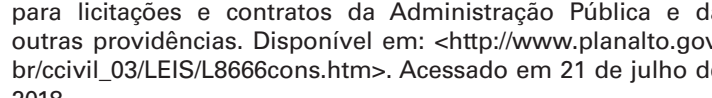

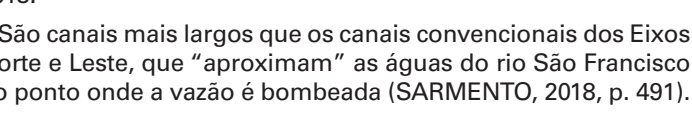

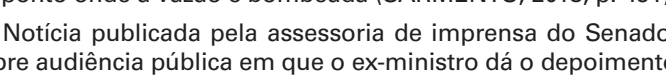

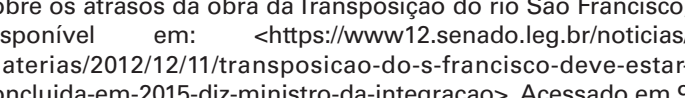

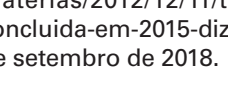

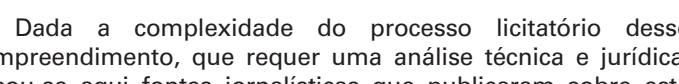

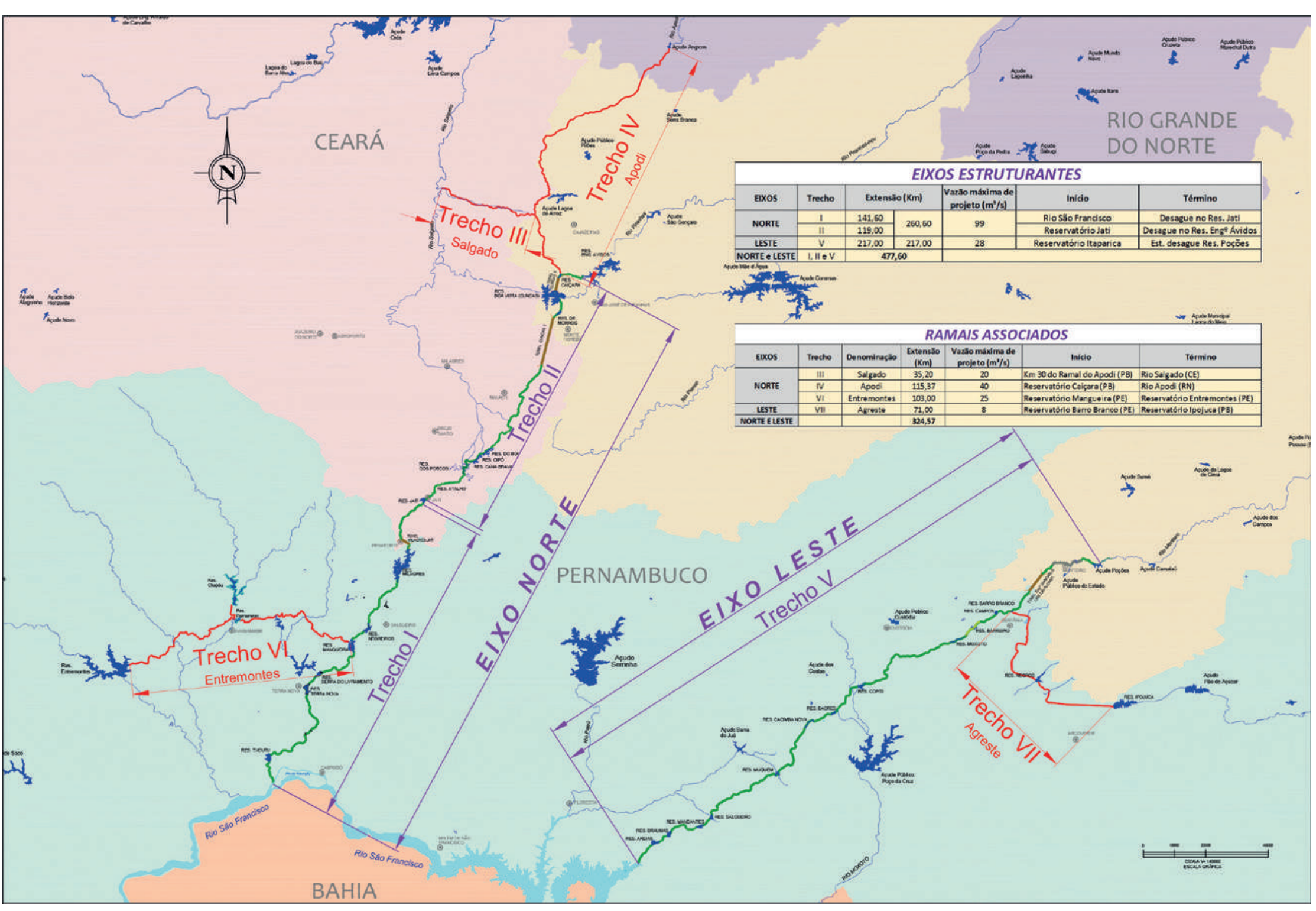

em audiência pública no Senado em técnicos, que não foram explicitados acima dos $25 \%$ (VASCO, 2012, s/pi dezembro de 2012, enumerou as causas por Bezerra na audiencia pública no SALOMON, 2011, s/p).

dos atrasos e paralisaçōes: o grande Senado mencionada acima, pode-

número de empreiteiras e o complexo se citar por exemplo o fato de que as Ou seja, apesar da grande expertise projeto, tais como a falta de uma análise das licitacões não tinham tecnologias viabilizando assim a obra o parcelamento precisa do solo, que ger enssuíam do PISF em muitos trechos, que também execução; problemas de inserção da obra distintas formas de construir e distintos foi reflexo dessa nova organização físicono território, tais como a inexistência de recursos tecnologicos, o que gerou financeira, na prática se tornou bastante titularidade de terras, que ele classificou problemas e demandou reparos e complexo, e os baixos preços das "como problemas relacionados à ajustes importantes de obra, dando empresas vencedoras provavelmente "burocracia" das desapropriaçoes - algo ocasião, portanto, a atrasos (ALMEIDA, devem ter guiado muito mais a definiçấo técnicas, um critério que deveria ser removidos -; problemas de fiscalização Dessa forma, em 2011, seis dos catorze questionado.

na obra, conforme apontado por órgãos lotes se encontravam paralisados, de controle oficiais - oTribunal de Contas fazendo com que novas licitaçōes e Em 2012, com essa necessidade de novas da União (TCU) e a Controladoria Geral contratos tivessem de ser feitos para a licitaçoes, o Ministerio da Integração da Uniao (TCU) - a Contomo pagamento execuça dios drechos ná finalizados $(\mathrm{MI})$ reorganizou a obra reduzindo os

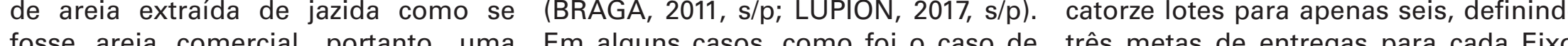
areia mais cara. $\mathrm{O}$ ex-ministro também contratos para construção de túneis, nomeadas $1 \mathrm{~N}, 2 \mathrm{~N}, 3 \mathrm{~N}, 1 \mathrm{~L}, 2 \mathrm{~L}$ e $3 \mathrm{~L}^{13}$ (ver apontou problemas de capacidade os aditivos superaram $25 \%$ do valor do Figura 2), com o intuito de facilitar a técnica e financeira das construtoras contrato, o que não é permitido pela gestão da execução e das contratações. e a necessidade de incrementos e legislação. Porém, segundo Fernando Abaixo, a Figura 1 apresenta um mapa adiçoes de serviços novos, que geraram Bezerra, na mesma audiência em da transposição, dividida nos trechos, desacordos entre empresas e governo 2012 (VASCO, 2012, s/p; LUPION, 2017, enquanto, na sequência, as Figuras 2 e VASCO, 2012, s/p). $\quad$ que os túneis são máquinas caras e a da transposição com as metas da mapa Para exemplificar esses problemas mobilização de novo maquinário não organizadas por entregas de cada trecho, seria vantajosa às empresas, portanto, e uma tabela da relação das construtora

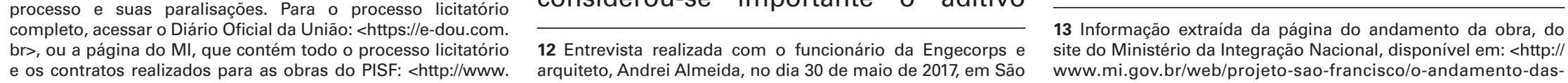




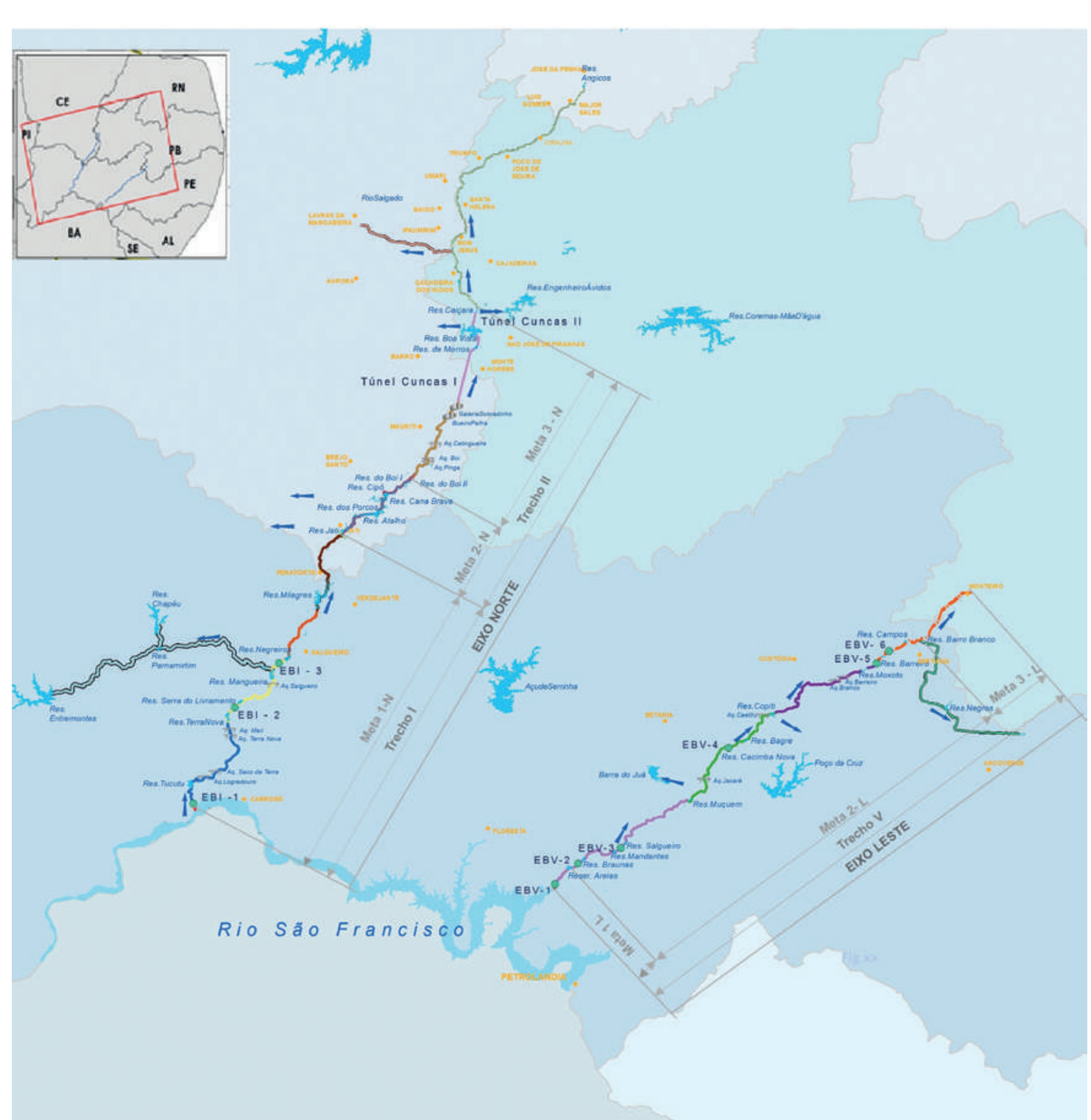

responsáveis pela elaboração do projeto infraestrutura e financiamento privado e a construçao de cada trecho ou sub- de campanhas eleitorais.

Isso fez com que, por exemplo, em 2016, a construtora Mendes Júnior, responsáve um trecho de $140 \mathrm{~km}$ (1N) do Eixo Norte,

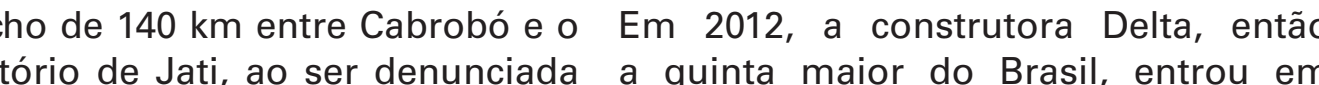

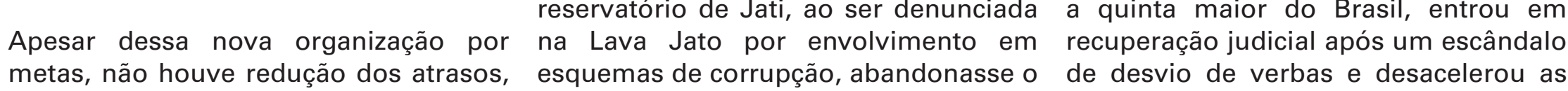
metas, nao houve reduçao dos atrasos, esquemas de obras, alegando incapacidade obras do Eixo Norte. Também houve organização de obra e realização de financeira em cumprir os dois contratos casos de corrupção relacionados novas licitaçốes a previsão era de que pelos quais era responsável. Em diretamente à Transposição, como as obras fossem finalizadas em 2015, conjunto com o Tribunal de Contas da ocorreu em 2015, quando a Polícia conforme o depoimento do ex-ministro União (TCU), o Ministério da Integração Federal prendeu executivos das Fernando Bezerra ${ }^{4} \mathrm{em}$ 2012. Isso se deu Nacional analisou várias alternativas empreiteiras Galvão Engenharia, OAS, pois, além da complexidade da obra, o legais para a troca da empresa e decidiu Coesa e Barbosa Mello, suspeitos de momento político nacional se tornaria por uma nova licitaçao para substituir a envolvimento no superfaturamento bastante conflicuoso a partir de 2014, empreitera (M1, 2017). desvio de $\mathrm{R} \$ 200$ milhoes em dois lotes Lava Jato 15 Comandada pelo Ministério Eram dois contratos avaliados em Público Federal (MPF), esta consistiu R $\$ 1,2$ bilhăo. A empreiteira deixou

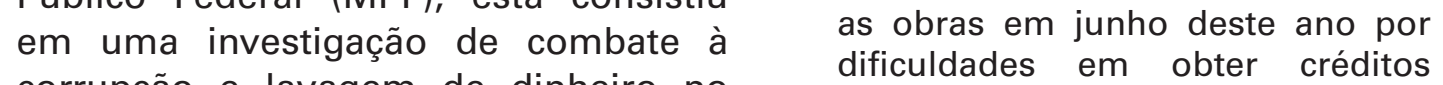

corrupçáo e lavagem de dinheiro no Brasil, investigando empreiteiras,

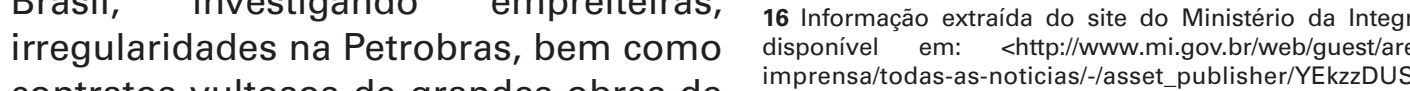

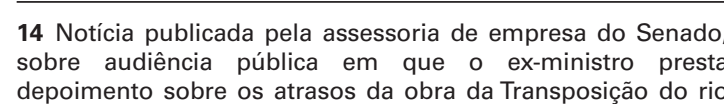

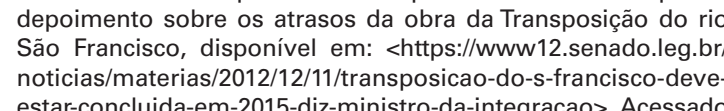
estarconcluida-em-2015-diz-
em 9 de setembro de 2018 .

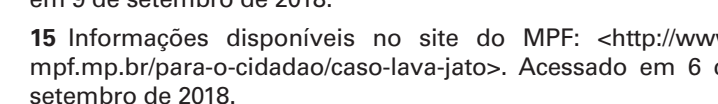

Figura 2-Metas da obra

Figura 3 - Tabela discrim
construçao de cada treche.

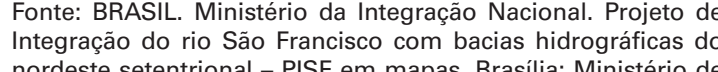

geradas pelo envolvimento em esquemas de corrupção denunciadas pela Operaçao Lava Jato. A soluçăo encontrada foi substituir a empresa 2016)

o projeto (LUPION, 2017, s/p). Ou seja, problemas de gestão e de condução de processos licitatórios, a partir de 2014 passaram a ser tambem de natureza política.

m sumário executivo do Projeto (PISF) foi aca do Rio Sáo Francisco Integração (MI) e publicado em abril "Edital de licitaçăo para obras da Transposičąa do Rio Sàa

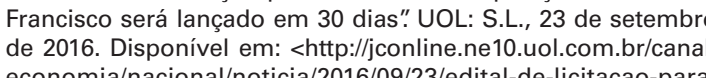

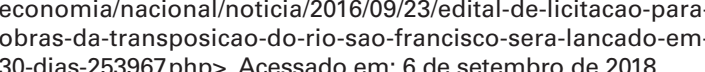

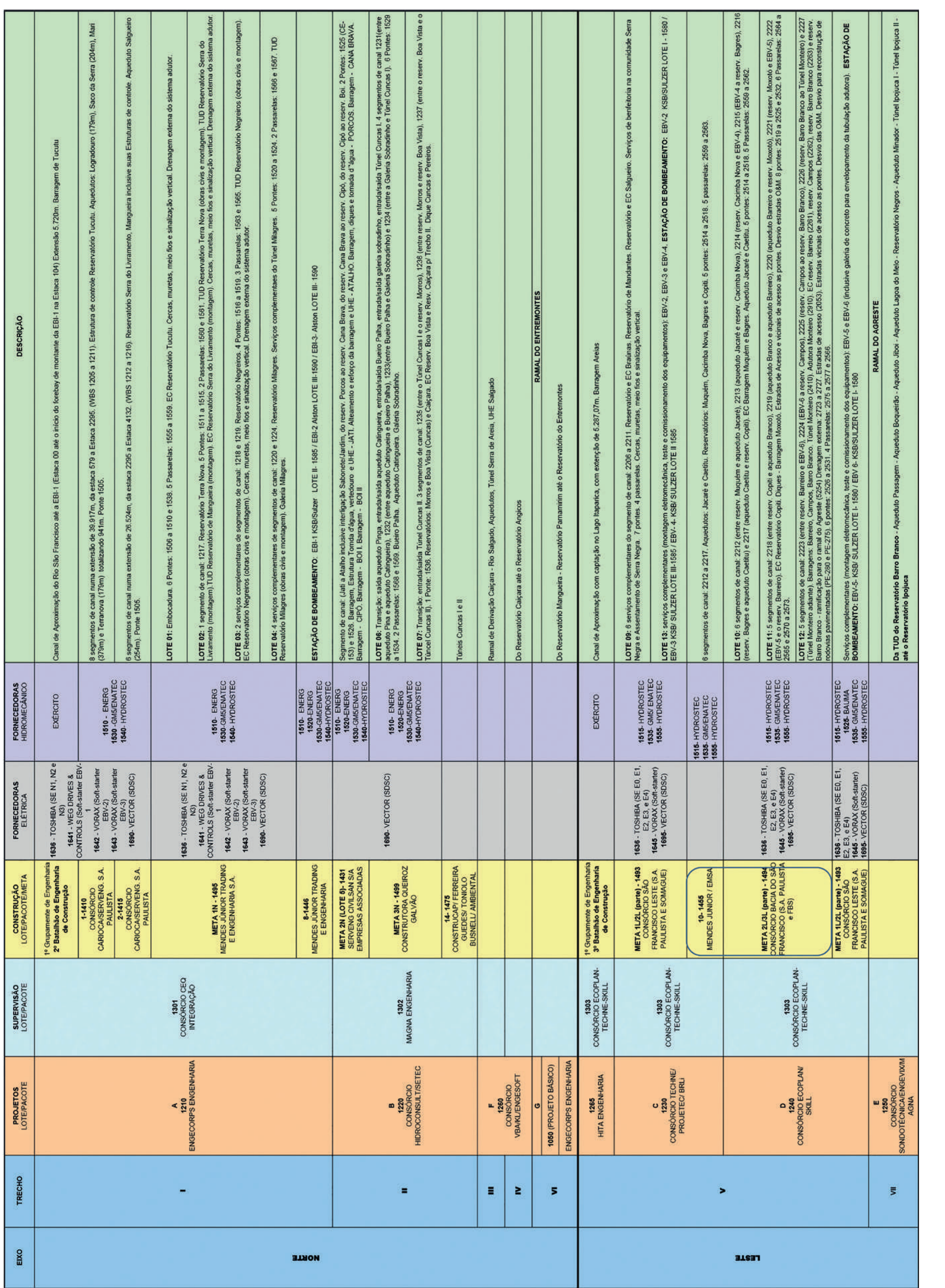




\section{EXXO NORTE - Avanço Físico Operacional - 94,92\%}

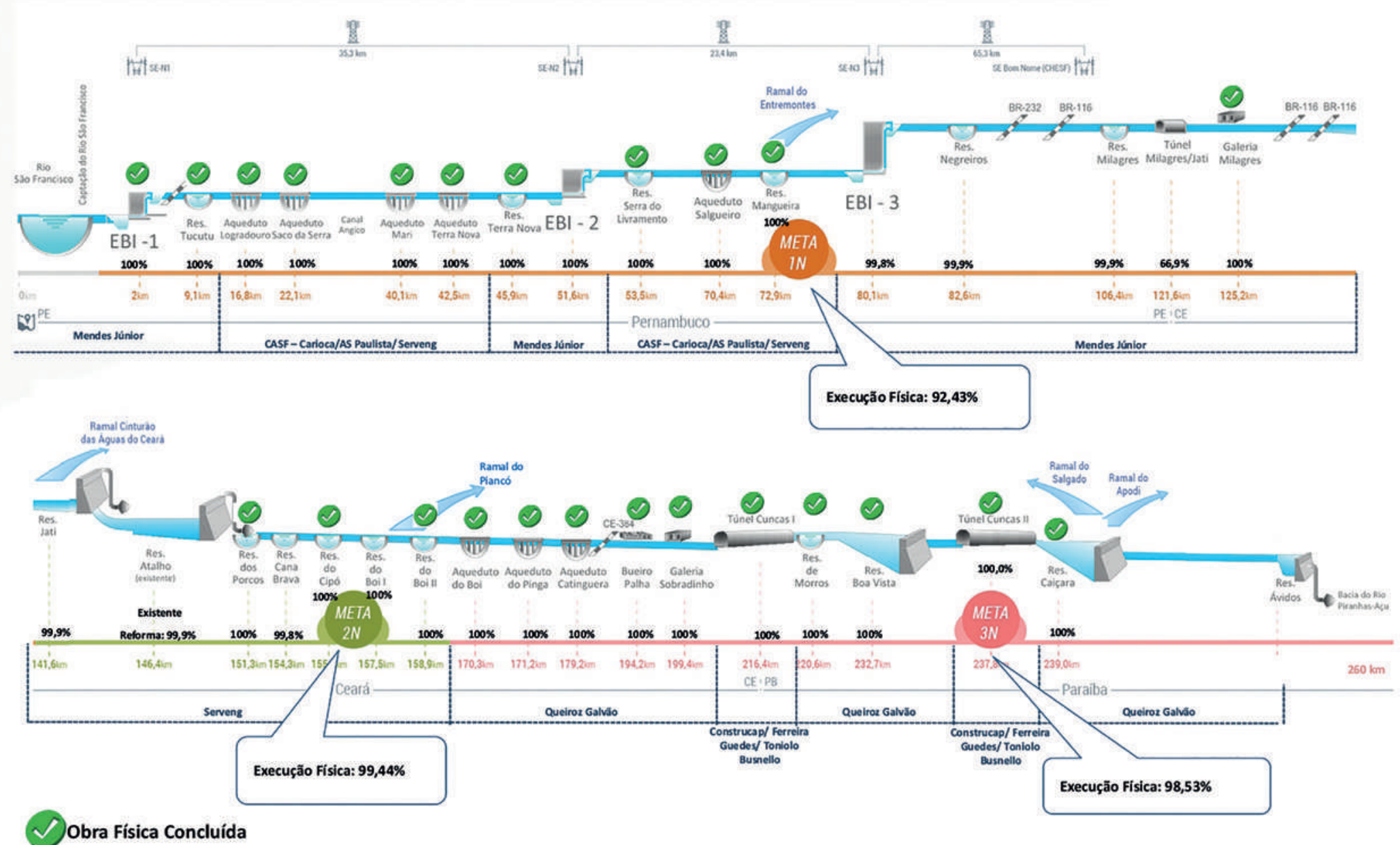

EXO LESTE - Avanço Físico Operacional - 100\%

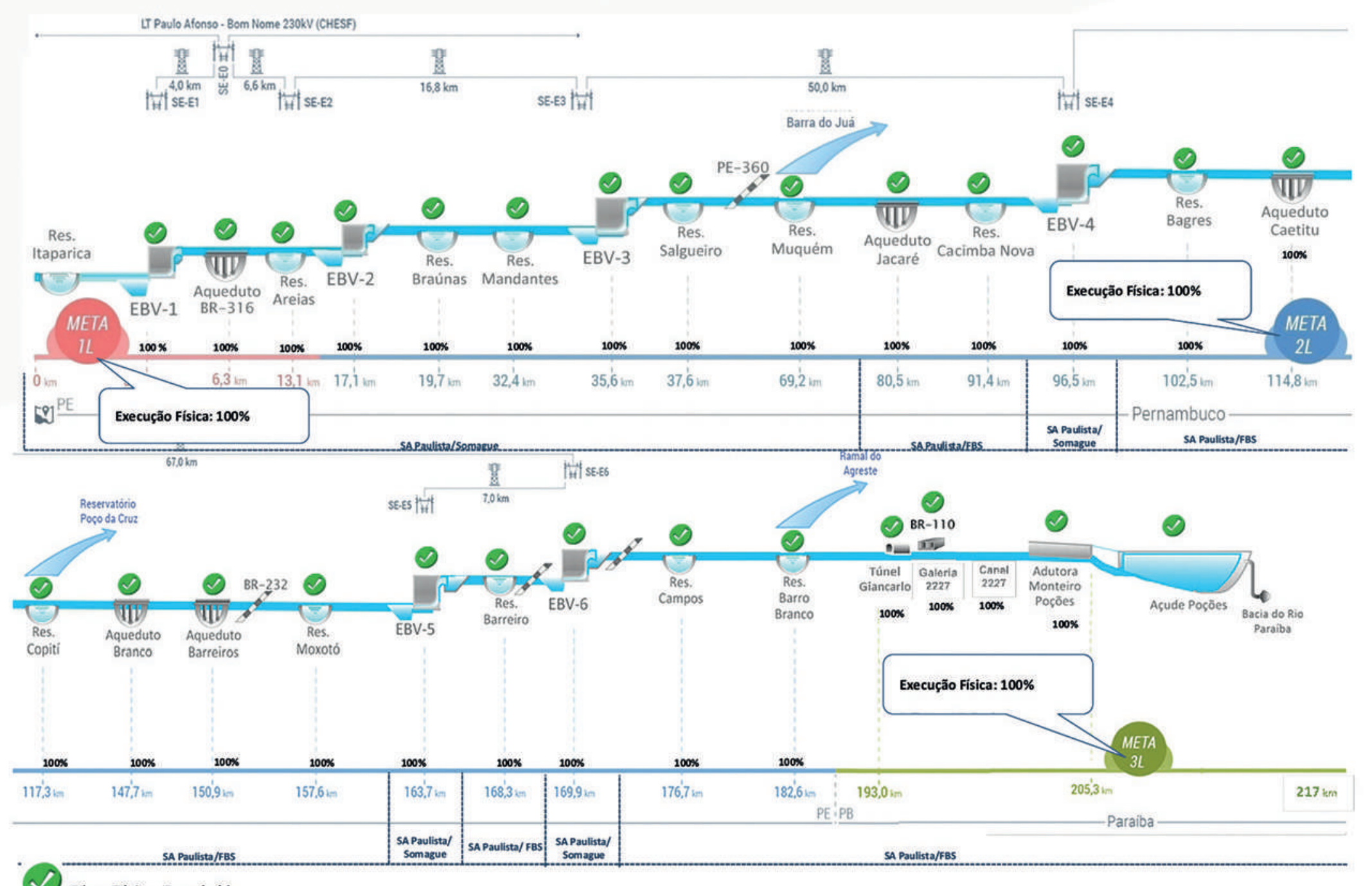

Huura 4-Andamento da execuçăo do Eixo Norte.

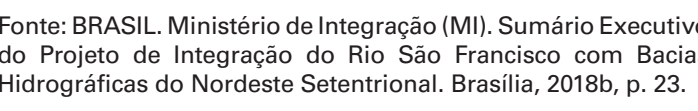
Figura 5 -Andamento da execuşăo do Eixo Leste.

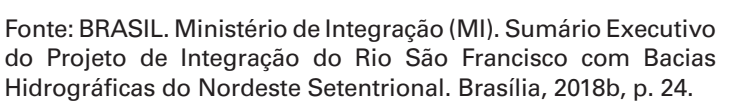

revisāo de orçamento fin

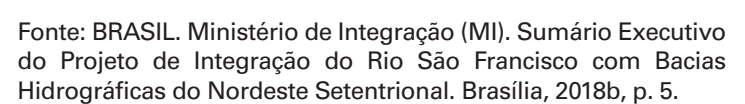

Figura 7 - Valor aprovado para o empreeendimento do PISF
segundo os balançsos do PAC de 2007 e 2010 . Elaboracąa: Irani Eonte: BRASLL, 2007,
TOTAL

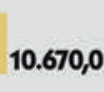

$.664,5$

OBRAS CNIS

ELETROMECÂNICA

\section{SUPERVISĂO E} GERENCIAMENTO

PROJETOS BÁSICOS

EEXECUTIVOS

PROGRAMAS

AMBIENTAIS

PREVSTO

REALIZADO

Valoresem RS (minhóes)
Atualizaçâ: $30 / 03 / 2018$

82,3

\begin{tabular}{|c|c|c|c|c|}
\hline \multirow[b]{2}{*}{ Assunto } & \multicolumn{2}{|c|}{ Balanço 2007} & \multicolumn{2}{|c|}{ Balanço 2010} \\
\hline & Valor impresso & $\begin{array}{l}\text { Valor minimo do } \\
\text { arredondamento }\end{array}$ & $\begin{array}{l}\text { Valor máximo do } \\
\text { arredondamento }\end{array}$ & Valor impresso \\
\hline Eixo Leste & 1,6 & 1,55 & 1,95 & \\
\hline Eixo Norte & 3,4 & 3,35 & 2,95 & \\
\hline \begin{tabular}{|l|l|} 
PBAs \\
\end{tabular} & 0,226 & 0,226 & 0,226 & 0,22 \\
\hline Soma & 5,206 & 5,128 & 5,124 & 5,02 \\
\hline
\end{tabular}

de 2018 na página do Banco Nacional No 10 balanço do PAC, ${ }^{19}$ que tinha como do Desenvolvimento (BNDES), ${ }^{18}$ data de referência abril de 2007, o valor apresentando como foram organizadas aprovado para a conclusão das obras andanto da previsão orçamentária da obra (do início $\mathrm{PAC}_{1}^{20}$ cuja data de referência era de até a previsão de conclusão), que naquele dezembro de 2010 (ver Figura 7). O fato momento fol orçada em R\$ 10,7 bilhôes de em 2018 o Ministerio da Integração (BRASIL, 2018b, p. 5). Tambèm foram Nacional apresentar como previsão os apresentados os valores pagos no PISF, $\mathrm{R} \$ 10,7$ bilhoes de reais, embora tenha civis, supervisão, gerenciamento, projeto e da obra, não significa que isso de fato açōes ambientais, conforme se observa ocorreu. Ao contrário, segundo Irani na Figura 50. Braga Ramos, ${ }^{21}$ assessor e engenheiro que atua nas áreas de recursos hídricos $\mathrm{e}$ desenvolvimento regional no Ministerio de Integraçāo, portanto um administrador público que tem afinidade com a leitura houve alteração do valor aprovado nara o empreendimento. Tendo isso em vista, Ramos elaborou uma tabela a partir dos dois balanços do PAC em questão para evidenciar como o valor previsto se manteve (Figura 7 acima).

1910 Balanço do PAC. Brasilia_2007. 
Isso porque, muito embora tenha havido aumento em seu tempo de execução e palavras, de uma conta que, embora atrasos, paralisaçoes e recontratações de ter apresentado problemas de ordem existente, năo é direta e tampouco de construtoras, ê preciso distinguir jurídica, necessitando a realização de simples, nem para quem estava na

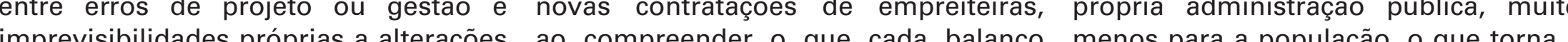
ou limitaçōes na forma desas a alteraçoes ao compreender o que cada balanço menos para a populaçăo, o que torna a valor da obro Porém essa distincão não do ra ño se apresentou alteracão no bastante limitada. Dessa forma e uma conta simples e tampouco existe valor previsto para o empreendimento faltou à populaça informacões mais do PISF. Não sendo o objetivo desta precisas tanto no âmbito das ações será explicado a seguir. dissertação a investigação aprofundada socioambientais, conforme se pôde sobre a gestâo financeira e jurídica da ver no capítulo 2, quanto técnicas e Como foi dito anteriormente, O PAC obra, buscou-se aqui de todo modo orçamentárias, o que deveria ser um orco una problemas de gestão foram aparecendo, esses valores. de grande porte, causando muites de grande porte, causando muitas
transformaçoos na vida das pessoas aprimorada. Dentro disso, a forma de Houve uma tentativa do governo por onde ela passou, conforme sera contabilizar a obra no PAC foi mudando federal em externalizar esses processos evidenciado no item 3.2.2.

ao longo dos anos. Por exemplo, os ao público, torná-los transparentes. valores apresentados nos balanços Por exemplo, no portal SIGA Brasili2 A Figura 6 demonstrou que financeiros financeiros, tendo sofrido mudanças o quanto foi gasto em cada ação gasto com a execução dos programas do orçamento. Até 2012 referiam-se a cada trecho, considerando-se as ações o valor gasto e a análise qualitativa do orçamentos de obras feitos em datas relacionadas aos PBAs. Porém, para que foi executado das compensações muito antigas e, em 2012, as datas de saber o total que foi gasto, é necessário ambientais, apresentado no relatório referência foram 2011 e 2012, quando entrar com os códigos de cada ação elaborado pelo Ministério da Integração as novas licitações foram feitas. Além (especificados no início desse item Nacional (MI) sobre a implementação disso, até 2011 as despesas ambientais 3.1.2) e somar valores ano a ano - um dos PBAS, citado no capítulo 2 (BRASIL, e fundiárias estavam desvinculadas do processo trabalhoso, pouco direto e 2018 a) ${ }^{26}$ foi possível compreender que balanço da obra e apenas a partir de 2012 pouco apreensivel publicameram incorporadas. Também até 2011,
foram não entrava na conta aquilo que não Outro exemplo é o Painel de Obras, ${ }^{25}$ relação à potência do que se poderia ser estava em condições de ser contratado, plataforma para acompanhamento em relação ao porte da obra dos canais por restrições legais, ambientais ou das obras promovidas pelo governo em si, como se, apesar do discurso de de outra ordem e, portanto, os valores federal em andamento, teoricamente desenvolvimento social e regional, as estavam subestimados. Entre 2011 mais acessivel e simples de manusear ações relacionadas à inserção da obra 2013, a Administraça começou a do que o SIGA Brasil. No Painel de no territorio tenham sido concisas aprender como fazer a conta e, portanto, Obras é possivel consultar valores significando apenas $14 \%$ do valor gasto (RAMOS, 2018, informaçãa verbal) .23 ${ }^{23}$ e em que estágio a obra se encontra. relaciona diretamente com esseprogram Para se consultar a obra do PISF, ela federal que viabilizou a obra, o PAC, pois Outra questão muito importante a se foi separada por Eixos Norte e Leste. os investimentos em infraestrutura nele considerar nas previsoes orçamentarias Apesar disso, náo é possivel encontrar elencados conformam uma carteira de do PAC equevalores referentes a reajuste muitas informaçoes alem do valor que projetos construida setorialmente, do

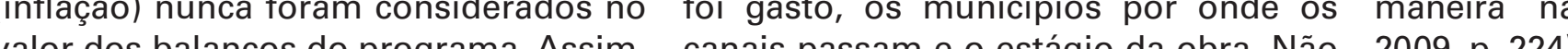
valor dos balanços do programa. Assim, canais passam e o estágio da obra. Não 2009, p. 224.

enprendimento, distinguindo, de um rén muitos dos programas ambientais que de valor em decorrencia de erros de estava sendo executado.

projeto e dificuldades na contrataçào

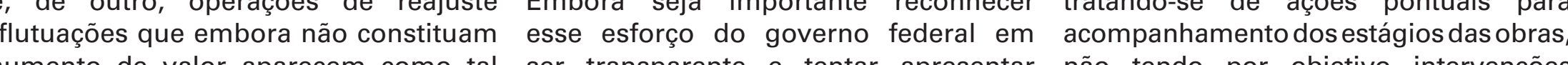
sob a ótica financeira e do orçamento os valores, balanços e andamento para transformaçōes a longo prazo em público), seria necessário analisar das obras em páginas oficiais, a partir termos de desenvolvimento social cada contrato, seus aditivos, seus das questões apresentados acima foi territorial. Os programas compensatórios reajustes, uma analise complexa e mais possivel compreender que a análise e socioambientais e os programas adequada a especialistas ou agentes do orçamento do PISF revela-se algo estratégicos de apoio ao desenvolvimento

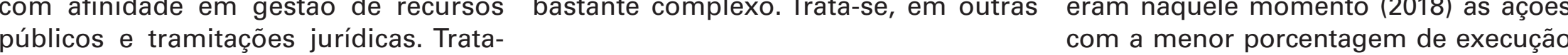
se de um cenário bastante difícil de 24 Potral SIGA Brasil, disponivel em: entp::// física $(75,34 \%$ e 87,63\%, respectivamente

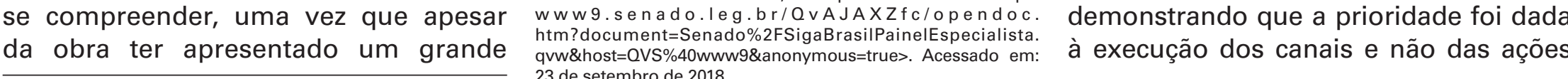

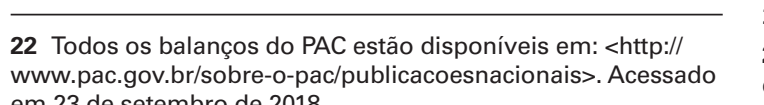

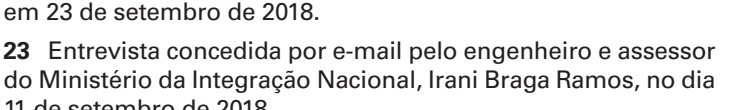

Figura 8 - Linhas dos Programas Ambientais (PBAs),
porrentagem concluida da execuçáo fisica e einvestimento
previsto

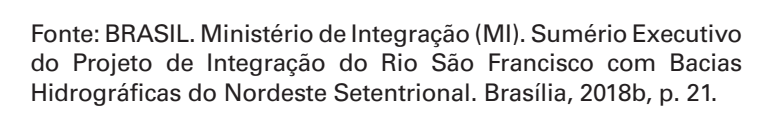

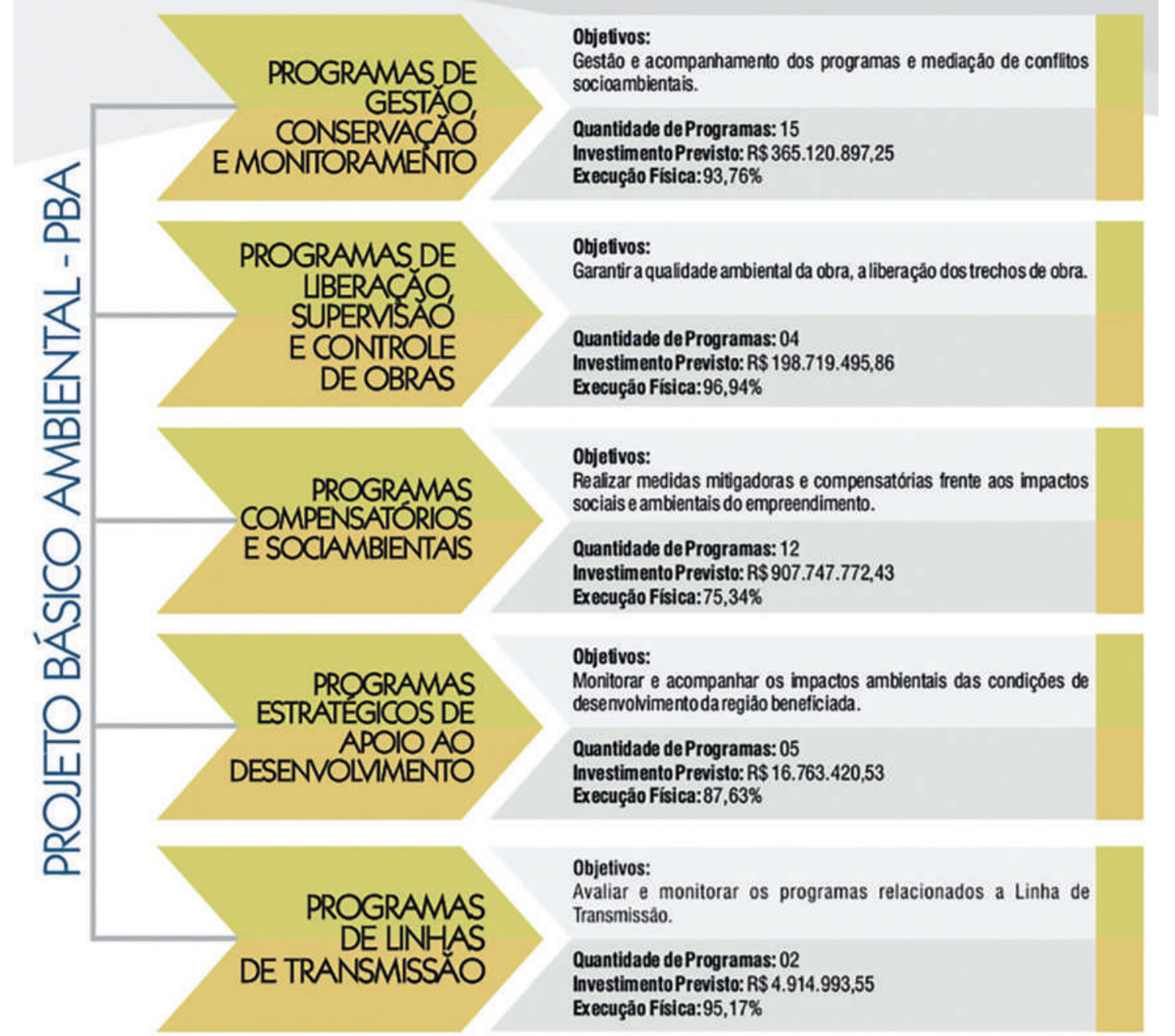

Quantidade de Programas Ambientais: 38

Investimento Previsto: R \$1.493.266.579,62

Execução Física: 91,12\% - Março/2018

socioambientais. Além disso, o sumário às transformaçōes territoriais (de executivo em questäo (2018b), pouco desenvolvimento e socioambientais), demonstrou em que consistia a execuçăo dizem muito do programa que viabilizou dessenvolvimento e compensaçóes do desenvolvimento nacional e do socioambientais. crescimento econômico, o PAC consistiu

em um programa cujo conjunto de

O sumário executivo $(2018 b$, p. 21 - açōes dispersas e desarticuladas não ver Figura 8) também apresentou que garantiu um crescimento econômico $91,12 \%$ da execuçao fisica dos programas sustentado e tampouco pode ser ambientaisestavamconcluidasemmaço entendido como um programa integrado de 2018, o que entra em con tho com as de desenvolvimento. No sentido mais 2 acerca da incompletude da execução relacionou com as planos e políticas de nos PBAs denunciada em notícias de desenvolvimento regional, tais como jornal, ou na notificaçáo do Ministerio o Plano Nacional de Desenvolvimento Público Federal (MPF) ao Ministério Regional (PNDR) (LEITAO, 2009, da Integração Nacional (MI) sobre as pp. 220, 224) e, além disso, no PISF, obras de saneamento em Monteiro (PB). Essa discrepância de informaçōes sumário executivo da obra (2018b) eas denúncias da não execução de medidas preventivas e compensatórias que reiterada pelo fato de que a Licença de Operação (LO) do PISF ainda não havia sido cono (LO da, mesmo após mais de em 2017.

A simplificacãa da execução dos
PBAs da obra, principalmente dos voltados as questoes relacionadas

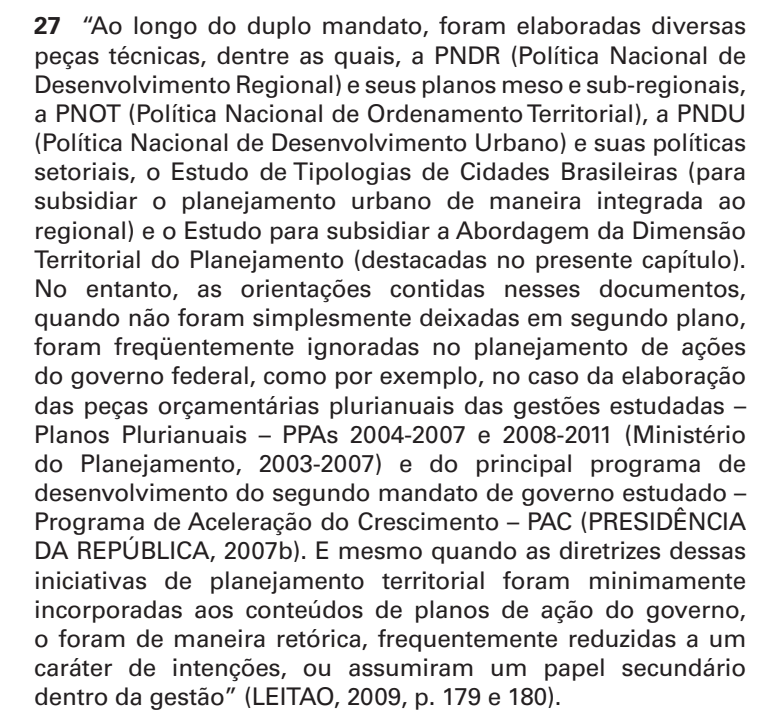


não se viabilizou uma execução mais aconteceu, como essas medidas foram um modelo de economia exportadora, consistente dos PBAs, em especial incluidas no programa com propositos resultando, no Brasil ena America Latina, socioambientais.

que não tinham sido contemplados em ostas originais (LEITÃO, 2009, divanal nas mudanças ocorridas na (ivisao internacional do trabalho face às

No PAC foram previstas algumas ações que fizeram referência ao território Apesar dessas (poucas) referências ao e re território, o PAC, nas palavras de Vainer Dessa forma, uma obra construída ais como as medidas de: recriação dá de maneira desigual no espaço e que, o território de uma forma financeira das superintendencias regionais de portanto, o ritmo geral de crescimento náo articulada necessariamente com desenvolvimento (SUDAM e SUDENE, e um componente de ritmos desiguais. os planos de desenvolvimento, ou sen mediante Leis Complementares $n$ 1240 0 PAC náo abordou a quasta da priorizar as açoes de desenvolvimento do Marco Regulatório do Saneamento e é nesse sentido que Vainer (2007) sem contradições. No próximo itam (Lei $\mathrm{n}^{\circ}$ 11.145/200730); regulamentação afirmou que "o silêncio sobre o território buscou-se apresentar o constitui a obra do artigo 23 da Constituição Federal de no PAC não é casual." Para o autor, o em execução, ilustrar o que foram os dois 1988 (que define de forma cooperada território é visto no programa como canais atravessando a região, como eles as atribuiçoes da Uniāo, Estados e mero "local de investimentos", o que, incidiram, se relacionaram, impactaram Municipios para exercicio da gestão em ultima instância, condena o espaço ou transformaram os locais e paisagen ambiental, atraves do Projeto de nacional a uma tendencia inexoravel a a por onde passam.

Complementar $\mathrm{n}^{\circ} 388 / 2007$, em

três medidas de rebationento

erritorial foram elaboradas desde a Umverdadeiroplanodedesenvolvimento primeira gestão do governo federal modelo econômico em questão (LEITÃO petista (no âmbito dos Ministérios da 2009, p. 220), ou se articularia com os Integraçao Nacional, das Cidades e do planos e programas de desenvolvimento Meio Ambiente, respectivamente) e e regional, ou seja:tanto comosespecíficos foram incorporadas ao discurso do PAC do projeto - que como já foi visto no de maneira programa. Entretanto, isso não só não o que importava de fato era a obra não os programas complementares de

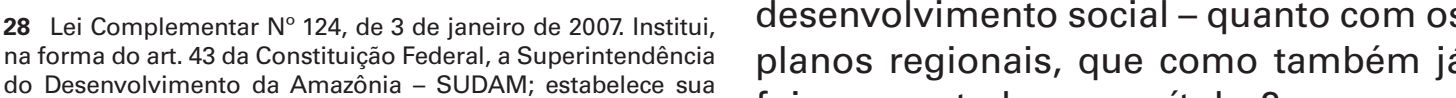

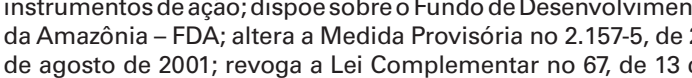

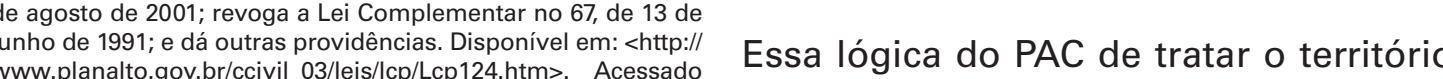
em 14 de dezembro de 2018. 29. Lei Complementar $\mathrm{N}^{\circ}$ 125, de 3 de jeaneiro de 2007 Institui, (VAINER, 2007), remete a um ideário do do Desenvolvimento do Nordeste - SUDENE; estabelece sua tipo neodesenvolvimentista, baseado Instrumentos de a acáa; a attera Lei no 7.827 , de 27 de setembro em estratégias de desenvolvimento 2001; revoga a Leic Complementar no 66 , de 12 de junho de que visanm fortalecer Estado e mercado,

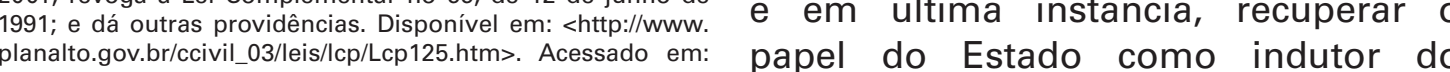
4 de dezembro de 2018.

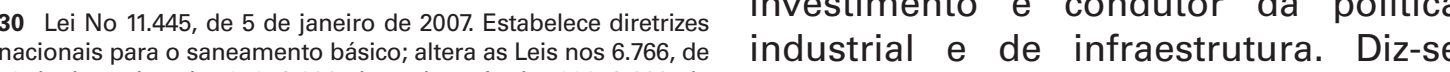

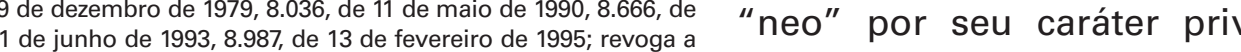
Lei no 6.528, de II de maio de 1978; e da outras providencias. prioriza estratégias de desenvolvimento

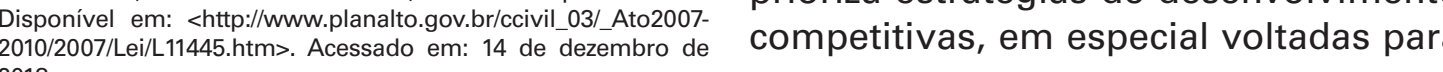

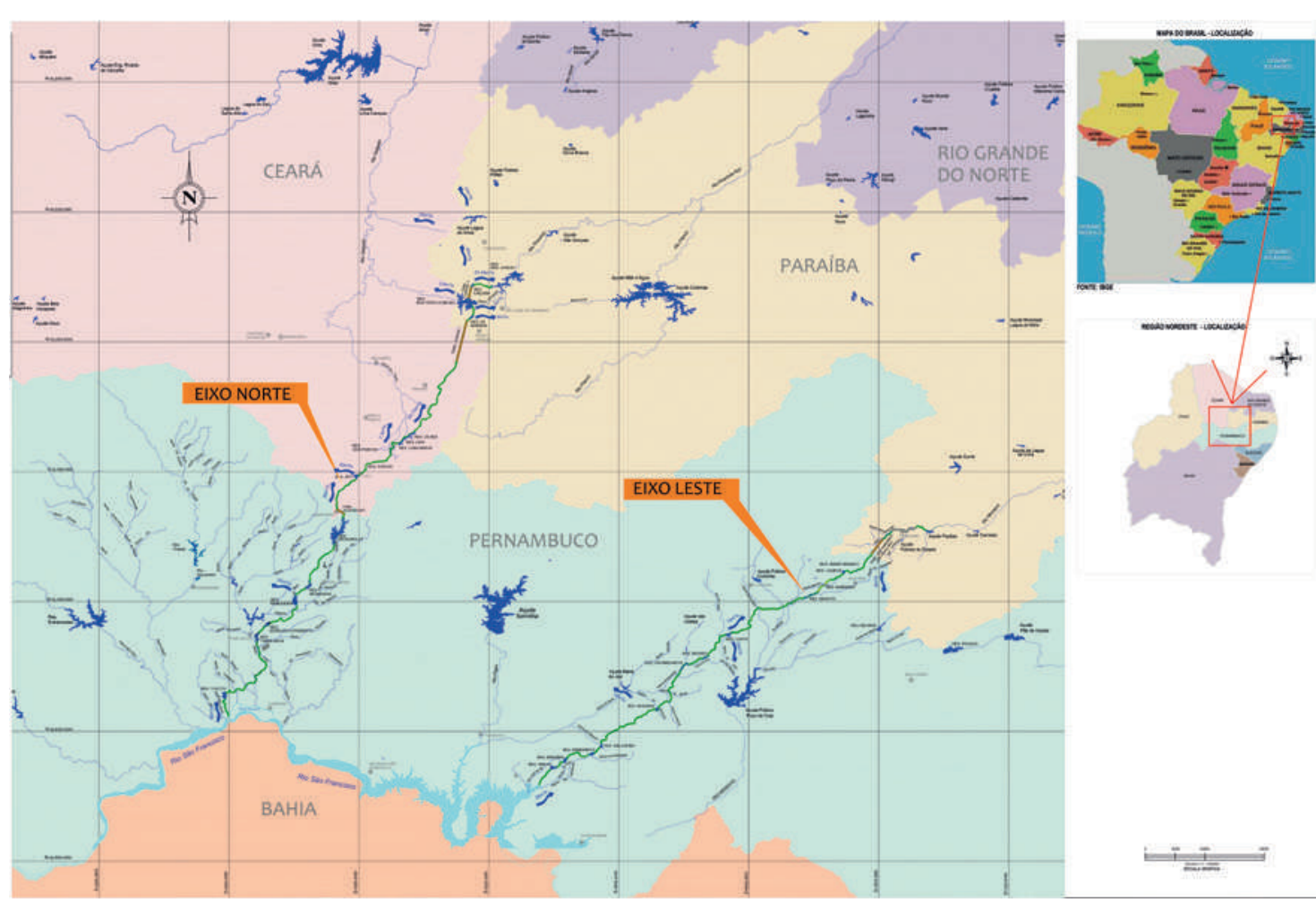

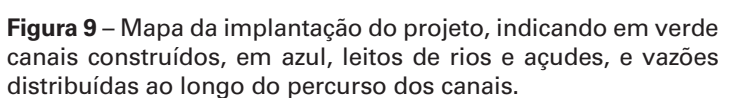

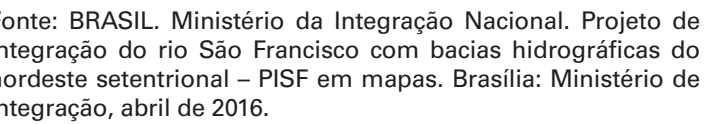

oprojeto deTransposiçăofoiapresentado pelo leitor, em sua magnitude seu

descrição, incluindo as condicioção e

estabelecidas. Apesar disso, $\mathrm{O}$ intuito deste item foi o de superar a as cartografias apresentadas até então abstracão das representacōes tecnicas e năo evidenciam com clareza essa obra cartograficas, bem como o falseamento na realidade, seu porte, seu desenho, que esses fatores originam ao não pois as cartografias representadas na revelar claramente o alto impacto da escala regional geram una abstraçáa obra sobre o teritório. Com isso (aue faz parte da linguagem técnica-

propõe-se evidenciar como a obra de Transposição se inseriu no território,

cassa forma será apresentado aqui eixos que atravessam quatro estados cada elemento construtivo da obra, cujo representados apenas com "linhas" conjunto constitui o funcionamento dos nos mapas, de modo a possibilitar uma canais, e assim contrapor os detalhes leitura mais aproximada do que significa técnicos-tipo e/ou diagramas de como essa obra e sua compreensão por quen sáo esses elementos construtivos da nunca a visitou.

obra com fotos tiradas em campo.

Dado o porte do projeto, tornou-se difícil categoria desses elementos. Desse completos em linguagem técnica eixos modo, pretende-se ilustrar a relaçấo uma escala aproximada em que seja entre o projeto e o construido, buscando possivel ver os detalhes de cada trecho, possibilitar a compreensão da obra como por exemplo, a variação de níve 


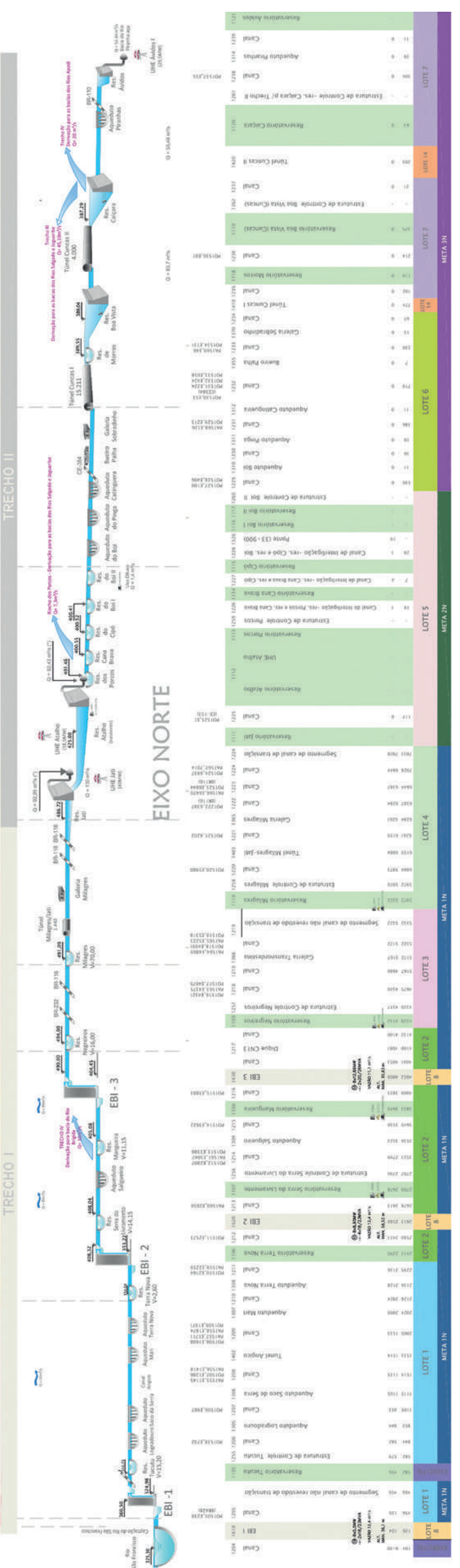

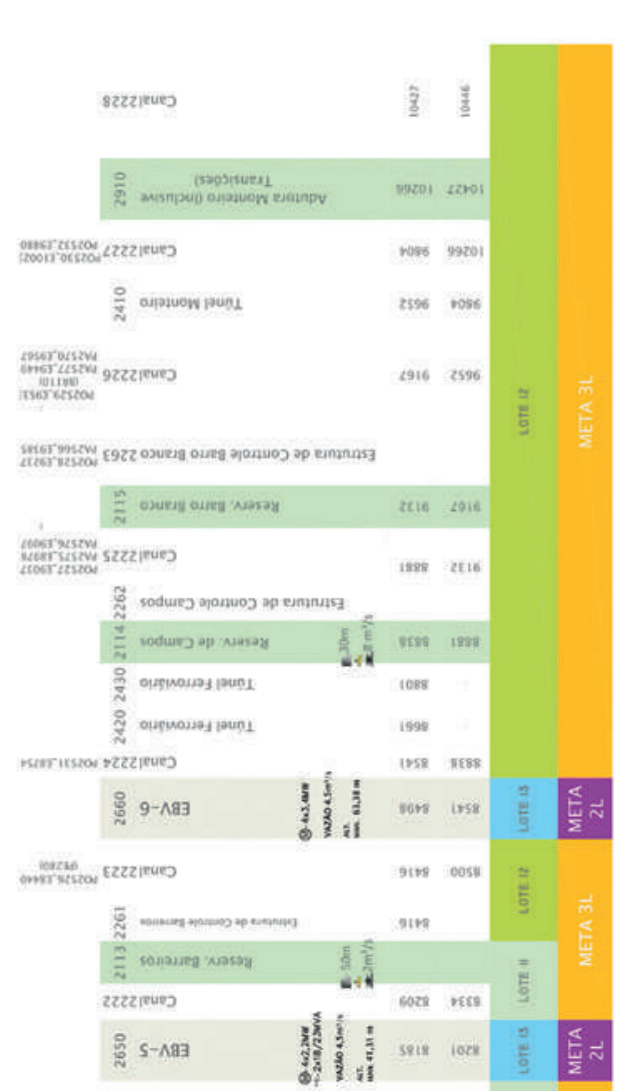

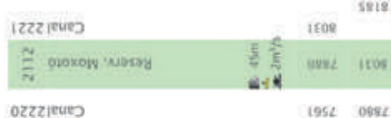

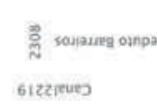

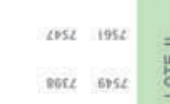

11)

屴
岁
즌

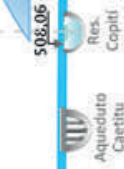

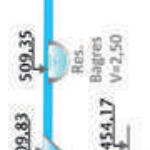

은

1 (1)

1 เ

2.

औ.

5

sizines

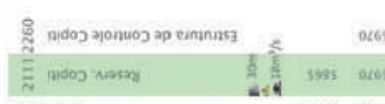

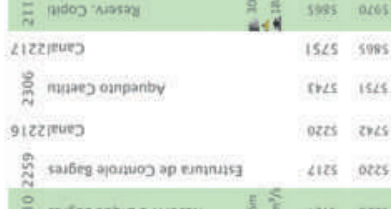

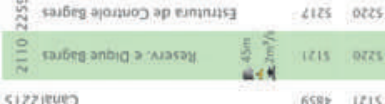

重-

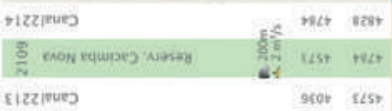

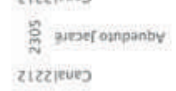$$
\text { zizaner }
$$$$
\text { som }
$$

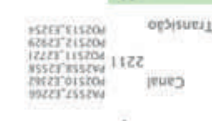

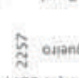

11220 binutury

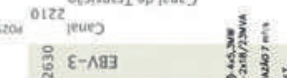

,

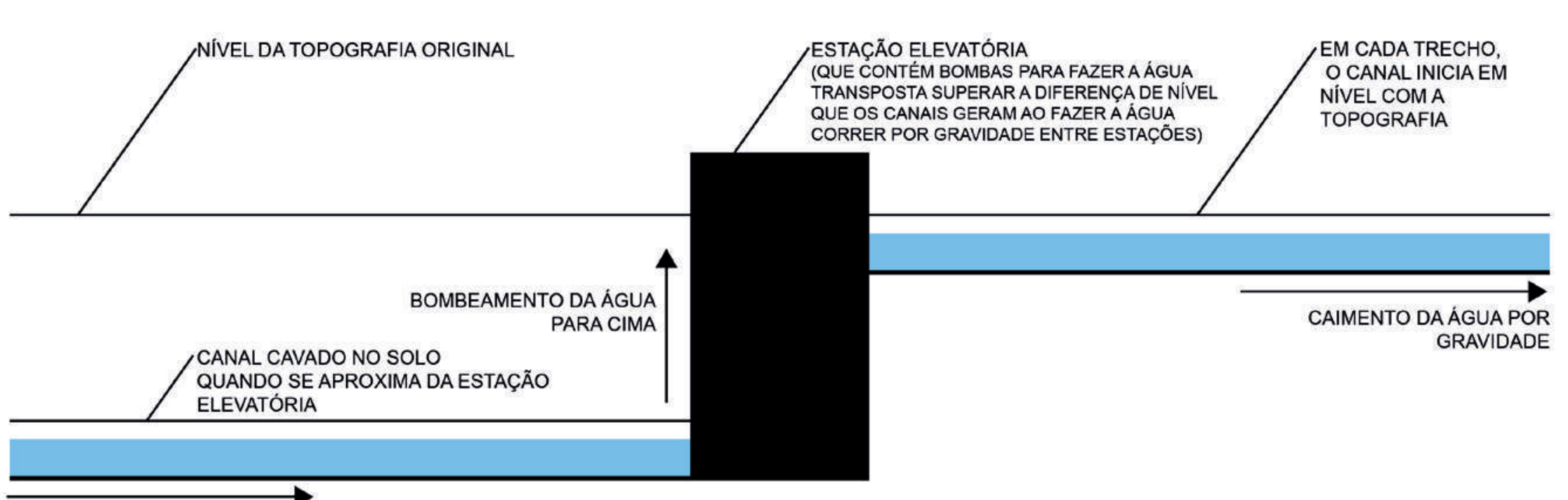

$\underset{\text { CAIMENTO DAAGUA POR }}{\longrightarrow}$

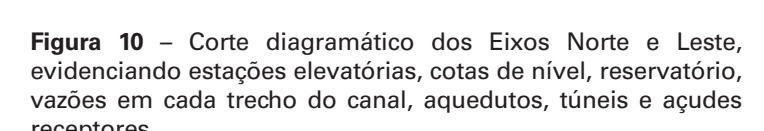

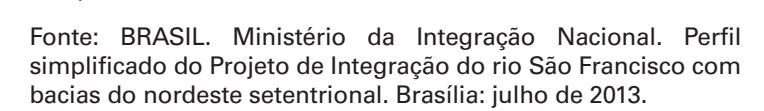

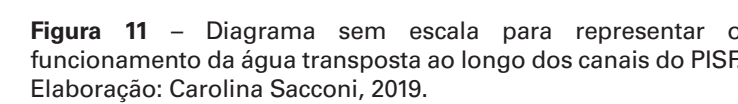

Fonte: Trabalho de campo.

ao longo de sua extensão, onde estão (RN), Santa Cruz (RN) e Armando Ribeiro localizados os aquedutos, estaçôes de Gonçalves (RN) (BRASIL, 2004, p. 37). bombeamento, tuneis etc. Dessa forma

o Ministerrio da Integraçáo Nacional O Eixo Leste possui cerca de $220 \mathrm{~km}$ (MI) representou o projeto em um e é composto de cinco estaçōes de escala, com as informações necessárias túneis e nove reservatórios de pequeno para entender a implantação do projeto porte (BRASIL, 2004, p. 38). Segundo a naquela topografia (ver Figura 10), um Figura 11, esse eixo varia $299,87 \mathrm{~m}$ de corte muito bom para se começar a altura, ${ }^{32}$ tendo sua captação na represa entender o funcionamento da obra. de Itaparica, no município de Floresta, O Eixo Norte é composto por mais alto na estacão de bombeamento 6 aproximadamente $402 \mathrm{~km}$ de (EBV-6) de nívaç508 87 , Bombeamento 6 canais artificiais, quatro estaçōes de finalizada no Acude de Pocõos, no nível bombeamento, vinte e dois aquedutos 568,50 . Esse Eixo transporta em média, seis túneis e vinte e seis reservatórios de $18,3 \mathrm{~m}^{3}$ de água por segundo e foi pequeno porte. Ainda foram previstas projetado para levar água para os açudes duas pequenas centrais hidrelétricas Barra do Jua (PE), Poço da Cruz (PE), junto aos reservatórios de Jati e Atalho, Poçoes (PB) e, atraves do rio Paraíba, e 12 MW de capacidade (BRASIL, 2004, desaguam, aos acudes Camán (PB) p. 37) . Eso canal segundo a Figura Epitácio Pessoa (PE) também conhecido 2 abaixo, varia $164,10 \mathrm{~m}$ de altura, ${ }^{31}$ por Boqueirão.

tendo a captação no nível $325,30 \mathrm{~m}$ em

Cabrobo, chegando à altura maxima de OEixo Norte foi dividido em cinco trechos, $490 \mathrm{~m}$ em relaçáa ao nivel do mar na denominadostrechos $1, \mathrm{II}, \mathrm{III}, \mathrm{IV}$ eVl, sendo estaçáo de bombeamento 3 (EBI-3) e e que os trechos $I$ e $I$ sáo referentes ao

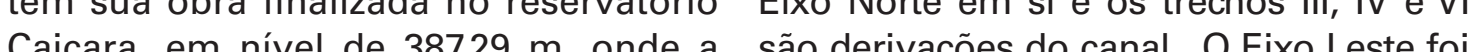
água deriva por cursos naturais de rios dividido em trechos VeVIII sendo oVo Eixo para as bacias do rio Salgado, Jaguaribe, Leste inteiro e o trecho VIl uma derivação Apodi e por meio do aqueduto Piranhas dele. Esses trechos foram distribuidos para o reservatorio Engenheiros Avidos, entre empresas diferentes tanto para o que abastece a bacia do rio Piranha- desenvolvinento dos projetos execulvos, Açu. O Eixo Norte levara agua para os que tiveram como base o projeto do e Piranhas Acu (PB e RN) A Apodi (RN) Engenharia ${ }^{33}$ quanto para a engecaro da fornecendo água para os açudes Chapéu $(P E)$, Entremontes (PE), Castanhão (CE), $32299.87 \mathrm{~m}$ de altura equivaleria a um edificio de Engenheiros Ávidos (PB), Pau dos Ferros 33 Informacăo verbal concedida em entrevista com Andre

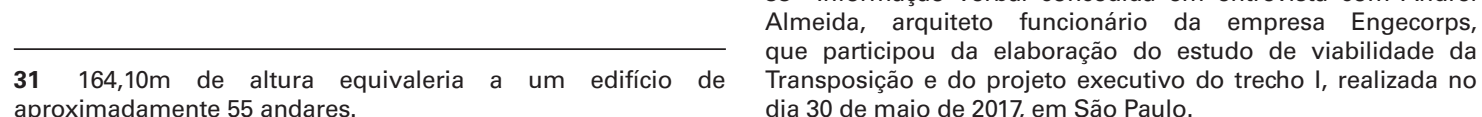


obra, conforme já apresentado no item A Figura 13 apresenta a chegada do anterior e na tabela da Figura $3 . \quad$ canal em uma estaçao elevatória no Eixo Para essa pesquisa, foi realizado um Leste, proxima a Monteiro (PB) tambem, Para essa pesquisa, foi realizado um para ilustrar como o canal chega abaixo conais pessm ou seja, cruzando com as do nivelda topogo o ca orignal.

do Ministério da Integracãão Nacional (MI) Almeida ${ }^{34}$ arquiteto integrante apresentado na Figura 10, e foi possível equipe da Engecorps, que participou verificar que os canais iniciam seu curso da elaboração do estudo de viabilidade acompanhando o perfil topográfico e da Transposição e do projeto executivo aos poucos váo cavando a terra, com do trecho l, o profissional explica que $1 \%$ para corram com a gravidade. No momento aerofotogrametria para que os canais em que começa a haver uma diferença fossem posicionados na região em muito grande entre o caimento do canal função da topografia, com o objetivo de a topografia, ou seja, no momento em que se intervisse o minimo possivel no que o canal penetrou significativamente solo, reduzindo assim os custos da obra. no solo, há uma estação elevatória, que Além disso, Almeida disse que, com o o desnivel. na estação elevatória, a água volta a vazios, fugindo dos perímetros urbanos, correr pelo canal novamente pela força povoados etc.

da gravidade, até a próxima estação ou
reservatório (ver diagrama da Figura 11).

Para manter o caimento e transpor obstáculos, algumas soluçoes foram aquedutos nos locais de cruzamento com riachos e rios ou a construção de túneis com o objetivo de ultrapassar grandes relevos. No entanto, esses detalhes serão apresentados a seguir, quando cada

As Figuras 12 e 13 a seguir ilustram esse diagrama em fotos. A primeira, Figura estação elevatória, enquadrando a saída da água bombeada e retomando seu curso pelo canal.
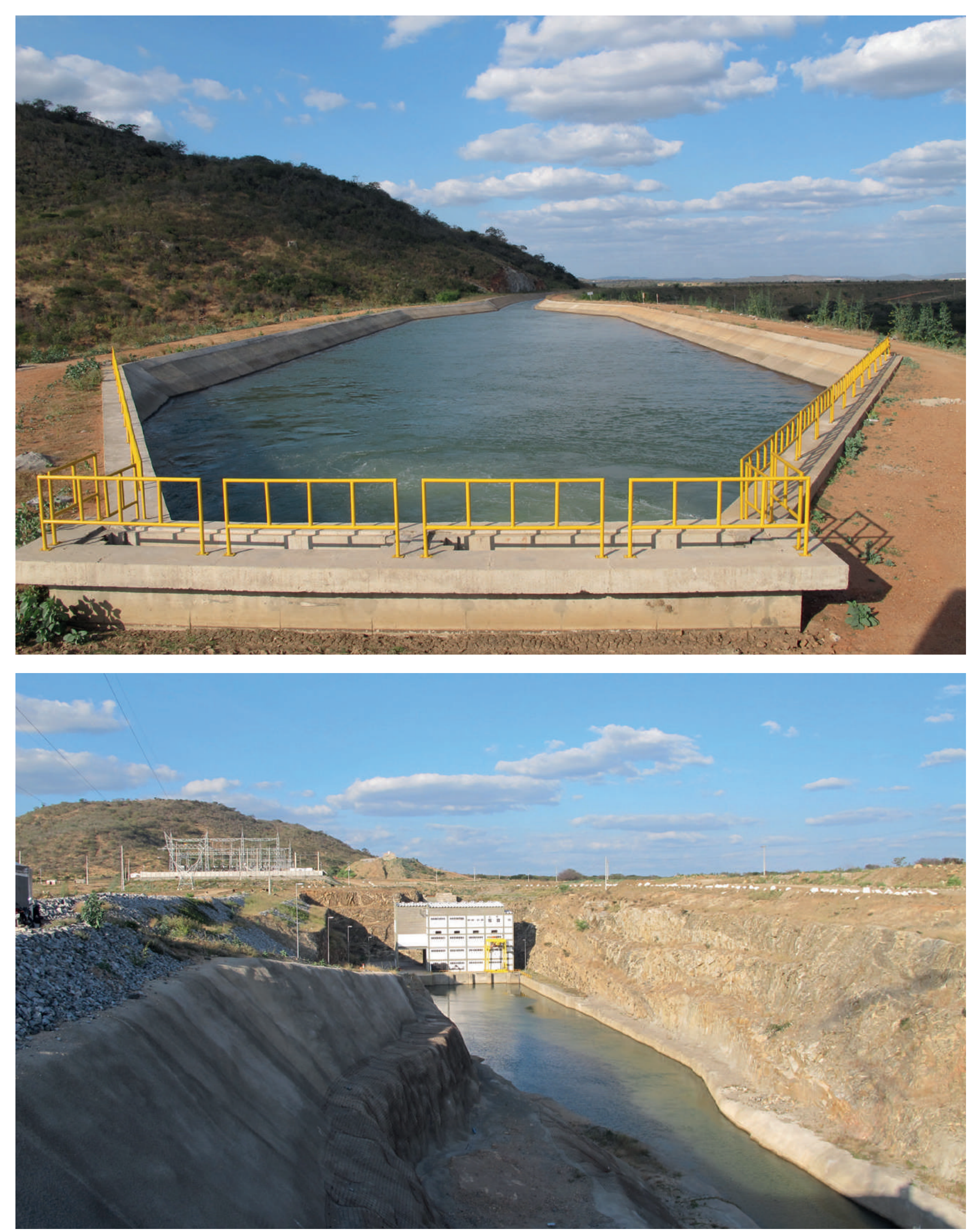

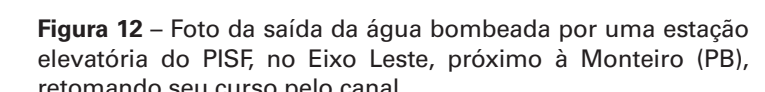

Foto: Carolina Sacconi. Monteiro (PB), setembro de 2017

Figura 13 - Estąăo de bombeamento no Eixo Leste. 

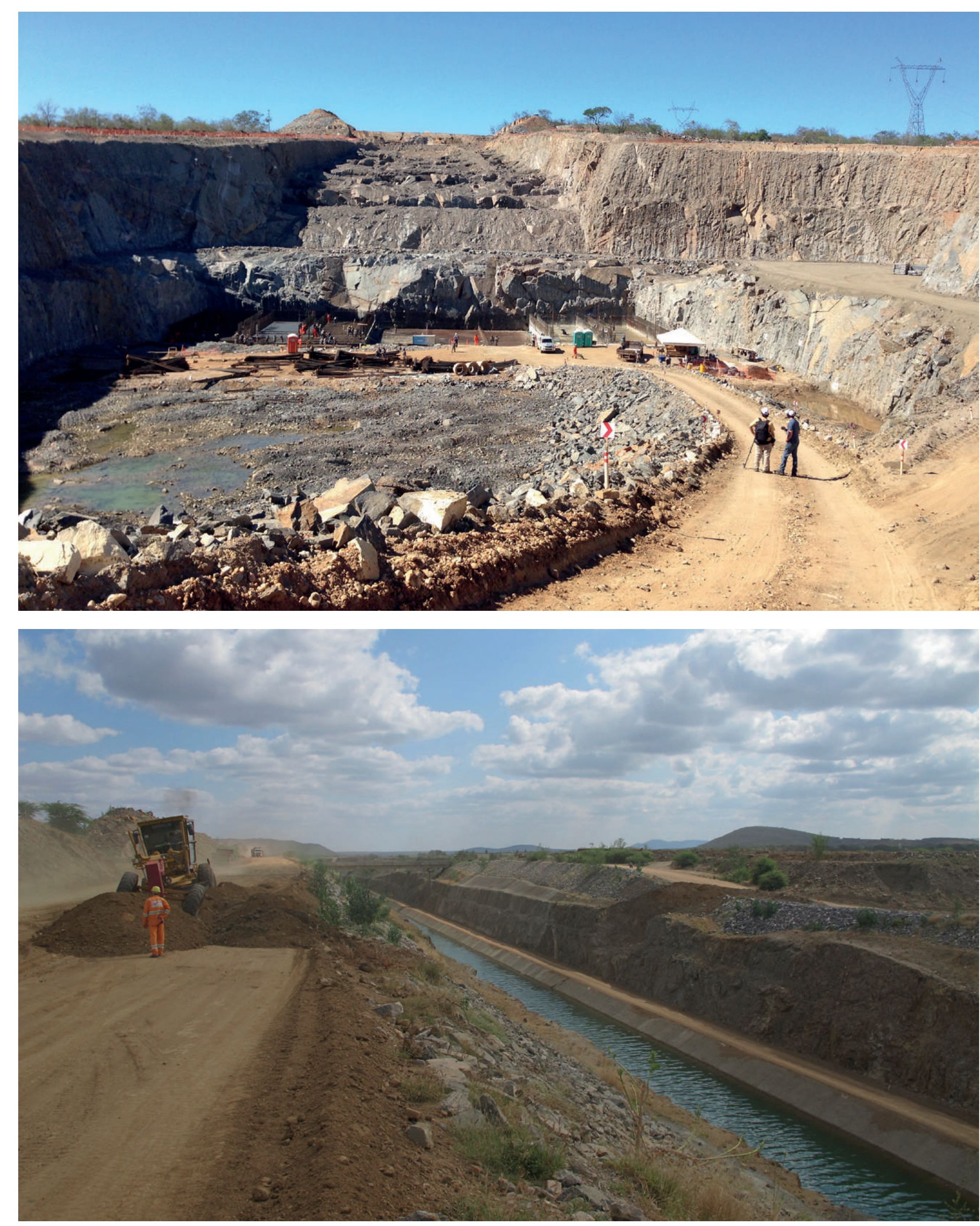

Apesar disso, ainda assim a obra possuiu um grande trabalho de terraplanagem e corte-aterro, conforme demonstram as Figuras 14 e 15, se tornando uma grande interrupção na continuidade do territorio, um objoto intransponivel, a pontes, conforme será apresensado mais adiante. $E$, apesar de os engenheiros terem buscado considerar os locais mais vazios para localizar os canais, ainda assim se tratava de uma região habitada, ainda que náo o parecesse, de forma que os canais o praram uma um lado, a obra impactou e transformou muito a paisagem, os fluxos, as vidas de quem lá morava; por outro, pouco se relacionou com o pré-existente, pouco se permitiu que a infraestrutura fosse apropriada por quem la vivia, uma infraestrutura presente fisicamente e evidenciedo methor no item 32.2 sobre " "presenca-ausência" da obra. Ou seja, pode-se perceber que o critério para os desenhos dos canais foi de fato mais técnico-topográfico e menos territorial, no sentido do culdado com os locais e passo

Na Figura 16, são apresentadas algumas seçōes-tipo que foram elaboradas nos Estudos de Viabilidade TécnicoEconômica e Ambiental (2000b, p. 188) e detalhadas posteriormente nos projetos executivos, como ilustrado na foram implantados em os canais diferentes momentos da topografia e tipos de solo da região. Apesar de aparentar simplicidade, a obra exigiu grande sofisticação das empreiteiras na construçáa, dada sua escala e a engenhosidade do projeto, o que, como já foi dito no item anterior, dado construtoras, gerou muitos problemas de execução.

Quando se vai a campo, essas seçōestipo dos canais ganham a dimensão do

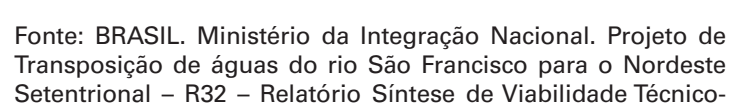

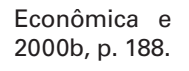

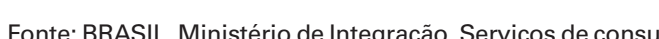

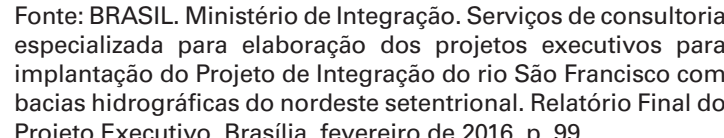

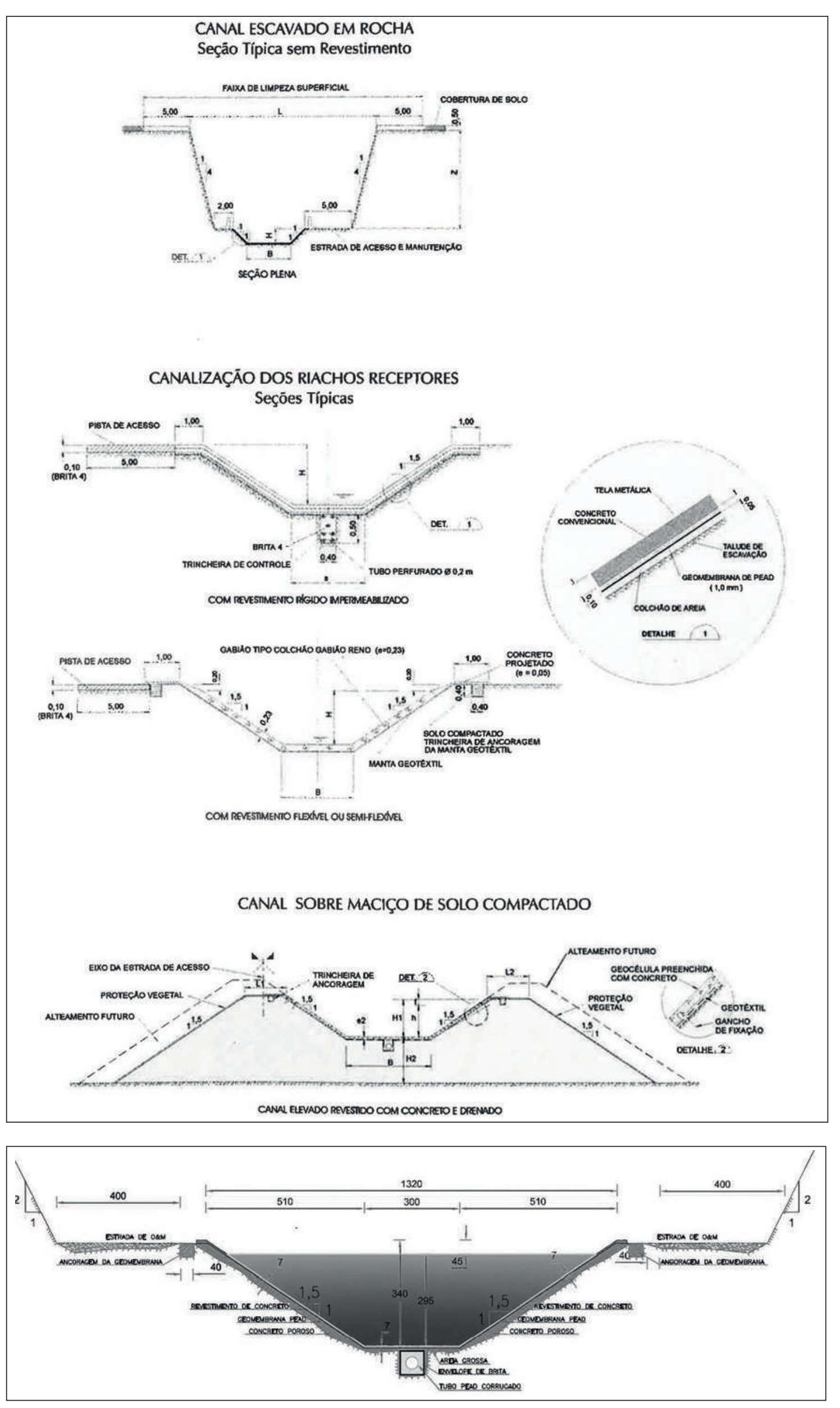




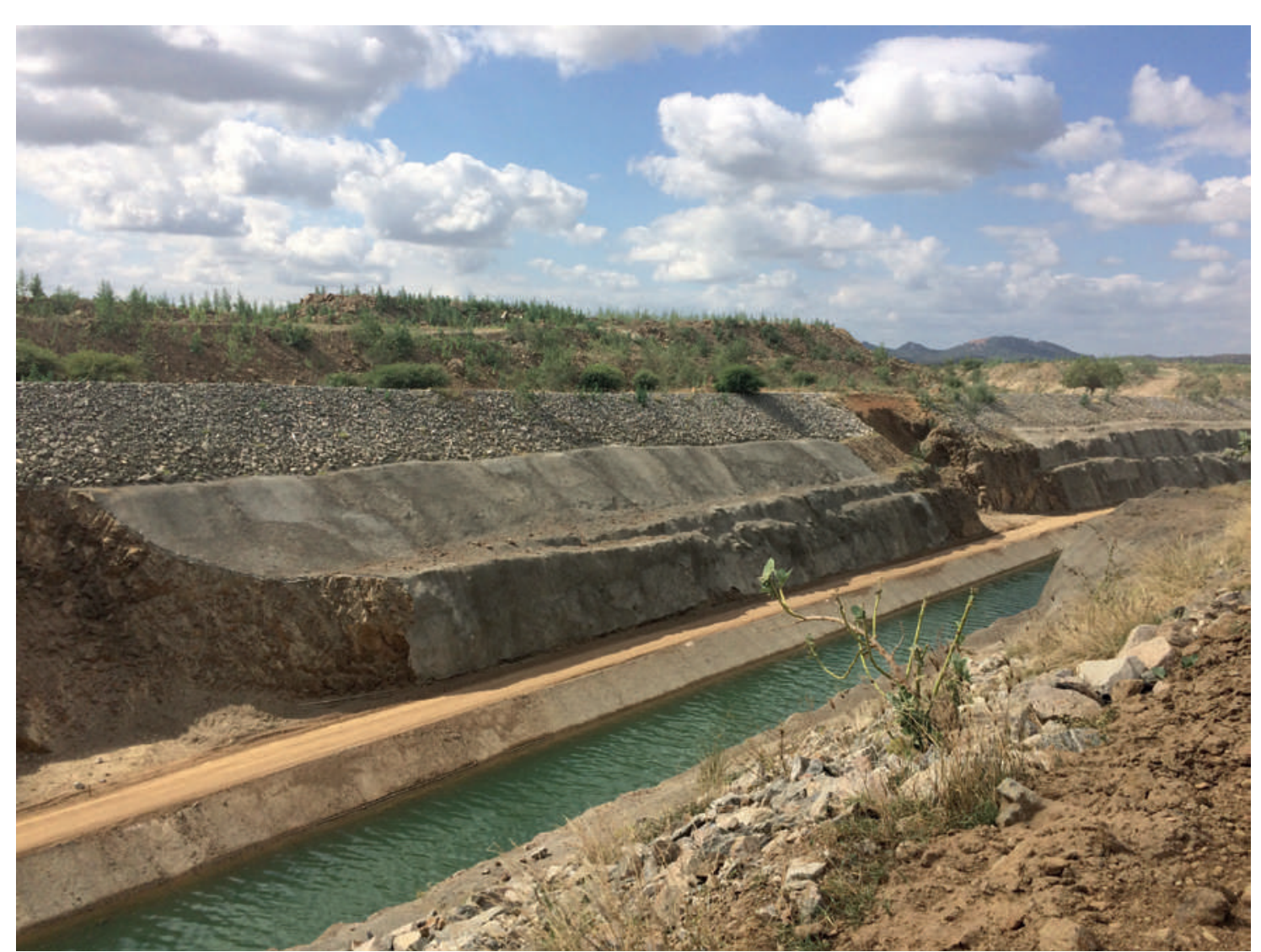

Figura 18- Eixo Leste, próximo a Monteiro.
Foto: Carolina Sacconi. Monteiro (PB), setembro de 2017. Figura 19 -Exxo Leste, próximo a Monteiro.
Foto: Carolina Sacconi. Monteiro (PB), setembro de 2017

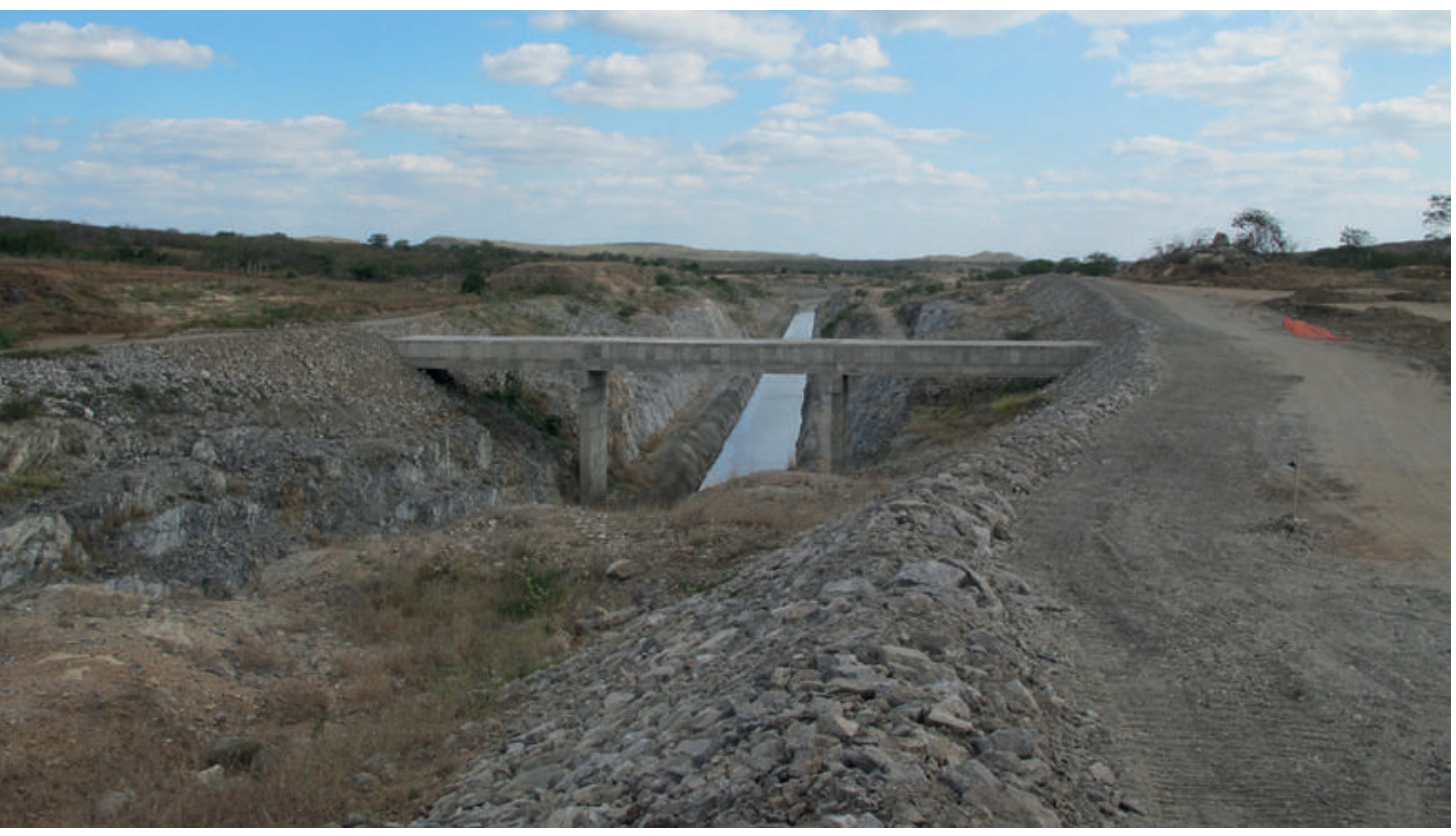

que significam executadas. Desenhadas, calculado dessa forma trouxe melhor se de uma obra bastante contundente não pareciam tão incisivas na paisagem custo-benefício. Em relação a esses no território, ou seja, que modifica quanto de fato são. Por exemplo, as cálculos de evaporação, tanto ao longo paisagem, interrompe osfluxoseatravess

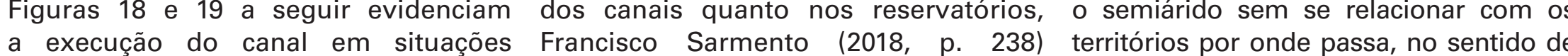
de escavação em rocha, conforme explica em seu livro que o conceito de ser uma infraestrutura que não permite demonstrado nas seções-tipo das sinergia hídrica tratava justamente dos ser utilizada por quem ali vive para outros Figuras 16 e 17 . cáleulos da vazáo precisa que deveria usos (como por exemplo para lazer, para $\begin{array}{lll}\text { Ainda na entrevista concedida por Andrei } & \text { ser transposta para que o mínimo de } & \text { banho, ou mesmo para abastecimento, ja } \\ \text { que como se poderá ver mais adiante, nem } & & \end{array}$ Almeida, ${ }^{35} \mathrm{o}$ arquiteto comentou que $\mathrm{todo}$ mundo que está nesse percurso seria estudadas, como por exemplo, transpor representam os canais em cartografias espaços de convivência e acessibilidade através de canais subterrâneos ao invés oficiais e desenhos técnicos, seguem de nâo permitir que a população acesse dos canais em concreto a céu aberto abaixo algumas fotos aereas (Figuras 20, essa infraestrutura. $\mathrm{O}$ acesso à obra e afirmou que, mesmo considerando 21, 22 e 23) do Eixo Norte, publicadas na restrito aos funcionários da obra e do a evaporaçáo que a água sofreria por Folha de Sáo Paulo (2018), ${ }^{37}$ que ajudam governo federal e, ao longo de toda a como e sua inserção no teritório, como uma faixa de $200 \mathrm{~m}$ de terras, havendo

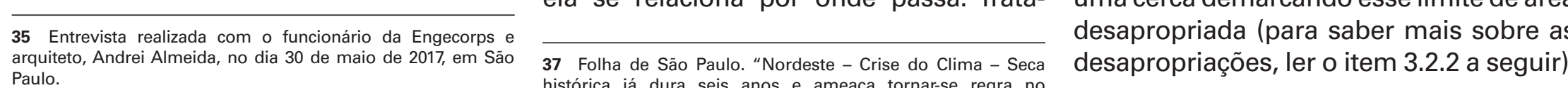

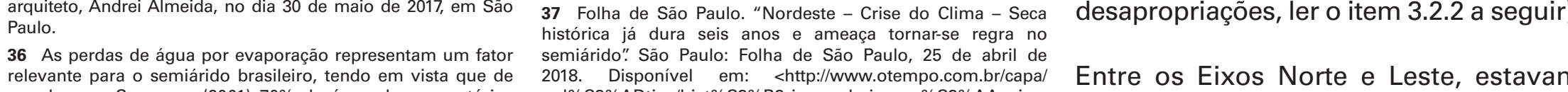

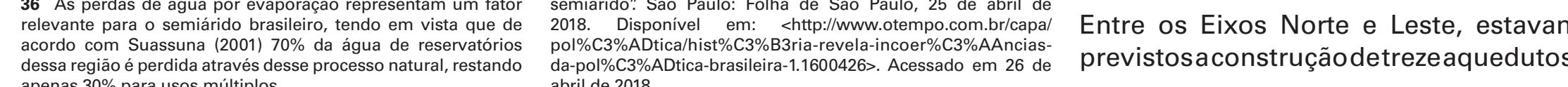

Figura 20 a 23 - Imagens a ́reas do Eixo Norte,
se trata de uma obra impactante no teritório,

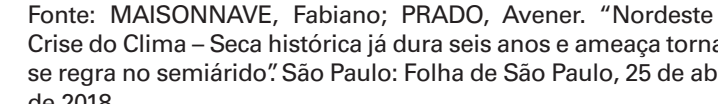
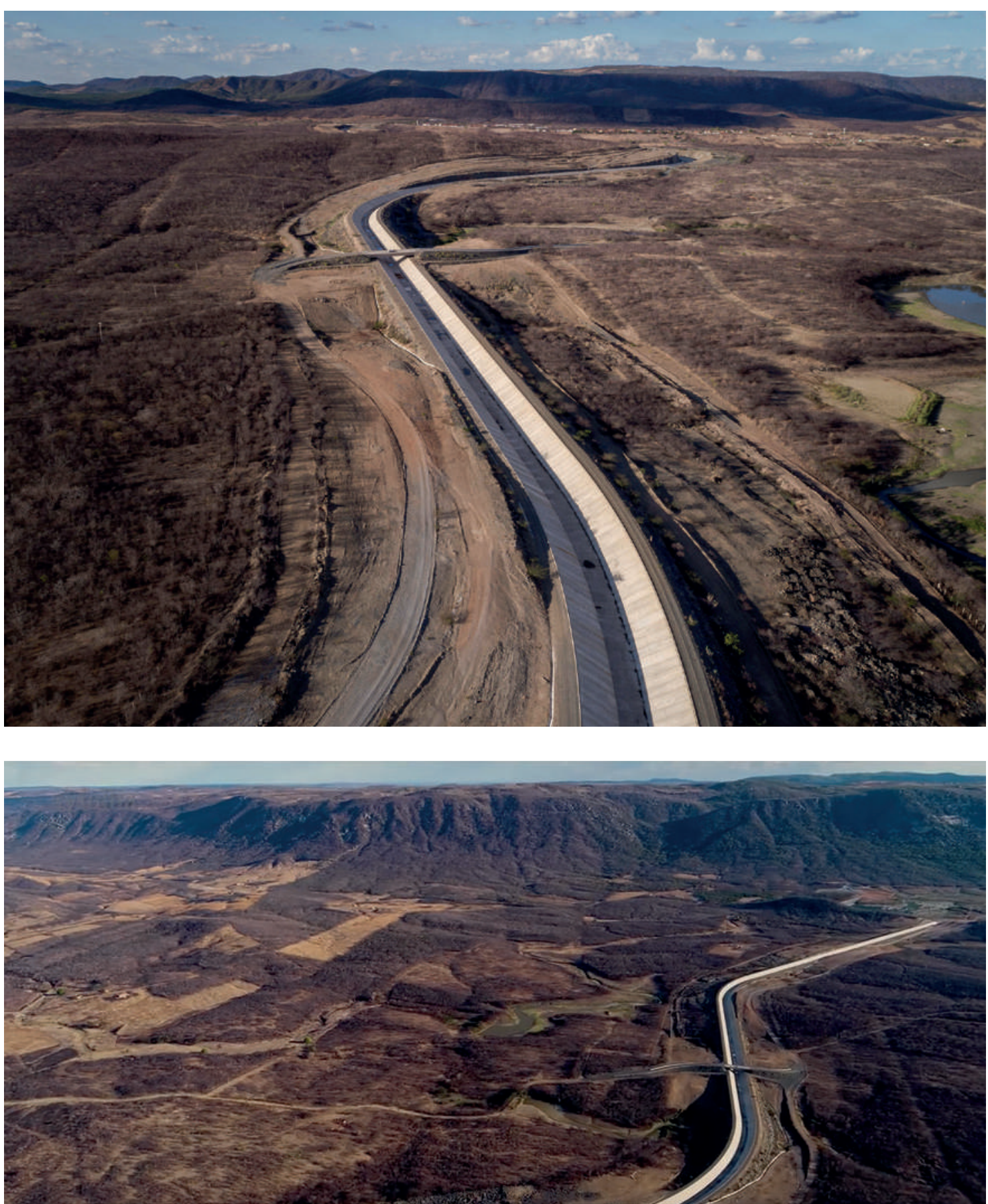

nove estações de bombeamento, vinte sete reservatórios, além da conexáo subestaçồ de $230 \mathrm{~kW}$. $270 \mathrm{~km}$ de linhas de transmissão em alta tensão, algumas pontes e passarelas para travessia dos canais e quatro túneis. A seguir, o projeto será apresentado detalhadamente, contraposto e ilustrado com o que foi construido na obra. Serao localizados em cartografias específicas cada u canais, além de apresentados detalles técnicos e fotos da obra de cada um.
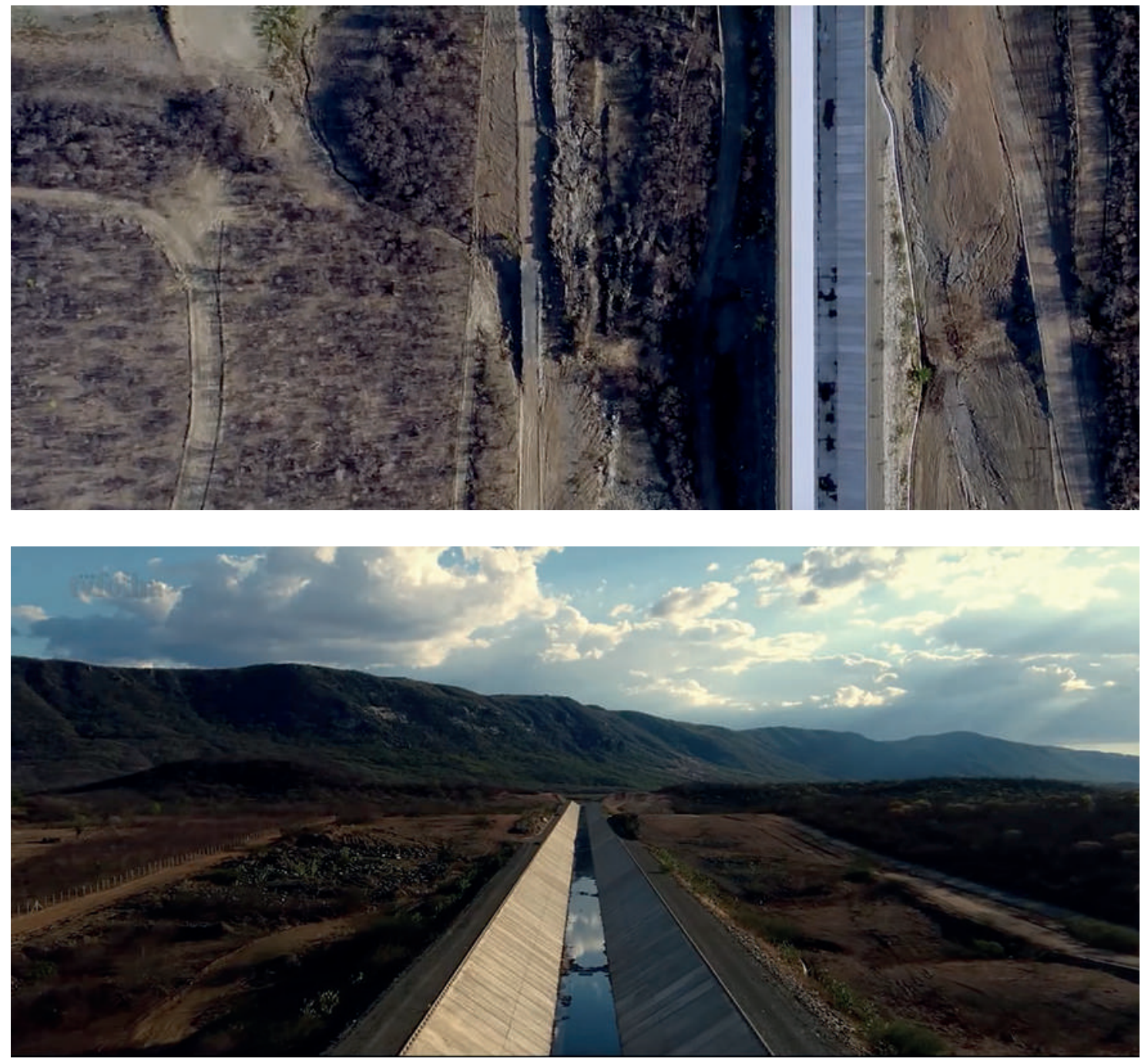


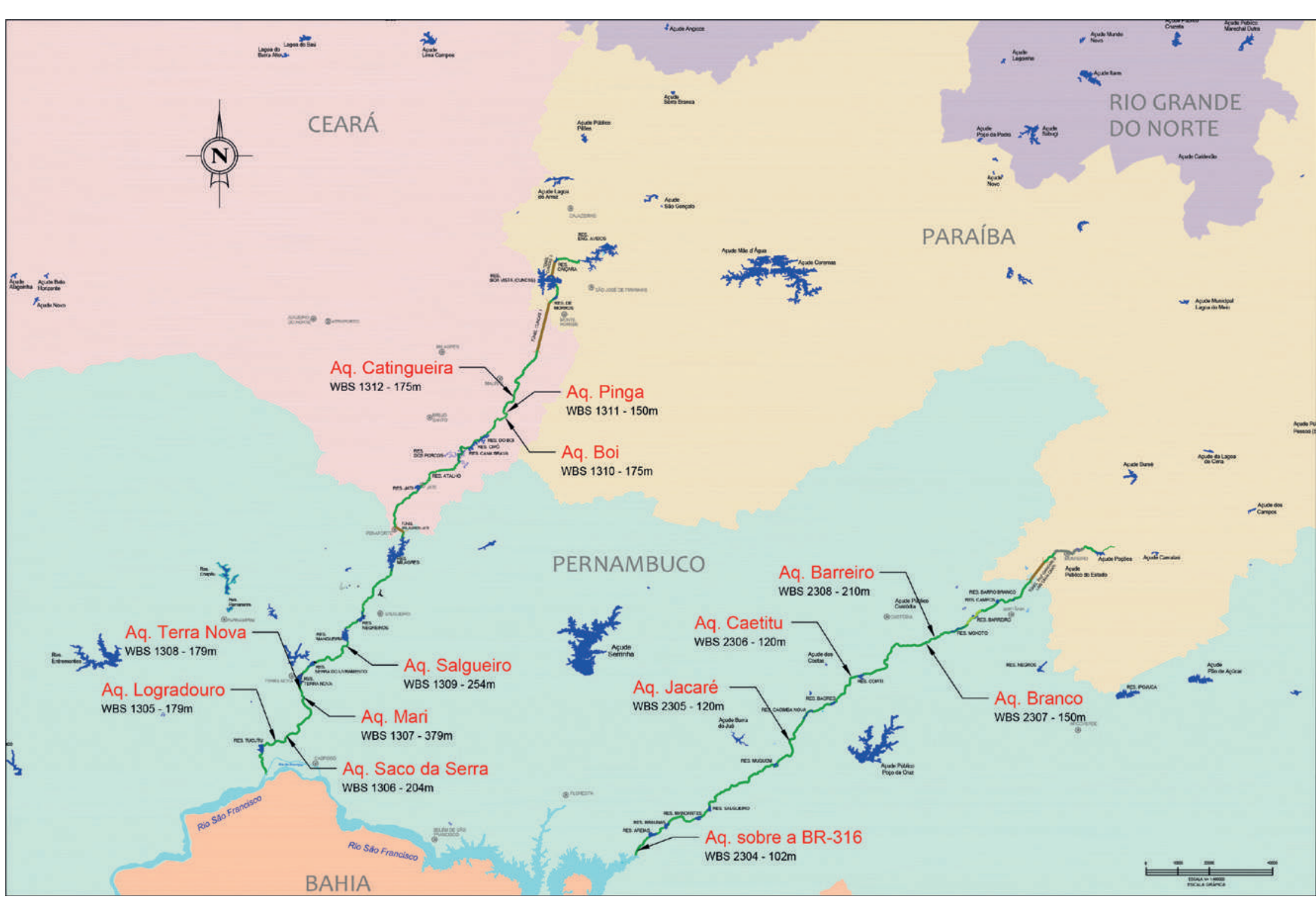

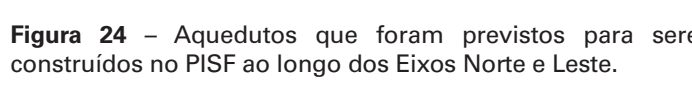

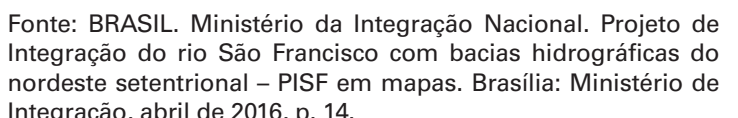

\section{Aquedutos}

A soluçãa dos aquedutos foi dada para
os casos em que os canais do PISF dentro, apoiadas em pilares também cruzavam algum outro corpo d'água, pré-moldados em concreto (ver Figuras estradas, ou mesmo para casos de 25 e 26 ). Trata-se de um desenho que forma que os aquedutos permitiriam função de se transpor o volume de água não alterar o caimento constante da dos canais de um lado para o outro. água transposta. Conforme a Figura 24, no Eixo Norte, foram previstos oito, e no Na obra, os aquedutos foram Eixo Leste cinco aquedutos. Th Muito embora essa solução do (MACEDO, 2017, informação verbal), história da construção da humanidade, funcionando apenas com essa vazão em que os aquedutos faziam parte da em setembro de 2017, poucos meses paisagem das cidades, conformando após a sua inauguração oficial. Segundo praças, locais de convivência ou até o arquiteto Andrei Almeida, ${ }^{39}$ isso mesmo, o mais obvio, acesso à agua, ocorreu porque o PISF tem autorização esse elemento na obra do PISF náo para operar segundo duas condiçoes: pilun nes, amponcia doermite uma no rio São Francisco está abaixo de relaça com essa obra construída ou 95\%, ele pode retirar uma vazão de ate cesso à água Trata-se de um aqueduto

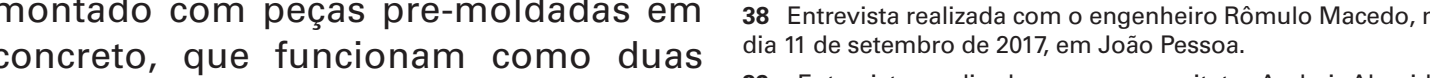

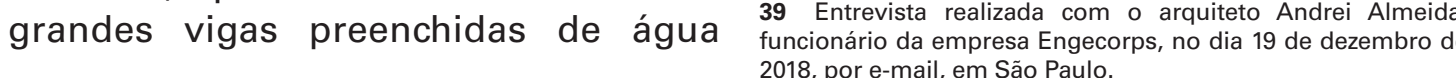

$26,4 \mathrm{~m}^{3} / \mathrm{s}$, o que significa operar com $5 \%$ de sua capacidade de projeto. Por exs situaç̃o, que é a mais provável e a que mais ocorre, assim como o porte dos aquedutos construidos tambem foram previstos para suportarem apenas $25 \%$ da capacidade da vazão autorizada.

Eventualmente numa cheia, quando chover muito no rí São Francisco "verter", isto é, extravasar de tanta a vazão retirada do rio, subindo para $114,3 \mathrm{~m}^{3} / \mathrm{s}$. Nessa situação, as bombas funcionariam por mais tempo e os reservatórios do PISF infraestrutura fixa permaneca a mesma do início, porém seria utilizada a pleno (canais até o topo, barragens atè o topo etc.). No futuro, desde que a Agência Nacional de Águas libere uma outorga maior do

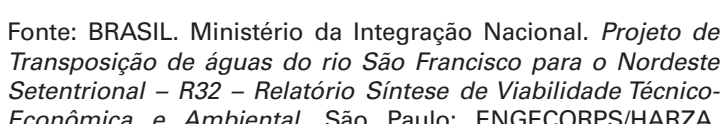
EEconomica

longitudinal de aquedutos.

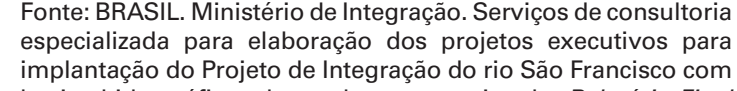

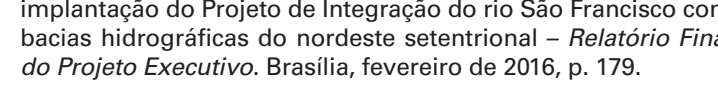
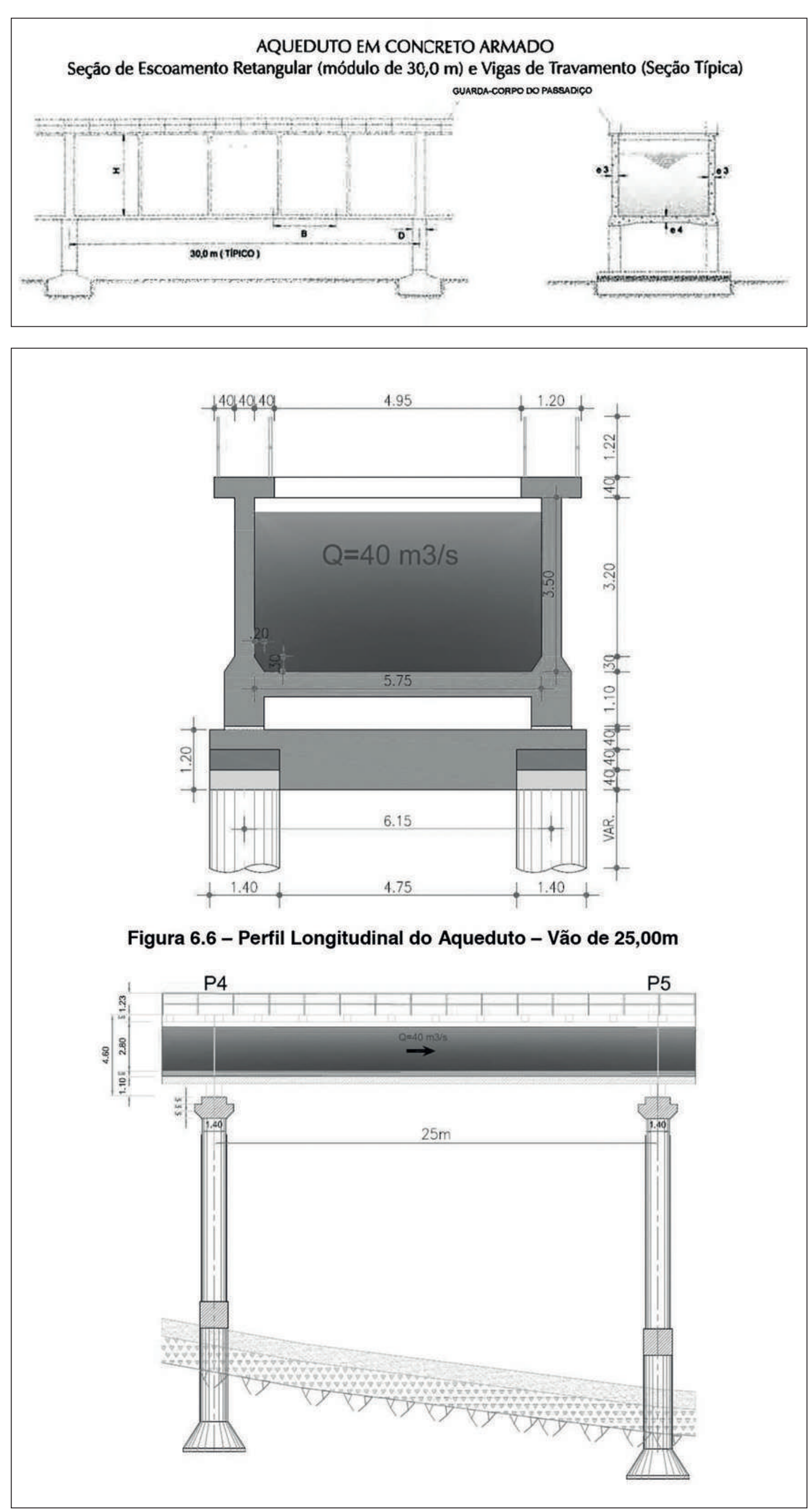

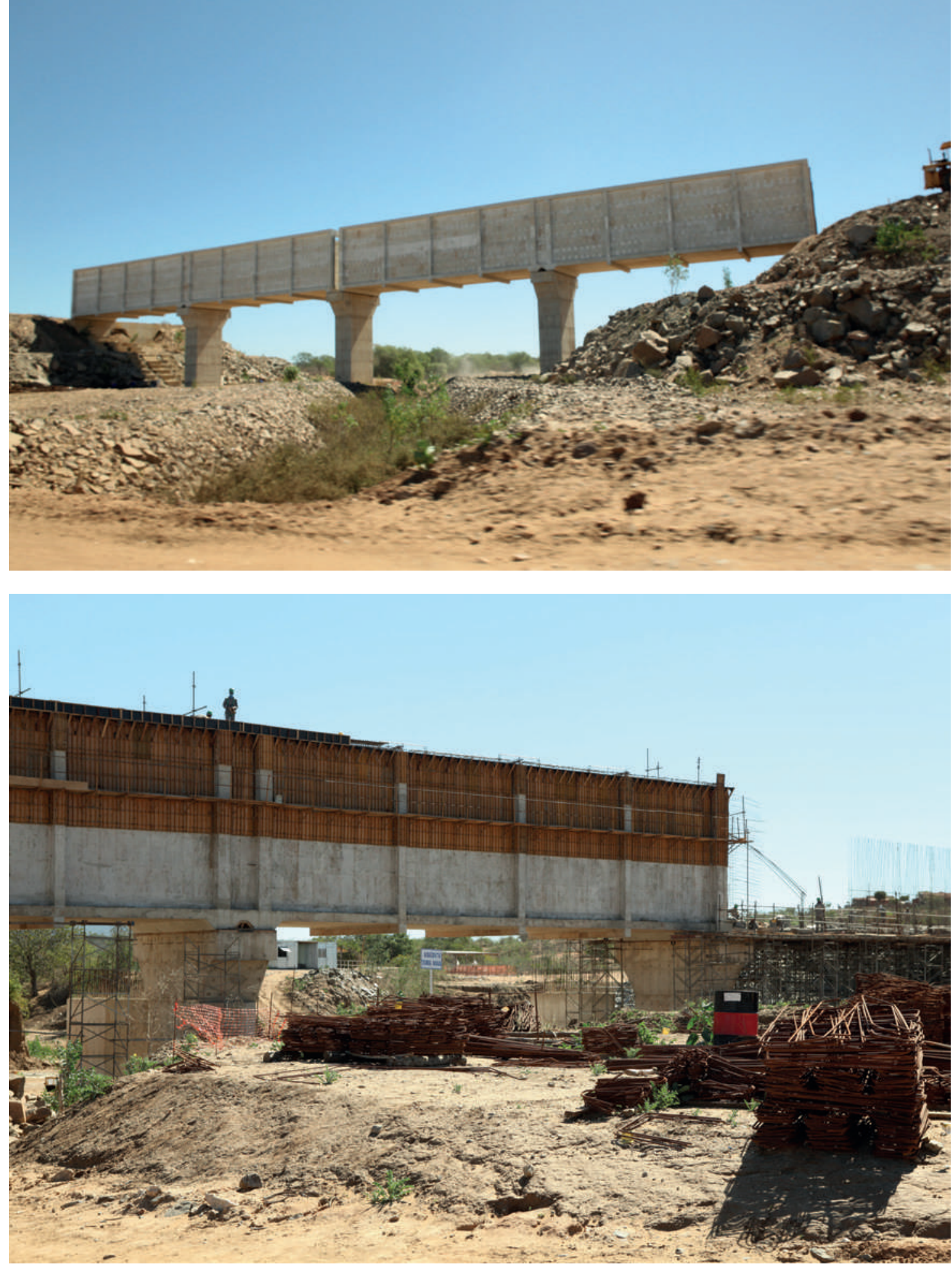

que a atual que descrevi acima, essa os canais continuarão os mesmos. mas as estaçoes de bombeamento aquedutos serão duplicados, atingindo a capacidade máxima projetada - Informação concedid Almeida funcionário da no dia 19 de dezembro de 2018, por e-mail, em São Paulo.

conforme o previsto no governo $\mathrm{FHC}$ divulgado no governo Lula.

As Figuras 27 e 28 ilustram aquedutos sendo construidos no Eixo Norte, próximo a Cabrobo (PE), em 2013. Interessant com a paisagem, uma infraestrutura asseptica, um "viaduto" para a água de grande impacto na paisagem.

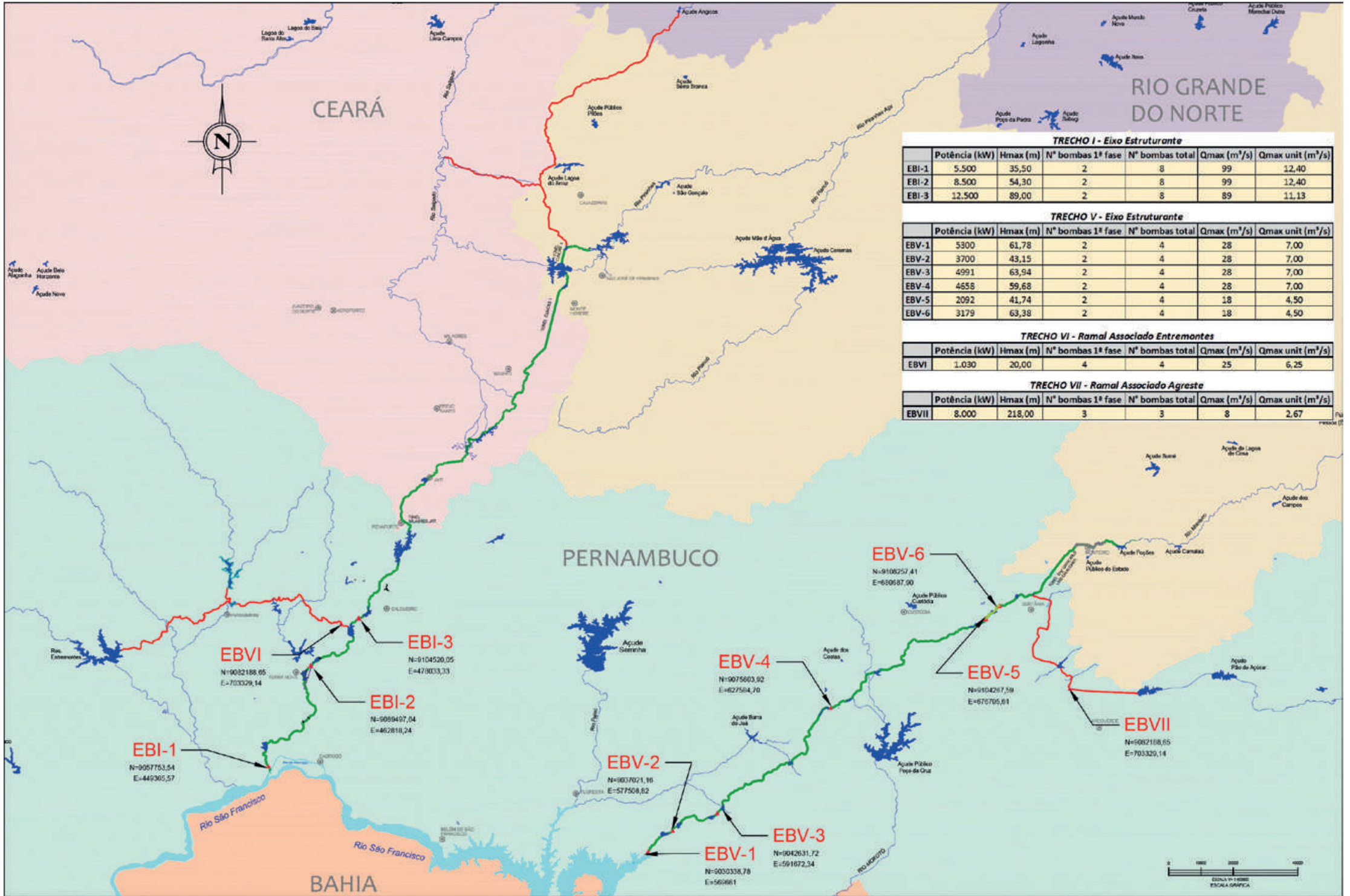

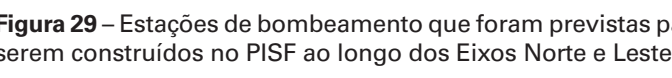

Estações elevatórias (EBs)

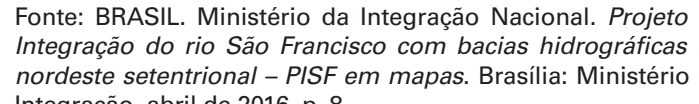

de bombeamento de água

No Eixo Norte, foram previstas a obra promovia na paisagem. A segui construçaoo de três estaçōes elevatórias fotos da mesma estação elevatória, a

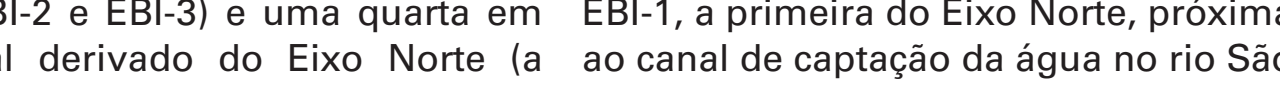
EBIVI), o Ramal Entremontes. Já no Eixo Francisco. As primeiras fotos são da EBILeste, foram previstas a construção de 1 ainda em obras (Figura 31 e 32) e as 2, EBV-3, EBV-4, EBV-5 e EBV-6) e uma obra concluída (Figuras 33, 34, 35 e 36). sétima em um ramal derivado do Eixo Leste (a EBVII), o Ramal do Agreste. A A Estas estações elevatórias funcionam onde foram previstas as estações:

como uma espécie de casa de máquinas do PISF, contendo as bombas para Como já apresentado anteriormente do canal. A seguir, nas Figuras 37 e 38 , neste capítulo, as estaçōes elevatórias respectivamente, uma foto de uma estação

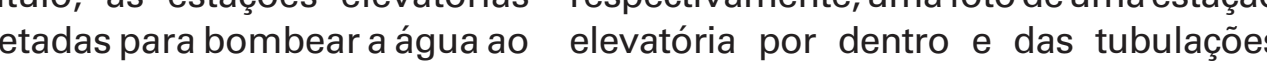
longo do percurso dos Eixos, de maneira por onde a água passa e é transposta

Essa vazão adicional aos $26,4 \mathrm{~m}^{3} / \mathrm{s}$, que poderia chegar até $114,3 \mathrm{~m}^{3} / \mathrm{s}$, seria a destinada a outros usos que
estimulariam o desenvolvimento regional a partir do PISF, conforme previsto desde os Estudos de Inserçāo PISF foi retomando cada vez mais seu carácter de ser apenas uma grande obra hídrica e abandonando sua funcão de obra para desenvolvimento regional, o caimento dos canais, que fazem com sairá a continuação do canal (conforme que a água corra por gravidade em diagrama da Figura 30 bem ilustra). uma inclinação de $1 \%$ em linhas gerais, conforme ilustra a Figura 30

Justamente por ser o momento da obra em que a infraestrutura transpõe a topografia, nos pontos das estaçōes elevatorias era um dos momentos mais perceber as diferenças de nível que a 

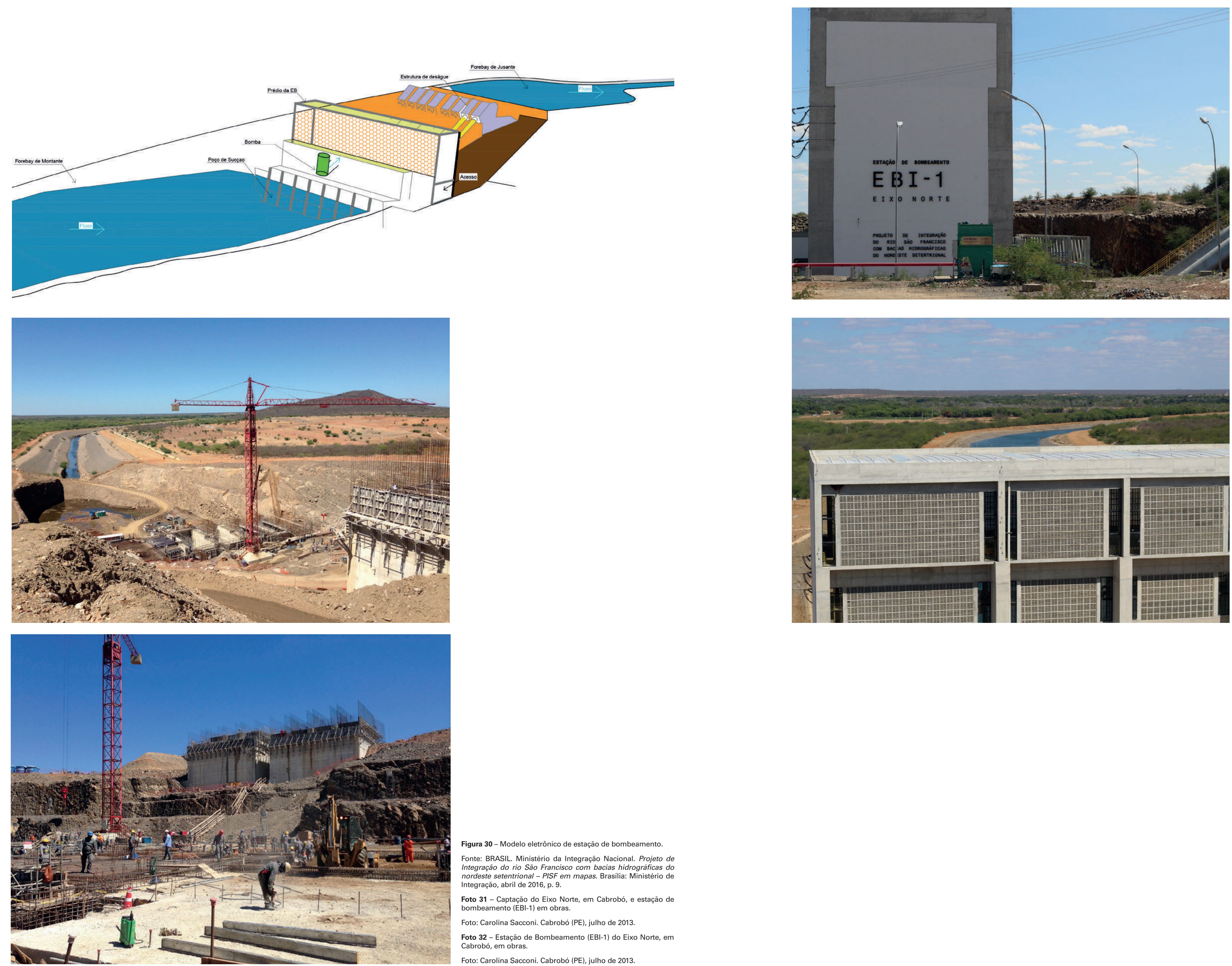

Fonte: BAASL

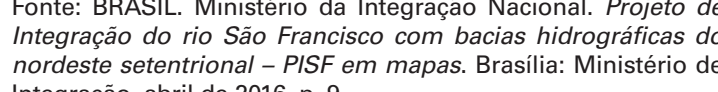

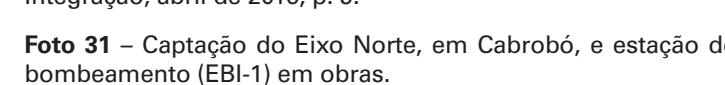

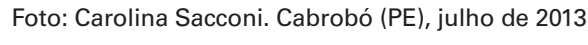

Exio Norete

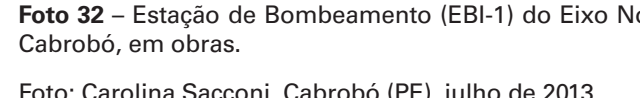

Cabrobó (PE), setemb

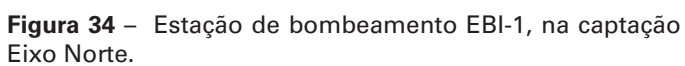

Foo Andrea Muner. Cabrobó (PE), setembro de 2017 

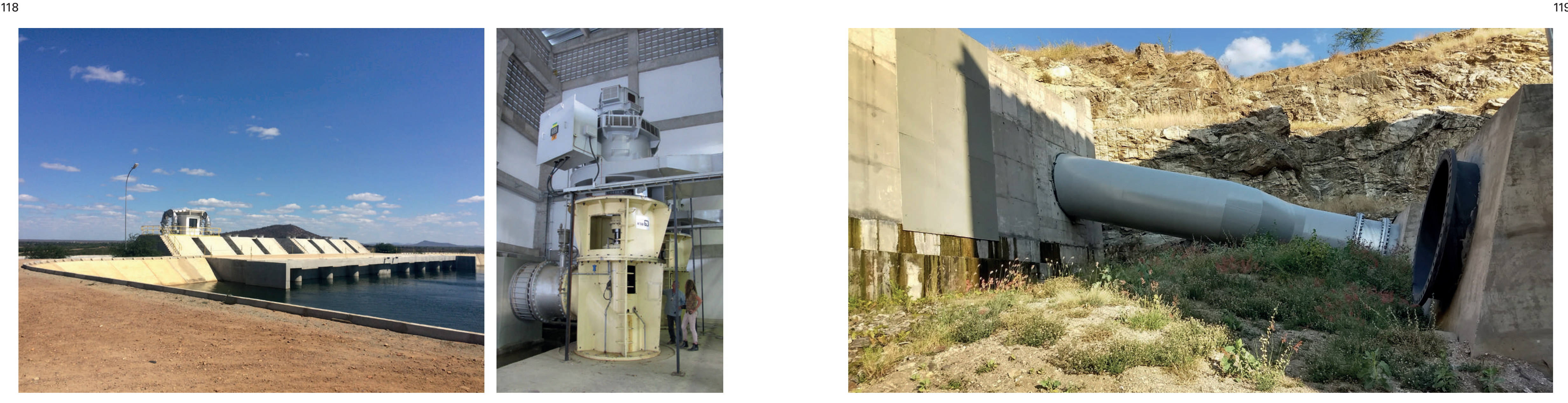

Figura 35 - Foto panorâmica da estaçăo de bombeamento
EBb-1, na captaça do Eixo Norte. Foto Ana Carvalho. Cabrobó (PE), setembro de 2017.
Figura 36 - Estą̧ăo de bombeamento EB-1, na captaçăo

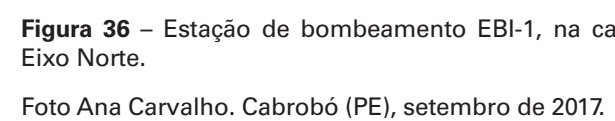

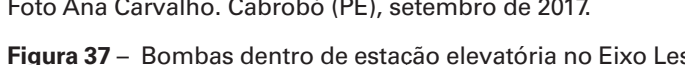
Foto Carolina Sacconi. Monteiro (PB), setembro de 2017. Figura 38 - Tubulaçäes da estąāa elevatótia por onde passa
agua bombeada para o nivel mais alto novamente. Foto Ana Carvalho. Monteiro (PB), setembro de 2017.

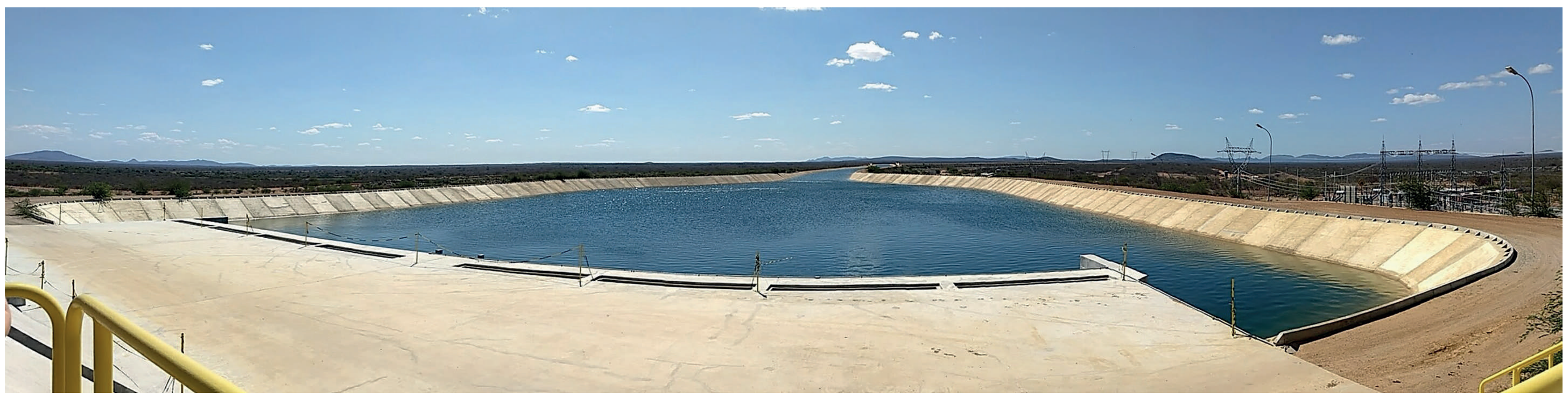




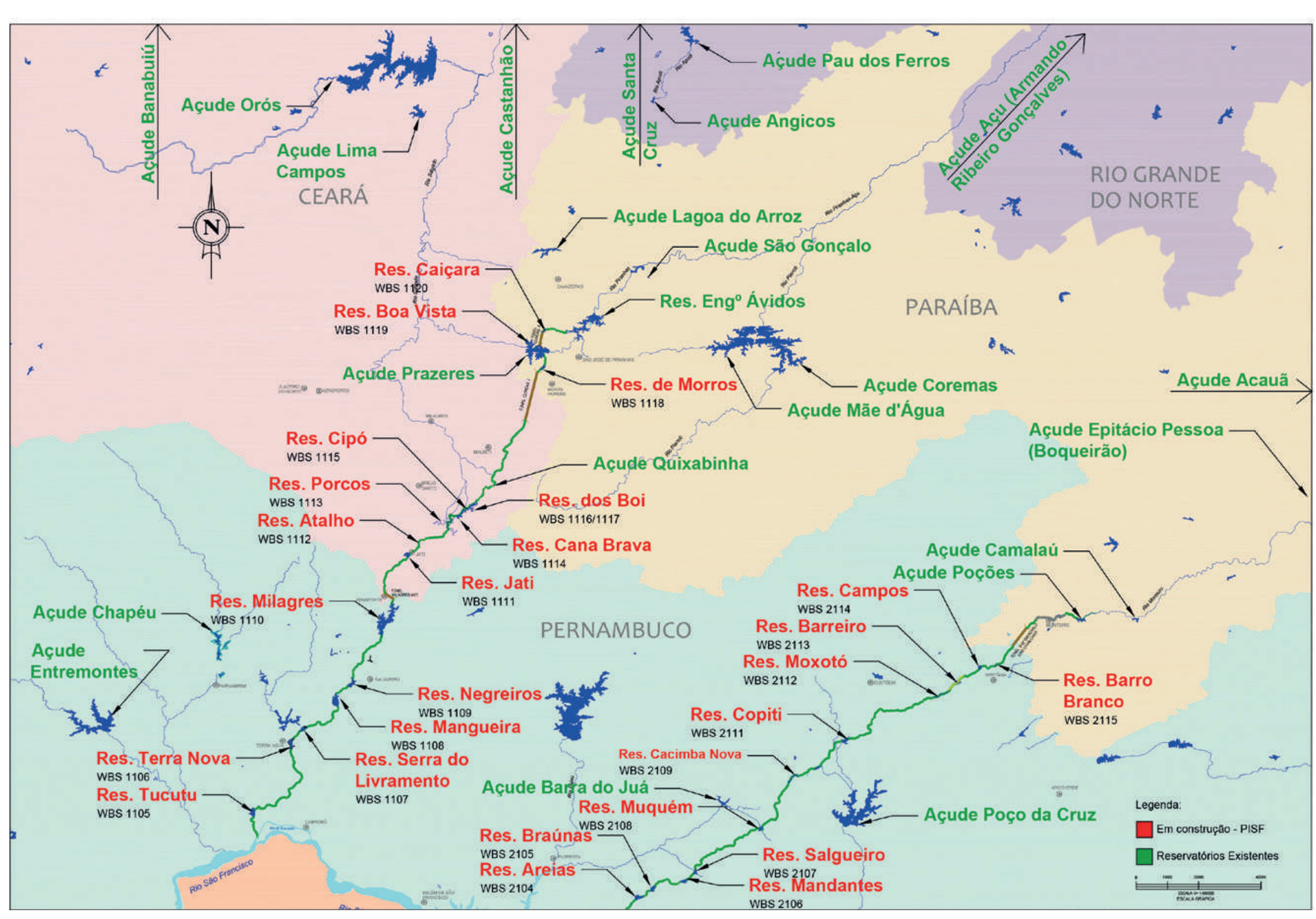

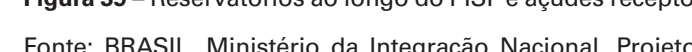

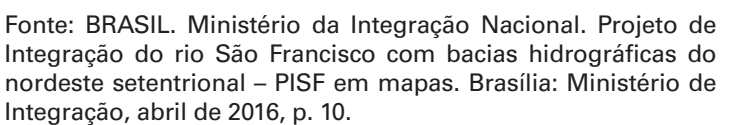

\section{Reservatórios e açudes}

Para o sistema hídrico proposto pelo respectivamente, $40 \mathrm{MW}$ e $12 \mathrm{MW}$ de PISF, foram previstos tanto a construção capacidade (BRASIL, 2004, p. 37).

Em setembro de 2017, quando o trabalho Na Figura 39 (e também nas Figuras 40 realizado 41 o reservatório se ençantrav e 41, que são ampliaçōes da Figura 39, ainda em obras, que no Eixo Norte estavam sendo respectivamente, a primeira o Eixo paralisadas. Tratava-se de um cenário Norte e a segunda o Eixo Leste), e possivel bastante impactante, pois, o reservatório visualizar em vermelho os reservatorios de Jati, uma infraestrutura que ocupa uma PISF, e em verde os reservatórios que já a obra paralisada apresentava um ceńrio existiam foram incorporados ao sistema, de uma paisagem devastada e desabitada havendo inclusive uma diferenciação muito trabalho de movimentação de terra, da nomeaçấo, sendo os reservatórios desmatamento da caatinga, barragens, existentes chamados de açudes. tubulaçōes, uma intervenção brutal na Um dos maiores reservatórios que foi paisagem e de grande porte, em que a planejado para ser construido pelo PISF para se entender aquela dimensão, era (ver tabela da Figura 40), localizado no se compreender a área que seria a para estado do Ceará, a $59,1 \mathrm{~km}$ de Salgueiro futuramente com a obra pronta, conforme (PE). Nele, estava prevista uma pequena evidenciam as Figuras 42,43 e 44. central hidreletrica, assim como reservatório de Atalho, no Ceará, com, ${ }_{41}$ No item 3.2.2., haverá mais detalhes sobre esse trabalho

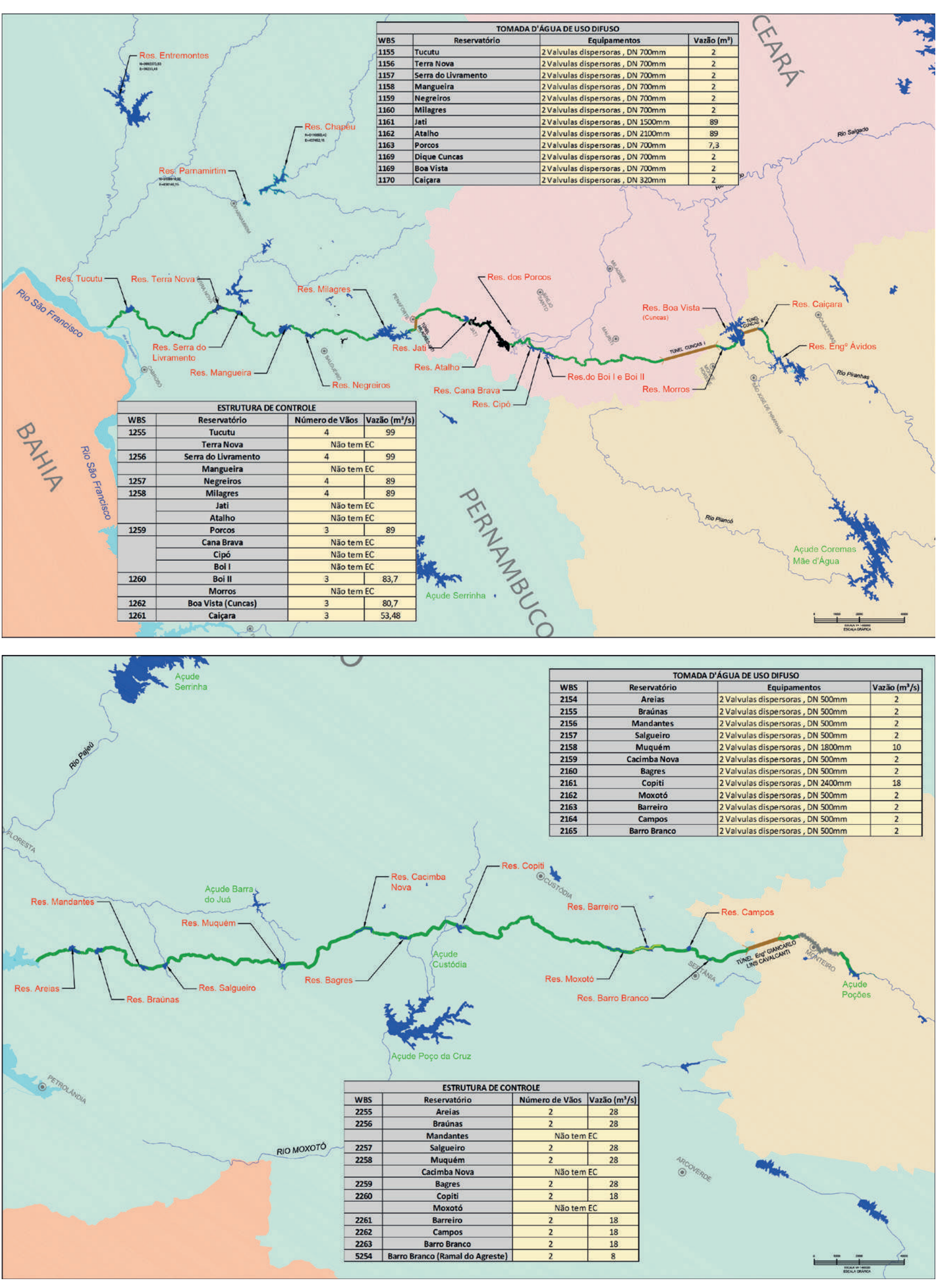

Figura 40 - Reservatórios no Eixo Nore Figura 41 - Reservatórios no Eixo Leste.

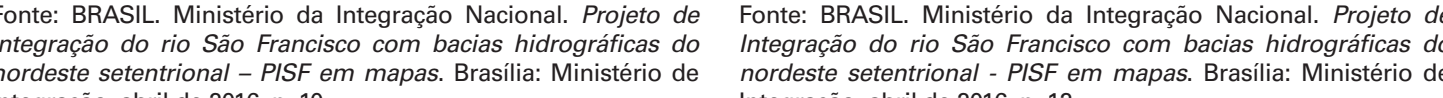



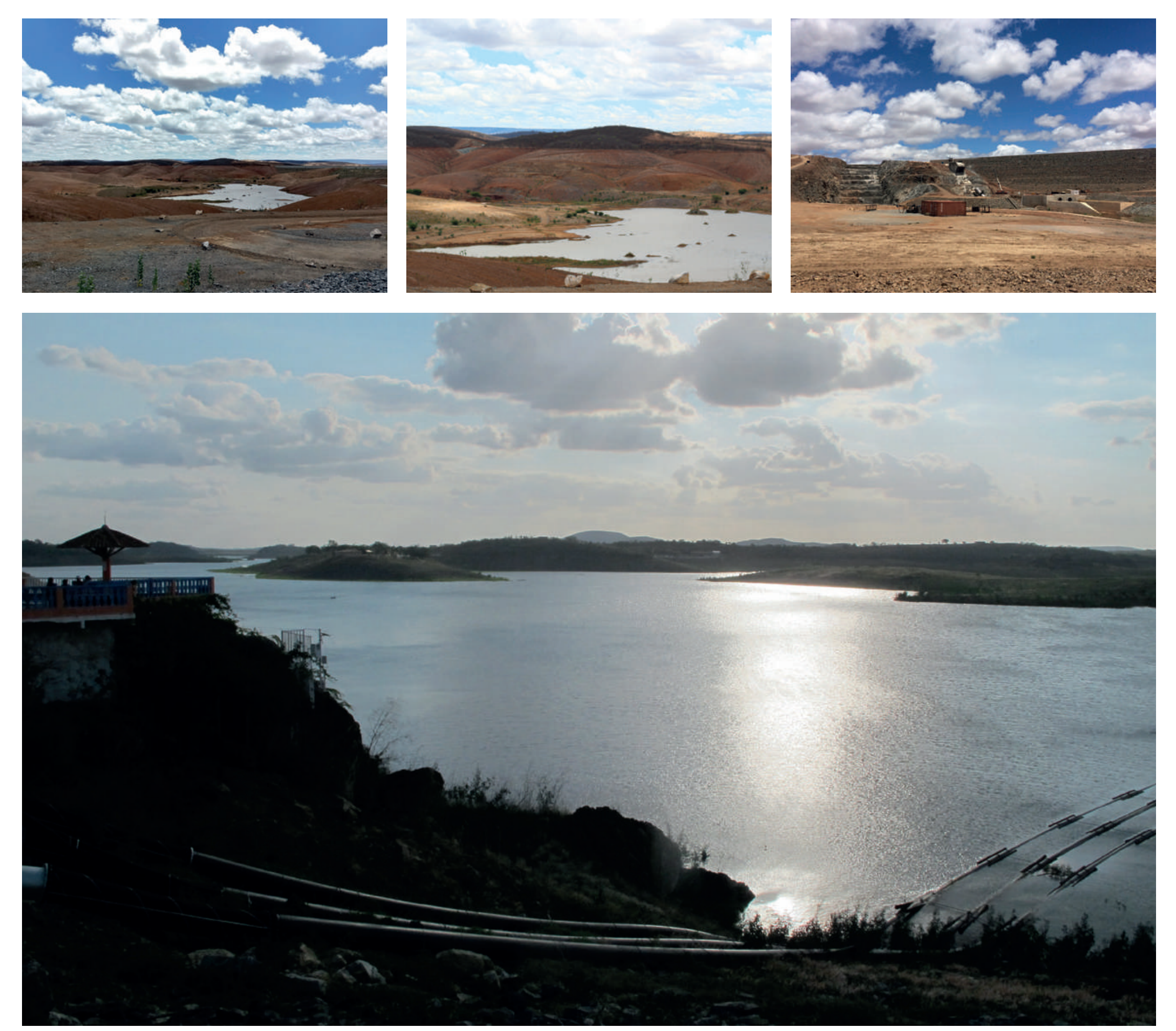

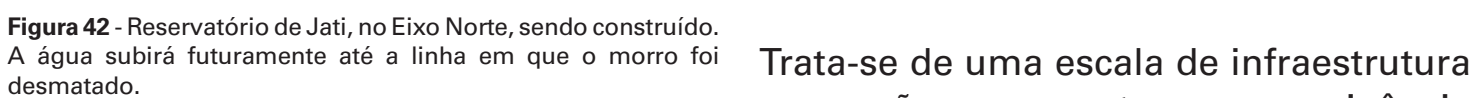
Foto: Carolina Sacconi. Jati (CE), setembro de 2017. que não comporta a convivência Figura 43-Reservatorio de Jati, no Eixo Norte, senco

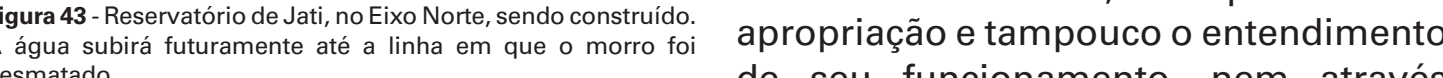
Foto: Andrea Muner. Jati (CE), setembro de 2017. $\quad$ de seu funcionamento, nem através Figura 44 - Reseservatorio de Jati sendo construido. capítulos anteriores, nem à olho nu, Foto: Carolina Sacconi. Jati (CE), setembro de 2017.

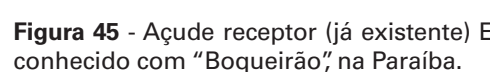

Foto: Carolina Sacconi. Campina Grande, setembro de 2017. havendo muitos conflitos e impactos relacionados com a inserção desta obra no territorio, uma obra muito impactant A seguir, a foto da Figura 45 ilustra um
reservatório existente que foi integrado ao sistema do PISF, o açude Epitácio Pessoa, conhecido como açude do Boqueiráo. O abastecimento destes açudes que foram incorporados no PISF gerou polêmicas a partir da falta projeto, conforme será apresentado no projeto, confor
item 3.2.

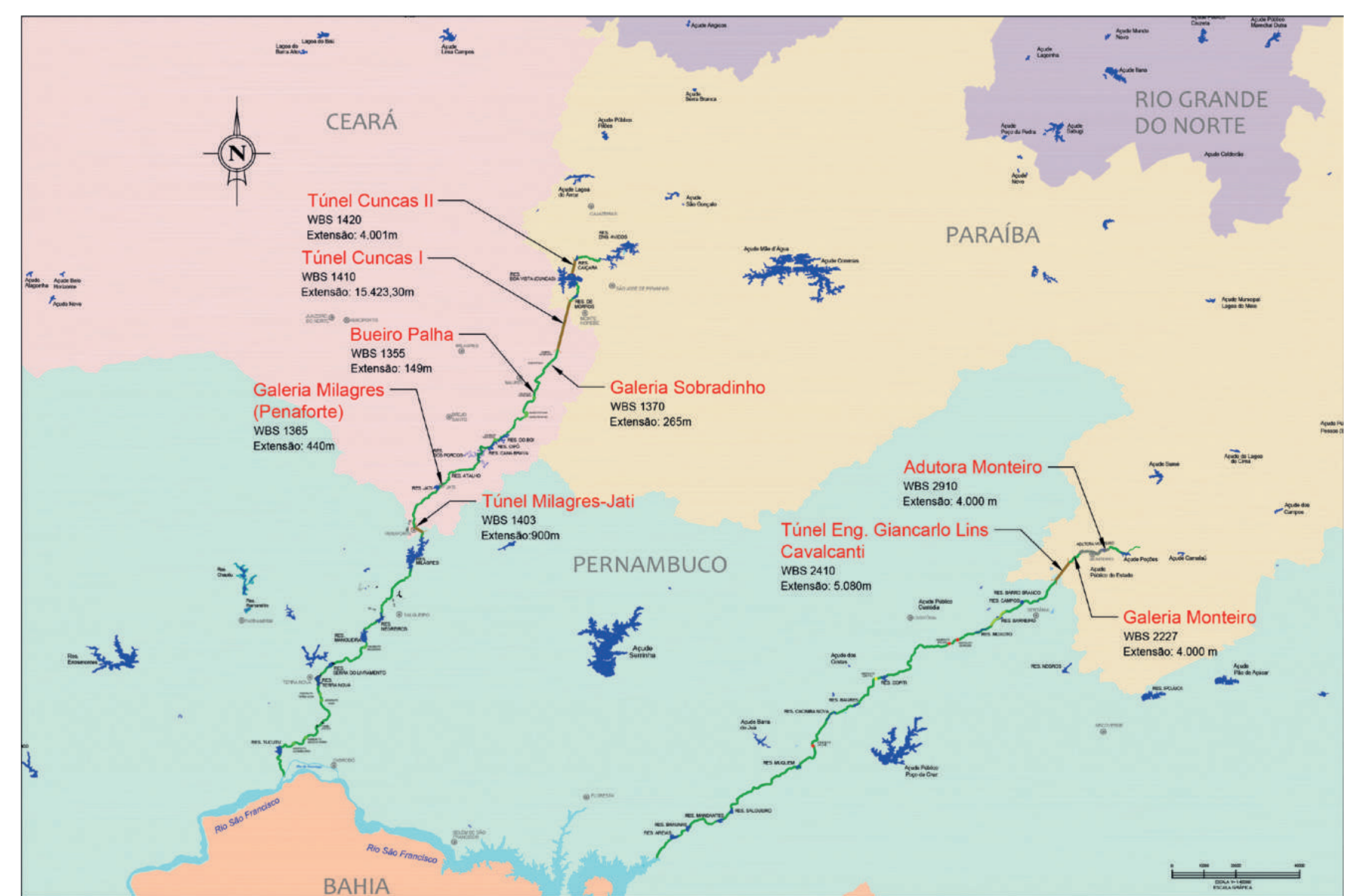

Figura 46 - Túneis e galerias do PISF.

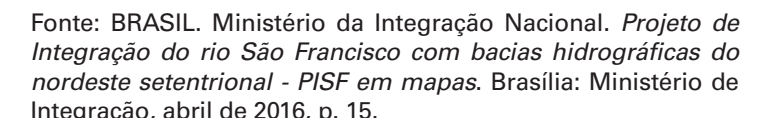

\section{Túneis}

Como mencionado anteriormente, foram estudadas alternativas em relaçâo à sollçá Sãon Francisco e a anspor as que se chegou foi a de que os canais à céu aberto em concreto seriam a melhor alternativa à Transposição (ALMEIDA, 2017, informação verbal) ${ }^{24}$. Porém, apesar da solução final decidida ter sido a dos canais superficiais os túneis foram inevitáveis, dado que o desvio dos macicos geológicos no percurso dos Eixos seria mais caro lou até mesmo inviável) do que a perfuração para se fazer o túnel.

Em um total de $477,60 \mathrm{~km}$ de canais, contabilizados entre os dois Eixos, a de $7,17 \%$, sendo $21,178 \mathrm{~km}$ de túneis no Eixo Norte e 13,080km no Eixo Leste (ver Figura 46). No Eixo Norte a ocorrência 42 Entrevista realizada com o funcionário da Engecorps e
arquiteto, Andrei Almeida, no dia 30 de maio de 2017 , em Săo
Paulo. 
de túneis é maior pois visivelmente topografia é mais acidentada, conforme a Figura 47 demonstra, dada a Chapada no Eixo Norte, foi projetado o túnel Cuncas I, o maior da América Dara transporte de água, com $15 \mathrm{~km}$ de

Em campo (ver Figura 48), foi visível nas obras do PISF que se tratava de um solo rochoso, o que se confirmou tambem pelos detalhes apresentados no Relatório Sintesental da Transosicão do ra Sáo Francisco (BRASIL, 2000bo do rio conforme a Figura 49 a seguir apresenta. Sobre essa formação geológica do semiárido e as características hídricas dessas regiōes mais rochosas, Suassuna (2001, s/p) explicou:

O Escudo Cristalino, que representa cerca de $70 \%$ da área semiárida geralmente rasos, nos quais as a aflorar em alguns pontos. [...] Um rio que corre sobre o cristalino apresenta-se, na epoca das chuvas, do volume de água caído, com enchentes descomunais. Uma vez encerradas as chuvas, volta ao seu leito normal, diminuindo a vazáo época do ano, interrompe o seu curso. Eum rio temporário. O melhor exemplo a ser citado de um rio que corre sobre o escudo cristalino, na Ceará, considerado o maior rio seco do mundo (SUASSUNA, 2001, s/p)
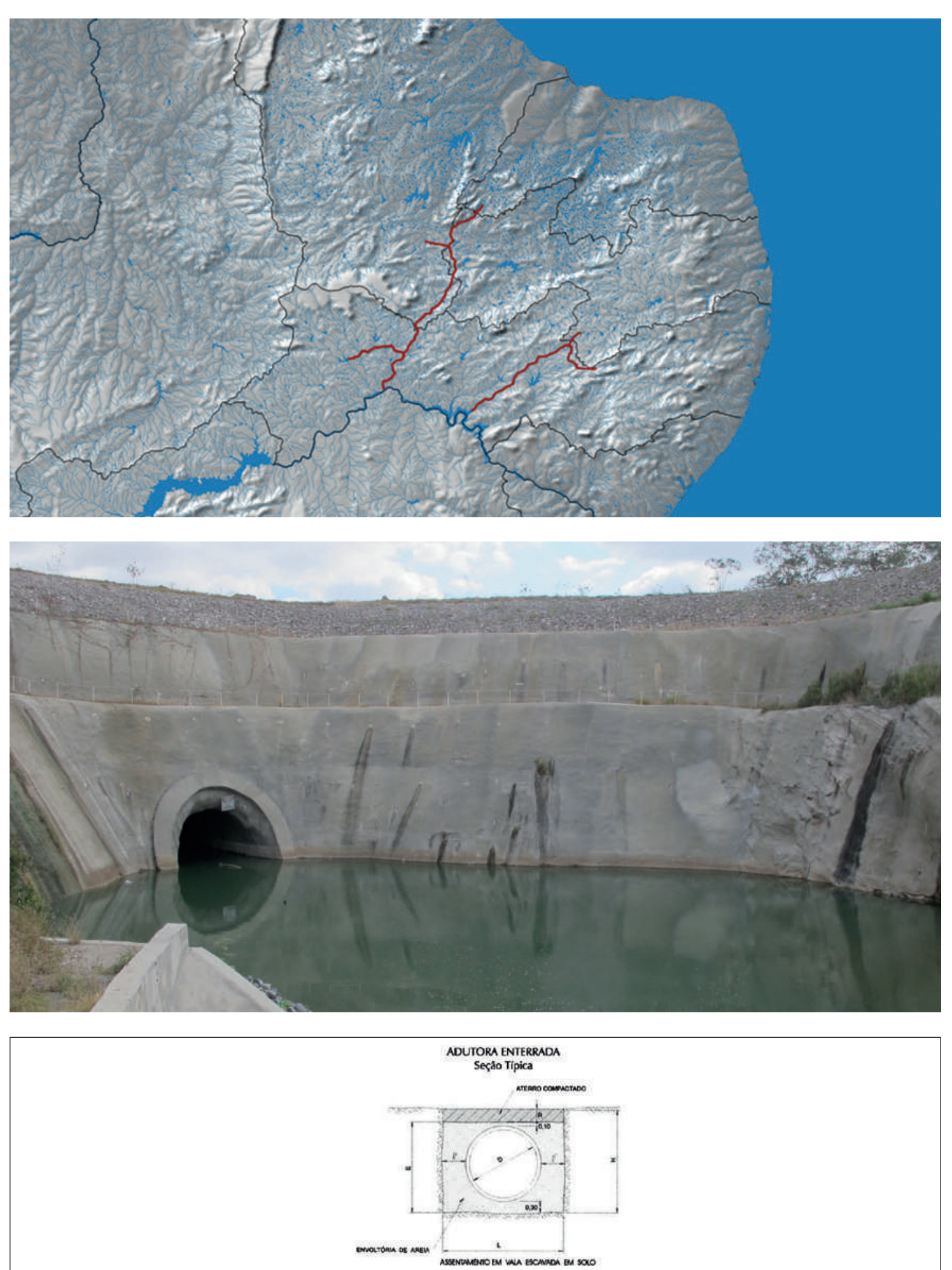

seposestipeas
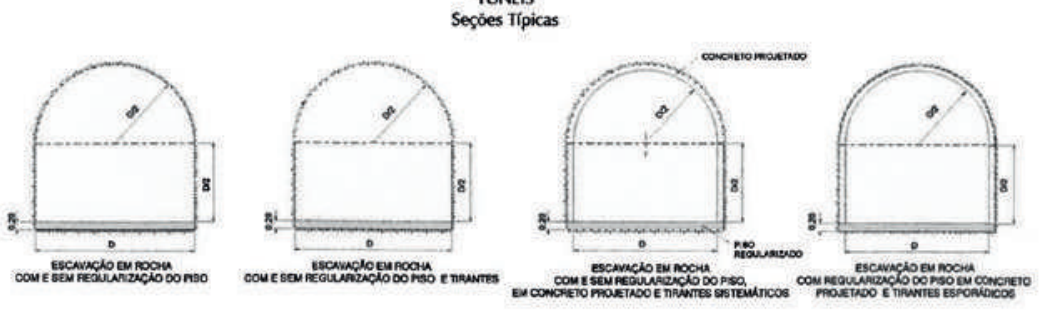

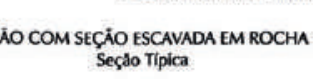

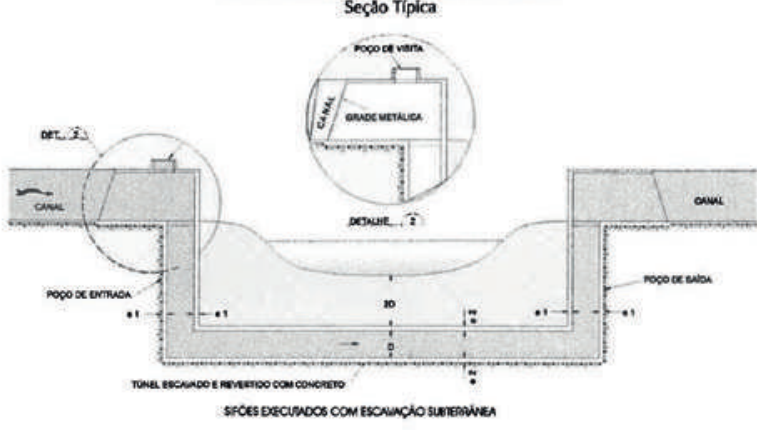

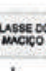

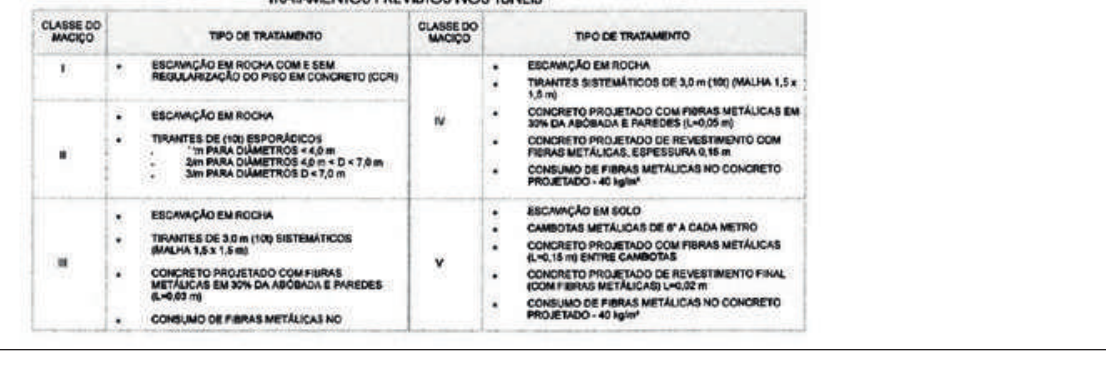

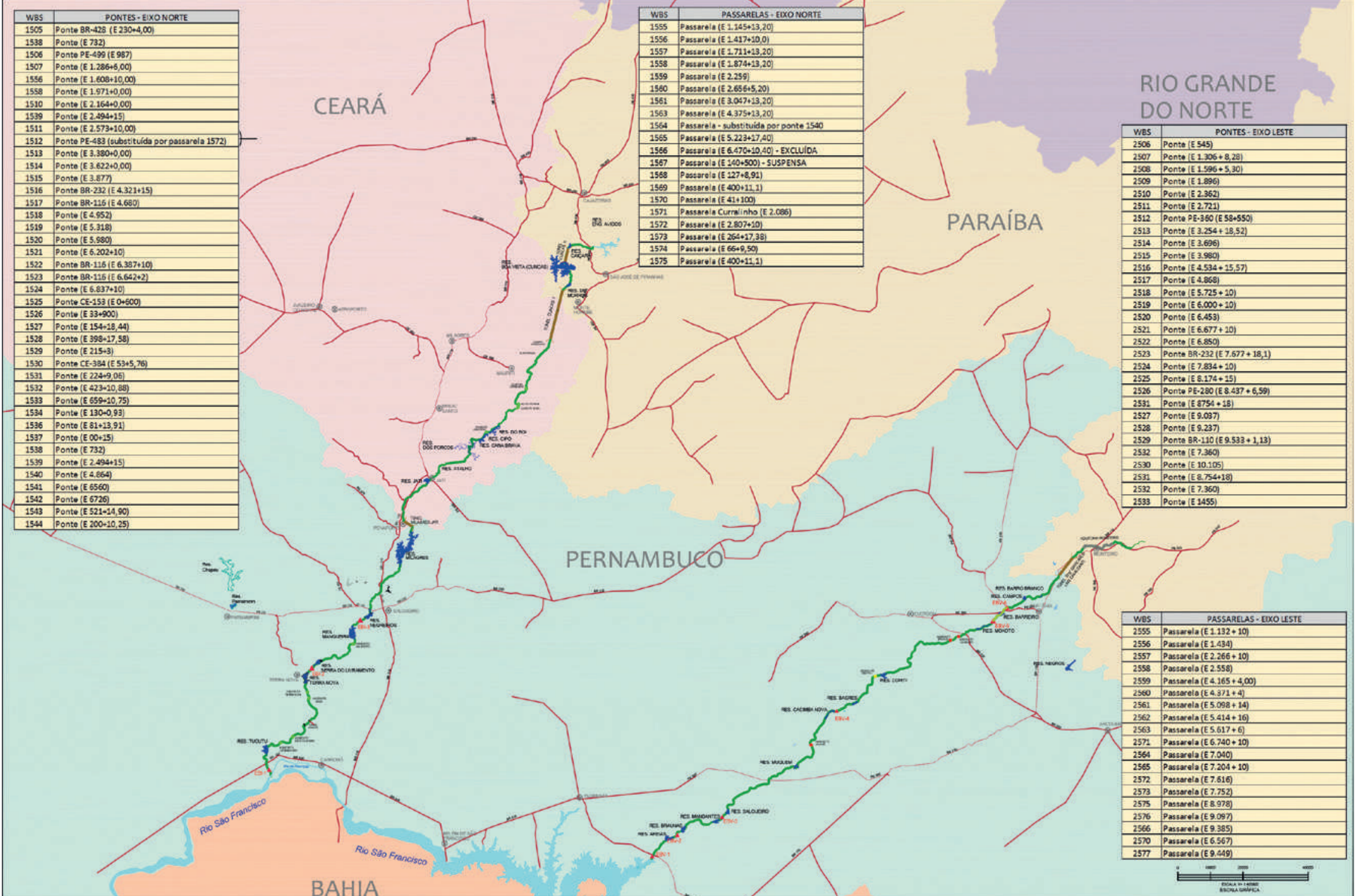

Figura 50 - Pontes e passarel

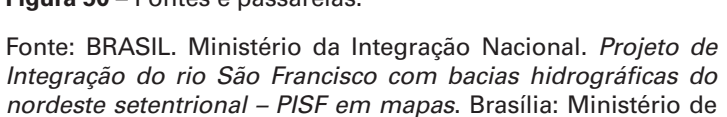

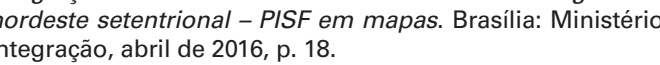

\section{Pontes e passarelas}

Em relação às travessias do PISF, essa Isso reitera a característica dessa obra grande infraestrutura que corta o territorio ter se tornado um elemento abrupto semiálido, foram previstas tanto pontes, na paisagem, uma vez que, dada a exemplo com estradas (ver Figuras 51 e objeto bastante intransponível. Além 53), quanto passarelas, para interligar por disso, quando essa acessibilidade è vezes os lados do território que os canais permitida, funciona apenas como uma dividiram (ver Figuras 51, 52, 54 e 55). transposição do canal, sem que as Porém, conforme a Figura 50 demonstra $\begin{aligned} & \text { pessoas possam se apropriar e usufruir } \\ & \text { daquela infraestrutura. Uma relação }\end{aligned}$ em tabelas, a quantidade de travessias, apenas visual, uma presença forte e uma em especial de passarelas, foi muito ausência de conectividade com aquele pequena, uma vez que no Eixo Leste, que espaço vivido.

possui $220 \mathrm{~km}$, foram previstas apenas

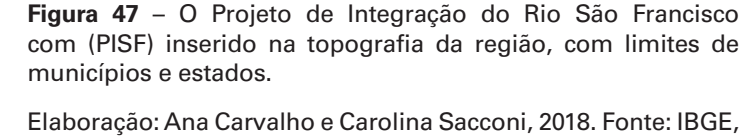
dia $11 \mathrm{~km}$ entre cada passarela, uma

2016; Mi, 2018; Natural Earth, 20

No Eixo Norte essa média é pior ainda
uma vez que ele possui $402 \mathrm{~km}$ e foi Fotra 48 -Tunel no Eixo Leste. prevista uma quantidade de passarelas semelhante ao outro Eixo, vinte passarelas, o que dá uma média de 20,1

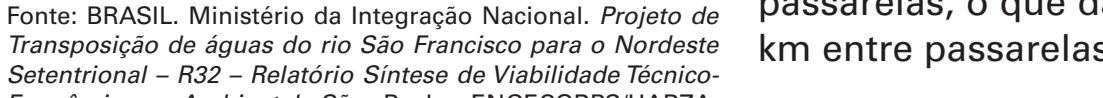


Travessia para Pedestres $\mathrm{e}$ Animais

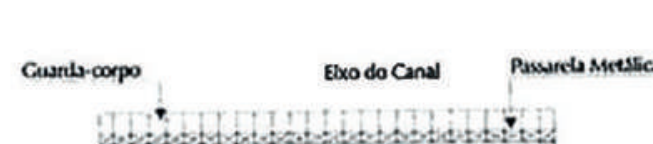

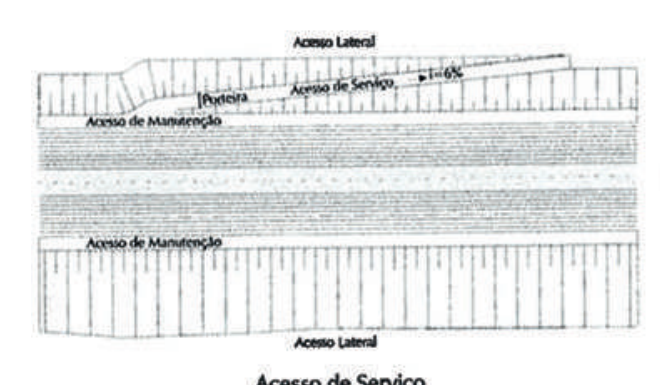

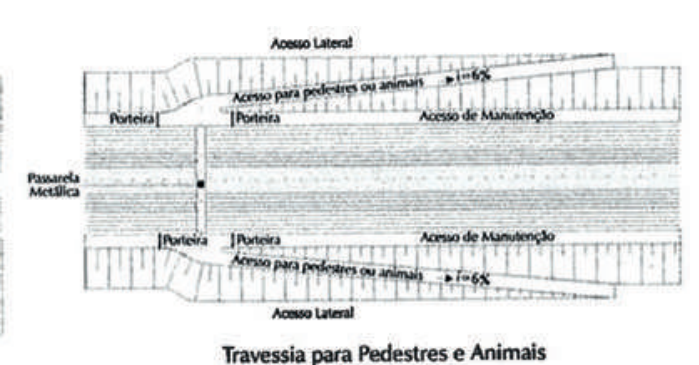

Travessia de vecculos Sobre o Canal
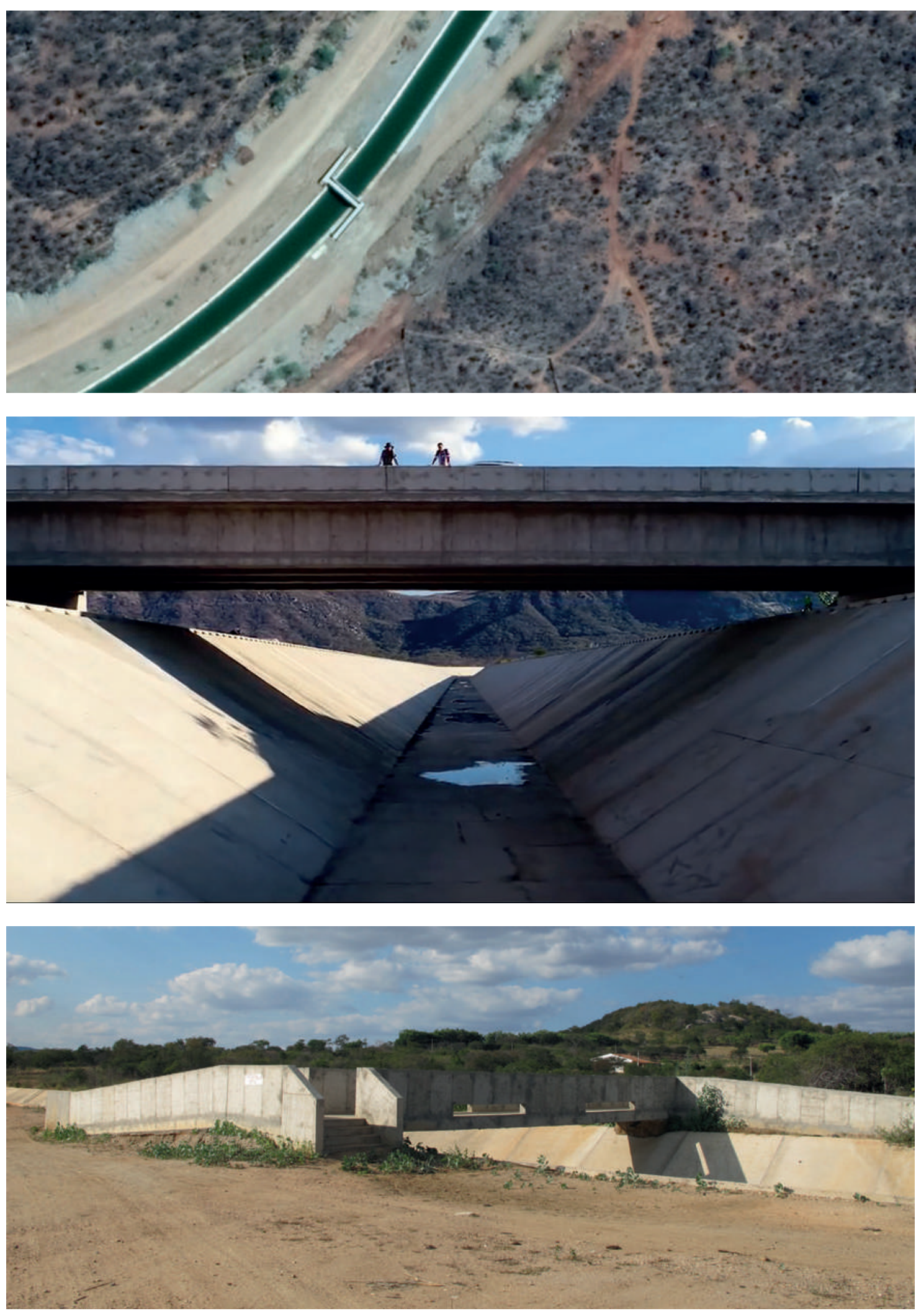

Figura 51 - Desenhos técnicos de passarelas

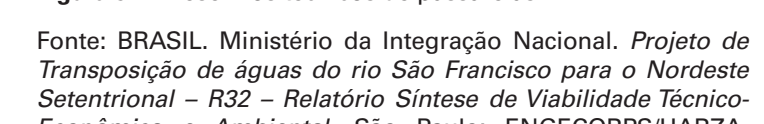

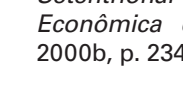

Figura 52 - Foto aérea de

For

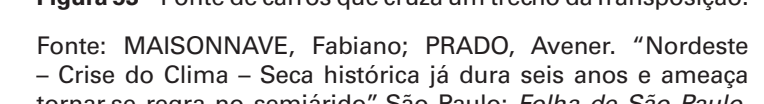
tornarse regra no
25 de abril de 2018

Figura 54 - Passarela no Eixo Leste, com rampa e escada.

Fott: Andrea Muner. Monteiro: setembro de 2017.
Figura 55 - Passarela no Eixo Leste, com rampa e ess

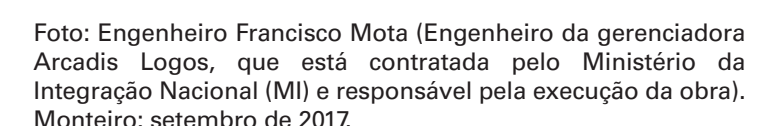

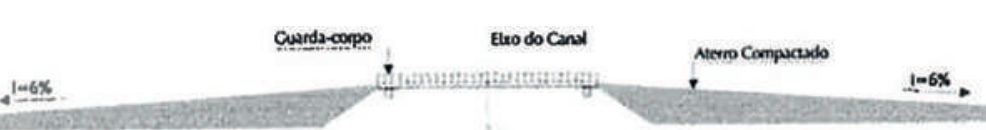

Seşio Tipica da Travessia de Vérculos sobre Canal

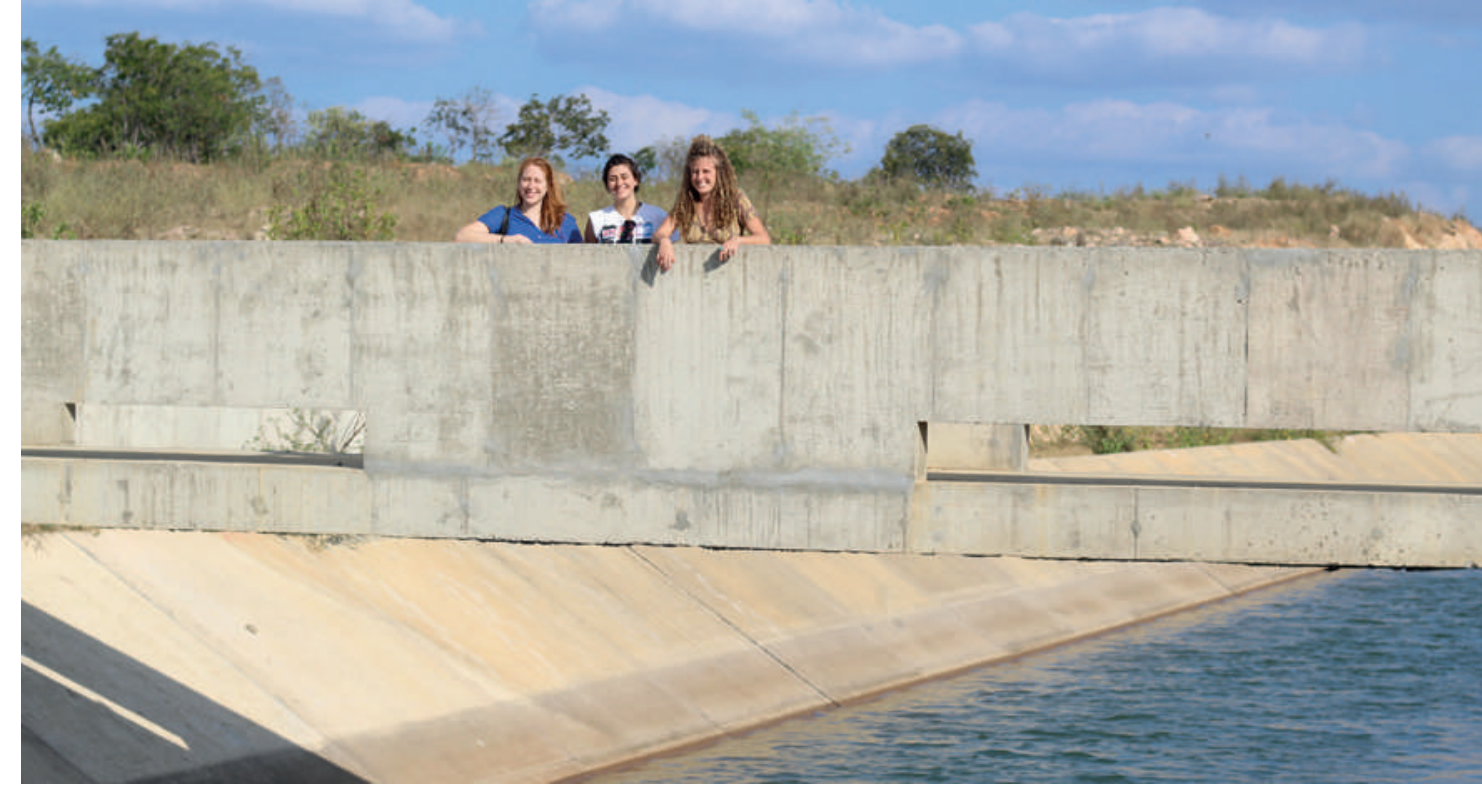

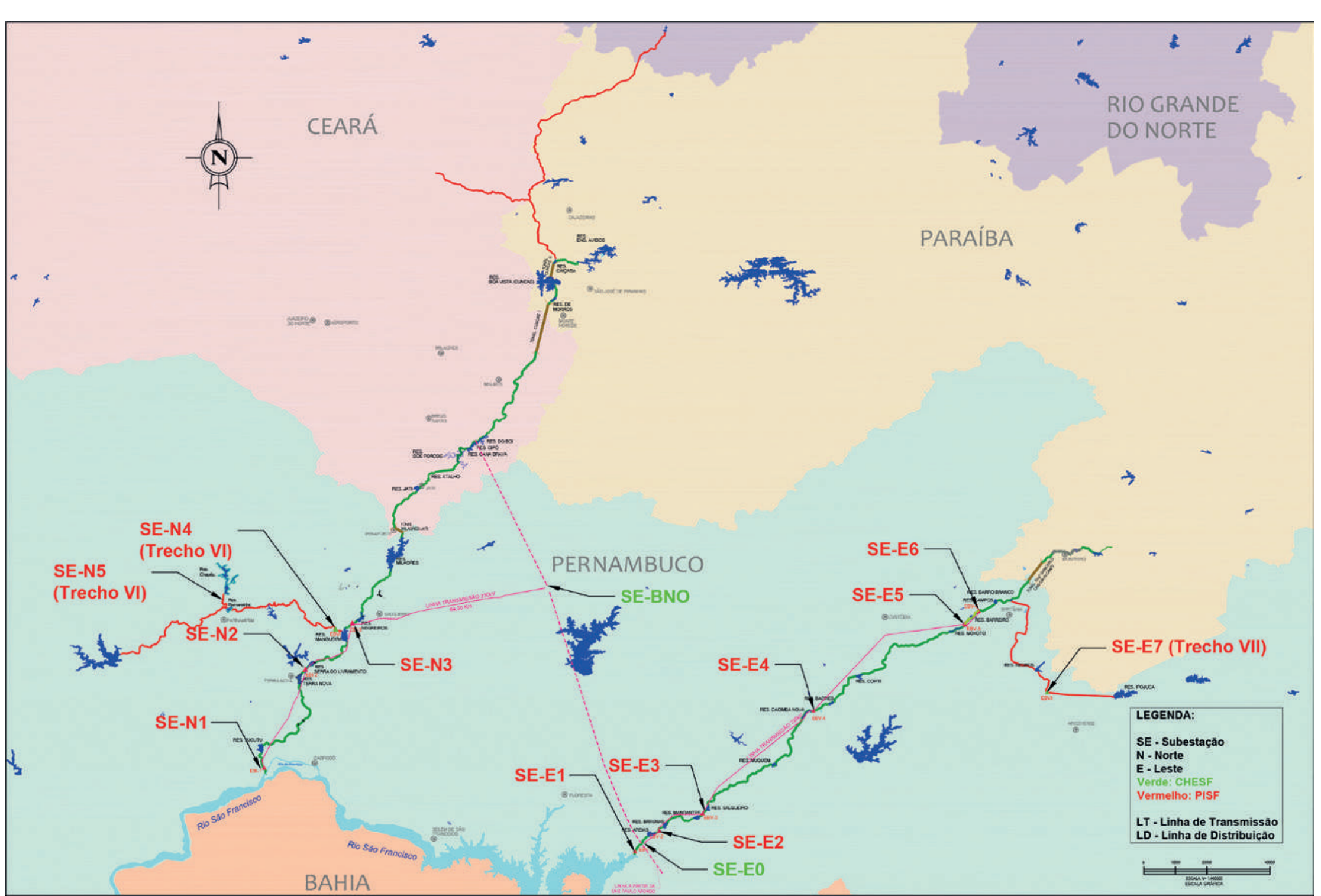

Figura 56 - Linhas de transmissä.

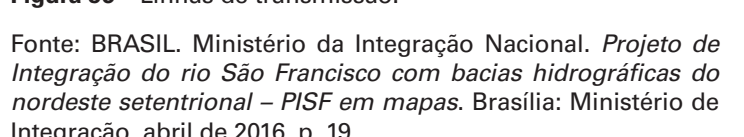

Linhas de transmissão

Segundo o Relatório Final dos Projetos Executivos do Lote A - Volume 1 - Texto
Descritivo - Tomo I (BRASIL, 2012, p. 85), que foi desenvolvido pla, 2012, $\mathrm{p}$. Engecorps contratada pelo Ministério da Integracão Nacional (MII), relatório a partir do qual todos os demais projetos executivos foram desenvolvidos, as estaçoes elevatorias de bombeamento da agua (EBs) foram planejadas para (SE) a limentadas por subestações SE-N1, SE-N2 e SE-N3 nO Eixo norte e SE-E1, SE-E2, SE-E3, SE-E4, SE-E5 \& SE-E6 no Eixo Leste. Estas subestações seriam supridas eletricamente através de linhas de transmissaao provenientes do sistema da Companhia Hidrelétrica do Săo Francisco (CHESF), ou seja, Francisco. As subestacões form locadas na margem direita dos canais, a cerca de $80 \mathrm{~m}$ a montante das estações de bombeamento, conforme ilustram as Figuras 57 e 58 .
O PISF até 2018 comprava a energia a Codevasf, para abastecer as estações de bombeamento e demais usos por meio de sua rede de transmissão própria (LTs), que envolve sua própria e algumas subestaçoes (SE). Essa infraestrutura CHESF, mas sim ao MI.

Como o bombeamento de água gasta funcionar as bombas, foi estudada um gerador de energia hidrelétrica. Desta forma, o projeto considerava duas Pequenas Centrais Hidrelétricas aproveltando a água reservada em Jati gasto de energia de se transporas águs até o Ceará e dessa forma reduzir o custo de operação do sistema. Elas estavam

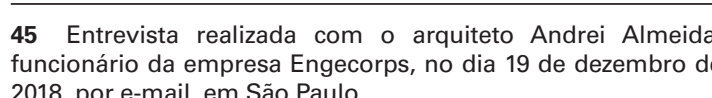
possibilidade de o próprio PISF ser (PCH) dentro do sistema do PISF, isto é, previstas para com capacidade final de respectivamente.

Porém, segundo o engenheiro Andrei Almeida, ${ }^{46}$ da empresa Engecorps, que continuava envolvida ao projeto, prestando consultorias para o Mi em endo sido usinas náo foram equipadas, ivis das usinas. Ao não gerar energia, maior custo operacional do PISF se ornou o da compra de energia da CHES aproximadamente $R \$ 131.000 .000$ só de energia em 2018 para operar o sistema embrando que somente o Eixo Leste havia sido inaugurado para testes. Como a questão da energia ainda era 2018, mesmo que em hona em pré-operação do Eixo Leste e vésperas 46 Entrevista realizada no dia 19 de dezembro de 2018, por 47. Entrevista realizada no dia 19 de dezembro de 2018, por
e-mail, em Sä Paulo. 


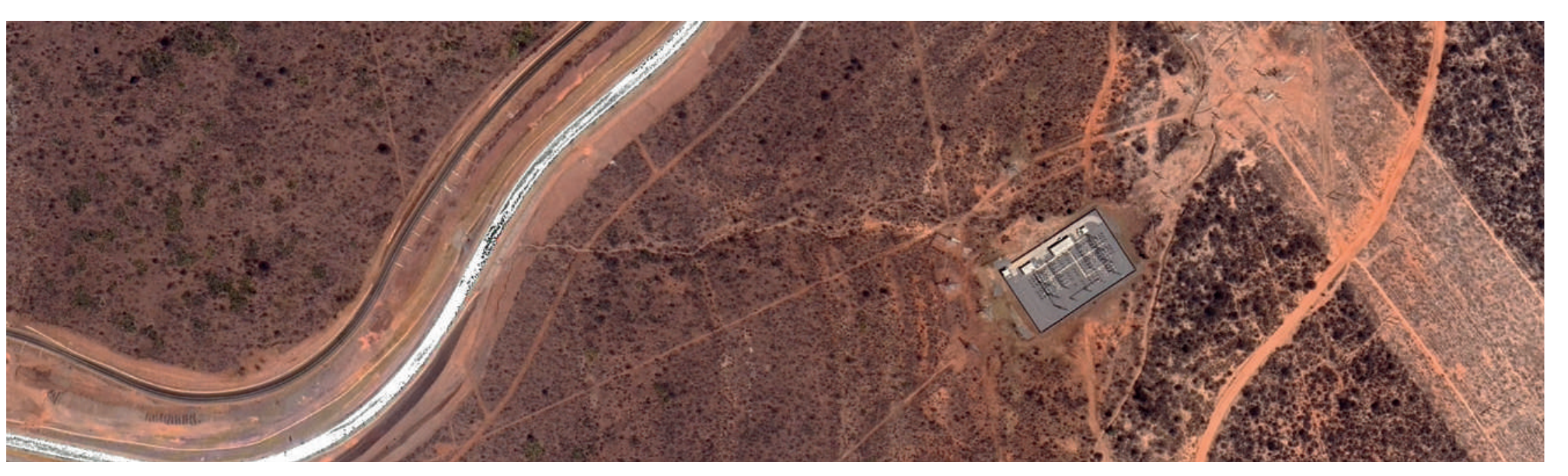

3.2.2

A presença-ausência da obra

no território

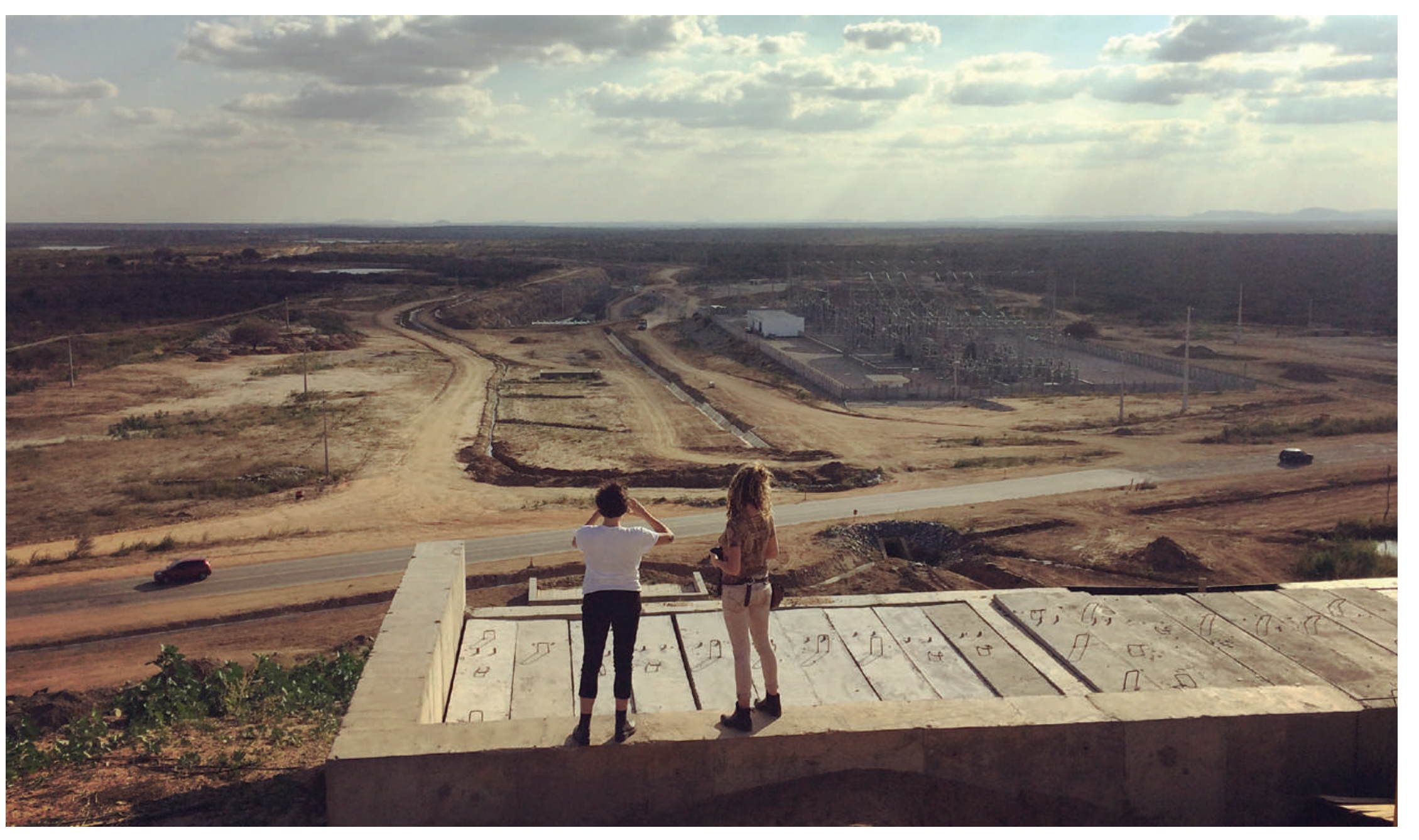

de conclusão das obras do Eixo Norte, Notas gerais sobre o item 3.2.1 governo federal estava estudando

que significa esse sistema, que apresenta fontes renováveis como a solar e eólica como se deu efetivamente essa obra na aquela infraestrutura Trata-se, em suma (IICA, 2018), ${ }^{48}$ com apoio do Instituto realidade. Em campo, trata-se de uma de um sistema que năo foi proposto para Interamericano de Cooperação para a obra surpreendente por seu porte e se relacionar com seu entrono, embora Agricultura (IICA) e financiamento do abrangência territorial. Esse esforço de seu impacto no espaço seja marcante,

falta de definição da operação do sistema território foi importante para compreender É justamente dessa "presençaque pode eventualmente gerar uma de que tipo de obra estamos falando, uma ausência" gerada a partir da construção com a reduçãa do consumo de energia magnitude no território, no sentido de setentrional, que o próximo item 3.2.2. pelo sistema, possivelmente reduzida a tarifa da água cobrada pelo PISF fluxos e se tornou uma infraestrutura em campo, reiterados com notícias e por aos estados receptores, dado que o custo pouco acessível e passível de ser vezes confrontados com algumas ações com energia representa cerca de metade apropriada e relacionada com o entorno. previstas nos PBAs, pretendeu-se ilustrar do custo operacional, que é repassado aos

Também foi importante compreender espaciais e territoriais

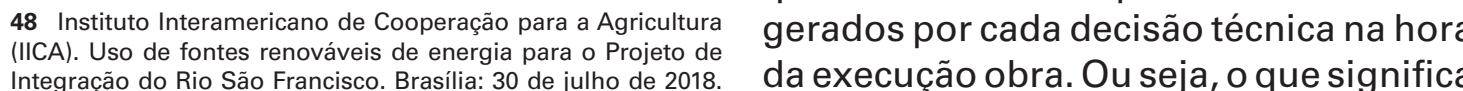

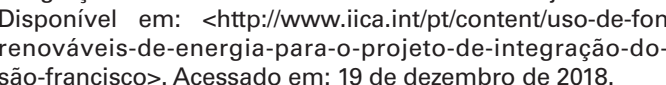
sá.-franciscos?. Acessado en: 19 de dezembro de 2018.

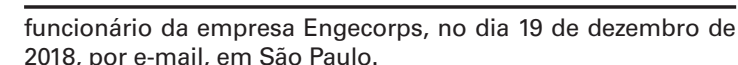
como essa obra passa pelo território e se

(1)

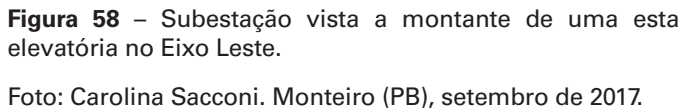

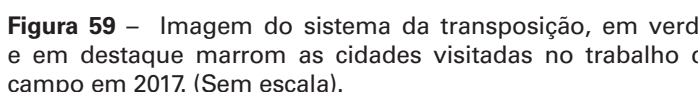

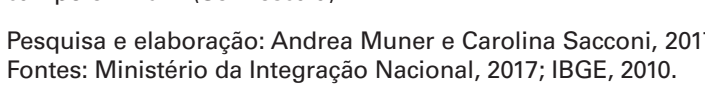

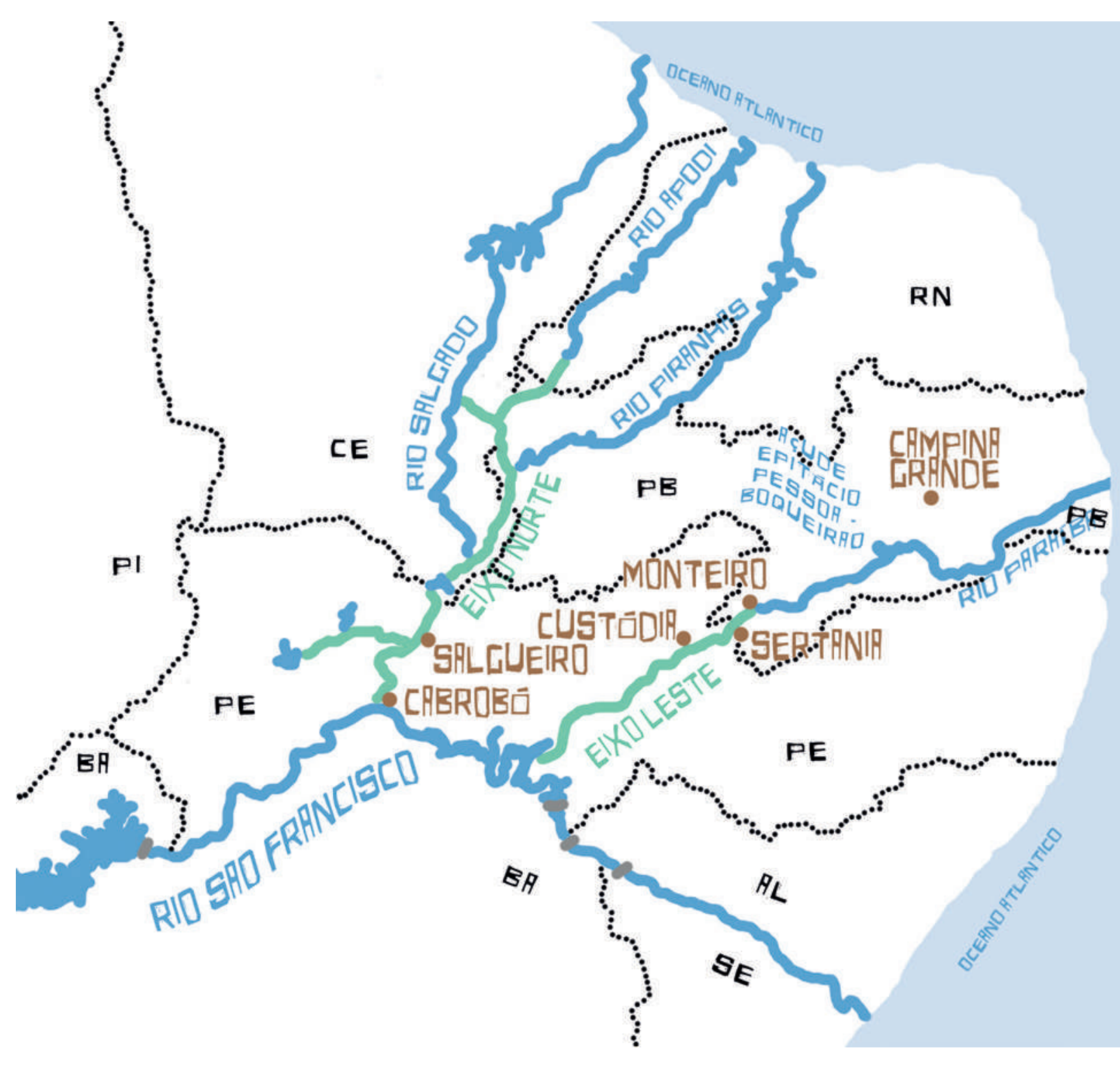

Um trabalho de campo foi realizado ${ }^{50}$, (Campina Grande - PB, Monteiro - PB em setembro de 2017, nos estados Sertânia - PE, Custodia- $P E$, Salgueiro campo, foram percorridos $1500 \mathrm{~km}$ entre Trukás (PE).

os estados acima citados e o enfoque

viagem, que durou nove dias, contou havia sido inaugurado no inicio do como apoio do Ministerio de Integração, mesmo ano e se encontrava em periodo que concedeu equipe e automóvel para de pre-operaçäo. O Eixo Norte naquele o acompanhamento dos deslocamentos, conforme a Figura 59 ilustra visitou- Grande (PB) que fez uma cartampente se trechos e canteiros da obra, acudes às alunas da pesquisa e as receberam existentes e em construção, cidades no campus; de lideranças da Terra Indigena Truka, que as hospedaram

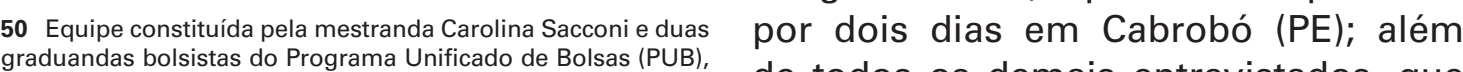

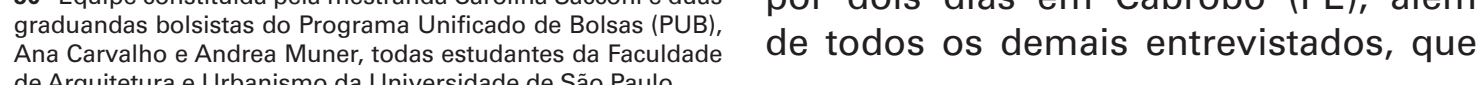




\begin{abstract}
$\begin{array}{ll}\text { se disponibilizaram para as conversas receios em relação ao projeto. } & \text { vezes, sua presença se fez não pela obra, } \\ \text { e fornecimentos de informaçoes. } & \text { mas pela água, o que também gerou }\end{array}$
Foram entrevistados entidades $O$ objetivo deste item foi o de evidenciar

governamentais em instância federal, comoaobraserelacionoucomosdistintos
estadual, municipal; população atingida; assentamentos, aglomerados urbanos e Os estudos de caso foram: a cidade população beneficiada; especialistas em territórios ao longo de seus eixos. Para de Campina Grande, seu papel na projeto de Transposição e especialistas caso, sejam situaç̃oes-tipo, sejam locais da gestão de recursos hídricos: o açude de recursos hídricos que são professores específicos, com distintas características do Boqueirão, a escala da infraestrutura universitários; funcionários de indústrias entre si, para evidenciar as diversidades do PISF e o entendimento da obra pela locais, comerciantes e prestadores de do que existe ali naquela regiáo e as populaçáo, o rio Paraiba perenizado, serviço. Ao todo, foram realizadas vinte consequencias e transformaçoes a transformando o cariri; monteiro na e uma entrevistas em campo e, tanto partir da inserção da obra no território. mídia pela conclusão do Eixo Leste e previamente quanto posteriormente 0 conceito aqui utilizado para fazer
ao campo, foram realizadas outras essa análise, conforme foi apresentado
\end{abstract} dez entrevistas, que contribuíram não na introdução dessa dissertacão, apenas para a preparação da viagem, o da presença-ausência (LEFEBVRE, mas também para outras questões da 1983), par dialético que vai ser usado pesquisa." As entrevistas não foram para explorar criticamente a obra feitas com um questionário padrăo, atticulando as distintas relaçoes desta mas sim com um método qualitativo, obra com os espaços por onde passou, possivel envolvimento do entrevistado indiretas. A presença-ausência das ou com o projeto ou com a obra. ${ }^{52}$ no território indica as contradiçães entre o processo de concepcão de projeto Para o trabalho de campo, foram de planejamento, de execução da obra, priorizadas cidades do Eixo Leste, da ação do estado e da inserção da justamente porque ele se encontrava em territorial do PIS

Eixo Norte se encontranava com as obras As situações apresentadas aqui paralisadas. Por isso, as entrevistas constituem um quadro temporário, ambém dastransformaçōes noterritório, momento da obra, que, conforme até as questões mais atuais daquele mencionado acima, ainda não estava momento, das questoes relacionadas ao concluida, portanto entrevistas feitas periodo de teste de funcionamento, de em um contexto de uma obra que recicio de abastecinento da gestao dos estava em execuçao, de um projeto em e implantação, mas que serviu para se
refletir sobre o como foi esse processo.

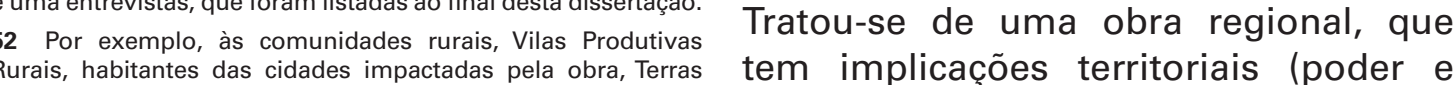

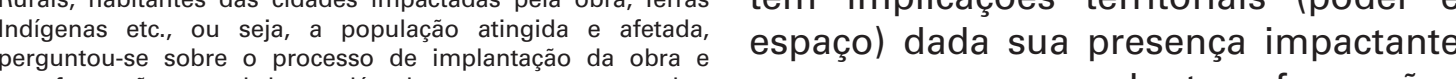

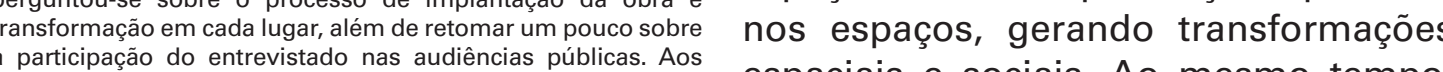

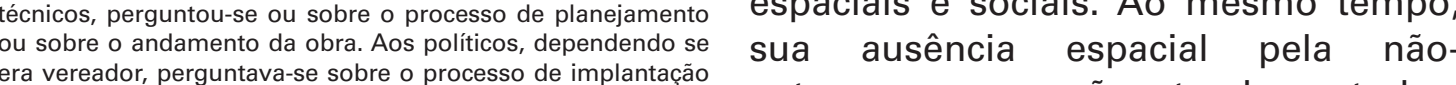

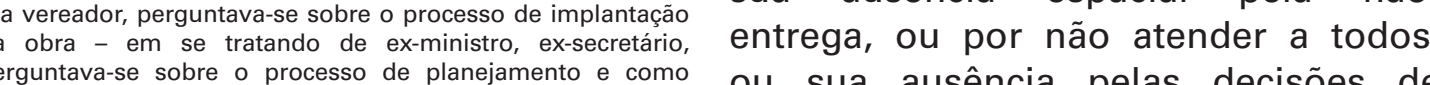

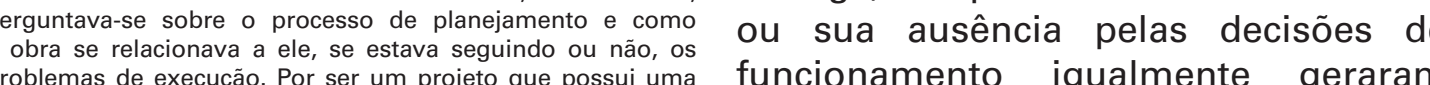

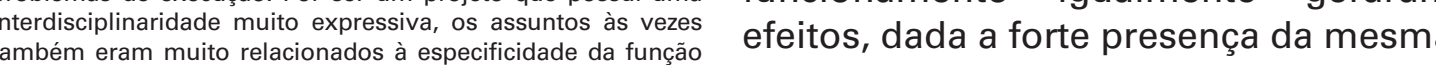

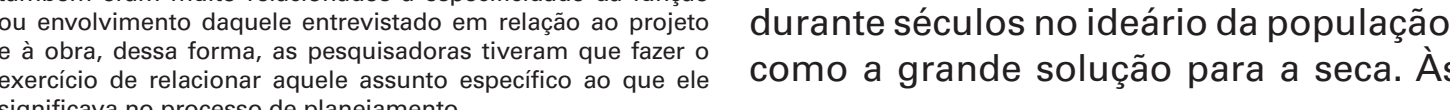

Campina Grande: o papel do

racionamento de água na cidade

(e região) para a finalização

do Eixo Leste e a gestão dos

recursos hídricos como um tema

cotidiano

Localizada no Agreste da Borborema (conforme demonstra a Figura 60), cidade de Campina Grande, que desde o século XVII era entreposto comercial importante que interligava o litoral ao nos dias de hoje o segundo maior município do estado da Paraíba, depois de João Pessoa, um polo regional que contém cerca de 407.472 habitantes (IBGE, 2018) e com um salário médio mensal de 2.1 salâtios minimos (BBGE,

A Universidade Federal de Campina Grande (UFCG), criada em 2002, foi sediada na capital do município e entro universitario, um processo que foi sendo construido desde a fundação da Escola Politécnica da Paraiba (Poli), em V2, na gestác do presidente Getullo acelerou o desenvolvimento da cidade, promovendo mudanças econômic sociais, culturais e urbanas, atraindo outras universidades e tornando Campina Grande uma cidade que atrairia cada vez mais estudantes de vários

Localizada em uma das regióes mais secas do Brasil, o cariri paraibano (ver ( nenhuma fonte hidrica perene, natural Desde 1957, o município de Campin Grande passou a ser abastecido pelo qualquer outro açude no semiárido, tem variação do seu volume conforme o regime de chuvas. Dessa forma

53 Os dados comparativos de renda dos municíipios Instituto Brasileiro de Geografia e Estatisticica (IBGE) Grande está disponivel em: <https://lidades ibge gov br/brasil/pb/campina-grande/pesquisa/19/29765> 54 Informaçōes extraidas do site da Universidade
Federal de Campina Grande (UFCG), disponivel em: <http://www.ufcg.edu.br/prt ufcg/assessoria Imprensa/mostra_noticia. php? codigo $=19438$

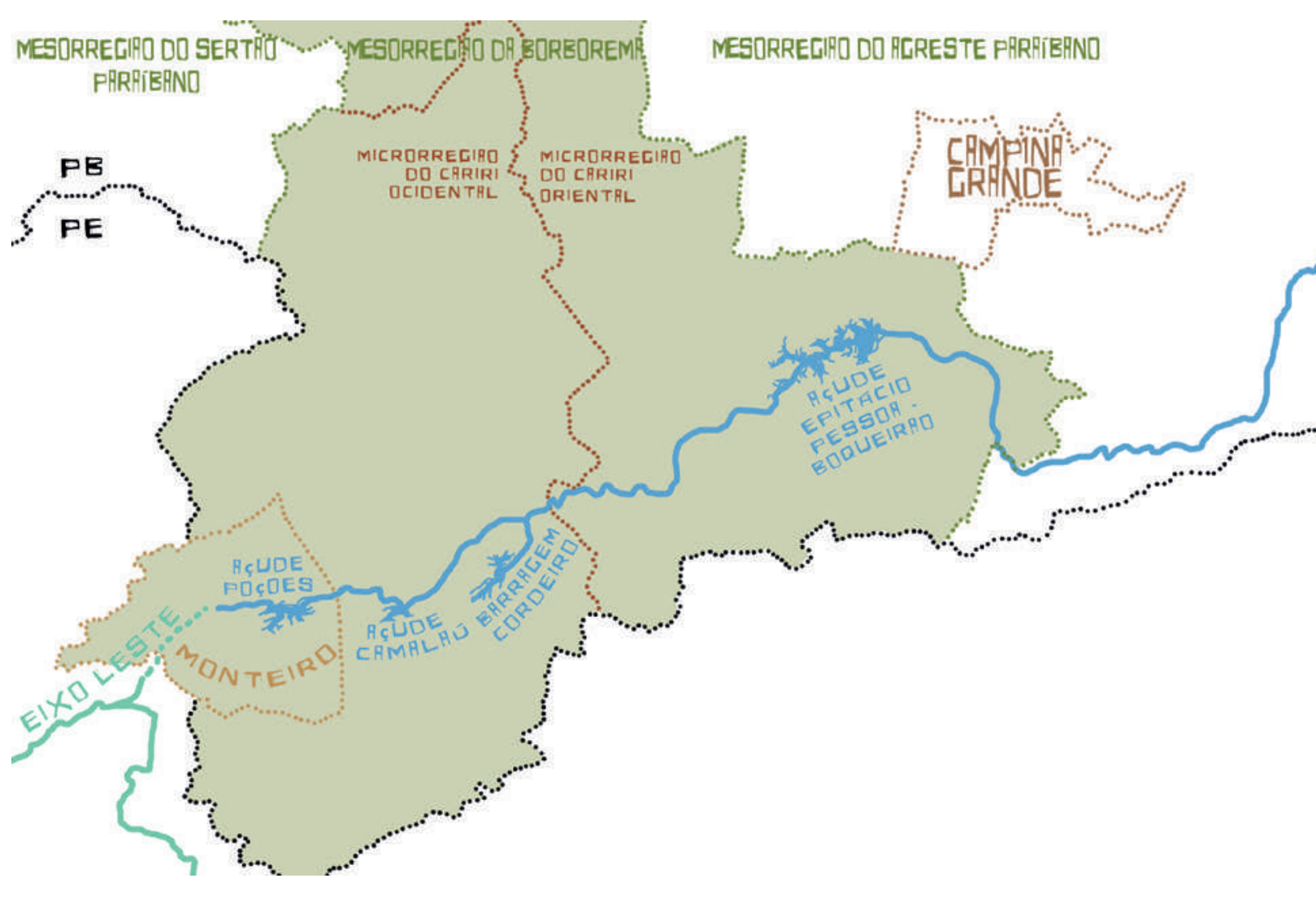

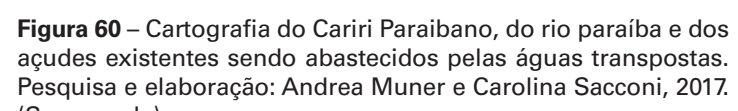




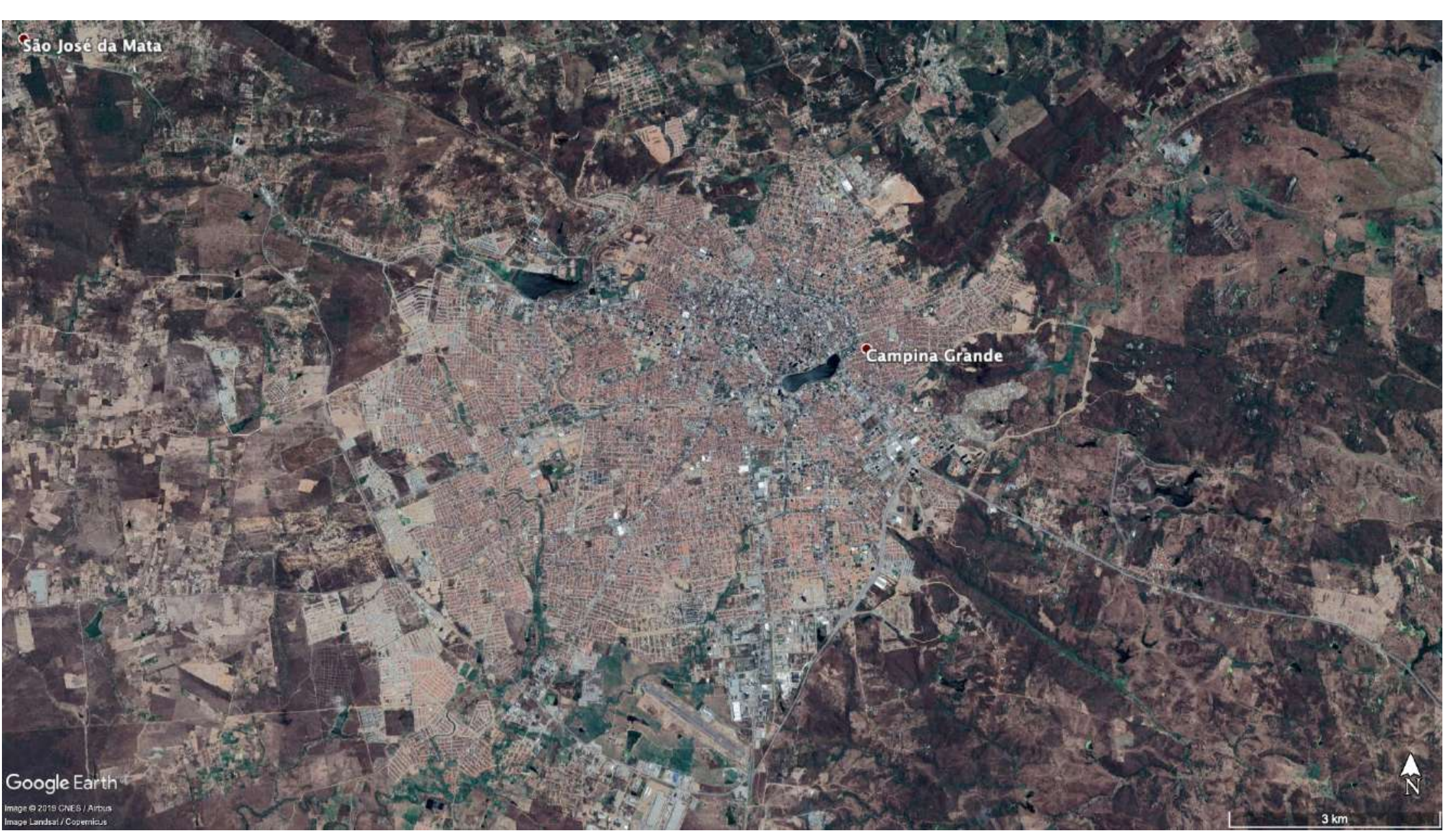

Figura 61 - Foto satélitie de Campina Grande, uma cidade méd
e centro regios Fonte: Google Earth, 2018.

ao longo dos séculos, o crescimento em geral, a obra não passavafisicamente, além de ser um projeto histórico, que demografico em especial da cidade de mas se fez presente colidianamente na permanecianoimaginário da populaçâa gerou diversas crises hídricas. Em sua

penúltima crise, na década de 1990, o Enquanto as águas do PISF não Assim, quando a água transposta projeto daTransposição foi retomado. chegavam, Campina Grande entrou em chegou, apesar de ter salvado um racionamento que durou dois anos e município de um colapso hídrico, se Já no século XXI, quando o PISF já estava oito meses. Nesse periodo, os que tinham instaurou uma grande polêmica em em construçao, Campina Grande, em uma dinheiro para armazenar água (ver Figura torno da suspensão do racionamento. nova crise, immulsionaria a conclusăo das 62 ) passavam bem pelos dias de seca e os Uma parte da populaçáo foi contra àr pressas, diferentemente do Eixo sem Norte (que se encontrava com as obras 2017, informação verbal:56 JÚNIOR, totalmente cheio. Outras, em especial as paralisadas) salvando a cidade e região OLIVEIRA, 2017, informação verbal),57 famílias que mais sofriam com a seca de um grande colapso hidrico (REGO, intervalo sujeito a variaçoes, conforme especialistas que compreendiam como 2017, informação verbal). ${ }^{.5}$ notícia de jornal ilustrada na Figura 63. deveria funcionar o PISF, defendiam suspensão do racionamento (REGO, Dessa forma, em Campina Grande, a obra Para o Professor Janiro Costa Rego, o 2017, informação verbal).59 Após essa do PISF se fez presente de forma muito racionamento resultava da má gestáo polêmica, mesmo com as águas do do elemento que motivou sua execucão: 2017, informacão verbal) ${ }^{58}$ e essa região, o racionamento sofreu algumas

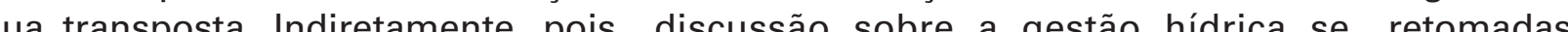
ali, tanto na cidade quanto no municipio tornou um tema cotidiano para quem

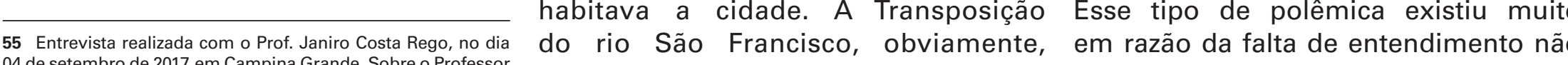

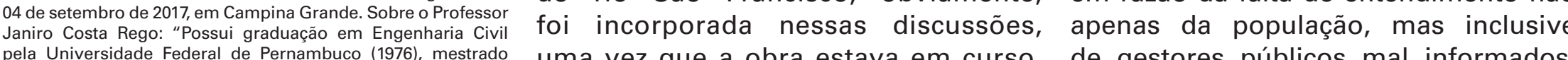

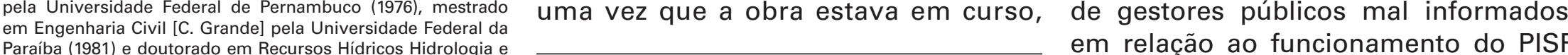
Adraulica pela Gottried Wilhelm Leibniz Univiversitít Hannover 56 Entrevista realizada no dia 04 de setembro de 2017, em conforme será apresentado no item

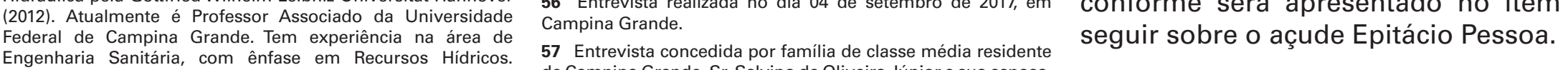

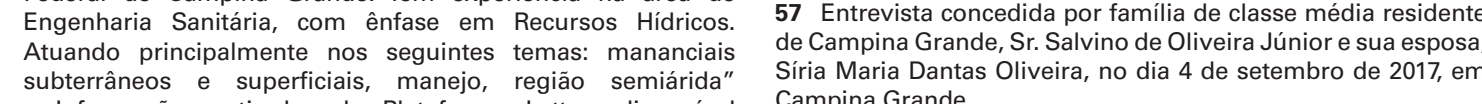

58 Entrevista real
Campina Grande.

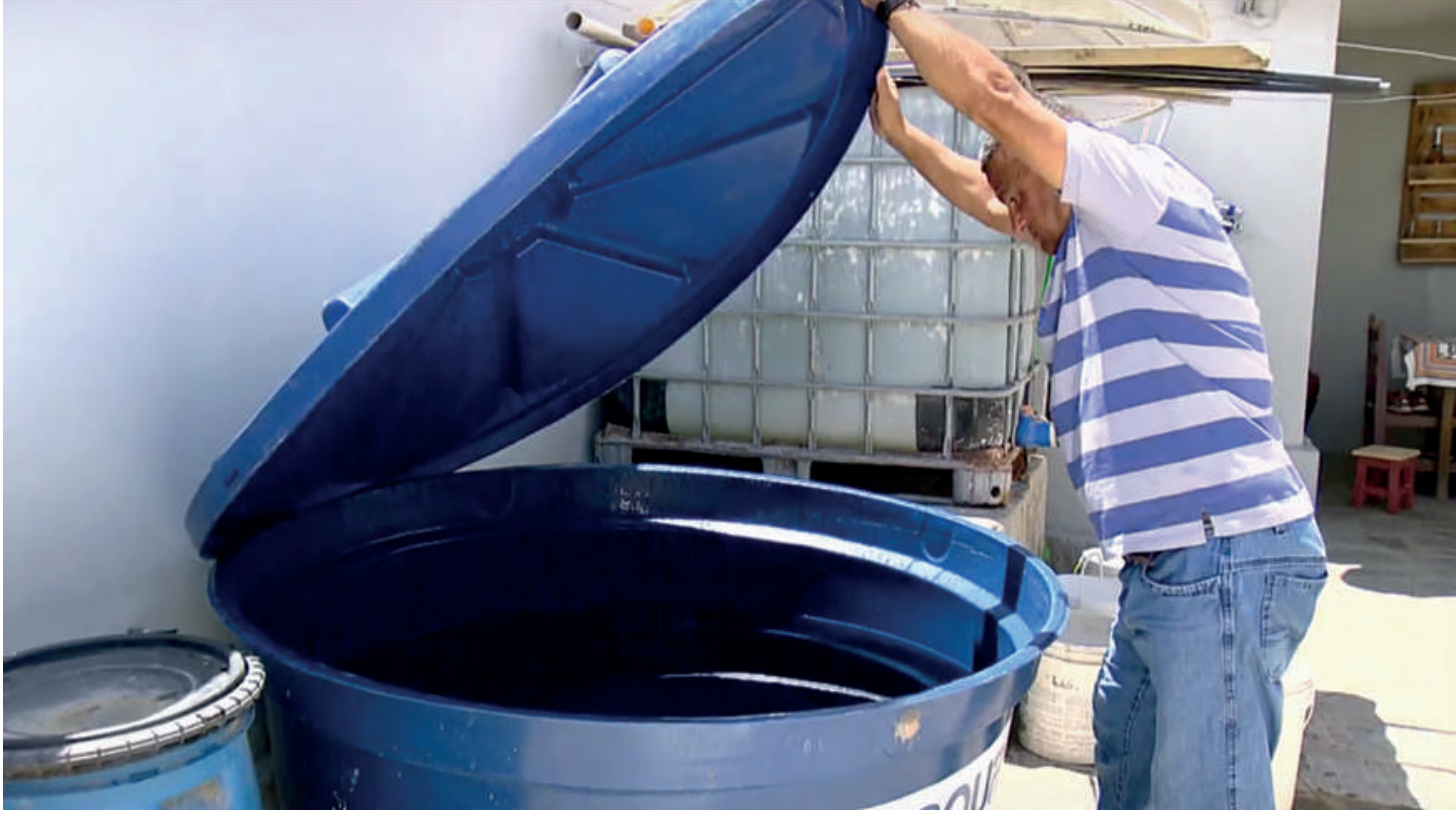

\section{Moradores têm água apenas uma vez por semana em Campina Grande} Em alguns pontos da cidade a água chega na sexta-feira e acaba antes da interruppão programada,

4.

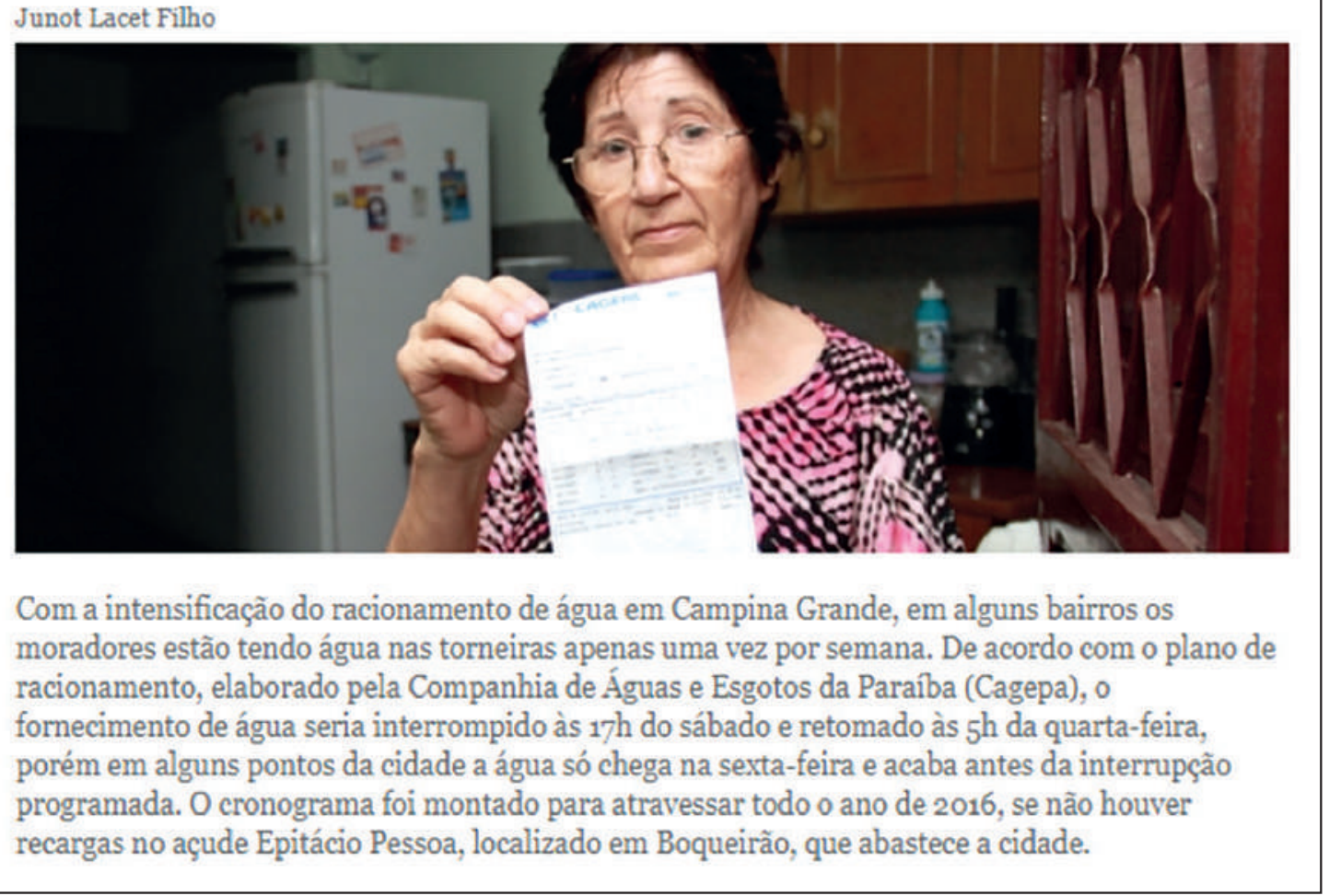

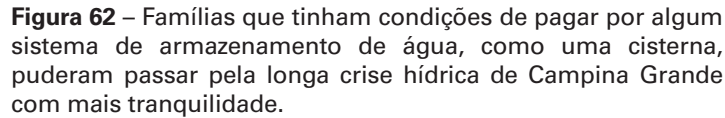

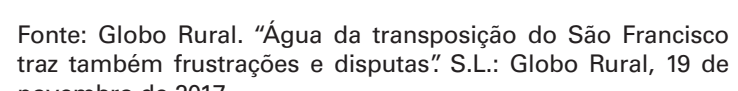

Figura 63 - Noticia de jornal sobre familias afetadas pelo
racionamento

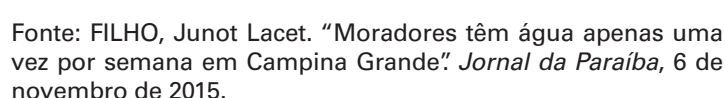


Boqueirão: a presença da água e a ausencia de entendimento da obra pela população

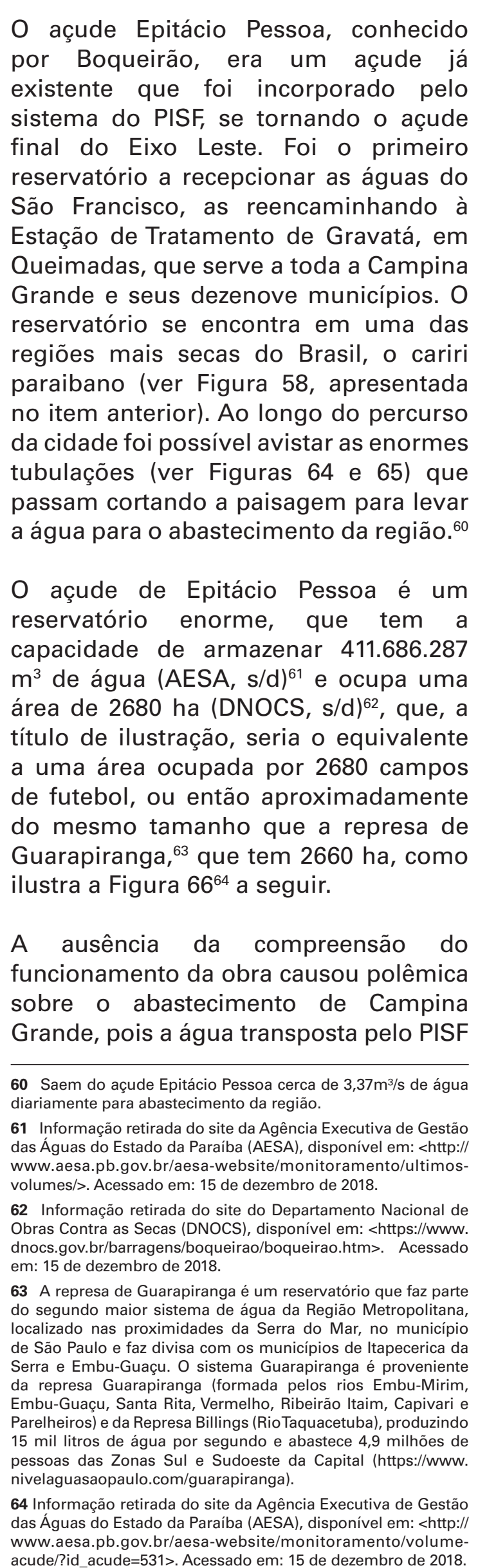

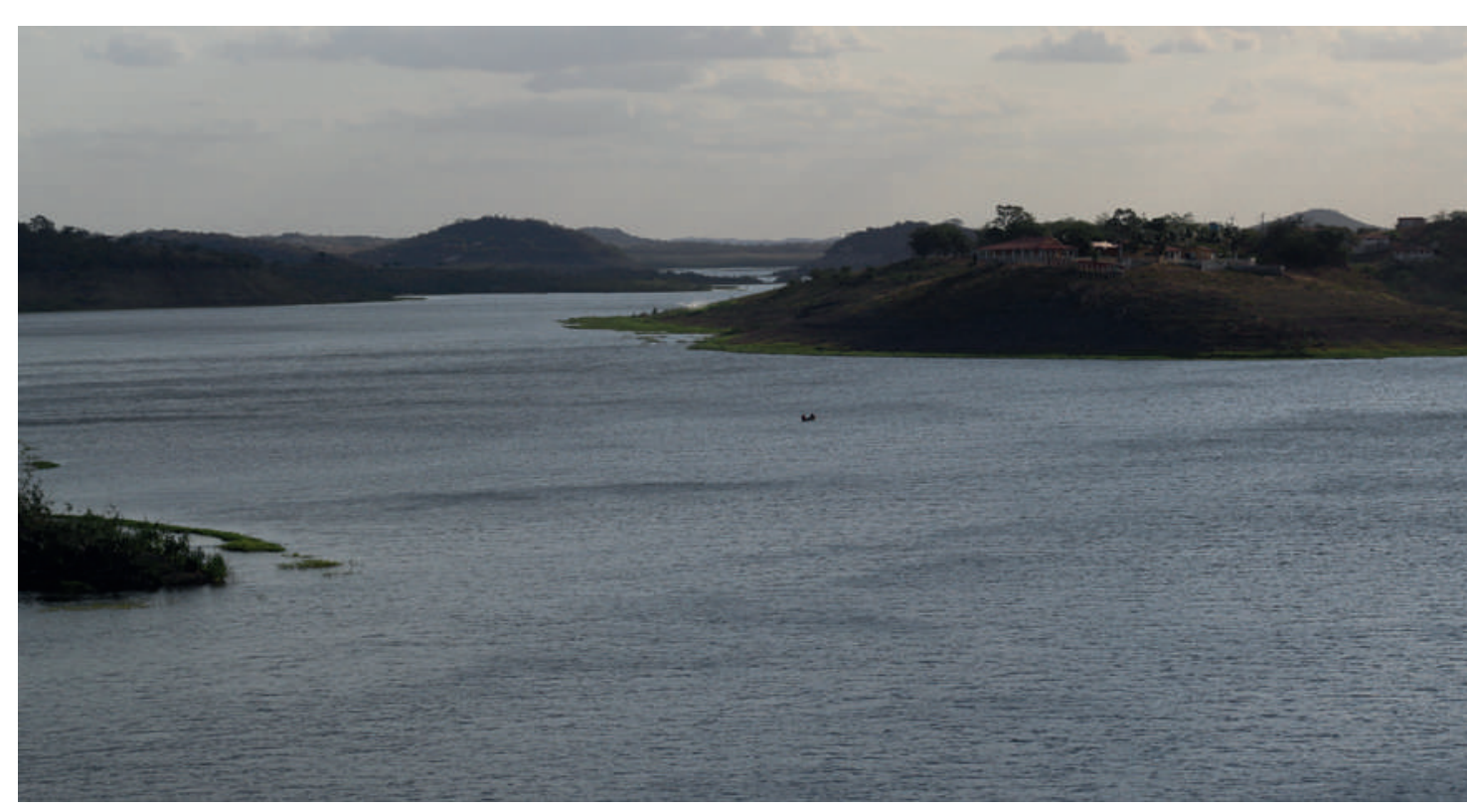
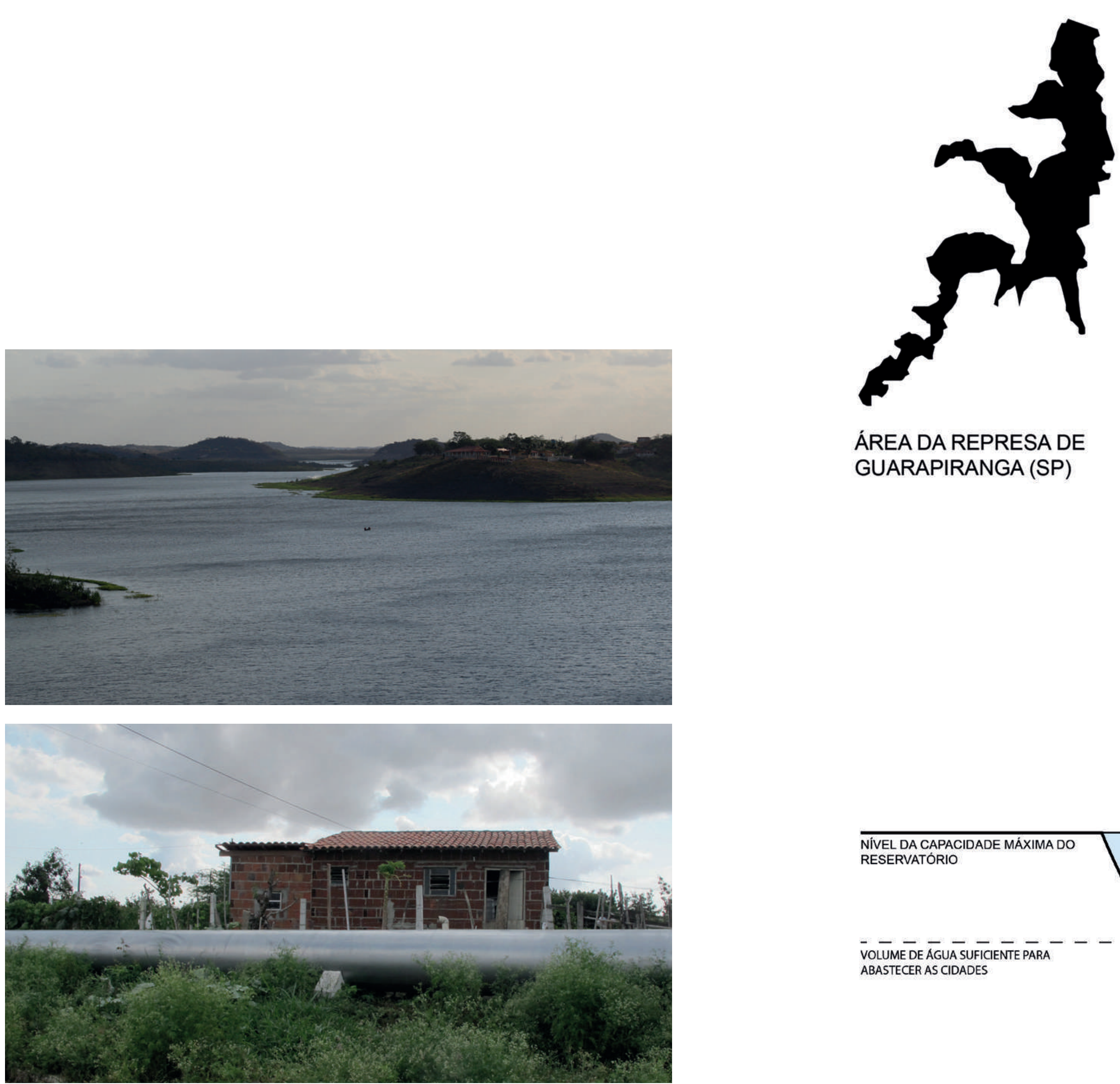

AREA DA REPRESA DE GUARAPIRANGA (SP)

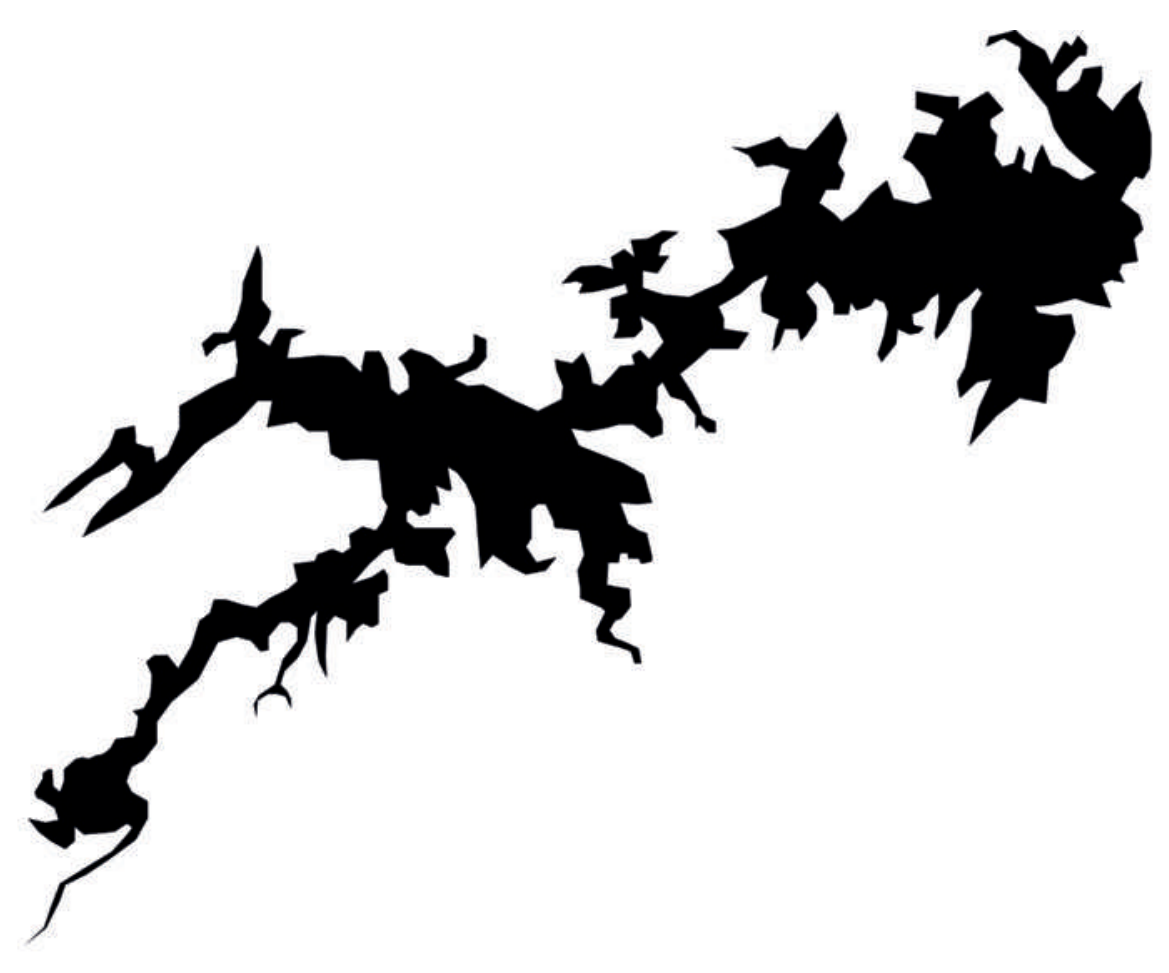

RESERVATÓRIO EPITÁCIO PESSOA

o $1 \mathrm{~km}$

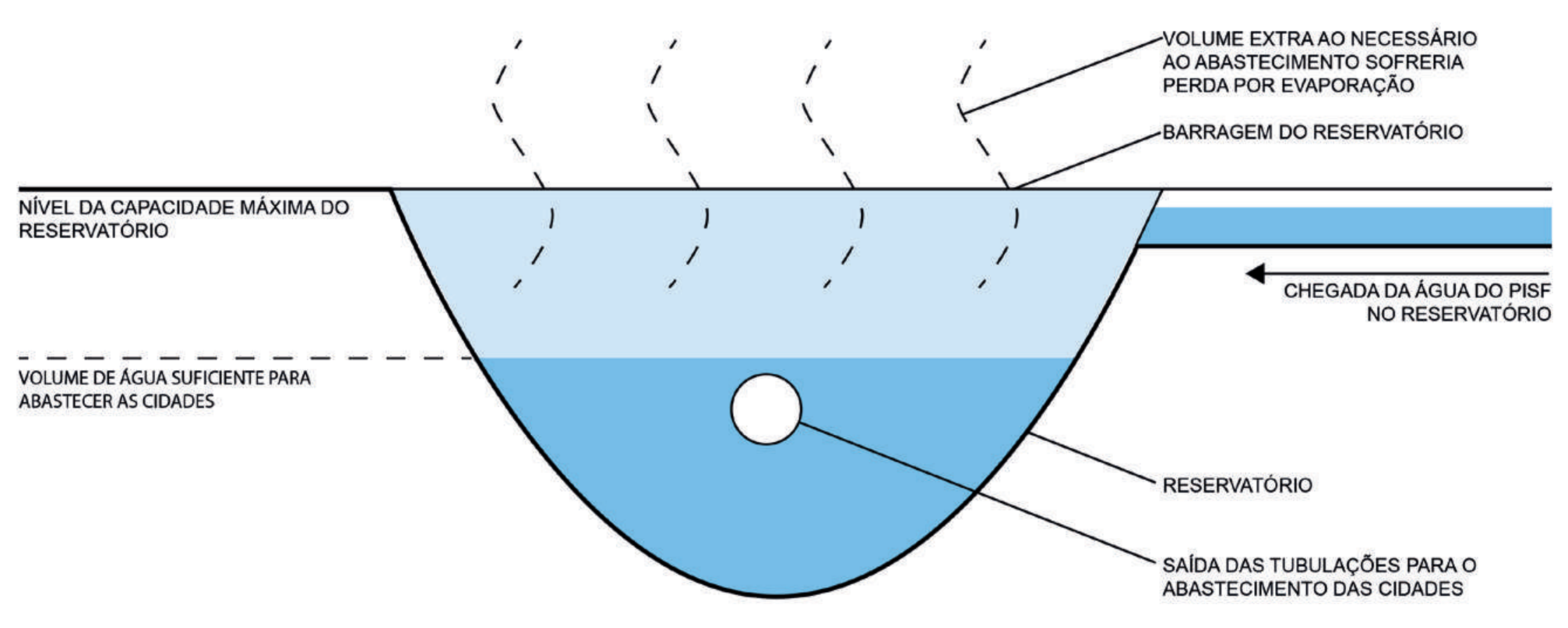


Rio Paraíba perenizado:

obra que transformo

o cariri paraibano

não foi prevista para a recomposição do Esse conceito da sinergia hídrica volume total do açude, mas sim para explicaçăodoconceltodofuncionamento garantir o nivelminimo que oresenvacorio hidrico do projeto, foi abordado nos demanda para o abastecimento da documentos técnicos da Transposição região. Esse cálculo da vazão do do rio São Francisco e nas entrevistas PISF, chamado de sinergia hidrica, ja realizadas para essa pesquisa, mas fo que o mínimo de água fosse perdido por e nada clara no RIMA ${ }^{68}$ documento evaporaçăonos reservatorios, como seria que seria utilizado para a divulgação do o caso se o excedente de água transposta projeto à população.

casse armazenada nos mesmos (REGO,

2017, informação verbal;:65 SARMENTO, Além dessa polêmica, ocorrida mais na 2017, informação verbal;:66 MACEDO, cidade de Campina Grande, também lustra a Figura 67. Esse, nivel minime houve alguns contitos em relação às será alcançado a partir de uma retirada que residem próximas ao Boqueirão, constante de água do São Francisco de ou mesmo às margens do rio Paraíba, $26,4 \mathrm{~m} / \mathrm{s}$, que depois será distribuída em como será visto no próximo item. Ou porcentagens por estado. Seja, a presença da água, por um lado trouxe a soluçãa para o colapso hídrico Sobre o conceito de sinergia hidrica do de uma das regioes mais secas do Brasi participou da elaboracão do projeto ao de gestão, controle e implantação do pro de três gestões distintas (ltamar projeto pelos governos, escancarando a Franco, FHC e Lula) explicou: ausência de entendimento generalizado $\begin{array}{ll}\text { É maximizar a sinergia, porque as } & \text { em relação ao funcionamento do } \\ \text { PISF, não apenas pela população, mas }\end{array}$ [...] Um terço da água é utilizado também por administradores públicos.

e os outros dois terços da água

que chega em média a cada ano

[nos reservatórios] se divide entre

Em periodos de seca e vertimento.

reservatórios secam e os maiores

remanescem. ATransposição foi feita

para resolver isso, essa é a filosofia

por obrigacăo, pois o clima força isso,

remos usar essa água que a gente

perde porque a gente tem a garantia

da Transposiçāo. Se faltar àgua, liga

a torneira do rio São Francisco e
está resolvido - Informacão verbal

concedida em entrevista pelo

engenheiro Rômulo Macedo, no dia
11 de setembro de 2017, em João Pessoa.

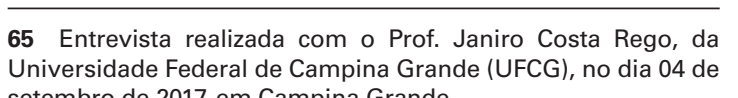
66 Entrevista realizada com o Prof. Francisco Jacome
Sarmento, da UFPB, no dia 11 de setembro de 2017 em Joäo
Pessonat 67 Entrevista realizada com o engenheiro Rôn
dia 11 de setembro de 2017 , em Joào Pessoa.

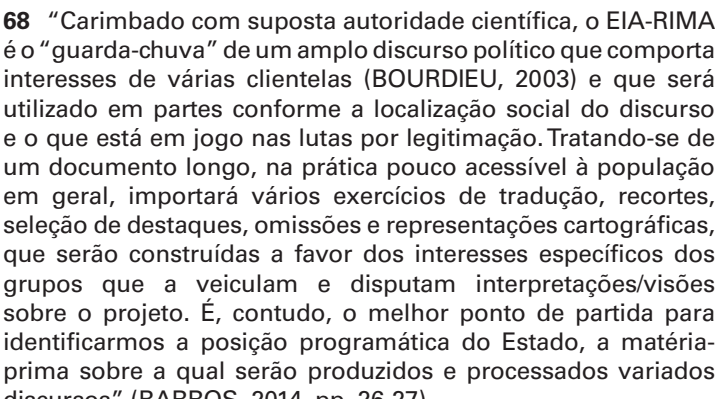

A Transposição proporcionou uma presença-ausênciamuitotransformadora no rio Paraiba e seus arredores. Tratavase de um rio que era intermitente, um rio que desaparecia e voltava nos periodos mais secas do Brasil o cari paraibaes e cuja ocupação e cultura de seu entorno se fazia em função dessa característica. Com a execução da obra do Eixo Leste, passou-se a desaguar a agua transposta em seu leito natural (ver Figura 69), tornando o rio Paraiba artificialmente trajetos, acessos, cotidianos, atividades,

rio perenizado, por um lado, trouxe problemas de inserção do novo projeto, como de tornar inacessível to rio do rio (ver Figura 70), deixando, por escolas (MENEZES, 2017, informação verbal) ${ }^{69} \mathrm{~A}$ responsabilidade desse tipo de adequação de acessibilidade que o rio Paraiba perenizado demandou năa

[...] a própria comunidade fez de (adera uma pontezinha, para criança atravessar, pra ela poder
pegar um ônibus do outro lado do Rio. E ai a gente verificou, o município verificou, foram sete ou oito passagens molhadas. Ai a gente georreferenciou, fui ao ministério com o Governo do Estado, dencia mandamos para o $\mathrm{Ml}$, que por sua vez realizou como resposta que era - Governo do Estado que era para verbal concedida em entrevista pelo vereador Cajó, no dia 05 de setembro de 2017, em Monteiro.

Por outro lado, a água trouxe muita alegria para a população, que se

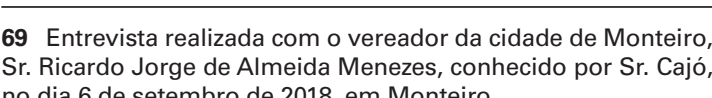

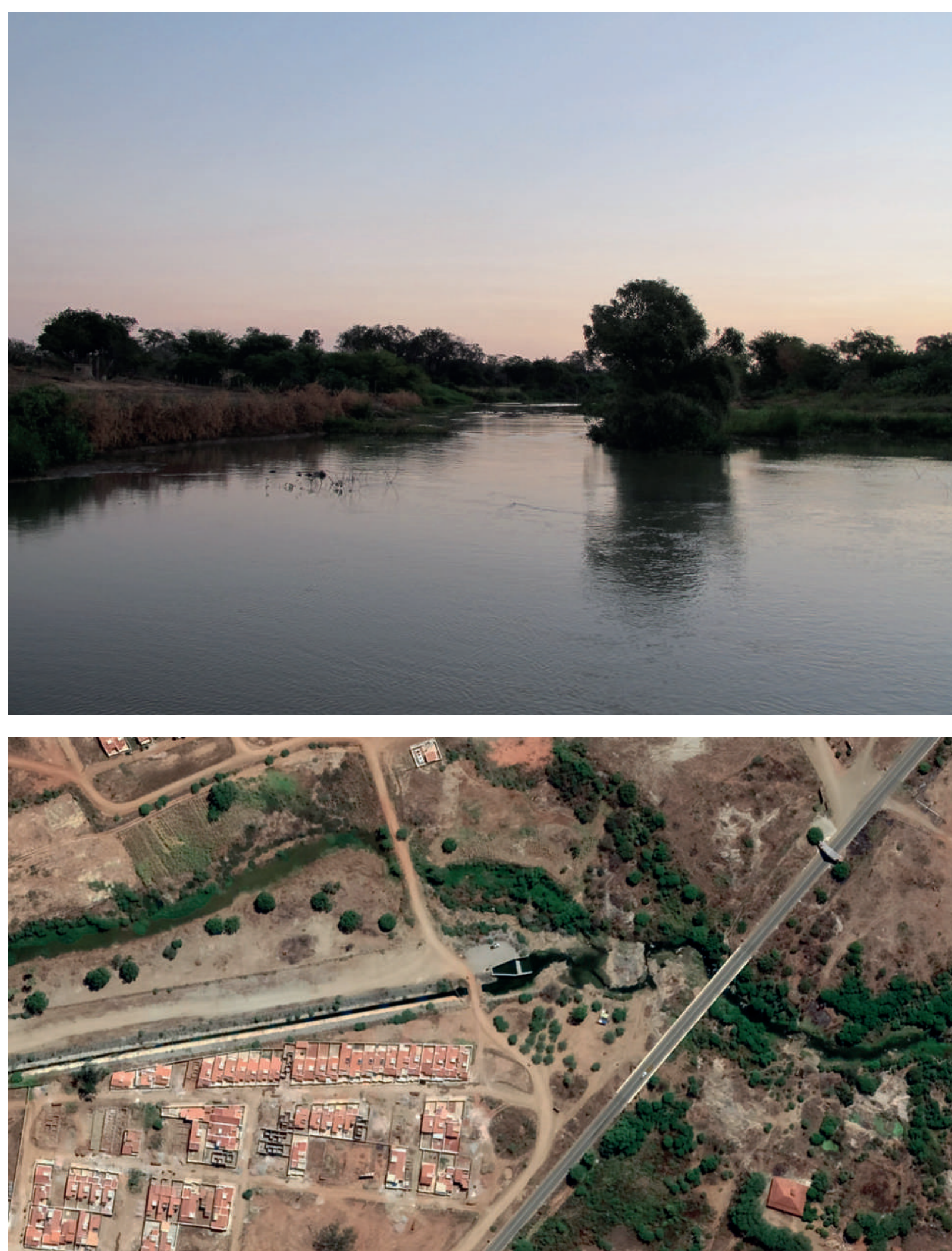

Figura 68 - Rio Paraiba, que agora é perene Foto: Ana Carvalho. Rii Paraiba ( PBB), 05 de setembro de 2017. Fonte: Google Earth, 2019 

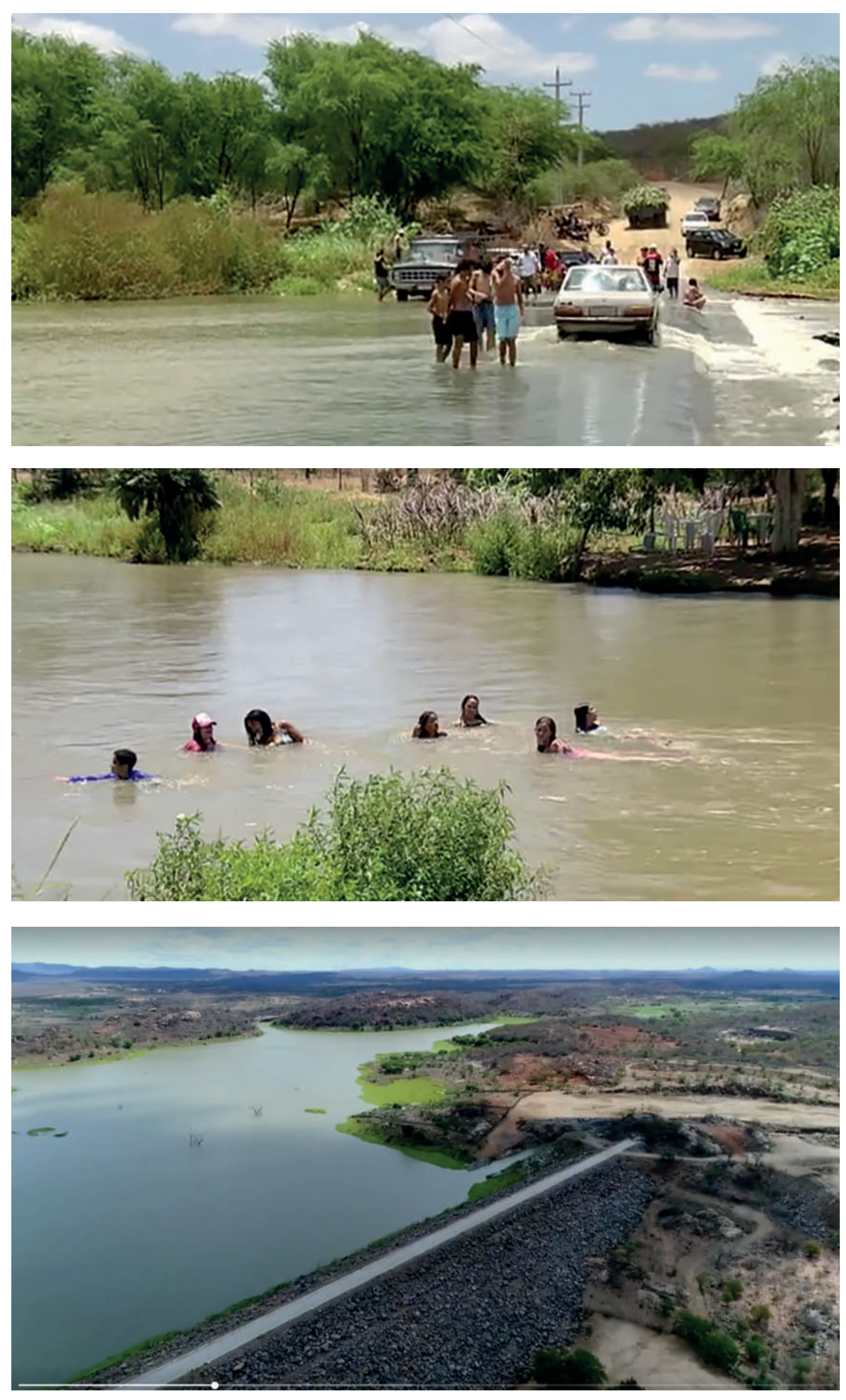

Figura 70 - Estrada que foi inundada pelo rio Paraiba, agora
perene.

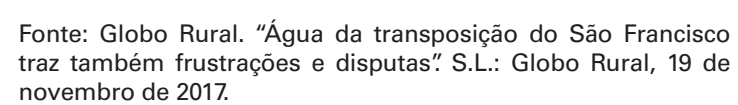

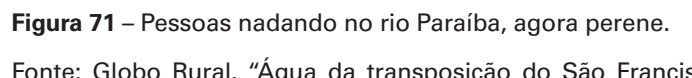

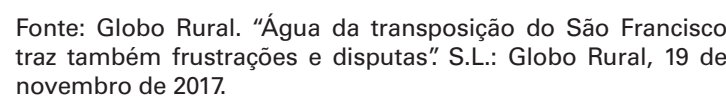

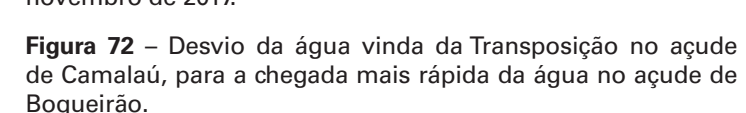

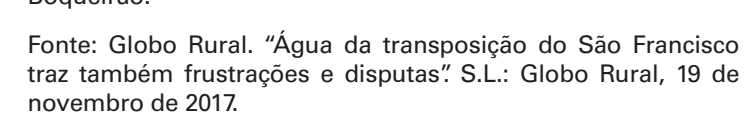

desde para o lazer (ver Figura 71, em que pessoas estáo nadando no leito perene do Paraiba), até para alividades econômicas e consumo. Porém, essa apropriaçáa, em especial relacionada à maneira de agua, gerou problemas, de ou mesmo notícias de jornal, ${ }^{70}$ quando a gua do São Francisco chegou, seu uso ainda não havia sido regulamentado $\mathrm{e}$ muitas bombas foram apreendidas.

Sobre a Transformação da paisagem e dos recursos hídricos que a presença da

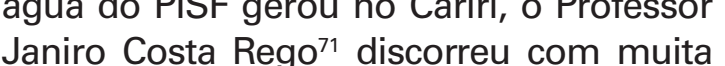
sensibilidade, explicando que, por um lado, $\mathrm{a}$ água seria instantaneamente apropriada pela população, dada a raridade que era abundância da água naquela regiáo, como de fato ocorreu. Por outro lado, a obra teria sido pouco pensada nesse em relação às suas infraestruturas, que muitas vezes não são viáveis de serem utilizadas para outros fins como o lazer, mas também, em relação à gestảo da utilizaçao dos recursos, como seria o caso do rio Paraiba. Rego ainda observou que,
mais do que a falta de recursos hídricos no semiárido, a seca sempre foi fruto de um problema de gestão desses mesmos recursos e com a Transposição isso não seria resolvido automaticamente, pelo administraçăo e distribuição desse recurso: O Cariri está como nosso Nilo, de
repente perene! Porque os rios Ino cariri] não são perenes! Aqui no Nordeste a partir da faixa da Zona até no máximo $100 \mathrm{~km}$ dá para interior semiárido, perene. [...] Com exceção do São

70 Exemplo sobre esses confitios por retirada da água fón.
do permitido ao longo do osistemario Paraiba - reservatón

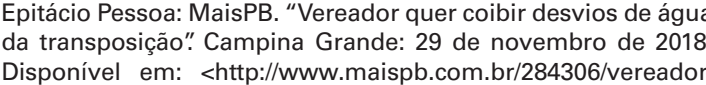

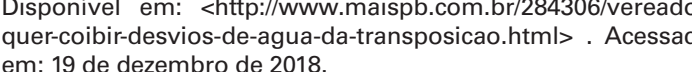

11 Entrevista realizada com o Prof. Janiro Costa Rego,
Universidade Federal de Campina Grande (UFCG), no dia 04 suas nascentes em outros pontos $e$ aqui, principalmente os do cariri nao chegam sequer ser classificados pela hidrologia de intermitentes. A Os perenes correm o ano todo, os intermitentes correm parte do ano depois secam, e os efémeros correm são efêmeros. Só qundo hov escoa, passou aquela áqua da chuva o rio abaixa e seca. E agora nós temos com a Transposição uma mril que nós temo grande, desde [...] imagine os ribeirinhos, vendo essa água là passando. Vai haveruma muito cuidado com a fiscalização dessa água, do uso dessa água. A grande questão agora é a gestấo dessa agua - Informaçáa verbal Prof. Janiro Costa Rego no dia de setembro de 2017, em Campina Grande. A partir do momento que o rio deságua Uu seja, ao mesmo tempo que os desvios usos possíveis da água é de comunidades localizadas às margens A decisão da AESA, apresentada na (Boqueirão) abastecidos pelo rio Paraíba Reunião do Comitê da Bacia do Rio ficaram sem água. No imediatismo das Paraíba, no dia $31 / 08 / 2017^{73}$, foi de questões emergenciais, o rio ficou cheio e permitir a retirada do sistema ${ }^{74}$ desde $o$ os açudes ao longo de seu percurso, vazios. rio Parába até o reservatório de Epitácio
Pessoa, apenas para cultivo em lotes de Portanto, a presença-ausência da água da água do rio São Francisco transposta transposta no rio Paraiba se deu com a a partir de um rio intermitente que se 72 Cada estado vai poder usurfurir de uma porcentagem da tornou perene; também se deu a partir

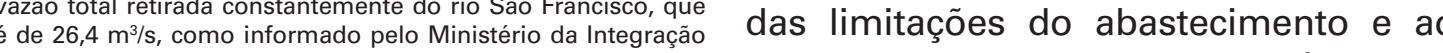

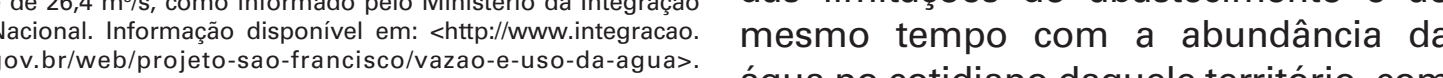
Acessado em 02 de fevererior de 2018 73 Informacáo obida pee
em PDF fetita nesse dia. água no cotidiano daquele território, com a transformação da paisagem, dos fluxos

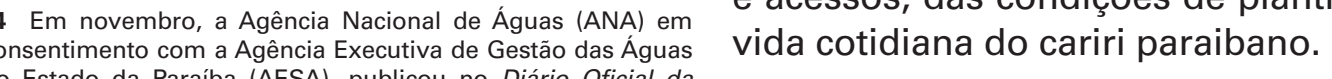

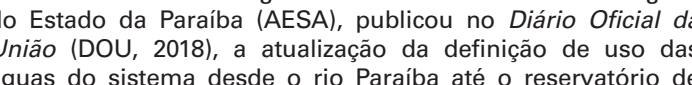

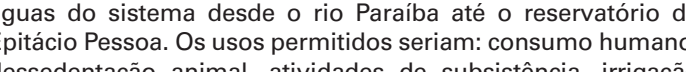

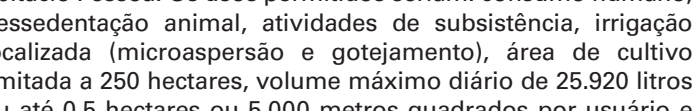

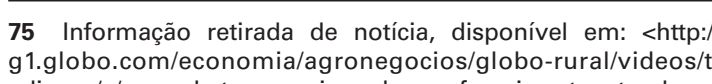

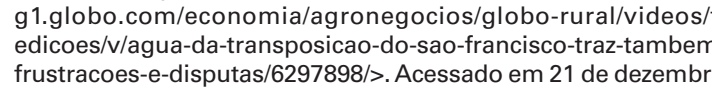


Monteiro na mídia: a "conclusão" do Eixo Leste e os problemas de implantação dos PBAs

Monteiro é um município localizado cariri paraibano, com cerca de 33.000 habitantes (IBGE, 2018), cuja sede municipal e onde o canal do Eixo Leste da Transposiça do rio Sáo Francisco (ver Figura 73). Por nosa im Paraba localização no sistema do PISF, a presença da obra na cidade fez com que Monteiro se tornasse uma cidade bastante protagonista na mídia sobre os acontecimentos em torno da chegada da obra: tanto em relaçáo aos problemas recorresentadas por duas inas vitorias, diferentes do Eixo Leste. Conforme já mencionado no capítulo 2, uma foi feita pelo entáo presidente Michel Temer, no dia 10 de março de 2017 (ver Figura 75), com participaçăo de representantes institucionais e pouca populaçăo; $e$ president ver Figura 76) que atraiu milhares de pessoas. Na época, a disputa política pela "autoria" do projeto e responsabilidade pela obra dividiu-se entre grupos ligados ao Partidos dos Trabalhadores e PMDB. Além dessa importância política, tratase de uma das poucas cidades em que Transposição gerou transformaçoes
físicas em seu tecido urbano diretamente, pois o Eixo Leste passa literalmente dentro da cidade. Mesmo que no perimetro urbano o Eixo tenha passado em túnel, ele causou algum impacto canal gerou por onde passou $5 \mathrm{~km}$ que pela construcão do canal de drenagem de água pluvial acima do túnel do Eixo Leste (ver Figura 74). Esse sistema de canais subterrâneos e superficiais, geraram uma barreira fisica na cidade e
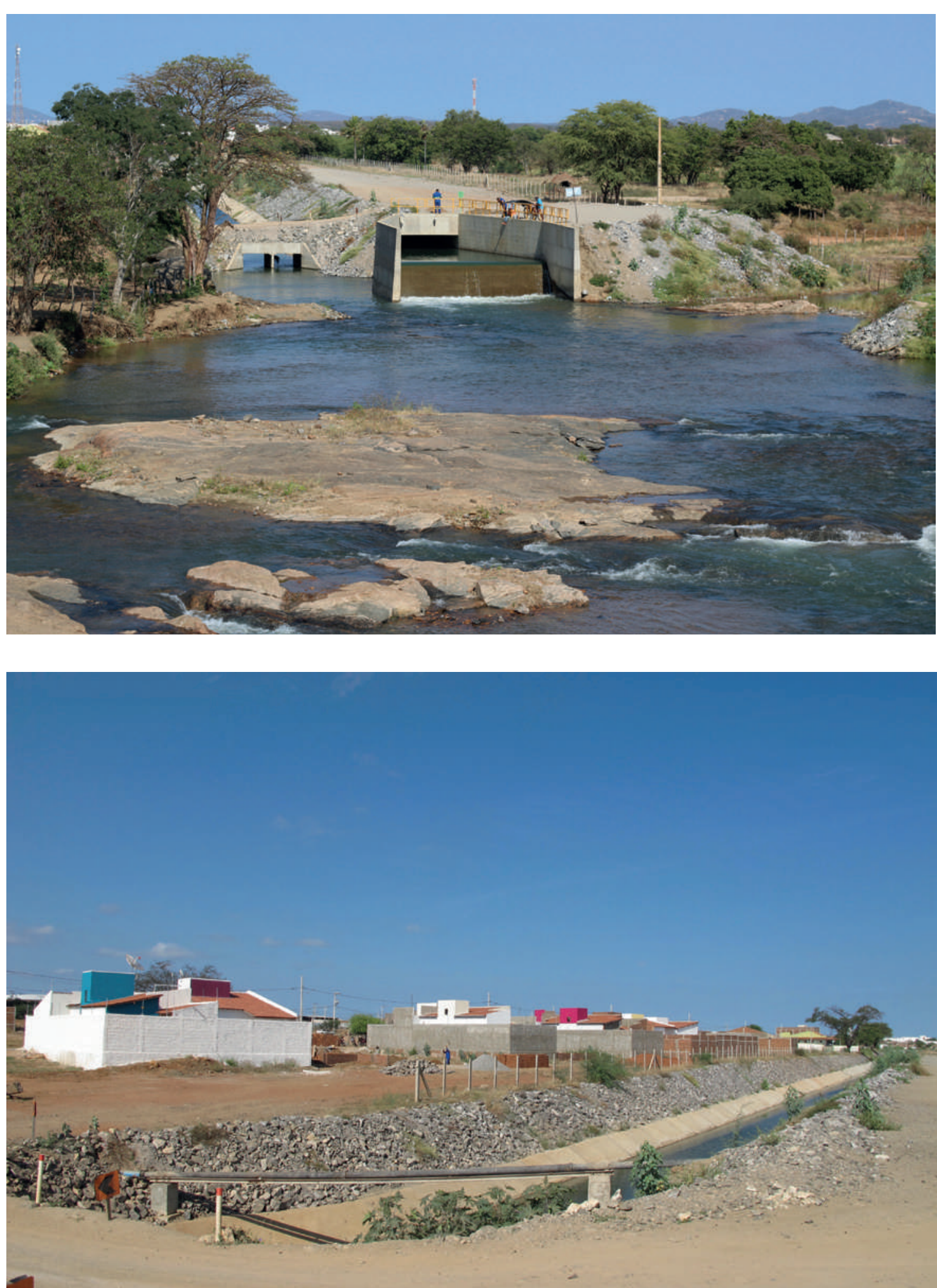
e acessos na face norte de Monumero crescimento do tecido urbano com novos empreendimentos (ver figura 74 e também comparar as fotos aéreas
das Figuras $77,78,79$ e 80 a seguir),
Figura 73 - Deságue do Eixo Leste no rio Paraiba Foto: Carotina Sacconi. Monteiro (PB), 06 de setembro de 2017. .

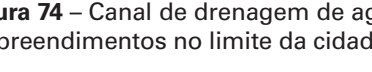

impulsionado por um maior fluxo de pessoas e dinheiro. A consequência disso foi aumento do valor da terra
$\mathrm{e}$ dos aluguéis (MENEZES, 2017, dos aluguéis (MENEZES, 2017 informaçao verbal).76 Ainda assim, em salários mínimos sendo que em 2006 15 salários mínimos (IBGE, 2018) 77 emonstrando que, apesar dessa o dinheiro não ficou para a população.

Em entrevista com o vereador Ricardo Jorge de Almeida Menezes, conhecido expansão imobiliária se deu, antes da efetiva chegada da obra no município, a partir da especulaçáo das pessoas com o cenário futuro que o PISF traria, como, por exemplo, da possiblidade de ao passar pelo municipio, se tornar merimetro irrigado assim como em Petrolina, com a possibilidade de haver interesses de estrangeiros nas terras futuramente.

A expansão imobiliária já tinha em Monteiro [antes da obra], o pessoal fica especulando que ser uma nova Petrolina querque verbal concedida em entrav pelo vereador Cajo, no día 05 de

Sr. Cajó também relatou que com chegada da obra vieram trabalhadores trabalhado na obra em outros pontos, ou que queriam trabalhar. Com o fim majoritário das obras do Eixo Leste,

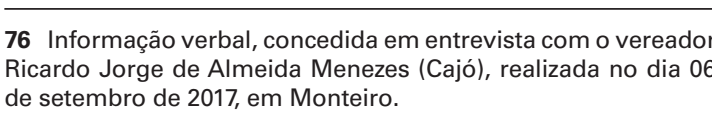

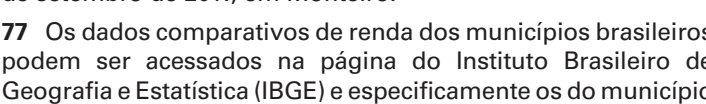

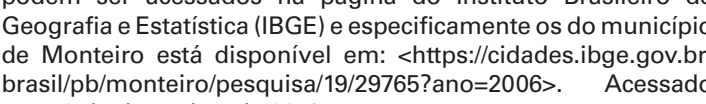

78 Entrevista realizada no dia 06 de setembro de 2017, en
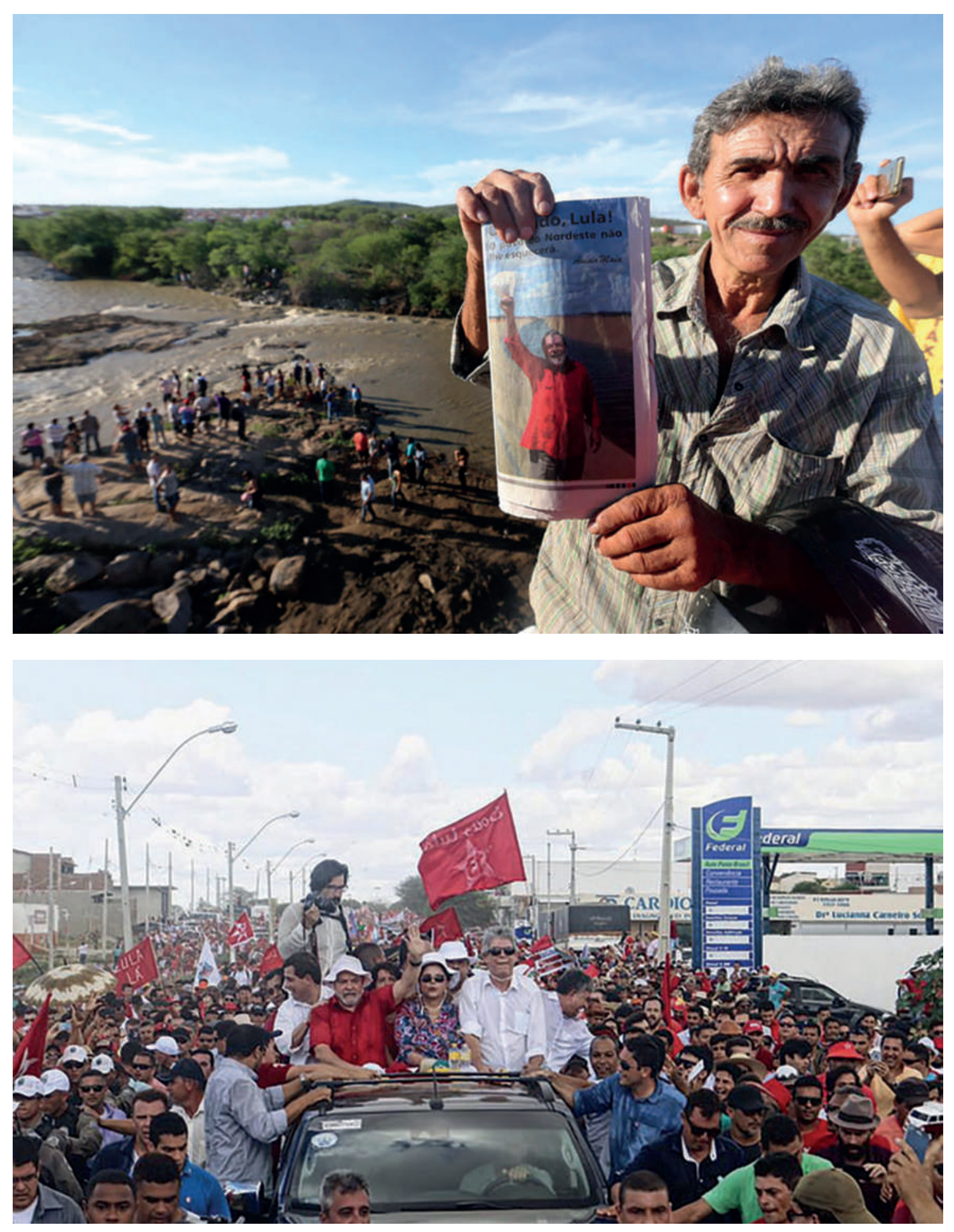

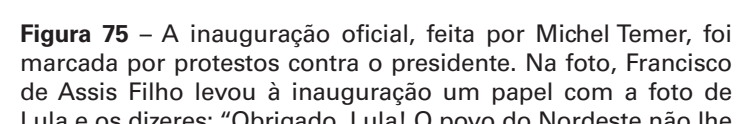

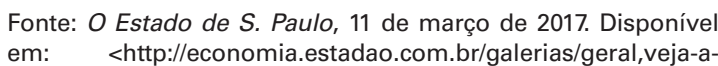
transposica-do-rio-sao-francisco-na-paraiba, 300977. Acesssad Figura 76 - Lula a Dilma levam multiăo de mais de $50 \mathrm{mil}$
pessoas à inauguracáa do Exio Leste em Monteirio.

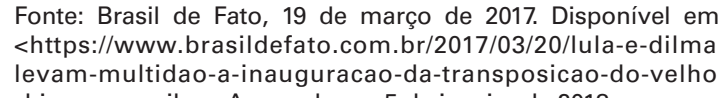



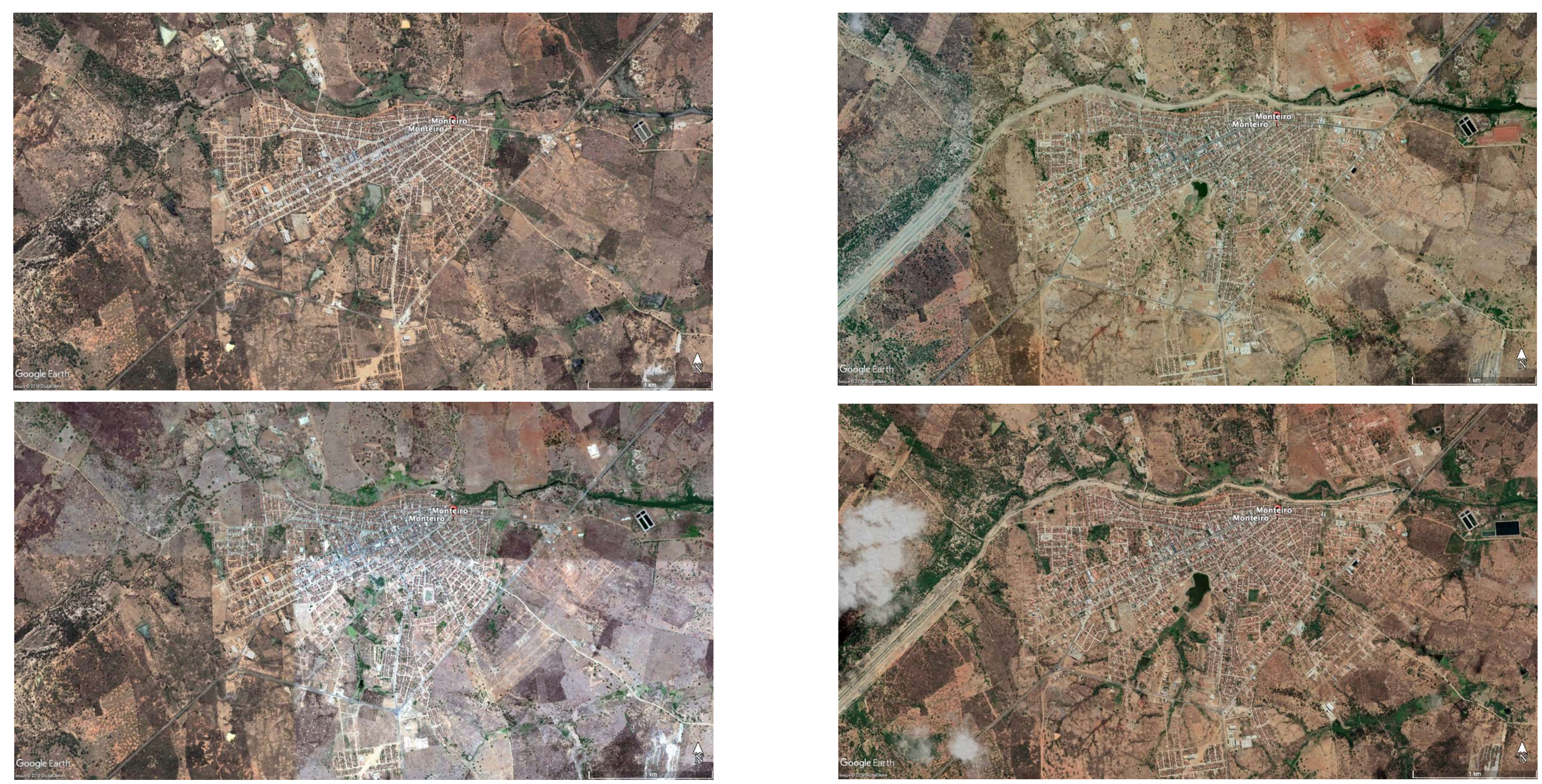

muita gente ficou desempregada e outros passaram a trabalhar nessas empreendimentos:

Tem muita gente aqui de Custódia, de Sertânia. Então, Monteiro, $10 \%$ ou $15 \%$ das pessoas tào
desempregadas. Monteiro tem hoje, muita construção de casas,
então esse pessoal tá mais ligado à entáo esse pessoal tá mais ligado à não sentiu muito. Eu usei um termo: "depressão pós transposição", que foi o que aconteceu em Custódia, a cidade toda entrou em depressão,
porque, foi feito um investimento muito grande durante a obra -
porque o municíio recebe $5 \%$ de toda mão de obra, o ISS [...]. Mas transposição vai fazer falta. Como se pode ver nas fotos de satélites $\begin{aligned} & \text { de fluxos de pessoas e de capital na } \\ & \text { cidade. Além disso, a presença da obra }\end{aligned}$ entre se fez. Alem disso, a presença da obra

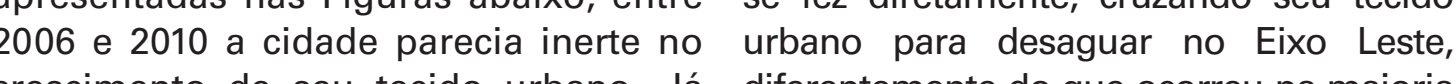

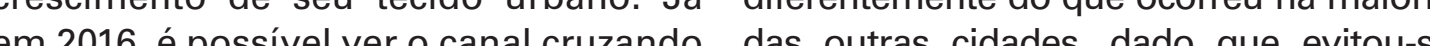
a cidade e a faixa de terra desapropriada; passar os canais por locais mais povoados em 2018 alguns empreendimentos (ALMEIDA, 2017, informaçāo verbal).99

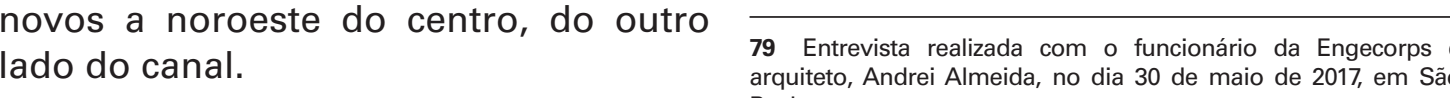

Figura 77 - Foto aérea via satélite de Monteiro em 2006. Figura 78 - Foto aérea via satếlite de Monteiro em 2010. Figura 79 - Foto aerea viva satelite de Monteiro em 2016. Funa $80-$ Folo aerea via satelle de Monteroem 2018. 

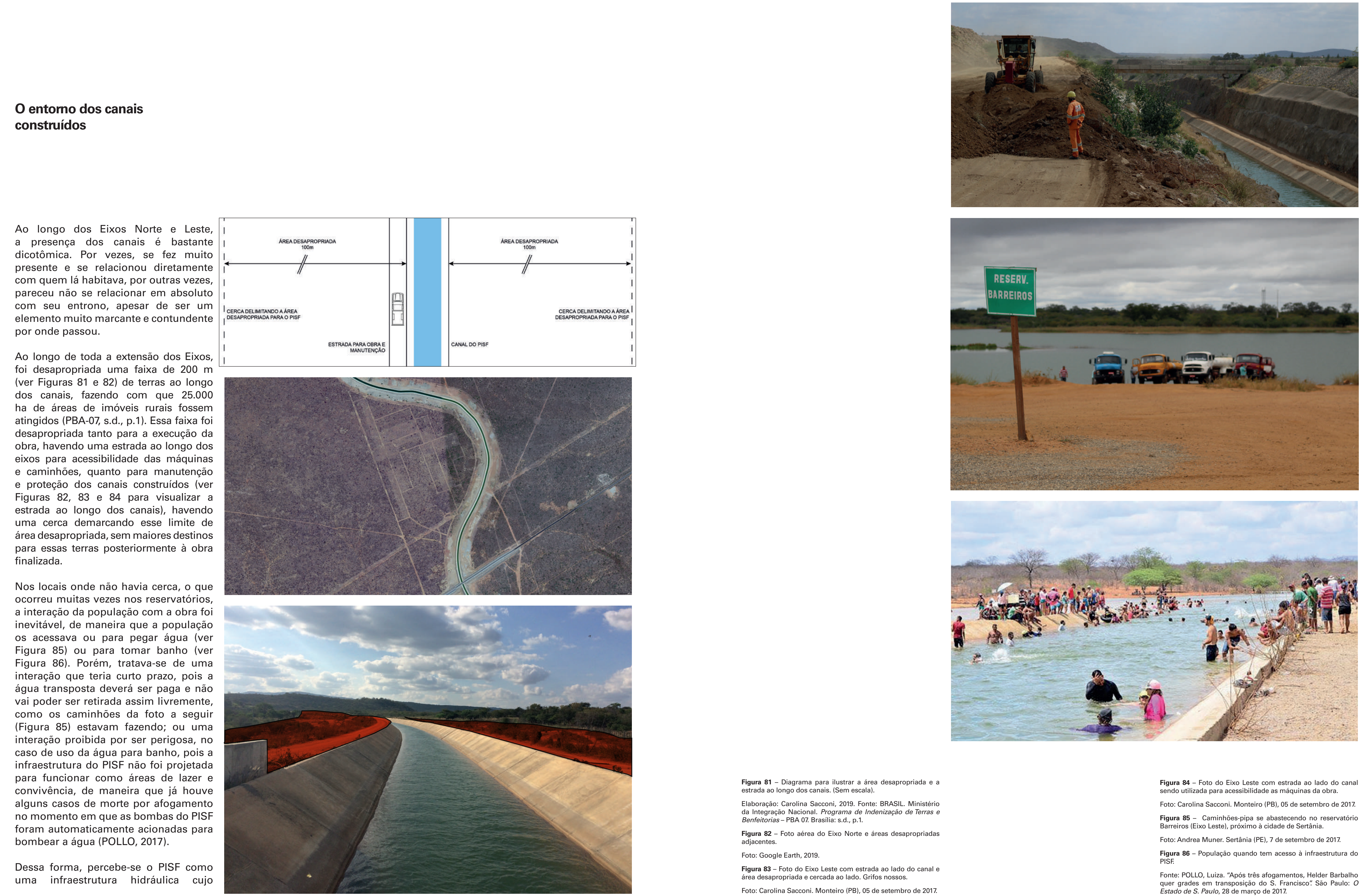

Ao longo dos Eixos Norte e Les
a presença dos canais é bastan
dicotômica. Por vezes, se fez mu
presente e se relacionou diretamente

com quem lá habitava, por outras vezes,

Ao longo de toda a extensão dos Eixos, (ver Figuras 81 e 82) de terras a (V) Nos locais onde não havia cerca, o que uma infraestrutura hidráulica cujo
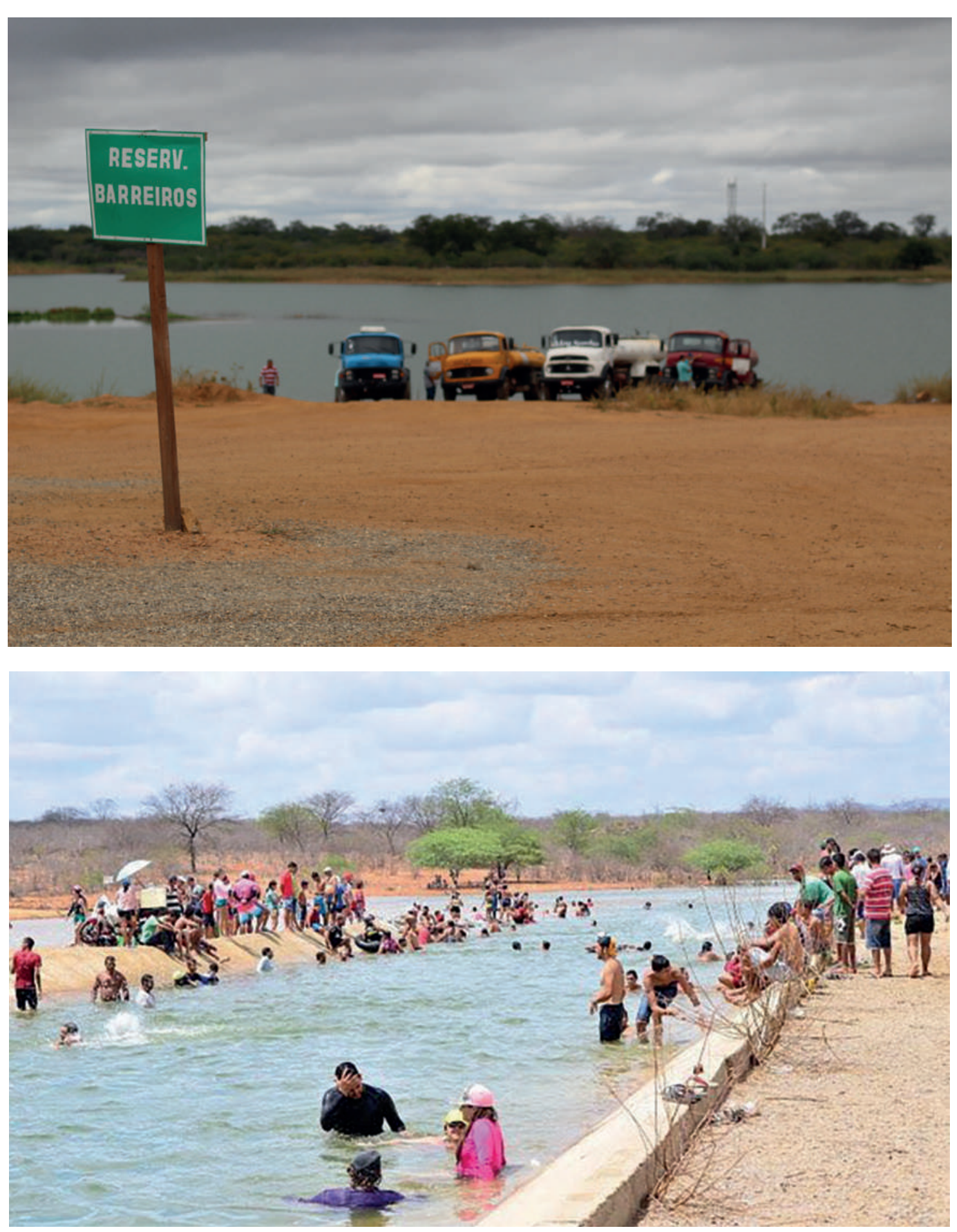

Figura 81 - Diagrama para ilistrar a a area
estrada a a longo dos canais. Semem escalal.).

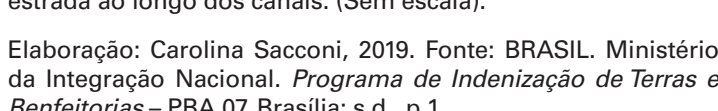
Figura 82 - Foto aérea do El Exo Norte e áreas desapropriadas Foto: Google Earth, 2019.
Figura 84 - Foto do Eixo Leste com estrada ao lado do canal Foto: Carolina Sacconi. Monterio (PB), 05 de setembro de 2017

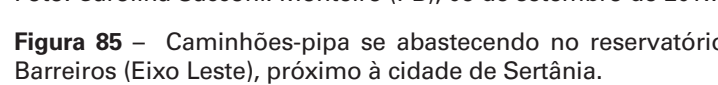
Foto: Andrea Muner. Sertânia (PE), 7 de setembro de 2017.
Figura 86 - Populacāo quando tem acesso à infraestrutura do

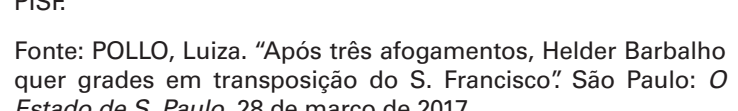


funcionamento foi pensado para não . de àguas do São Francisco, um projeto por onde atravessaria no sentido de ua habitabilidade, ou sem levar em conta as possiveis apropriaçōes, apenas áreas imediatamente habitadas para evitar esse tipo de interação.

Em relação aos estudos de ordem terriorial, na gestão FHC, através da elaboração dos Estudos de Inserção apresentado no capítulo 2, houve um apresentado no capítulo 2 , houve um
levantamento dos programas públicos de irrigação, dos tipos de solo, dos tipos de produtores dessa região, entre outros levantamentos, com um vies bastante crítico aos modelos de produção que năo fossem irrigados, condicionando a questão da instabilidade hídrica à Porém, mais do que a questão hídrica, um dos grandes problemas que sempre não apenas do semiárido, mas também em todo o Brasil, é a concentração de terras, poder e riqueza, resquícios ainda 1985, p. 60).

Diante disso, no projeto de Transposição vigente, a única ação perante a questão fundiária do PISF foi colocada através do PBA-19, referente ao "Programa do Entorno dos Canais", cujo objetivo foi de regularizar as terras do entorno, um raio de $5 \mathrm{~km}$ a partir dos Eixos, de registrados em cartório, situação que representava $26 \%$ das propriedades ao longo da Transposição (PBA-19, s.d., p. 1). Porém, o texto do programa declarou que năo tinha por objetivo controlar regiôes, que, com a Transposição em funcionamento, certamente ocorrerão território uma ocupação desigual do para longe dos canais

[...] a expectativa gerada pela projeto na região implavocaráááa prossõos do sobre as áreas a serem beneficiadas, que se traduz, geralmente, no mais próximas e mais das terras cultivo. Este fato pode gerar o êxodo de pequenos produtores (posseiros, pequenos proprietatios e produtores
sem terra) e o aumento repentino e exagerado do valor de venda dos imóveis rurais, caracterizando açoes de especulaçáo imobiliária dos valores de eventuais processos
de desapropriação, revenda

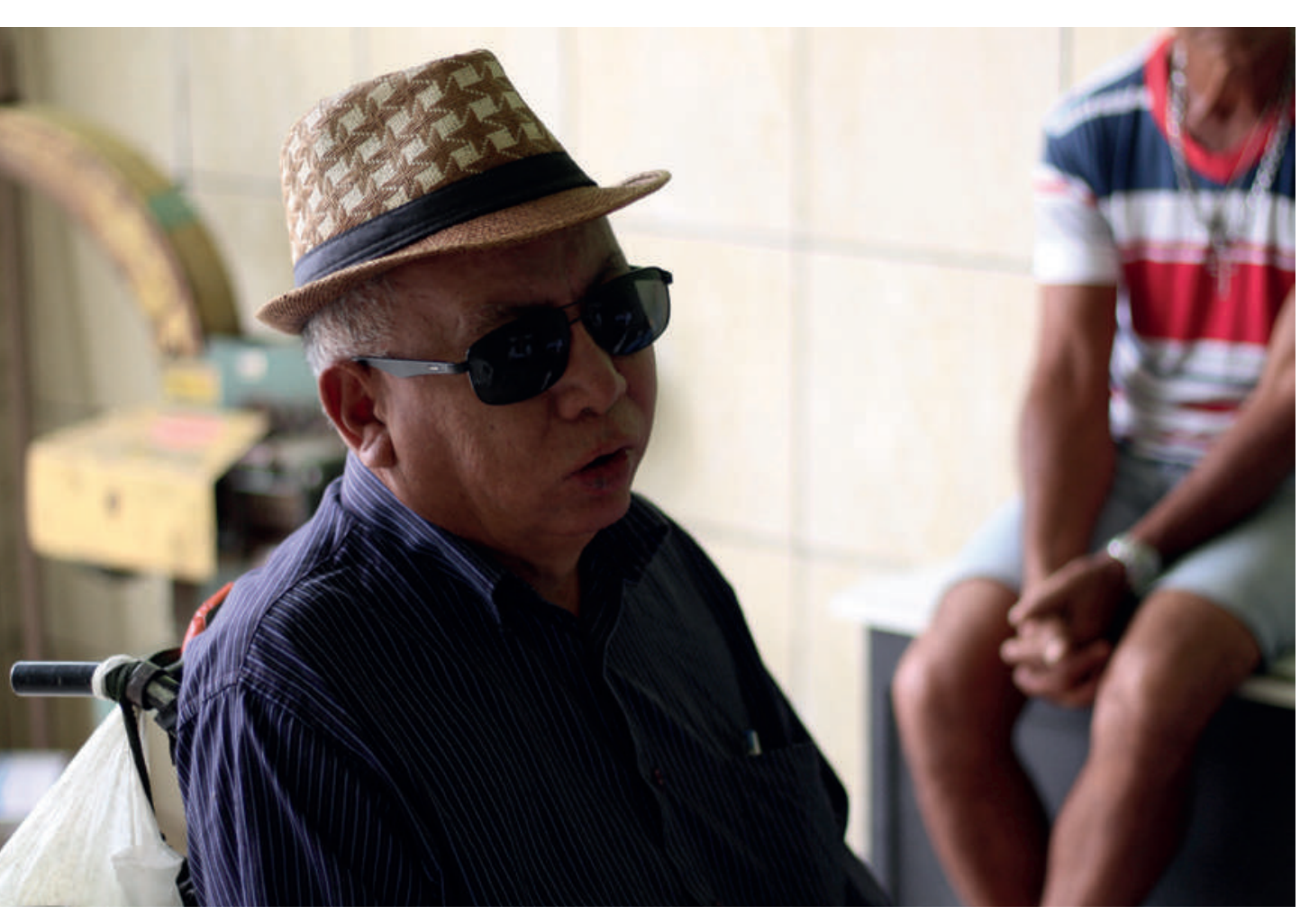

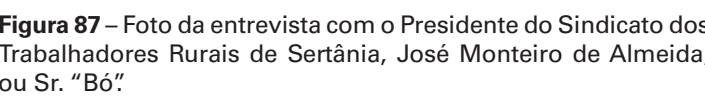
oto: Andrea Muner. Sertânia: 07 de setembro de 2017

posterior das áreas ocupadas ou terras quando da incorporaçăo dos benefícios previstos. Não se pretende com a execução deste Programa mpedir a ocorrência de da região, pois estas se configuram
como inevitáveis, pois nada impediră que os detentores dos imóveis, agora devidamente legalizados, satisfatória. Busca-se sim fortalecer a posiça principalmente dos de boe qualidade cortad terras empreendimento frente às açōes dos agentes do mercado de terras
locais (PBA19, s.d., p. 2). Em entrevista concedida para o sistema hídrico de drenagem presente pesquisa, o Presidente do Ministério de Integração refez alguns Sindicato dos Trabalhadores Rurais de poços, mas posteriormente suspendeu Sertânia, José Monteiro de Almeida, essa ação depois, alegando que conhecido por Sr. "Bó" (Ver Figura 87), haveria abastecimento com a água da comentou que, mesmo antes que o Transposição. Enquanto a obra não era gente interessada nas terras, que por de ser abastecidas com carro pipa por ainda não estarem recebendo as águas um bom tempo:

transpostas, permaneciam, todavia, baratas, processo que também ocorreu mas cidades, como Sertânia: ${ }^{80}$

Já tem gente de olho já [nas terras porcue a águ ainda não começou a eles começam a chegar. Porque terra aqui e barato por enquanto. mesmo que está compranda já

Na zona rural você tem que ter poço.
Chama-se poço artesiano, que são até $50 \mathrm{~m}$ de profundidade e é um Unte de água que o pessoal usa. custa em torno de 3 mil reais. Para você botar as bombas fica em torno de 5 mil o conjunto do poço. [...] $A$ locais que o canal passa com 30,40 metros de profundidade. Ai o que
acontece? Os poços no raio de 1 ou

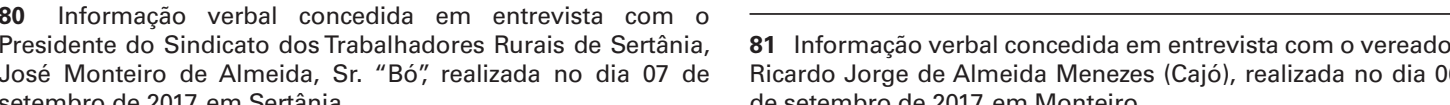

$1,5 \mathrm{~km}$, secaram. A gente identificou mo mécia 50 poços de pessoas que Faz uns três anos que a gente alertou "olha tem uns poços que secaram". Vem a fiscalização, identifica, vem refazer [...] Essa semana, teve um vão mais fazer os poços porque
vão fazer o abastecimento. Como vai demorar de dois a três anos, enquanto isso, fica o abastecimento por carro pipa. - Informação verbal
concedida em entrevista pelo vereador Cajó, no dia 05 de setembro de 2017, em Monteiro.

Sr. Bó também comentou sobre os Segundo o mesmo PBA-15 (s.d., p. 12), poços que secaram e que não foram as localidades priorizadas foram as refeitos, além de outros impactos nas populosas e aquelas menores e situadas propriedades rurais da região, como próximas ao traçado do sistema adutor, a
a perda das cercas e a dificuldade em serbeneficiadasa partirdos reservatórios

a perda das cercas e a dificuldade em serbeneficiadas a partirdos reservatórios
se criar animais a partir disso, uma vez do PISF. As comunidades com mais
que muitas famílias não têm condiçôes dificuldade de serem abastecidas a que muitas famílias não têm condições financeiras de fazer esses reparos:

Em Sertânia, la obra] removeu muitas famílias, secou poços das perderam a cerca e as familias agora não conseguem criar animais. 0 sindicato está preocupado com as indenizaçōes das familias que năo

mate
dificuldade de serem abastecidas a
partir do canal ou dos reservatórios do sistema, segundo o mesmo PAB15 (s.d., p.12) deveriam ter soluçōes alternativas de abastecimento a serem estudadas, de maneira que fossem contempladas. Porém, em nenhum momento essas soluçôes alternativas ficaram claras para essa população em fosse a mais vulnerável, no sentido de estar mais isolada de infraestruturas O PBA-15 - “Apoio Técnico para e muitas vezes sendo famílias muito
Implantaçăo de Infraestrutura de pobres, sem muitas alternativas para Abastecimento de Águas ao Longo além de esperar a chuva, ou fazer um dos Canais" ${ }^{82}$ relacionou duzentas poço artesiano, quando as condiçôes
e cinquenta e cinco localidades e terra e financeiras permitissem. e cinquenta e cinco localidades e
povoados rurais situadas dentro da Área Diretamente Afetada (ADA) pelo $c$ Contraditoriamente, tendo vivem cerca de nove mil quinhentas e nas içẽes, essas famílias rurais situadas cinquentas famílias e aproximadamente com umainfraestrutura hídrica construíd quarenta e cinco mil pessoas, que seriam abastecidas pelas aguas transpostas
(PBA-15, s.d., p. 4). Entretanto, essa lista foi pouco (ou nada) divulgada, fazenda com que em campo muitas pessoas e indenento do engenheiro Irani Ramos ${ }^{8}$ como evidencia o depoimento abaixo fundo em todos os casos: o PISF propōe Sr. Bó. Além disso, em um universo de um desenvolvimento regional para doze milhöes de pessoas que, segundo quem? Como funcionará a distribuição
o EIA-RIMA (BRASIL, 2004 p. 9), de água? Quanto ela vai custar? Um seriam atendidas pelo PISF, conforme desenvolvimento que é voltado para o menciona capítulo 2, 45 mil abastecimento das cidades, mas como ele abastecimento por essa água transposta, PBA-18, de "Apoio e Fortalecimento do o que reforça que a prioridade do PISF Projetos de Assentamentos Existentes
seria de atender as cidades do "Nordeste
ao Longo do Canal", que propôs garantir Setentrional", sendo muito pertinente o acesso a água a essas cidades para 0

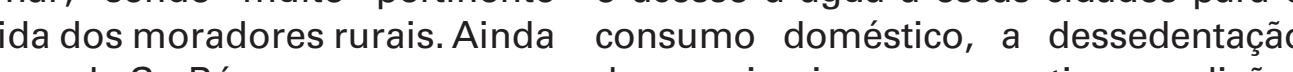
nas palavras de Sr. Bó, dos animais e garantir condiçōes

[...] a questão do impacto no necessárias à pequena irrigação, onde e 82 BAASIL. Ministério da Integracáa Nacional. Apoio Tecenico foi cartografado e tampouco esgotariam

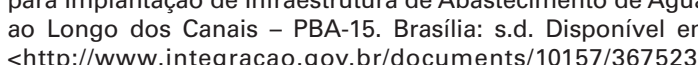

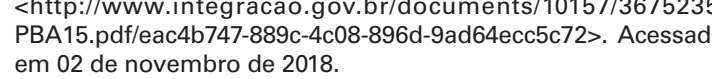

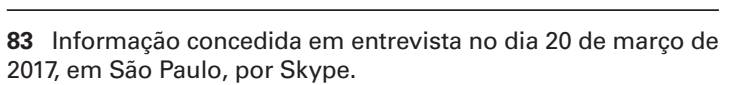
regional.

A seguir, alguns questionamentos do $S$ Bo sobre essa inserção pretendida do uma série de d́vidas à populaço que habita as áreas afetadas:

De que forma essa água também vai ser distribuida nos rurais tambem. Porque, o que a gente sabe, é que abastecidos. Vão vir com água que ver, não só a questão da água animais e também da produção. Ou se Sertânia vai usar essa água só para o consumo humano, ou para de Salgueiro, naquela região o evaporação é muito grande dess águai os canos a céu aberto, os
açudes cheios de água, a infiltração evaporação da água é muito grande. Se não usar aquela água,
ela vai evaporar e infiltrar. E ai? O pessoal como é que fica? Precisando
de água para produzir... porque não
tem melhoria na qualidade de vida sem produção.

u seja, os programas mais territoriais, u seja, os que trataram da questão producão apoío ao abastecimento e pontuais e limitadas, pouco claras, e não $m$ verdadeiro plano de desenvolvimento re PISF ali representaria. Tratou-se de ma obra de uma obra que intervém de modo contundente no territorio, ransformando a paisagem, alterando uxos. O próximo item tratará das Vilas

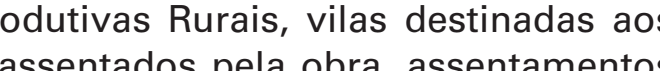
de também se previa o incentivo à gricultura familiar promovida pelo PISF, vivez o programa, teoricamente, mais oria um projeto de Ineráveis. Mas o que se viu na prática mbém teve limitações nesse sentido, mo veremos a seguir. 
As Vilas Produtivas Rurais

(VPRs) à espera da água

prometida

PBA-0 $8^{84}$ do Projeto de Integração do Rio São Francisco, referente ao Programa de Reassentamento das Populaçoes, indicou que 25 mil hectares serian desapropriados ao longo dos dois canais, atingindo 1889 propriedades rurais e reassentando 845 familias
(PBA-08, s.d., p.3). Para reassentar a população impactada e que optou por ser reassentada e não indenizada, foram construídas dezessete Vilas Produtivas Rurais (VPRs), localizadas dentro de uma sendo quinze no Eixo Norte (ver Figuras Para essa pesquisa, foram visitadas duas
$88 \mathrm{e} 89$ ) e 2 no Eixo Leste (ver Figuras 90). Vilas Produtivas Rurais em 2017, uma no Eixo Norte, a Vila Uri (ver Figura 92)
no No projeto das VPRs cada família próxima à cidade de Salgueiro (PE), que reassentada receberia dois lotes: um lote fora construída havia 7 anos, e outra de 1 ha irrigado com as águas transpostas no Eixo Leste, a Vila Lafaete (ver Figura para a promoção da agricultura familiar; 93), próxima à cidade de Monteiro (PB), e um lote "seco, de 4 ha, ou seja, que era mais recente, funcionando há segundo, o lote seco, ainda haveria uma os casos, foi possivel percern ambos casa de alvenaria para a família morar. Transposição transformou em absoluto Veja-se na Figura 91 um exemplo de a vida daquelas pessoas, que haviam planta da VPR Uri, em Salgueiro (PE), em deixado suas antigas casas e modos de que em azul turquesa saao os lotes secos, vida para tras, vivendo em um modelo de onde cada família teria uma casa e em comunidade rural novo para elas. Apesar marrom, os lotes irrigados. disso, tambem em ambos os casos, Em relação a todas as VPR terem (PB) onde as águas do São Francisco como objetivo a agricultura irrigada corriam, o cultivo do lote irrigado ainda como modo de produção das famílias não existia, pois a água ainda não tinha reassentadas, o Presidente do Sindicato sido levada para là.

dos Trabalhadores Rurais de Sertânia

"PE), Jose Monteiro de Almeida, Sr. Ou seja, muito embora aquelas pessoas "Bo", criticou a proposta do Ministerio tenham optado por viver o modo do da Iregraça a Nropional do sentido de vida que a Transposiçáo havia proposto famílias não haviam sido consultadas promoveria grande parte da agricultura sobre como e o que elas teriam afinidade familiar oficialmente promovida pelo e vontade de produzir:

Eu acho assim, que tem que ter um planejamento, uma capacitação, produtores para realmente ver o que eles querem produzir. Tirar um grupo

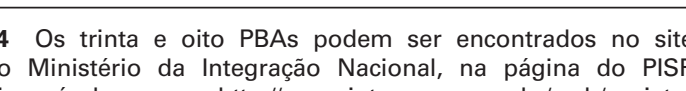

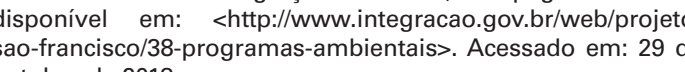
Projeto, o plano até então não havia sido concretizado, fazendo com que espera pela agua ora viesse por meio de frustraçāo, ora por meio de esperança. dera a Transposiçáa presente na vida transformadora, porém incompleta no que havia sido proposto.

Olha, é maravilhoso. Você mora no sertão central, nunca imagin
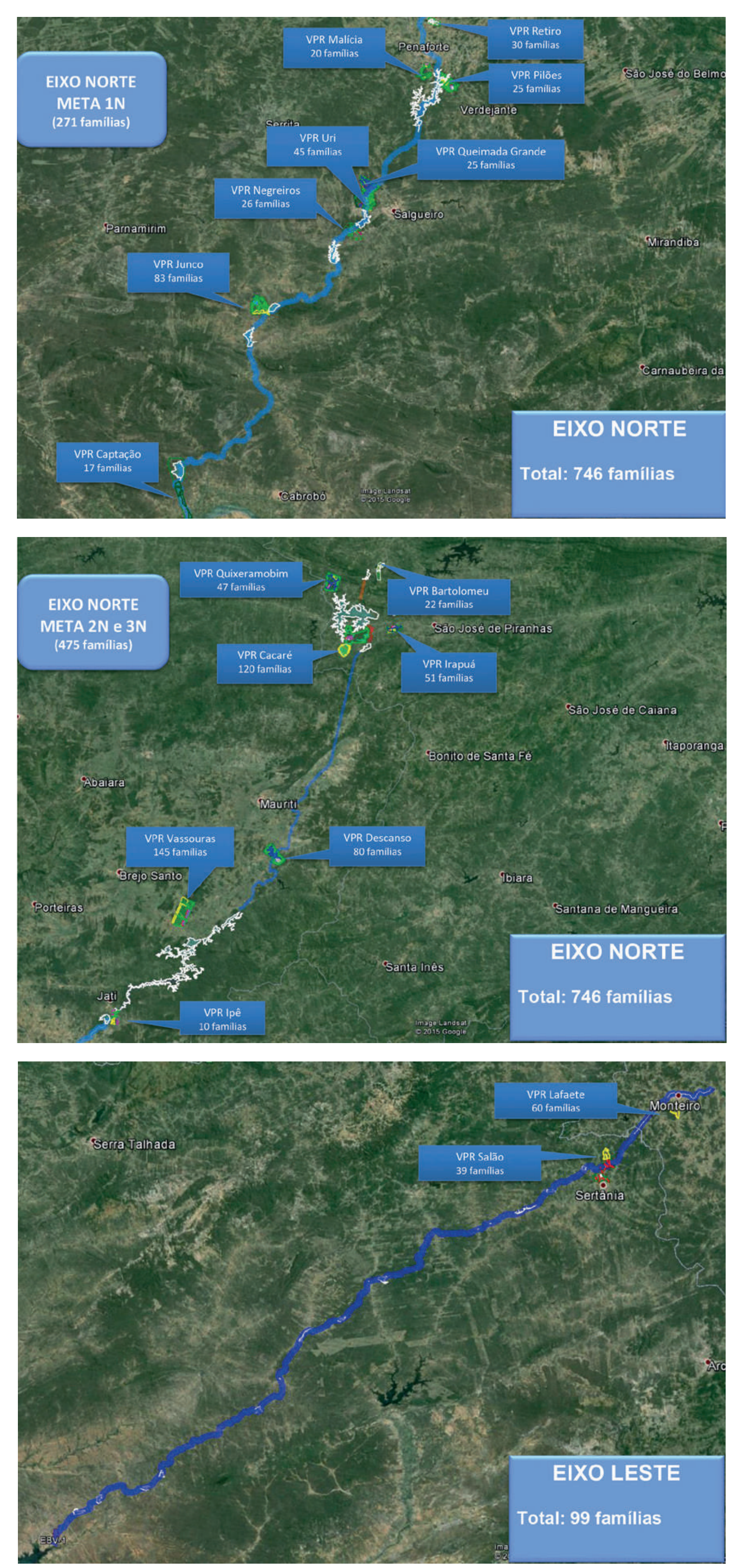

rara 88 -Vilas Produtivas Rurais (VPRS no E Eixo Norte, meta I

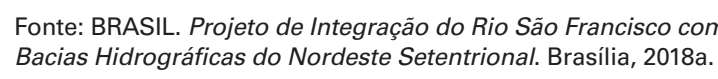

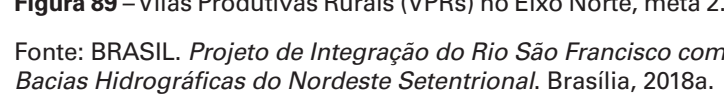
Figurra 90 - Vilas Produtivas Rurais VPRSs no Eixo Les

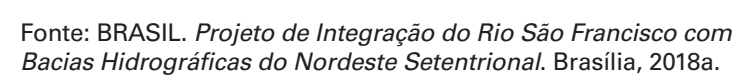


Francisco aqui e irrigando, os seus
filhos issoé maravilhoso se a água chegar, vai melhorar a vida de muita gente - Informação verbal concedida em entrevista por Sra. Marinelma, Uri. no muncipio dro Silguiro, Uri, no municipio de Salg
dia 9 de setembro de 2017.

A visita realizada para essa pesquisa na Vila Produtiva Lafaete $(\mathrm{PB}){ }^{85}$ onde o Ministério de Integração se fazia mais presente que naVPR Uri (PE), por ser um assentamento recente, foi acompanhada por dois funcionarios da gerenciadora Helena Barrose o engenheirocivil Marcus Leme. Como se trata de uma VPR em que a Helena Barros estava trabalhando com frequência, ela conseguiu reunir aproximadamente vinte moradores para a entrevista (ver Figuras $94 \mathrm{e}$ 95). Porém, a conversa for um pouco dificil, pois é Ministério de Integração, tenha inibido os moradores em dar algumas respostas. $\mathrm{Na}$ conversa com os moradores na VPR Lafaete, os habitantes relataram um pouco sabre como se deu o processo de receberam um aviso do governo federal de que a Transposição passaria por ali e, os que optaram por ser reassentados foram cadastrados em uma lista para 0 reassentamento nas VPRs. Enquanto as vilas eram construidas, receberam um auxílio moradia do governo federal morando na VPR, enquanto a água não chegava, como os moradores não podiam produzir com a agricultura irrigada, eles recebem um valor em torno de $R \$ 1320,00$ para manutenção da vida na VPR. Quando a a gua chegar, esse até não haver mais ${ }^{87}$ De acordo com a 85 A visita àvila Produtiva Rural Lafaete foi realizada no dia 06
de setembro de 2017 .

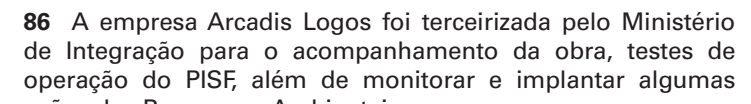

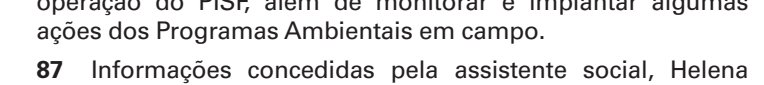

Programa de Reassentamento de Populações
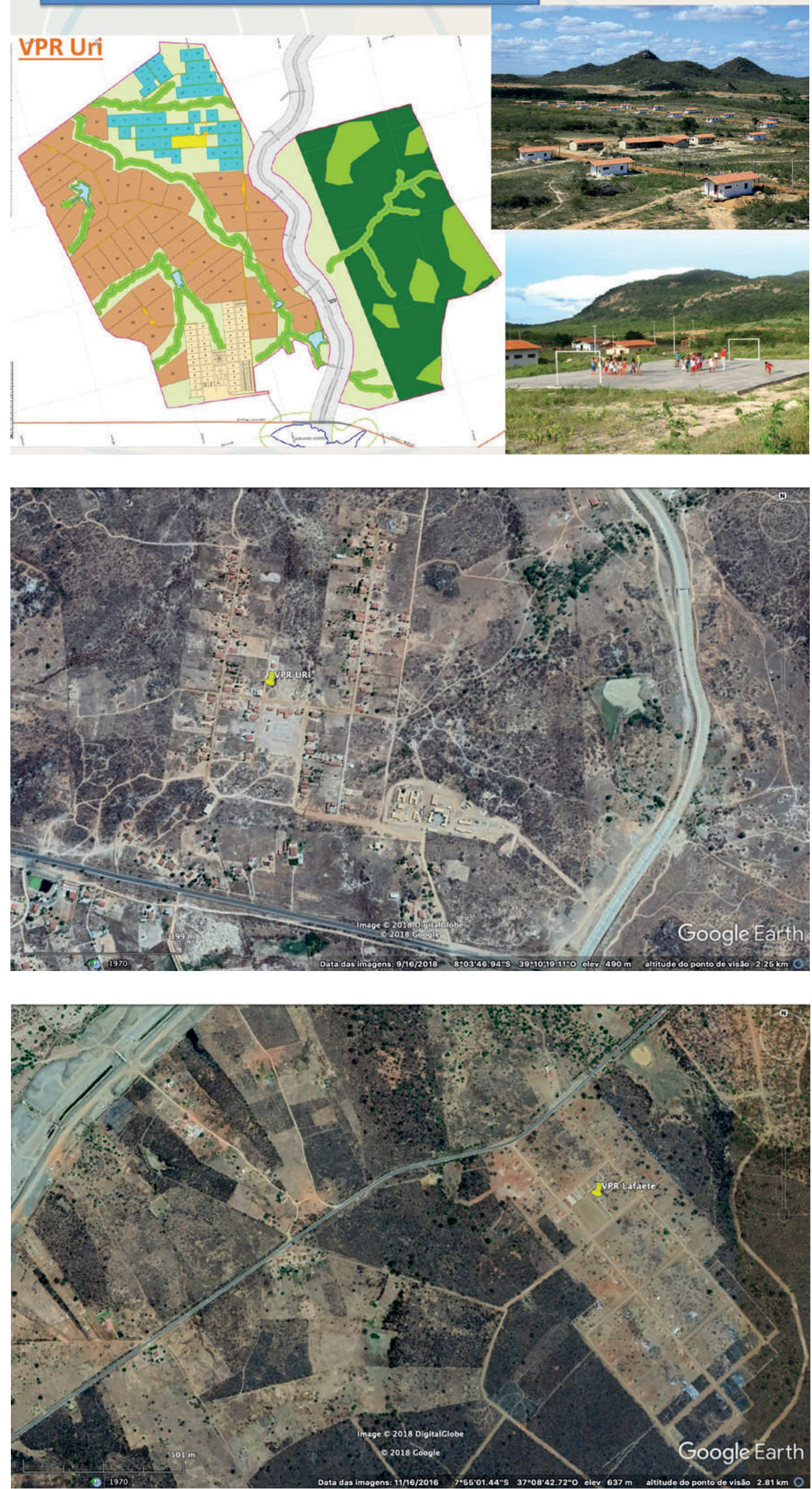

Figura 91 - Planta da Vila Produtiva Rural Uri, em Salgueiro (PP

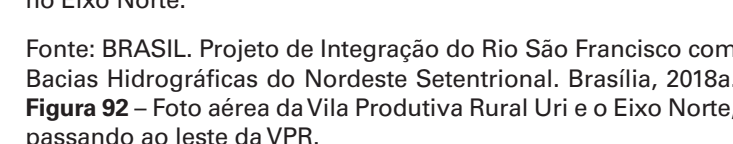
Figura 92 - Foto aérea daV.
passando ao leste da VPR. 2016 assistente social Helena Barros,

Toda familia está recebendo mínimo ene a salario próxima inovaçâo prevista, vai ser um salário. Quando eles receberem o sistema, que está previsto para salário mínimo durante seis mer mes.

Sobre o processo de adaptação, os moradores daVPR Lafaete contaram que e de capacitacăo dos reassentadipativas gerenciadora. Alguns comentaram petar muito contentes com a nova morada, pois antes possuíam casas de barro e na VPR eram de alvenaria. Outros não eram proprietários do local de onde foram removidos e com a VPR agora possuiam seu pedaço de terra. Porén muitos disseram que o processo de que eles próprios haviam construído, as vezes há mais de 60 anos, sendo derrubadas. Também comentaram sobre uma dificuldade de se adaptar ao novo modo de vida em comunidade, com Entrevistamos a família da Sra. Sobre o processo de elaboração do EIAcasas proximas unas das outras como Marinelma (ver Figura 96), moradora RiMA e a participaçaao da população, a corre nas vilas, ja que antes moravam da Vila Uri desde o inicio. Ela comentou Sra. Marinelma comentou que ela ia às perdido suas casas e se distanciado naquele momento ia esporadicamente de onde hoje é aVPR para participar das do modo de vida que levavam, na VPR para acompanhar como andava audiências. Entretanto o processo não era muitas haviam investido em maiores o assentamento, muito embora o Ml participativo, os moradores se sentiam infraestruturas para suas residências, não tomasse providências em relação às inibidos de contrapor os organizadores como por exemplo, a construçāo de transformaçoes que vinham ocorrendo e que foi um processo impositivo. A poços artesianos, plantaçós e reformas. naVPR, contorme sera descrito a seguir. necessidade de sair de suas casas para Já na VPR Uri (PE), que já existia há sete (PB) a água ainda não havia chegado, nesse tipo de empreendimento, tamaxém anos no momento da entrevista, os principalmente pelo falo de que as obras não foi uma opção:

depoimentos recolhidos trouxeram alguns do Eixo Norte não estavam finalizadas, elementos relacionadosàstransformaçoes de maneira que a comunidade estava da concepção territorial que a VPR teria, sendo abastecida por poços ou carro justamente por conta dessa longa espera pipa. Sra. Marinelma disse que, segundo da água e a nấ inplataçáo da produçáa o Mi, os moradores daVPR só receberiam agricola irrigada. Diferente daVPR Lafaete, o curso técnico de irrigação quando ninguém da depoimentos dos moradores mais livres. não irrigadas para subsistência, como viviam antes de serem reassentados pela obra de transposição.
Eles vieram e empossaram nossa terra para o projeto. E não tinha tinha que sair de lá. Eles precisavam da área, né? - Informação verbal concedida em entrevista por Sra.
Marinelma, moradora da Vila Produtiva Rural Uri, em Salgueiro, no dia 9 de setembro de 2017 


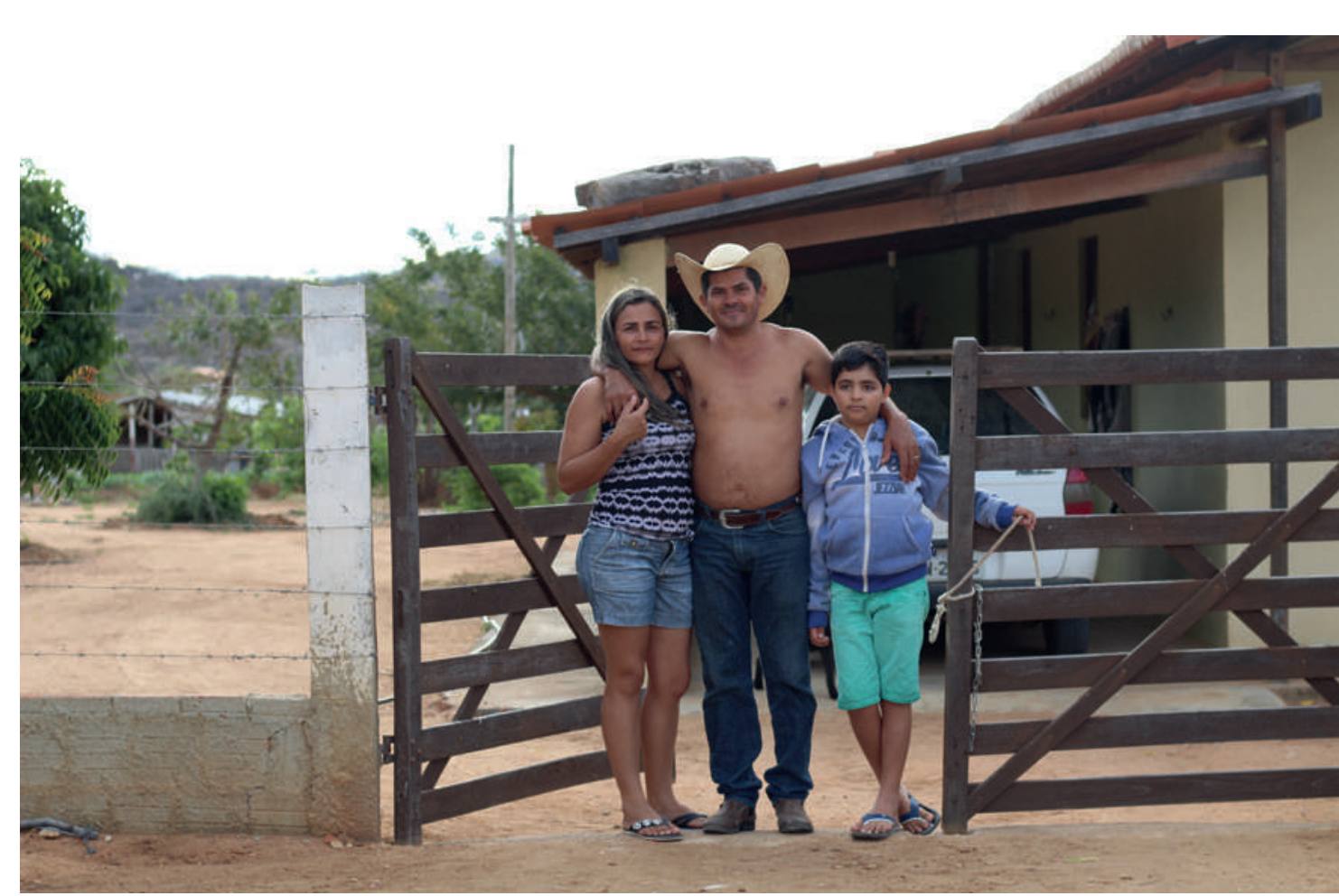

chegada da água e talvez com a falta de seus vizinhos. Segundo ela, se houvesse abastecimento semelhantes às de suas

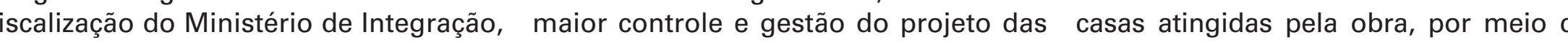
EV e

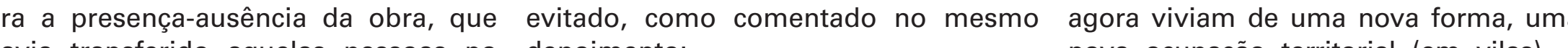
hevia

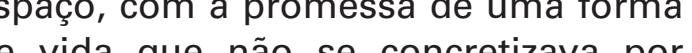
completo. E a vila, com a ausência da agua, também agora se transformava em algo mais parecido a um loteamento fural, que estava sendo sub-loteado do que com uma vila produtiva. S

No início não podia vender, era para mesmo muitos, estáo loteando que entrou, não está tendo muito mais. Hoje mesmo, para ser sincera, eu năo estou muito satisfeita como sobreviver do gente náo tem viver, que é plantando e criando, principal
pequeno.

[...] disse que a gente tinha que fazer
denuncia oficial. Eu disse, vem cá, eu não vou pegar um vizinho meu uma pessoa, e vou denunciar ele vista aqui? Você, do MI, sabe muito bem de quem são os lotes, sab muito bem o lote que está sendo foi feita a reuniâa , já foi comentado sobre isso. Mas eles querem que gente escreva, tire uma fotinho de para eles. Eu náo vou fazer isso uma pessoa daqui? $\mathrm{E}$ eu vou viver como aqui?

Apesar de todos esses problemas, Sra. Marinelma e sua família têm esperanç de que quando a água chegar, a vida de todos ali irá melhorar. Seu marido apenas Sra. Marinelma também contou que lamenta que o PISF poderá prejudicar uma pessoa comprou uma parte do ainda mais o rio São Francisco, "que erreno de seu vizhou uma pate do

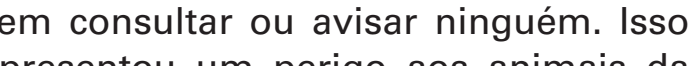

merigo aos animais da Essa esperança da família da Sra. Vila, que corriam o risco de cair no poço, Marinelma revelou algo que se passou Marinelma. Em uma das visitas feitas a dialética da presença-ausência da obra pelos representantes do Ministério da na vida dessas pessoas, que foram mora Integração Nacional (MI), ela comentou nas vilas estimulados pela promess sobre esse problema e foi orientada de uma melhora de vida, a partir do formal por escrito e enviar ao MI. capacitacão para se viver da agricultura Porém, nem a moradora nem nenhum irrigada. Com a não chegada da água morador se sente à vontade em fazer as famílias tinham condições de tal reclamação formal, pois tem medo

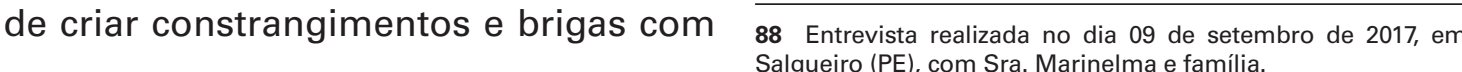

Centros Urbanos e os impacto de uma grande obra em municípios de economia frágil

$$
\mathrm{PE}_{\mathrm{PB}}^{\mathrm{P}}
$$

Ao longo do trabalho de campo, visitouse algumas cidades tanto do Eixo Leste, quantodo EixoNorte. Foramelas:Campin Grande (PB), Monteiro (PB), Sertânia (PE) Custódia (PE), Salgueiro (PE), Cabrobó ne (ver Figuras 97 - municíipios visitado no Eixo Norte). Em todas essas cidades os relatos das diversas categoria entrevistadas - comerciantes, gestores públicos, professores, moradores beneficiados e impactados pela obra tiveram semelhanças em relaça construc̃̃o do PISF causou Com que à Campina Grande, um município mais estruturado economicamente, capital é um polo universitário e regiona cujo salário médio mensal era de 2, salários minimos em 2016, os demais municipios possuiam uma economia mais baixo do salário médio mensal: Salqueiro (PE), Custódia (PE) e Sertânia (PE) o salário médio era de 1,8 salários mínimos; em Monteiro (PB), de 1.7; em Cabrobó (PE), de 1,5 (IBGE, 2016).

Com exceção de Campina Grande que possuía uma população estimada municípios visitados por onde a obs passou consistiam, em grande parte, em municípios também de portes parecidos, tendo Custodia (PE), Sertânia (PE), Cabrobo (PE) e Monteiro (PB) um pouco mais de 30 mil habiantes (BBE, 208). Já Salgueiro, uma cidade um pouco maior que as mil como um centro urbano regiona equidistante de quase todas as capitais nordestinas. Na cidade de Salgueiro ocorre entroncamento de importantes obras de infraestrutura do Nordeste: o Eixo Norte da Transposição do rio Sáo Francisco, importantes rodovias, a BR-116 e a BR-232, que cruzam a região de Norte a Sul, Leste a Oeste (ver Figura 98). Ainda assim, foram estas obras que moveram a economia do municipio nos últimos anos.
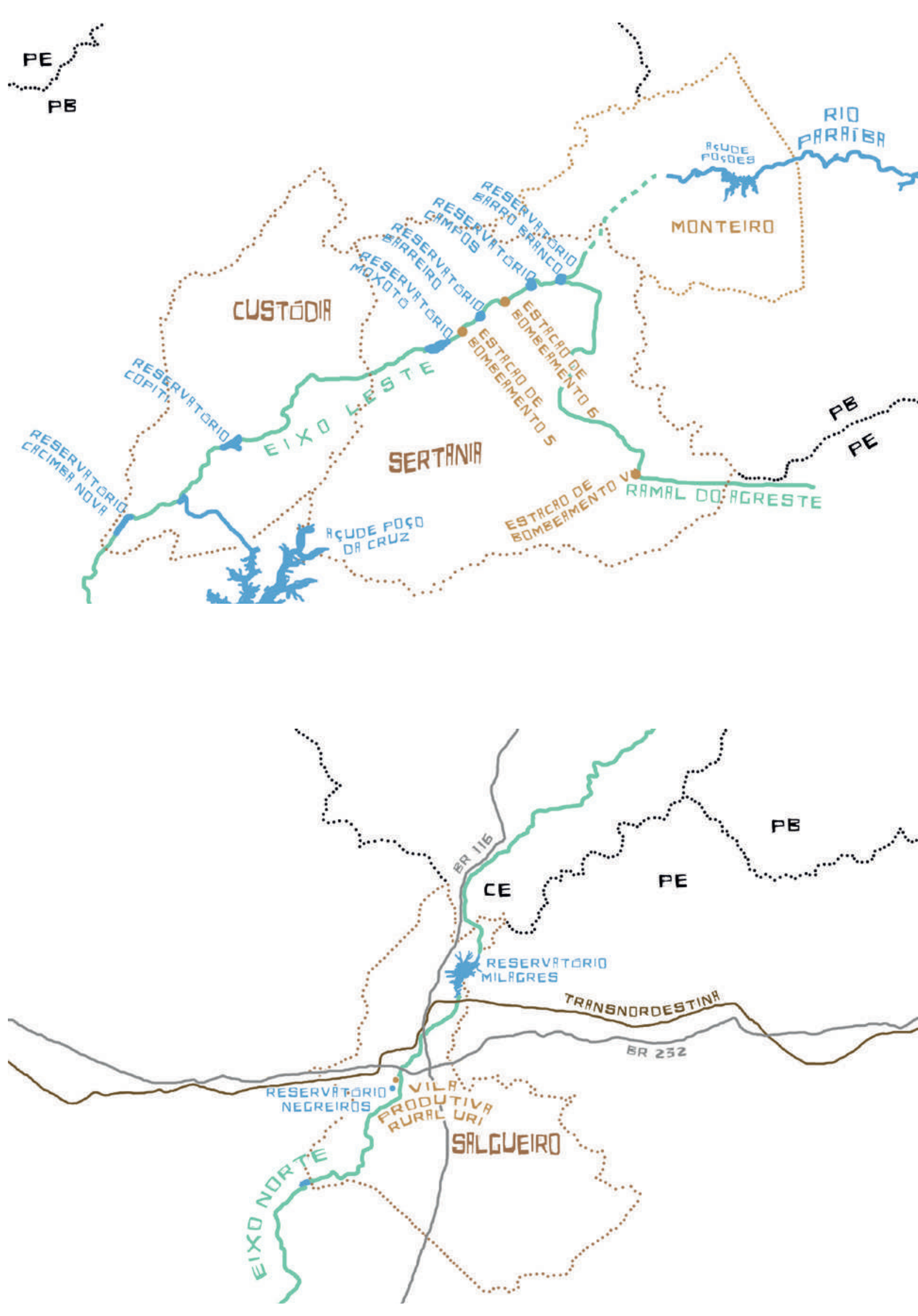

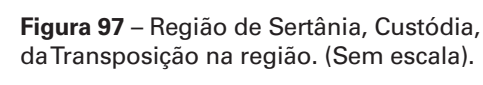

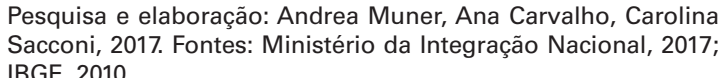
Figura 98 - Salgueiro e o cruzamento de difierentes

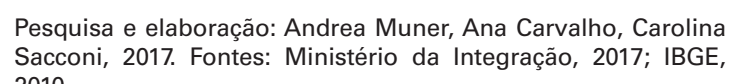




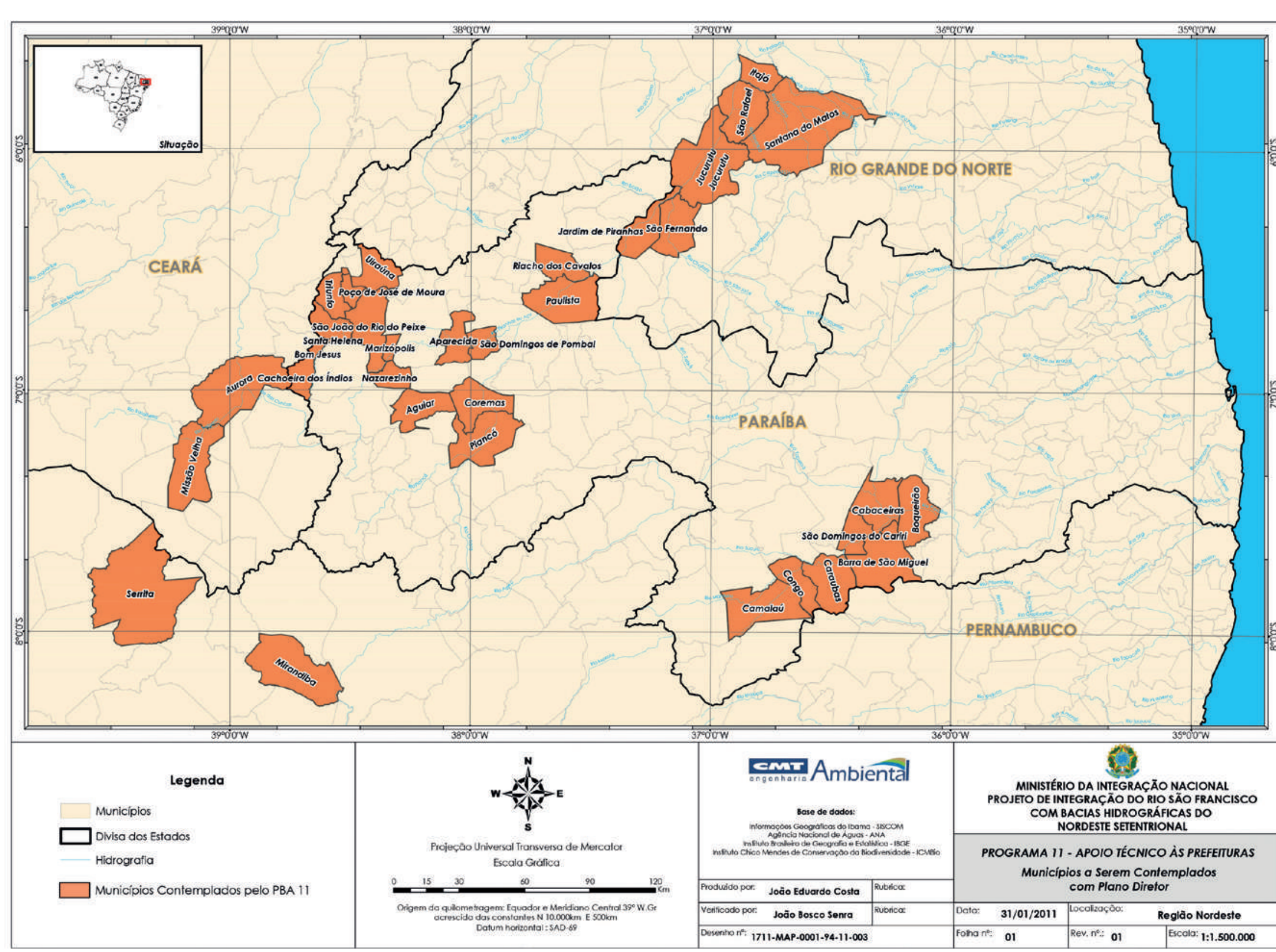

Esses municípios que não tinham uma Truká, etnia indígena cujo território se conomia bem estruturada sofreram localiza em Cabrobó, que narrou um mpactos semelhantes a pafir da pou

insactos esses relatados em entrevistas Tais impactos incluem: aumento do preço dos aluguéis e da terra, como exemplificado no item sobre Monteiro (PB); aumento do movimento no comercio e melhora na economia trouxe consigo muitos que a obra de fora; aumento de violência, uso de drogas e gravidez precoce; êxodo rural e imigração para essas cidades por conta da movimentaçăo de capital que abra trouxe; novos empreendimentos imobiliários e crescimento da malha mpreendimentos e ofertas de crédito entre outros. Um bom exemplo foi descrito pelo Sr. Aurivan dos Santos Barros, conhecido por Sr. Neguinho Truká (ver Figura 100), cacique do povo que passaram por act dizia que isso iria durar tempo. Aqui quase ninguém te mundo tem seu próprio pé de meia

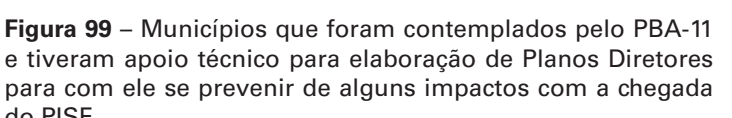

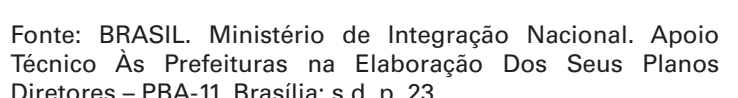

para fazer, os seus plantios. O cara unha um pé de meia com o plantio
uma vontade de comprar um carro. Com o holerite da firma ele dava com o que ele tinha e ficava pagando o carro com o que ele foi desempregado, perdeu tudo. entrevista pelo Cacique Nega en no dia 08 de setembro de 2017, em Cabrobó.

Esses são indícios bastante comuns dos efeitos de uma grande obra em um município que não é bem estruturado economicamente, desencadeando, durante aquele periodo, a circulaçao de mais pessoas, criando maior demanda por serviços e, portanto, gerando

Prevendo isso, O PBA-11, referente ao "Apoio Tecnico As Prefeituras $n$ Elaboração Dos Seus Planos Diretores" foi elaborado para auxiliar prefeituras que não tinham Planos Diretores a impactos que a obra gerou. As cidades criar açoes estratégicas que deveráo em que a obra já havia passado viviam ver inplenentas pelo poder Publico uma espécie de "depressão pós vervicos o dos instrumentos de gistã Transposiçá, has palavias de Sr. Cajó, dministrativa consideradas de modo a equipá-las pessoas endividadas pois o fluxo de para responder às possíveis demandas dinheiro havia diminuído, ou mesmo que advirão com a implantação do desempregadas. E quase nada daquela empreendimento, garantindo-se que as movimentaçáo havia sido revertido em mesmas não afetem prejudicialmente melhorias urbanas. É nessa direção astabilidade dos centros urbanos que vai o comentario envolvidos, assim como o bom

desenvolvimento das atividades pp. 4-5). O PBA elencou nove cidades no Eixo Leste que e não possuíam Plano Diretor, e vinte quatro no Eixo Norte (ver Figura 99). Segundo o PBA-11, os Planos Diretores seriam elaborados essencialmente de

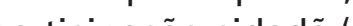

Apesar de o PBA-11 ter tido o objetivo de prevenir alguns dos inconvenientes da chegada do PISF, o documento colocou que, por outro lado, outros inconvenientes seriam de baixa como a fluência de pessoas de fora em busca de emprego e a própria apreensão motivada, entre os habitantes locais, face às possiveis mudanças em suas rotinas pela presença das obras e, futuramente, a operaçao do empreendimento (PBA-
11, s.d., p. 2). Porém, trata-se de uma Em Custódia ocorreu o mesmo. Segundo 11. uma vez que esses inconvenientes e de um hotel na cidade do gasolina são os mais comuns óbvios que que abriu esses empreendimentos ocorrem com a chegada de uma grande durante a obra da Transposição, o PISF obra em pequenos municipios, como movimentou a economia local, proen se o ir-e-vir de pessoas de fora das a finalização da obra no município, cidades náo se relacionasse às questóes também trouxe forte ocorrência de (entricas desemprego:

Apesar deste PBA-11, com os depoimentos coletados e também com a observaçăo de cada cidade
Boa parte das pessoas que zona rural. Ainda que alguns tenham como mototáx emprego, a maior parte permanece dea regada. Uns voltaram para mototáxi, outros vão embora, surgem municipios, ou boa parte, acho que mais de 70 ou de zona urbana ou de zona rural, meio meio, na verdade. [...] E o pessoal foi de $90 \%$ foram embora. - Informação verbal concedida em entrevista Trabalhadores Rurais de Sertânia José Monteiro de Almeida, Sr. "Bó, o dia 7 de setembro de 2017, em

[...] a transposição foi um benefício construçáa civivil, o mercado mobiliário, gerou emprego. [...] A investiram em uma casa própria. 


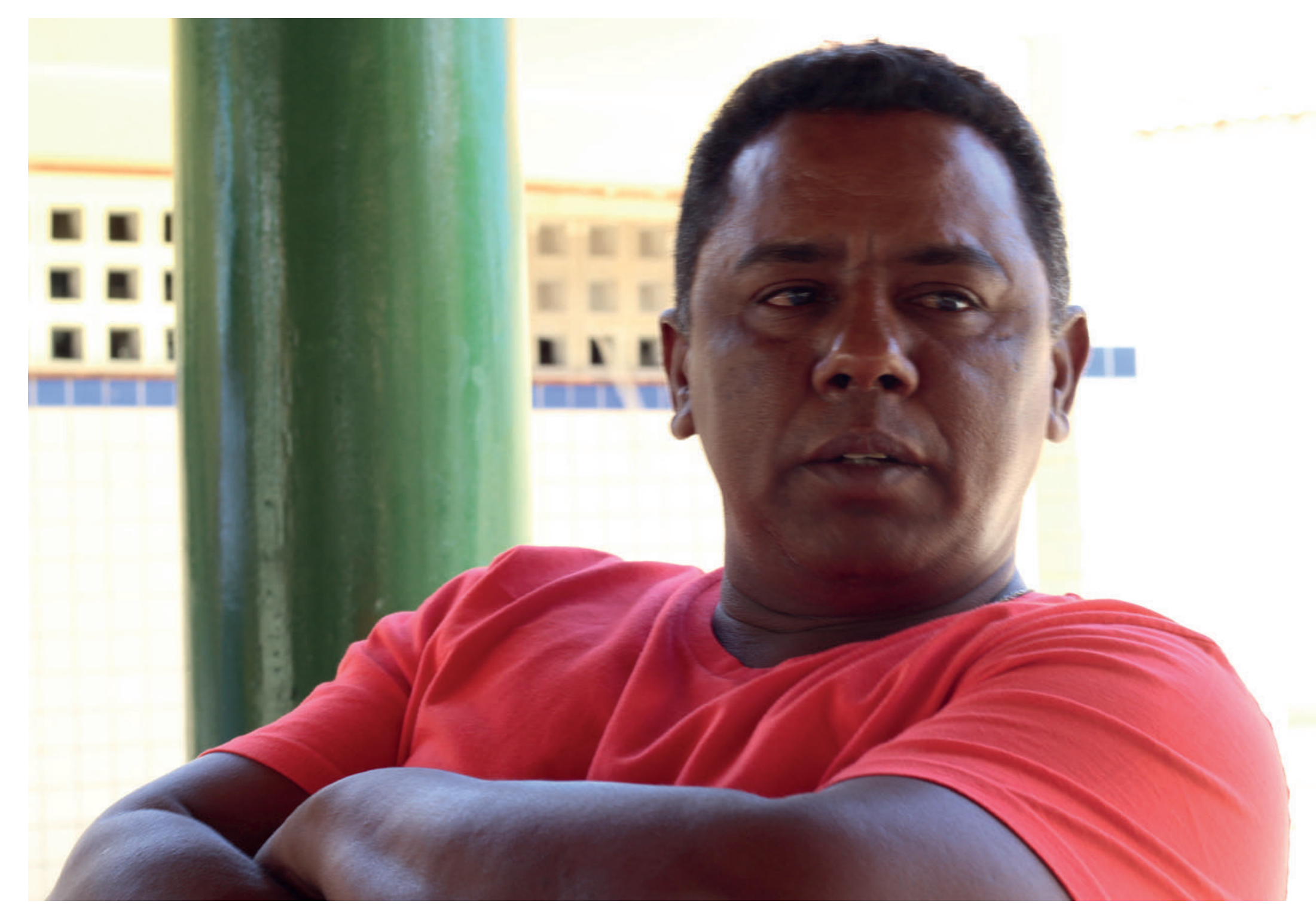

Lojas de móveis cresceram, vieram açamba. [...] O valor dos imóveis aumentou, a prefeitura investiu em pavimentação, iluminação. [...] Mas desemprego, o fluxo de pessoma na cidade diminuiu. Houve uma "expansão física" da cidade, mas alguns empreendimentos pararam.com Sr. Albino, proprietério de pisto de gasolina e de hotel na entrad da cidade de Custódia, no dia 7 de setembro de 2017

Em relação a Cabrobó, Maria José Gomes Marinheiro, lideranca indígena da etnia Tumbalalá, conhecida como Sra. Maria Tumbalalá (ver Figura 101) que tambem era diretora de uma escola pública em Cabrobo, relatou que o municipio náo passou por obra. Segundo a liderança, o dinheiro que chegou na cidade através do grande para infraestrutura urbana, como para escolas, hospitais etc. Maria Tumbalala ainda disse que houve crescimento da da questão socioambiental ter piorado com o desmatamento da caatinga para e pôde ver um desequilíbrio ambiental atraves da presença de animais que não se via antes na cidade.

Eu acredito que [a Transposiçāo] trouxe. Se você procurar, o que é que tem que foi a Transposiçao que deixou pra Cabrobo, náo tem. Nao que não teve plajipa, en acredito para receber. Porque, quando vocé faz um plano, voce tem as açoes e você tem as perspectivas qual foi a acão bem-sucedida, que teve êxito? Então, eu não vejo. Aqui em Cabrobó náo foi ampliado um hospital, náo foram ampliadas as produçôes, de cultura, ou producões de acolher jovens, náo tem nada. 0 hospital continua sem estrutura [...]. questão da prostituicão, as drogas, drogas que não se falava aqui em Cabrobo, hoje falam. Veio muita questão sociommbiental pioçau Voce hoje vê formiga dentro das casas, muita muriçoca, você về animais que vocề nunca viu dentro da cidade. Com o desmatamento codinho Transposição, vem um desequilíbrio ambiental grande. Você vê micos, camaleoes, cobras. (...) - Informaçă Sra. Maria Tumbalalá, no dia 8 de setembro de 2017, em Cabrobó.

seguir, a partir de fotos aéreas, fotos de campo e fotos do Google Street Vousas Visf nos muscla visitados por onde a obra passou e a ( transformações centros urbanos por a obra passou, Campina Grande un uretamente, conforne a obra passou em anterior desse capítulo.

Em Cabrobó (PE), entre 2008 (Figura 102) 2017 (Figura 103), tambem foi visive o crescimento do perimetro urbano da cidade, em especial no lado norte da

A seguir a Figura 104 evidencia um lado mais antigo da cidade de Cabrobé (PE) em contraponto com a Figura 105, que evidencia esse bairro novo, que começo a expandir com a chegada da obra em 2007. Pode-se ver que a cidade cresceu sem nenhuma infraestrutura urbana, sem

\section{Figura 100 - Foto da entrevista com a Sr Neguinho Truká}



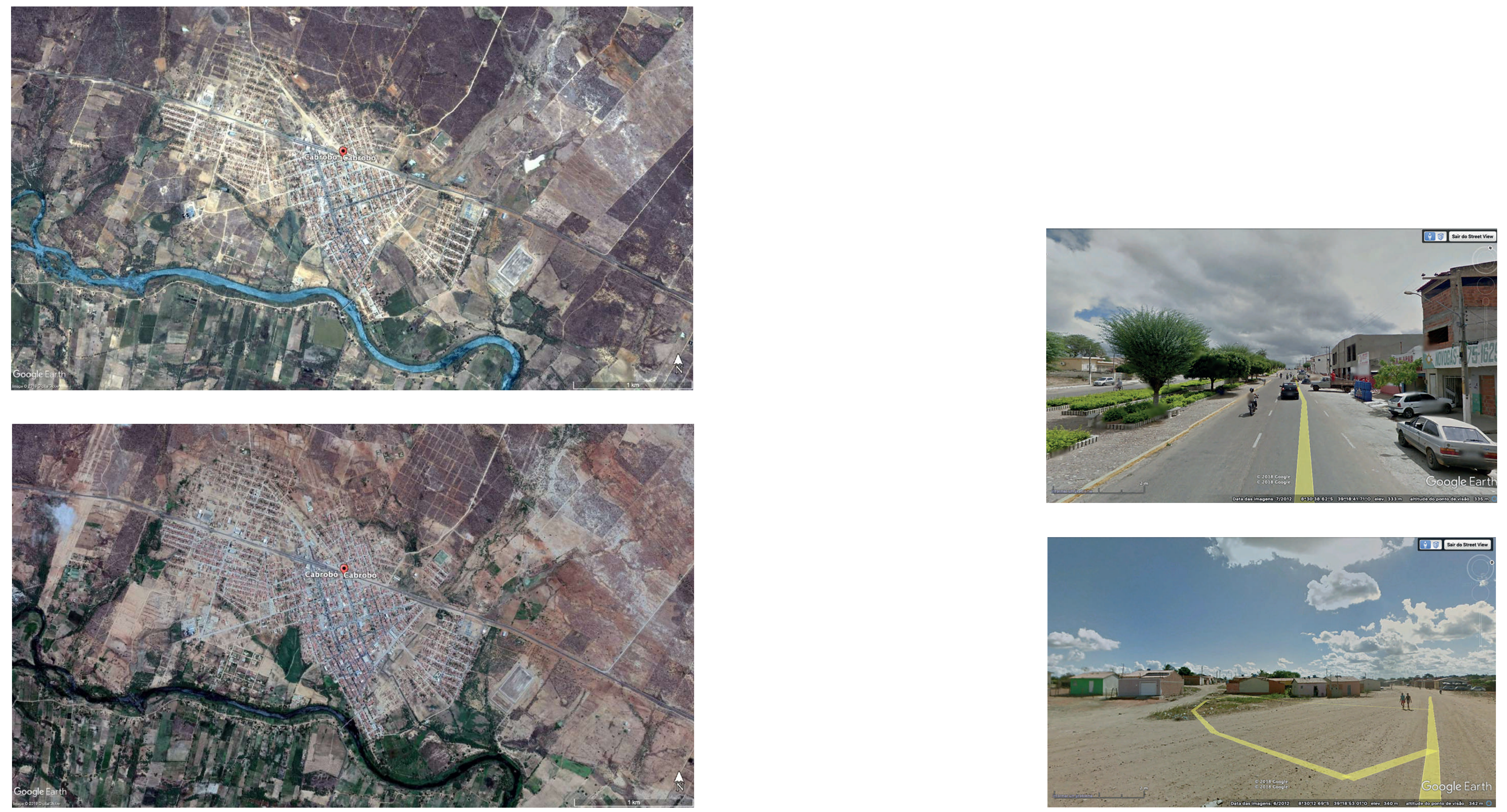

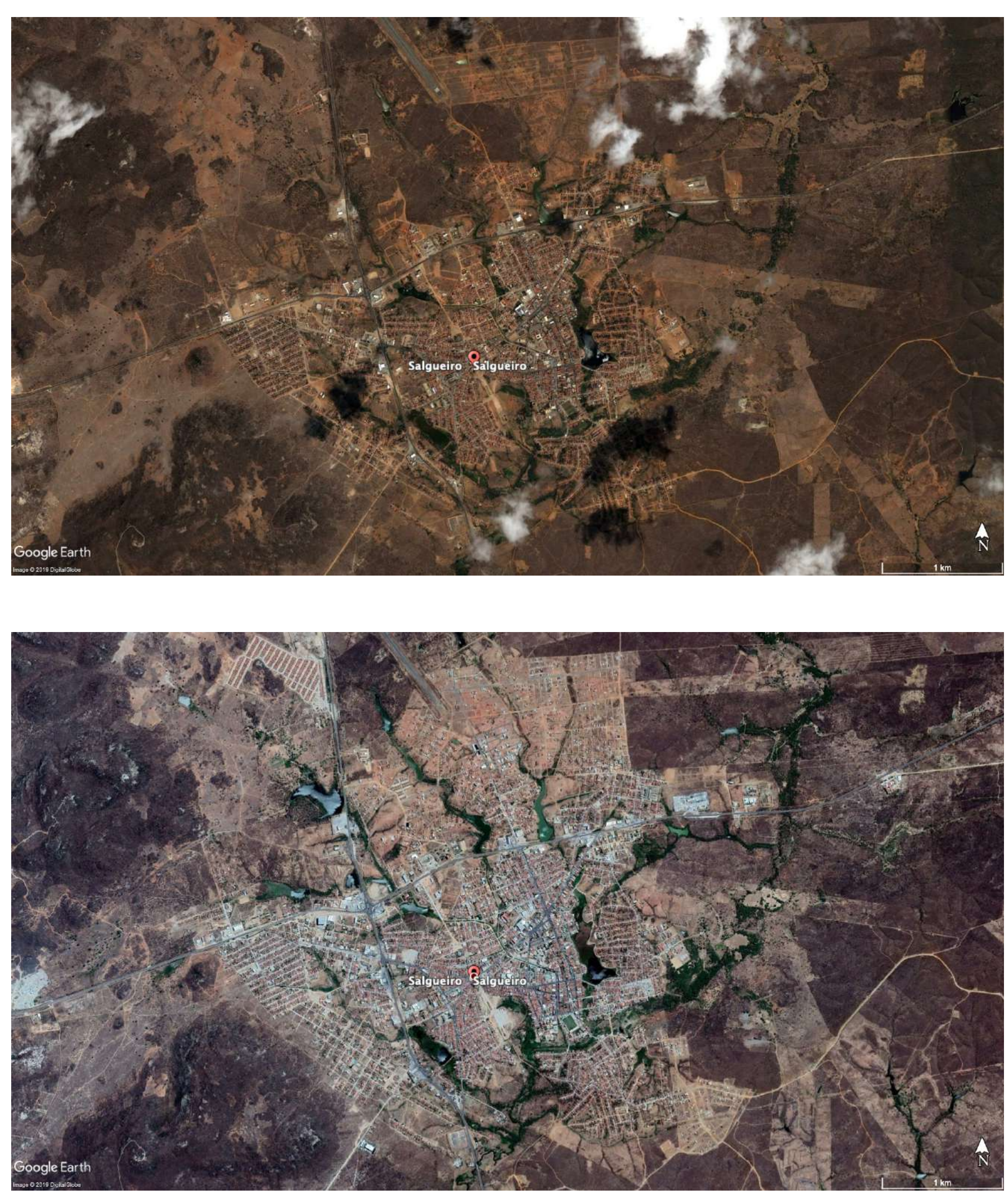

Em Salgueiro (PE), entre 2007 (Figura 06) e 2018 (Figura 107) a cidade se expandiu em especial ao norte, em
relação à BR 252 que corta a cidade de relação à BR 252 que corta a cidade de leste a ãste, mas tamberm houve ur

A seguir, algumas fotos desses novos (Figuras 108, 109 e 111), visitados em um trabalho de campo realizado em 2013. Pode-se observar que se tratava de empreendimentos quitas vezes cornes com referenciais externos de formas de vida, referenciais externos à cultura da cidade. As Figuras 108, 109 e 110 exemplificam um pouco esse tipo de empreendimento descolado da realidade da cidade. condominios fechados, dasaços de lazer cercados imagem de uma habitacão luxuosa como a existência de duchas externas, piscinas, cercamentos etc.

$\mathrm{Na}$ cidade também havia alguns empreendimentos realizados pelo

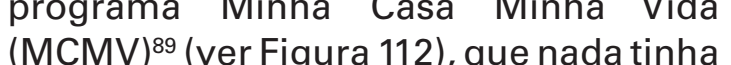
a ver com o impacto do PISF na cidade mas com a política macroeconômica do governo Lula para o Brasil naquele momento, que investiu em construção civil, atraves do mesmo programa que promoveu o PISF. O PAC. Apesar desse federal, era possivel perceber grande parte dos empreendimentos na cidade eram promovidos por empreendedores privados em que o público-alvo eram essas pessoas de fora que vinham trabahar na obra. Muitos desses empreendimentos pareciam vazios quando o segundo trabalho de dissertação, em 2017.
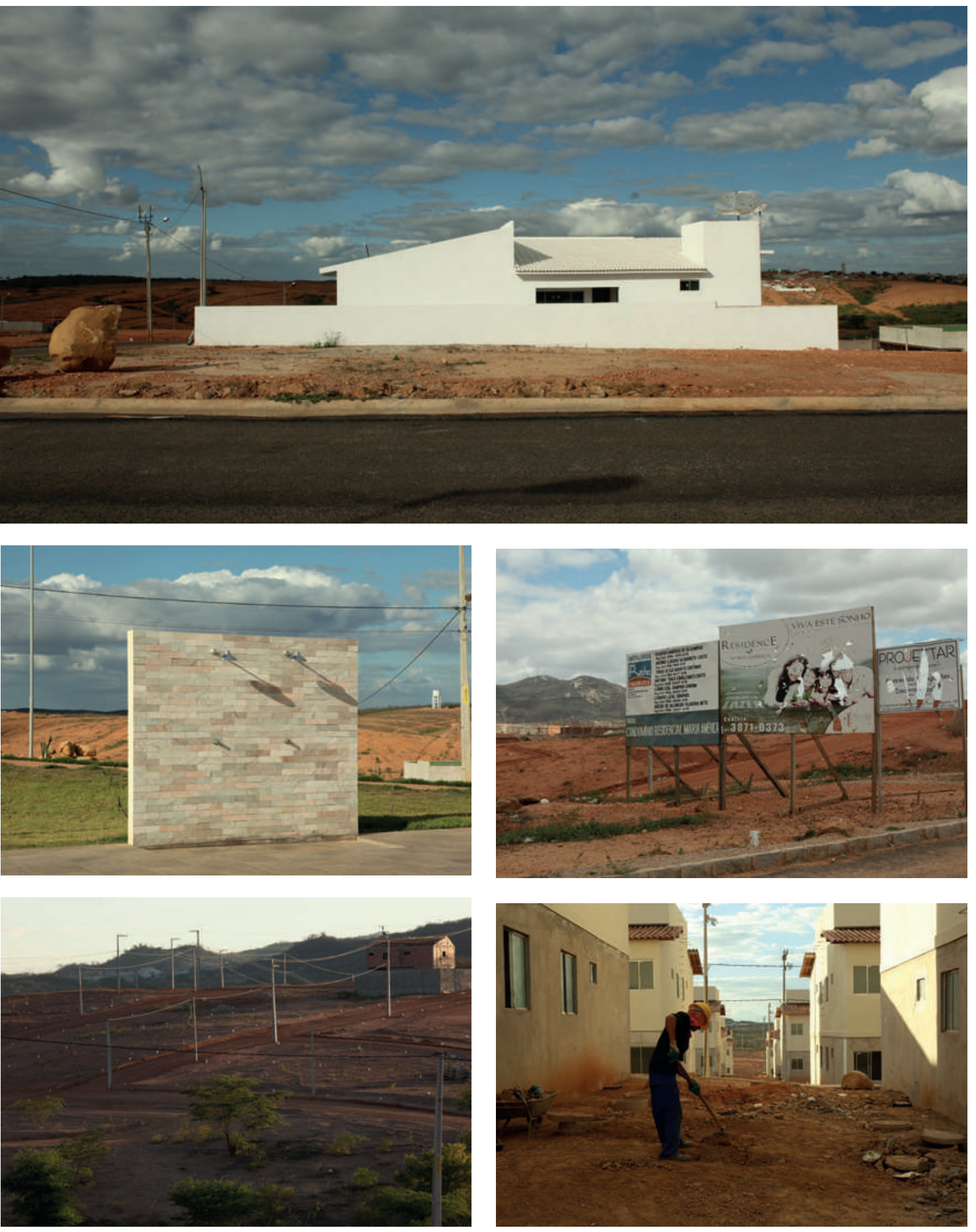

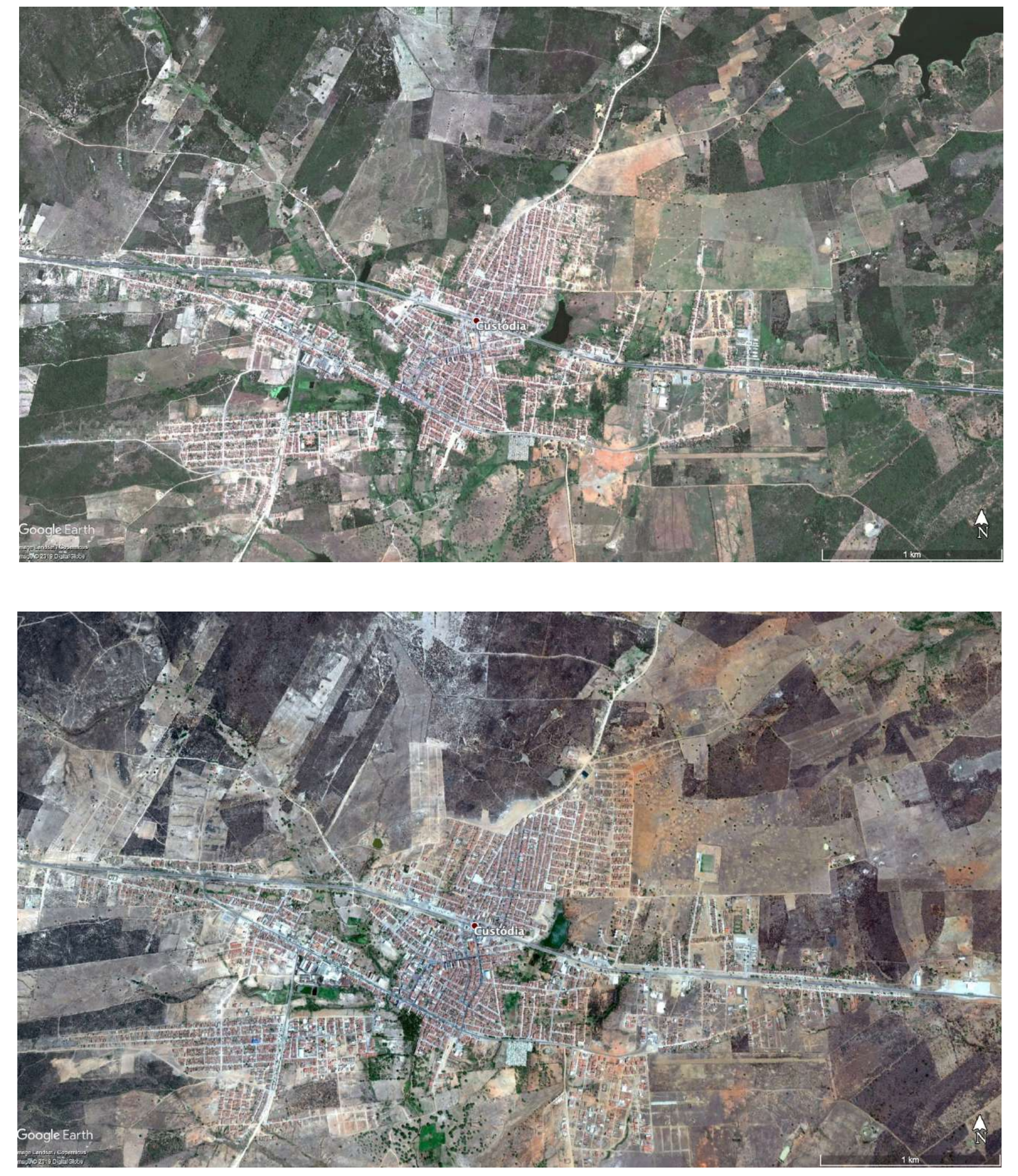

Em Custódia (PE), entre 2010 (Figura o crescimento da malha urbana da cidade com novos loteamentos em todo nordeste, sudeste e sudoeste.

Na Figura 115, a foto da avenida principal da cidade ilustra como se tratava de uma cidade pequena, de beira de estrada, que repentinamente recebeu alguns serviços
que destoavam dos fluxos e usos que que destoavam dos fluxos e usos que
costumavam existir na cidade (como o costumavam existir ha cidade (como o 115), frutos dos impactos do PISF na cidade.

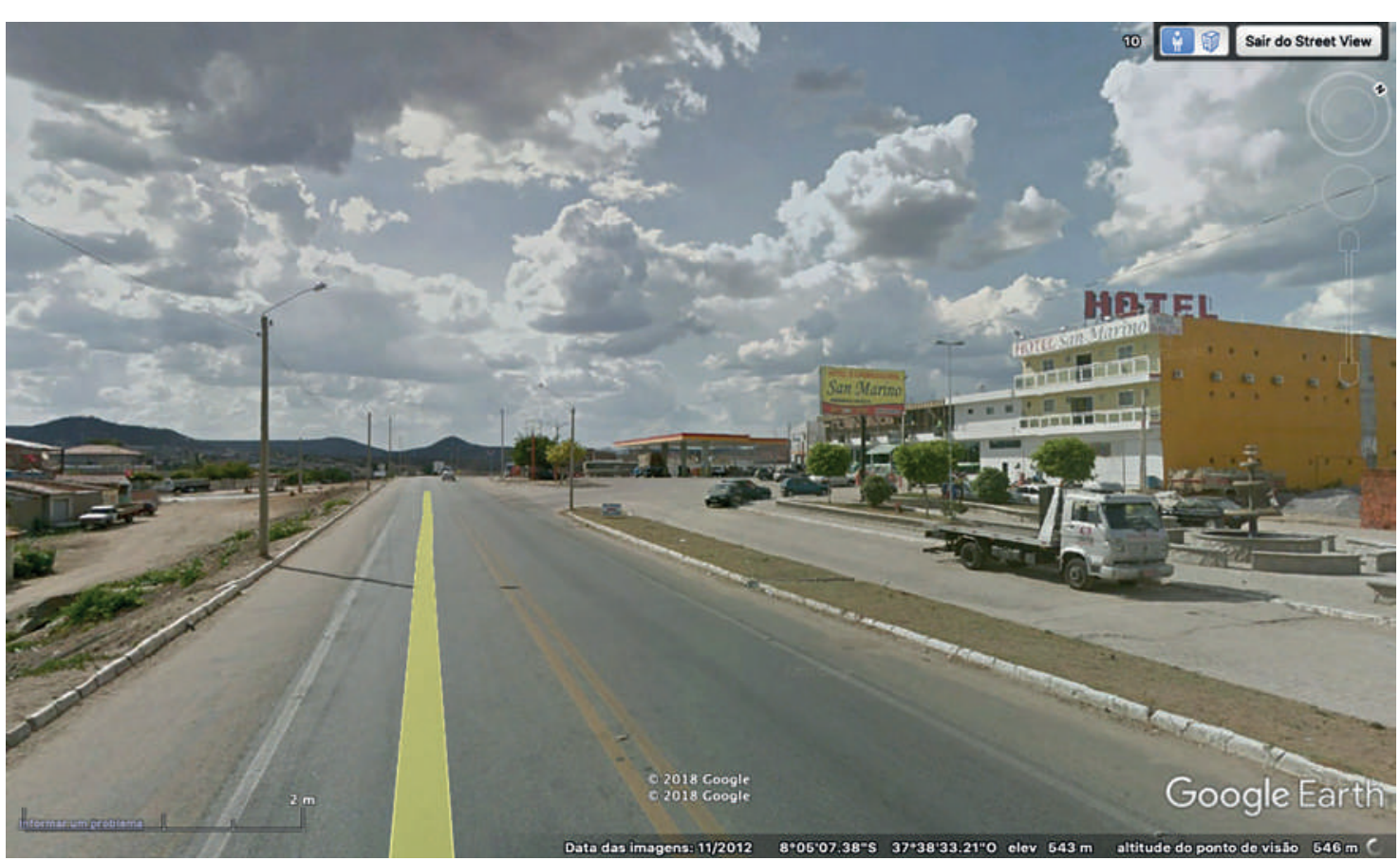

Figura 115 - Foto da avenida principal de Custódia 

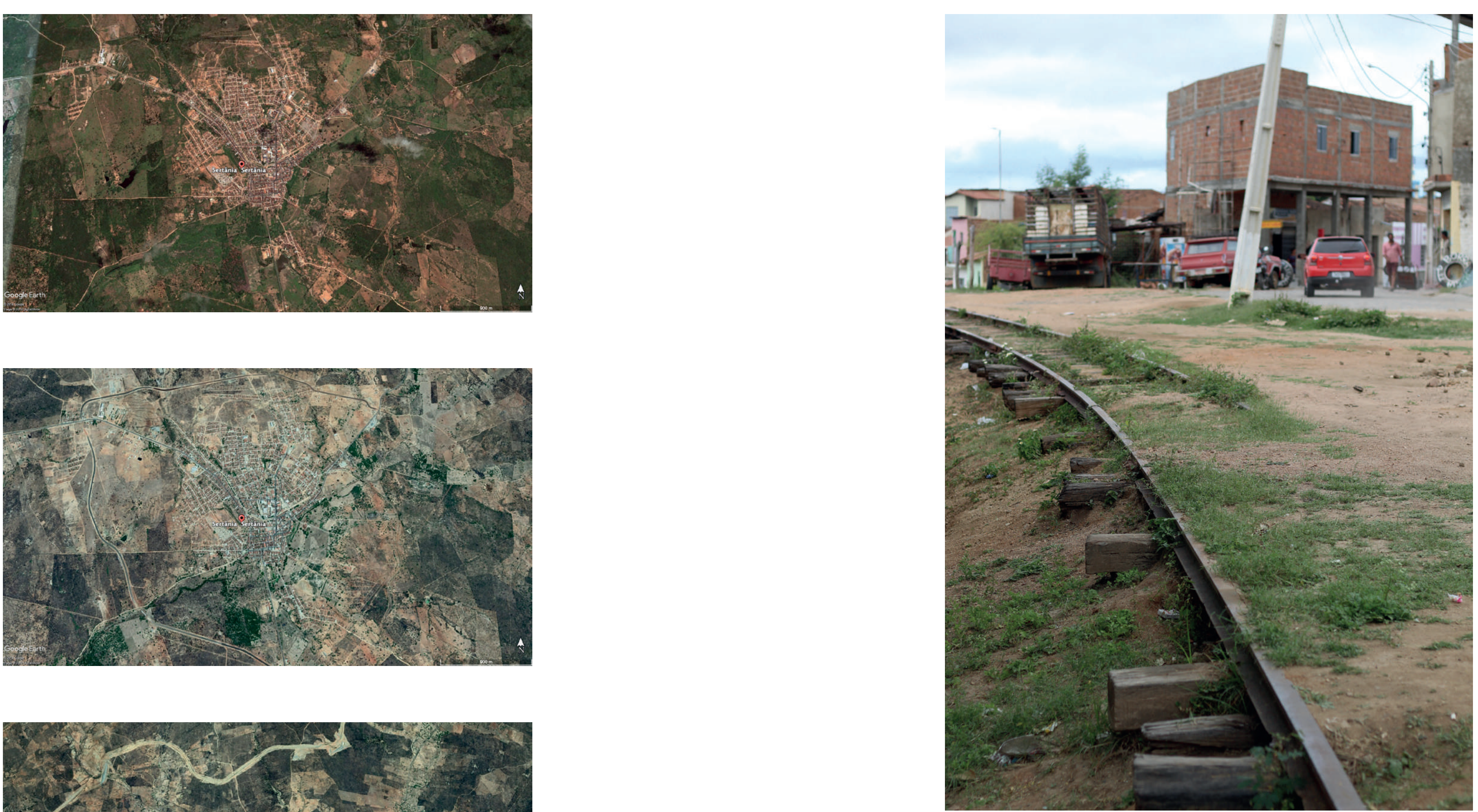

Em Sertânia (PE), entre 2010 e 2018 (ver ciguras 116 e 117 for possivel ver que cidade se expandiu para o sentido norte cida cidade, direçáo por onde tambem o

A seguir, nas Figuras 119 e 120, fotos (1) como o capital obra não ficou na cidade, não se Transformou em melhorias urbanas. Tata-se de uma cidade bastante pobre,

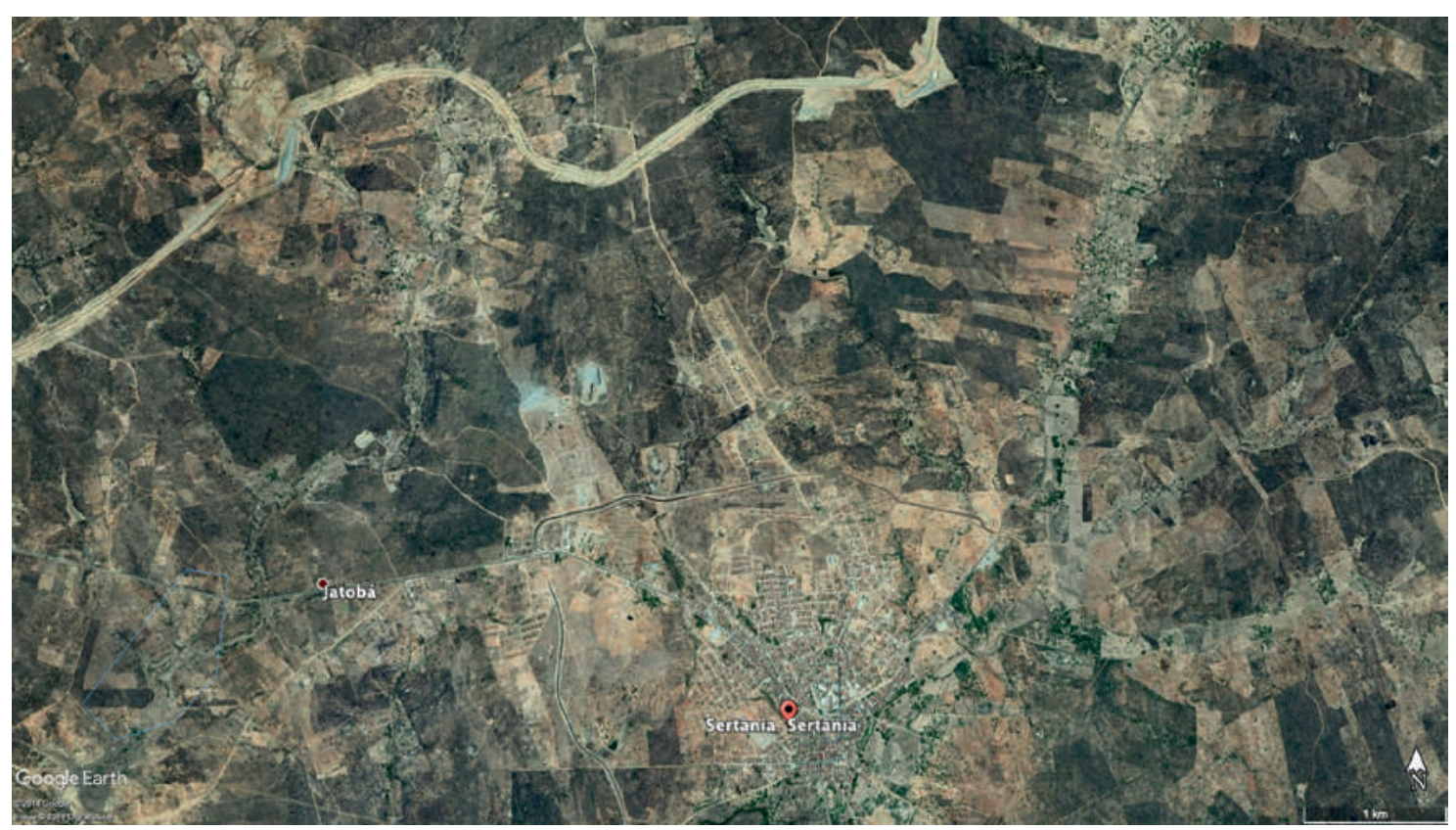

Figura 116 - Foto a área de Sertânia (PE) em 2010.

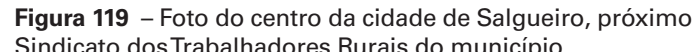

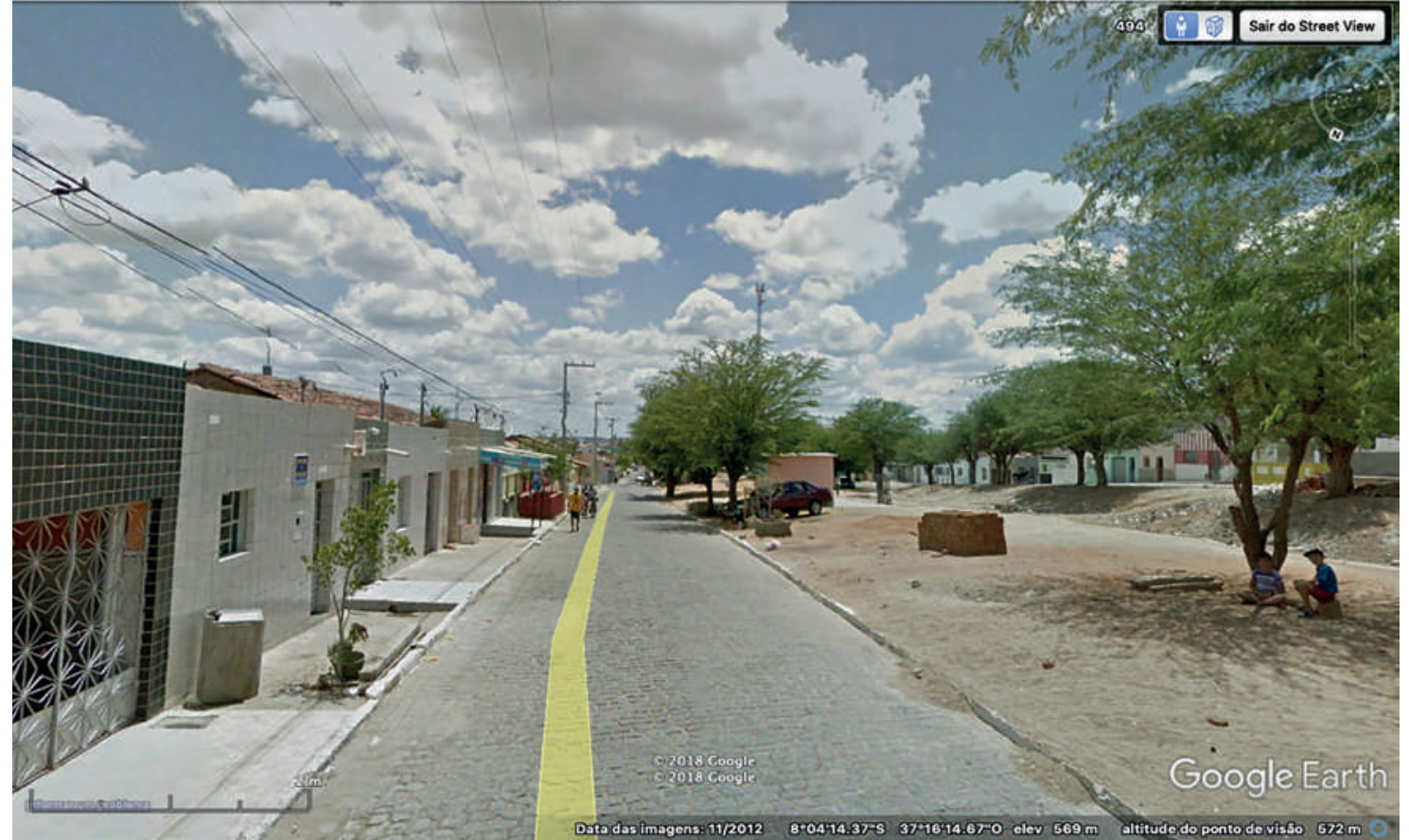

165 Google Street View, 2012. 

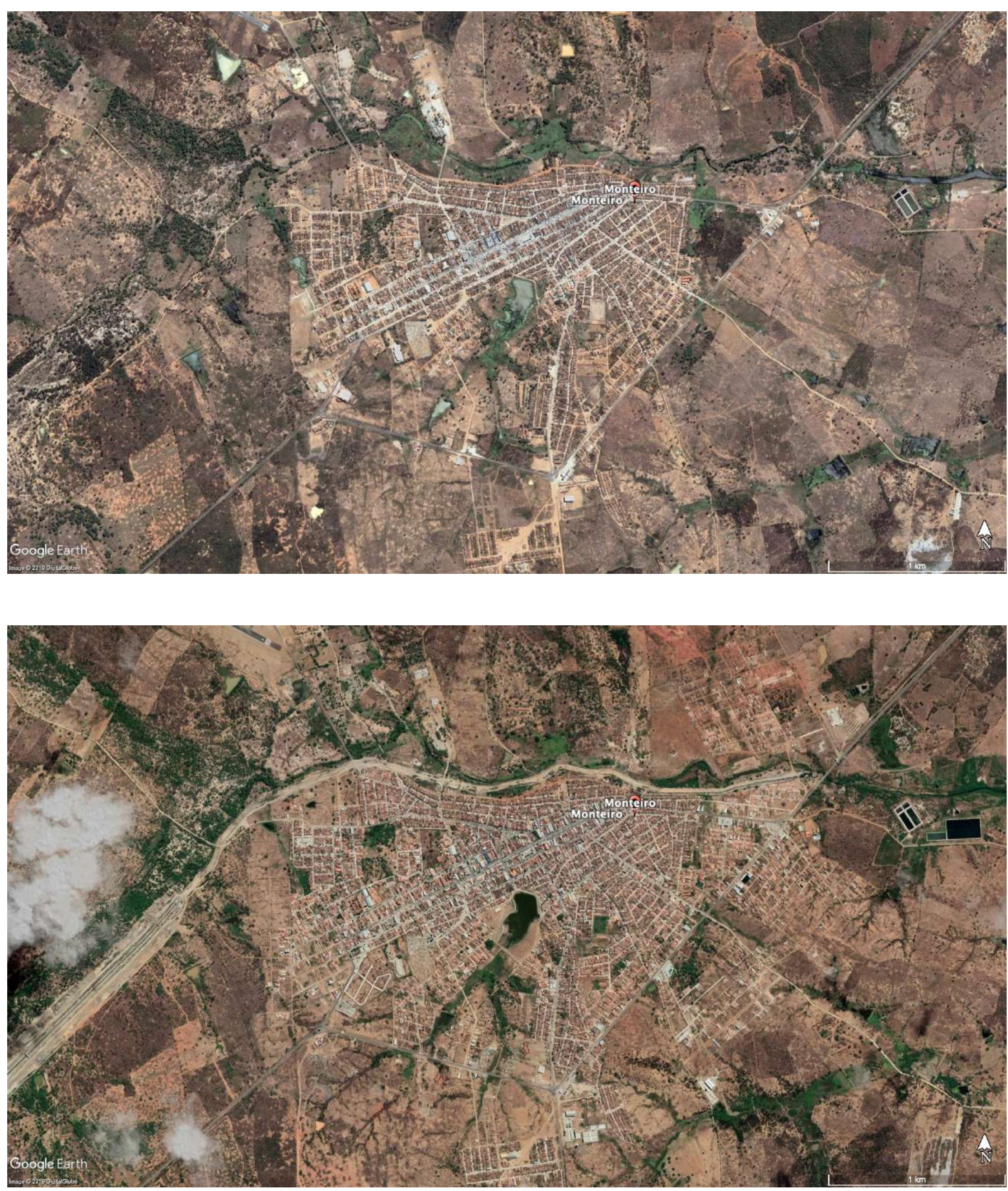

0 crescimento do perímetro urbano em Monteiro (PB) também foi muito visivel. Entre 2006 (Figura 121) e 2016 (Figura 122),
o crescimento na borda sul da cidade foi o crescimento na borda sul da cidade foi
grande, pois na borda norte o canal do Eixo Leste passou conformando de certa forma uma barreira a ser transposta, uma vez que o acesso à outra margem do canal mais ao norte ficou mais restrito, conforme é possível ver na Figura 122. Como jà mencionado em item anterior desse capitulo sobre Monteiro, o canal limitou a quantidade de acessos ao none da cidade, expansão da cidade para esse lado.

Na Figura 123, é possível ver uma tomada da avenida principal da cidade feita pelo Google Street View, na qual, à direita, aparecem algumas casas mais antigas e

uma mais ao fundo com are

nova, que acabou de ser reformada, construcão civil imobiliária que ocorreu com a obra.

Ou seja, a partir da observação dos centros urbanos dos municipios visitados por onde a obra passou, foi possivel observar que as transtales foram muito mais frutos de impactos próprios à passagem de grandes obras por municípios pouco estruturados socioeconomicamente, do que transformações causadas por açōes do governo, seja em instância municipal ou federal. Isso significa que forma trututa e não coordenada de no crescimento urbano, seja nos tipos de empreendimentos (serviços, comércios, condominios residenciais, de forma que esse fluxo de capital e dinheiro que passou por esses municipios não foi revertido em melhorias urbanisticas e foi embora, deixando muitos residentes das cidades por vezes endividados ou tendo seu negócios tornados obsoletos diante das novas dinâmicas econômicas desencadeadas nas cidades.

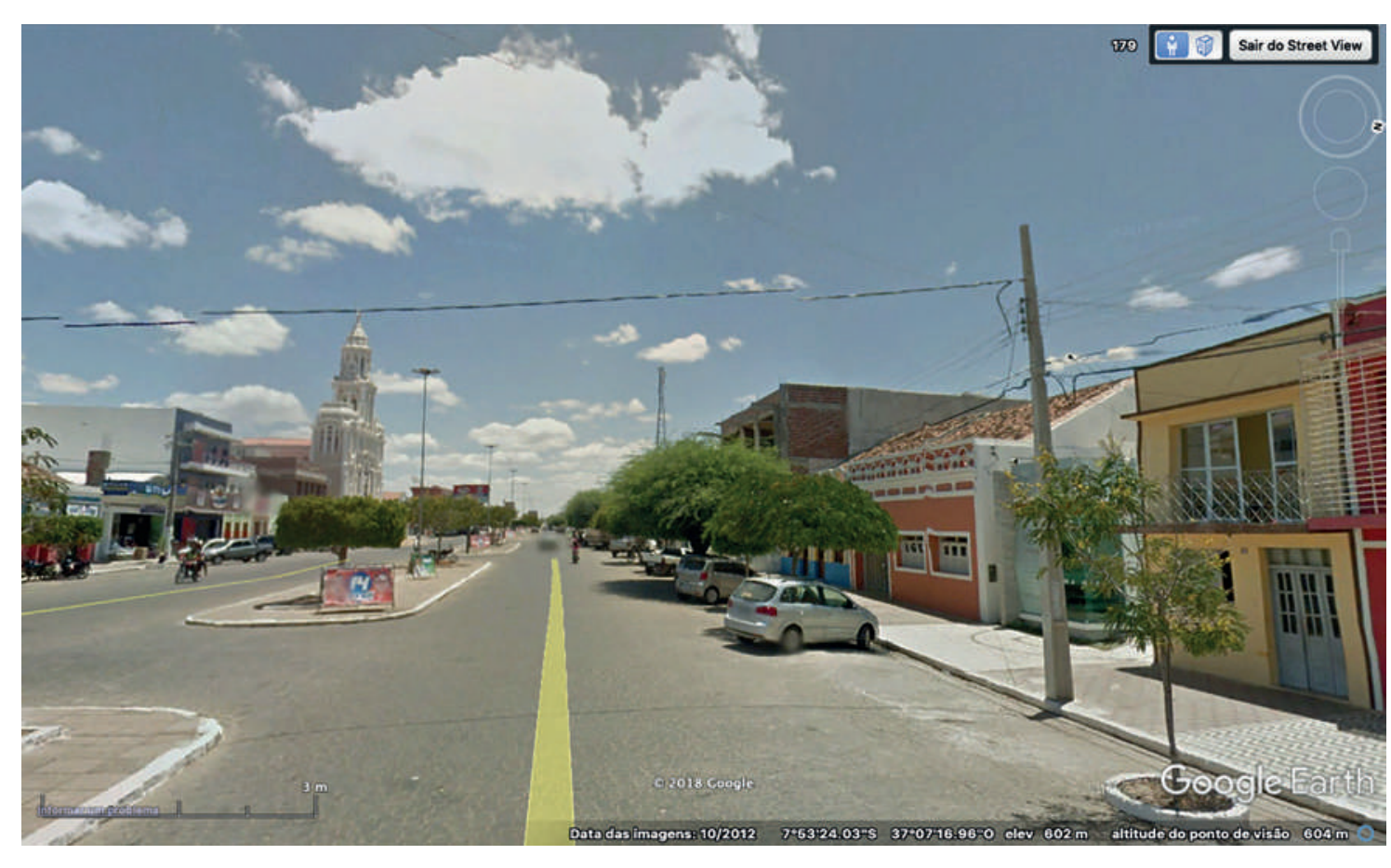


A invisibilidade da questão

indígena no PISF

O conflito com os povos indígenas talvez degradações desde a década de 70, com tenha sido uma das questōes mais a construção de usinas hidrelétricas, graves do processo de planejamento desmatamento e assoreamento, algo etnias Truká e Tumbalaláao (ver Figura ribeininhos. Uma “Carta vida dos povos 124, que localiza as terras indíg Figs das Indígenos de Pernambuco Sergipe 124, que localiza as terras indigenas das Indigenas de Pernambuco, Sergipe, estiveram na frente da resistência contra e disponível na página do Conselho as obras da Transposição, foi possível Indigenista Missionário (CIMI) ${ }^{93}$ foi perceber que o que esteve em disputa publicada como forma de protesto do nesse processo foram as formas de vida, povos indígenas contra a Transposição: uma disputa injusta, em que as formas de ocupar o territorio ou as formas de viver indigena fora ou as for wideradas a seguir.

Além de os canais terem atravessado diretamente e impactado os territorios do povo Truka, Tumbalala e Pipipã (Eixo Norte e Leste), os povos ribeirinhos do rio Săo Francisco, tais como os Tuxá, próximos à margem, tais como Pankararé, Pankararu, Kalangó, Geripankó, Kaxangó, Kalancó, Akonã, ficaram preocupado com a sustentabilidade do rio São Francisco dada a vazáo retirada para a Transposiçaao, uma vez que o rio ja se encontrava em estado crítico antes tecnicamente 0 PISF tenha garantido que a vazão retirada do rio seria insignificante e a contrapelo do Programa de Revitalização da Bacia do Rio São Francisco (2004), o rio veio sofrendo

90 As entrevistas fertas com liderancas dos povos Truká
Tumbalalala aconteceram em Cabrobó (PE), em setembro de

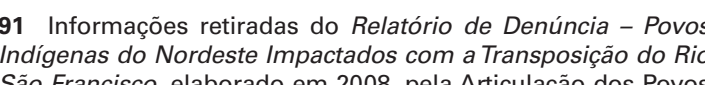

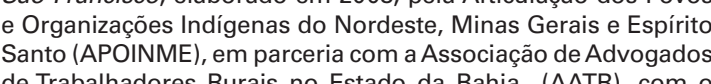

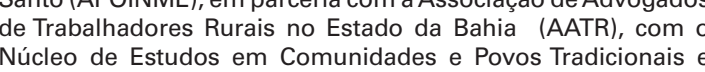

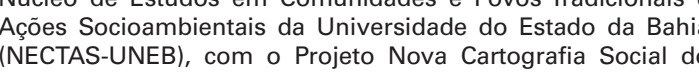

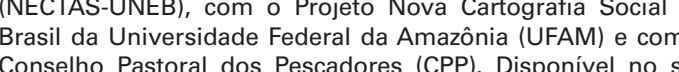

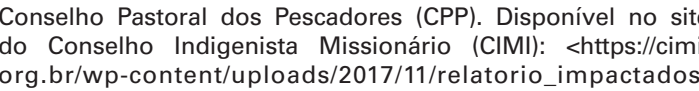

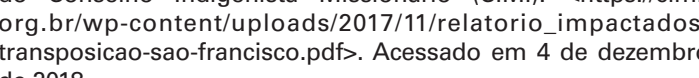
Nós, lideranças dos povos indígenas de Ibotirama, Tumbalalá, Kiri de Muquém do e Alagoas: [...] Projeto de Transposicaso repúdio ao Francisco pois a nossasobrevivenco econômica e cultural depende do p. El deste que irrigamos a terra para plantar e pescamos o peixe têm tudo a ver com o rio, nossa ciências estẫo nas águas do "Velho Chico" Já sofremos bastante com as transformaçoes sofridas pelo rio, por que inundaram terras tradicionais, extinguiram muitas espécies de peixes $\mathrm{e}$ animais terrestres, Parte do rio onde atrassa ciénciána. nado, hoje atravessamos pé, nenhuma daquelas obras beneficiaram nossos povos provocaram o desmatamento consequência, a desertificcação, além do desvio das aguas para irrigaçâa das grandes fazendas. Tudo isso,
além do despejo de dejetos, esgotos

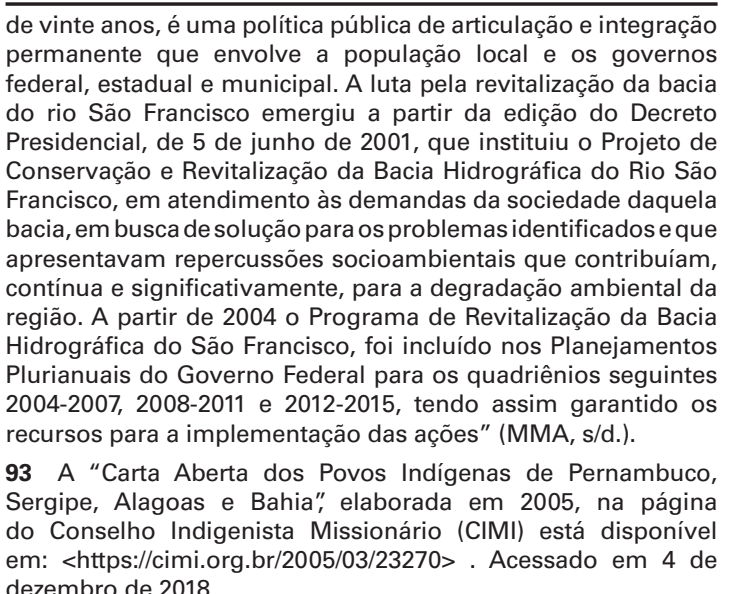

e agrotóxicos, são derramados no rio, que está morrendo (CIM)
$2005)^{94}$

Em entrevista ${ }^{95}$ realizada no âmbito da presente pesquisa, o cacique do povo
Truká, Sr. Aurivan dos Santos Barros, conhecido por Sr. Neguinho Truká, a apresentado anteriormente neste capítulo, contou sobre como era a vida na região na sua infância, quando a vida era regrada pelas cheias do rio Săo Francisco. A degradação do rio se iniciou
quando as hidrelétricas começaram a ser construídas pela Companhia a ser construidas pela Companhia no fim da década de 70 . Sr. Neguinho Truká comentou que não era contra Transposição e muito menos contra levar agua aos vizinhos que estáo passando sede. Porem, era contra a forma como a obra foi sendo realizada, questionou falou sobre a revitalizacão do rio São Francisco que não está sendo feita:

A nossa briga não era para barrar o empreendimento, esim para garantir outra, não tem como você rasgar $700 \mathrm{~km}$ de canal, tirar uma água que já está em um fluxo baixo sem para manter até o nivel que já tem. Sem contar com isso você tem os peixes que sobraram, algumas espécies menos novas que tem no rio, elas também vão junto com lontra, o surubim, o dourado, as rutas da margem do rio, as árvores, todas as plantas medicinais que a desce o que com indice de sobe e do rio se tornou uma imensa salina! As enchentes eram justamente para lavar e deixar as terras férteis, para sem utilizar nenhuma gota de

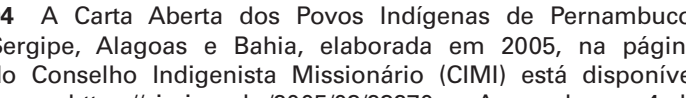

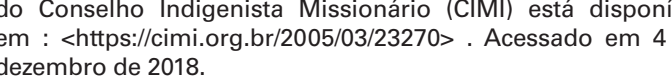
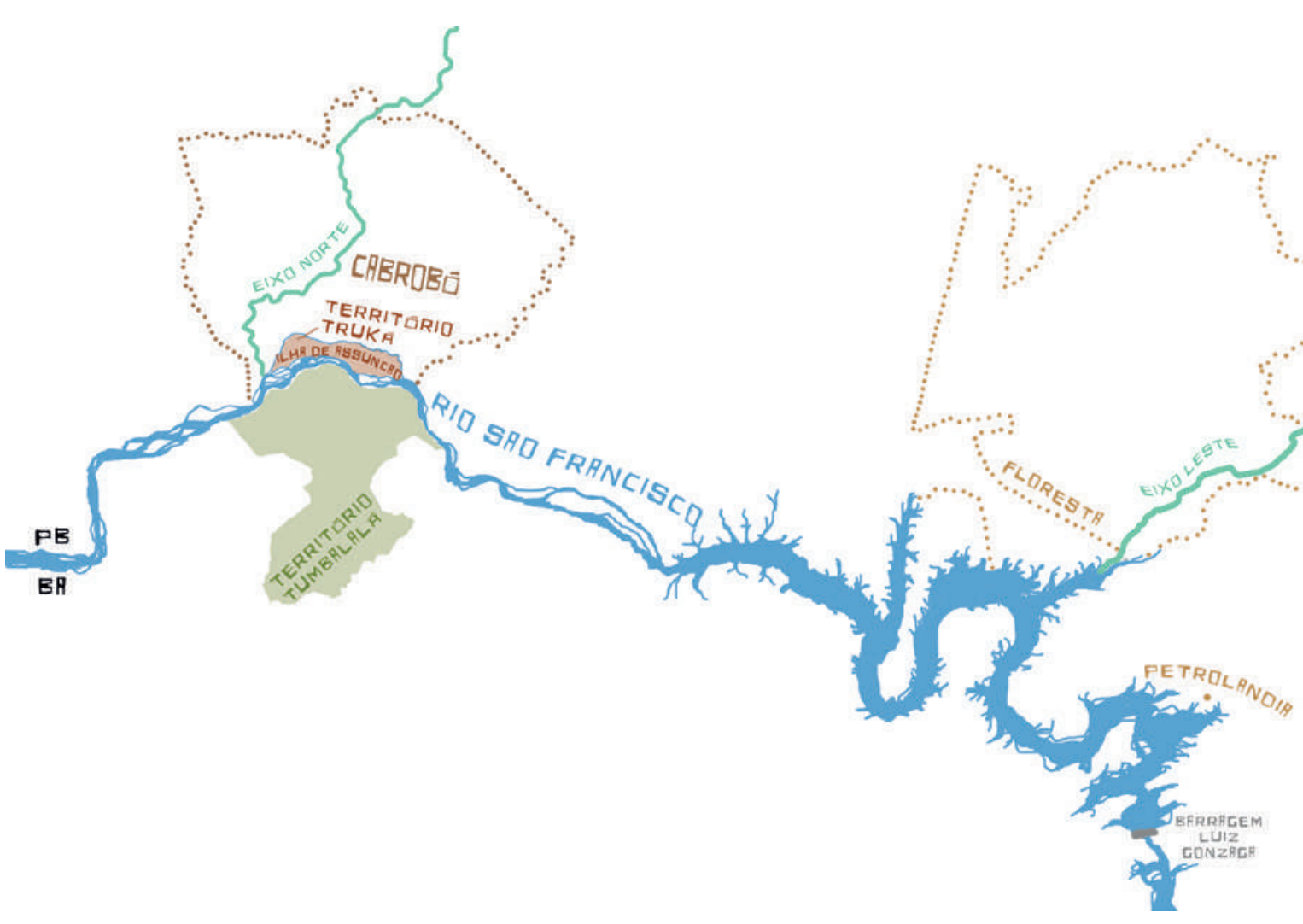

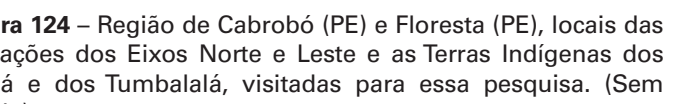

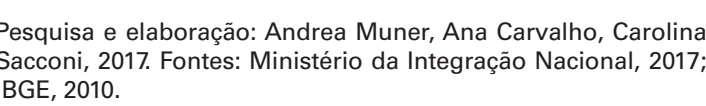

agrotóxico e veneno. E partir de 79 quando eles trancam Sobradinho a gente aqui já sofre esse impacto. Ai vida do rio Então hojar o que toda vive aqui já é uma parte morta do rio que a gente considera. - Informação verbal concedida em entrevista pelo setembro de 2017 emo dia o8

No Relatório de Denúncia - Povos a Transposição do Rio São Francisco (TOMÁZ et al 2008)96 foi relatado desrespeito contra as etnias no processo de planejamento da obra, a fragilidade entorno das demarcaçoes de terra dos maioria não possuíam demarcação:

Como muitos territórios inserem-se em areas diretamente afetadas tanto pelo Projeto da Transposição quanto Dor outros empreendimentos
desenvolvimentistas, os Povos

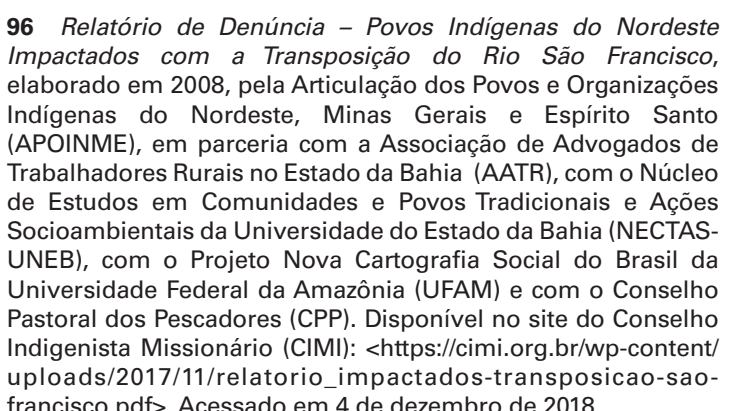

gumentam que o Governo não quer demarcar justamente para deixar essas áreas liberadas para as demarcados a menor aguardam há anos a revisão povos atingidos, a exemplo dos Anuma área demarcada nấ têm construção dos canais avança por eles (TOMÁZ et al, 2008, p. 31).9?

Essa fragilidade jurídica em relação às demarcaçōes gerou graves conflitos a disputa pela aprovaçáã Transposição, como a perseguiçaa dígenas, conforme foi relatado tanto entrevistas de campo quanto no elatório em questão:

[...] a insegurança territorial, contra a transposiçâao do Rio São

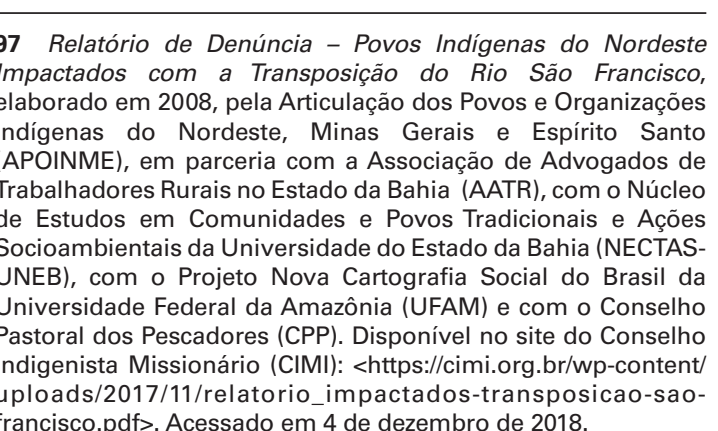


Francisco, tem gerado inúmeros conflitos para os Povos Indigenas
da Bacia do Săo Francisco. As açoes violentas comportam desdeo 0 assassinato de lideranças indigenas
como foi o caso da ocorrência de 5 assassinatos do Povo Truká (erritoriall como processos judiciais de criminalizaçăo, com o forte aval [e..] (TOMÁZ et al, 2008, p. 38).98

Em decorrência desses conflitos, foi com a sociedade. A partir daí, surgiua

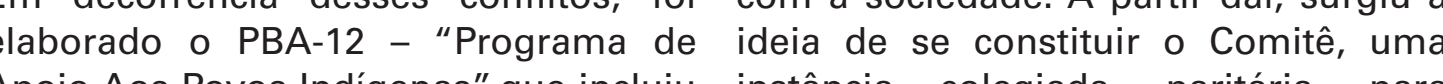
Apoio Aos Povos Indigenas, que incluiu in

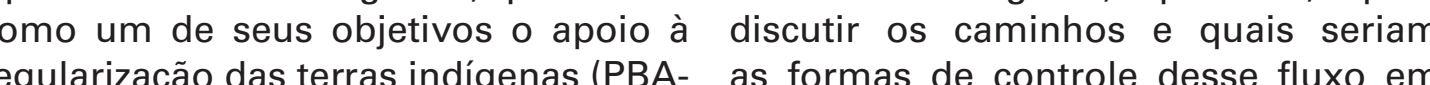
12, s.d., p. 13), contemplando os povos relação ao projeto de Transposição. indígenas residentes nas proximidades Quando se instituiu o CBHSF, elegeramda área diretamente afetada pelo empreendimento, sendo eles os povos civil organizada, do governo federal Truká, Pipipã, Tumbalală e Kambiwá, que otalizam aproximadamente nove mil e irrigantes, e dos governos dos estados, Figura 125). Por outro lado, apesar do de Saneamento (COMPESA). Porém programa, muitos territórios originários depois de um tempo, Sr. Issor passou exemplo o território Tumbalalá. Os pue participazano corajosa e saiu do Comitế, foram demarcados, of arala. Os que pa de muita luta. A Sra. Maria Tumbalalá, ja apresentada em item anterior desse

Ospovosindígenasna regiãodeCabrobó, canteiro de obras do Eixo Norte feita como os Trukás e Tumbalalás, além de pelos povos indígenas no momento terem sofrido muito com a degradação construção do canal, um protesto contra luta pela demarcação de suas terras. Transposição e também de luta por $\mathrm{Na}$ época da Transposição, essas suas terras:

Ocupamos o canteiro de obras, O exército fez uma barreira para
intimidar os manifestantes. Eram mais de 1500 pessoas, minha Globo Rural anunciou a ocupação. Secretário do prefeito ligou para mim para negociar. Depois que saimos, conseguimós a retomada 10 anos e até hoje nâo foi feita a demarcação das terras. O povo Truká tambem fez uma retomada proxima - Informacão verbal concedida em entrevista por Sra. Maria Tumbalalá, no dia 8 de setembro de 2017, em Cabrobó.

O Sr. Ailson dos Santos, conhecido por Sr. Issor Truká, irmão de Sr. Neguinho

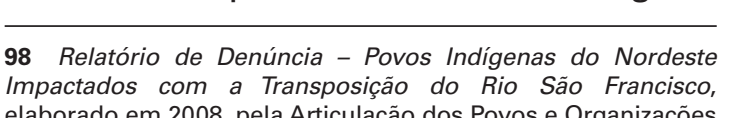

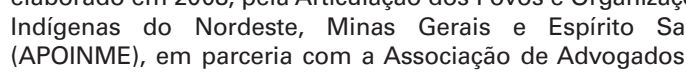

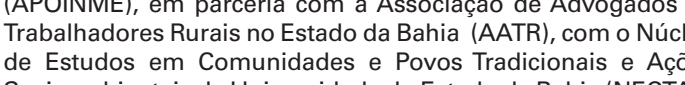

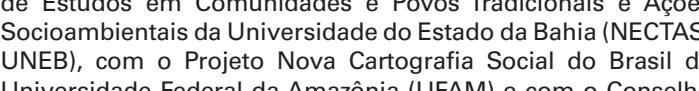

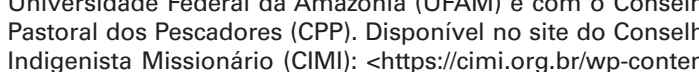

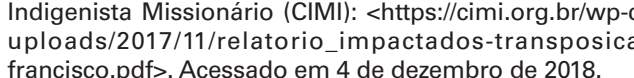

questões se acirraram ainda mais. $S$. Neguinho e Sr. Issor Truká comentaram acerca da dificuldade que eles tiveram em participar das assembleias de discussão do empreendimento, dos a discursos enganosos sobre abra, das perseguiçoes politicas e ate assassinato de lideranças que se a questão da indígenas. Os Trukás conseguiram demarcar parte de suas terras, diferente dos Tumbalalás, que até hoje não são reconhecidos, conforme descrito anteriormente.

[...] primeiro o nosso território está dentro do território tradicional do meu povo. E o que a gente discutia

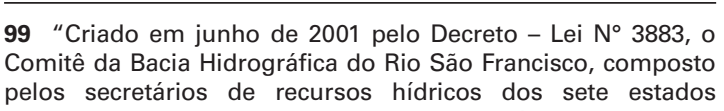

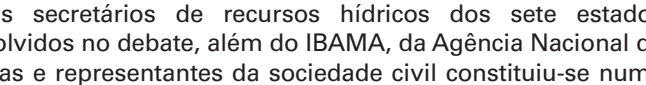

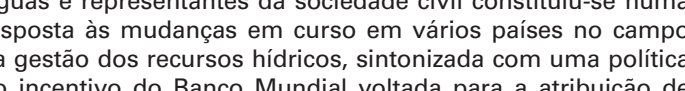

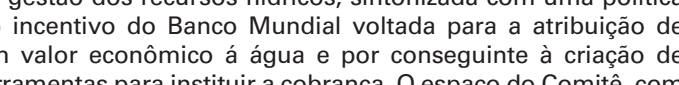

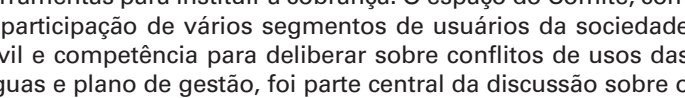

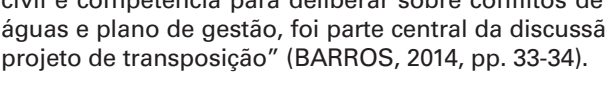
100 Entrevista realizada com Sr.Ailss
setembro de 2017 , em Cabrobo (PE). luta que regulariza nossa terra, já que vocês văo passar o empra jádinento - Informação verbal concedida em entrevista pelo Cacique Neguinho, no dia 08

Sobre as audiências públicas, eles disseram que elas aconteceram, mas chegar ao final, quando se levantavam suestionamentos sociais, ou até mesmo eram por vezes impedidas de pautas vinham prontas e pouco para discussão, de maneira que que foi aprovado eram as propostas den tenicos. Eles avaliaram que faltou com visão mais ampla pociopoliticas cosparo para a do participantes eram praticamente brigadas a aceitar o que era proposto, que causou muito conflito. Os irmãos

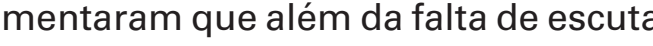
sojeto pouco respeitou a forma como on pupavan indigenas enxergavam ua cultura e forma de viver, de forma a a obra impactou aquele patrimênio cultural de forma muito agressiva. É e se depreende de trecho do mesmo do Sr. Issor Truká:

E a populacão indígena, e
populacão quilombola que estão no Eixo? Por que não foram ouvidos? Porque nos temos, estou falando do povo Truka, nos temos uma relação musso bioma a Nós tratama, que relaçăo próxima e humana com
Caruá, que é uma fibra, com Jurema, que é sagrada para a gente, o Angico. São árvores que para nós, na nossa cultura, são sagradas. E eles passaram por cima de tudo! Daí o impacto cultural gente tem ao monumentos que pedras que se formaram ao longo da história, e que para a gente, com os ensinamentos dos nossos mais fontes, de referência para nossos rituais sagrados. E eles explodiram tudo com dinamite! E não teve reparação. Hoje a Transposiçâoo tem de nossos antepassados, que e período bem anterior o povo Truká quando alguém morria os rituais funebres eram feitos e as pessoas Eles passaram por cima de tudo!

A Sra. Maria Tumbalalá confirmou o que os Srs. Neguinho e Issor Truká
haviam contado sobre as audiencias

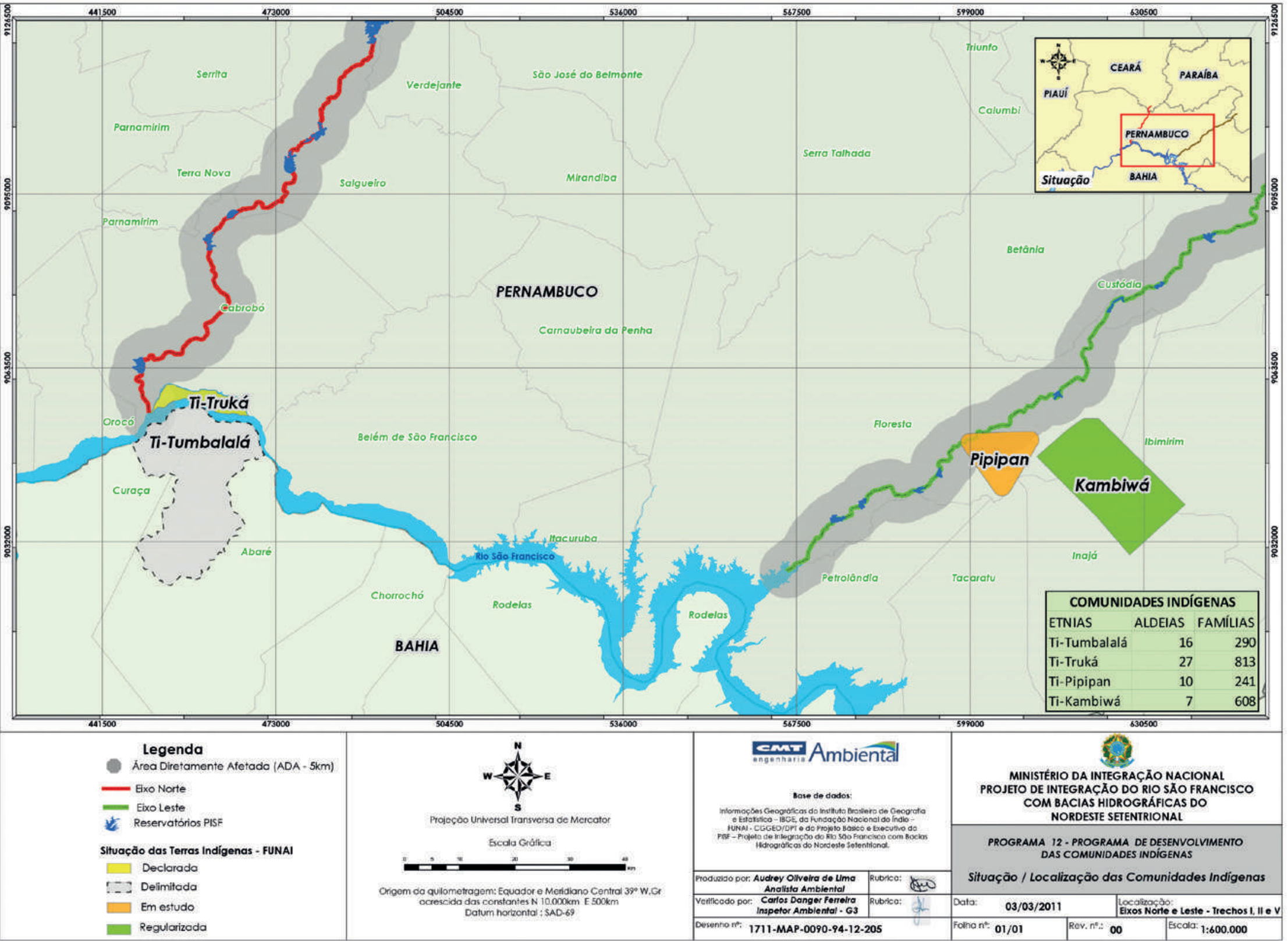

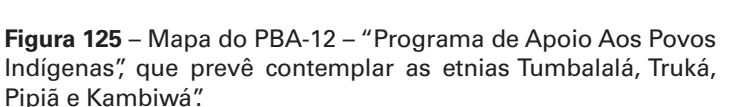

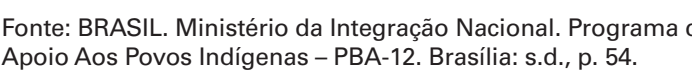

públicas para discussão do EIA-RIMA, sobre as pautas e decisōes impostas, mpedimentos de participação, assim polía para deixar a cidade inacesivel Território Indígena Truká foi demarcado em uma itha do rio Sáo Francisco, a tha de Assunçao), ou mesmo sobre o agendamento em cima da hora de uma assembleia em Salvador, em pleno a participação da população:

[...] não houve consulta prévia.
Quando eles faziam as reuniōes Quando eles faziam as reunióes
deles, já vinham com as regras, deles, já vinham com as regras,
com os regulamentos, já decididos. o que eles queriam? Que a gente
assinasse, para referendar que

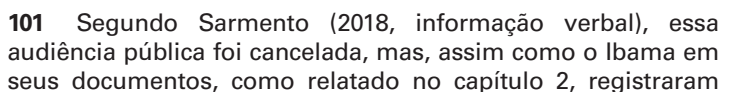

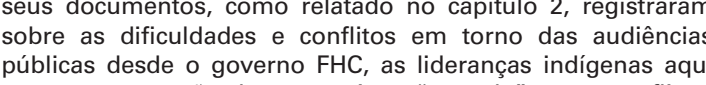

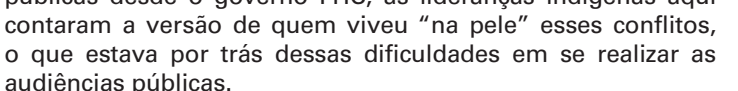

tinha acontecido. [...] Como é que você chama o povo ribeirinho daqui, para ir para um encontro
em Salvador, vespera do Carnaval, no centro de convençōes? É para acontecer uma consulta na llha de Assunção, aqui em Cabrobó. Eles fecharam a ponte tudinho. fechou a ponte e não A policia consultar o povo [...] Queriam que os indigenas assinassem os papéis afirmando que foi feita audiência Truká disse "não, nós não vamo assinar isso não". Porque o que é que eles queriam? Uma assinatura da gente, para referendar que e que nós tinhamos aceitado! Eles queriam uma manobra, que os povos Truká, Tumbalalá, Truxa referendado - Informacava tudo concedida em entrevista por Sra.
Maria Tumbalalá, no dia 8 de setembro de 2017, em Cabrobó.
Além disso, Sra. Maria se queixou que o povo Tumbalala sequer era chamado menos considerado nos estudos de impacto ambiental e compensacões. Quem os alertava e os chamava para participar das audiências era o povo Truká, que, de acordo com trecho do mesmo depoimento de Sra. Maria,

Um dia eu estava em Juazeiro da Bahia, e fiquei sabendo que estav tendo uma assembleia para se
discutir a questâo da água. E eu fui ara lá. E quando nós chegamos a, no projeto, não tinha o povo minha etnia é aqui no Municíipio de E eles Curaça, e o povoTumbalalá. que Cabrobó iria ser contemplado, com algumas situações, por causa do povo Truká. Porque ia atingir o ver o mapa não me identifiquei perguntei "cadê o povo Tumbalalá

. 


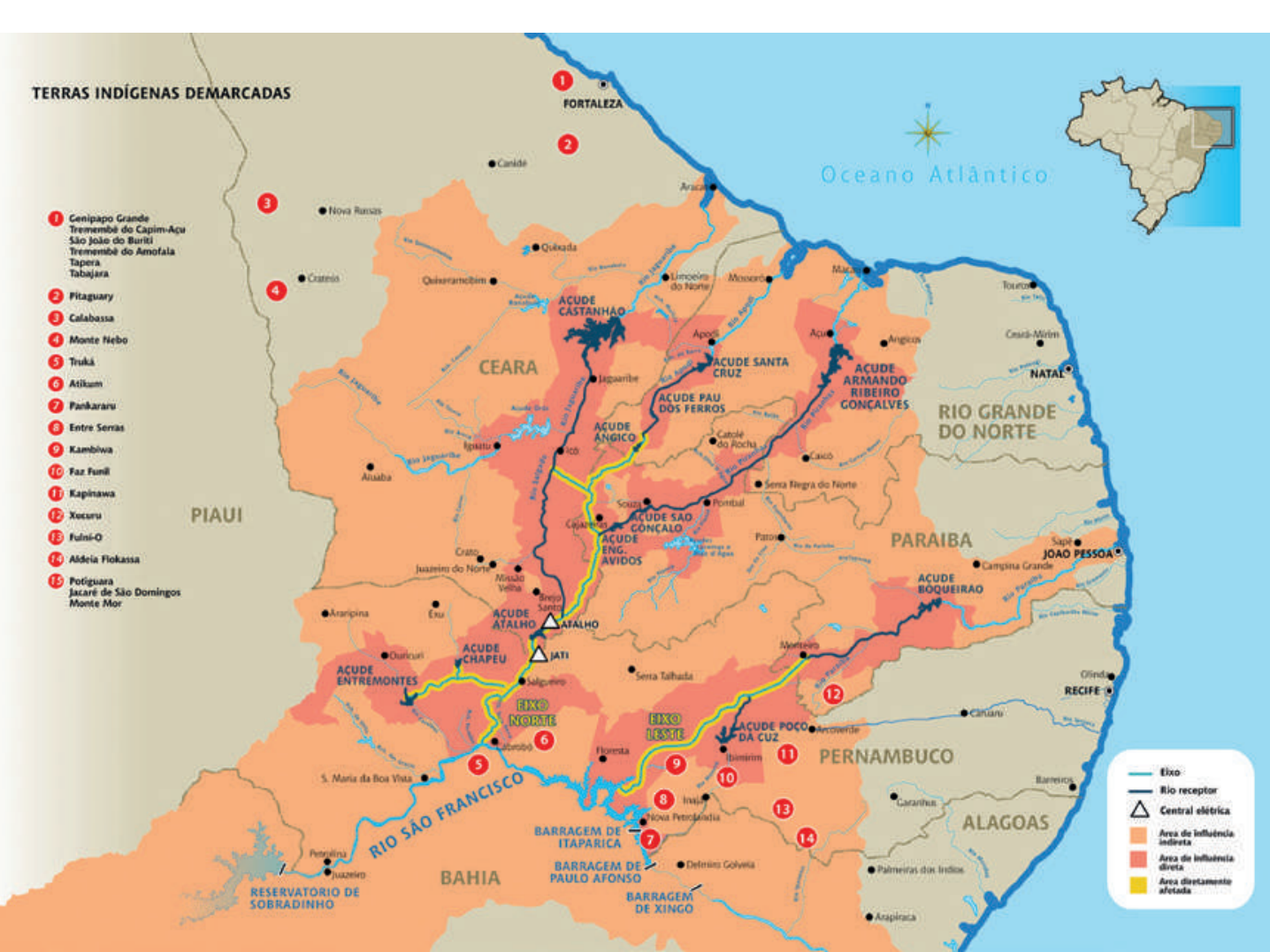

aqui na Bahia?". E eles disseram não. e outro para outro? Vocês acham que o Rio São Francisco vai ter uma vazão de um lado do Pernambuco e
não vai ter do lado da Bahia?' Aí foi isso... e nós fomos à luta".

foram discrepantes as cartografias

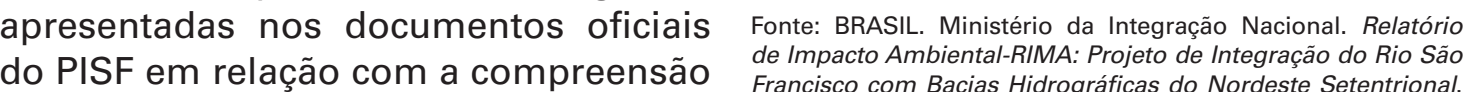
geográfica dos habitantes dessas regióes, ou seja, com a realidade das populaçoes indigenas. O PSF se tratou aquelas culturas, reiterando problemas A partir das conversas com as lideranças aquécicos de violações de direitos indígenas, foi possivel perceber que a ligada a uma outra noção de território que não se define em áreas demarcadas, mas que toma a caatinga como um paisagem por meio dos quais criam suas referências etemplos. Essa forma deviver e enxergar o território não corresponde à forma "oficial" das demarcações, muito menos com a trazida pelo EIA-RIMA, que representou de forma inerte e pouco Embora isso tenha sido de certa form. corrigido posteriormente pelo PBA-12 - EIA-RIMA inicialmente apresentou as Terras Indígenas dos povos, que tanto lutaram nesse processo pelo seu reconhecimento e pela violaçáo de seus direitos, como se náo estivessem nas areas de influencia direta, conforme

Em contraste com essa cartografia apresentada no EIA-RIMA, um grupo de pesquisadores elaborou publicaçōes a partir de cartografias sociais, elaborada em conjunto com as etnias indigenas Jocais, território a cultura a ocupaçáo complexidades de cada um, conforme as Figuras 127, 128, 129 e 130 a seguir: As cartografias das Figuras 127, 128,129 e 130 demonstram como
Figura 126 - Mapa das Terras Indigenas apresentado no EAA

\author{
(n)
}

Olha, a gente resume tudo dizendo

assim: o Estado é impositor, ele você é obrigado a digerir aquilo ali entendeu? A transposição el náo vai dar certo agora. [...] O projeto de Transposçao traz tress questoes impacto socialeimpacto cultural São três questões que eles conseguem exterminar qualquer sociedade. E o projeto de Transposição é isso:
ninguém foi ouvidol Porque quand tinha as audiências públicas sociedade ia para o embate junto ao Ministerio Publico, enquanto mediador social, e o estado botava mas elas foram, na grande maioria elas foram impedidas de chegar ao final, de ser realizada. Então aquilo que eles escolhiam que era a ideia vinha os questionamentos sociais, aí criava aquele clima e não se encaminhava mais nada. Mas o que eles haviam apresentado que sevi - Informação verbal concedida en entrevista por Sr. Issor Truká, no día 08 de setembro de 2017, em Cabrobo. pensamento do uma obra de um deu certo na época do Império e que
Jura 127 - Cartogratia Social do Povo Truke Fonte: ALMEDAA, A; MARIN, R.; SANTOS, J. let all

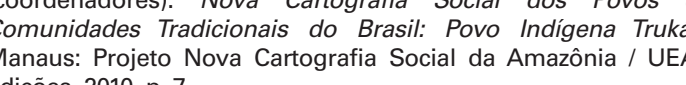

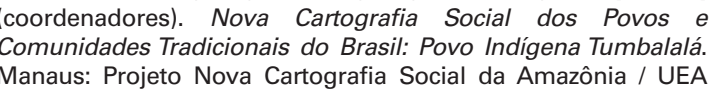
Inura 29 - Cartografia Social Povo Pipipà

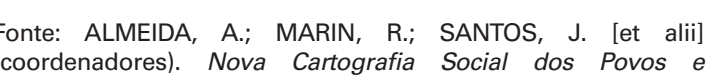

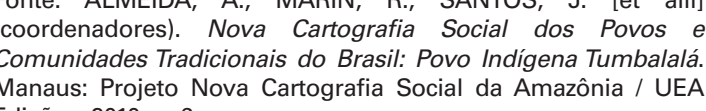
Figura 130 - Cartografia Social do Povo Kambive

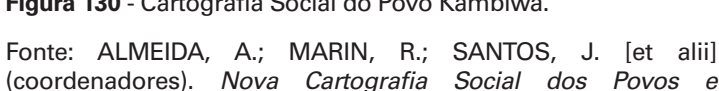

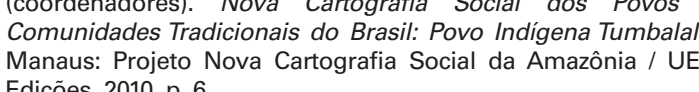
Fonte: ALMEIDA, Air MARIN, R.; SANTOS, J let alint

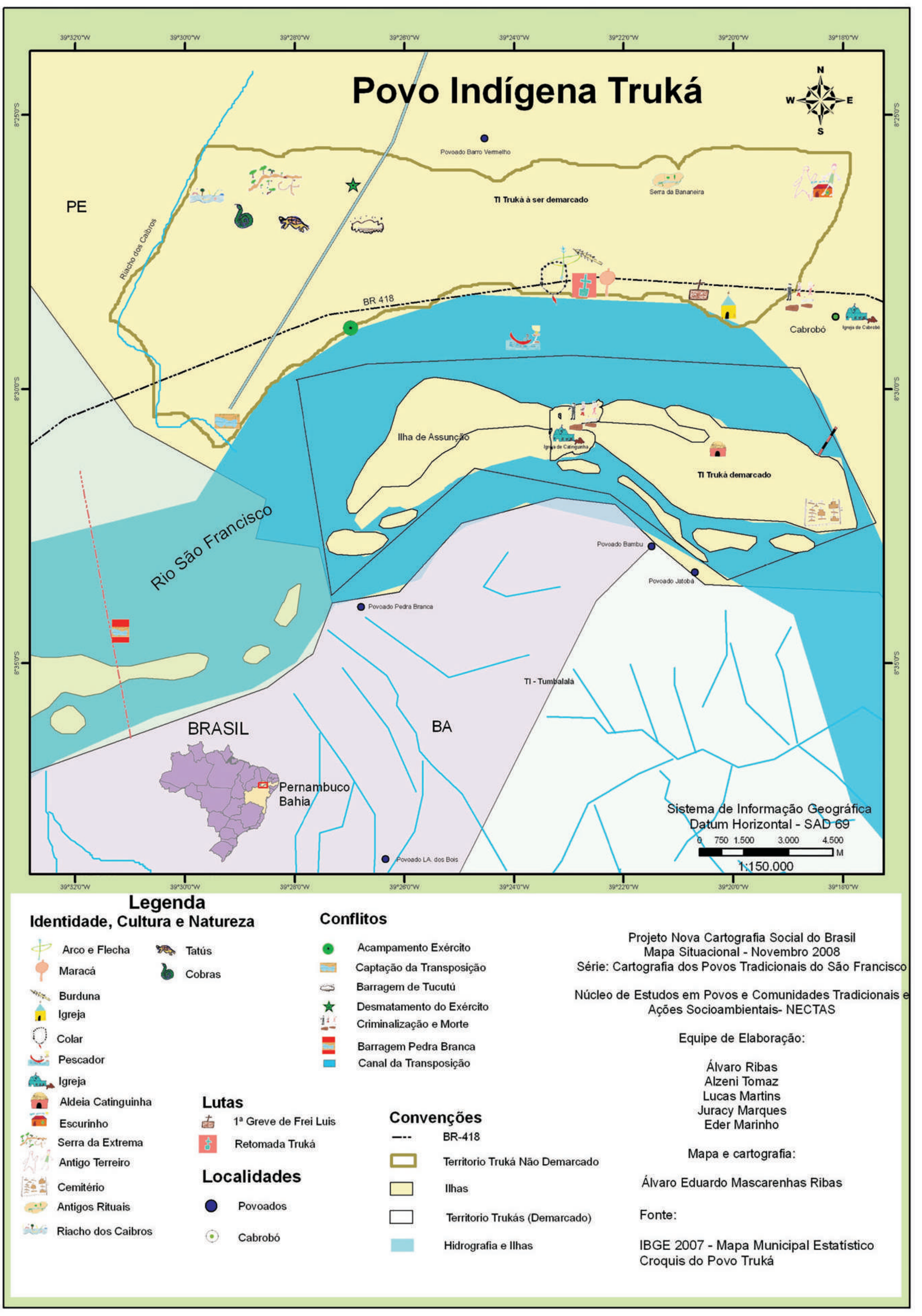



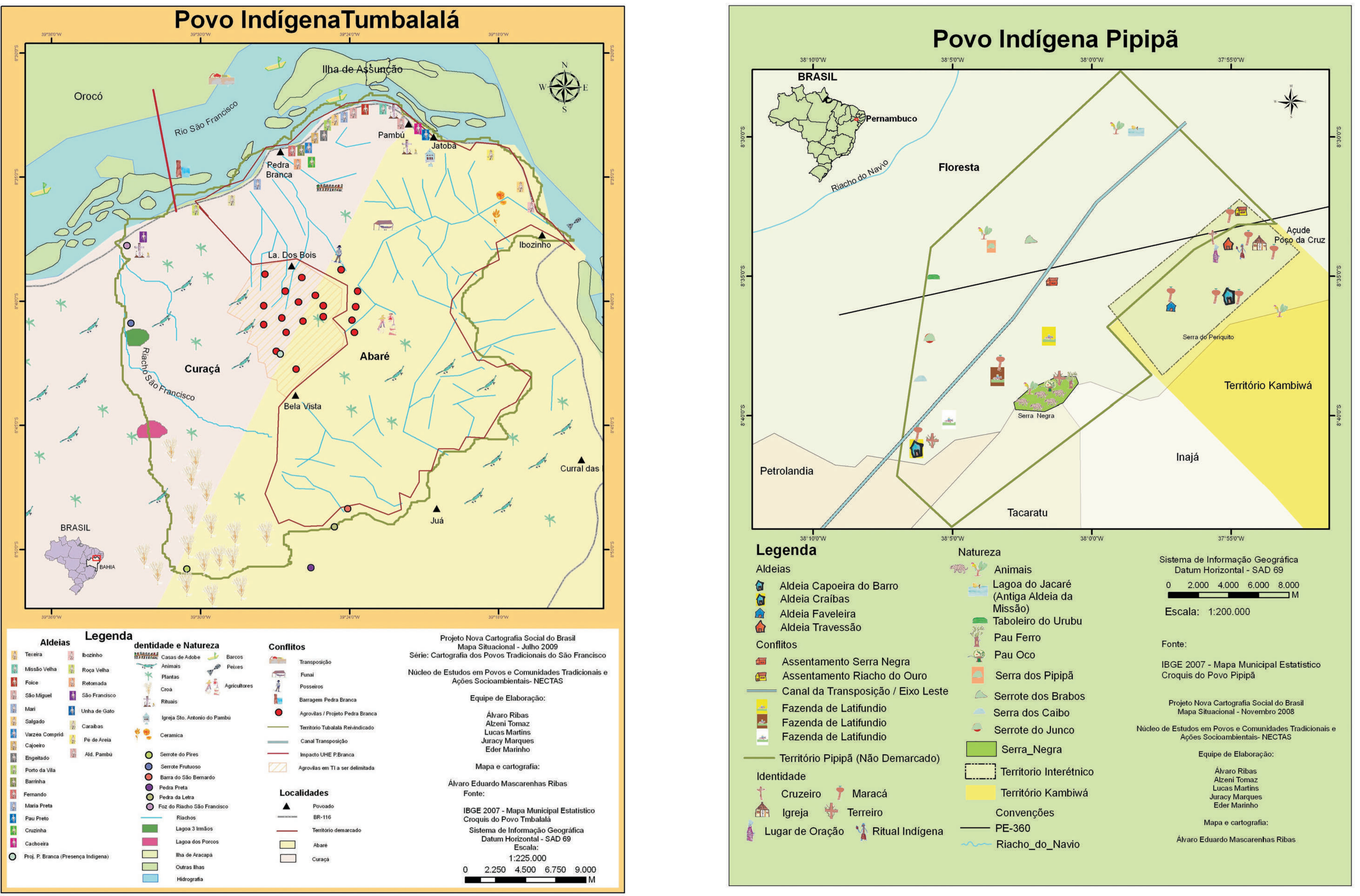


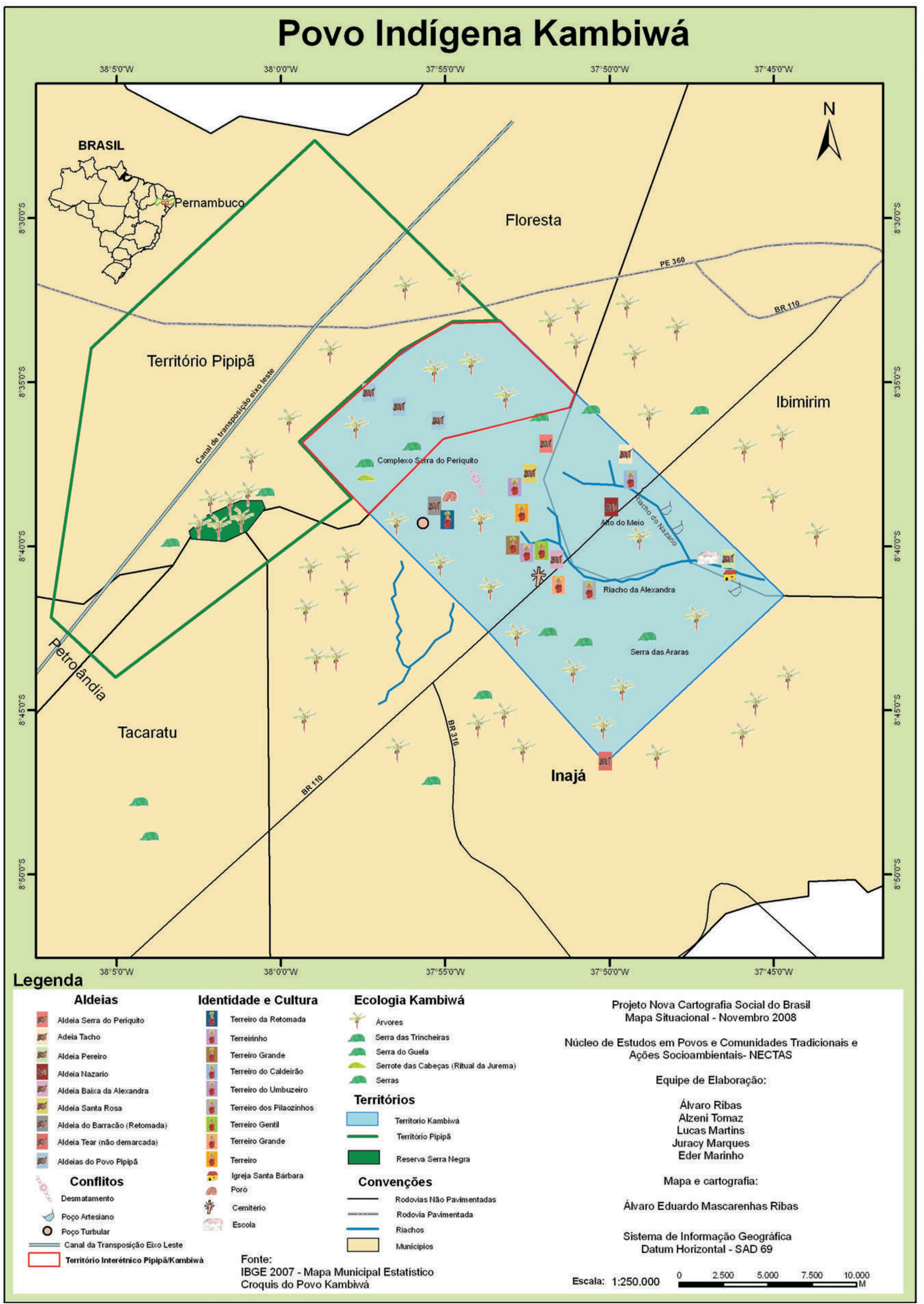




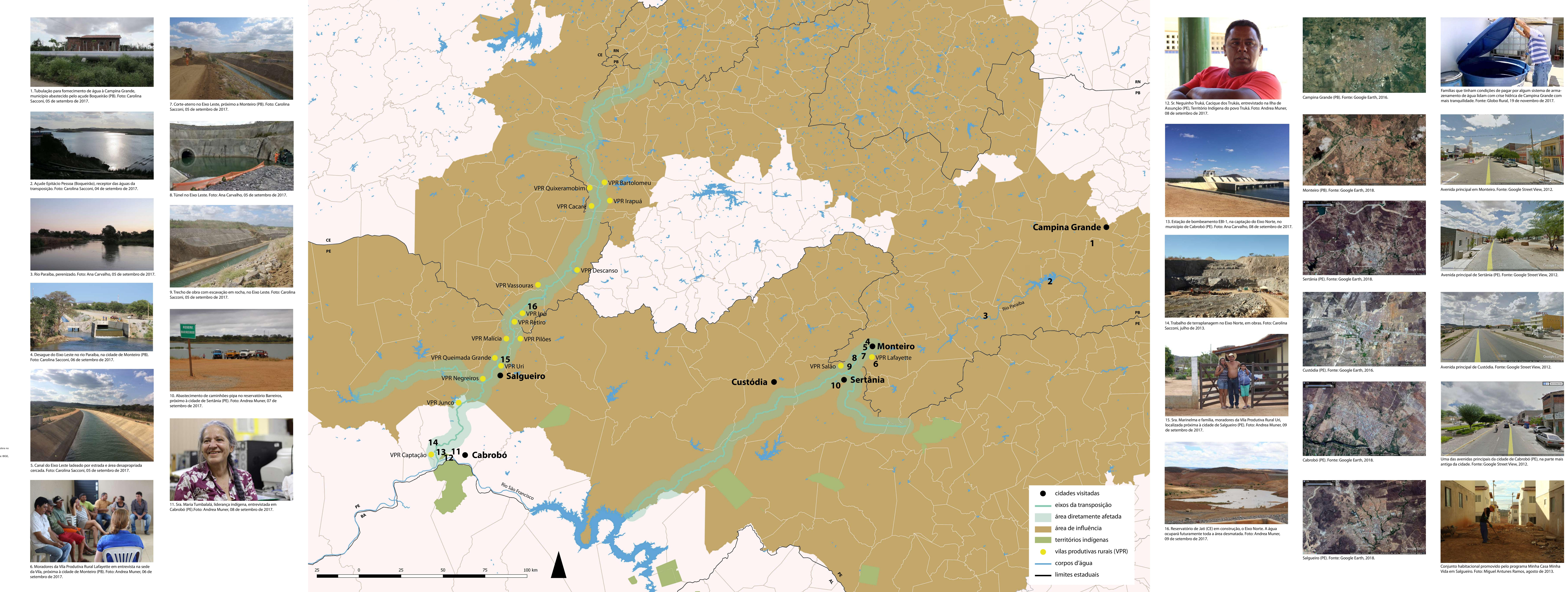




\section{Considerações finais}

A Transposição do rio São Francisco é um projeto que possuiu uma causa legítima, a ocorrência de grandes secas decorrentes das chuvas intermitentes do semiárido brasileiro. Já presente como ideia há dois séculos no imaginário da população da região semiárida brasileira, o projeto foi apresentado como solução para os problemas promovidos pelas secas, ou, mais recentemente e contraditoriamente, como a obra que passaria pelo território semiárido sem necessariamente abastecer todos os espaços. Foi um projeto muito noticiado, muito estudado e também muito polêmico, compreendendo muitos estudos que conformam um vasto arcabouço documental, elaborados com o intuito de justificar a obra.

A pesquisa aqui realizada demonstrou que houve muitas contradições nos processos de concepção, planejamento e obra, etapas que foram tratadas ao longo dos três capítulos anteriores, demonstrando a presença-ausência que o projeto, planejamento ou obra promoveram no território, no ideário e nas vidas das pessoas residentes da região semiárida. Dessa forma, serão reforçadas aqui as principais considerações de cada capítulo em relação à Transposição do rio São Francisco, que serão organizadas junto às principais discussões que surgiram ao longo da pesquisa. Pretendeu-se, com essas discussões, compreender como essa obra incidiu sobre o território, identificando sua presença em cada lugar bem as ausência que causou nessas mesmas regiões, analisando criticamente o processo de planejamento e a obra executada e permitindo reflexões sobre a ação do Estado perante a prática do desenvolvimento regional a partir deste estudo de caso.

O semiárido brasileiro, do ponto de vista pluviométrico, possui uma média de chuvas maior em relação a outros semiáridos no mundo, de $800 \mathrm{~mm} /$ ano, sendo o grande problema não a quantidade de água de chuva ao longo do ano, mas a forma como as chuvas se distribuem no tempo e no espaço semiárido (EMBRAPA, s/d).1 Dessa forma, alguns hidrólogos, tais como o Prof. Janiro Costa Rego, entrevistado para essa pesquisa, alegam que, dada a intermitência das chuvas, uma boa gestão de recursos hídricos das bacias hidrográficas do semiárido poderia garantir a segurança hídrica para as cidades e povoados da região, não sendo necessária uma obra do porte da Transposição do rio São Francisco para solucionar a falta de água no semiárido.

As questões da escassez de recursos hídricos da região poderiam ser supridas com uma boa gestão dos recursos próprios da região de cada bacia. Se a gestão adequada tivesse sido bem feita, essa obra da Transposição seria, assim, dispensável, principalmente em relação ao abastecimento humano. Para a parte de irrigação talvez possa-se dizer que faltaria água, mas para abastecimento humano não faltaria se tivesse tido boa gestão. - Informação verbal retirada de entrevista concedida por Prof. Janiro Costa Rego, no dia 04 de setembro de 2017, em Campina Grande.

A má gestão dos recursos hídricos está associada a uma má distribuição de terras e a consequente desigualdade socioespacial, que conforme Oliveira (1985, pp. 54-55), seria estruturante na formação da região nordestina. O histórico investimento em infraestruturas hídricas, tais como a construção de açudes e reservatórios, evidenciaram que esse tipo de investimento seria tão importante quanto investir em políticas sociais para quebrar as tradicionais relações socioeconômicas que intensificam a desigualdade de renda e poder na região.

Em complementação a essa ideia, segundo os hidrólogos Eng. Irani Braga Ramos (2017, informação verbal)²

1 Informações retiradas de artigo da Embrapa, disponível em: <https://www.embrapa.br/tema-convivencia-com-a-seca perguntas-e-respostas $>$. Acessado em 10 de janeiro de 2018. 2 Entrevista concedida pelo engenheiro e assessor do Ministério da Integração Nacional, Irani Braga Ramos, no dia 20 de março de 2017, em São Paulo, por Skype. 

Prof. Francisco Sarmento $(2017$, das bacias da região semiárida evitaria Nesse momento de retomada do projeto
informação verbal), ${ }^{3}$ que em equipes a necessidade dessa grande obra de alto de transposição e da elaboração dos diferentes participaram da elaboração impacto ser executada.

e/ou implementação do projeto em

Jus versoes mais recentes, a obra se Em entrevista realizada para a presente eja, sendo concebidanto regional, ou apenas como uma infraestrutura hídrica, mas como uma obra de transformacão e fortalecimento econômico e social do forma como a obra do PISF foi sendo construída, perdeu-se a oportunidade de
investir mais em programas ou projetos investir mais em programas ou projetos as
complementares aos canais para socis promover o desenvolvimento regional,
pois eria uma obra com muito potencial para promover mudanças importantes
semiárido.

$\begin{array}{ll}\text { seu planejamento, o governo federal, } & \\ & \end{array}$

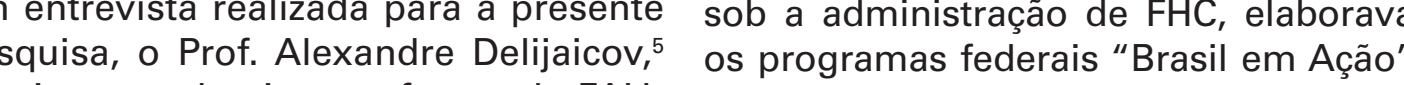
(1996-1999) e, posteriormente, o "Avança artificiais, tais como o Canal do Midi, na objetivo a criacão de Eue tinham como (T) (TA) nos Estados Unidos da América, Conforme apresentado no capítulo 1 , ensas o projeto dos ENIDS tinha um enfoque competitivo e logistico, revisitando cidades, de forma estruturante formulaçoes clássicas da ciencia regiona para as respectivas de áreas de mercado, de centralidades a gioes, demonstrando, portanto, que urbanas e dos determinantes da grande infraestrutura seria capaz concentração e do crescimento de promover o desenvolvimento ao diferenciado de regiōes na medida em longo de toda sua extensão. Porem, que projetava um crescimento que Tranciso a ro Francisco, a relaça da obra com o eixos ou vetores de desenvolvimento Para eles, a matriz do grande eixo de en infraestrutura de alto impacto não seria a maneira transformadora e estruturante estivesse garantido. Em especial, o Prof. economicamente, mas sim, muito Nessa perspectiva, a ação estatal no Francisco Sarmento ${ }^{4}$ - engenheiro que presente em seu impacto e ausente campo do desenvolvimento territoria

participou tanto no desenvolvimento do no que toca a uma reestruturação ficava reduzida à previsão de oferta projeto e na elaboração dos Estudos de Inserção Regional (BRASIL, 2000a) no Interministerial no governo Lula -, a
obra só se justificaria se a sua inserção regional contemplasse a articulação
com programas de desenvolvimento, com programas de desenvolvimento,
estimulando economicamente região, conforme as potencialidades
(geológicas, hídricas e também sociais) previstas e sugestôes (administrativas e
econômicas) elaboradas nos estudos que conformaram o planejamento do projeto. Nesse ponto, seu posicionamento
se aproximou ao posicionamento já ao defender que a obra, destinasta Rego, para garantir a segurança hídrica, sem ações e intervençôes complementares, não se justificaria, o que se leva
pensar que, conforme Rego alegou, para solucionar apenas a escassez hídrica 3 Entrevista realizada com o engenheiro e Prof Francisco
Jascome Sarmento, no dia 11 de setembro de 2017 , em Joä
Pessoa. Jacome sarmento, no
Pessoa.
4 Entrevista surracitad de infraestrutura de transportes em tradição brasileira de ação regiona mpacto foi pouco questionado ao longo historico de concentraçáo pontual do das versões do projeto. Pelo contrario, a desenvolvimento no território naciona 年a retomada, independentemente dos visando a inserçao na economía de cada governo em questão priorizava, a do projeto de tra nposica A vue, com concepcâa de setransporáquas através de poucas modificações, foi ao fim e a un grande eixo foi mantida e ate mesmo cabo executada, teve sua concepção d duplicada, com a proposta do Eixo Leste, desenvolvimento e inserção do território daborada governo FHC. A noçáa de elaborados nesse contexto, o que esta grande obra, como se pode ver nos resorçou a necessidade desta tentativa de capitulos 1 e 2 ganhou força a partir da um panorama de como foi a insercão da década de 1990, no governo $\mathrm{FHC}$, quando obra como um todo na região semiárida começaram a ser elaborados os Estudos o que se buscou realizar no capítulo 3. de Inserção Regional (BRASLL, 2000a), No início do governo Lula em 2003, sociais contrárias ao projęo (SARMENTO, réomou-se pela última vez o projeto, trouxe a ideia de que a Transposiçã drica vinculada a uma ideia de

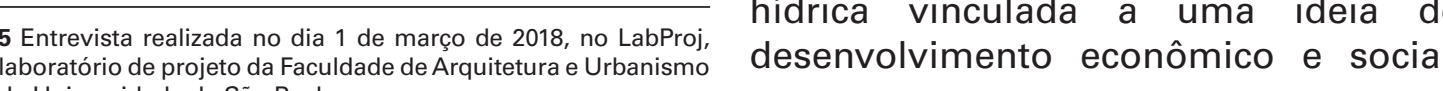

governo federal indicava, naquele projetos, propondo-se também um alegando-se que as leis de licenciamento nicio de gestão, que a questão regional possivel modelo de gestão. Os estudos ambiental passaram a ocultar os na agenda política. Desta forma, a analise calculos, argumentações propor soluções paliativas, sem que PISF adquiriu, em seu discurso oficial, teóricas e análise de resultados, se questionasse e de fato alterasse uma visão integrada do territorio, demonstrando um embasamento o modo de desenvolvimento que

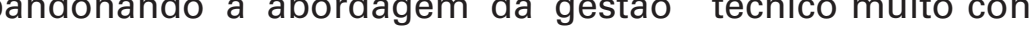
anterior (de ação mediante implantaçáa a obra, estudos estes que seriam de eixos de ino mojeto das desigualdades regionais com no próprio Estudos os PBAs do PISF, elaborados na gestão cocuperaçāo do poder de articulação das objetivo interferir no projeto, nem constituintesdolicenciamento ambiental

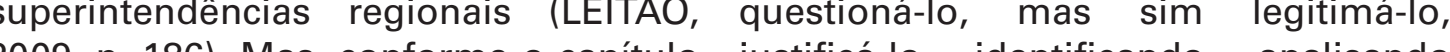
2 demonstrou, no caso da Transposicão justificá-lo, identificando, analisando do rio São Francisco, o governo Lula poderiam reforcar sua concepçăo de retomou a documentação produzida inserção regional, excluídos os aspectos na gestão anterior, tanto a relativa ao puramente de engenharia de obras e projeto quanto a que se refere aos ambientais, alvos de outros contratos
estudos de viabilidade e os de inserçâa (BRASIL, 2000a, tomo l, pp. 1-2). Isso se regional, para assim reelaborar o EIA constituiu como uma contradição interna do IBAMA para houvesse nenhuma alteração técnica relevante em termos de sua concepca como projeto de grande impacto.

reavaliação de se esta alternativa, a da adequada às condiçỗes socioeconômicas $\mathrm{e}$ ambientais. Esse documento

Dessa forma, conforme apresentado funcionou como o arcabouço técnico importantes do planejamento da que vinham ocorrendo no governo FHC, Transposição do rio São Francisco momento de grande discussão em torno voltados à questão regional do projeto da pauta ambiental, de acirramento das foram os Estudos de Inserção Regional disputas políticas e ideológicas em torno (BRASIL, 2000a), que auxiliaram do projeto, conforme fo
inclusive em definiçōes técnicas do item 2.2. do capítulo 2.

projeto dos canais, tais como as vazóes necessárias para suprir a as vazonda hídrica da regiâo e os documentos relação aos questionamentos 2004) e pelos trinta e oito PBAs (BRASLL, estes últimos resultantes dos diretrizes estabelecidas no EIA.

rata-se de reflexos da promulgaçáo de instituídas na Constituição de 1998 . Embora tais leis tenham representado No caso dos Estudos de Inserção direitos sociais e para a preservação Regional, apresentou-se boas e do meio ambiente, promovendo Já os trinta e oito PBAs, escritos

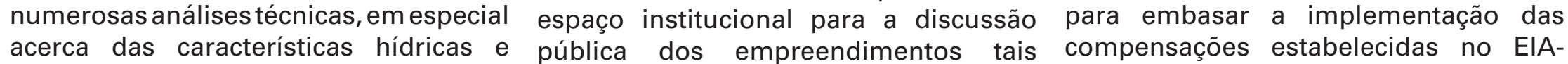
geomorfológicas para a inserção dos como a Transposição, o processo de RIMA, embora tenham sido mais canais nas áreas mais proveitosas para institucionalização do debate teve específicos e explicativos em relação à o estímulo de atividades econômicas, contradiçōes, havendo muitas críticas cada ação, não apresentaram cartografias além de análises das articulações daqueles que se entendiam como para localizar onde seria executado cada 
e nem de onde seriam mobilizados do modus operandi de aprovação de
recursos para implementação, sendo, empreendimentos via licenciamentos embora menos genéricos eu o ERIA- ambientais federais, uma vez que Tratou-se de uma obra muito complexa

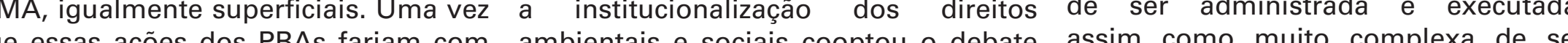
compreendida publicamente em relação sua função de ser apenas um sistema institucional, mas de fato aprovar a sua execuçâo, gestấo e custos, dado drico para superar a seca, estimulando estudos com soluçōes paliativas aos que a organizaçao físico-financeira atividades para o desenvolvimento impactos do empreendimento. Porém, da obra e do programa próprio PAC e local apesar dos problemas de planejamento, sofreu alteraçoes ao longo dos anos talvez fossem uma das partes mais e diretrizes, que ocorreram em especial no capítulo 3, para que a obra fosse mportante de todo o planejamento. nos documentos do licenciamento viabilizada, ela foi parcelada em lotes Uma apresentação simplificada dessas ambiental do PISF (EIA-RIMA e PBAs), é - inicialmente catorze, posteriormente ações, reiteradas pelas contradições da inegável que se trata de um projeto que reduzidos em seis -, havendo inúmeras presença-ausência da obra levantadas tem um vasto arcabouço de estudos e em campo apresentadas no capítulo que, apesar da Licença de Operação (LO) desenvolvimento reginal a partir dessa implantados em sua completude. obra de infraestrutura ficou apenas no campo administrativo, permanecendo a Transposiçăo na categoria de mais uma a exescampasso entre o planejamento e grande obra hidrica de combate à seca. programa federal através do qual a obra (Desama de Aceleração com pessoas impactadas pela obra programa que, muito embbora tivesse o trouxeram à tona queixas com relação discurso do desenvolvimento nacional e do para apresentação do Projeto através públicos para a execução de grandes obras do EIA-RIMA, em que as pautas vinham de infraestrutura, por vezes retomando
prontas e não havia espaço para projetos que estavam praticamente alterações e absorção de críticas. Essa abandonados desde a década de 1980, informação foi confirmada, ainda que fazendo o Brasil superar a crise econômica por outro ângulo, em entrevista com - Engenheiro Ivan Telles de Sousa,
coordenador da reelaboração do EIARIMA entre os anos de 2003 e 2004 Dessa forma, conforme evidenciado na empresa Ecology and Enviroment no capítulo 3, as ações orçamentárias do Brasil, terceirizada pelo Ministério executadas em relação ao PISF foram da Integração Nacional. Ele comentou açoes que se traduziram em obras APs e da forte rejace da realização das APs e da forte rejeição da população ao dos canais de transposição em sli,
projeto, além da dificuldade de mediar Eixo Norte (código da daca: 5900 ) do projeto e compatibilizar as propostas outras referentes a açôes relativas às entre os estudos de engenharia e os compensações ambientais, comuns ambientais. Talvez esses conflitos, a da poputactipaçáo e falta da real escuta estudos tenham prejudicado a aderência desta obra ao contexto socioespacial
do semiárido. Em alguns casos, como evidenciado no item 3.2 .2 do capítulo 3 , relatos de campo demonstraram que alguns grupos atingidos foram não
apenas não escutadas, mas também desconsideradas em sua cultura, história e forma de apropriação do território, como foi o caso das comunidades
indígenas Truká e Tumbalalá, cujas lideranças foram entrevistas para presente pesquisa.

A crítica de Acselrad (2010) aos todo auxiliou na compreensão de que as falhas notadas nos documentos da Transposição do rio São Francisco
consistem até certo ponto em reflexos GRealizada am 15 de dezembro de 2017 , em Săo Paulo, por Skyoe

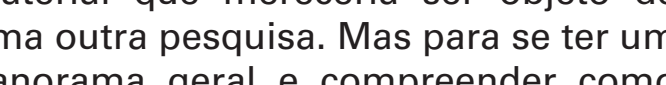
panorama geral e compreender como como esse programa por meio do qua executou o PISF teve implicações dretas com a presença-ausencia da obra de

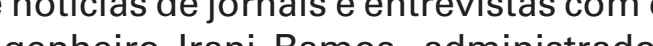
eúblico e assessor da Ministério da cãoa Nacional.

aos dois Eixos, tais como a de Comessas paralizaçōes e recontratações, reassentamento de população (código a obra atrasou quase dez anos em relaçãa
da ação: 12EO) e a de recuperação de a sua previsão inicial de conclusão reservatórios estratégicos existentes Porém, conforme demonstrado no que se interligarão ao PISF (código da capítulo 3 , apesar dos atrasos e 12G6). Ou seja, o PAC consistiu em imprevistos, não fol

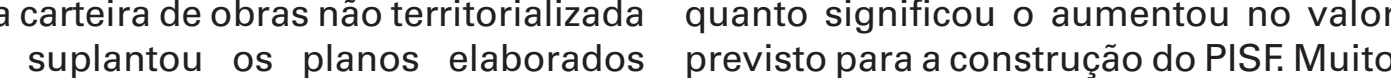
promover açónes dispersas e embora as notícias de jornal denunciem Ittadas à implementação das ações entre os balanços do PAC não se custo, previstas nos documentos visando o aumento destinado ao Projeto, em razão desenvolvimento regional e social e às da mudança na forma de contabilizar

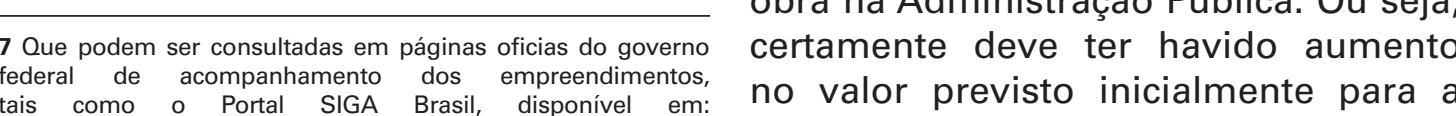
xecução do PISF, mas as transformaçõe

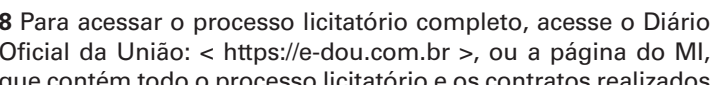

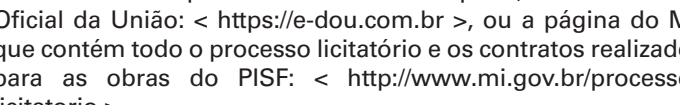

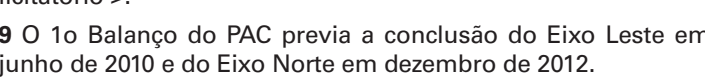

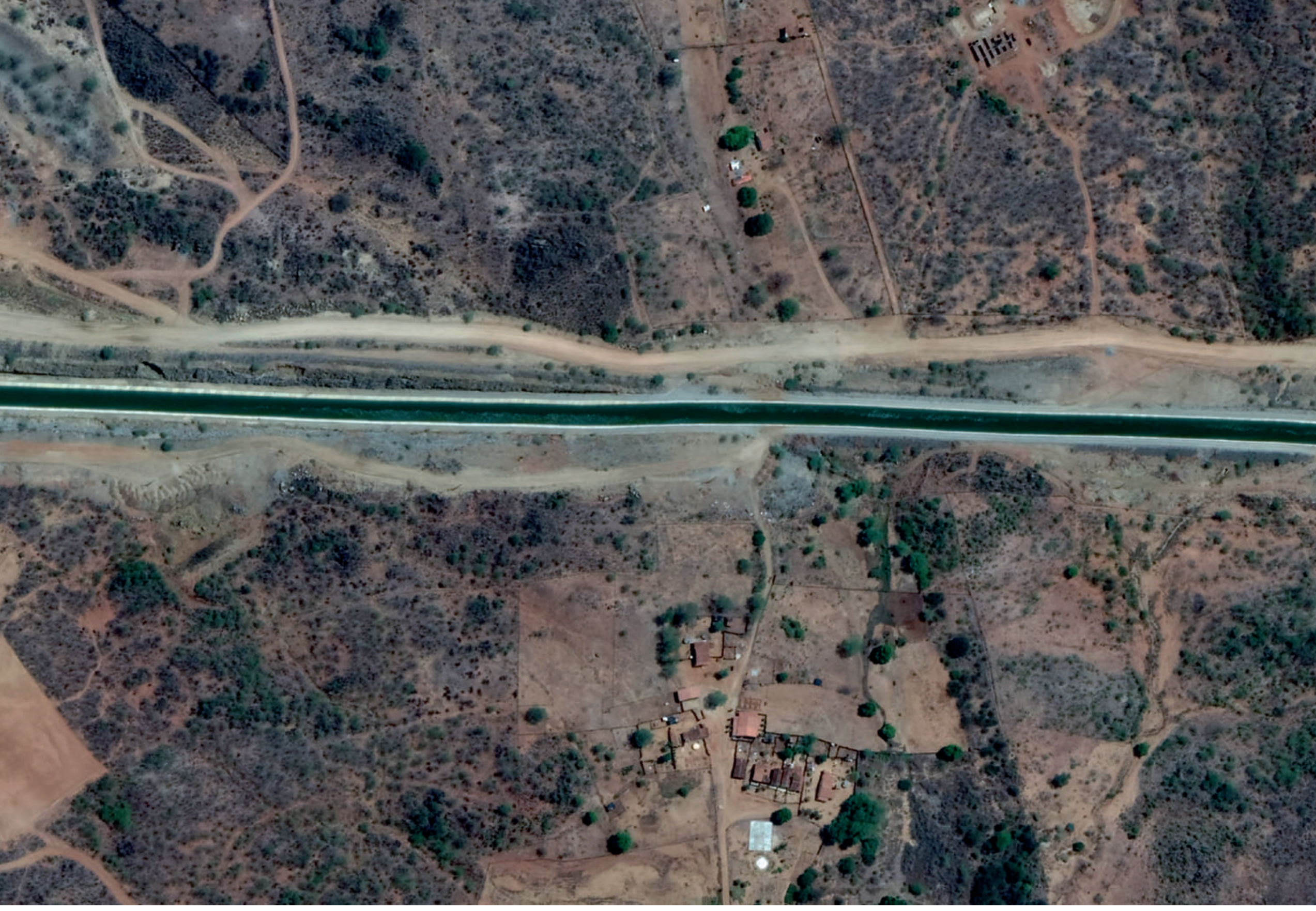

Figura 1- Exxo Leste dividinn or
Fonte: Google Maps, 2019 (LEITÃO, 2009, p. 246), (em grande parte erroneamente) que
PAC se confundem com o que realmente planejamento (EIA-RIMA, PBAs, Estudos significou aumento. O que se sabe é
que o valor atualizado previsto até a finalização de todo empreendimento é de $R \$ 10,7$ bilhōes de reais (BRASIL,
$2018 \mathrm{~b}$ ) e que o PAC realizou uma manobra que o PAC realizou uma manobra administrativa multo
complexa, por um lado permitindo dificultando a gestão desses milhar de contratos e a compreensão pública

Por fim, os sumários executivo realizados pelo Ministério da Integração Nacional, apresentados no capitulo 3, começaram a apresentar com mais público, ainda que não estivessem todos esses documentos organizados em um só lugar nas páginas oficiais para fáci oi possivel identificar não só o valor final previsto do PISF, mas também construção dos canais, digramas explicativos do projeto, algun mapas localizado as (poucas) açốes compensatorias executadas e graficos celacionados à execuçaro e custos obra. Com os sumários executivos disparidades entre os documentos do foi muito presente e impactante igualmente ausente e incompleta em dessa obra, que talvez tenha ficado acesso. Através deles, ainda que em
uma linguagem simples e resumida De obra apresentam a 政 a I EIA-RIMA a gra discurso official ou regiôes, de a nvolvimento eçâ entre

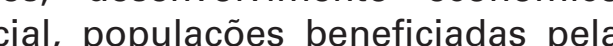
agua, vilas produtivas para promover que o que foi priorizado foram as obras dos canais. năo apenas entre documentos oficiais, apresentou-se no item 3.22 do capítulo 3 , a execução da obra, dando seguimento às contradições da concepção do projeto de forma que a obra, dialeticamente sua inserção territorial.

A centralidade conferida pelo
governo federal à implementacão do PAC, em detrimento das açōes de planejamento territoria de recuperar o papel planejador do
Estado nacional (por iniciativa de setores progressistas dentro das gestōes estudadas), frequentemente
elaboradas com envolvimento
Essas contradições também apareceram mas especialmente entre estes e 
de amplos setores da sociedade, reproduz no campo territorial as
contradiçōes e a desarticulação entre órgãos do governo federal, com concepcooes distintas de
desenvolvimento territorial, que se empenham na criação de planos, comunicam e se subjugam (LEITAO, 2009, p. 178

Dessa forma, o PAC reiterou o caráter de infraestrutura dessa obra e não 0 de desenvolvimento territorial e
social. Isso, somado à deficiência dos instrumentos ambientais e aos essa água, qu quem poderia consumir de regularização das terras desse entorno problemas de planejamento, gerou que sai da infraestrutura federal, a os pequenos proprietários ao longo

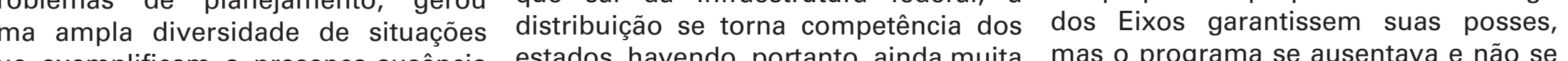
da obra no território uma serie de indefinicãa em relação à quais lugares articulava a nenhum programa federal território, uma serie de indefinição em relação à quais lugares articulava a nenhum programa federal
da aderência da obra ao receberiam a água. O que se sabia era no sentido de controlar de alguma forma território.

Essas presenças e ausências se deram de formas ora físicas, objetivas indiretas, utilizando-se aqui o conceito e posteriormente o item 3.3 reuniram A começar pelo fato de se tratar de umama A começar pelo fato de se tratar de uma
obra de muita presença por onde passa impactante, mas que não permite uma relação com seu entorno, ausente em na O território em dois lados, possuindo
poucas passarelas ao longo de seus poucas passarelas ao longo de seus
eixos, não sendo uma infraestrutura apta à convivência com a população residente neste entorno. Trata-se de apresenta riscos quando possível de ser acessada, de maneira que já houve alguns casos de morte por afogamen no momento em que as bombas do
PISF foram automaticamente acionadas para bombear a água (POLLO, 2017). A porte e impacto não foram apresentadas nas cartografias oficiais, de maneira que
$\mathrm{o}$ item 3.1 fez um esforço de demonstrar construtivo, seu dimensões do PISF ao leitor.

Ainda que já em período de pré- intermitente, mas também a vida, o praticamente pronta, a operação do várzea.

significativas. Tais como o valor da água Alem disso, houve quem precisou se por $\mathrm{m}^{3}$, uma vez que o governo federal retirar de suas casas para que a obra ainda estava estudando alternativas passasse, recebendo uma indenizaçâa renováveis de produção de energia a ou se transferindo para uma Vila de comprar energia da CHESF, o que o presente momento da conclusão A MEIDA, 2018 que o abastecimento das comunidades no momento em que a água chegasse. Ou rurais ocorreria apenas quando possível, mesmo, no caso da questão indígenas, 0 pois, atender todas as comunidades Projeto previu o auxílio da demarcaçãa no percurso tornaria o projeto inviável de terras, que historicamente estavam
financeiramente, uma vez que a sendo disputadas, mas que ao mesmo água transposta seria uma água cara tempo, reduziu o território indígena a
(RAMOS, 2017, informação verball). Ou uma área bem menor, destruindo as seja, a Transposição estaria destinada a demais áreas com as obras dos canais,

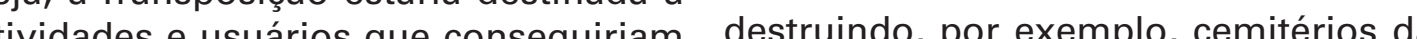
arcar com os custos dessa operação de etnia Truká (SANTOS, 2017, informação nsposição. verbal).

Dessa forma, por vezes os Eixos Estas foram algumas das manifestações passaram por lugares sem os abastecer, de presença-ausência que a obra fisicamente obra muito impactante promoveu ao longo de seus eixos acima), mas não beneficiando famílias capitulo 3, mas aqui se quis retomar

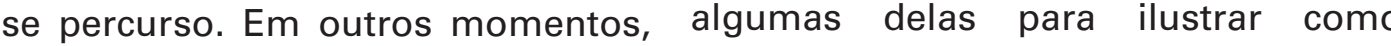
S canais em si náo chegaram perto, mas essas contradiçōes se deram entre o

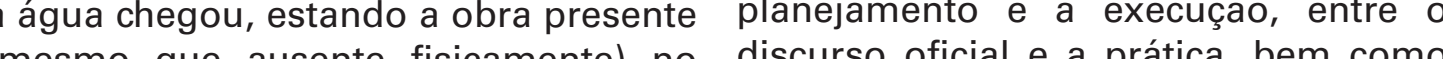
(atidiano dus ausenta foi mais preciso fazer racionamento de do Projeto está mal resolvida. gua com a chegada da água transposta, como foi o caso de Campina Grande. No Conforme descrito ao longo destas caso do rio Paraiba, a agua despejada consideraçóes finais, essas contradiçoes do patriz do projeto degrandeimpacto peis sua característica natural de ser um rio uma obra com a magnitude apresentada

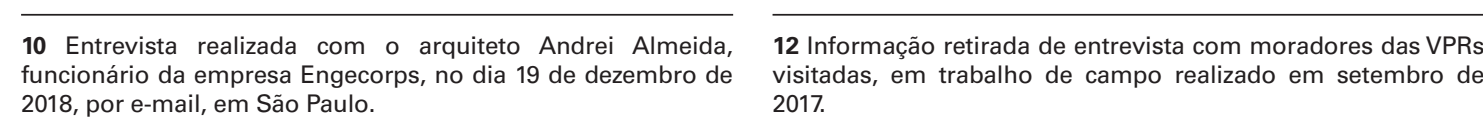
11 Informaçăa concedida em entrevista no dia 20 de março de 13 Entrevista realizada com Sr. Ailson dos Santos, no dia 08 no item 3.2.1 talvez não fosse possivel junto com a proposta de Transposição de que essa grande obra se justificaria causar pouco impacto, muito embora do rio São Francisco para o nordeste como a grande solução para as secas, acreditem que se o planejamento tivesse militar.Trata-se de uma transposição que desenvolvimento, com um traçado que sido implementado em sua completude, propõe transferência de águas do rio se manteve independente do objetivo garantindo o desenvolvimento regional Tocantins para o rio São Francisco, com final e indepente de como esse grande e social, ela se justificaria mesmo sendo o intuito de trazer mais água ao rio, que objeto se relacionaria como o território por

diminuicăa do seu volume, desde quá e es Entretanto, o que é levado a se pensar barragens hidrelétricas da CHESF foram é que, muito embora no planejamento construídas no final da década de 1970
tenha havido problemas, indefiniçoóes de e início da década de 1980 (CIMI, 2005). comoser executado, ogrande motivo que tenhatornadoessa obramaisumagrande obra hídrica no semiarido, e não uma hína grande obra de infraestrutura

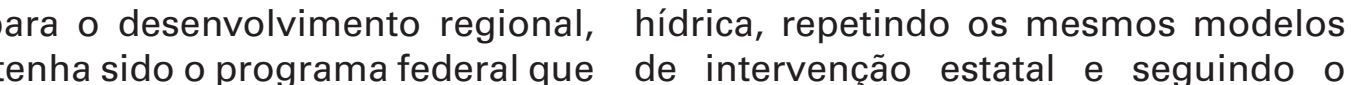
a viabilizou. Um programa que possuiu paradigma da grande infraestrutura ou grande capacidade administrativa que fez com que essa e outras grandes desenvolvimento, que promovem que, contraditoriamente, não se dos territórios, tratando-os a partir de as planos e políticas interesses para investimentos. Além 2009, p. 220 e p. 224) e, além disso, estatal repetidamente identificada foi a no PISF, não viabilizou uma execução da atuação em situaçōes emergenciais mais consistente dos PBAs, em especial os mais ligados às tran

Muito embora essas considerações e não estruturantes. Esse tipo de ação
estatal já era encontrada no século $\mathrm{XIX}$, quando o Estado criava frentes de trabalho para empregar a população stejam sendo feitas aqui, a obra ainda não foi concluída em sua completude e
sua operação ainda vai ser iniciada, de modo que outras vai ser iniciada, de quando o Eixo Leste do PISF foi concluído futuramente avaliar se os programas Grande de um colapso hídrico, sendo a serão desenvolvidos e atrelados ao isolada, ficando em segundo plano as PISF, viabilizando o acesso à água para ações mais estruturantes e de longo diferentes grupos sociais e promovendo prazo relacionadas ao desenvolvimento o desenvolvimento regional. Além disso, regional.

a ideia de se transpor outros rios no para reflexa do que não do rio São Francisco, embora houvesse p fazer, ou como fazer. Por exemplo, entre um discurso técnico e/ou político que
os anos de 2017 e 2018 , foi retomado embasasse as especificidades de cada como pauta no Senado (Senado Notícias, versaao do projeto ao longo da história, 2017; G1, 2018) $)^{14}$ um projeto que surg

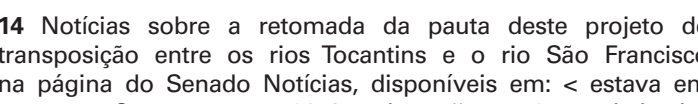

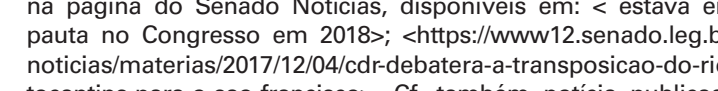

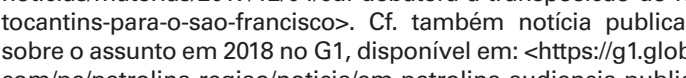
inclusive a última, que foi construída, as divergências e permanências entre
elas evidenciam que o projeto foi pouco questionado em seu modelo de infraestrutura. Permaneceu a ideia $=$ que tanto um século de execução de projetos hídricos, de acúmulos de experiências formulação de um pensamento cítico sobre a questão da pobreza ordestina, o que ainda impera nas ja, pouco relacionada com o contexto local e pouco articulada com planos progranas de desenvolvimento

presença da obra no território e no cotidiano da população através da água, do ideário construído longo de sua história, das promessas gestão dos recursos hídricos de dos recursos hidricos, ou a revelou contradicões entre a obra, descompassos os documentos do planejamento Fecução, Transposiçáa do rio sáo ucas açōes territoriais.

PISF se tornou mais uma grande de

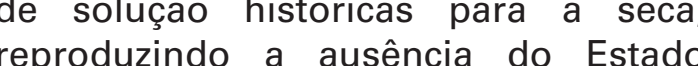
acões para reduzir a pobreza promover mudanças substanciais para o desenvolvimento regional. a implementaçáa de programas socioambientais, talvez tenha-se perdido uma oportunidade histórica de

O PISF é um projeto complexo e a presente pesquisa levantou como foram udou ao longo do tempo. Além disso, grande obra desterritorializada ou 
sua execução até 2018, realizando um panorama geral até o presente momento, sendo que seu desenvolvimento não se encerra nesta dissertação. Caberá às próximas pesquisas analisar os resultados de sua operação, assim como aprofundar alguns temas levantados na presente pesquisa que podem ser mais bem investigados, tais como uma análise mais aprofundada do processo licitatório e do custo real dessa obra, ou a comparação desse projeto com outros de transposições pelo mundo, ou mesmo eleger uma das situações de campo reveladas nesta pesquisa e aprofundá-la em relação à presençaausência dessa obra.

Dessa forma, a presente pesquisa teve o intuito de contribuir criticamente com essa maneira de intervenção no território e essa concepção de desenvolvimento, indagando se o modelo da grande infraestrutura seria o mais adequado para aquela realidade e buscando compreender como ocorreu a inserção desses dois grandes eixos de desenvolvimento naquela região. Restam aqui duas perguntas retóricas sobre o tema abordado: A matriz de grande impacto vale a pena? É necessário reproduzir velhos paradigmas para solucionar a seca e estimular o desenvolvimento? 


\section{Referências bibliográficas}

Anais do Fórum BNB de Desenvolvimento: Nordeste: estratégias de desenvolvimento regional. Fortaleza: Banco do Nordeste do Brasil, 2007.

AB'SÁBER, Aziz. "Sertões e sertanejos: uma geografia humana sofrida". Estudos Avançados [online], v. 13, n. 36, p. 7-59, ago. 1999.

ACSELRAD, Henri. “Ambientalização das lutas sociais - o caso do movimento por justiça ambiental". Estudos Avançados [online], v. 24, n. 68, pp.103-119, 2010.

ACSELRAD, Henri. "Justiça ambiental e construção social do risco". Trabalho apresentado no XIII Encontro Nacional da Associação Brasileira de Estudos Populacionais, Caxambu, novembro 2002. Disponível em: https://revistas.ufpr.br/made/ article/viewFile/22116/14480.

ACSELRAD, Henri. "Sustentabilidade e articulação territorial do desenvolvimento brasileiro". Trabalho apresentado no II Seminário Internacional sobre Desenvolvimento Regional - Programa de Pós-Graduação em Desenvolvimento Regional. Santa Cruz do Sul, 28 setembro a 01 de outubro de 2004.

ALMEIDA, A.; MARIN, R.; SANTOS, J. [et al] (coords.). Nova Cartografia Social dos Povos e Comunidades Tradicionais do Brasil: Povo Indígena Kambiwa. Manaus: Projeto Nova Cartografia Social da Amazônia / UEA Edições, 2010. Disponível em: http://juracymarques. com.br/site/cartografia-povo-kambiwa.

Nova Cartografia Social dos Povos e Comunidades Tradicionais do Brasil: Povo Indígena Pipipã. Manaus: Projeto Nova Cartografia Social da Amazônia / UEA Edições, 2010. Disponível em: http://juracymarques. com.br/site/wp-content/uploads/2017/08/05Pipipa.pdf. Acessado em 10 de novembro de 2017.

Nova Cartografia Social dos Povos e Comunidades Tradicionais do Brasil: Povo Indígena Truká. Manaus: Projeto Nova Cartografia Social da Amazônia / UEA Edições, 2010. Disponível em: http://juracymarques. com.br/site/wp-content/uploads/2017/08/03Truka.pdf. Acessado em 10 de novembro de 2017.

Nova Cartografia Social dos Povos e Comunidades Tradicionais do Brasil: Povo IndígenaTumbalalá. Manaus: Projeto Nova Cartografia Social da Amazônia / UEA Edições, 2010. Disponível em: http://juracymarques. com.br/site/wp-content/uploads/2017/08/04Tumbalala.pdf. Acessado em 10 de novembro de 2017.

AMORIM, Anália. Habitar o Sertão. São Paulo, Universidade de São Paulo, 1998. Doutorado em Arquitetura e Urbanismo.

ARAÚJO, Christianne Evaristo de. A partir das águas: argumentações midiatizadas, resistência popular e a transposição do rio São Francisco. Brasília, Universidade de Brasília, 2012. 310 Doutorado em Desenvolvimento Sustentável.

ARAÚJO, Tânia Bacelar de. “Brasil nos anos noventa: opções estratégicas e dinâmica regional". Revista Brasileira de Estudos Urbanos e Regionais [online], n. 2, pp. 9-24, nov. 1999.

BARBOSA, Humberto Alves; BURITI, Catarina de Oliveira. Um século de secas: Por que as políticas hídricas não transformaram o semiárido brasileiro? S.L.: Chiado, 2018.

BARROS, J. N. O desencantamento das águas no sertão: crenças, descrenças e mobilização social no projeto de transposição do rio São Francisco. Rio de Janeiro, Universidade Federal do Rio de Janeiro, 2014. Mestrado em Planejamento Urbano e Regional.

BORDA, J. Perea. Los ríos nos unen. Integración fluvial suramericana. Bogotá: Corporación Andina de Fomento, 1998.

CALLADO, Antônio. Os Industriais da seca e os galileus de Pernambuco. $1^{\text {a }}$ edição. Rio de Janeiro: Civilização Brasileira, 1960.

CAMPOS, José Nilson B. “Secas e políticas públicas no semiárido: ideias, pensadores e períodos". Estudos avançados [online], v. 28, n. 82, pp.65-88, 2014.

CONSÓRCIO BRASILIANA. Relatório Síntese do Estudo dos Eixos Nacionais de Integração e desenvolvimento. Contrato do Consórcio Brasiliana, junto ao BNDES. Brasília: maio de 2000.

CASTRO, César Nunes de. Transposição do rio São Francisco: análise de oportunidade do projeto. Instituto de Pesquisa Econômica Aplicada. Texto para discussão: 1577. Rio de Janeiro, fevereiro de 2011

COSTA, Ivoneide de França. Comissão Hidráulica do Império (1879-1880): profissionalização e técnica a serviço dos melhoramentos no século $X I X$. Rio de Janeiro, Fundação Oswaldo Cruz, 2013, 290 f. Doutorado em História das Ciências e da Saúde.

DEMENTSHUK, Marcia. “A Transposição, um projeto dos tempos do Império". S.L.: Agência Pública, 6 de fevereiro de 2014. Disponível em http://apublica.org/2014/02/transposicao-umprojeto-dos-tempos-imperio. Acessado em: 8 de julho de 2017.

DINIZ, Clélio Campolina. “Celso Furtado e o desenvolvimento regional." Nova economia [online], v.19, n.2, pp.227-249, 2009.

FILGUEIRAS, Alex Sandro. "A transposição do rio São Francisco". 6 de setembro de 2014. Disponível em: http://www.sabernarede.com. br/a-transposicao-do-rio-sao-francisco. Acessado em: 7 de agosto de 2017.

FILHO, Jose Alves de Figueredo. "Sobrevivência Portuguesa no Cariri Cearense". In: Anais do IV Simpósio Nacional dos Professores Universitários de História. São Paulo, 1969. Disponível em: http://anais.anpuh.org/wpcontent/uploads/mp/pdf/ANPUH.S04.12.pdf. Acessado em: 8 de agosto de 2017.

FIORAVANTI, Carlos. "O rio do Império". Pesquisa FAPESP. São Paulo, FAPESP, ed. 248, pp. 92-94, outubro de 2016. Disponível em http:// revistapesquisa.fapesp.br/2016/10/20/o-rio-doimperio.

FUINI, Lucas Labigalini. “O território em Rogério Haesbaert: concepções e conotações". Geografia, Ensino \& Pesquisa [online], v. 21, n.1, pp. 19-29, 2017.

FURTADO, Celso. Seca e poder: entrevista com Celso Furtado. São Paulo: Fundação Perseu Abramo, 1998.

A operação nordeste. Rio de Janeiro: Instituto Superior de Estudos Brasileiros Ministério da Educação e Cultura, 1959.

A Fantasia Desfeita. São Paulo: Paz $\overline{\text { eTerra, } 1989}$

Uma política para o desenvolvimento do Nordeste. Rio de Janeiro:

Presidência da República / Imprensa Nacional: 1959.

GOMES, G. M. Velhas secas em novos sertões. Brasília: Ipea, 2001.

HAESBAERT, Rogério. Des-territorialização e identidade: a rede gaúcha no Nordeste. Niterói: Eduff, 1997.

O mito da desterritorialização: Do "fim dos territórios" à multiterritorialidade. Rio de Janeiro: Bertrand Brasil, 2004.

“Dilema de conceitos: espaçoterritório e contenção territorial". In: SAQUET, M. A.: SPOSITO, E. S. Território e territorialidades: 


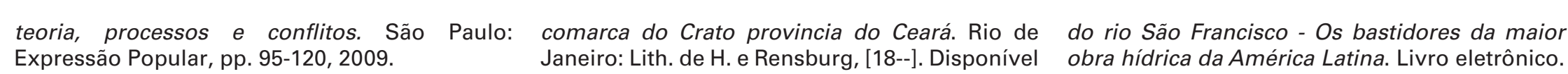

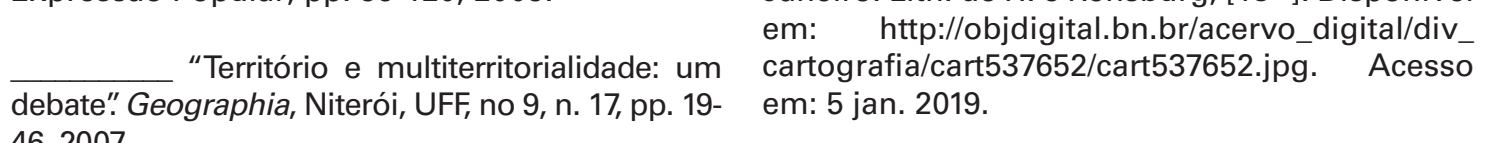

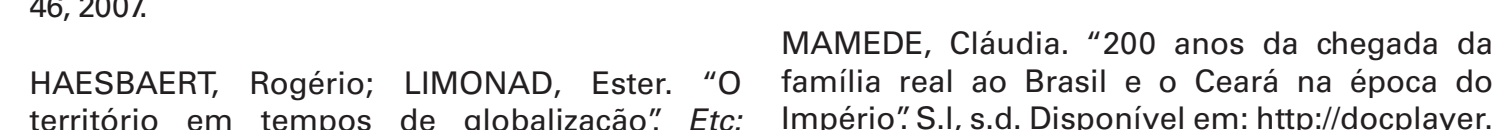

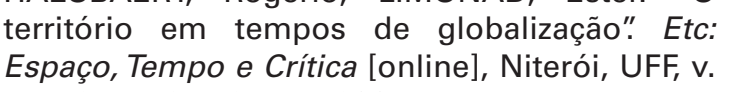
1, n. 2, pp. 39-52, ago. 2007.

HALEELD, Henrique Guilherme Fernando.

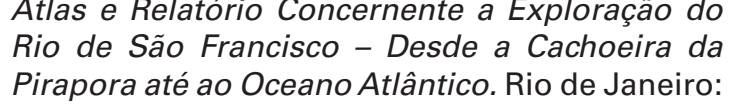

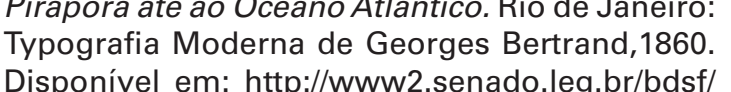
Dissonivel em:
handlefid//185636.

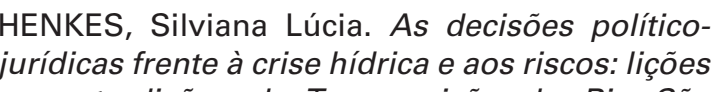
contradiçêes da Transposiçâa do Rio $S$ Universidade Federal de $\mathrm{S}$

HENKES, Silviana L. "A politica, o Direito o Desenvolvimento: um estudo sobre a

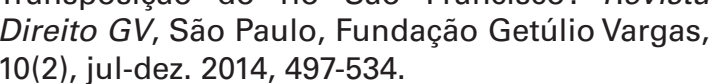
KATZ, Cláudio. América Latina: socialismo ou neo-desentivivimentismo. Trad.
Buenos Aires: CONISET, 2006.

LEFEBVEE, H. La production de r'spsace, 4e éd,
Paris: Editions Anthropos, 2000. Disponivel en

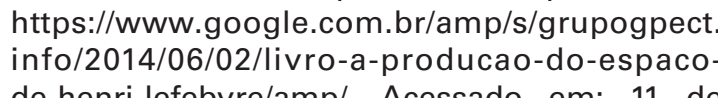
de-henri-lefebvre/ampl. Acessado em: 11 de

La Presencia y La Ausencia: Contribuición a L LaTeoria de las Representaciociones
Cidade do Méxio: Fondo de Cultura Económicas

LEITÃo, K. O. A dimensão territorial do Program - PAC no Estado do Pará en olugar estudo sobre à Amazônia no desenvolvimento do pais. Sảo aulo, Universidade de Sảo Paulo, 2009,
Doutorado em Arquitetura e Urbanismo.

LIAIS, Emmanuel. Hydrographie du haut San-
Francisco et du Rio das Velhas: ou, Resultats au point de vue hydrographique d'un voyage
effectué dans la province de Minas-Geraes. Paris
/ Rio de Janeiro: Garbnier / B.L. Garnier, 1865 . LIMA, Rosilene Cassiano Silva A. de; BURITI Catarina de Oliveira; BEZERRA, Hallyson Alves;
PATRícIO, Maria da Conceiçăo Marcelino. Abastecimento de água em Campina Grande hoje e amannäa. L LLivro Elico. In Campicicol. Campina
Grande: EDUEPB, 2013. LISBOA, M. A. "O problema das secas". Dnocs: pensamentos
pp.11-28, 1984.

LOUREIRO, Maria Rita; TEIXEIRA, Marco
Antonio C.; FEREIRA, Alberto. "Democracia desenvilvimento no Brasil contemporâneo:
conffitos e articulaçóes de interesses no Projeto Sao Francisco". Instituto de Pesquisa Econômica
Aplicada. Texto para discussão: 1883. Rio

MACEDO, M. A. de. Mappa topographico da com.br/14951685-200-anos-da-chegada-da
familia-real-ao-brasil-e-o-ceara-na-epoca-do-
mperio.html. Acessado em: 8 de agosto de 2017 . MARICATO, E. O impasse da política urbana no (I), AJ.Vozes, 2014 MARICATO, E. "Cidades no Brasil: capitalista predatório?". Revista Polititica Social Disponivel em: htp.//issuu. docs/revistaplataforma. Silva dos (orgs.) O semiárido Brasileiro: riquezas diversidades e saberes. Campina Grande: IISA
MCTI, 2013. Coleçâo Reconhecendo o Semiárido MARINHO, Roberto Alves da Silva. Entre o transiçóes paradigmáticas e sustentabilididade do desenvolvimento. Brasilia, Universidade de
Brasilia, 2006. Doutorado em Desenvolvimento Brasilia, 2006.
Sustentável.

MORAES, Eduardo José de. Navegação Interior para a juncáo de diversas bacias hidrográficicas do Brasil, ou rápido esboço da futurar rede geral
de suas vias navegáveis. Rio de Janeiro: Typ. Montenegro, 1869 MOURA, M. S. B. de; GALVINCIO, J. D.; BRITO,
L.T. de L.; SOUZA, L., S. B. de; SA, I. I. S.i SILAA,
T. G. F. da. Clima eágua de chuva no semi-arido. Empresa Brasilieira de Pesquisa Agropecuária
(EMBRAPA): 2007. Disponivel em: huttrs: ainfo.cnptia.embrapa.br/digital/bitstream/

NETO, Clovis Ramiro Jucá. "Os primórdios cearense: algumas notas"." Anais do Maseu
Paulista: Historia e Cultura Material [online],

ARMENTO, Francisco Jácome. Transposição do Sao Francisco - Realidade e obra a constru
1. ed. Brasilia: Edicel, 2005. SARMENTO, Francisco J.; MOLINAS, Pedro
"A Operacăo Dos Reservatórios Sujejitos Transposiçąa De Águas - Estudo De Caso Dos

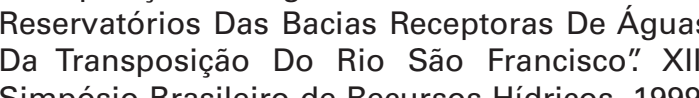
Simpósio Brasileiro de Recursos Hídricos, 1999 Belo Horizonte. Anais do XIII Simpósio Brasileiro
de Recursos Hidricos. Belo Horizonte: ABRH "A Gestão das Águas da
Transposição do Rio São Francisco no Nordeste Bansposiçăo do Rio Säo Francisco no Nordest
Brasileiro". XIV World Water Congress, 2011, ongress. 2011 desenvolvimento no Vale do São Francisco: Econtro de Geógrafos Brasileiros, Porto Alegres

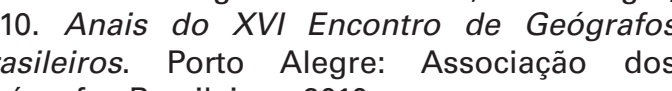
SOUZA, Alexandre do Nascimento. Licenciamento ambiental no Brasil soba
perspectiva da moderizazáo ecológica. São
Paulo, Universidade de Säo Paulo, 2009. SOUZA, Marcelo JoséL Lopes de. Oterritório:sobre espaço e poder. Autonomia e e desenvolvimento. R. L. (orgs.). Geografia: conceitos e temas. Ri
de Janeiro: Bertrand Brasil, 2001, pp. 77-116.

UASSUNA, João. "Potencialidades hídricas Nordeste brasileiro"." Parcerias Estratégicas
asilia, CGEE, n. 20, pp. 131-156, 2005. "Transposição de Águas do Rio de setembro: de 2001. Disponivel em: http: conw.fundaj.gov.br/index.php?option=com .

TOMÁZ, Alzeni [et al] (orgs.). Relatório de mpactados com a Transposiç̧ão do Rio São rancisco. S.L.: 2008. Disponivel em: https:///cim impactados-transposicao-sao-francisco.pdf.
Acessado en 4 de dezembro de 2018 . VAINER, Carlos B. "O PAC e seus impactos na politica de desenvolvimento urbano e regional:
XII Encontro Nacional da Associaçâ Naciona XIII Encontro Nacional da Associaçãa Nacional
de Pós-Graduaçăo e Pesquisa em Planejamento Urbano e Regional, Belém, 2007. (informação

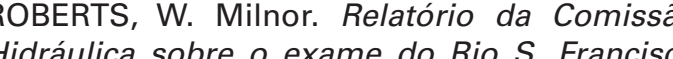
desde o mar até a cachoeira de Pirapora. Rio de : Typografia Nacional, 1880

ROLNIK, Rosely; KLINK, Jeroen. "Crescimento VILLA, Marco Antônio. Vida e morte no Sertäo: que nossas cidades continuam tâo precárias?":
Novos Estudos CEBRAP, São Paulo, CEBRA?,

ACCONI, Carolina Jessica Domschke. Xique Documentos técnicos oficiais Paulo, Escola da licenciamento ambiental Arquitetura e U Urbanismo. São Paulo, 2012 . 201
Disponivel Disponivel em: https://issuu.com/carolsacconi/
docs/tfg_carolsacconi. Acessado em 18 de

BRASIL. Ministério da Integracāo Nacional.
Atlas do Nordeste - Abastecimento Urbano de Aqua. Alternativas de oferta de água para sed municipais da Região Nordeste do Brasil e do
norte de Minas Gerais. Brasilia, 2006. Disponivel

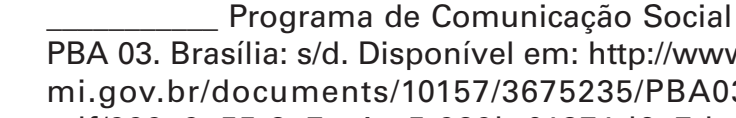

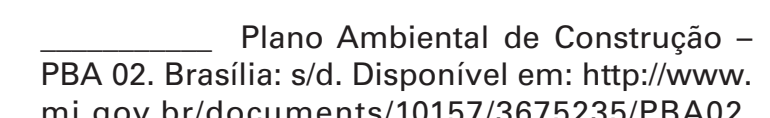

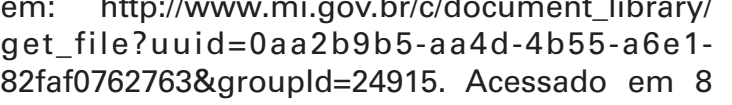
de outubro de 2018 .

Brasileiro. Nova Delimitacaão do Semi-Árido

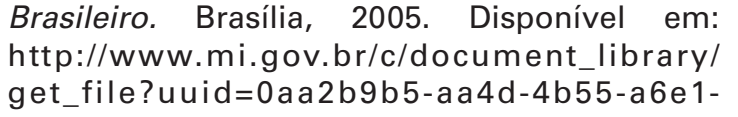
de outubro de 2018

anos Básicos Ambientais.

Plano de Gestāo, Controle
$\overline{\text { Ambiental }}$ Social das Obras - PBA s/d. Disponivel em: http://www.mi.gov.br/ documents/10157/3675235/PBA01.pd//ffa39768 de janeiro de 2019 mi.gov.br/documents/10157/3675235/PBA
pdf/cac7ffff-b914-4f6d-bac8-6a3a0f6f966 Acessado em: 16 de janeiro de 2019 pdf/9999e9e55-3a7e-4cc5-939b-01371d6e7dac

Programa de Educaçāa Ambiental
PBA 04. Brasilia: $s / d$. Disponivel em: http://www mi.gov.br/documents/10157/3675235/PBA04
ddf/d21 bfa21-f67e-4c65-994d-1aagba559316

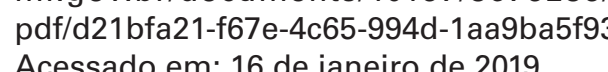

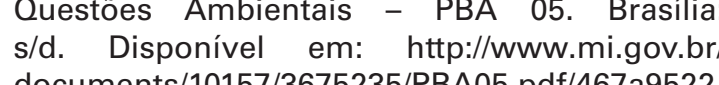
documents/10157/3675235/PBA05.pdf/467a9522.
8568-453a-a43b-e2ec258318fo. Acessado em: 11 de janeiro de 201

Salvamento Programa de Identificaçăo Salvamento de Bens Arqueológicos - PBA
06. Brasilia: s/d. Disponivel em: http://www mi.gov.br/documents/10157/33675235/PBA06.
pdf/48dea42c-2834-41ef-a842-3db610270dce.

Programa de Indenizacãa de
eitorias - PBA 07. Brasil Terras e Benfeitorias - PBA 07. Brasilia
s/d. Disponivel em: http///www.mi.gov.b.

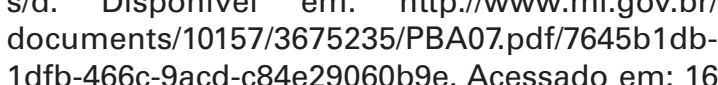
de janeiro 2019. de Populaçōes - PBA 08. Brasilia: s/d.
Disponivel em: hitpp///www.integracaoo.gov.br/ documents/10157/3675235/PBA08.pdf/156621 fbde janeiro de 2019.

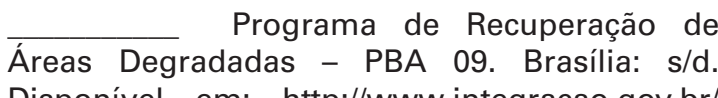

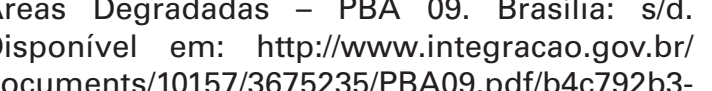
d28f-40d8-b7755-775e7dde9aa9. Acessado em:
de janeiro de 2019. Programa de Supressão de
Vegetação das Áreas de Obra e Limpeza dos Reservatórios - PBA 10 . Brasilia: s/d.
Disponivel em: http://wwww.integracaoo.gov.b documents/10157/3675235//PBA10.pdf/84933b3316 de janeiro de 2019

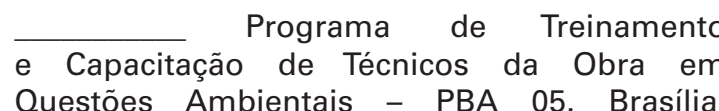

de Populaçōes - PBa de Re. Brasilia:

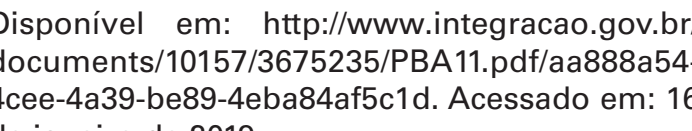
janeiro de 2019

Programa de Apoio as Comunidades
ndígenas - PBA 12. Brasilia: s/d. Disponivel em

hitp://Www.integracaa.gov.br/web//projeto-sao-
francisco/38-programas-ambientais/programa-
de-anoio-as-comunidades-indigenas. Acessado de-apoio-as-comunidades-i
em: 16 de janeiro de 2019 . $\begin{array}{r}\text { Programa de Compensaçâa } \\ \hline \text { Ambiental - PBA 13. Brasilia: s/d. Disponivel em }\end{array}$

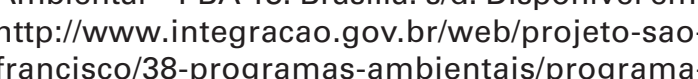
de-compensacao-ambiental. Acessado em: 16
de janeiro de 2019.

do Entorno e Programa de Conservação e Usoas dos Reservatórios PBA 14. Brasilia: s/d. Disponivel em: http://www.

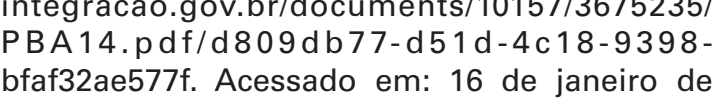
2019.

Programa de Implantaçăo de ao Longo dos Canais - PBA 15. Brasilia: s/d. Disponivel em: hitp://www.integracao.gov.br/
documents/10157/3675235/PBA15.pdfleac46747889c-4c08-896d-9ad646ecc5c72. Acessado em: 16
de janeiro de 2019.

de Água e A Apoio Técnico de Fora Pequenasas Atividades de Irrigacăo ao Longo dos Canais
para as Comunidades - PBA 16. Brasilia: s/d.

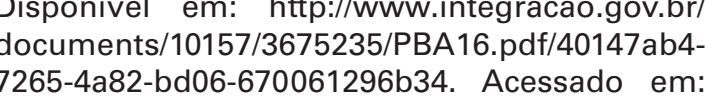
de janeiro de 2019

Programa de Desenvolvimento das
Comunidades Quilombolas - PBA 17. Brasilia: $5 / d$. Disponivel em: hittp://www.integracaoo.gov.br/ c7-4451-bf2b-67azaee194c7. Acessado em: 16

Programa de Apoio e Fortalecimento
dos Projetos de Assentamento Existentes ao Longo dos Canais - PAA 18 . Brasilia: sted.
Disponivel em: http://www.integracaoogov.br/ documents/10157/3675235/PBA18.pdf/612cfed2 2 janeiro de 2019.

ProgramadeApoio e Fortalecimento
s Projetos de Assentamento Existentes Longo dos Canais - PBA 18. Brasilia: s/d.
sponivel em: http:///www.integracaoo.gov.br/ documents/10157/3675235/PBA18.pdf/612cfed2de janeiro de 2019 Fundiária nas Áreas de Entorno dos Canais integracao.gov.br/documents/1015157/36752355/ 6625dfd844cd. Acessado em: 16 de janeiro de

Programa de Monitoramento
de Vetores e Hospedeiros de Doencas - PBA 20. Brasilia: s/dd. Disponivel em: http://www

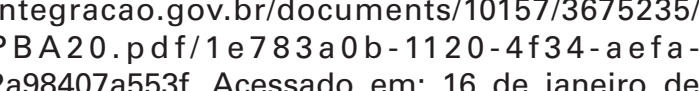
2019 c-4221-9da5-7e202c89237f. Acessado em: 16 Programa de Monitoramento
Qualidade da Agua e Limnologia - PBA Brasilia: s/d. Disponivel em: http://www

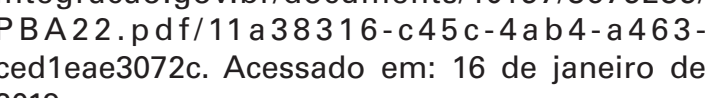

Fauna e Flora - PBA 23. Brasilia: $s / d$ onivel em: http:///Www.integracaoc.gov.bi

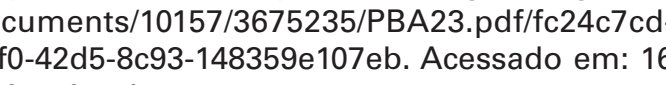
neiro de 2019.

Programa de Prevenção
Desertificaçãa - PBA 24. Brasilia: s/d. Disponive

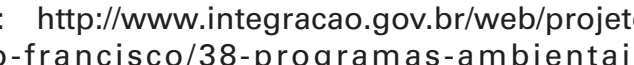
nas-ambientai

Programa de Monitoramento do Brasilia: s/d. Disponivel em: http://www (2) gracao.gov.br/documents/10157/3675235/ b294cc85ce. Acessado em: 16 de janeiro de Programa de Cadastramento de
ontes Hídricas Subterrâneas - PBA 26. Brasilia: d. Disponivel em: hth: htp///www.integracaca. gov. br/documents/10157//3675.h23/P/PBA26.
dff/98f7c626-1aba-48e4-b833-1 b0953abe60f. Acessado em: 16 de janeiro de 2019 Programa de Monitoramento
Processos Erosivos - PBA 27. Brasilia: $s / d$. ons: http://www.integracao.gov.br/ d59-4aa0-bc9b-e3f01 a5cbffi2. Acessado em: Programa de Monitoramento de
Cargas Sólidas e Aportantes nos Rios Receptores seus Açudes Principais - PBA 28. Brasilia

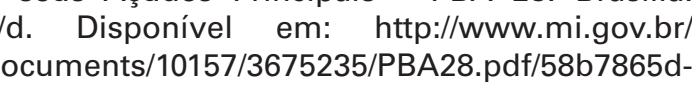
df-40dc-9d1e-dd2861ed781c. Acessado em: 16

$\begin{aligned} \text { Programa de Monitoramento de } & \\ \text { Cargas Sólidas Anortantes nos Rios Receptores } & \end{aligned}$ seus Açudes Principais - PBA 28. Brasilia d. Disponivel em: hitp://www.migov.br/
ocuments/10157/3675235/PBA28.pdf/58b7865d(16

Programa de Apoio ao
Desenvolvimento de Projetos Implantados, en

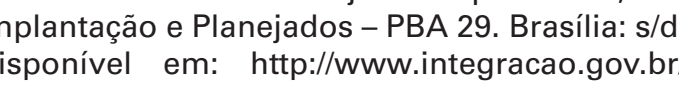
cuments/10157/3675235/PBA29.pdf/68660db9Programa de Apoio às Açōes
e Vigilância da Qualidade da Água para Consumo Humano - PBA 30. Brasilia: s/d. ocuments/10157/3675235/PBA30.pdf/4a12d309-

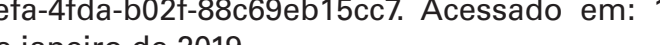

Programa de Apoio a Reducăa de
Prdas no Sistema de Abastecimento Público e 


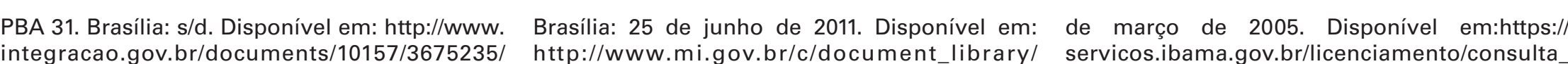

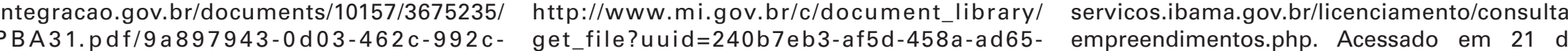

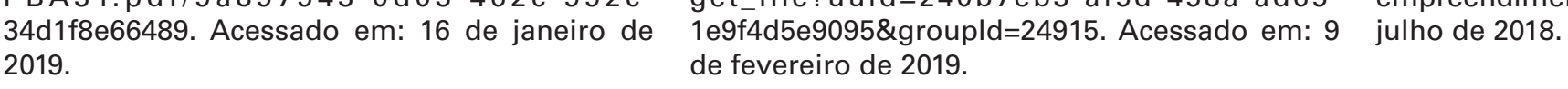

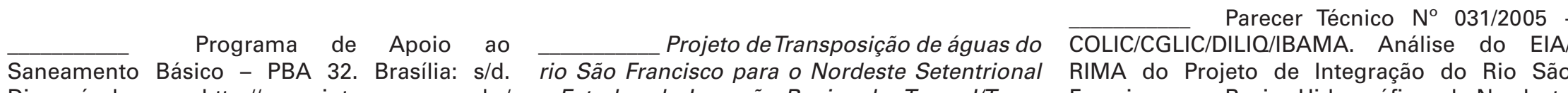

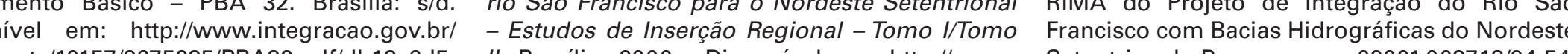

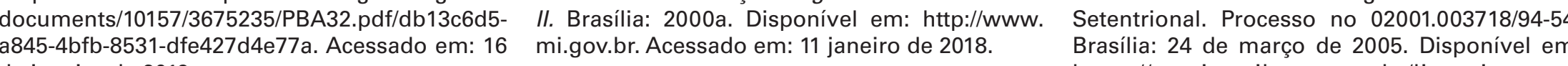

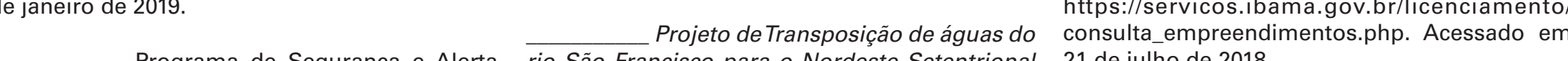

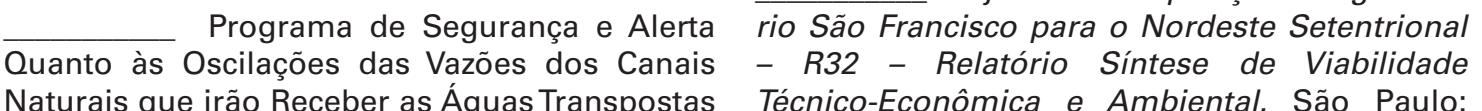

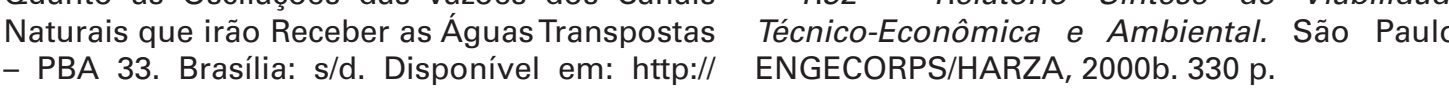
www.integracao.gov.bric/docoument_library/

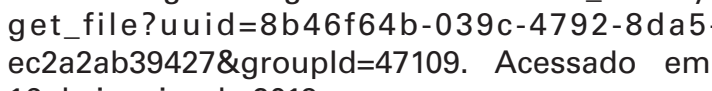

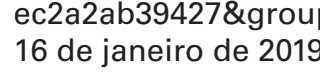

Programa de Relocação das

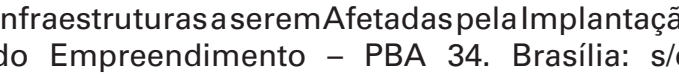

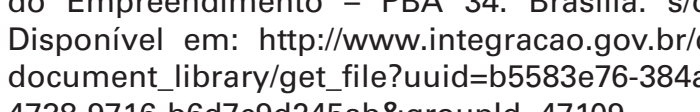

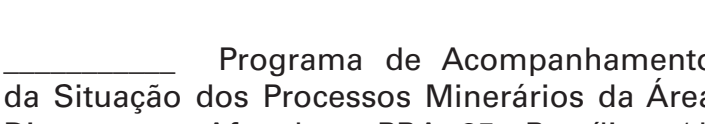

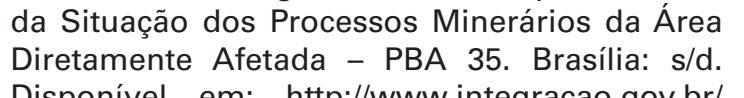

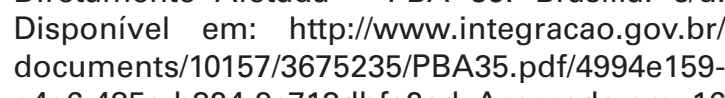
eas6-485--b324-9c7
de janeiro de 2019 .

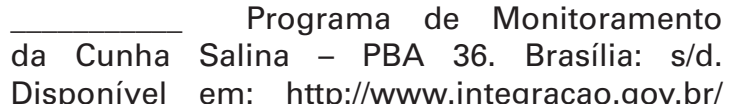

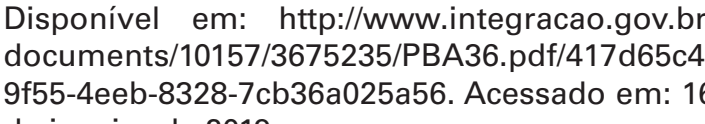
de janeiro de 2019 .

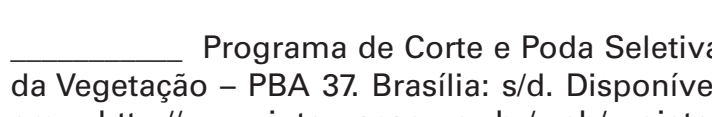

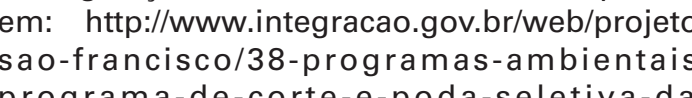
vegetacao. Acessado em: 16 de janeiro de 2019.

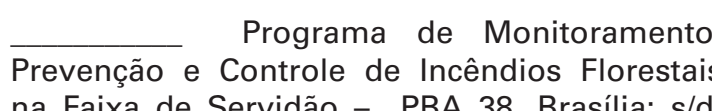

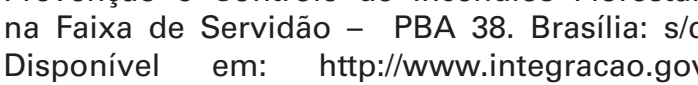

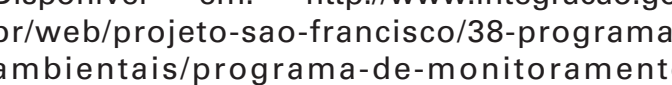
prevenca-a-e-controle-de-incendios-florestais
na-aiaxa-de-servidao. Acessado em: 16

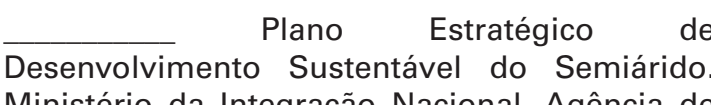

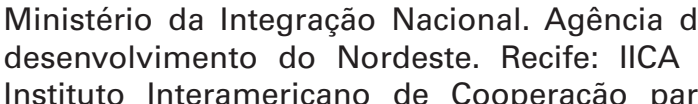

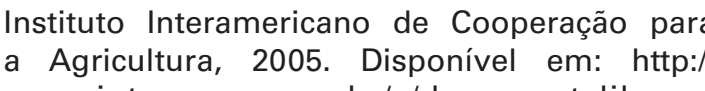

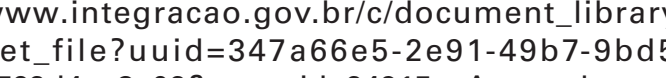
5762 2daeaese2 28 groupldde24915. Acessado em:
10 de novembro de 2018.

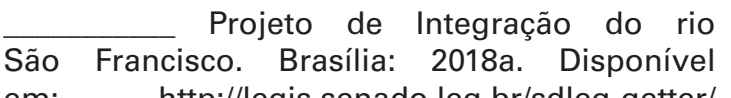

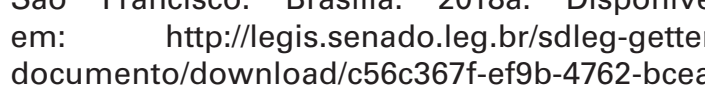

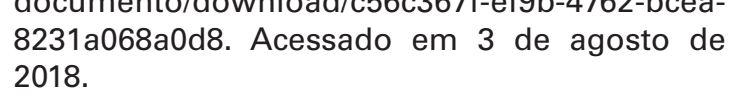

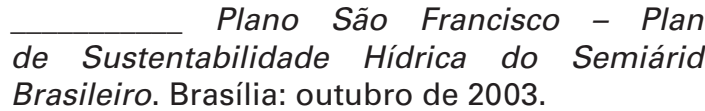

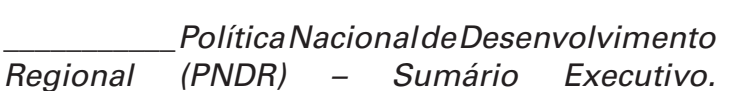

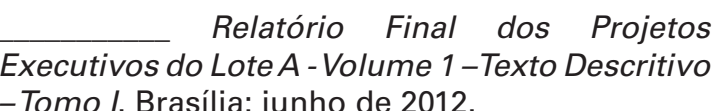

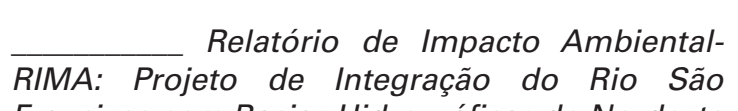

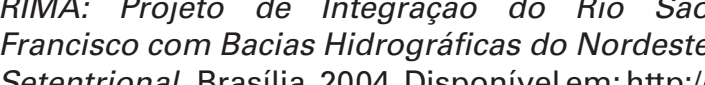
whw.mi.govivr. Acessado em: 21 dezembro de
2017

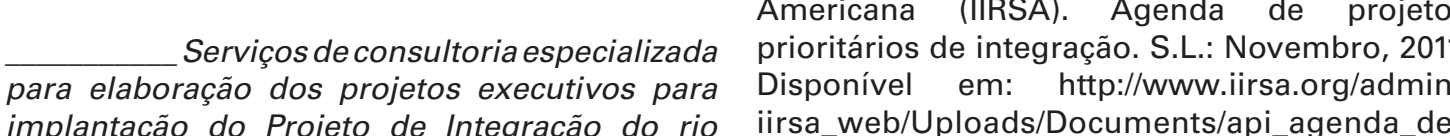
Sä Francisco com bacias hidrograficicas do do

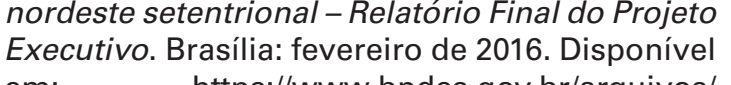

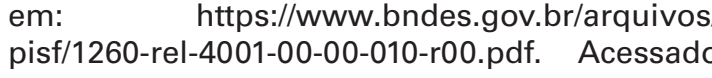

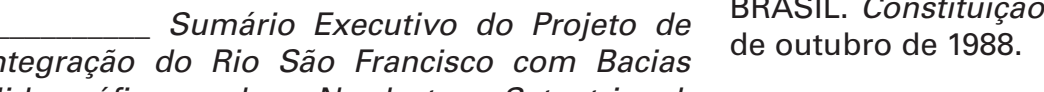

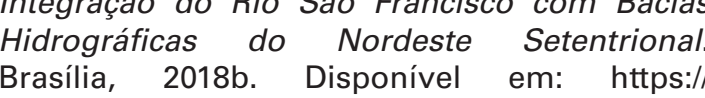

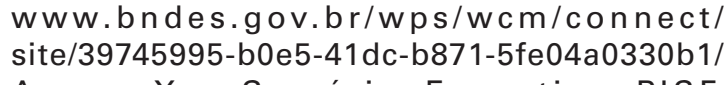

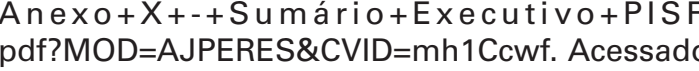
em: 06 setembro de 2018.

BRASLL Ministério da Transparência e
Controladoria-Geral da Uniâa. Relatoróio de

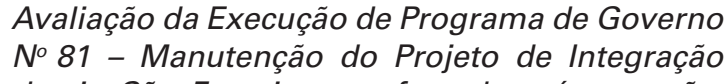
do rio Säa Francisco na fase de prí-operacäa.
Brasilia: novembro de 2017. Disponivel ema Brasilia: novembro de 2017. Disponivel em:
https:///auditoria.coguugov.br/downlload/10679.pdf. Acesssado em 02 de a agosto de 2018

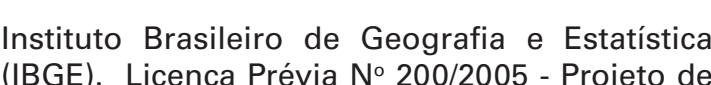
Integracāo de Bacias Hidrográficias do Nordeste
Setentrional. Brasilia: 29 de dezembro de 2005 .

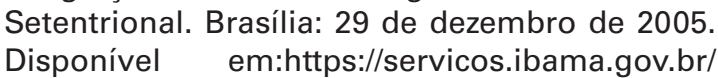
licenciamento/consultae empreendimentos.php.
Acessado em 21 de jullho de 2018 .

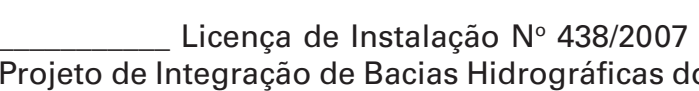

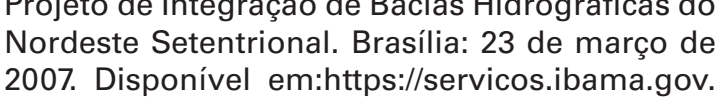
brllicenciamento/consulta aempreend
php. Acessado em 21 de julho de 2018 .

Licojecto de de Instalacăo № 925/2013

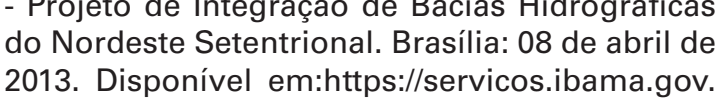

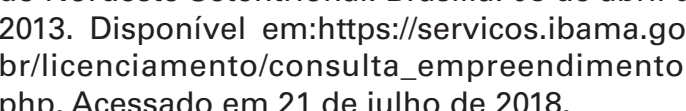
Parecer No 03172005 - COLIC/

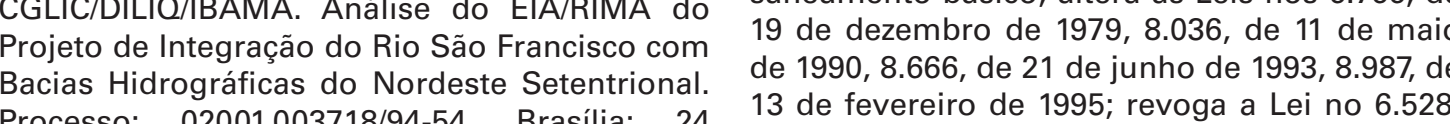

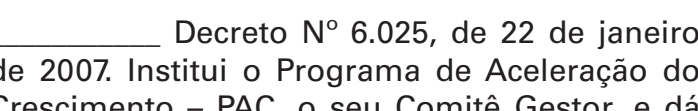
ncias. Disponivel em: http:///mw

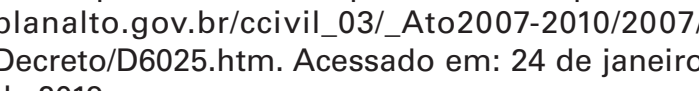
de 2

Decreto No $99.274 . \quad 1990$

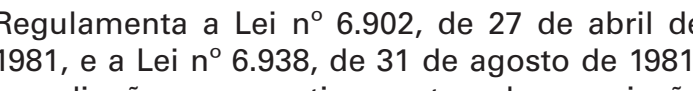
que dispoem, respectivamente sobre a criaçá

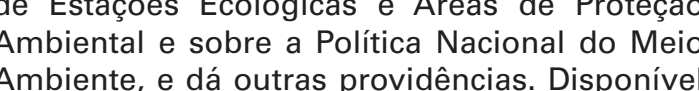

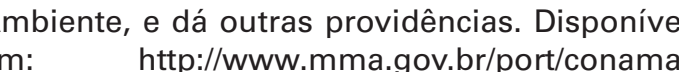

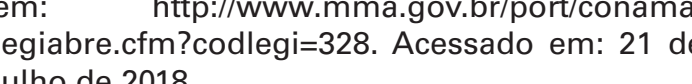

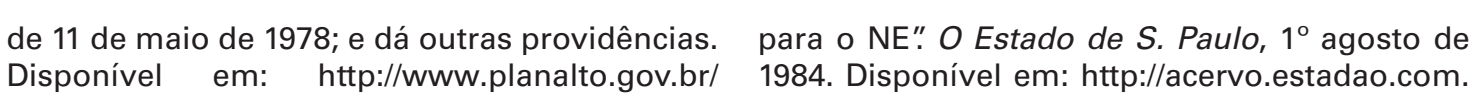

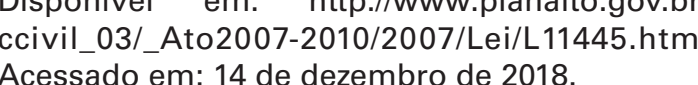
Lei $N^{\circ} 8.666$, de 21 de junho
993. Regulamenta 0 art. 37 , inciso $X \times 1$. (a)

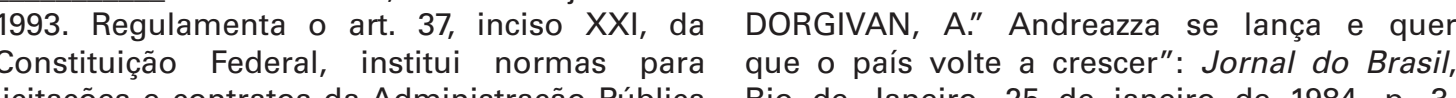

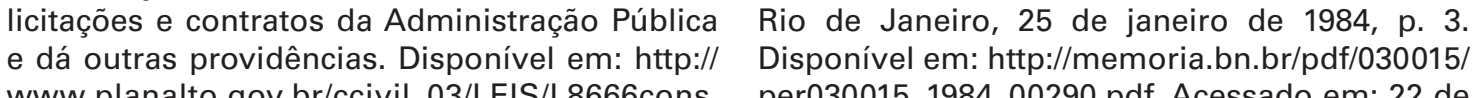

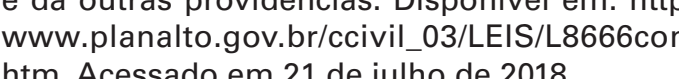

Lei Complementar no. 124 de 2007 .
hostitui, na forma do art. 43 da Constituic. Institui, na torma do art. 43 da constititicäo
Federal, a Superintendéncia do Desenvolvimenta

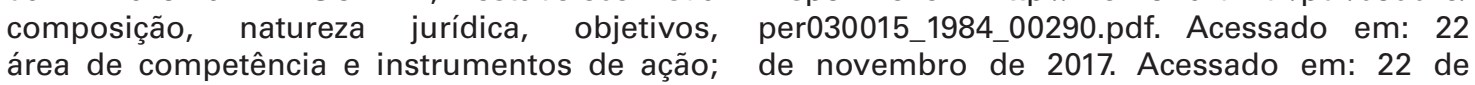

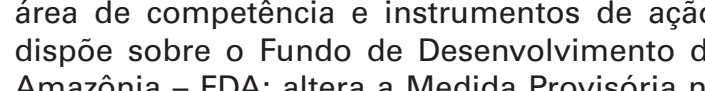
Amazônia - FDA; altera a Medida Provisisiria
2.157-5, de 24 de agosto de 2001; revoga a L

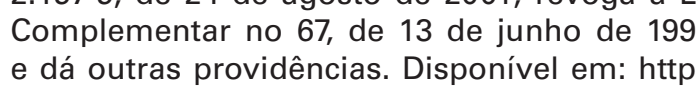

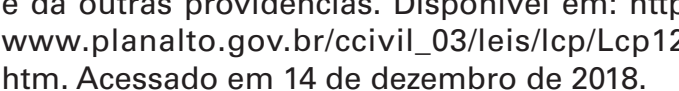

Lei Complementar $n^{\circ} 125$, de 3
de janeiro de 2007 . Institui, na forma do art. 43

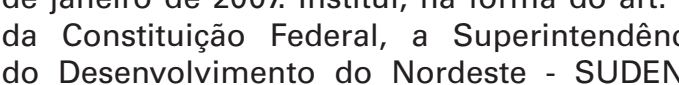
estabelece sua composigąo, natureza juridica,

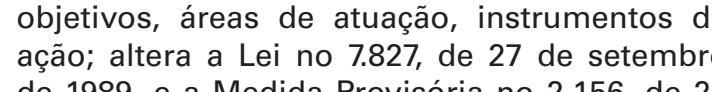

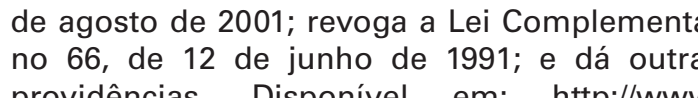

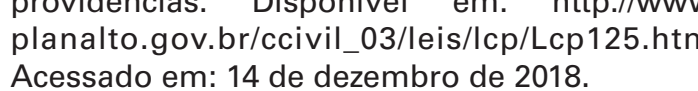

Medida Provisioria ${ }^{\circ} 459$, de 25 de
aarço de 2009. Dispoes sobre o Programa Minh

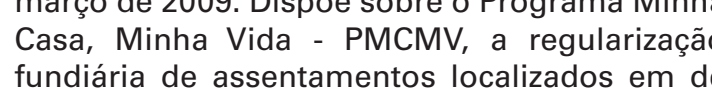
assentamentotos 5 colatizados em arreas urbanas,
da outras providencias.

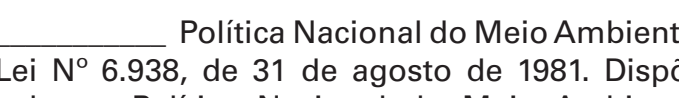
sobre a Politica Nacional do Meio Ambiente.
seus fins e mecanismos de formulacáa

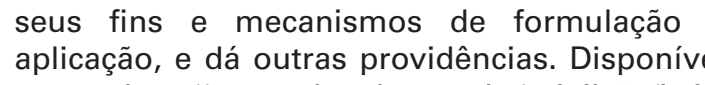

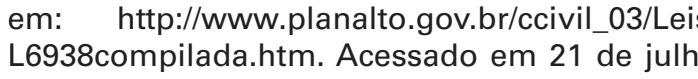
de 2018 .

Resolucăa CONAMA No 001 , de 23
de janeiro de 1986 . Disponivel em: hatp://www.

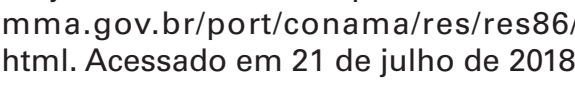
ma-vez-por-semana-em-campina-grande.h he

Publicações em jornais, revistas veículos digitais

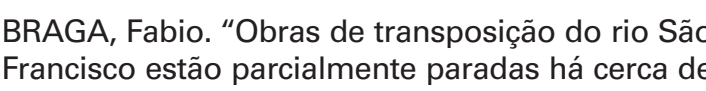
um ano; galpōes foram saqueados e mato cresese

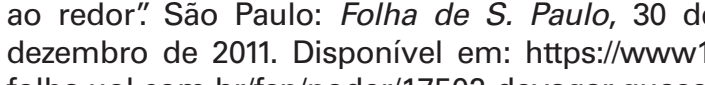

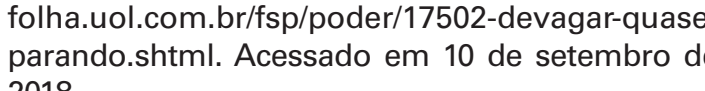

BORGES, Andre. “Transposiçăo do Săo Francisco

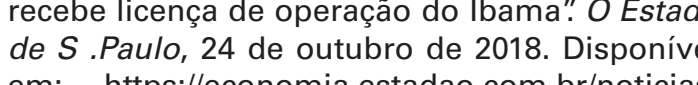

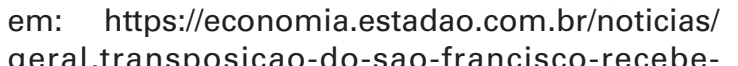

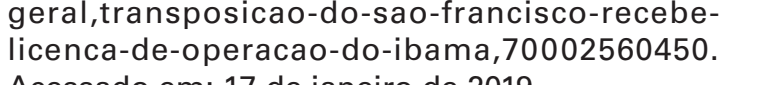
Acessado em: 17 de janeiro de 2019

CLAUSEL, Rubens Tellechea. “Água e tecnologe

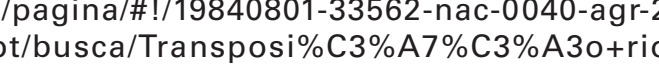
novembro de 2017

FILHO, Junot Lacet. "Moradores têm água apenas

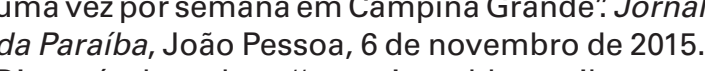

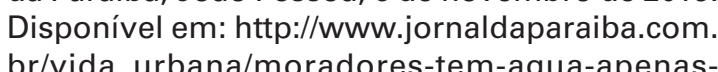
FRANCA, William, "FHC quer transposicáa
de rio no NE": Folha de S. Paulo, São Paulo,

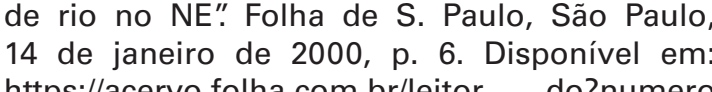

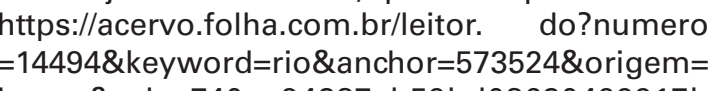
338. Acessado em: 18 de maio de 2018

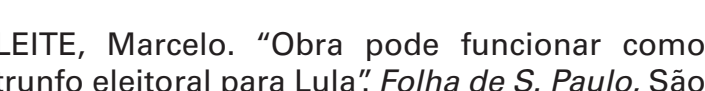
Paulo, 9 de outubro de 2005 , p. . . Disponivive lem

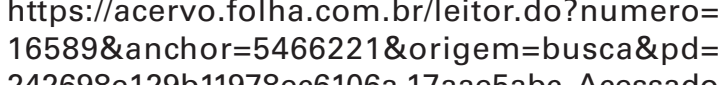
em: 7 de julho de 2018

LUPION, Bruno. "Por que a transposiçăo do

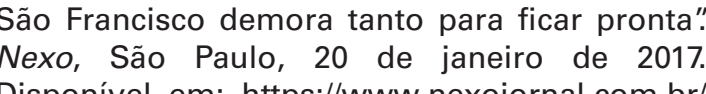

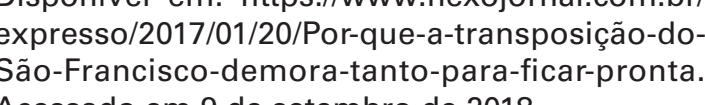

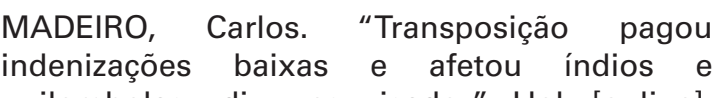

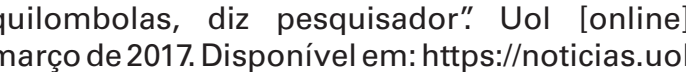

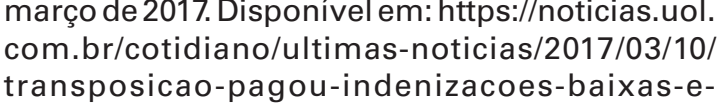

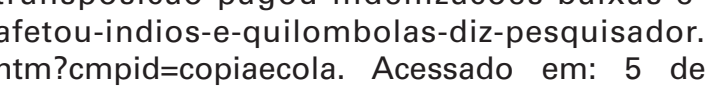
agosto de 2018 .

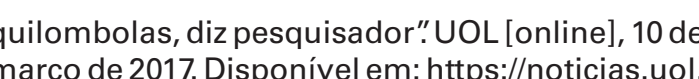

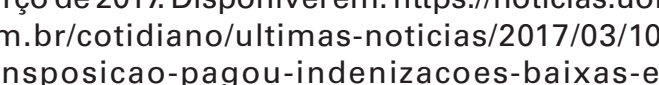
the

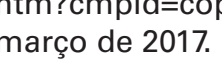

OLLO, Luiza. "Anós três afogamentose, Helder

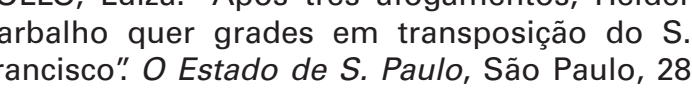
março de 2011. Disponivel em: https:///oliticica. tes-afogamentos-helder-barbalho-quer-grades 17 de dezembro de 2013

SALOMON, Marta. "Governofazalicititąăo de RS 1,2

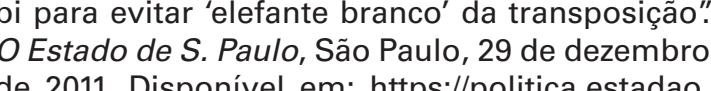
2011. Disponivel em: https:////politica.estadac -r-1-2-2-bi-para-evitar-elefante-branco-dasetembro de 2018.

RAUMANN, Thomas. "FHC desiste de transpor

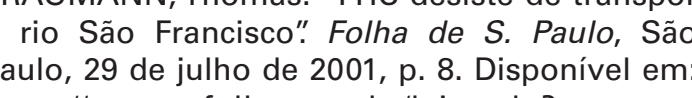
do?numero-

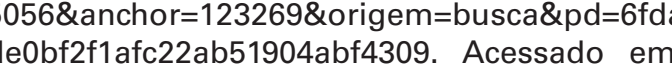

ASCO, Paulo Sérgio. "Transposiçắo do S

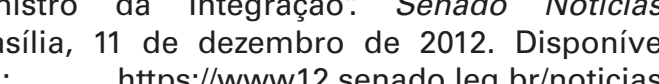
Materias/2012/12/1/1/transposicica-do-s-francisco. itegracao. Acessado em 9 de setembro de 2018

\section{Noticias sem autor definido}

"Água da transposiçăa do Sáa Francisco traz

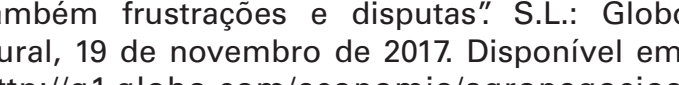

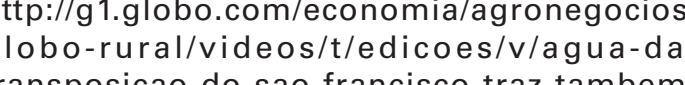

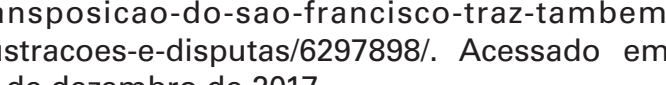

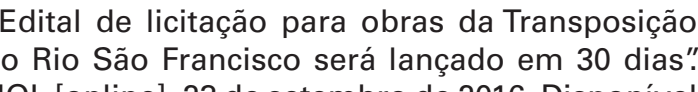

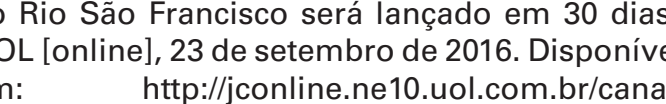

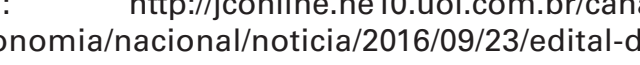

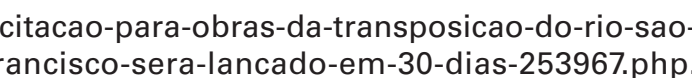
Acessado em: 6 de setembro de 2018.

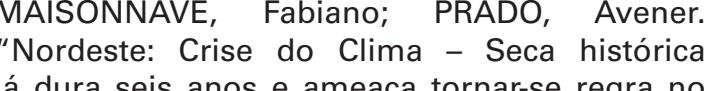

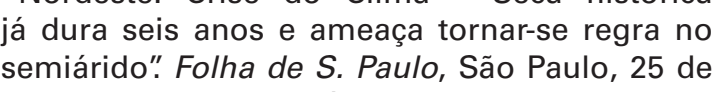
abril de 2018. Disponivel em: https:///arte.folha.
uol.com.br/ciencial/2018/crise-do-clima/nordestel seca-historica-ja-dura-seis-anos-e-ameaca-
lornar-se-regra-no-semiarido-/Acessado em 26 tornarse-regra-no
de abril de 2018.

MASONAVVE, Fabiano; PRADO, Avenar.
"Nordeste: Seca historicic iá dura seis anos

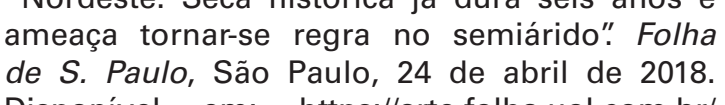
Governo quer levar água para 12 milhöes
de pessoas. Exito da obra depende de

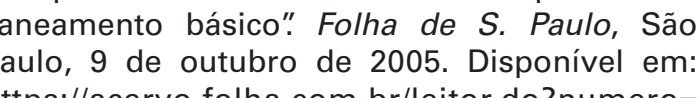
origem=busca\& d=28a299d808edcfoe 73317 d d0e 62686651 .

Lula e Dilma levam multidăo à inauguraçăo da

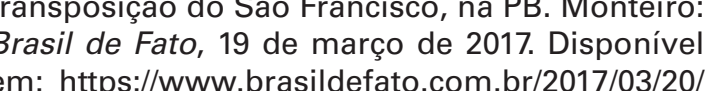
em: https://www.brasildefato.com.br/2017/03/20 a-transposicao-do-velho-chico-na-paraibal. istorica-ja-dura-seis-anos-a-ameaca-tornar-se

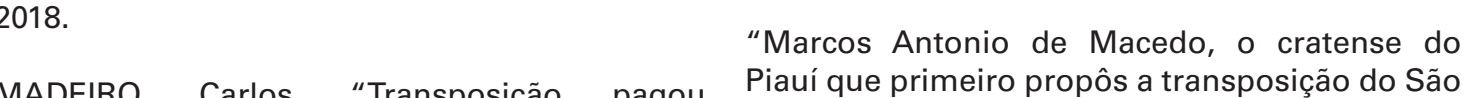

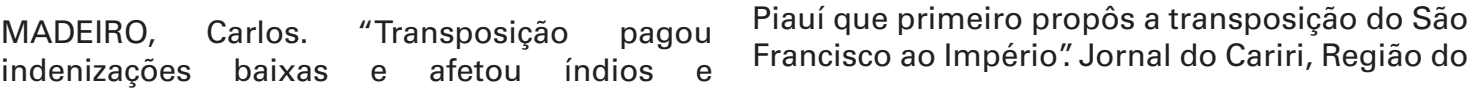


Cariri, junho de 2015. Disponivel em: https://issuu.
com/cearanews7/docs/jc-02a08junho2015/10. Acessado em: 7 de agosto de 2017

“MPF em Monteiro (PB) pede suspensão do
bombeamento da água no eixo leste. João Pessoa"."Ministério Público Federal, Procuradoria 2018. Disponivel em: http://www.mpf.mp.b. mpf-em-monteiro-pb-pede-suspensao-dobombeamento-da-agua-no-eixo-leste. Acessa do "MPF em Monteiro (PB) cobra explicaçăo sobre
esgoto no canal da transposiçăo". Ministerí "ssoto no canal da transposiçaoo". Ministér Paraíba [onlinel, 8 de fevereiro 2018 . Dissponivel em: http://Www.mpt.mp.br/ph/sala-de-imprensal
noticias-pb/rio-sao-francisco-mf-pb-oficia prefeita-de-monteiro-e-superintendente-da-
funasa-para-explicarem-esgoto-no-canal-da-
transposicao. Acessado em 10 de novembro de "Primeiro, colocamos o Brasil em açầo
Agora, Avanca Brasil, o plano que estim of desenvolvimento e gera milhöes de
ompregos". Folha de s. Paulo, Săo Paulo, de dezembro de 1999 , p.10 e 11 . Disponivel

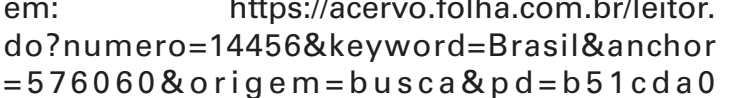
3d807a113ec9a139158dd82e. Acessado em:

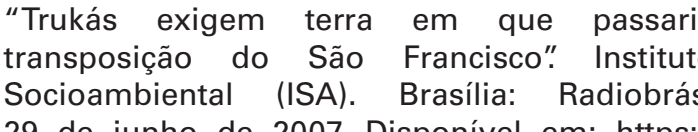
29 de junho de 2007 . Disponivel em: htps://
terrasindigenas.org. br/pt-br/noticia/47646

Uso de fontes renováveis de energia para
Projeto de Integracãa do Rio São Francisco. Instituto Interamericano de Cooperacáo para a
Agricultura (IICA), Brasilia: 30 de julho de 2018 . Disponivel em: http://www.iica.int/pt/conter projeto-de-integraçáa-do-rio-sara-francisco
Acessado em: 19 de dezembro de 2018 .

"Veja a transposição do Rio São Francisco
na Paraiba". O Estado de S. Paulo, São Paulo, 11 de marco de 2017. Disponível em: http://
economia.estadao.com.br/galerias/geral,vejaa-transposicao-do-rio-sao-francisco-na-
paraiba,30697. Acessado em 5 de janeiro de 2018. "Vereador quer coibir desvios de água da

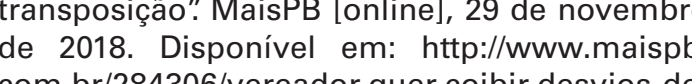
agua-da-transposicao.html. Acessado em: 19

Sites

Agência Executiva de Gestão das Águas do
Estado da Paraiba (AESA). Joâo Pessoa: s/d. website/monitoramento/volume acacude/?id
acude $=531$. Acessado em: 15 de dezembro

Banco Nacional do Desenvolvimento (BNDES). Projeto de Integracăa do Rio São Francisco com
as Bacias do Nordeste Setentrional. Disponivel em: https://www.bndes.gov.br/wps/portal/site/ home/transparencia/desestatizacao/processos
em-andamento/pisf. Acessado em: 6 do
setembro de 2018.
RASIL. Câmara dos Deputados. Leide Diretrizes quw\&host=QVS\%40www9\&anonymous=tru

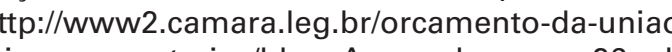
leis-orcamentarias/lo. Acessado em: 26 de Sobradinho. Recife: s/d. Disponivel en: hittps://www.chesf.gov.bri/SistemaChest/Pages/
StistemaGeracaolsobradinho.asp. Acessad RASIL.CâmaradosDeputados. LeeiOrçamentáth www2.camara.leg.br/orcamento-da-uniao/leis de 2019.

em: httrps://wwww.chest.gov.br//sistemachesto

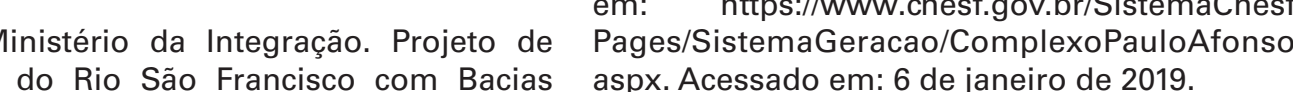
Hidrográficas do Nordeste Setentrional.
Disponivel em: http://www.integracao.gov.brl DiárioOficialdaUniäo(DOU). Disponivelem:http: web/projeto-sao-francisco/. Acessado em 20 de $\begin{aligned} & \text { pesquisa.in.govi.br/imprensa/jsp/visualiza/index } \\ & \text { jsp?data=11/01/2017\&jornal=38pagina=638totata }\end{aligned}$
agosto de 2018. BRASIL. Ministério do Planejamento, 2018 Desenvolvimento e Gestão. Conselho Sul-
Americano de Infraestrutura e Planejamento

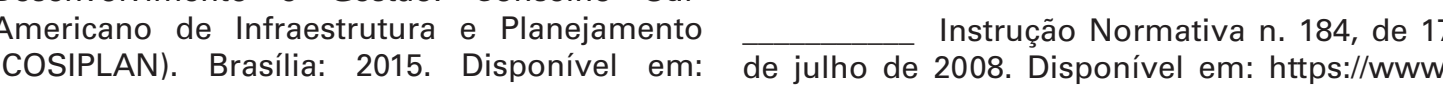

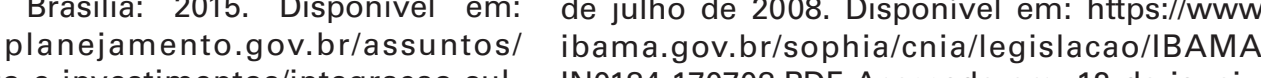
I lanejamento-e-investimentos/integracao-sul- IN0184-170708.PDF. Acessado em: 12 de janeiro americana/cosiplan-conselho-sul-americano-deagosto de 2018. BRASIL. Ministério do Planejamento

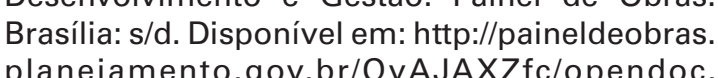
planejamento.gov.br/QVVAJAXZfc/opendoc.
htm?document=paineldeobras.qvw\&lang $=$ pt作

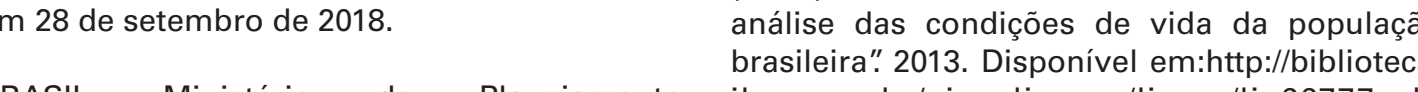
do Planejamento, ibge.gov.br/visualizacaol/ivros/liv66777.pd. Aceleraçāo do Crescimento. Brasilia: s/d.Projeto de Integração do rio Sá Francisco com as Bacias do Nordeste gov. Dis/brasilvel em: https://cidades.ibge

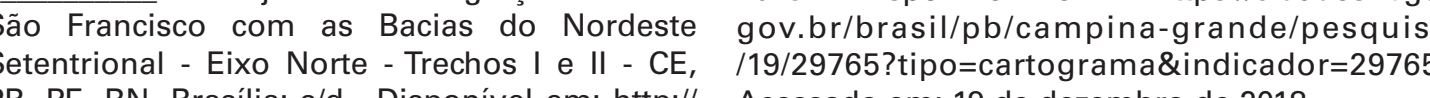
ww.pac.gov br/obra/4245. Acessado em 16 de 2018.

Brasilia: s/d. Disponive PAC-Publicaçęes Nacionais. br/sobre-o-pac/publicacoessnacionais. Acessado em: 23 de setembro de 2018

$1^{\circ}$ Balanço do PAC. Brasilia: 2007. Disponivel em: http://www.pac.gov.br/pub/up/ pdf. Acessado em 29 de setembro de 2018.

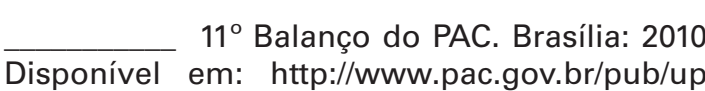

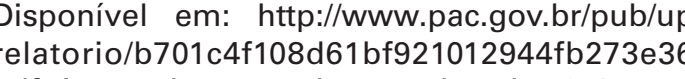
fr. Acessado em 29 de setembro de 2018. Projeto de Integração do rio São - Eixo Leste - PB e PE. Brasilia: s/d. Disponive em: http://www.pac.gov.br/obra//244. Acessado
em 16 de setembro de 2018.

BRASIL. Ministério Público Federal. Operação www.mpf.mp.br/para-o-cidadao/caso-lava-jato. Acessado em: 6 de setembro de 2018. BRASIL. Painel de Obras. Disponivel

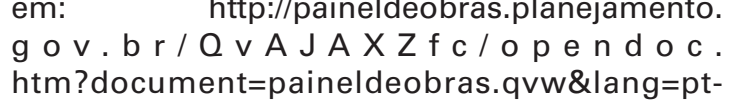

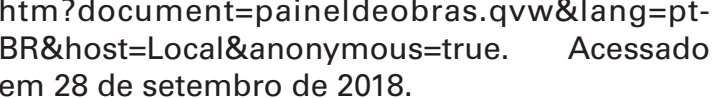

RASIL. Senado Federal. SIGA Brasil. Brasilia: s/d. Disponivel em: http://wwwg.senadoleg.
br/OvAJAXZfc/opendoc.htm?document=
Senado\%2FSigaBrasilPainelEspecialista. "Cidades - Monteiro". 2018 Disponivel em: https://cidades.ibge.gov.br/bras Acessado em: 19 de dezembro de 2018 . nstituto Brasileiro do Meio Ambiente e dos
necursos Naturais Renováveis (IBAMA. icenciamento Ambiental Federal do Projeto de Integraçâo do Rio São Francisco com
Bacias Hidrográficas do Nordeste Setentrional. Disponivel em: https://servicos.ibama.gov.br/ Acessado em: 9 de maio de 2018

Superintendência de Desenvolvimento do
ordeste (SUDENE). Quem foi Celso Furtado

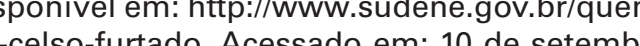

Nivel Água São Paulo - Sistema Guarapiranga
Sau Paulo: 26 de janeiro de 2019. Disponiv $\mathrm{m}$ : https://www.nivelaguasaopaulo.com/
ararapiranga. Acessado em 27 de janeiro de Superintendencia do Desenvolvimento do

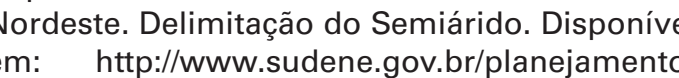
m: 8 de outubro de 2018

Universidade Federal de Campina Grande
UFCG). Instituicáa tem suas ráizes na Escola

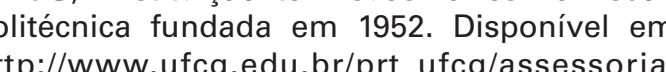
mprensa/mostra_noticia.php?codigo=19438. Acessado em: 19 de dezembro de 2018.

Verbetes CPDOC

Transposiçáa e do projeto executivo do Trecho 1 e 2019

CPDOC. "Mario Davi Andreazza". Disponive
em: http://www.fgv.br/cpdoc/acervoldicioniva (

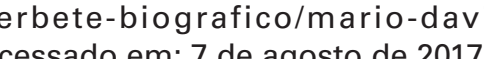

\begin{tabular}{c} 
"Aluisio Alves". Disponivel em \\
\hline http:://www.fgv.br/cpdoc/acervo/dicionarios
\end{tabular} verbete-biografico/alves-aluisio. Acessado em: 7
de agosto de 2017. "Bww.fgrvbrichi Veras". Disponivel em: http:// biografico/veras-beni. Acessado em: 7 de agos

semiárido Săo Francisco (CHESF)". Disponivo em: http://www.fgv.br/cpdoc/acervo/dicionarios sao-francisco-chest. Acessado em: 6 de janeide 2019 gvv.br/sites/default/files/verbetes/primeir
republica/INSPETORIA\%20FEDERAL\%200DE\% 20 . BRAS\% 20 CONTRA\% $20 A S \% 20$ SECAS Assado em: 7 de agosto de 2017.

Disponivel "Milagre Econômico Brasileiro",
em: http://www.fgy.br/cpdocl brasileiro. Acessado em: 6 de janeiro de 2019 verbetes/primeira-republica/ARARIPE, $\%$

Arquiteto urbanista e professor da Faculdade
Arquitetura da Universidade de São Paulo. egionaldelimitacao-do-semiarido. Acessado

Entrevistas realizadas

Ailson dos Santos (Issor)

Irmão de Neguinho Truká, o cacique, e lideran do povo indigena. Entrevista realizada
2017, em Cabrobó.

Albino

Dono de uma olaria e do hotel e posto de

Entrevista realizada
2017, em Custódia.

Entrevista realizada no dia 1 de marco de 2018
no LabProj, laboratorio de projeto da Faculdade
de Arquitetura e Urbanismo da Universidade

Pesquisador da saúde que estava em Cabrobo
tazendo estudo de campo na aldeia Truká

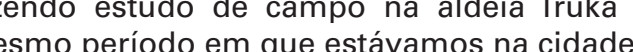

Entrevista realizada no dia 08 de setembro ,

Arquiteto da empresa Engecorps, que participo
"Inspetoria Federal de Obras
Contra as Secas (IIOCS)!'Verbete redigido por

em: "Tristão Alencar Araripe". Disponive

Entrevista realizada no dia 30 de maio de 2017, em Săo Paulo.

an Telles de Sous Engenheiro agrônomo, vice-presidente da
consultoria Ecology and Environment Brasil, Cartacho Porfírio Loureiro, Valdecir Azevedo e que coordenou o processo de elaboraçấo do o Estado da Paraiba (AESA)

Entrevista realizada no dia 15 de dezembro $d$ Diretor executivo de acompanhamento e 2017, por Skype.
controle, diretor de gestão e administrativo

Entrevista realizada no dia 11 de setembro de
2017, em Joäo Pessoa.

lene Pajeú (Pretinha Trul

Vereadora de Cabrobó.

2017, em Cabrobó.

Possui graduaçăo e mestrado em Engenharia
Civil e doutorado em Recursos Hidricos Civil e doutorado em Recursos Hidricos,
Hidrologia e Hidráulica pela Gottfried Leibniz Uiversidade Federal de Campina Grande. Atua na área de mananciais subterrâneos Entrevista realizada no dia 04 de setembro de
2017, em Campina Grande. Francisco Mota, Marcus Vinícius Leme e Helen

Entrevista realizada no di

2017, em Monteiro.

Fernanda Carolina Costa

Presidente do Sindicato dos Trabalhadores

Entrevista realizada no dia 07 de setembro de
2009, em Sertânia.

Alvogada que participa da elaboracāá do Obras e Fiscalizaçăão do Ministerio da Integraçăo
Nacional (MII). Brasil entre 2012 e 2013 e Ministro da Integraçăo
Nacional do Brasil entre 2013 e 2015, sendo Area de Influência do Municíío de Salgueiro
e seu Entorno", encomendado pelo estado de Pencumbor

Entrevista
por Skype.

Franciney Cardoso Froz

Analista de Infraestrutura, Chefe de Divisăo da

Entrevista realizada no dia 30 de agosto de 2017 por Skype.

É atualmente Secretário de Recursos Hírricos do
Ceará. Foi Secretário de Infraestrutura Hídrica do um dos principais responsáveis pelas obras

Entrevista realizada no dia 10 de janeiro de 2018, por Skype. mobilizacăa social no Projeto de Transposiçąa do do
rio Săo Francisco" (2014), fruto de seu mestrado

trevista realizada no dia 25 de maio de 2017. São Paulo.

Catural de Jaguarari (Bahia), é doutor em

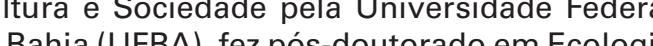
Humana na Universidade Nova de Lisboa (UNLcartografias dos povos indígenas afetados pela
Transposiçăo do rio São Francisco, publicadas seu site: http://juracymarques.com.br/site/ cantografias/. Na entrevista, ele me ajudou a a nos recebeu em Cabrobó nntrevista realizada no dia 23 de agosto de 2017 ivia Mirand

ossui graduação em Arquitetura e Urbanismo Mestrado em Geografia e doutorado em
Desenvolvimento Urbano e Regional (2007). ra Universidade Federal de Campinas. Trabalha com os temas: Técnicas de Avaliacăăo Urbano e
Regionais, Planejamento e Gestão do Espaço
Urbano. Conversa com dois trabalhadores e funcio
da administraçâo da empresa Tambaú.

\section{Marcos Godoi}

Engenheiro da Engecorps que coordenou Irani Braga Ramos Engenheiro e assessor do Ministerio da
Integração Nacional. Entrevistas diversas realizadas em São Paulo Entrevista realizada no dia 20 de julho de 2017. $\begin{array}{ll}\text { Entrevistas diversas realizadas em São Paulo } & \text { Entrevista real } \\ \text { por Skype e por e-mail, entre os anos de } 2017 & \text { em Săo Paulo. }\end{array}$ utora da publicacăáo "O desencantamento
las águas no sertâo: crenças, descrenças
a

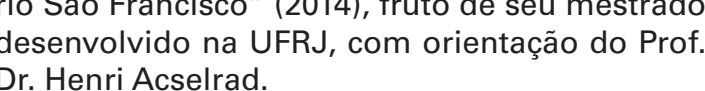

Entrevista realizada no dia 05 de setembro de 
Maria José Gomes Marinheiro (Maria Tumbalalá)

Liderança do povo indígena Tumbalalá, diretora da escola da cidade de Cabrobó.

Entrevista realizada no dia 08 de setembro de 2017, em Cabrobó

\section{Marinelma e família}

Moradores da Vila Produtiva Rural Uri, em Salgueiro.

Entrevista realizada no dia 09 de setembro de 2017, em Salgueiro.

\section{Maurílio Sampaio e Cléber Barros}

Maurílio é Secretário de Obras e Desenvolvimento Humano de Salgueiro e Cléber presta serviços para a construtora.

Entrevista realizada no dia 09 de setembro de 2017, em Salgueiro.

\section{Moradores da Vila Produtiva Rural Lafayette}

Entrevista realizada no dia 06 de setembro de 2017, em Monteiro.

\section{Neguinho Truká}

Cacique do povo indígenaTruká.

Entrevista realizada no dia 08 de setembro de 2017, em Cabrobó.

\section{Neuris Luna}

Assessora de Pretinha Truká, que nos acompanhou durante toda a nossa estadia em Cabrobó e nos levou para conhecer a captação do Eixo Norte, além de nos apresentar a Ilha de Assunção, território indígena Truká.

Entrevista realizada em 08 de setembro de 2017, em Cabrobó.

\section{Ricardo Jorge de Almeida Menezes (Cajó)}

Vereador da cidade de Monteiro.

Entrevista realizada no dia 06 de setembro de 2017, em Monteiro.

\section{Salvino de Oliveira Júnior e Síria Maria Dantas} Oliveira

Família que nos recebeu e hospedou em Campina Grande e concedeu uma entrevista sobre o racionamento severo dos últimos meses na cidade, antes da chegada das águas da Transposição do rio São Francisco.

Entrevista realizada no dia 04 de setembro de 2017, em Campina Grande.

\section{Severino de Normandia}

Auxiliar administrativo do Departamento Nacional de Obras Contra a Seca (DNOCS).

Entrevista realizada no dia 05 de setembro de 2017, no Açude Epitácio Pessoa.

\section{Vanessa Empinotti}

Prof. Dra. que leciona na UFABC, engenheira agrônoma, desenvolve pesquisa em governança socioambiental e em sua tese de doutoramento estudou a gestão dos recursos hídricos da bacia do rio São Francisco.

Entrevista realizada no dia 23 de janeiro de 2017, em São Paulo.

\section{Valdemiro Souza}

Engenheiro funcionário da Companhia de Água e Esgotos da Paraíba (CAGEPA).

Entrevista realizada no dia 05 de setembro de 2017, em Campina Grande. 


\section{$6^{\text {manows }}$}

6.1

\section{Tabulação de notícias}

A tabulação de notícias foi realizada entre os anos de 2017 e 2019, período de realização desta pesquisa, com notícias que foram publicadas semanalmente no Brasil sobre a Transposição do rio São Francisco.

Eventualmente, ao longo da pesquisa, foi necessário buscar informações em notícias de anos anteriores, integrandoas à tabulação de notícias semanais ao longo desses dois anos de trabalho.

As notícias foram organizadas por assunto (título da manchete), fonte com link, data por ordem cronológica, resumo e colunas para relacionar as notícias com os temas e assuntos que foram surgindo ao longo da pesquisa. Também foi realizado um banco de imagens a partir de notícias que traziam fotos ou mapas que interessavam à pesquisa, havendo uma coluna na tabulação para indicar quando havia imagem ou não, e quando havia, ela compunha um banco de imagens interno à pesquisa.

A tabulação de tabulação de notícias foi um trabalho de extrema importância para a dissertação, por vezes evidenciando informações ou situações que não apareceram em entrevistas e, desse modo, permitindo um acompanhamento aproximado do andamento da obra, das repercussões em campo, de suas presenças e ausências ao longo de sua construção. Para a realização da tabulação de notícias, houve grande colaboração das bolsistas de iniciação científica. 


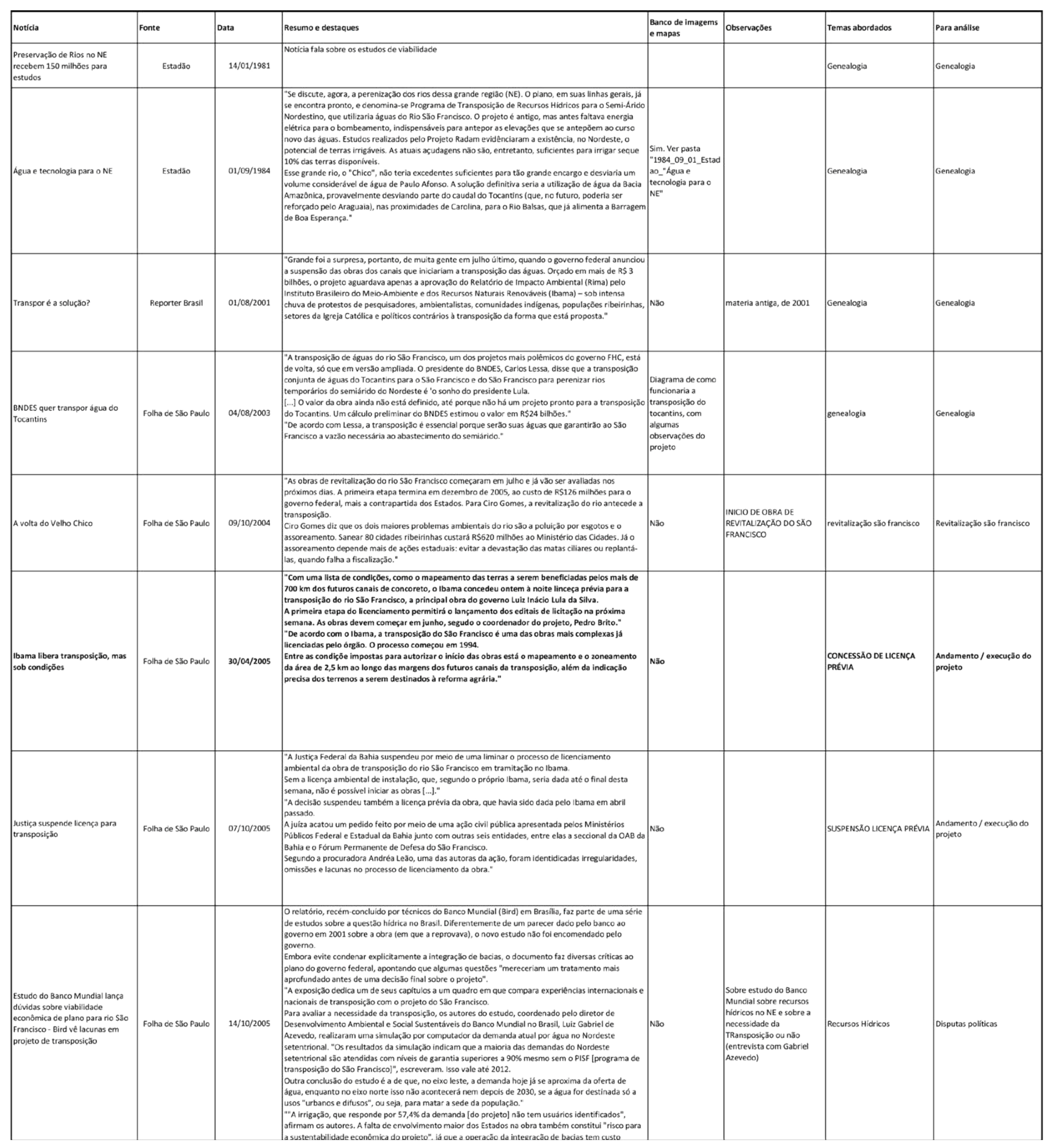

\begin{tabular}{|c|c|c|c|c|c|c|c|}
\hline 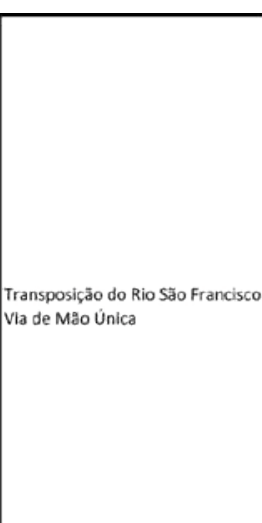 & 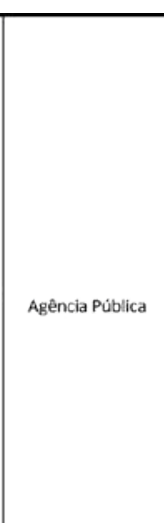 & 06020272014 & 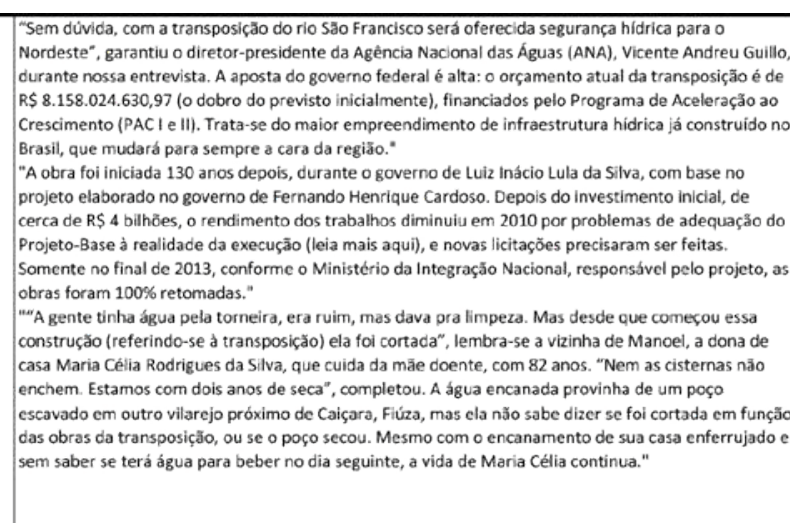 & $\mid$ & 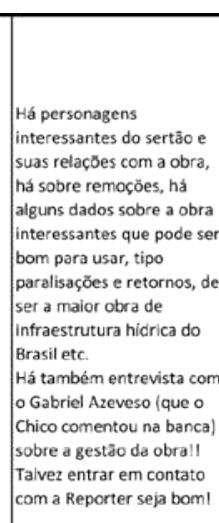 & 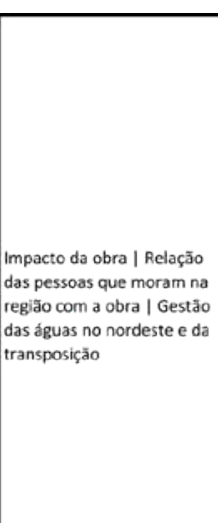 & 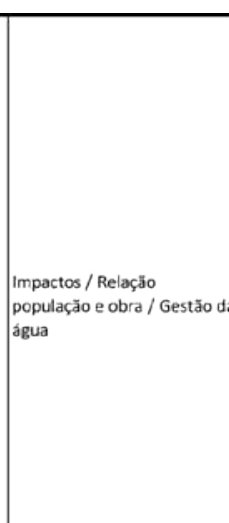 \\
\hline 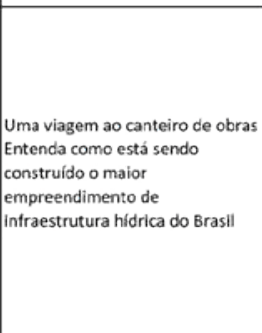 & 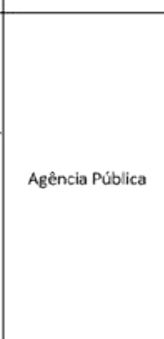 & 0602022014 & 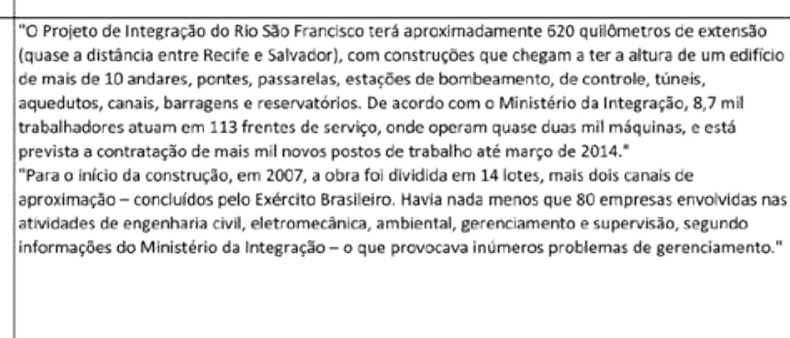 & 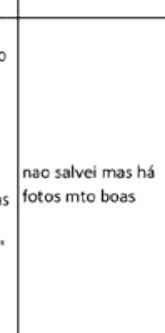 & 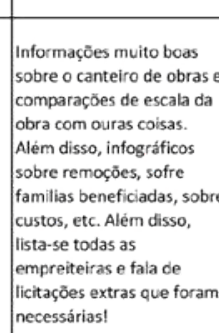 & 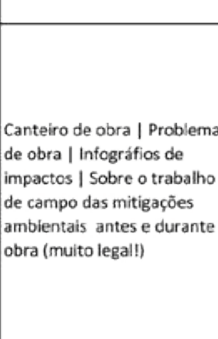 & 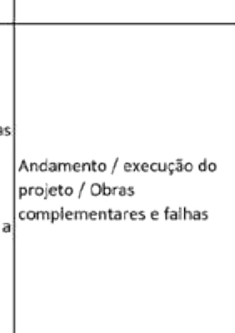 \\
\hline 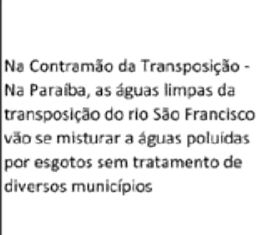 & 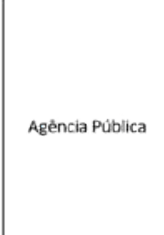 & 0602027014 & 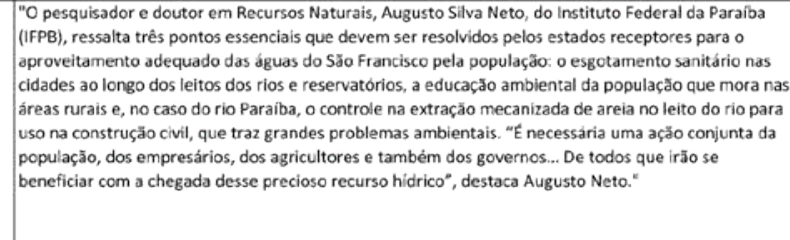 & : & 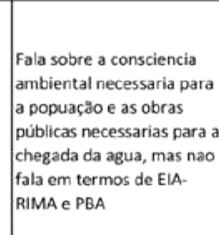 & & 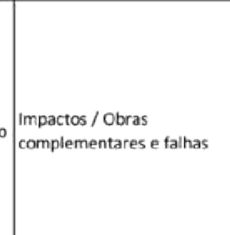 \\
\hline 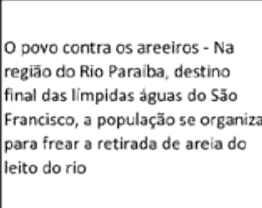 & Mescania ibibles & 06012202014 & 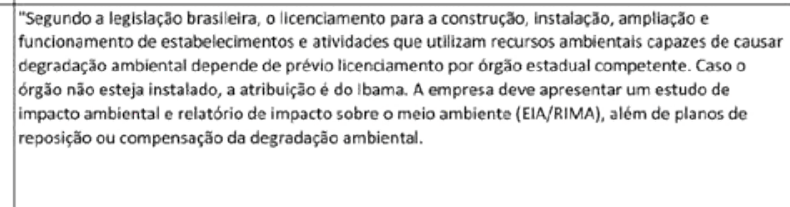 & nso & 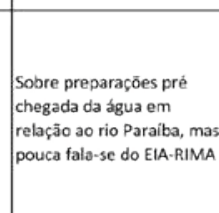 & 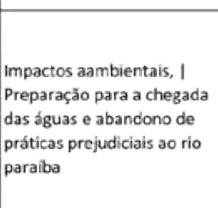 & 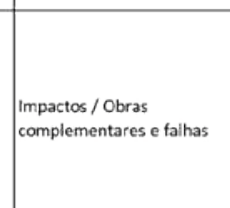 \\
\hline 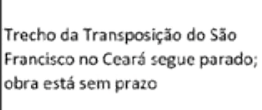 & Disirio o o Nodedere & 18/21/2017 & & nso & & 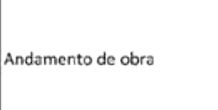 & 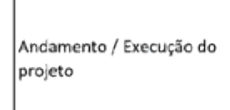 \\
\hline 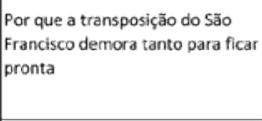 & Nexo & 2001720077 & & 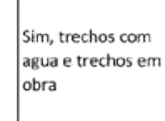 & the & captuluo 3 & 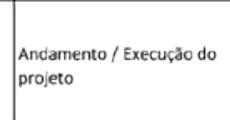 \\
\hline 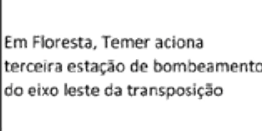 & vor & 3010120077 & 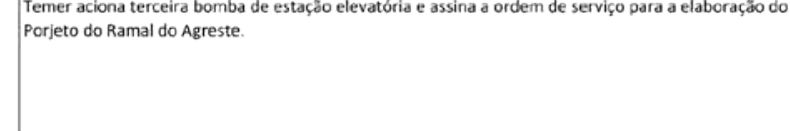 & Nion & & & 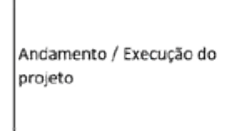 \\
\hline 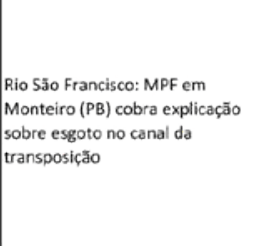 & Mpe & 02786/2017 & 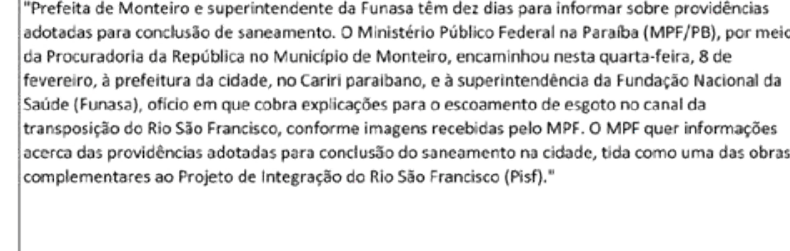 & 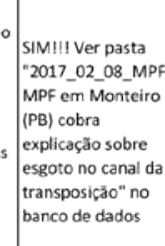 & & & 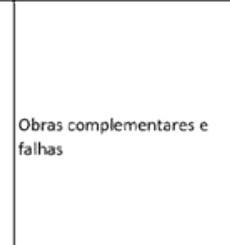 \\
\hline 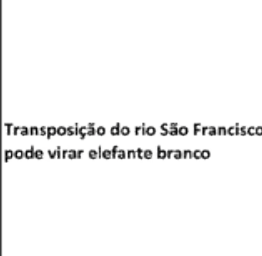 & same & $03 / 3032027$ & 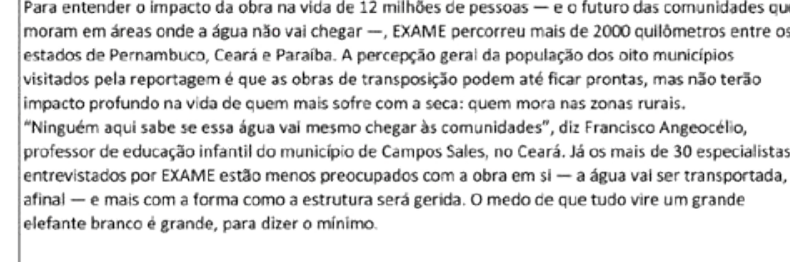 & nso & & 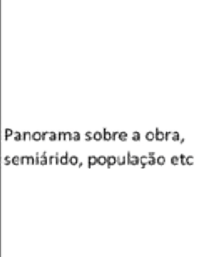 & Pancorans \\
\hline 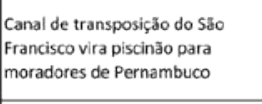 & Estadato & ${ }_{03305 / 2017}$ & 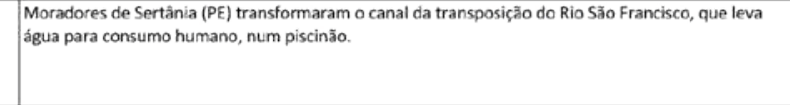 & nio & & 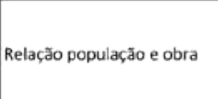 & 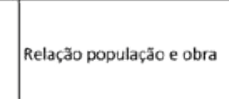 \\
\hline 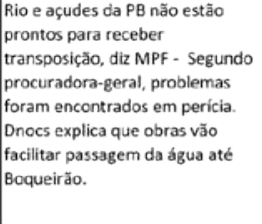 & ${ }^{61}$ & 030/7/2017 & 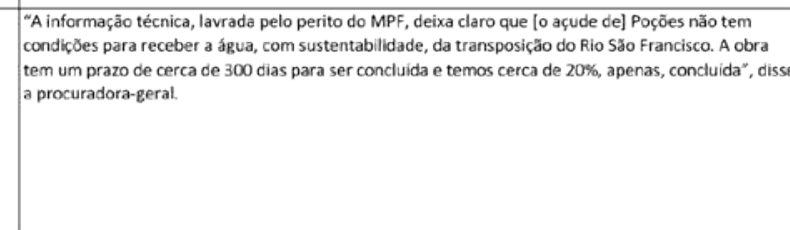 & 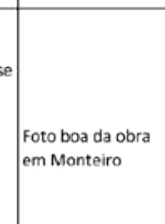 & & & \\
\hline 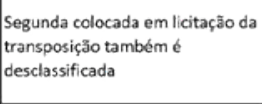 & Blog 0 PONO & 03708202017 & 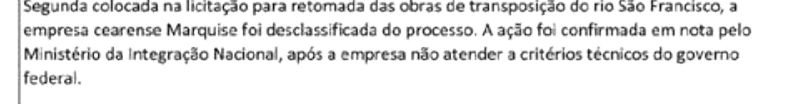 & Nono & & & 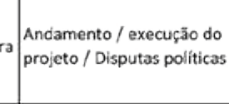 \\
\hline 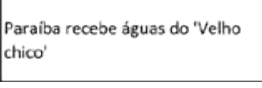 & Tribuma ob onote & 03/09/2017 & ratrasado & 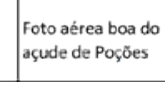 & & Andementerd de obre & 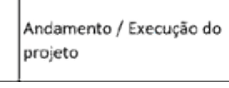 \\
\hline
\end{tabular}




\begin{tabular}{|c|c|c|c|c|c|c|}
\hline 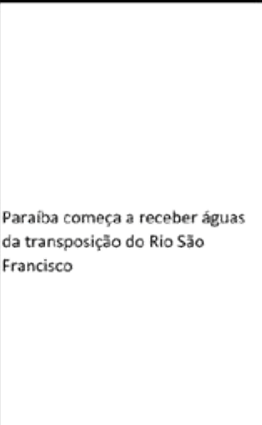 & ${ }^{61}$ & 03/10201017 & 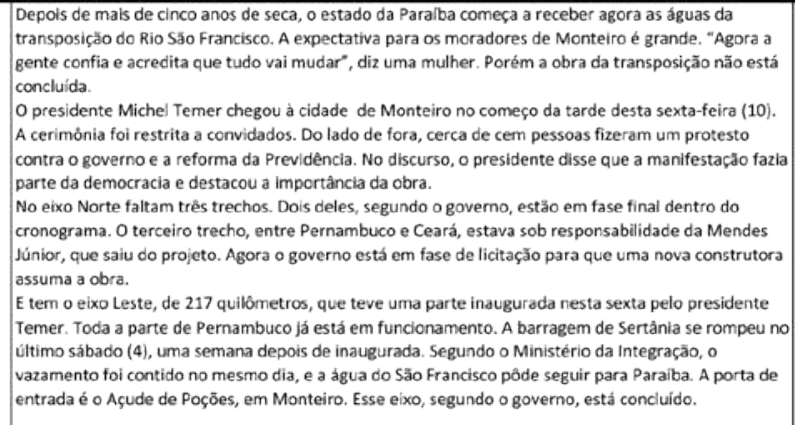 & & & 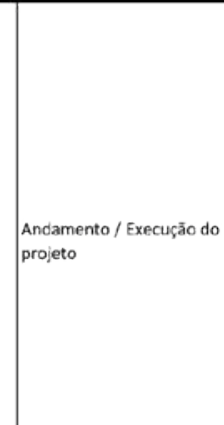 \\
\hline 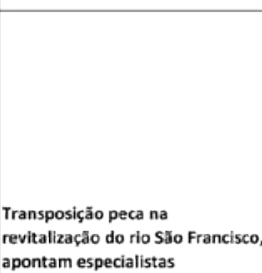 & vor & 03/10/2017 & 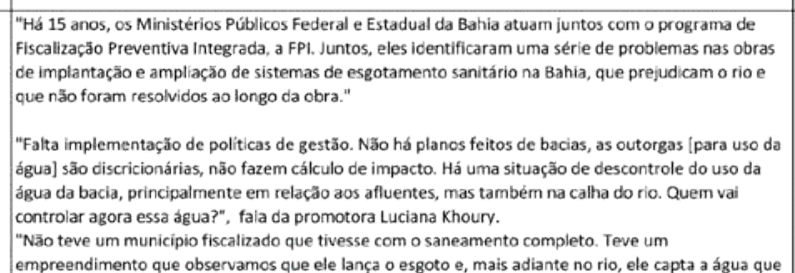 & 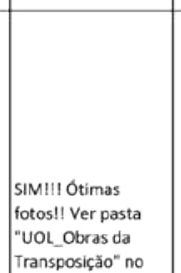 & & \\
\hline & & & 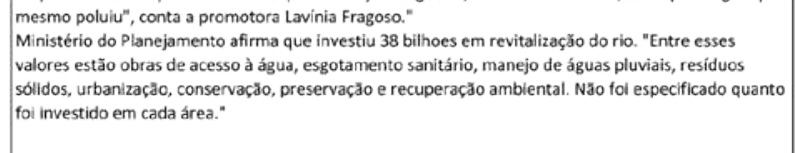 & & & \\
\hline 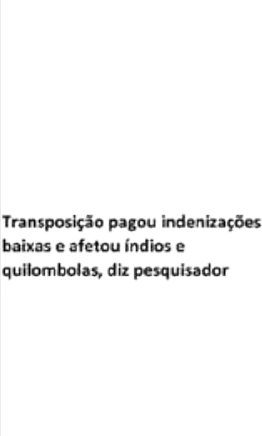 & vor & 03/10/2017 & 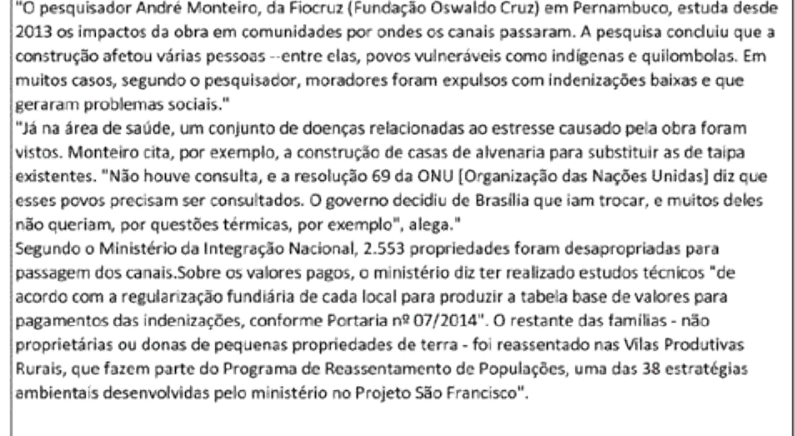 & 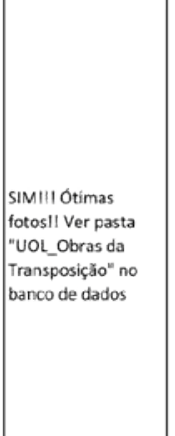 & Impactes & reactex \\
\hline 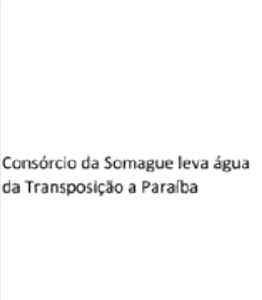 & conssuir & 03/10/2017 & 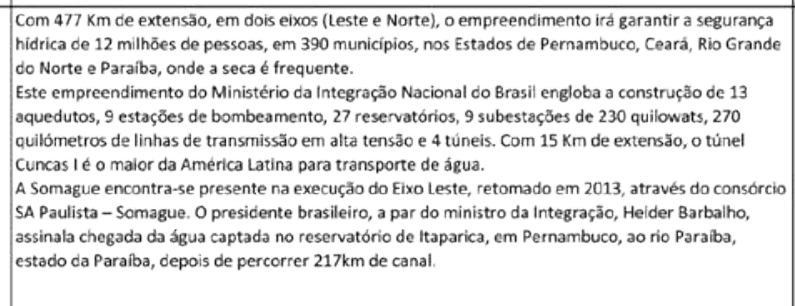 & & & 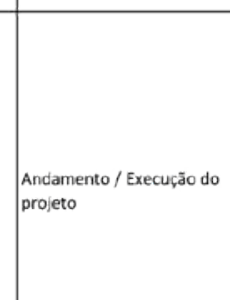 \\
\hline 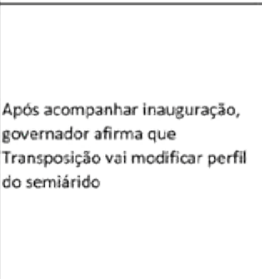 & Parababomber & 03/1/2017 & 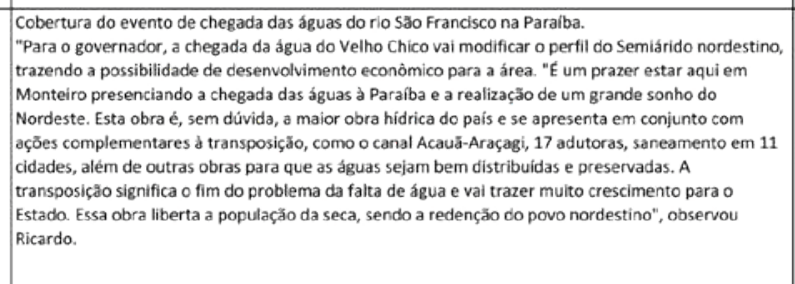 & wio & Politea & \\
\hline 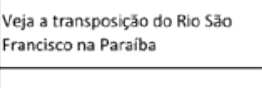 & Estatio & 0331120077 & 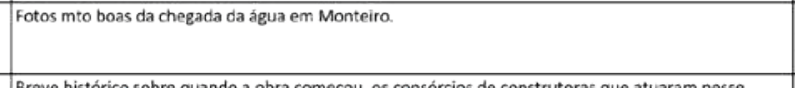 & sim & Andamener do do obra & 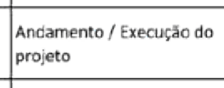 \\
\hline 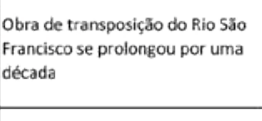 & 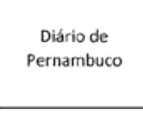 & 03/21/2017 & 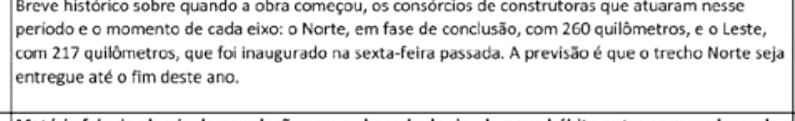 & wio & 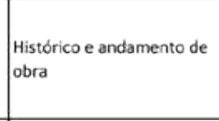 & 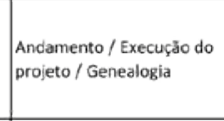 \\
\hline Wenhochico cherou & Estrabio & $03 / 21272017$ & 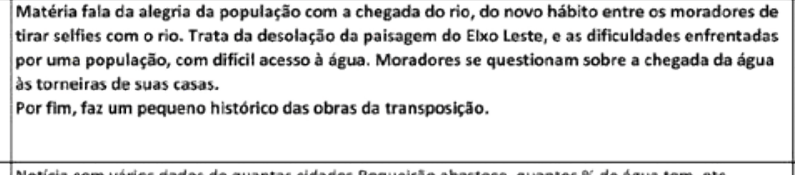 & 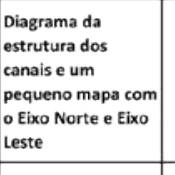 & Uubsaboe obtra & 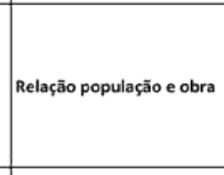 \\
\hline 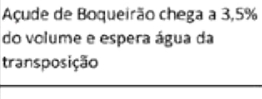 & ar & ${ }_{13 / 3 / 17}$ & & woo & 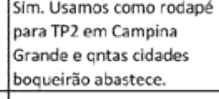 & estit do dis sen \\
\hline 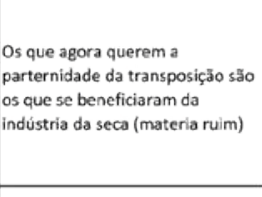 & ${ }^{61}$ & 13/303/2017 & 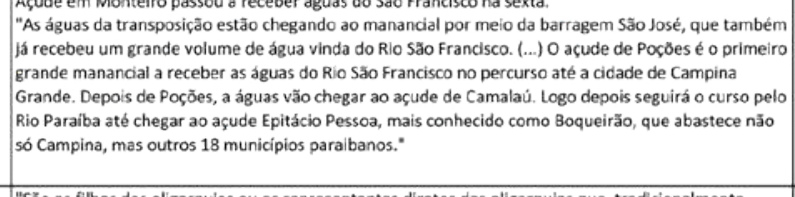 & 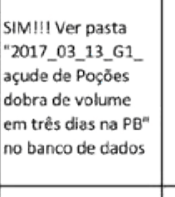 & 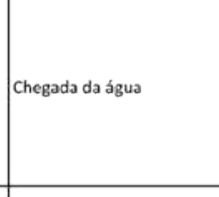 & 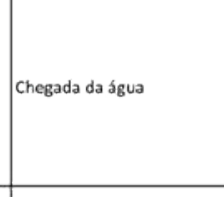 \\
\hline 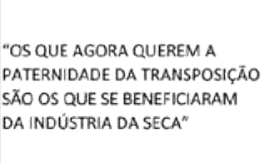 & Basal 2727 & 13/3037017 & 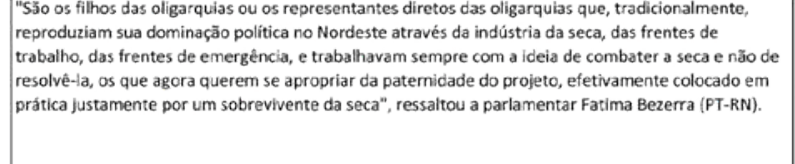 & wo & isputas polticias & soltectas \\
\hline
\end{tabular}

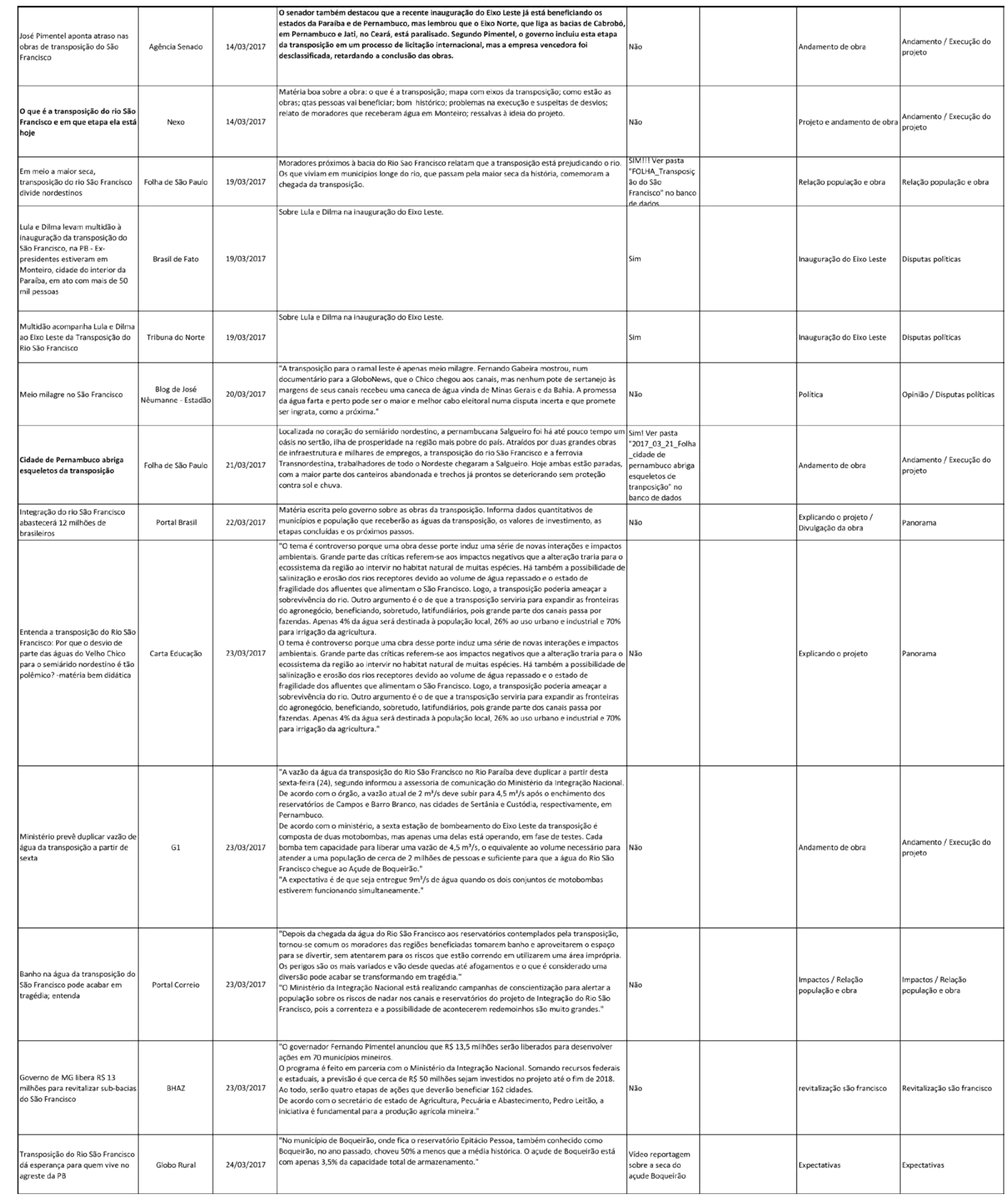




\begin{tabular}{|c|c|c|c|c|c|c|}
\hline 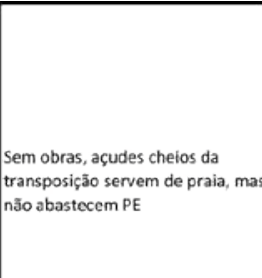 & vot & 24/63/3017 & 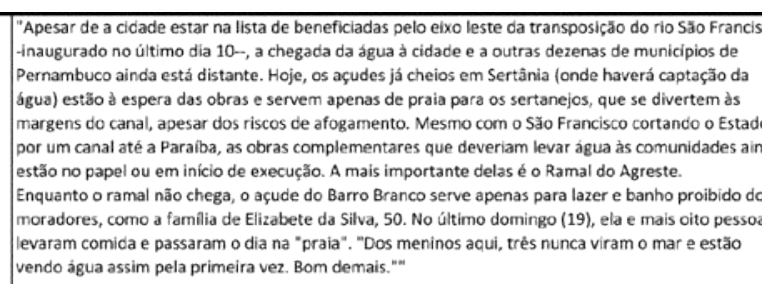 & 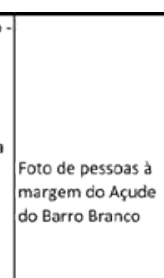 & 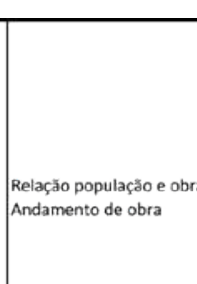 & 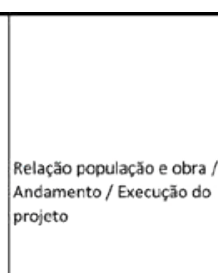 \\
\hline 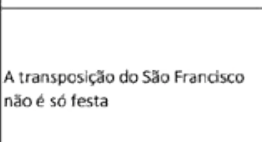 & 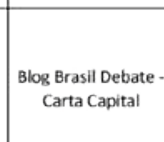 & ${ }_{160332017}$ & 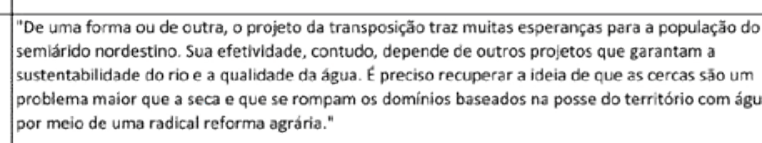 & Nao & conlabo & oninzoo \\
\hline 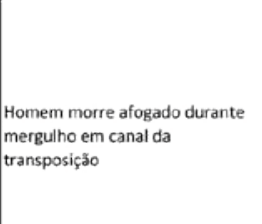 & PBA ANOA & 27/303/2017 & 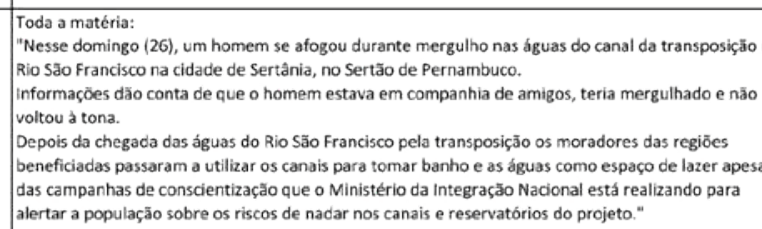 & Nao & 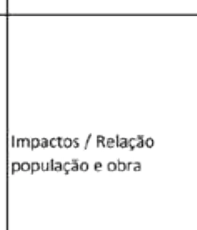 & 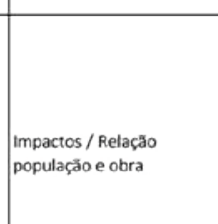 \\
\hline 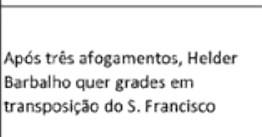 & ${ }^{6}$ & 281/3720179 & 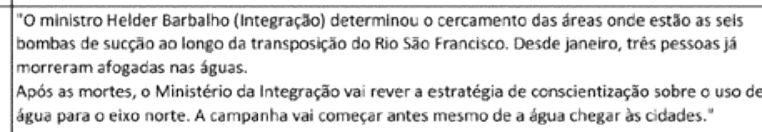 & 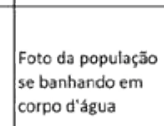 & & \\
\hline 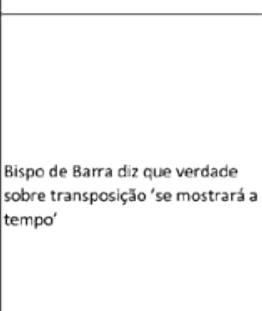 & Meidid a binia & 301332017 & 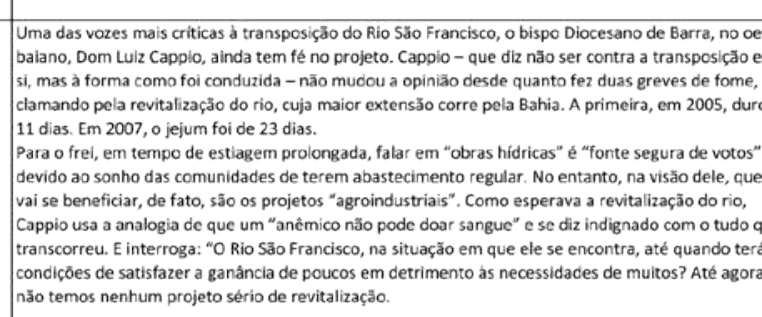 & no & Politica & \\
\hline 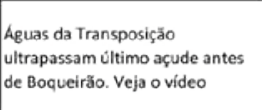 & Parababoline & 3003202017 & 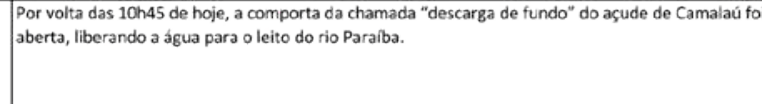 & 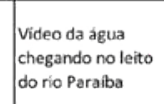 & & \\
\hline & Brasilar? & $33 / 42017.7$ & 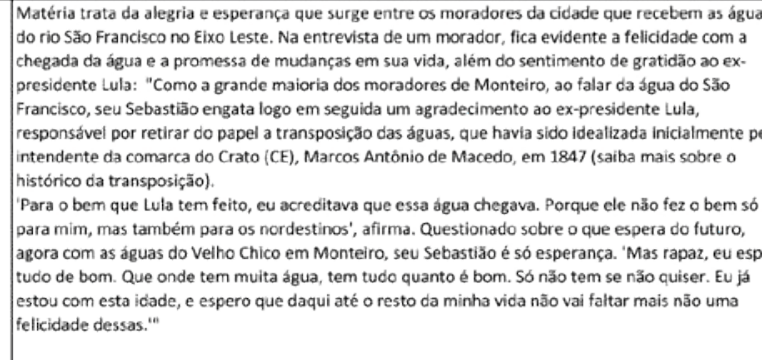 & 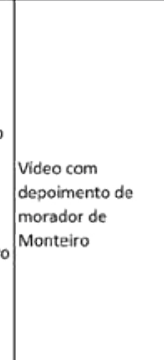 & & \\
\hline 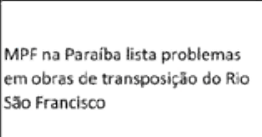 & Odsibicam & 04020272017 & 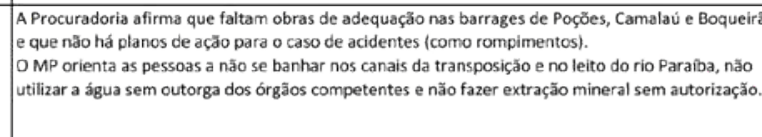 & Noo & 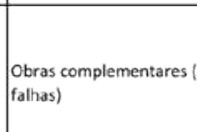 & tathes \\
\hline 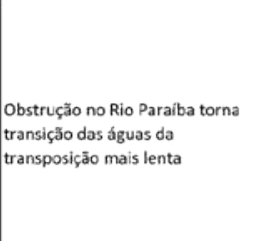 & Prasab online & 040272017 & 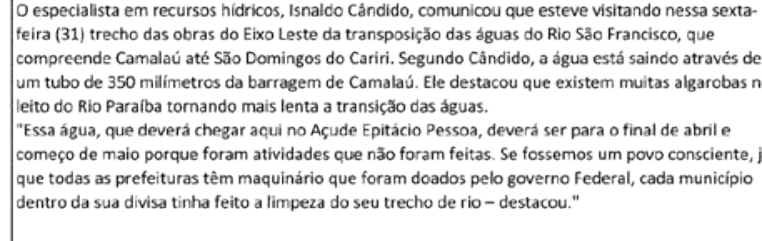 & soo & 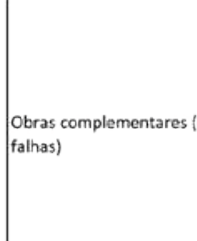 & 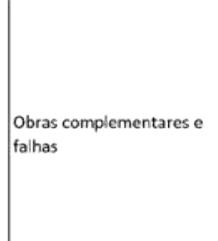 \\
\hline 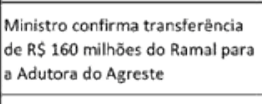 & 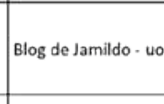 & $050 / 4202017$ & 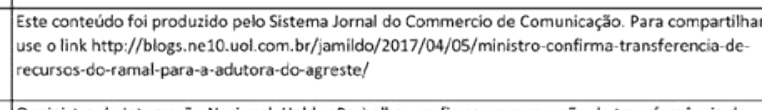 & 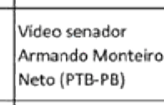 & Andamento ode obra & 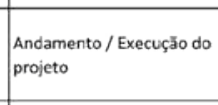 \\
\hline 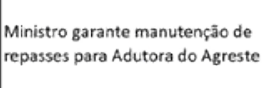 & reorine & 0606042027 & 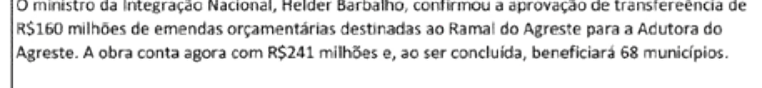 & Noso & 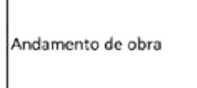 & \\
\hline 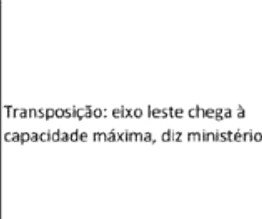 & & 040662017 & 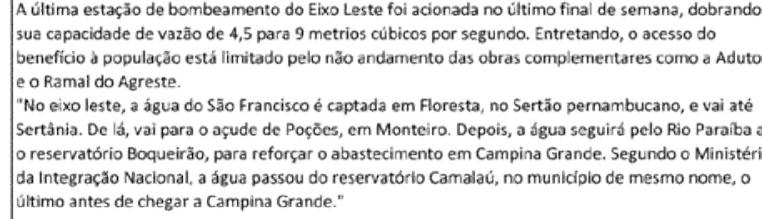 & not & mataneno de o obra & 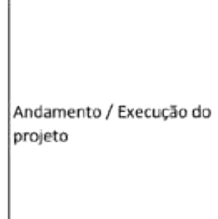 \\
\hline
\end{tabular}

\begin{tabular}{|c|c|c|c|c|c|c|c|}
\hline 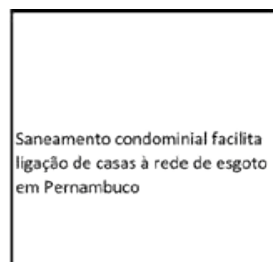 & sotoe & $07040 / 2017$ & 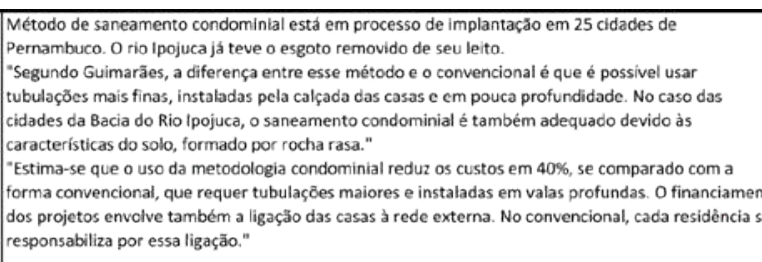 & tio & & & hase \\
\hline 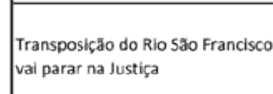 & val- bobe de elantioc & osolos/2017 & 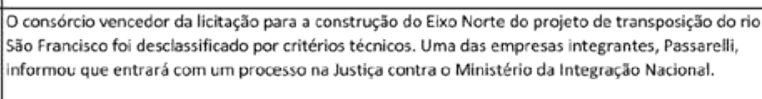 & wo & & Andamentio de obra & 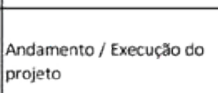 \\
\hline 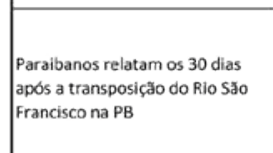 & at & ${ }_{1004 / 2017}$ & 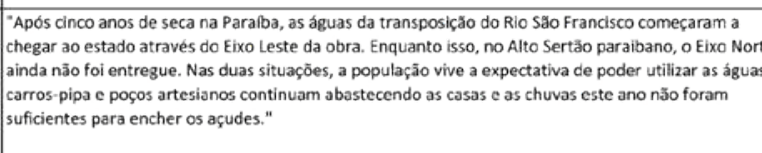 & 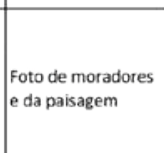 & & 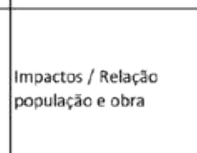 & 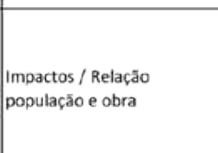 \\
\hline 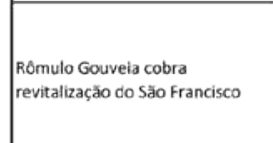 & pas ereara & 12/00/2017 & 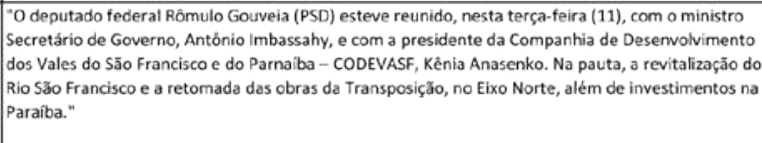 & soo & & & 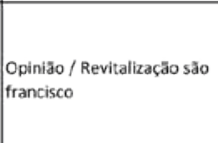 \\
\hline 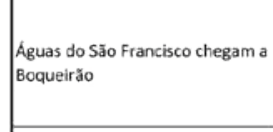 & Masps & 12/04/2017 & 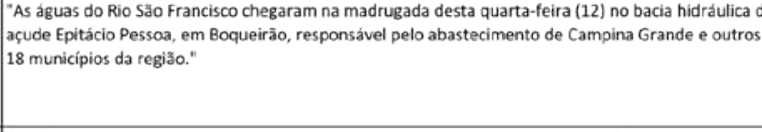 & 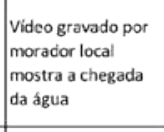 & & 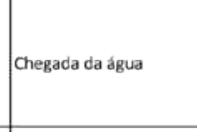 & new \\
\hline 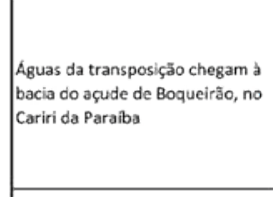 & ${ }^{61}$ & 12/04/2017 & 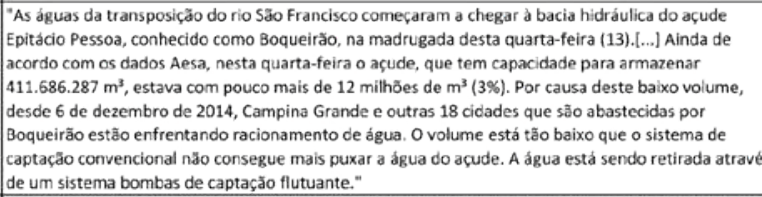 & 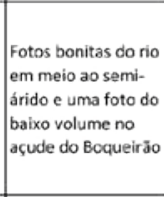 & & 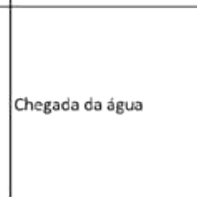 & 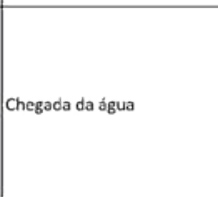 \\
\hline 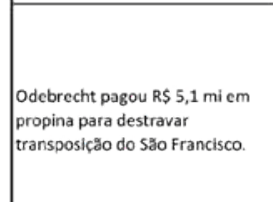 & vor & 19/40/2012017 & 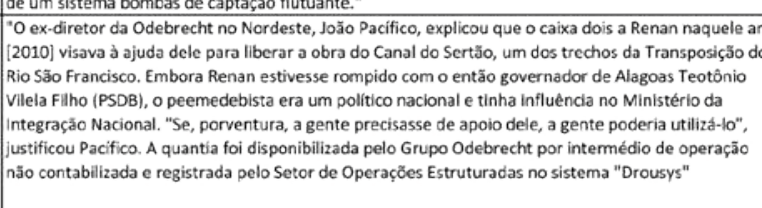 & so & & Ponitica & \\
\hline 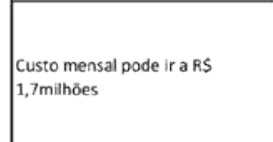 & Tribunas an on ote & ${ }_{1400402077}$ & 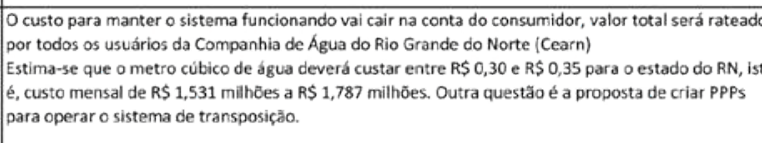 & & & & \\
\hline 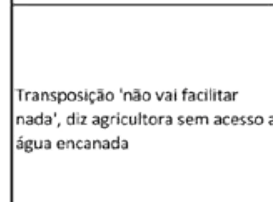 & 61 & 155042012017 & 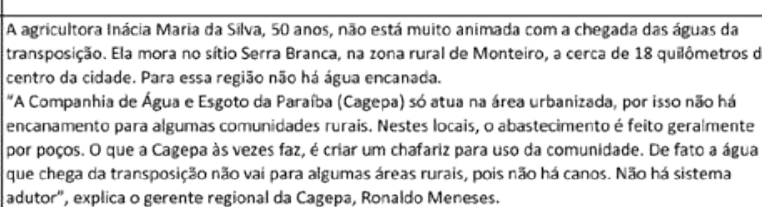 & treece & & & \\
\hline 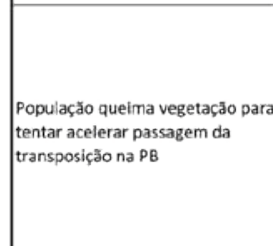 & 61 & 161004/2077 & 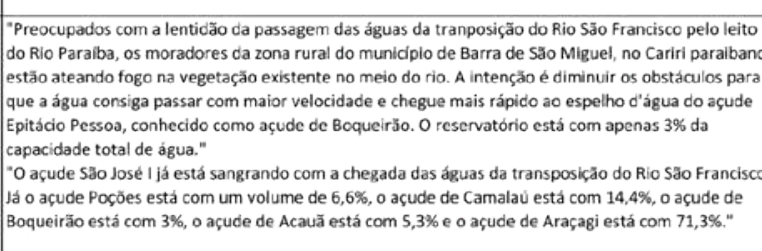 & 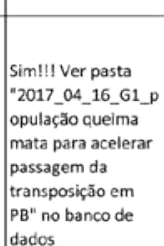 & & & \\
\hline 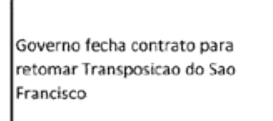 & same & 201040/2017 & 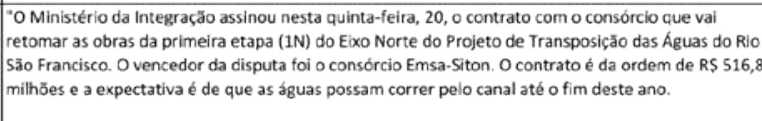 & inm!' & & Pointea & \\
\hline 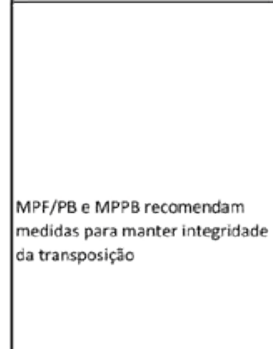 & Parabab Online & 201004/2017 & 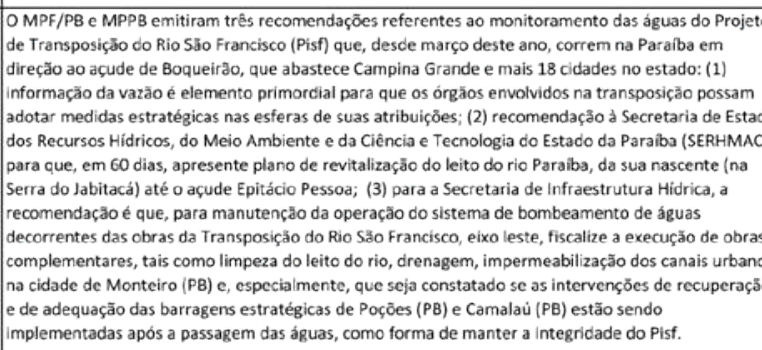 & & 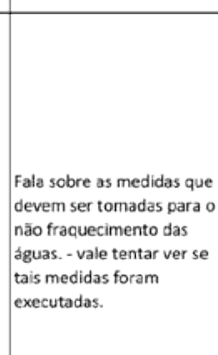 & & \\
\hline 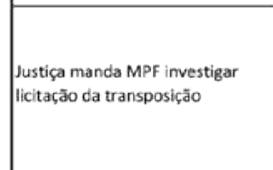 & Midia Ners & $21 / 04202017$ & 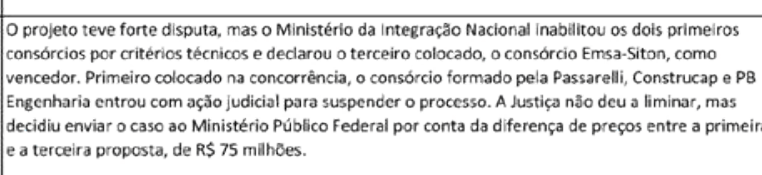 & & & Pontica & ropere \\
\hline 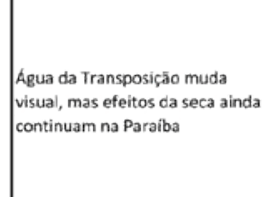 & ${ }^{61}$ & 2/100/2017 & 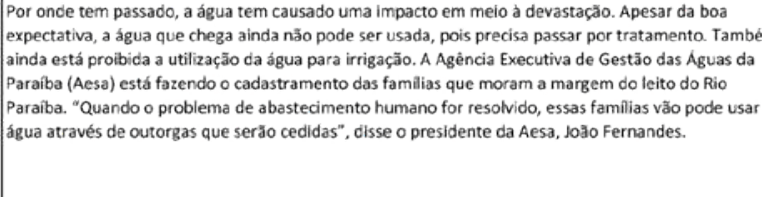 & 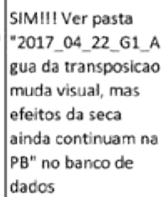 & & 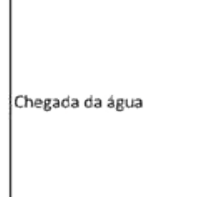 & \\
\hline
\end{tabular}




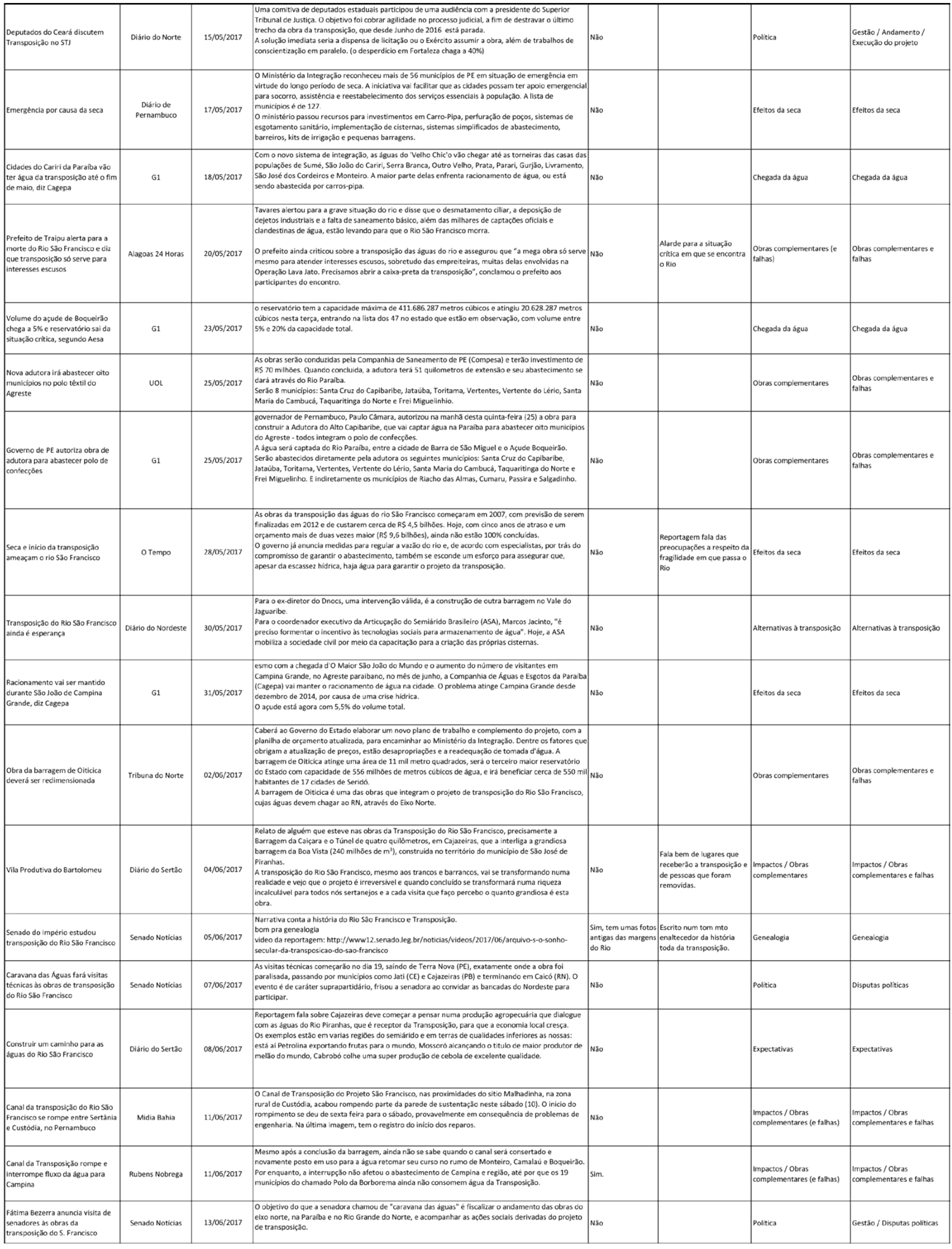




\begin{tabular}{|c|c|c|c|c|c|c|c|}
\hline 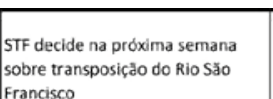 & Tritumas o oncre & 1406620207 & 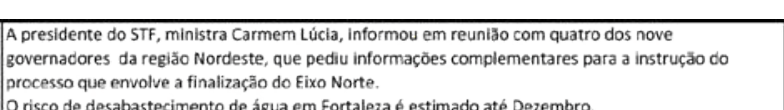 & noo & & & 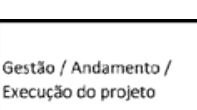 \\
\hline 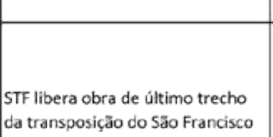 & Estabaso & 20106/2017 & 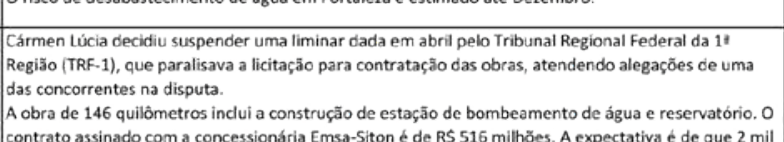 & & & & \\
\hline & & & 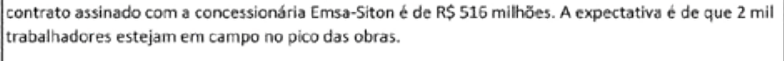 & & & & \\
\hline 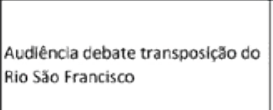 & Novon Noticias & 20106/2017 & 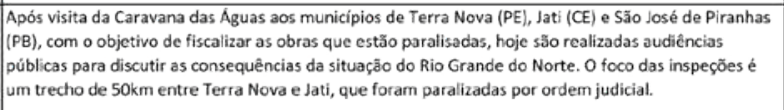 & wo & & & 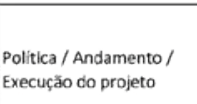 \\
\hline & & & 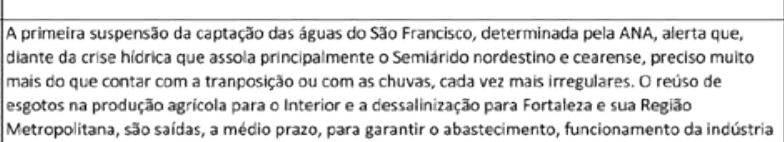 & & & & \\
\hline 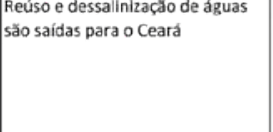 & roconocoder & 22106/2017 & 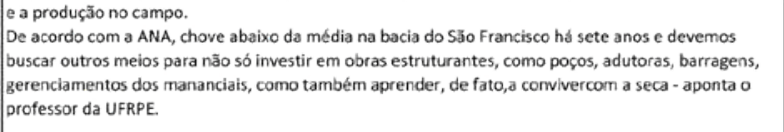 & 留O & 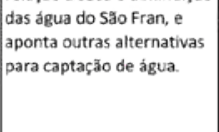 & & \\
\hline 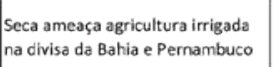 & c1 & 2506/502017 & 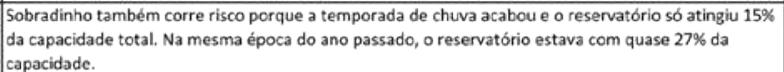 & sim & & 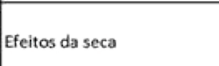 & 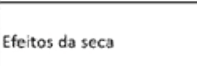 \\
\hline 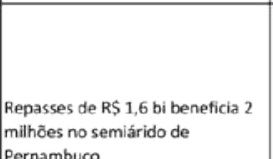 & Patat lasail & 20106502017 & 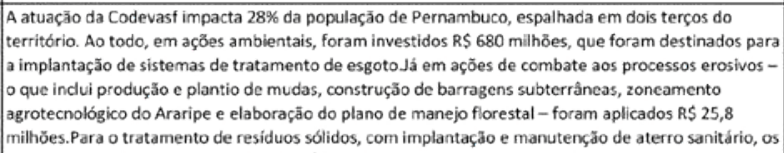 & & & & \\
\hline & & & 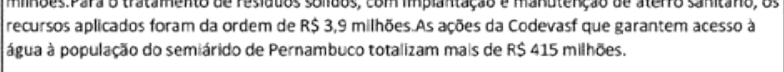 & & devast & & (almas \\
\hline & & & 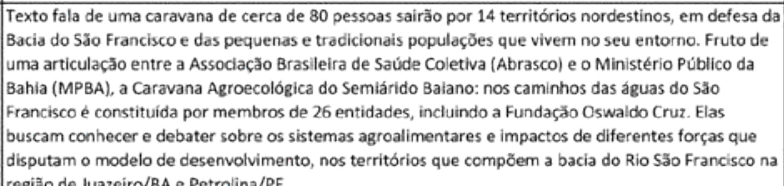 & & & & \\
\hline & 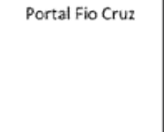 & 27/065017: & 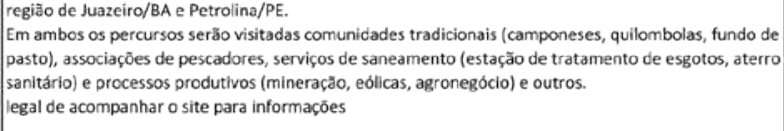 & & 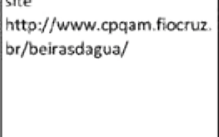 & & \\
\hline 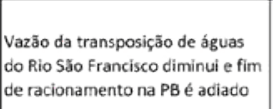 & ${ }_{1}$ & 12/07/2017 & 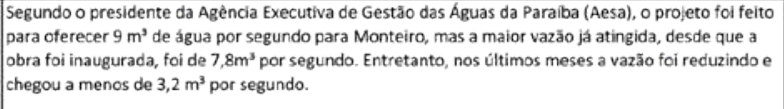 & 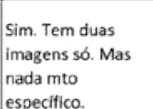 & & Sgus & \\
\hline 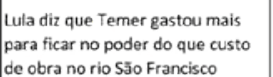 & vol & 27708202017 & & & & Certio & Sestio \\
\hline 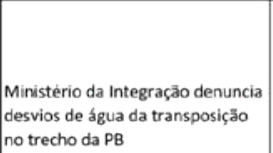 & ${ }_{1}$ & 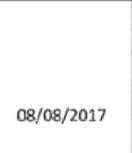 & 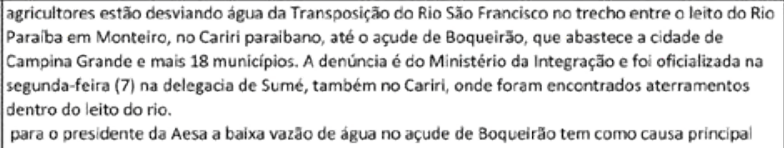 & \$o & 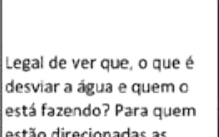 & & 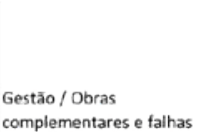 \\
\hline & & & 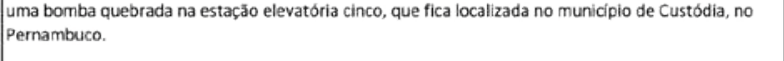 & & & & \\
\hline 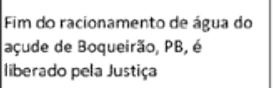 & ${ }^{6}$ & 2508017 & & Noo & & 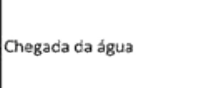 & cheseatd dat agus \\
\hline 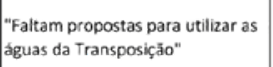 & Tribuna do Norte & 1000/2017 & 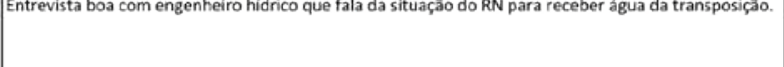 & wo & & 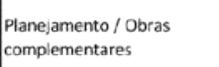 & 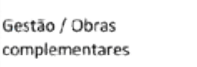 \\
\hline 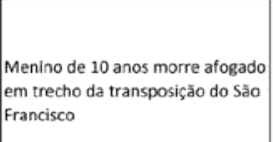 & Pranaba onine & 11/08/2017 & 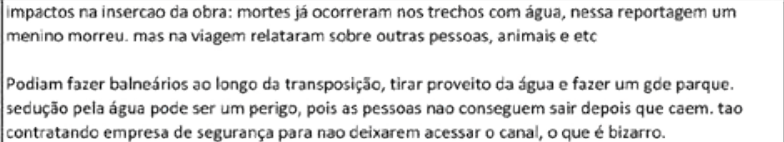 & nio & & 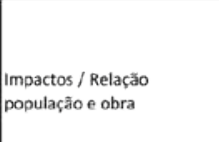 & 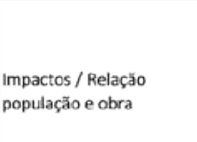 \\
\hline 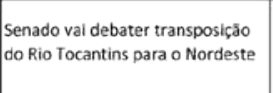 & senasobonocicas & 1330/2017 & 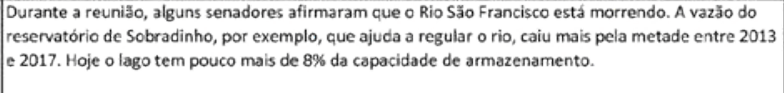 & No & & Genealogia? & Geneaseata \\
\hline 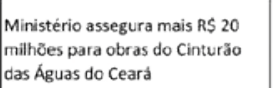 & 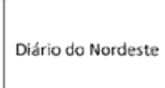 & 18109/2017 & 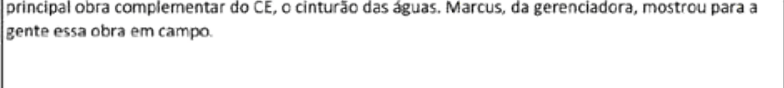 & Noo & & 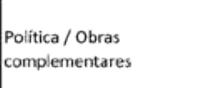 & 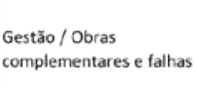 \\
\hline 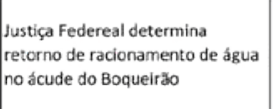 & 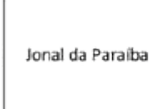 & $1908 / 2017$ & 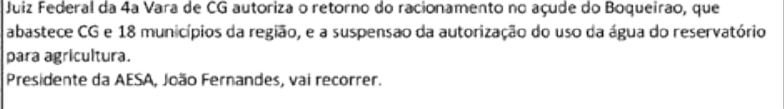 & so & & 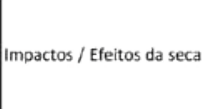 & 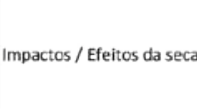 \\
\hline 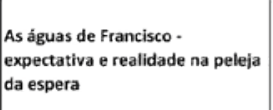 & Opovoromithe & semetas & 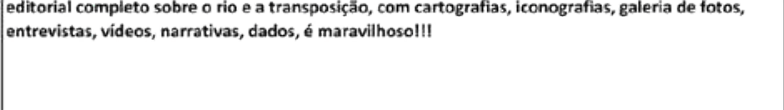 & moo & 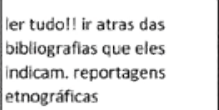 & 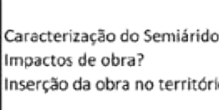 & encosans \\
\hline
\end{tabular}

\begin{tabular}{|c|c|c|c|c|c|c|c|}
\hline 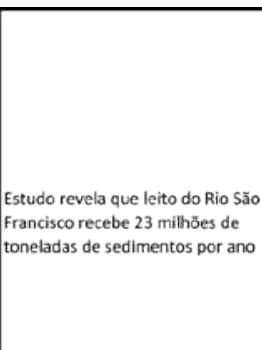 & EM & 2409520017 & 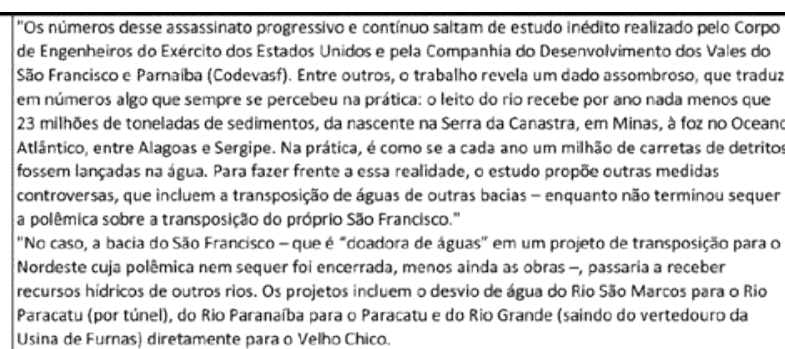 & 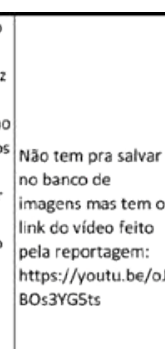 & & 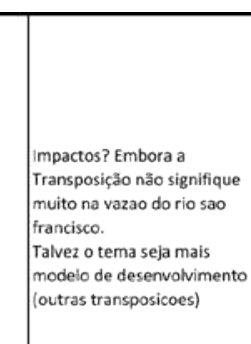 & 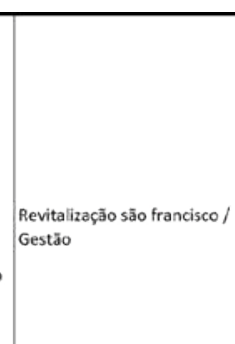 \\
\hline 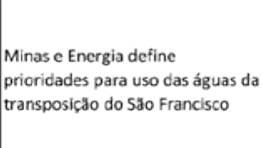 & 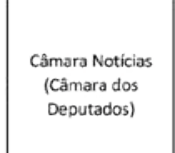 & 250982017 & 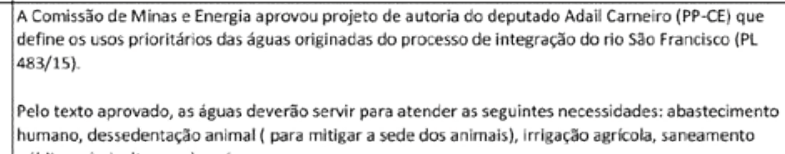 & Nio & & & Gestiod da sula \\
\hline 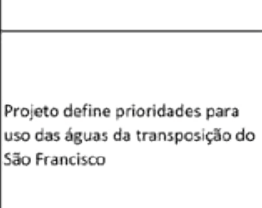 & Aqui icontece & 2601020027 & 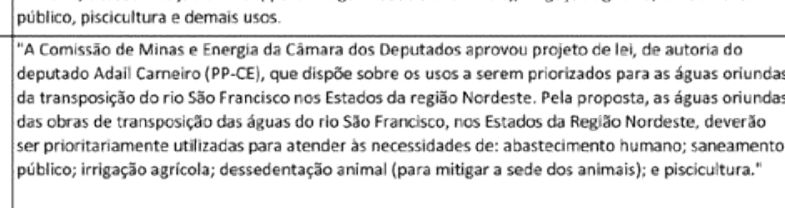 & nso & 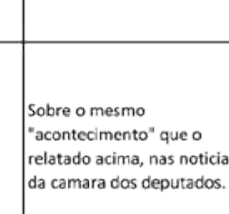 & 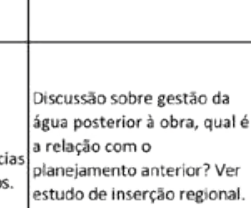 & 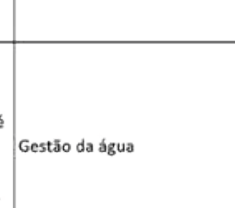 \\
\hline 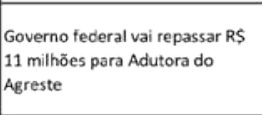 & vor & 22090202017 & 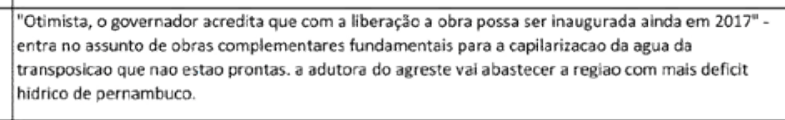 & Niso & & antiplanciamentio & 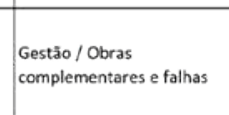 \\
\hline 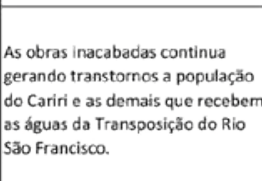 & TCariti & 200920207 & 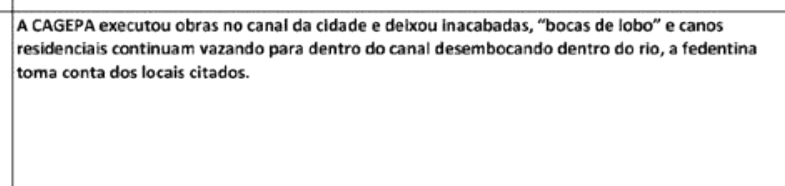 & sim & & & 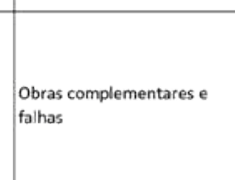 \\
\hline 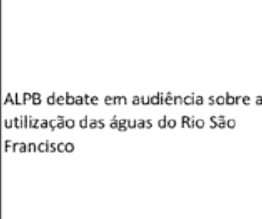 & Parablo onlitie & 2909/2017 & 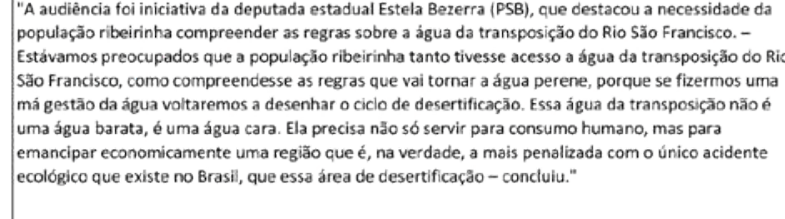 & nso & 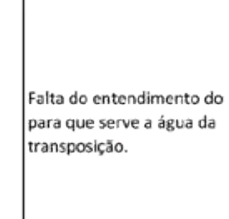 & 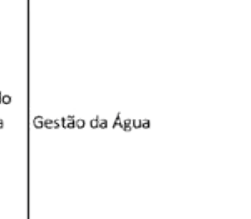 & gou \\
\hline 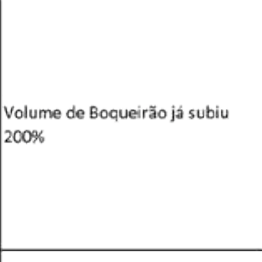 & PAseras & 04/10202017 & 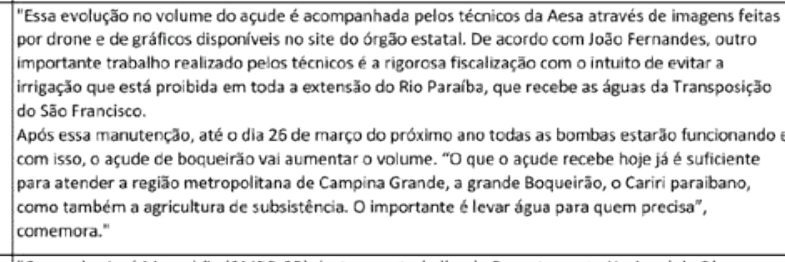 & & 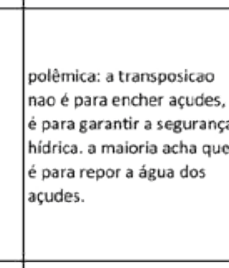 & 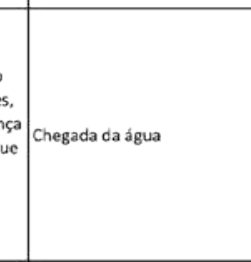 & chesesta \\
\hline 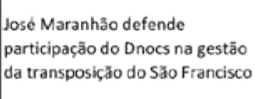 & 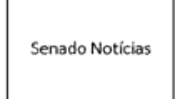 & 0410202017 & 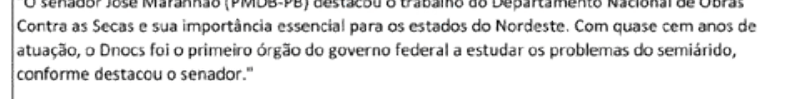 & Niso & & 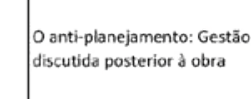 & 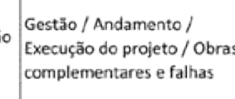 \\
\hline 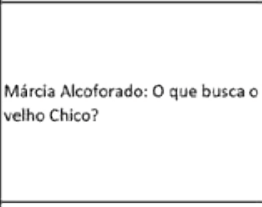 & 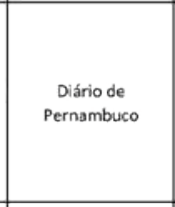 & 0410202017 & 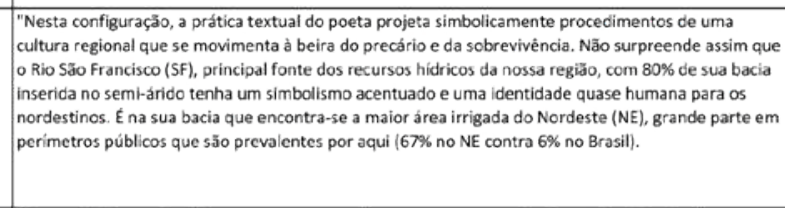 & ๓so & 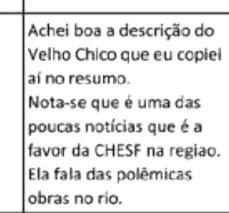 & tractizasis & 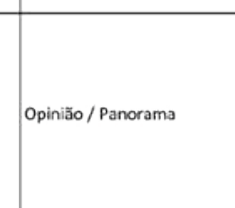 \\
\hline & & & 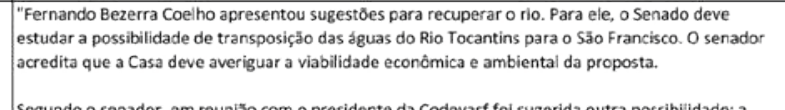 & & & & \\
\hline Tonsiser & 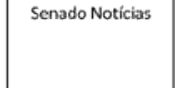 & callorolar & 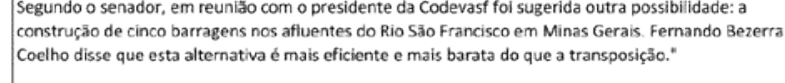 & 1500 & 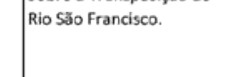 & 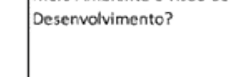 & \\
\hline 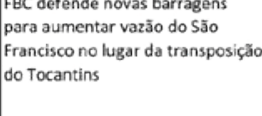 & Blogeteramitio & o5s1020077 & 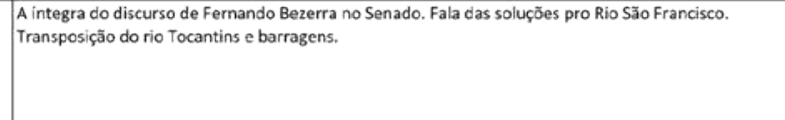 & thio & 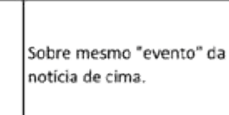 & & 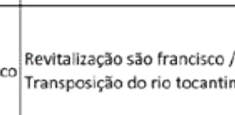 \\
\hline 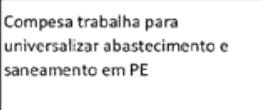 & vor & 07710202017 & 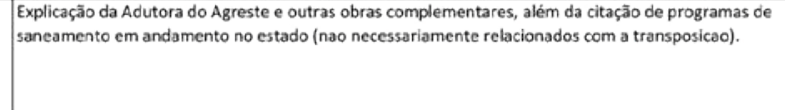 & niso & & & 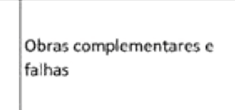 \\
\hline 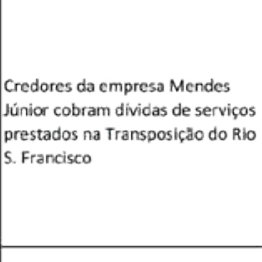 & ${ }^{6}$ & c910102017 & 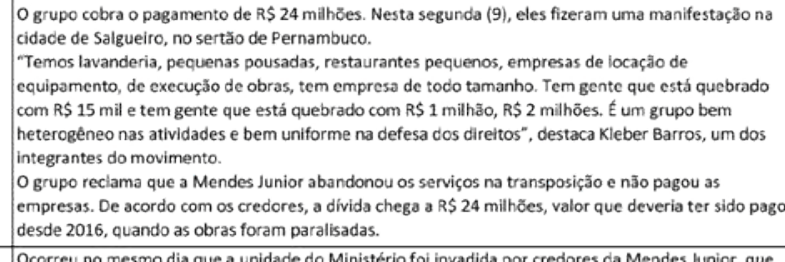 & Nao & & 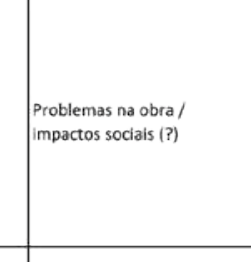 & 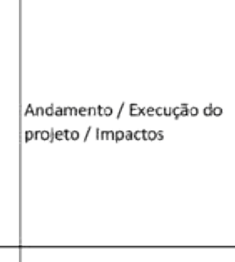 \\
\hline 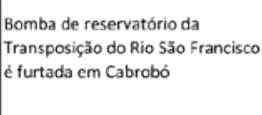 & 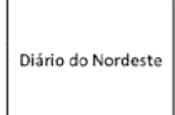 & 0910202017 & 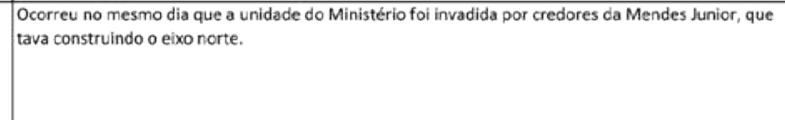 & nso & & 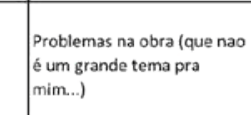 & 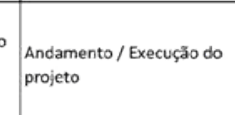 \\
\hline 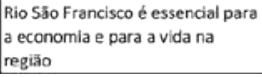 & ${ }^{61}$ & ${ }_{1610102027}$ & 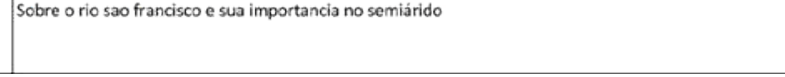 & Noso & & 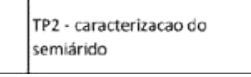 & Penorama \\
\hline
\end{tabular}




\begin{tabular}{|c|c|c|c|c|c|c|c|}
\hline 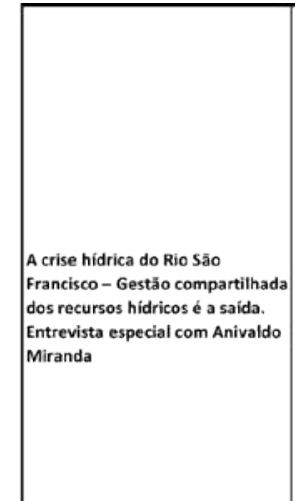 & Huonotine & 1810/02017 & 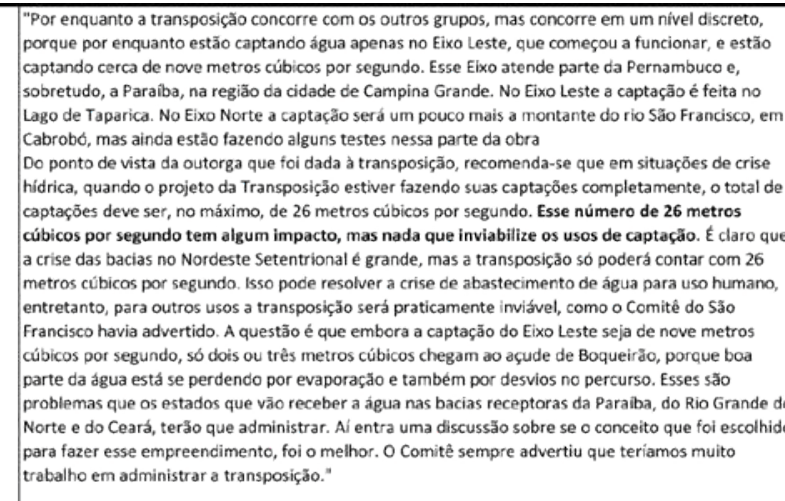 & Nio & & 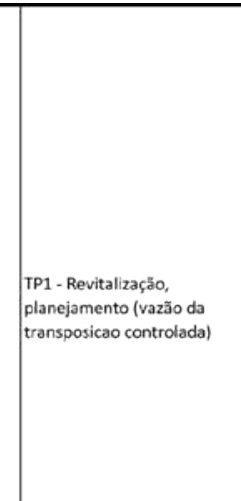 & 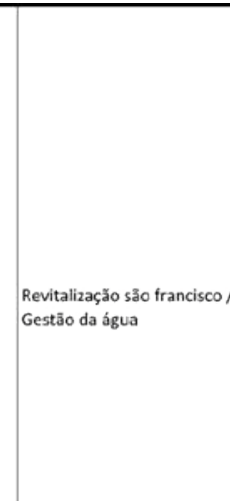 \\
\hline 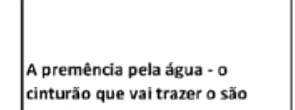 & opero onine & 18/10/2017 & 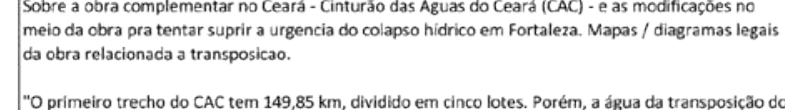 & & & 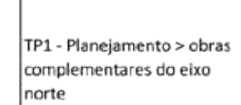 & \\
\hline & & & 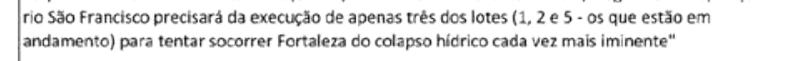 & & & 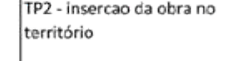 & \\
\hline 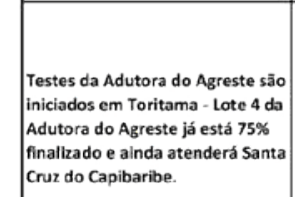 & ${ }^{6}$ & 201/102017 & 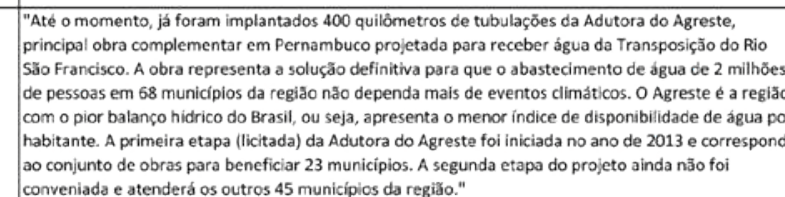 & & & 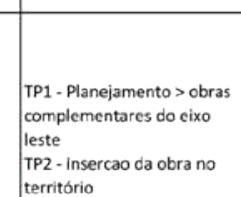 & 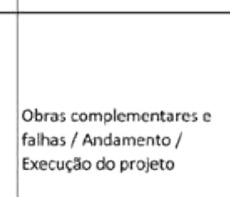 \\
\hline 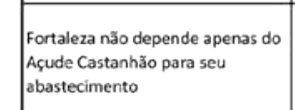 & 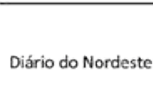 & ${ }_{23 / 10202017}$ & & sim & & 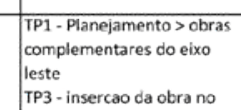 & 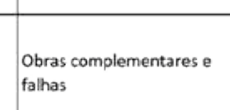 \\
\hline & & & 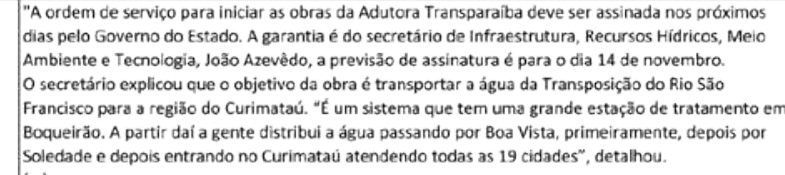 & & & & \\
\hline 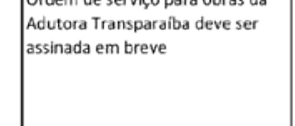 & Paratabacomber & 281/102017 & 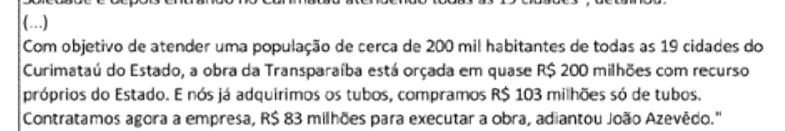 & Nao & & obas congementuress & 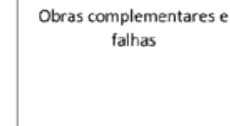 \\
\hline & Besaside fato & 341002007 & 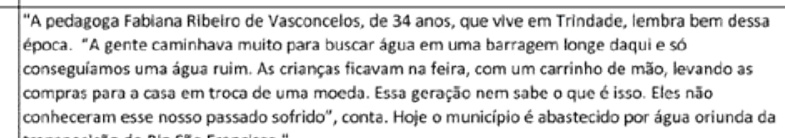 & Nao & & 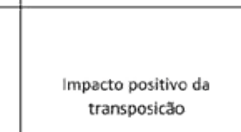 & Inposactos \\
\hline 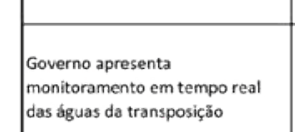 & wscom noticias & $000 / 1 / 12017$ & 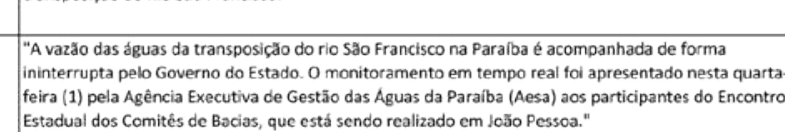 & Nio & & 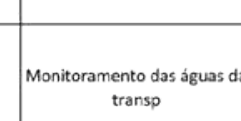 & 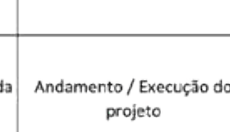 \\
\hline 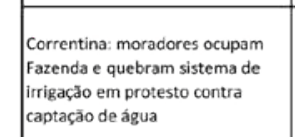 & Asenticiseretio & 02/1/20017 & 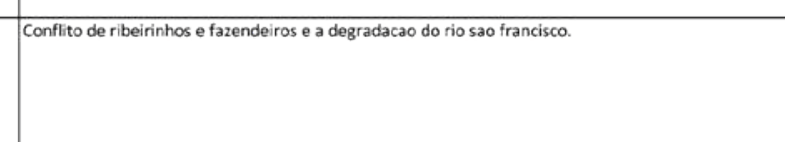 & wio & 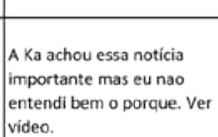 & 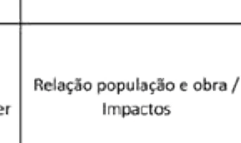 & 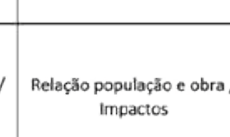 \\
\hline 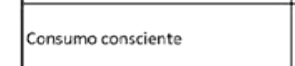 & 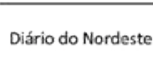 & 4/1/1/2017 & 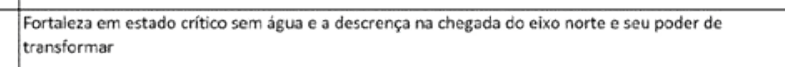 & wio & & 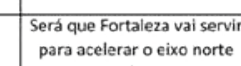 & 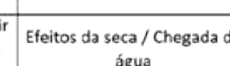 \\
\hline 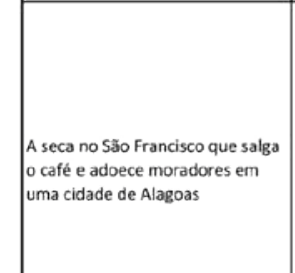 & Elopts & 6/11/2017 & 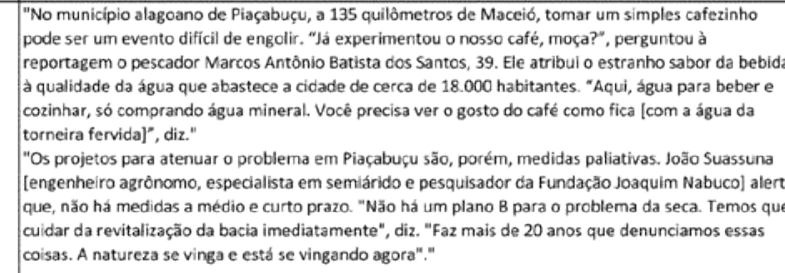 & & & Rios So forancsio & 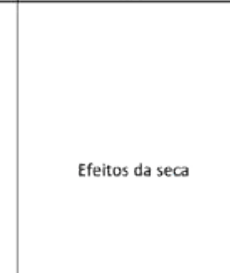 \\
\hline 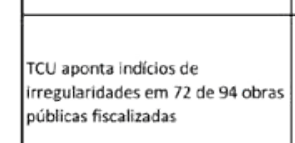 & 61 & $8 / 1 / 12017$ & 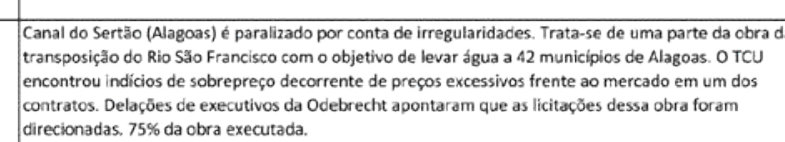 & woo & & 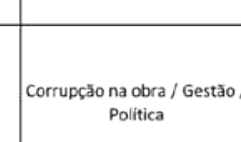 & \\
\hline 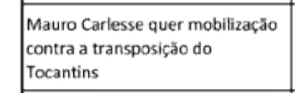 & conesebo reartins & 9/1/2007 & 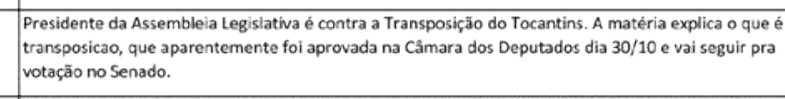 & soo & & $\begin{array}{l}\text { Obras complementeres. } \\
\text { Transposisforo o o orantins }\end{array}$ & obars complementarese \\
\hline 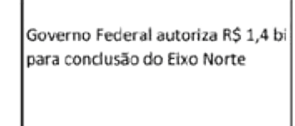 & Masp PB & 9/1/2007 & 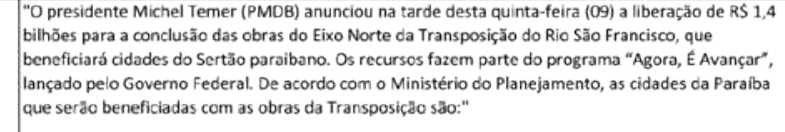 & Vao & & Andamerto de obra & 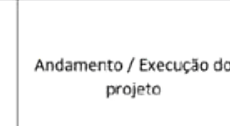 \\
\hline & Basalat7 & 1/1/120017 & 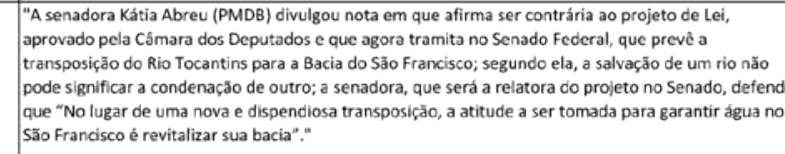 & & & 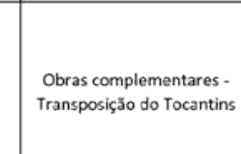 & \\
\hline
\end{tabular}

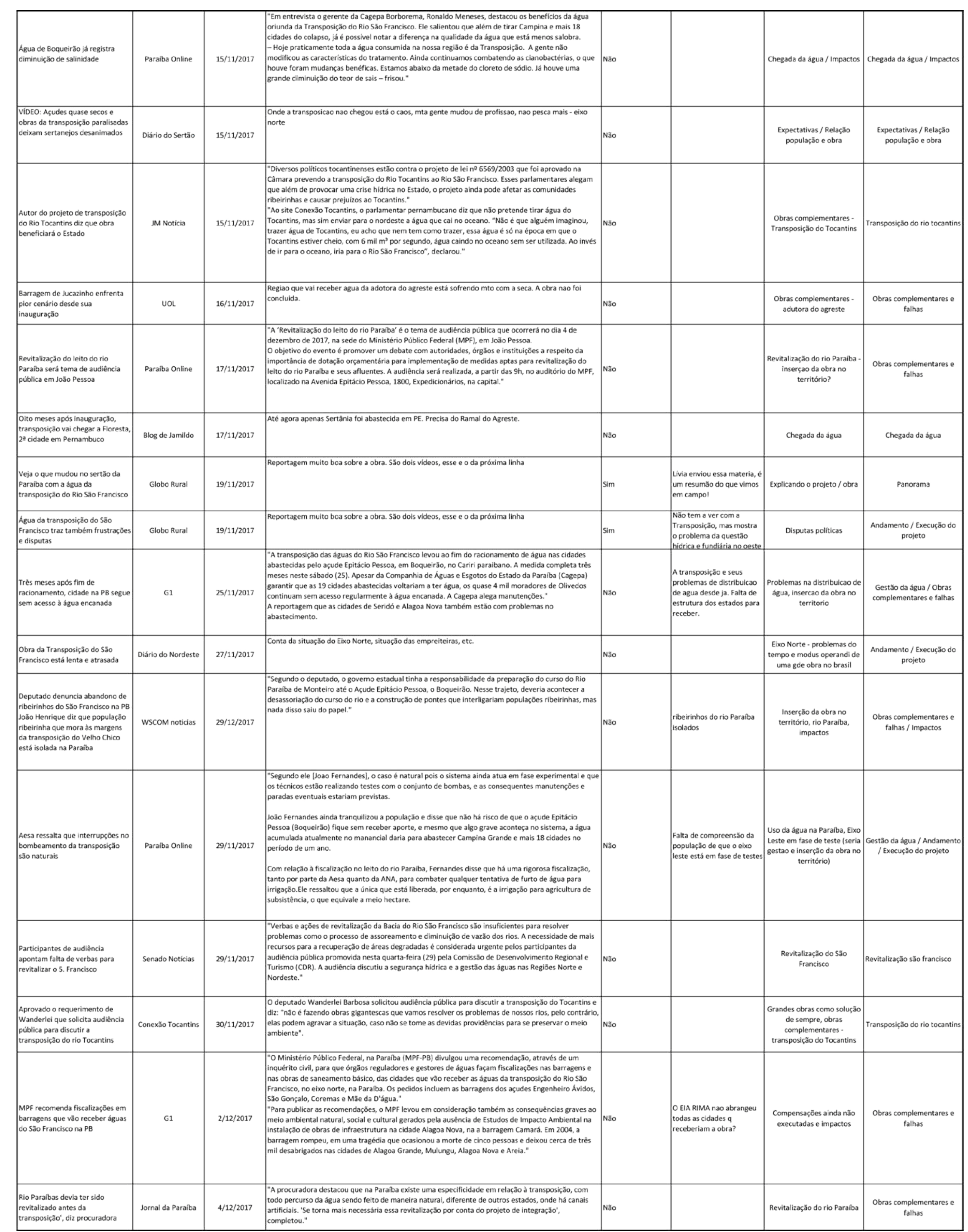




\begin{tabular}{|c|c|c|c|c|c|c|c|}
\hline 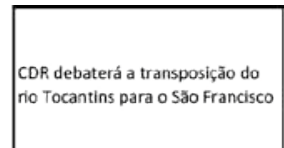 & Senato nocicias & 4/12/2017 & 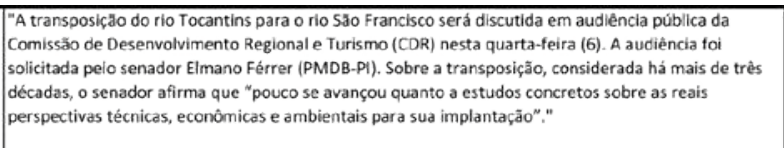 & Noo & & 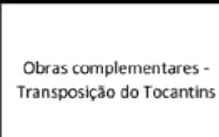 & \\
\hline & & & 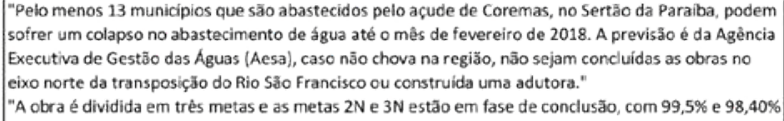 & & & & \\
\hline 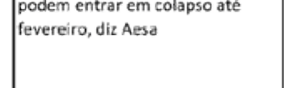 & at & 5/21272017 & 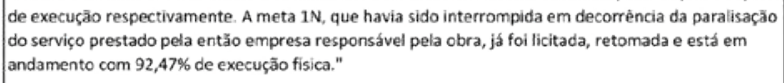 & 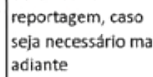 & 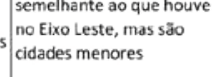 & 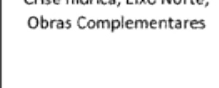 & 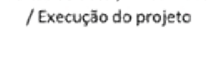 \\
\hline & & & 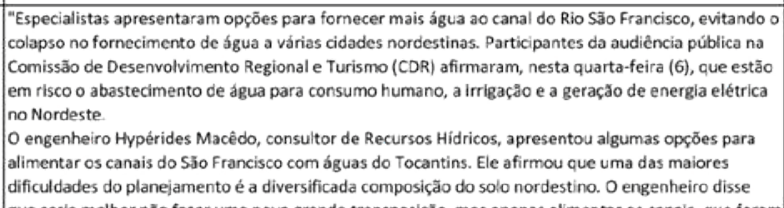 & & & & \\
\hline 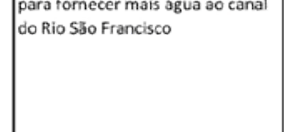 & 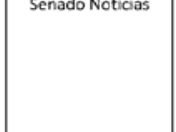 & (6/272017 & 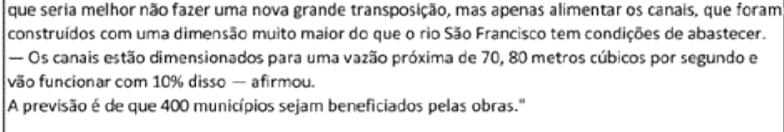 & & & sposisipo do Tocantin & 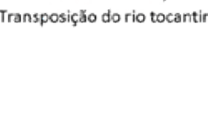 \\
\hline 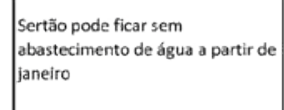 & "7 & 7/12/2017 & 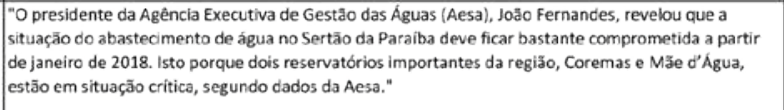 & nio & & 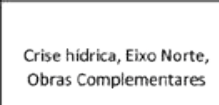 & Efetaros das sece \\
\hline 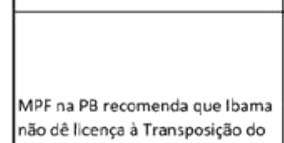 & & & 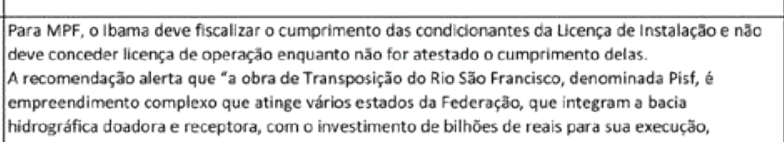 & & & & \\
\hline Soffandiso & ${ }_{61}$ & 11/1/2/2017 & 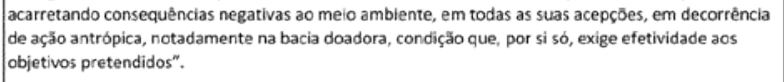 & 我 & IIII & 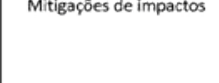 & manateses \\
\hline 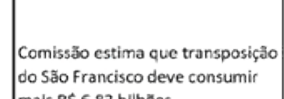 & Senardonoticicas & 15/1/272017 & 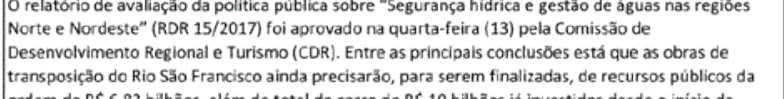 & Ià & & 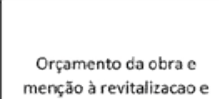 & 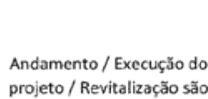 \\
\hline 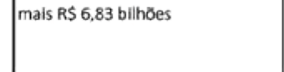 & & & 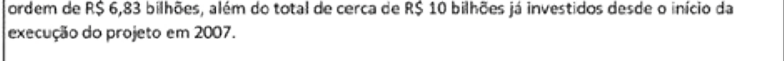 & & & gestrao & \\
\hline 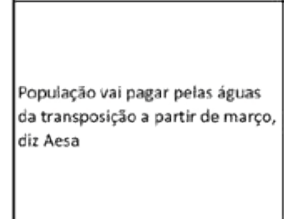 & Jormal das aratiba & 15/2122017 & 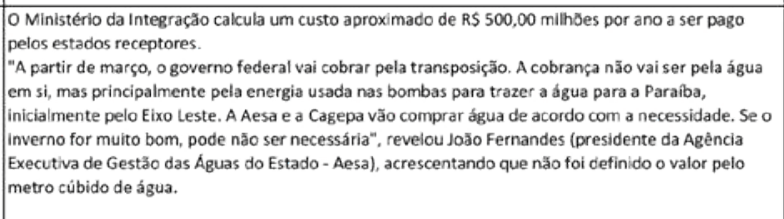 & so & & & Gestododiscen \\
\hline 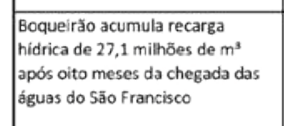 & 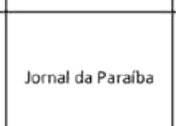 & 18/12/2017 & 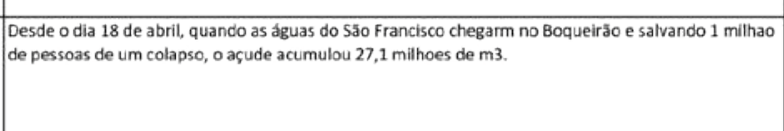 & nio & & & 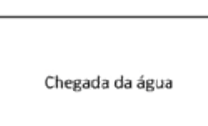 \\
\hline 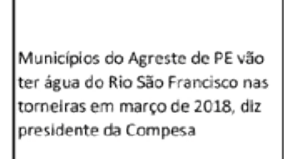 & ${ }^{6}$ & 18/1/202017 & 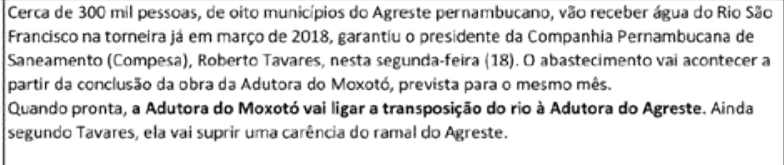 & soo & & & Evectations \\
\hline 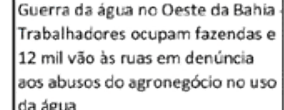 & Brasid de fato & 18/2/2017 & 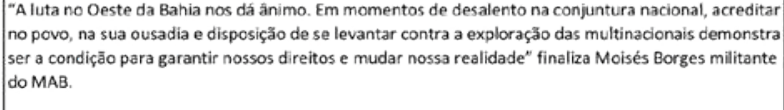 & wio & 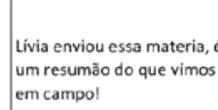 & jibtrouec & Imposates \\
\hline 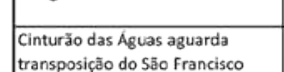 & 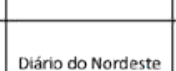 & 23/1/272017 & & Nao & & & \\
\hline & & & 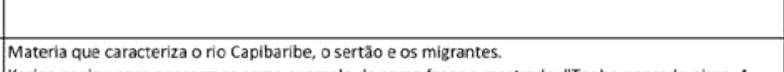 & 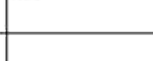 & & cars & talass \\
\hline Motre vida e eregering & vou & 25/12/2017 & 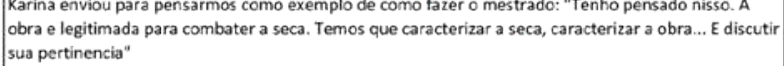 & nio & & 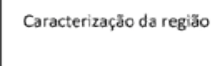 & Pensarame \\
\hline 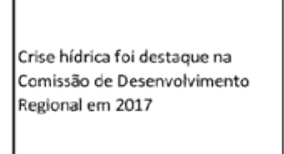 & Senato Noticias & $291 / 272018$ & 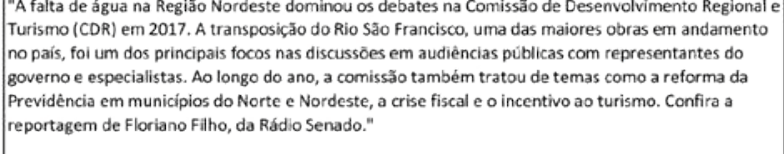 & แо & & 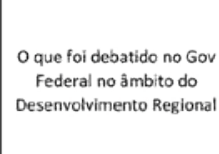 & Disoputas oflities \\
\hline 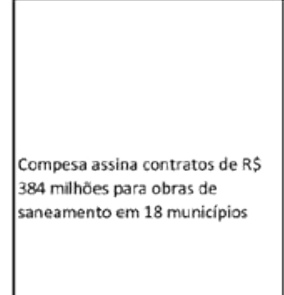 & 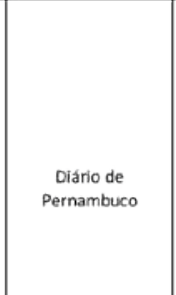 & $291 / 272018$ & 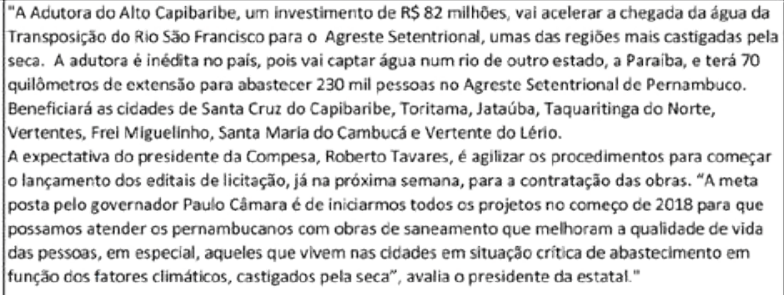 & wo & & 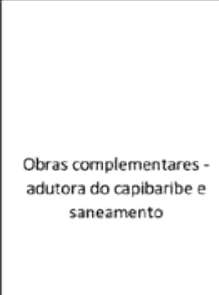 & tathas \\
\hline 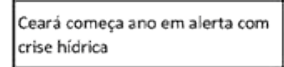 & 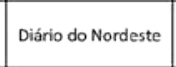 & 0200/201018 & 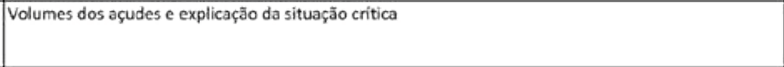 & Năo & & 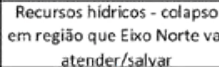 & Etataros dascen \\
\hline
\end{tabular}

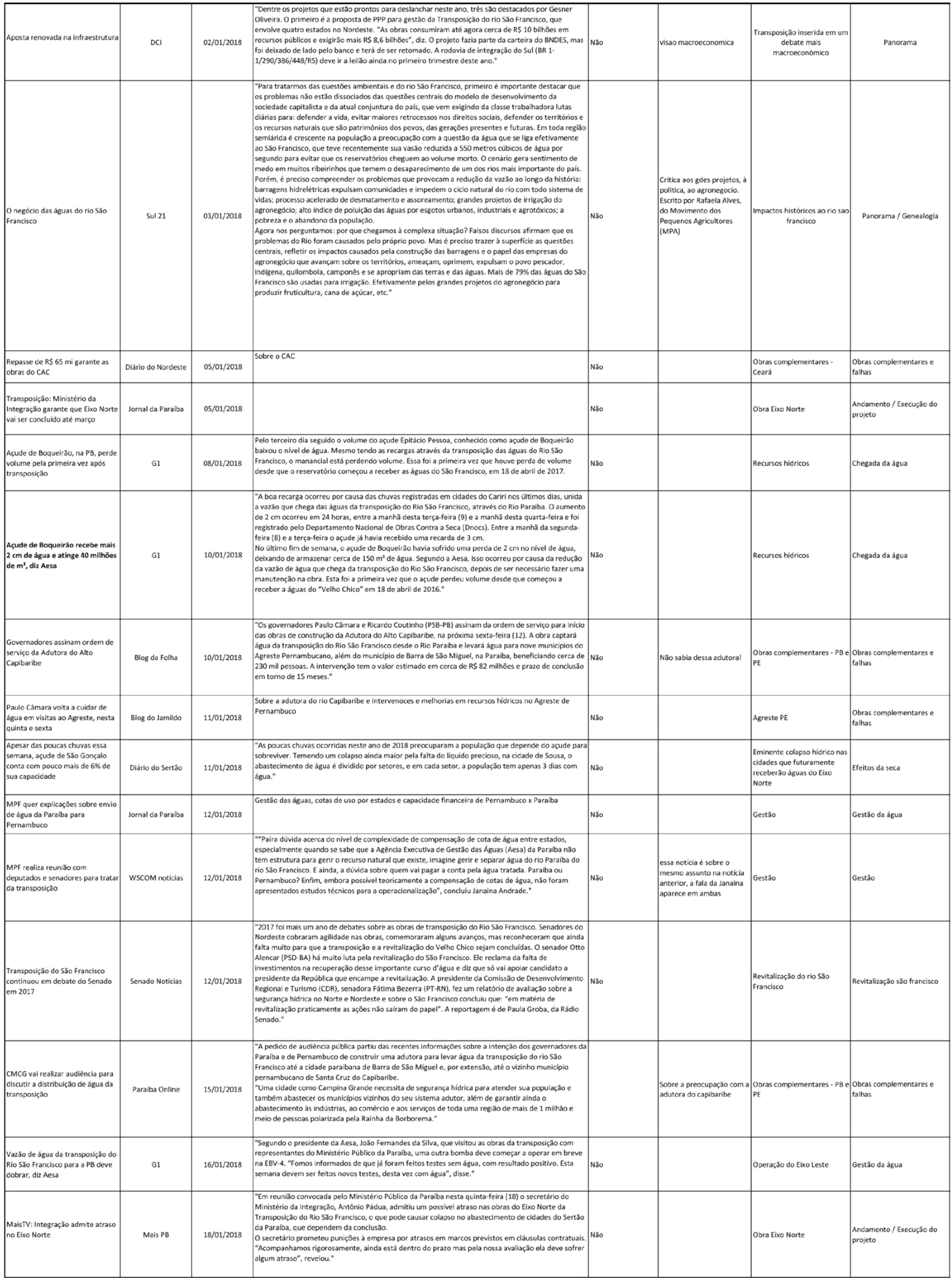




\begin{tabular}{|c|c|c|c|c|c|c|c|}
\hline 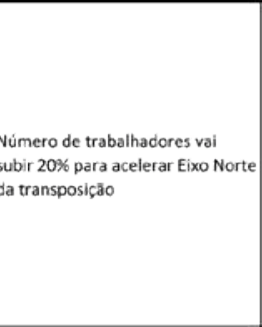 & Potate I Casiin & 2601/20138 & 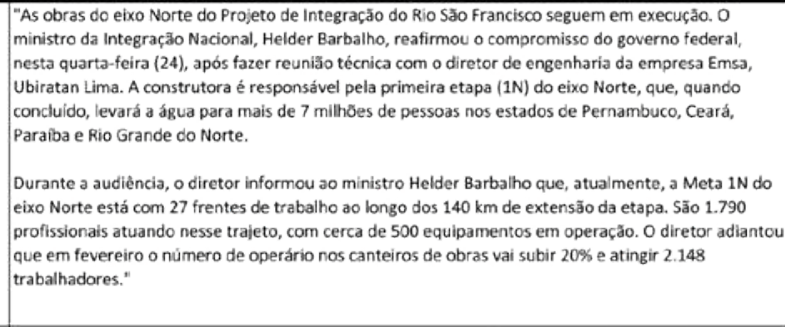 & Niso & & & 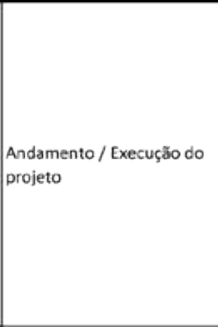 \\
\hline & & & 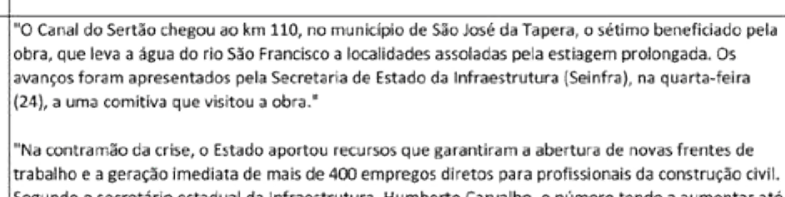 & & & & \\
\hline 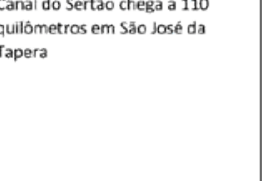 & Trthum a Hop & 27/01/2018 & 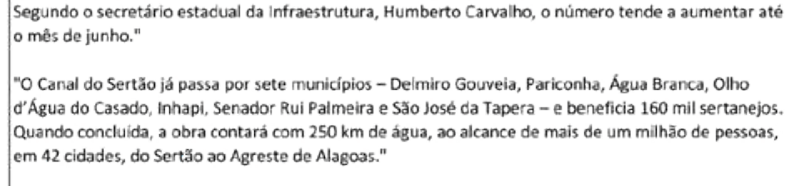 & No & & 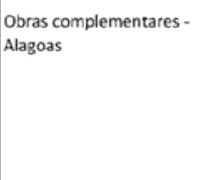 & 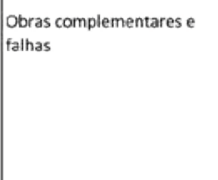 \\
\hline 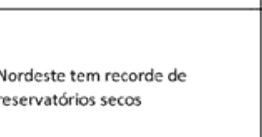 & masse & 28/1/2013 & 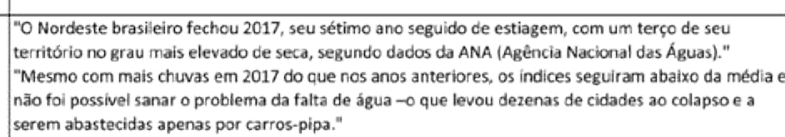 & wio & & ees & \\
\hline 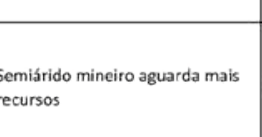 & Dibirio oc Comerecti & 30/1/2013 & 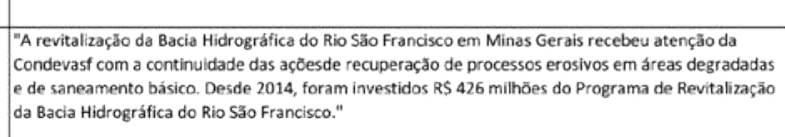 & nso & 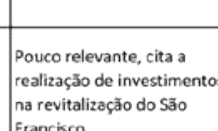 & 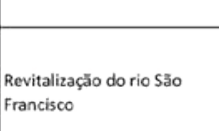 & \\
\hline & remandoconontar & $31 / 1 / 201018$ & 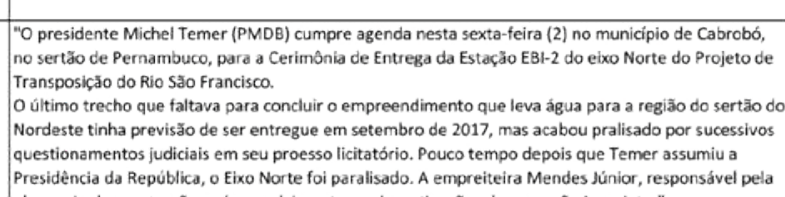 & wo & & & \\
\hline 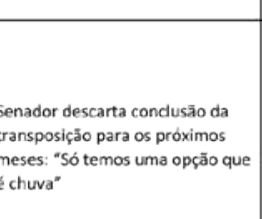 & 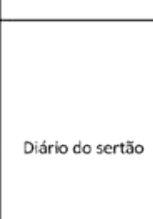 & 01/202013918 & 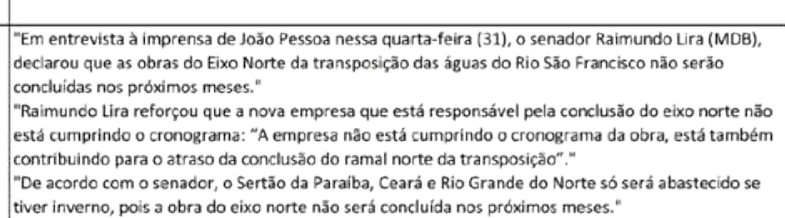 & soo & & & \\
\hline & ofoon & $001 / 20202018$ & 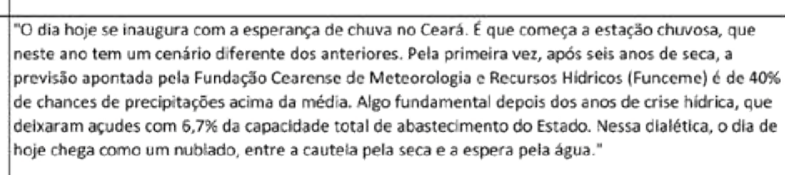 & so & & ear & \\
\hline 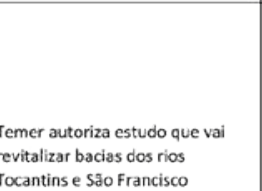 & Porat Az 2 & 02/02/2018 & 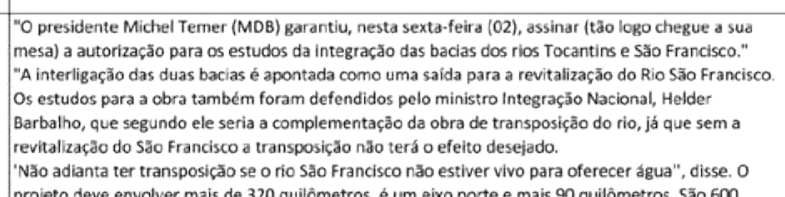 & so & & 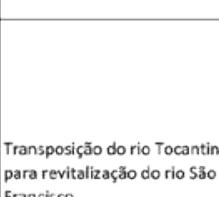 & \\
\hline & & & 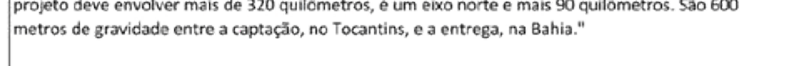 & & & & \\
\hline 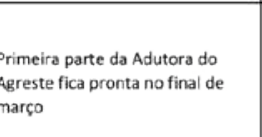 & vor & 1002/2013 & 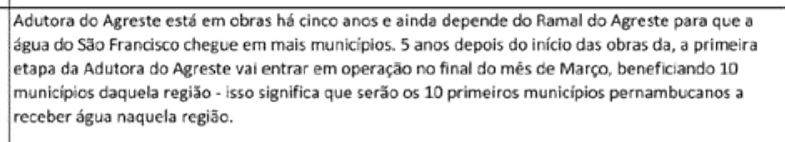 & woo & & 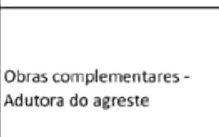 & Sans \\
\hline 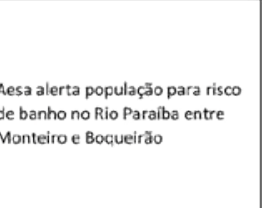 & ${ }_{61}$ & 14020201313 & 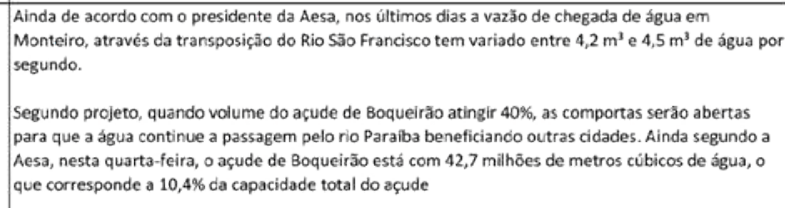 & siso & & iestio & 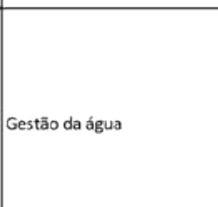 \\
\hline 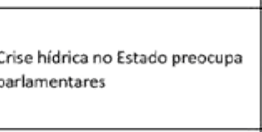 & 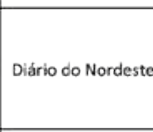 & 16/62/201818 & 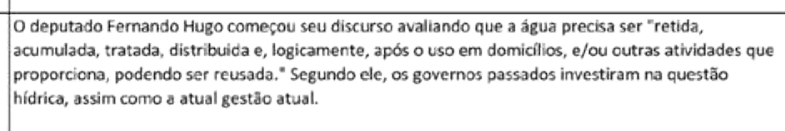 & Noso & 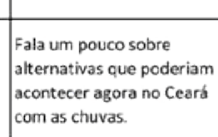 & 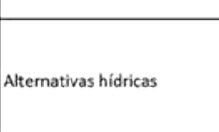 & \\
\hline 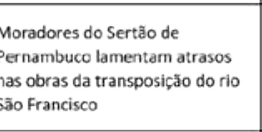 & ${ }^{\circ}$ & 200202/2018 & 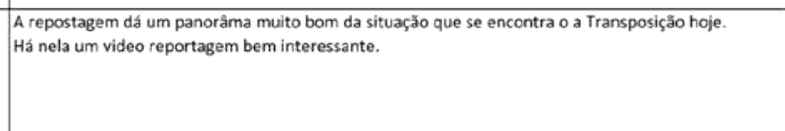 & inm. & & estäo & \\
\hline 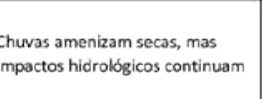 & Tribuna do Norere & 21/02/2018 & 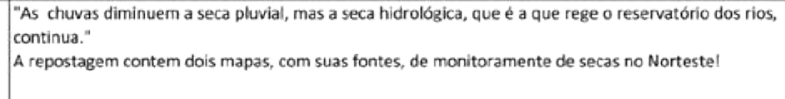 & sim & & sea & 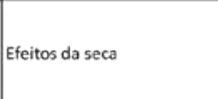 \\
\hline trans & globopray & 25020270018 & fonsteo & smm. assistro o video & & & 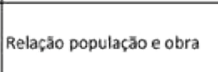 \\
\hline 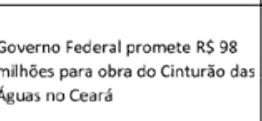 & ${ }^{61}$ & 28/202/2013 & 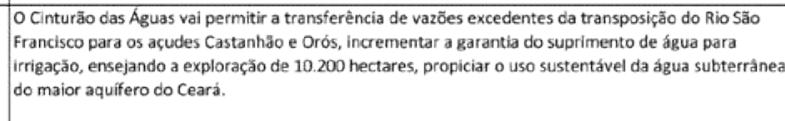 & soo & & 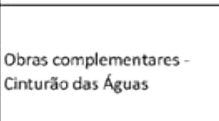 & batascor \\
\hline
\end{tabular}

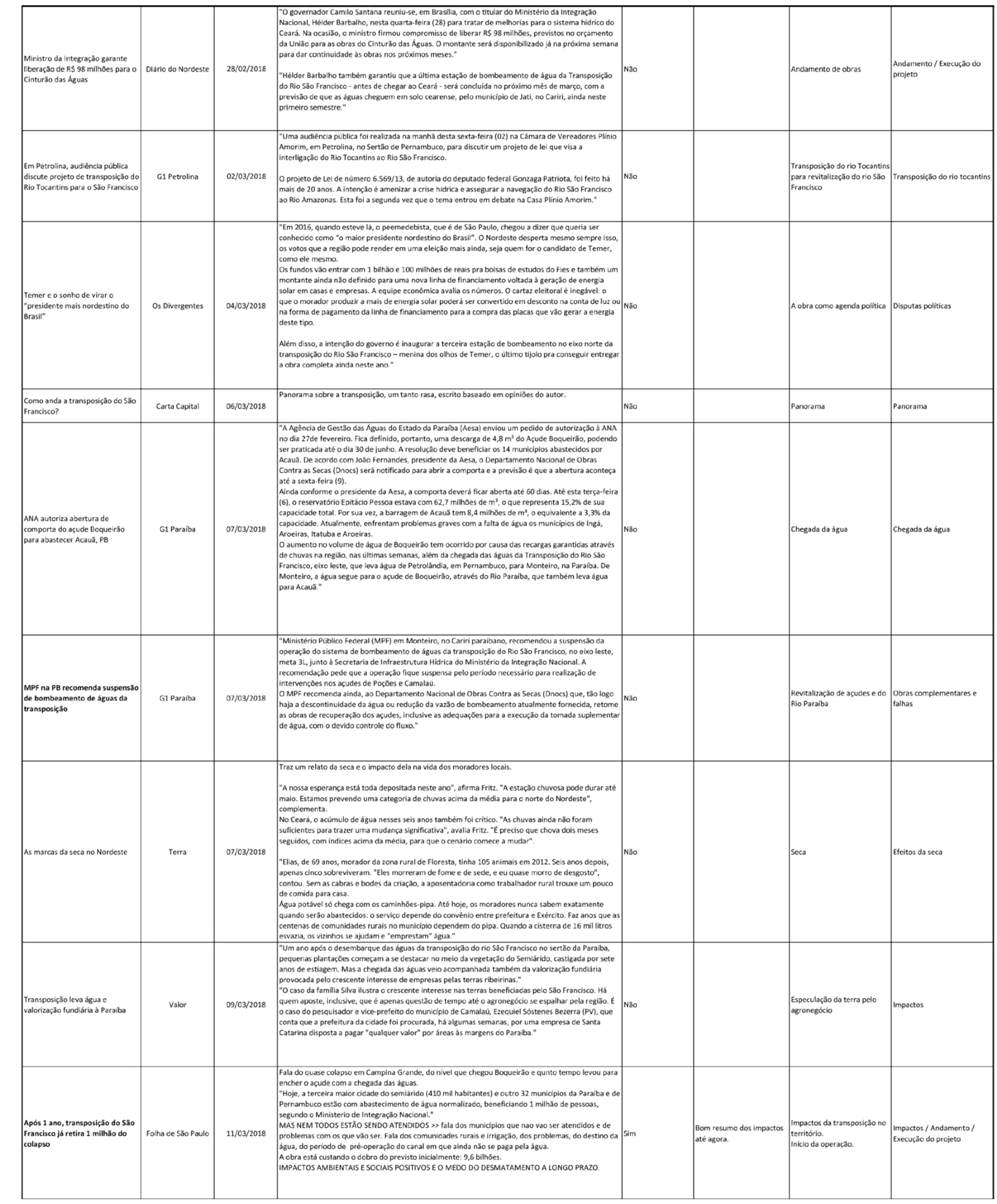




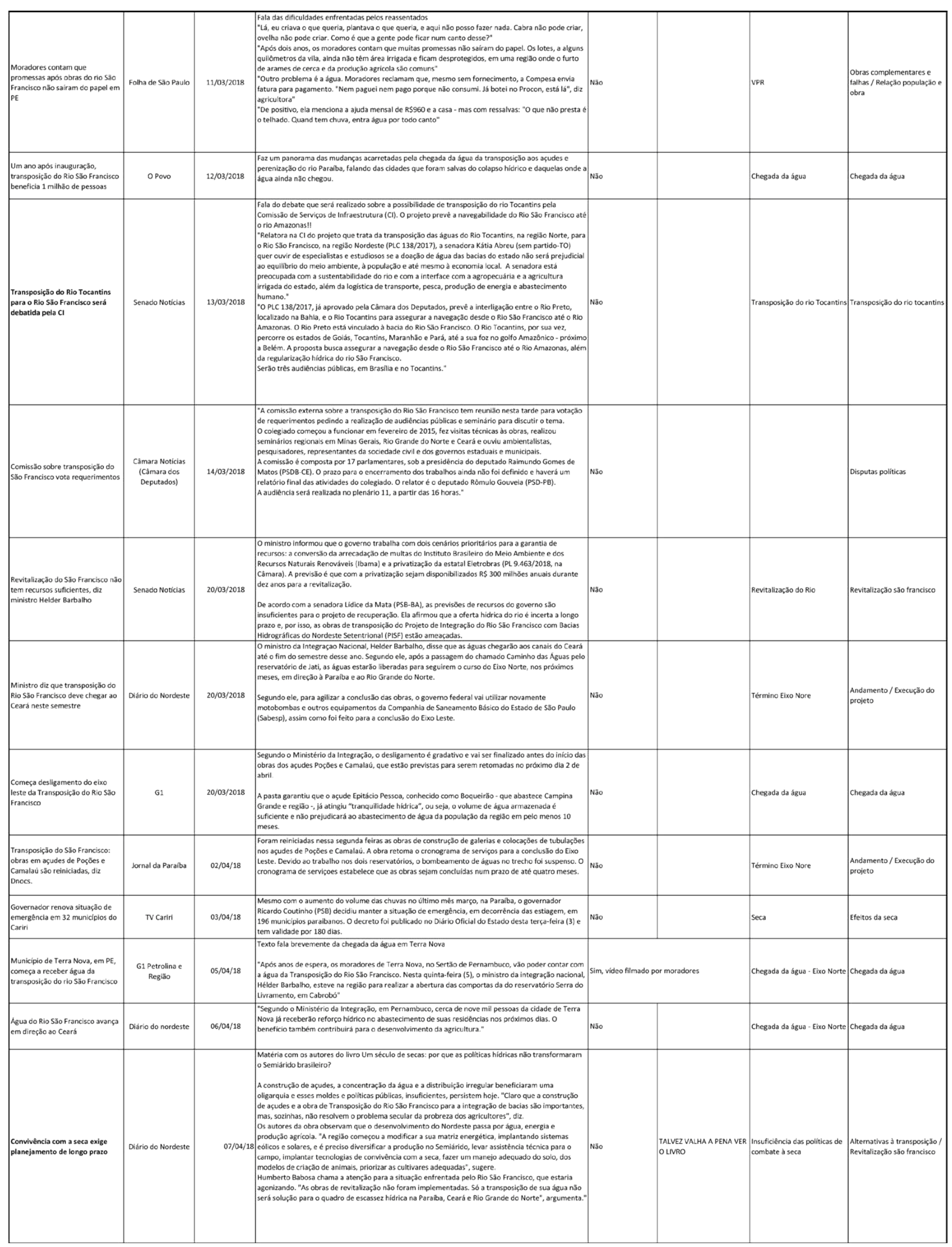

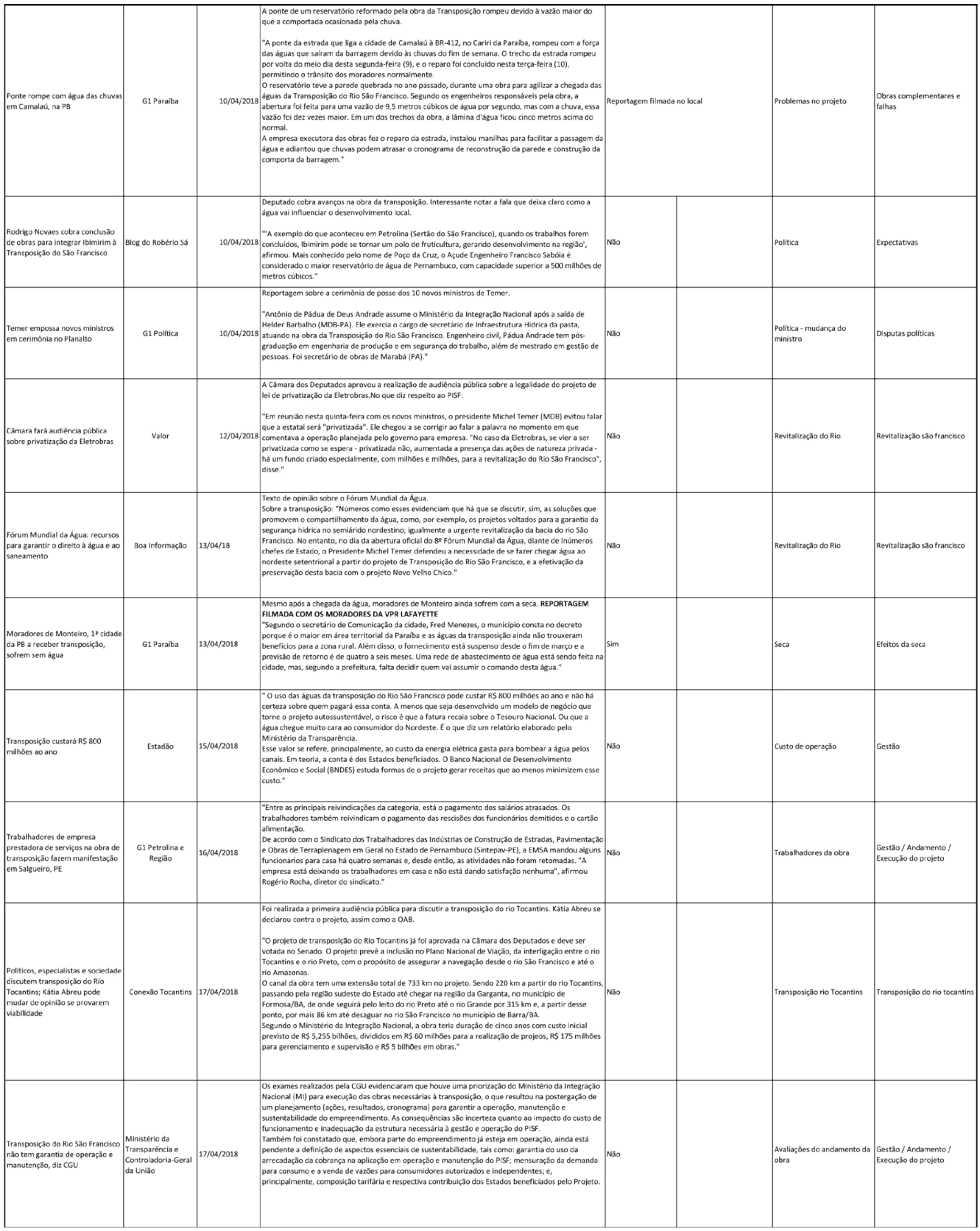




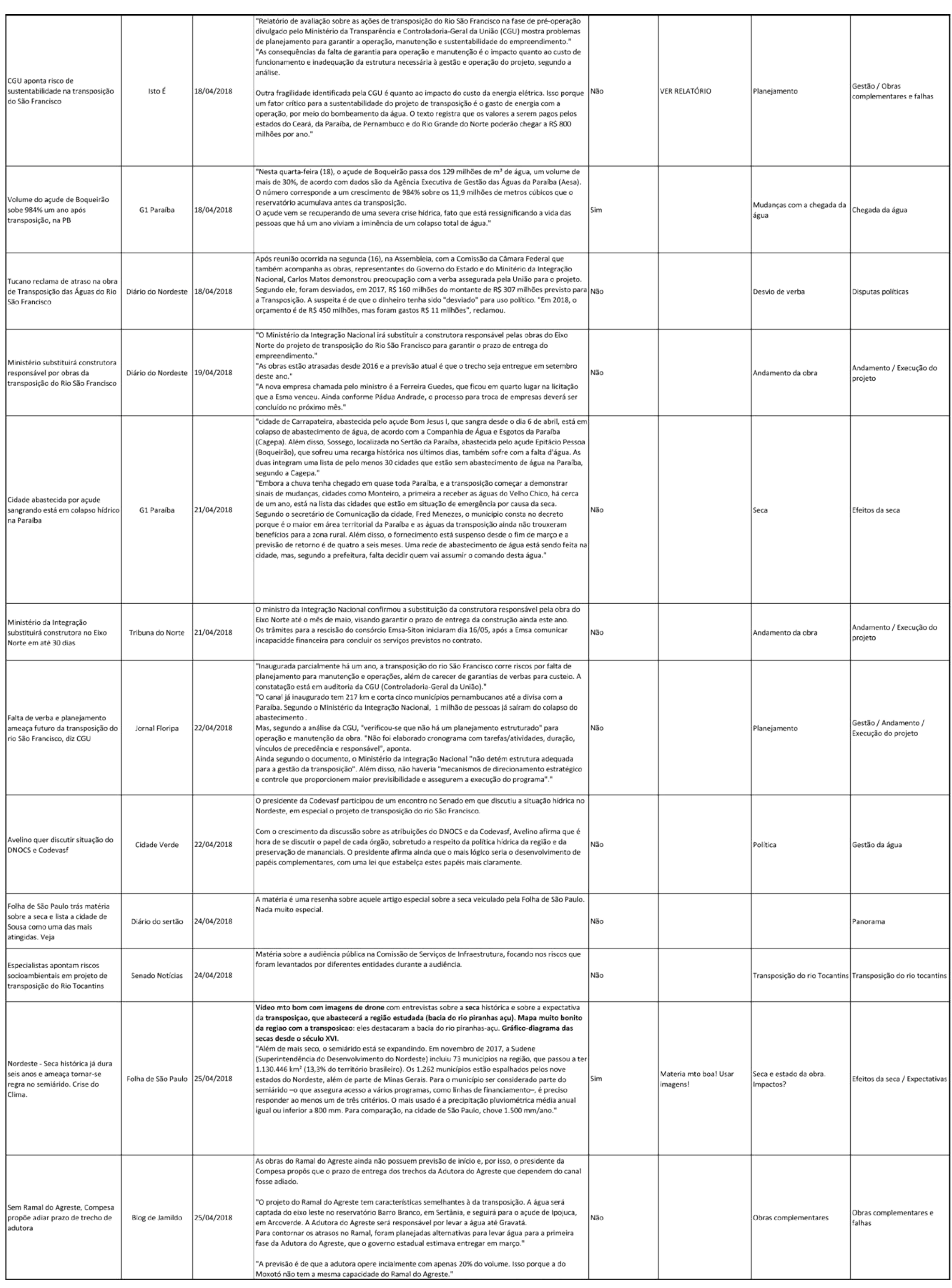

\begin{tabular}{|c|c|c|c|c|c|c|c|}
\hline 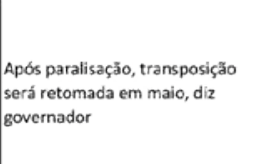 & oporo & 2601020183 & 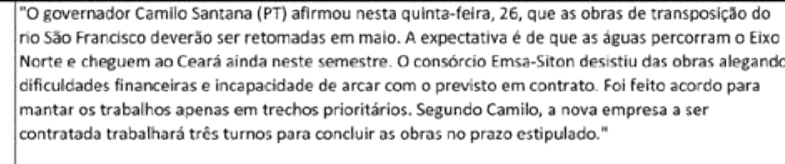 & Niso & & & poiventer \\
\hline 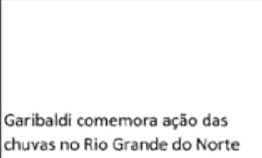 & Serasolonotocian & $6(104 / 2 / 2018$ & 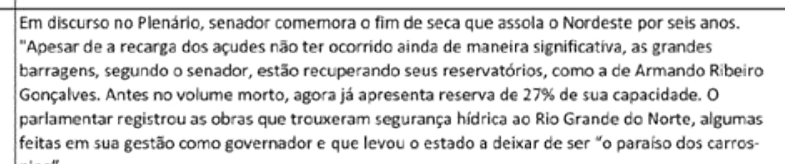 & & & & \\
\hline & & & 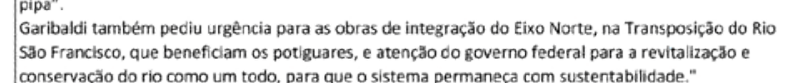 & & & & \\
\hline & & & 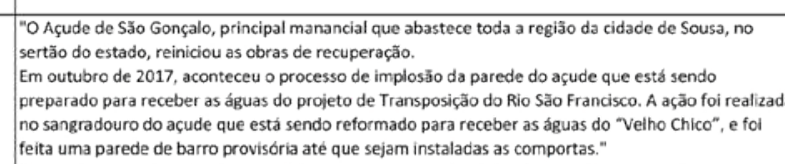 & & & & \\
\hline 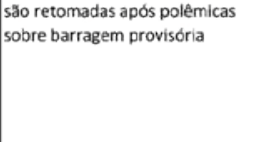 & 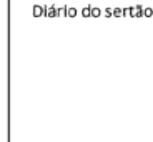 & 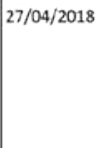 & 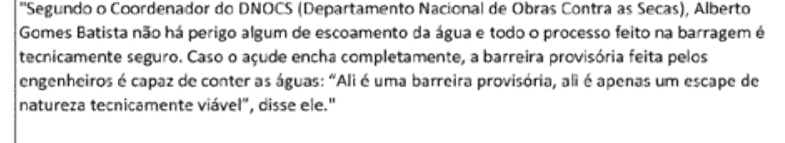 & 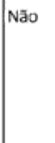 & & & laths \\
\hline 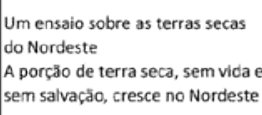 & Eocose & $280 / 2012018$ & 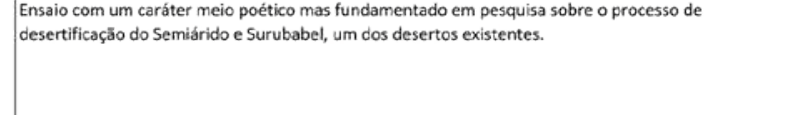 & Sim & 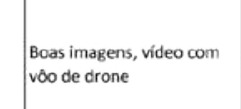 & & \\
\hline & Estrada & 20/20/2018 & 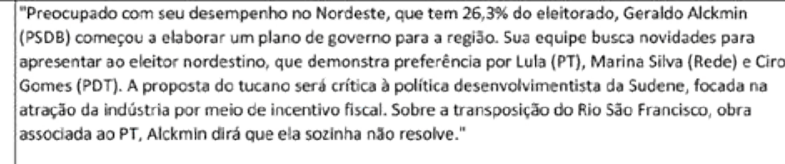 & Noo & & Pontula & \\
\hline & & & 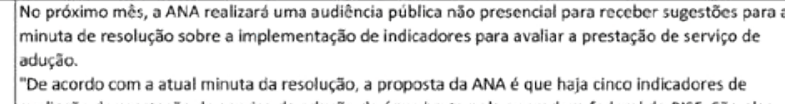 & & & & \\
\hline 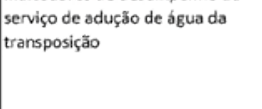 & Resus & & 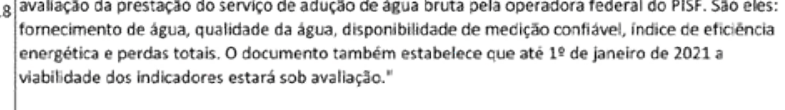 & 530 & & & \\
\hline 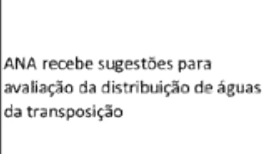 & 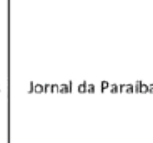 & & 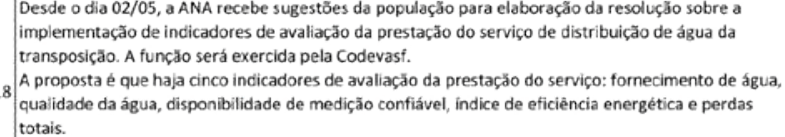 & N30\% & & & \\
\hline & opoove & & 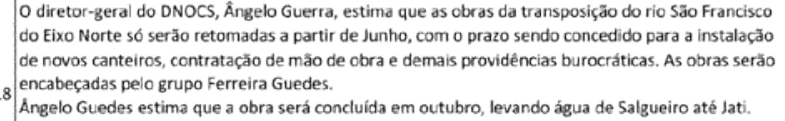 & soo & & & rocilete \\
\hline & & & 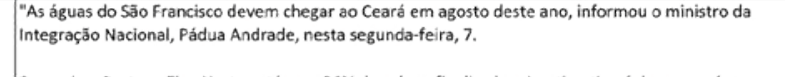 & & & & \\
\hline 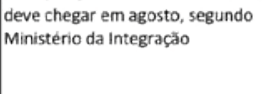 & Opouro & & 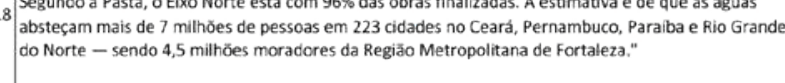 & ה30 & & & 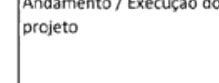 \\
\hline 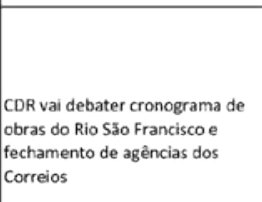 & Serardo Notricias & & 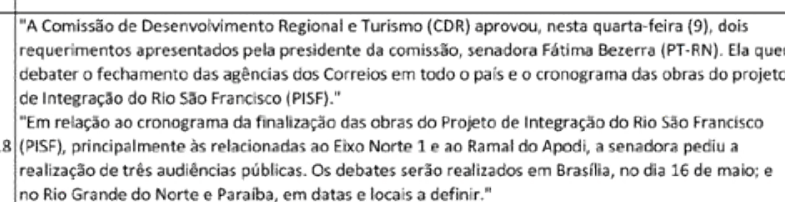 & 列 & & olitica & 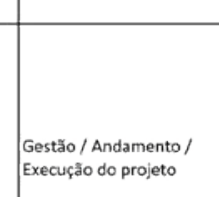 \\
\hline 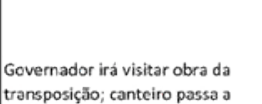 & ( & & 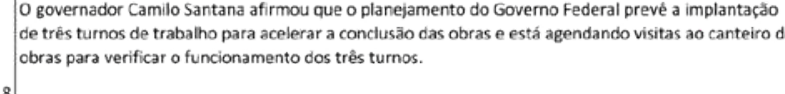 & & & & \\
\hline 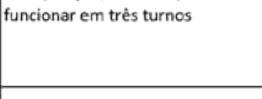 & 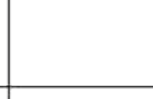 & & 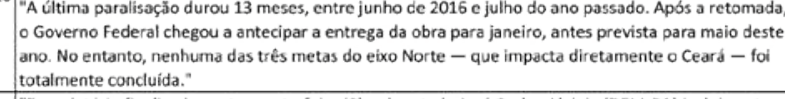 & & ate Fortclea & & proteto \\
\hline & & & 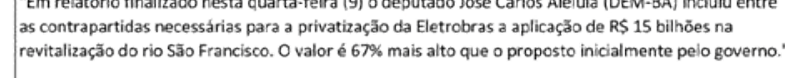 & & & & \\
\hline 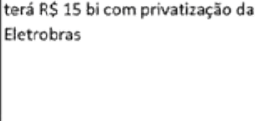 & 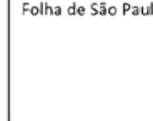 & & 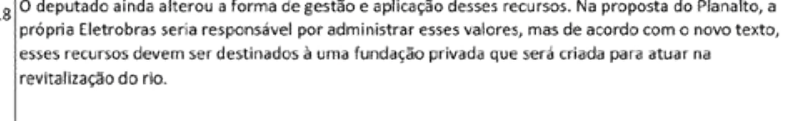 & so & & froncicer & \\
\hline 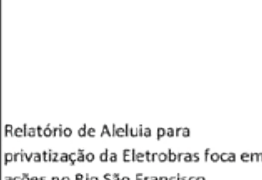 & Folbus obre & & 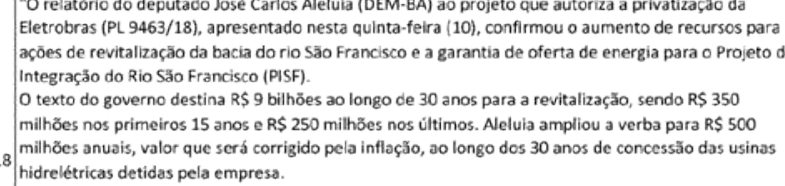 & & & 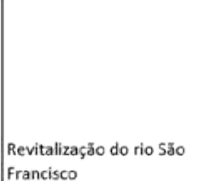 & \\
\hline & & & 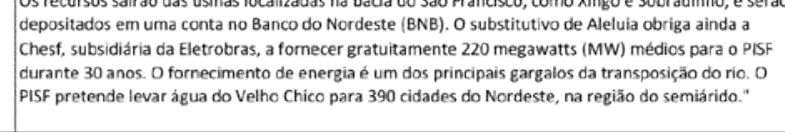 & & & & \\
\hline
\end{tabular}




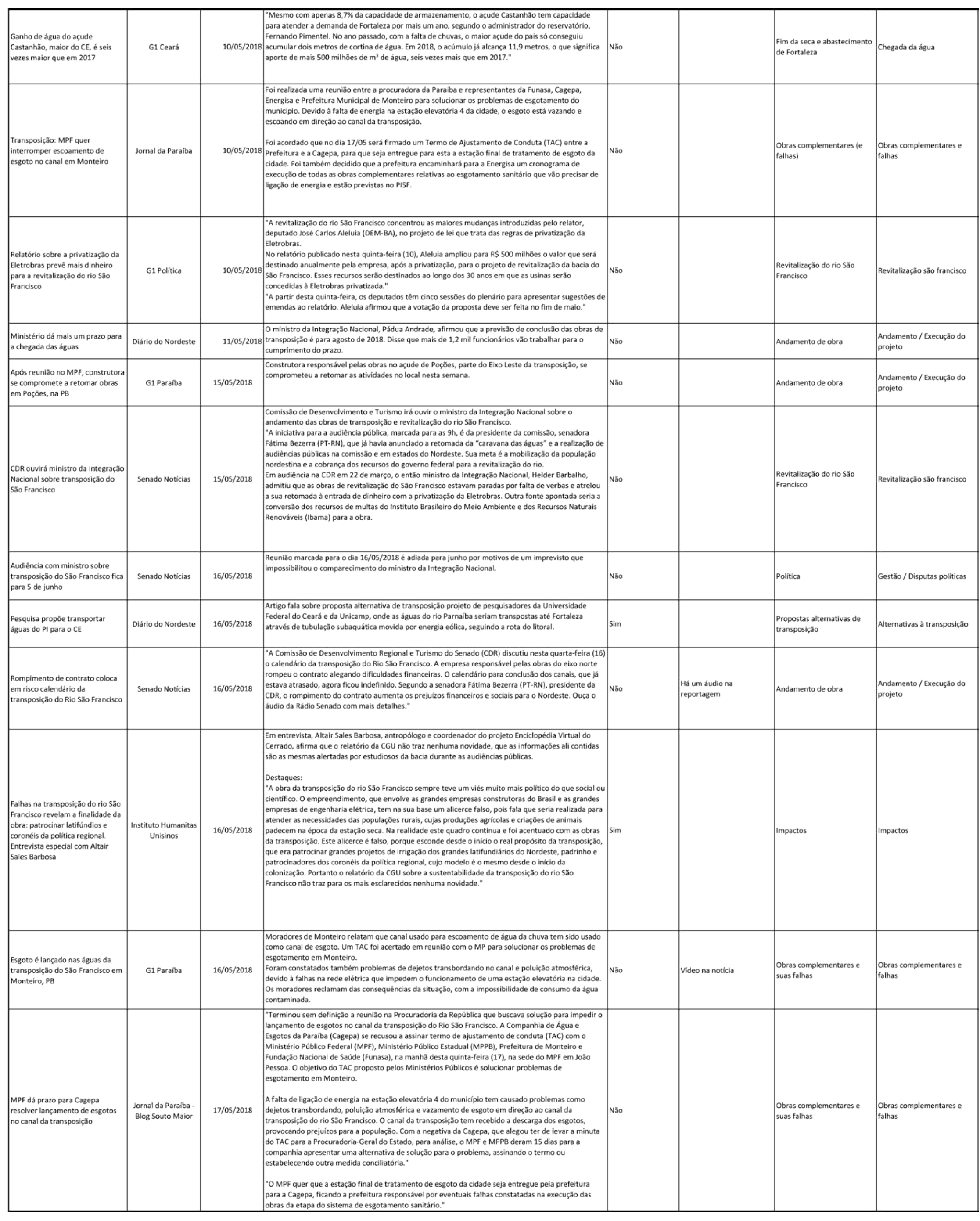

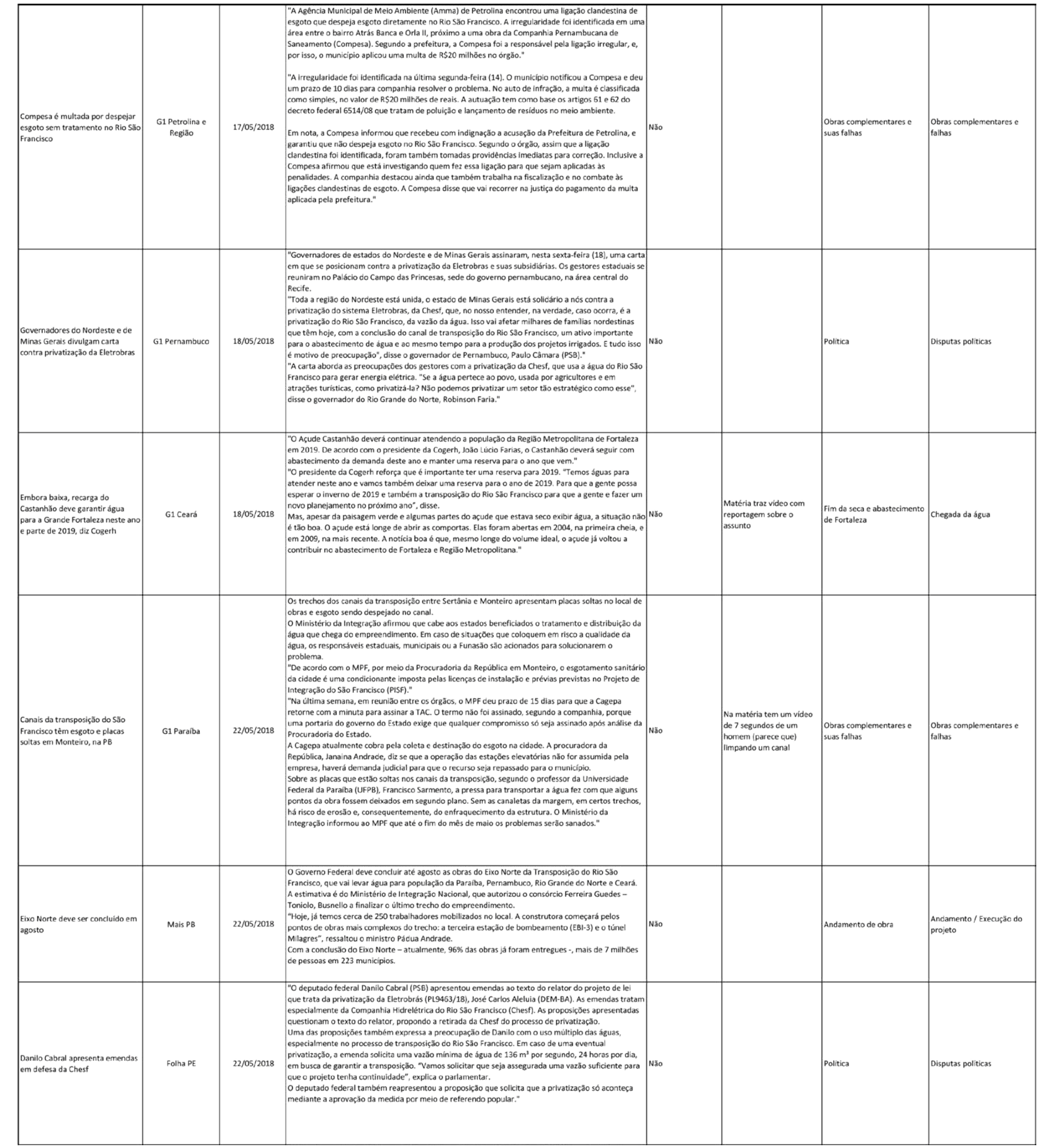




\begin{tabular}{|c|c|c|c|c|c|c|}
\hline 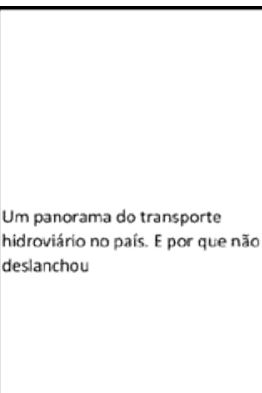 & Neesolararal & 3010552018 & 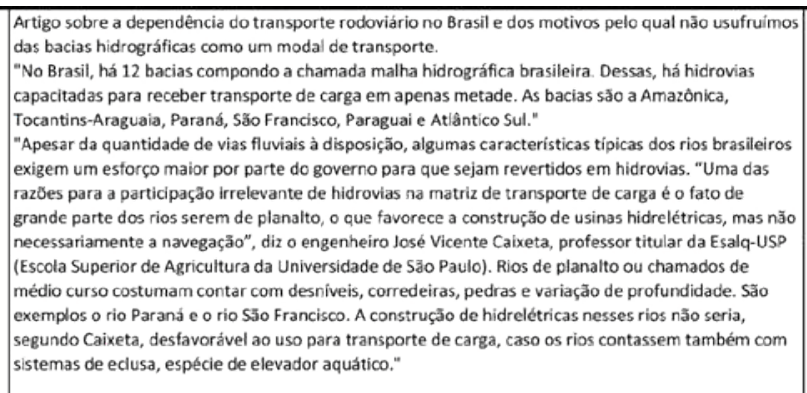 & sio & 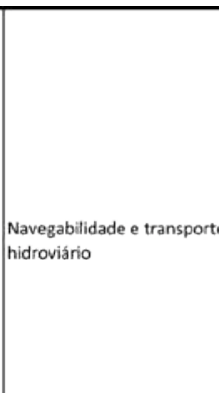 & encons \\
\hline 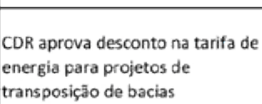 & Senason Noticias & 30/05/2018 & Tivi & Näo & Politica & Gestao \\
\hline 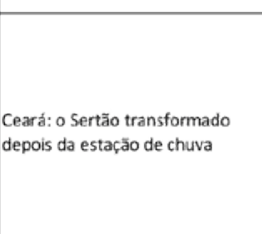 & opovo & 31/552018 & 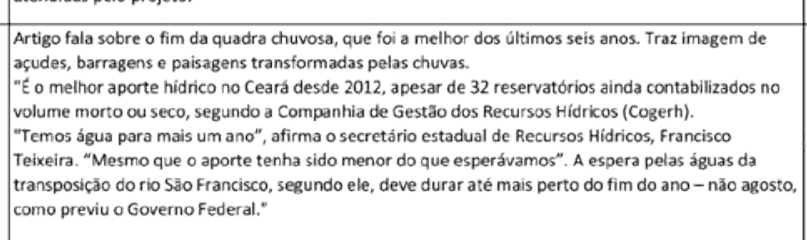 & sim & & creasas os at. \\
\hline & ibsio ob Nordeste & ox/5/201818 & 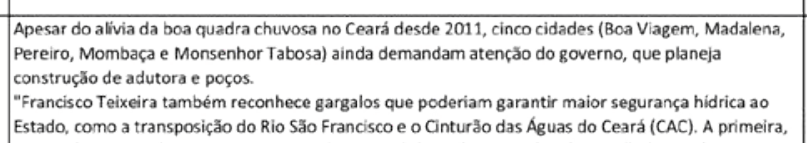 & Noo & & \\
\hline & & & 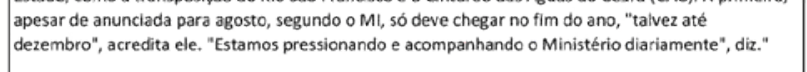 & & & \\
\hline 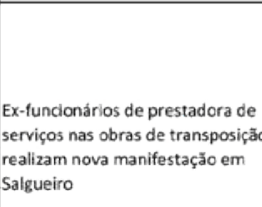 & abs do Roborioss & OANo6 2018 & 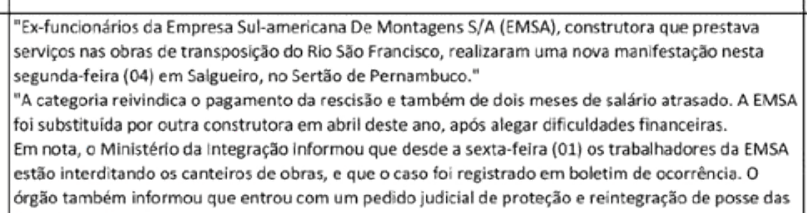 & sio & & \\
\hline 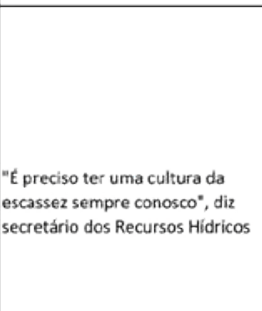 & opowo & os/oc/2018 & 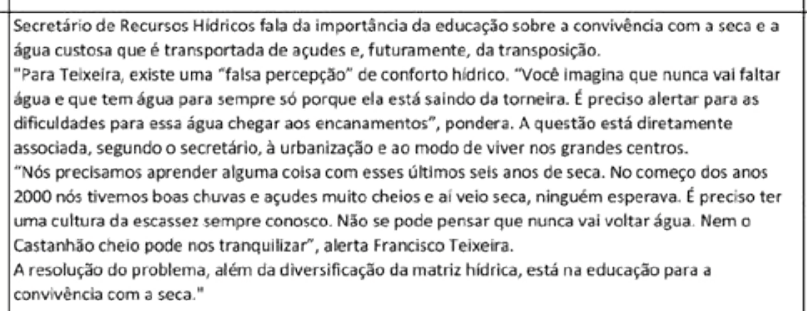 & woo & & \\
\hline 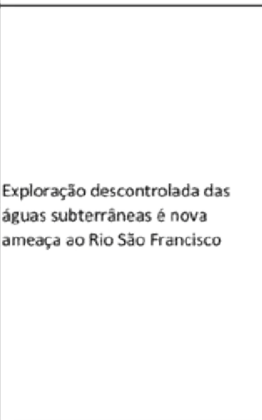 & 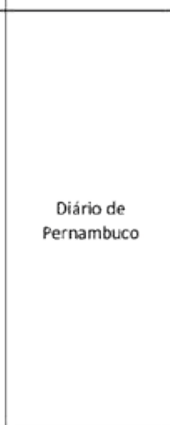 & 0506562018 & 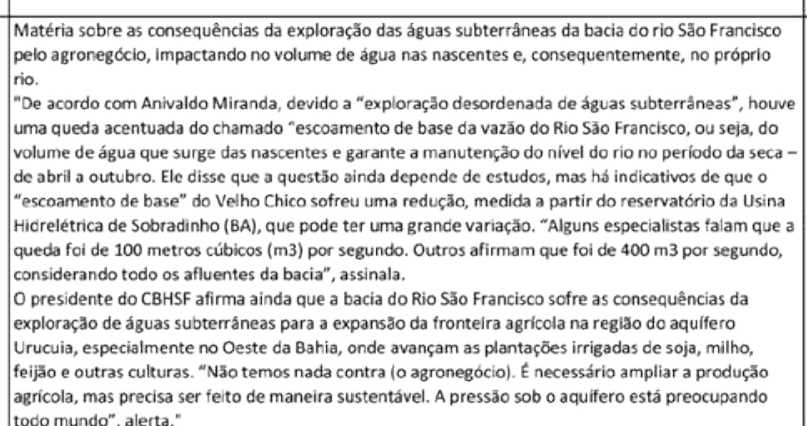 & . & & Impactos \\
\hline erip & Noon Noctias & o6/06/2018 & 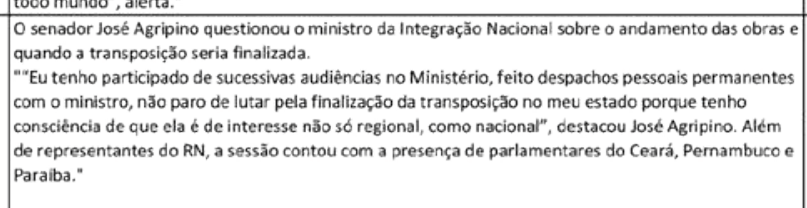 & wio & Potitia & \\
\hline 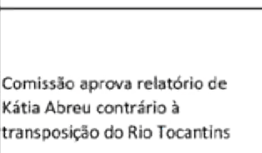 & coneses Tocantins & $07 / 06 / 2018$ & 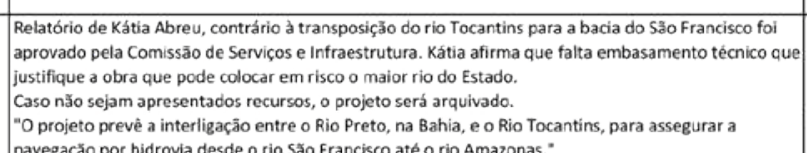 & wio & & \\
\hline 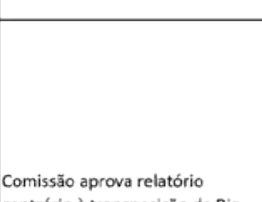 & & & 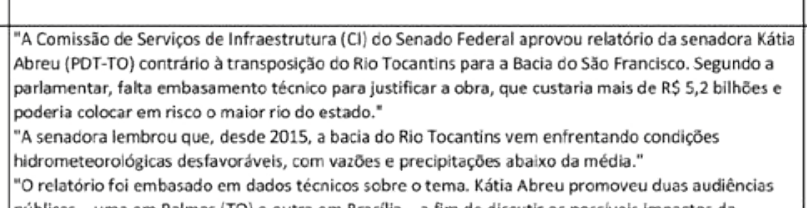 & & & \\
\hline & 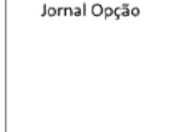 & 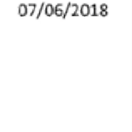 & 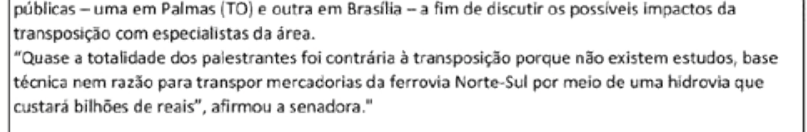 & Noo & & \\
\hline 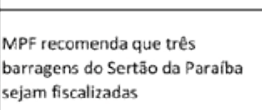 & G1 paraba & $07 / 6652018$ & 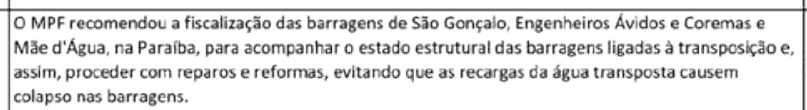 & wio & ibas complementaress & 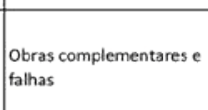 \\
\hline
\end{tabular}

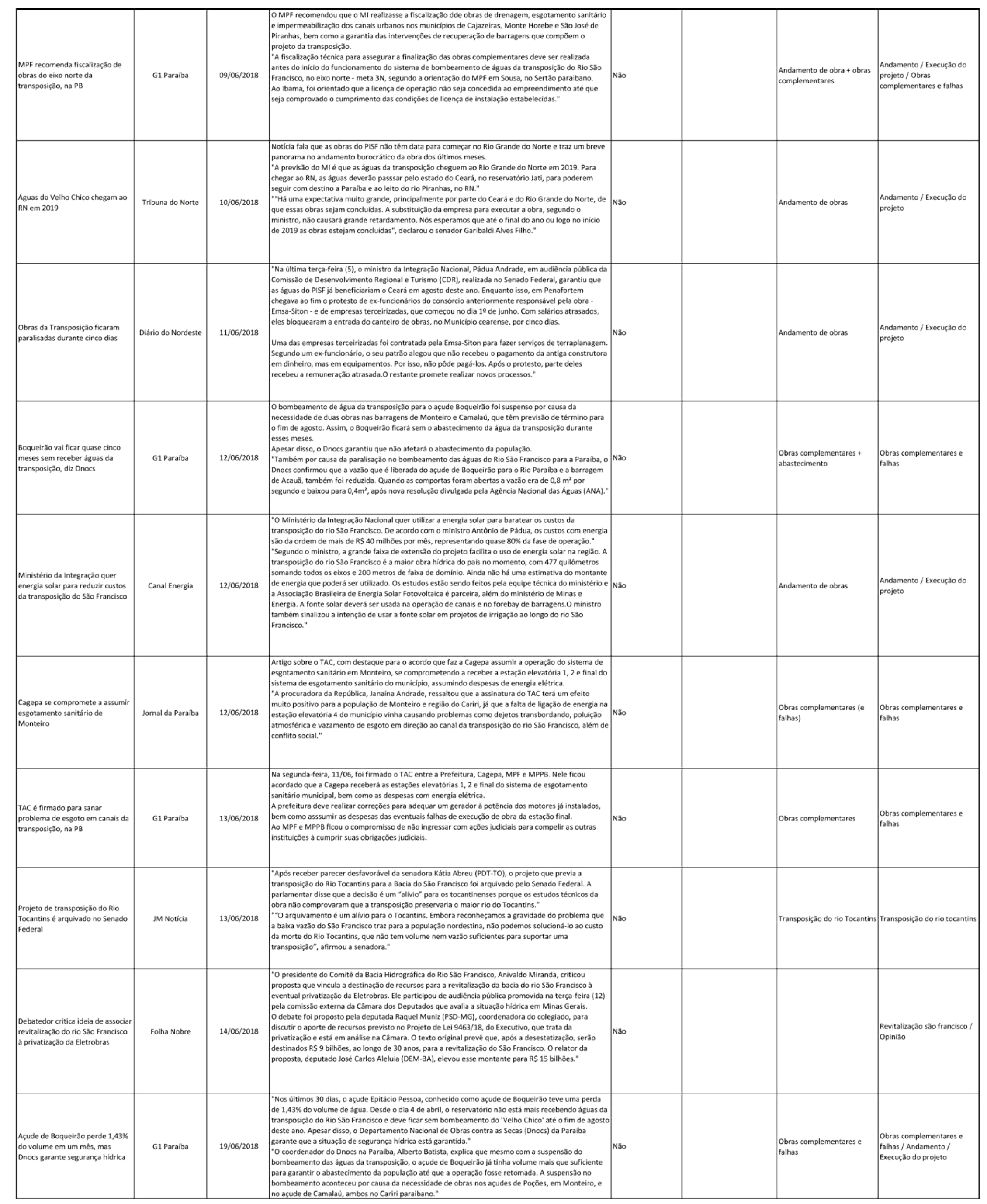




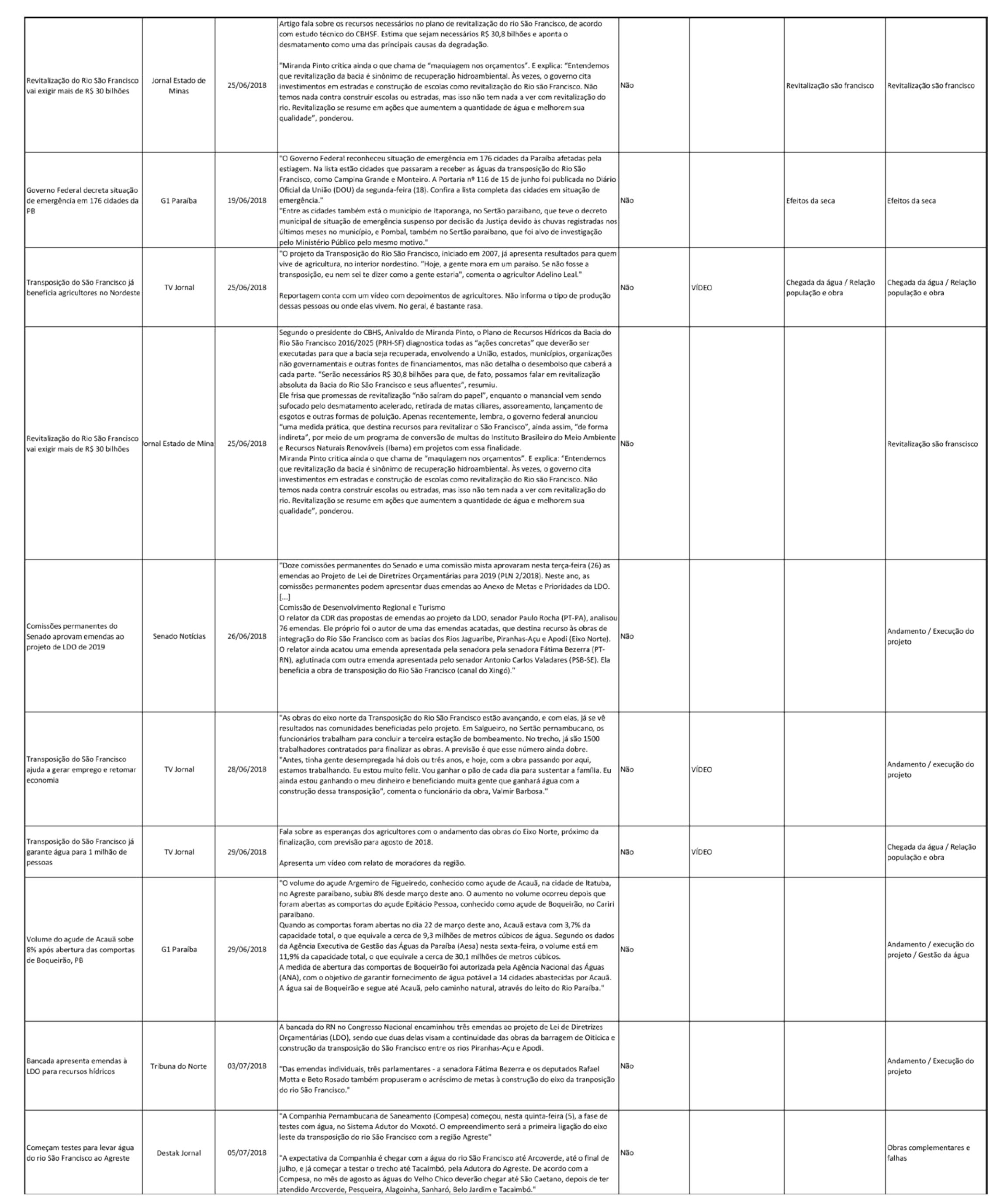

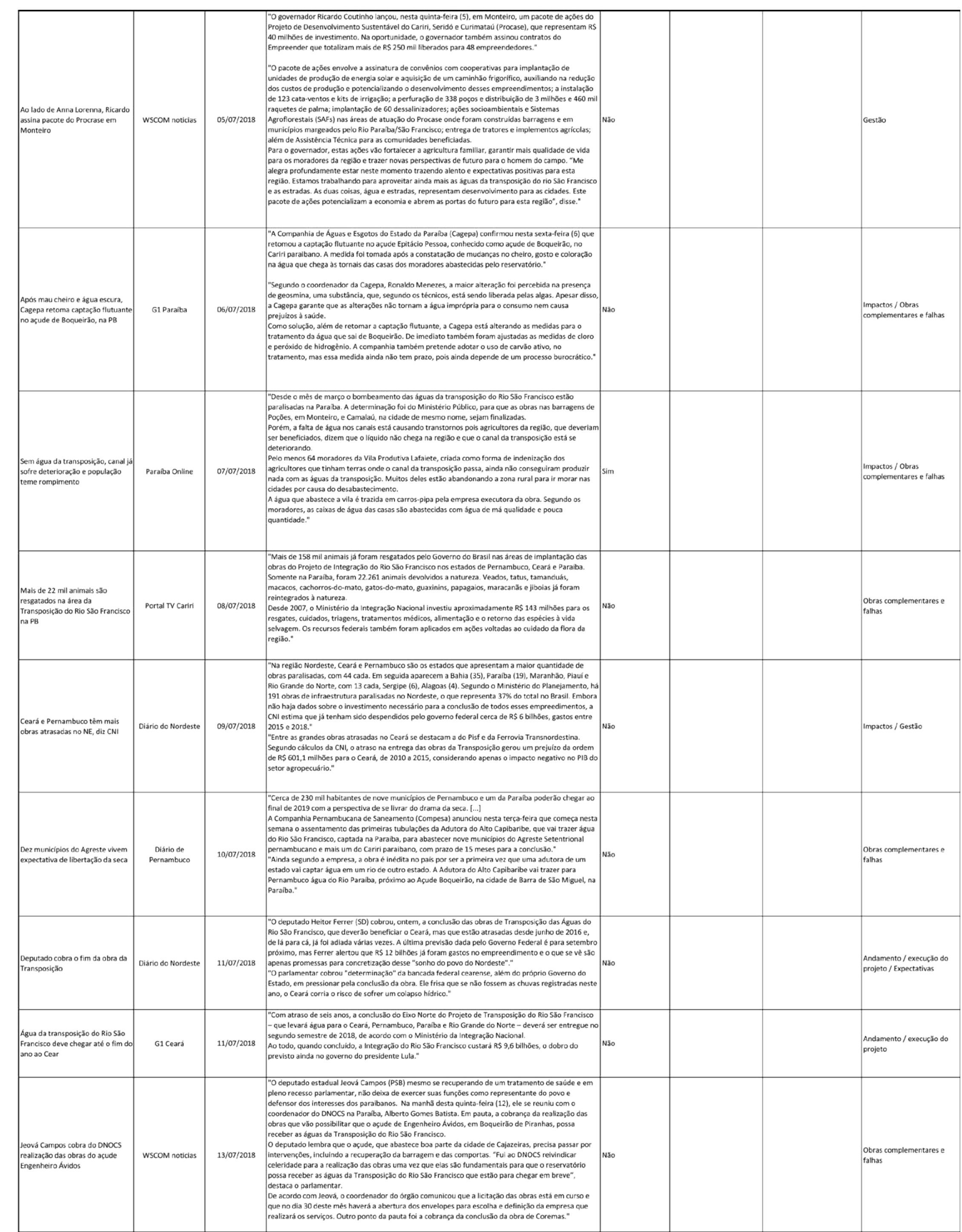




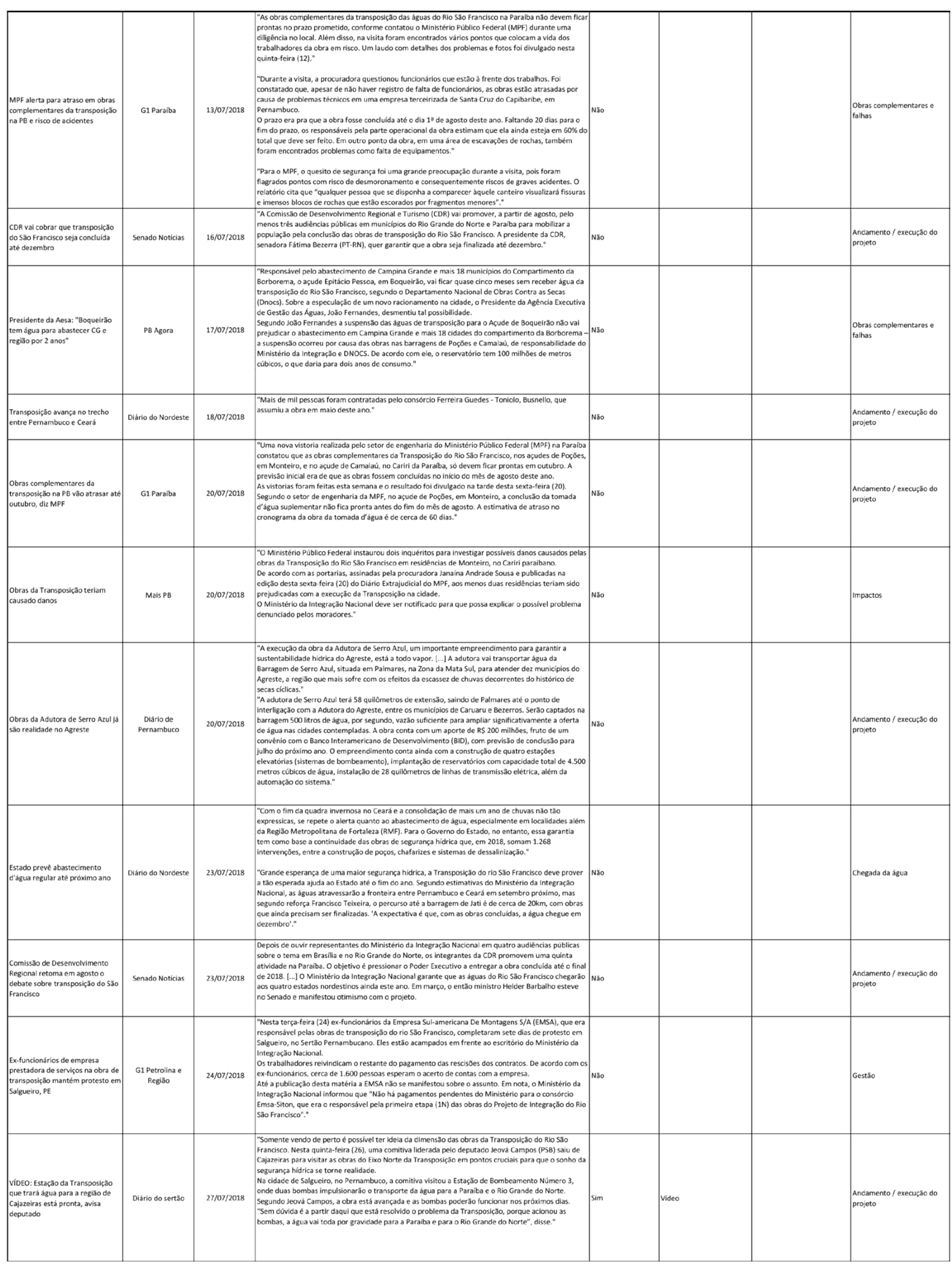

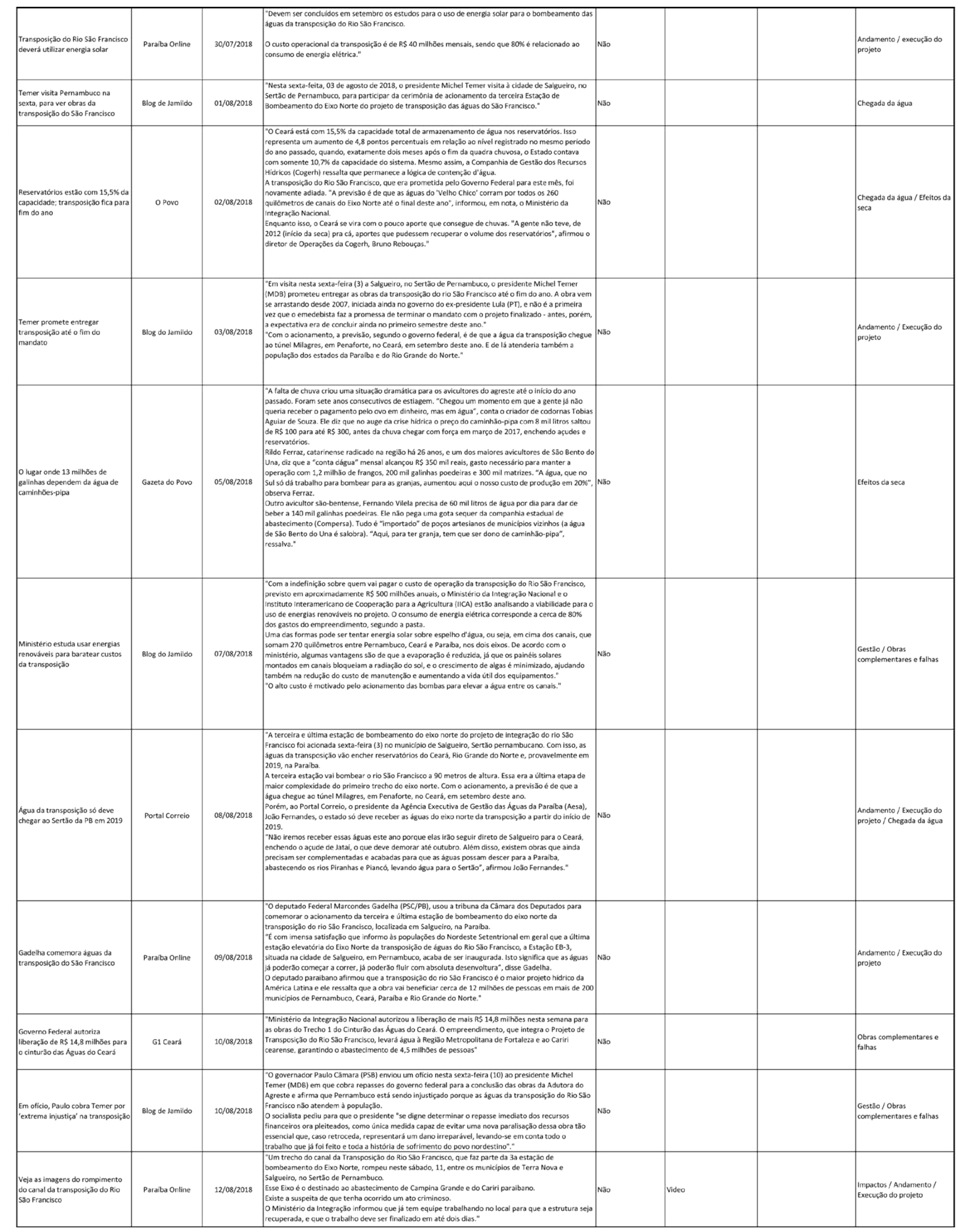




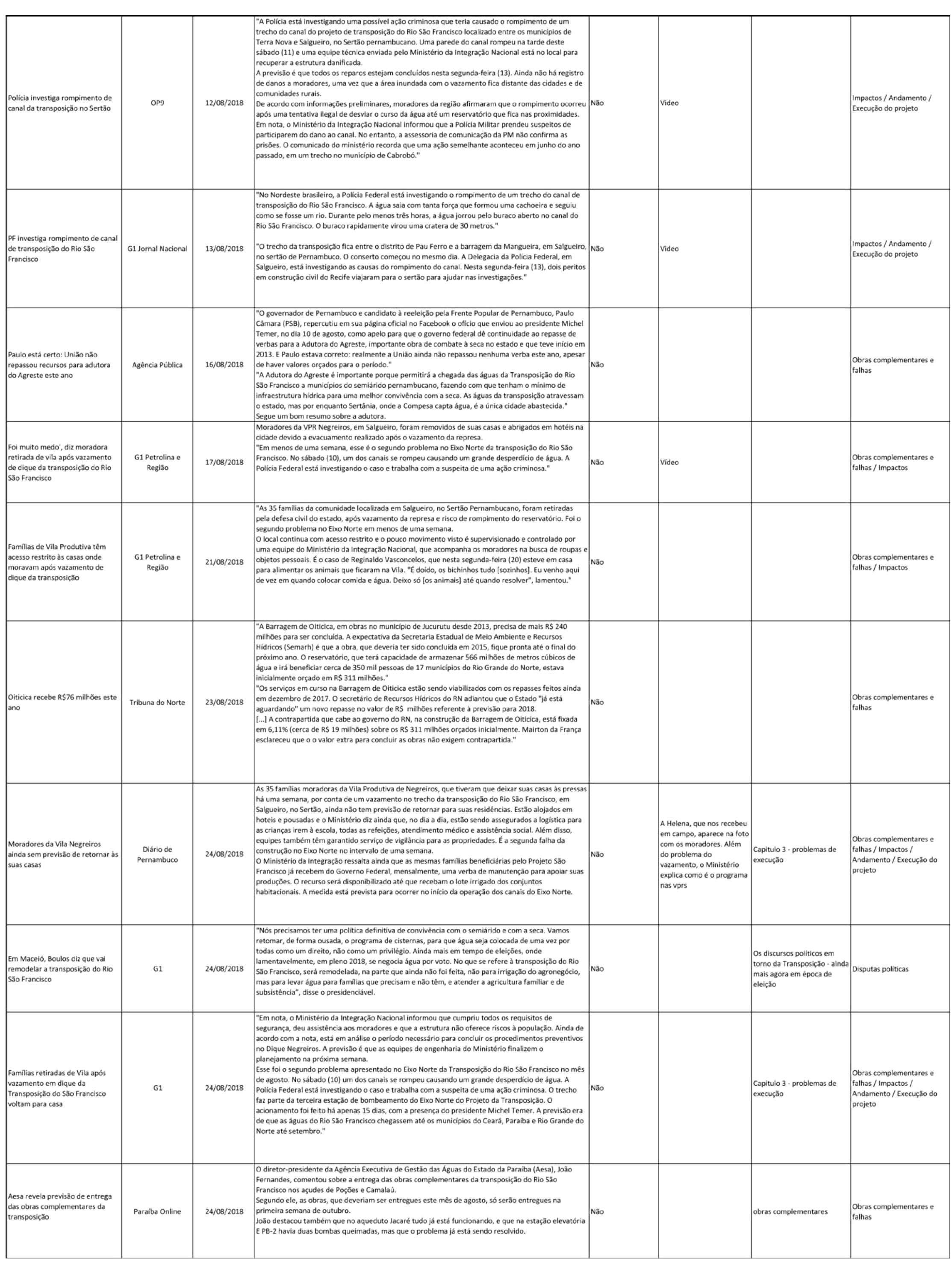

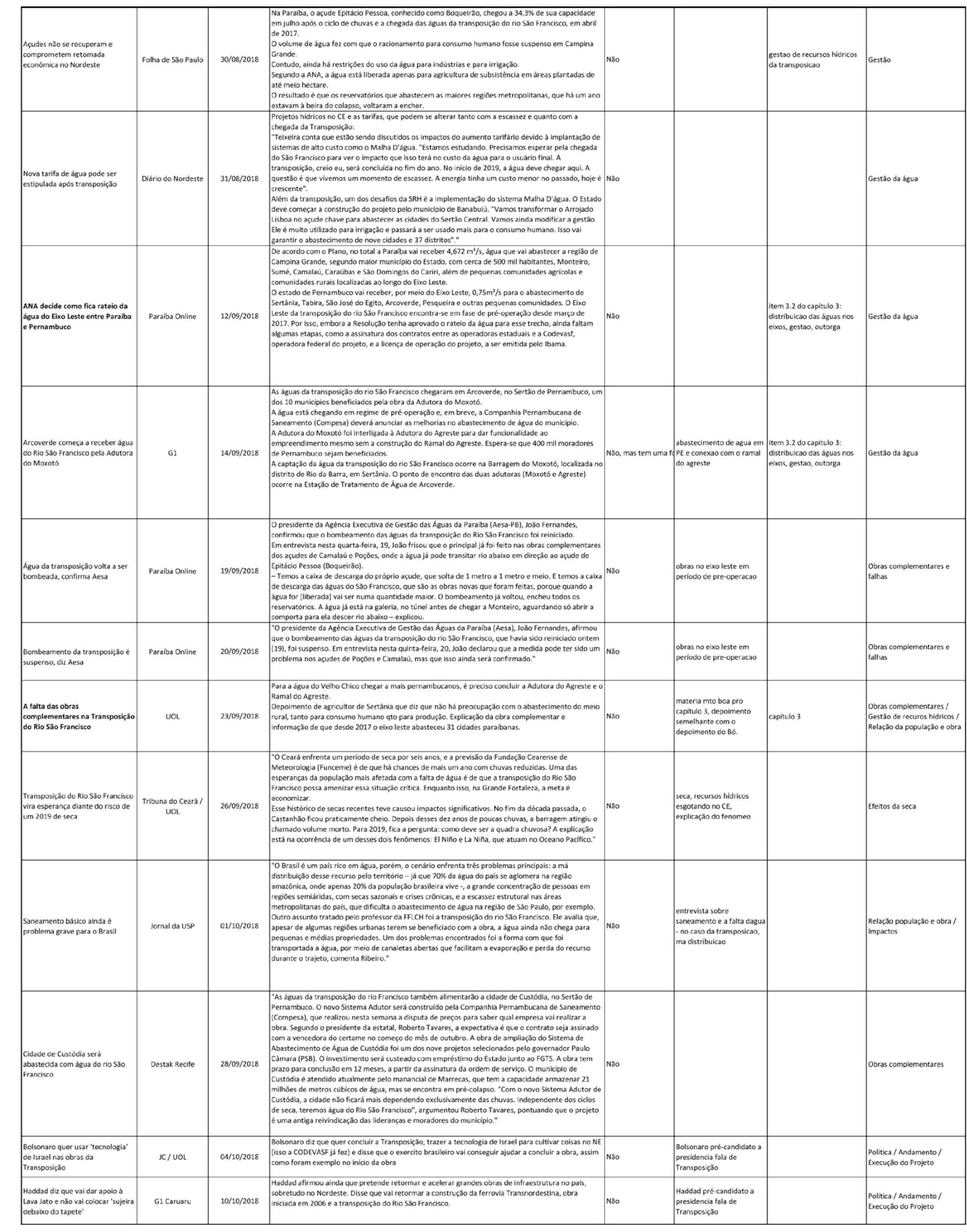




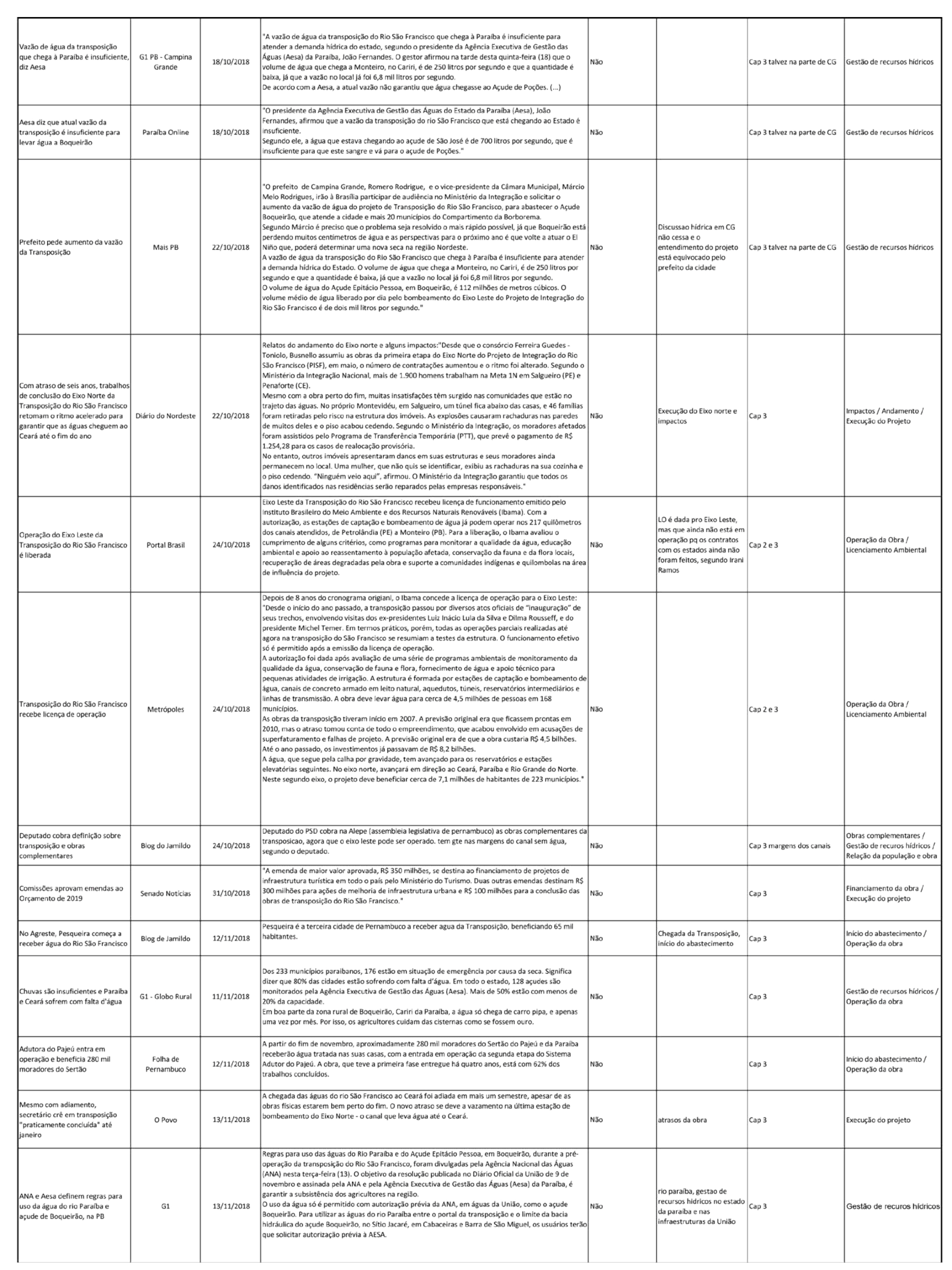

\begin{tabular}{|c|c|c|c|c|c|c|c|}
\hline 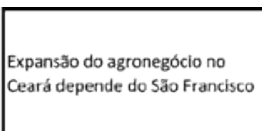 & opovo & $15 / 1 / 20018$ & 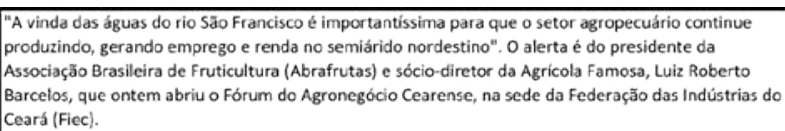 & 150 & 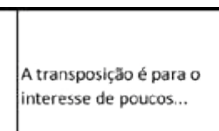 & & 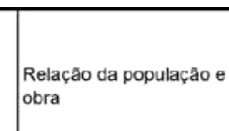 \\
\hline & & $20 / 1 / 12018$ & 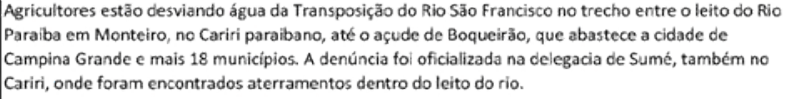 & NaO & 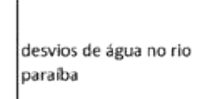 & $c_{p p 3}$ & 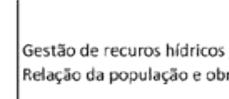 \\
\hline 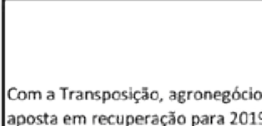 & & $9 / 1 / 2 / 2018$ & 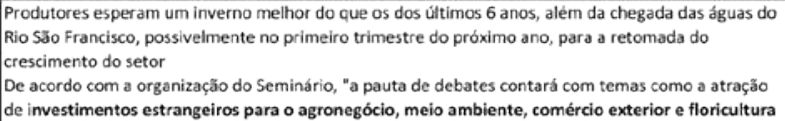 & Năo & & Can3 & \\
\hline 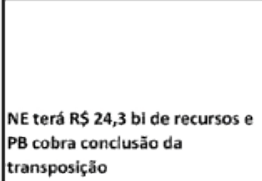 & salcorrie & 12/2/201018 & 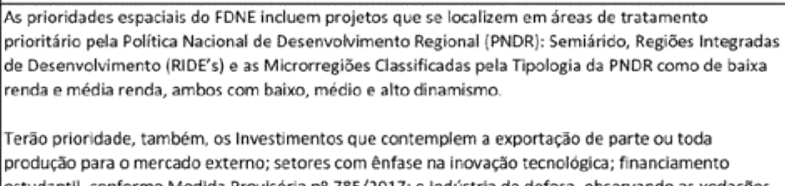 & Nao & 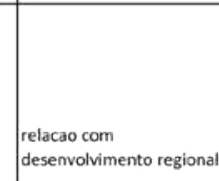 & Cap3 3 & \\
\hline 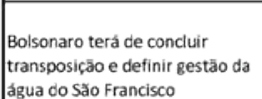 & anh ac S S So paulo & 16/1/2/2018 & 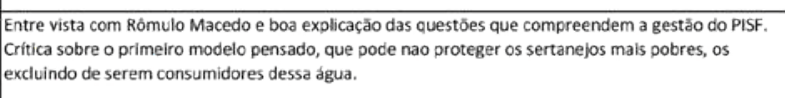 & $\mathrm{sim}$ & & ape 3 & \\
\hline 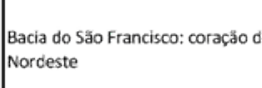 & utipos trassin & $18 / 12 / 2018$ & 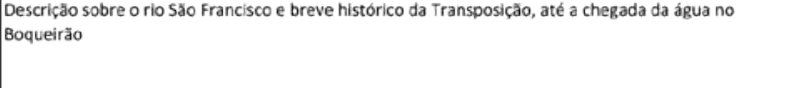 & wo & & Cop 1 & 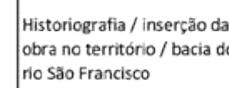 \\
\hline 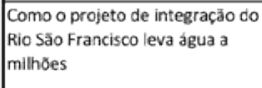 & muthost basis & 201212/2018 & 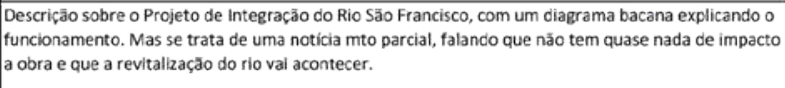 & $\mathrm{sm}$ & & Cap3 3 & 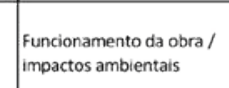 \\
\hline 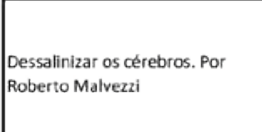 & & 27/12/2018 & 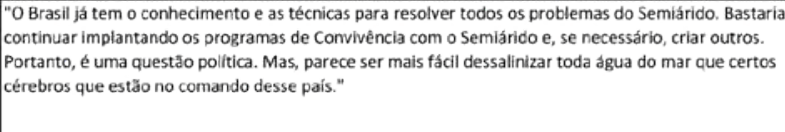 & Nao & 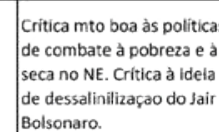 & 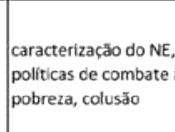 & pollutica \\
\hline 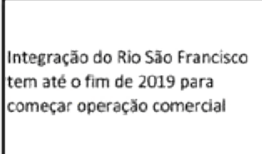 & opouv online & 27/12/2018 & 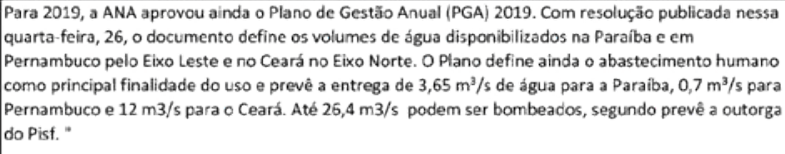 & va & 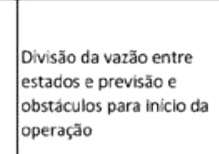 & cap 20043 & \\
\hline 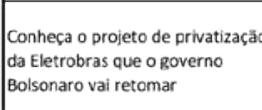 & pepa & 3/1/20:9 & 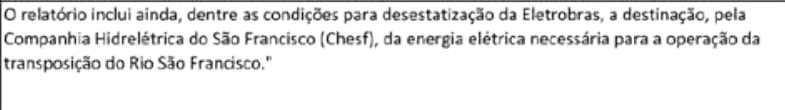 & & 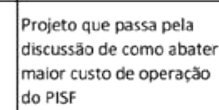 & ap 3 & 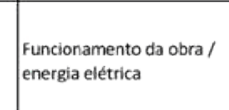 \\
\hline
\end{tabular}


